
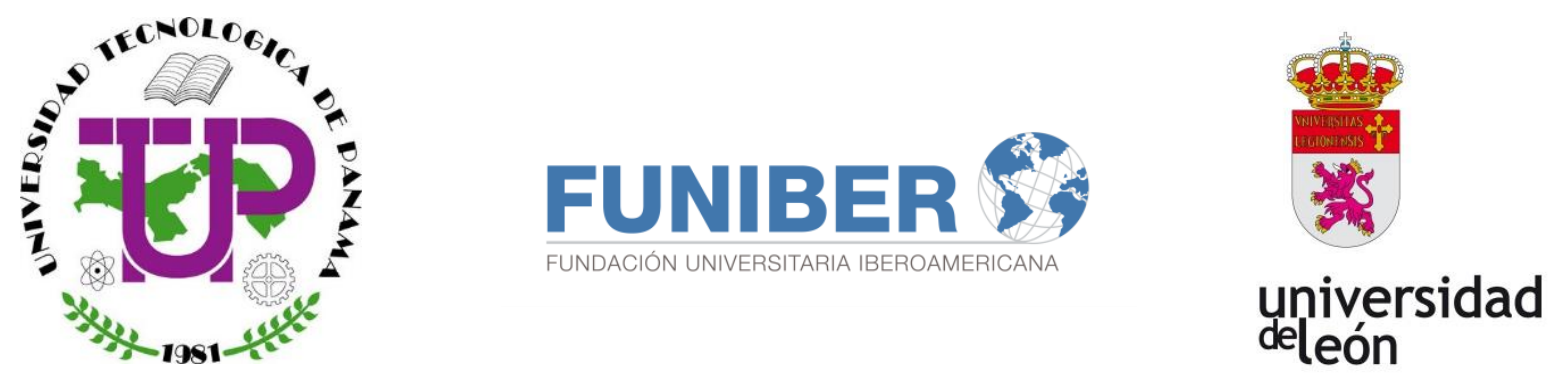

\title{
La imagen y la marca país: propuesta de un modelo estratégico de proyección-país para Colombia
}

Tesis Doctoral presentada por: LINA MARÍA ECHEVERRI CAÑAS

Dirigida por:

Dr. D. JOSÉ LUIS VÁZQUEZ BURGUETE Dr. D. CHRISTIAN ESTAY-NICULCAR 


\section{La imagen y la marca país: propuesta de}

un modelo estratégico de proyección-país para Colombia 
If you want to change the world, pick up your pen and write-. Martin Luther 


\section{Agradecimientos}

La realización de un doctorado va más allá del desarrollo de competencias investigativas enfocadas a cambiar la realidad de un contexto específico. Significó para mí, descubrir una pasión hacia la investigación que se ha convertido en un proyecto de vida profesional.

En el camino, me encontré con experiencias, trayectorias y vivencias que marcaron un nuevo norte en mi vida como estudiante y que se registraron en esta Tesis Doctoral. Especialmente de personas que fortalecieron mi carácter investigativo y que con paciencia y sensatez me orientaron para el desarrollo de una propuesta investigativa orientada a una necesidad emergente para mi patria Colombia. De acuerdo con lo anterior, quiero manifestar mis agradecimientos a un grupo de personas que me acompañaron y me apoyaron de manera incondicional durante este proceso.

Quiero agradecer al doctor Christian Estay-Niculcar, quien con sus conocimientos, paciencia y franqueza me enseñó a ser más exigente en mis análisis y trascender en mi trabajo investigativo.

Mis respetos al doctor José Luis Vázquez Burguete por su interés demostrado en mi proyecto, y sus oportunos comentarios y recomendaciones llenos de buenas pretensiones.

A mi profesor y amigo, Hernán Parra, por su buena voluntad al vincularse en una investigación que ha logrado generar adeptos hacia el concepto de marca país en Colombia.

Agradezco a mis estudiantes, quienes se comprometieron en el desarrollo de la investigación, con el interés de descubrir nuevos conocimientos para fortalecer la imagen del país del realismo mágico: Colombia.

Finalmente, mi eterno agradecimiento a mi familia, conformada por mi pequeña María Clara y mi esposo Sergio, que me motivaron en mi pasión investigativa, y a quienes profundamente valoro por su sacrificio en el inicio y final de esta experiencia. A mi padre, por entregarme todo su cariño y estar vigilante de que no desistiera del doctorado nunca. A mi madre, ejemplo maravilloso de perfeccionismo y persistencia, y a mi hermana, por ser trascendental en mi vida. Todos, son mi corazón y mi alma expuestos con humildad en esta aventura de Tesis Doctoral. 


\section{Acrónimos}

ALADI:

ANATO:

ANDI:

BID:

BRICS:

B2C:

B2B:

CBI:

CEPAL:

CIACEX:

CIVETS:

CRM:

CTC:

DANE:

E\&Y:

FENALCO:

GAP:

ICG:

INGUAT:

ISO:

MICI:

NBI:

NEF:

ONAPI:

ONU:

PROCOMER:
Asociación Latinoamericana de Integración

Asociación Colombiana de Agencias de Viaje y Turismo

Asociación Nacional de Industriales

Banco Interamericano de Desarrollo

Grupo de países conformado por Brasil, Rusia, India, China y

Sudáfrica

Business to Consumer, de la empresa al consumidor

Business to Business, de la empresa a otra empresa

Country Brand Index

Comisión Económica para América Latina y el Caribe

Comisión Interministerial para el Comercio Exterior

Colombia, Indonesia, Vietnam, Egipto, Turquía y Sudáfrica

Customer Relationship Management

Comisión de Turismo de Canadá

Departamento Administrativo Nacional de Estadística

Ernest \& Young Global Limited

Federación Nacional de Comerciantes

Brecha de mercado

Índice Global de Competitividad

Instituto Guatemalteco de Turismo

International Organization for Standardization

Ministerio de Comercio e Industrias

Nation Brand Index

The New Economics Foundation

Oficina Nacional de la Propiedad Industrial

Organización de las Naciones Unidas

Promotora de Comercio Exterior de Costa Rica 
PROEXPORT: Promoción de Turismo, Inversión y Exportaciones de Colombia

PROMPERÚ: Comisión de Promoción del Perú para la Exportación y el Turismo

SECTUR: $\quad$ Secretaría de Turismo de México

TOH: $\quad$ Top of Heart

TOM: $\quad$ Top of Mind

UAE: $\quad$ United Arab Emirate

UNCTAD: $\quad$ United Nations Conference on Trade and Development

UNESCO: $\quad$ United Nations Educational, Scientific and Cultural Organization 


\section{Índice General}

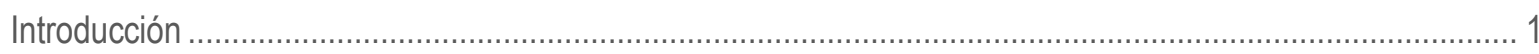

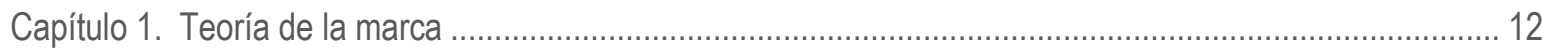

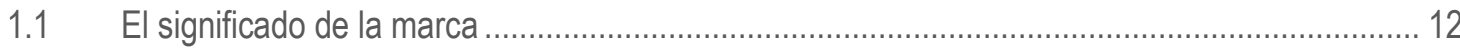

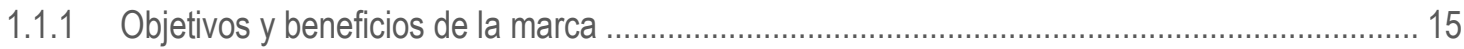

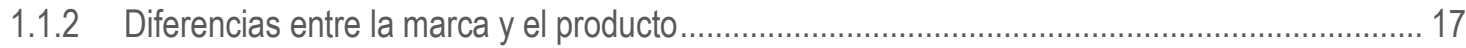

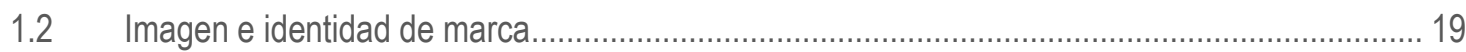

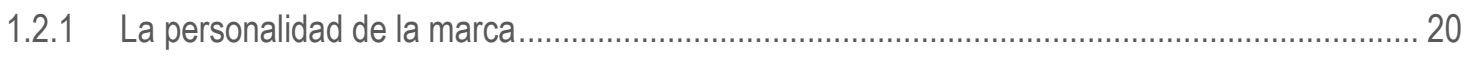

1.3 Posicionamiento de marca.................................................................................................. 22

1.3.1 Medición de posicionamiento de marca ........................................................................ 25

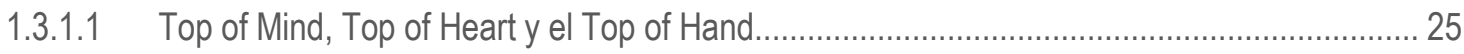

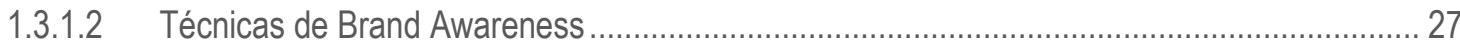

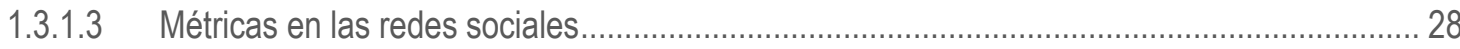

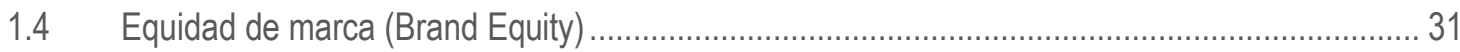

1.4.1 Medición de la Equidad de Marca ............................................................................... 33

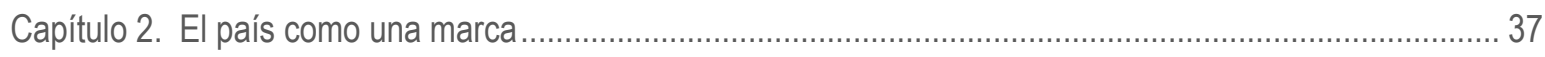

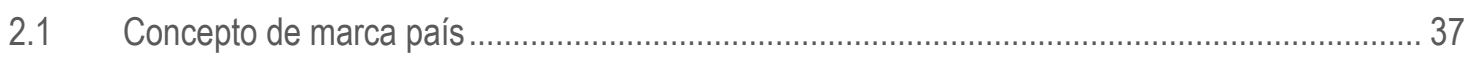

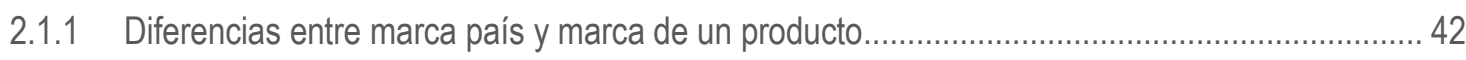

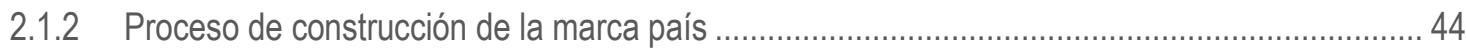

2.1.3 La marca país desde la perspectiva del marketing territorial y del marketing turístico ...............51

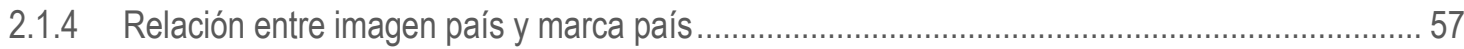

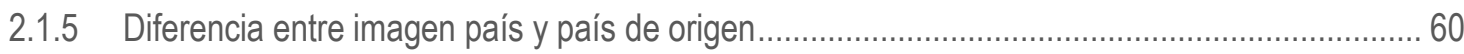

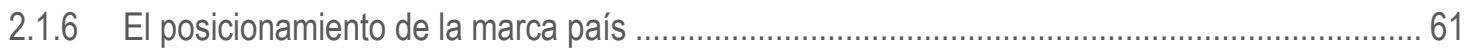

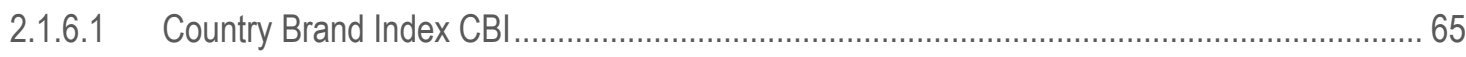

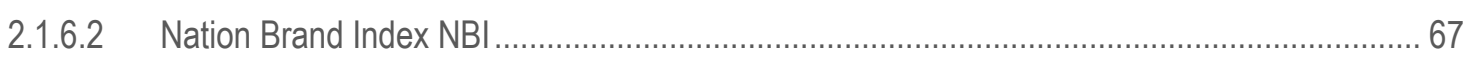

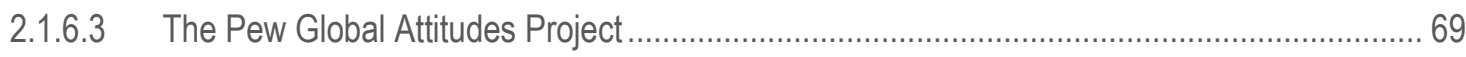

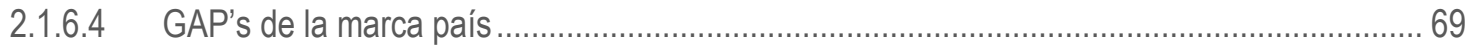

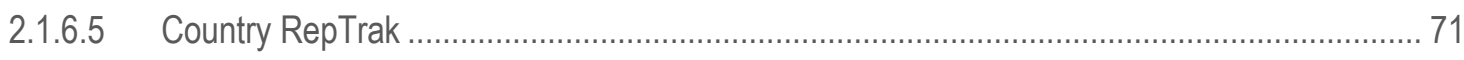

2.1.6.6 East West Nation Brand Perception Indexes.................................................................... 72 


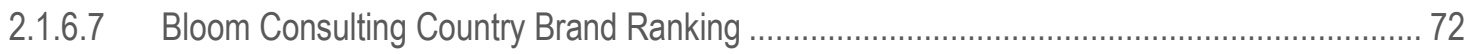

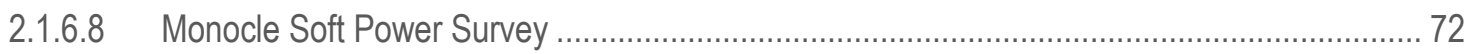

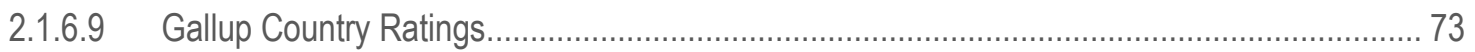

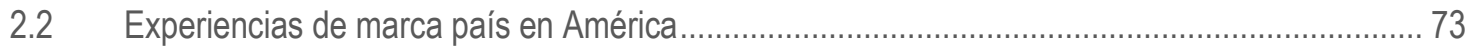

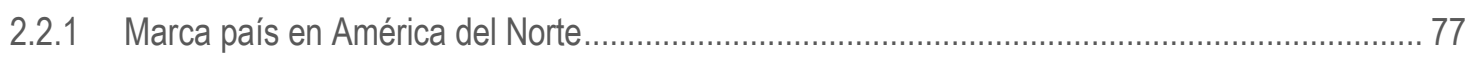

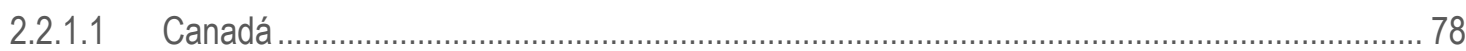

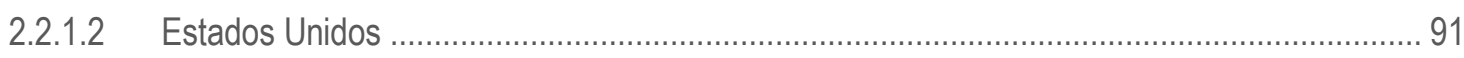

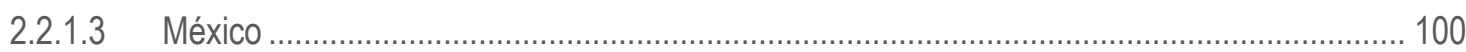

2.2.2 Marca país en América Central y el Caribe ….................................................................. 113

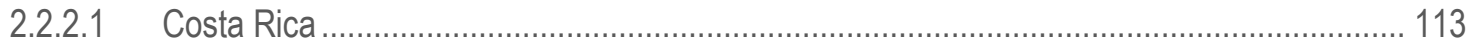

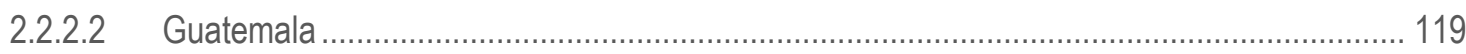

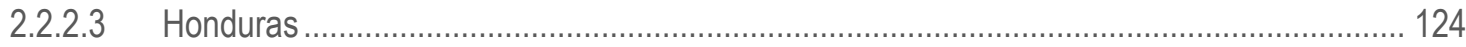

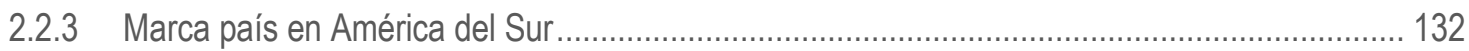

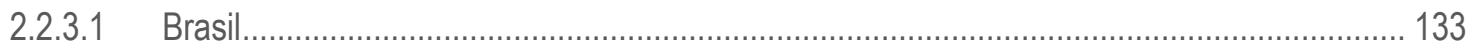

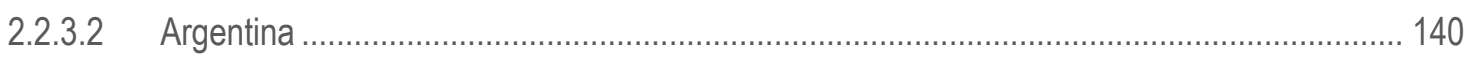

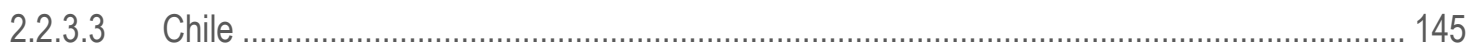

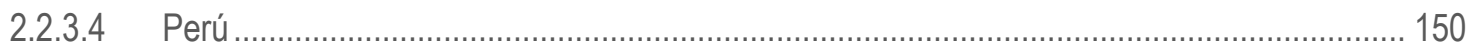

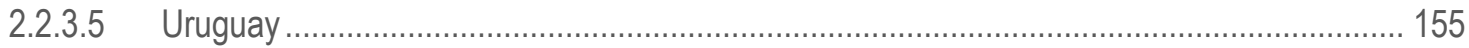

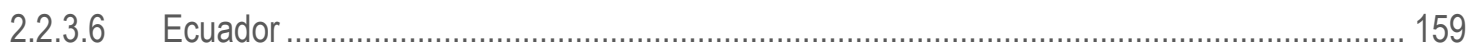

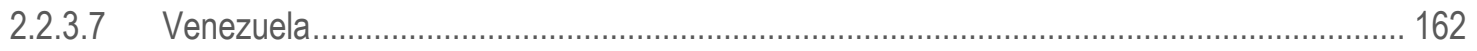

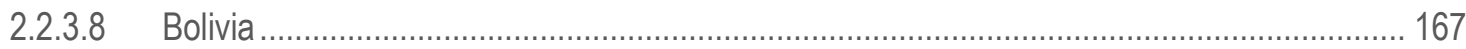

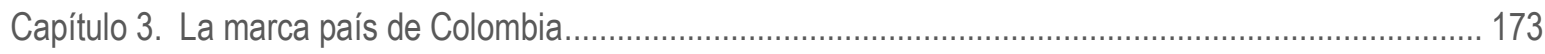

3.1 Hitos económicos y sociales de Colombia (1991-2013) .................................................... 174

3.2 Los orígenes de la marca país Colombia es pasión ............................................................ 185

3.2.1 El camino hacia la construcción de un símbolo nacional .................................................. 193

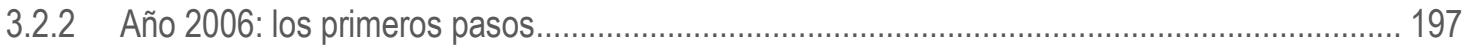

3.2.3 El crecimiento y evolución de la marca país Colombia es pasión.............................................. 200

3.3 Una nueva narrativa en imagen país: Marca país Colombia .................................................... 209

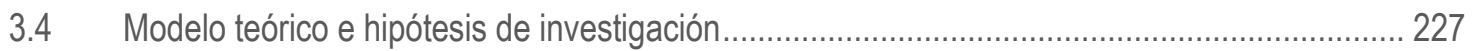

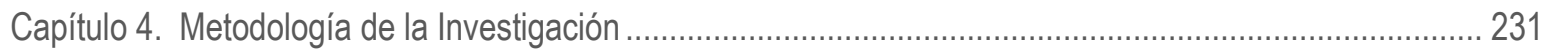

Capítulo 5. Imagen país de Colombia desde la perspectiva extranjera....................................................... 254

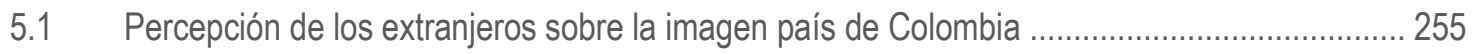




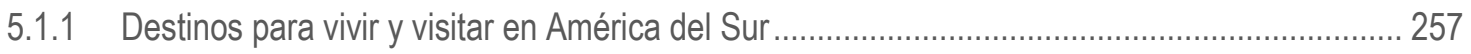

5.1.2 La imagen de Colombia desde una perspectiva de América ................................................ 260

5.1.2.1 La imagen país de Colombia desde la perspectiva del visitante .......................................... 267

5.1.2.2 La imagen país de Colombia desde la perspectiva del prospecto ...................................... 280

5.1.3 Análisis clúster sobre la imagen país de Colombia ................................................................ 291

5.1.4 Análisis de redes bayesianas sobre la imagen país de Colombia ........................................ 296

5.2 Modelo Estratégico de Proyección País (MEPP) .................................................................. 304

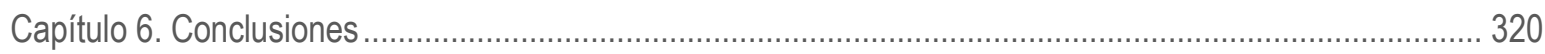

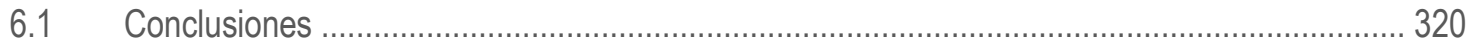

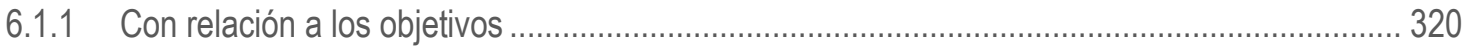

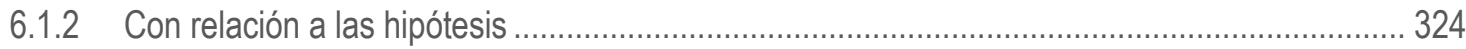

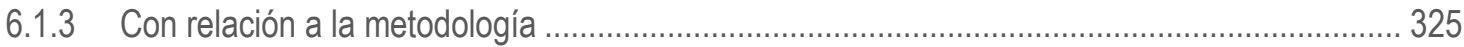

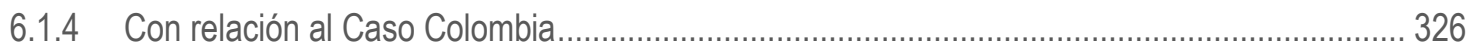

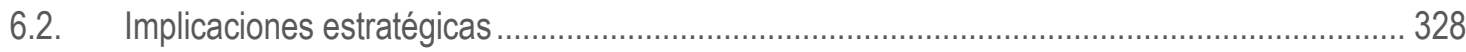

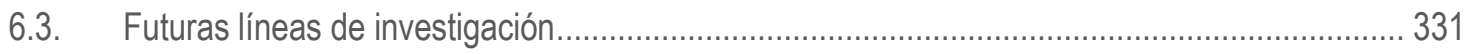

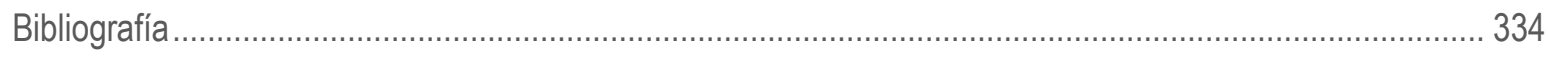

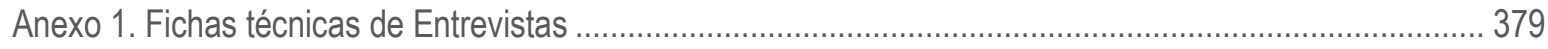

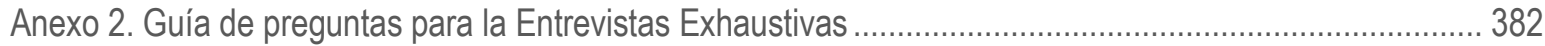

Anexo 3. Cuestionario para extranjeros visitantes empleado para la investigación empírica......................... 385

Anexo 4. Cuestionario para extranjeros prospectos empleado para la investigación empírica ...................... 386

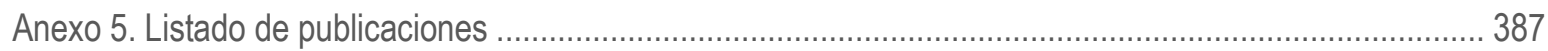

Anexo 6. Componentes de la Tesis y ubicación de las publicaciones .......................................................... 388 


\section{Índice de Cuadros}

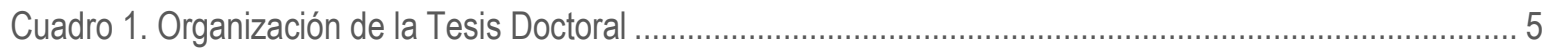

Cuadro 2. Diferencias conceptuales entre marca y producto ..................................................................... 18

Cuadro 3. Comparación Top of Mind, Top of Heart y Top of Hand .......................................................... 26

Cuadro 4. Métricas de Posicionamiento en Redes Sociales ...................................................................... 29

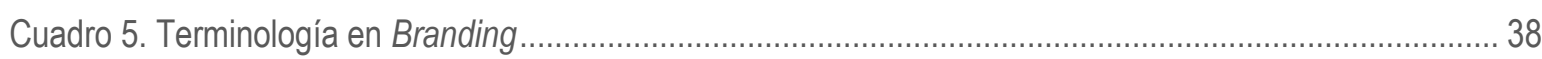

Cuadro 6. Diferencias entre marca país y marca de un producto................................................................. 43

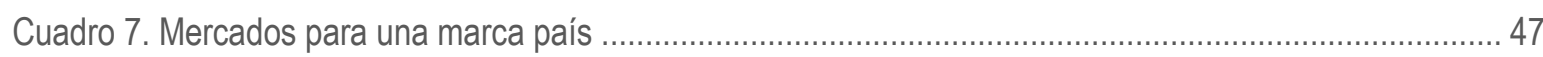

Cuadro 8. Principales grupos de interés a los que se orientan la estrategia de comunicación de un país....... 48

Cuadro 9. Comparativo de conceptos de marca país, marketing turístico y marketing territorial ..................... 55

Cuadro 10. Componentes del posicionamiento de la marca país................................................................. 70

Cuadro 11. Posiciones que han ocupado las marca país en el Country Brand Index América 2009-2012 ..... 76

Cuadro 12. Llegadas internacionales de turistas a Canadá ........................................................................ 90

Cuadro 13. Posicionamiento de las marcas país según Nation Brand Index NBI 2012 ................................. 98

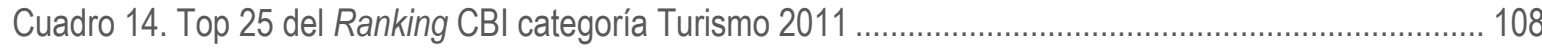

Cuadro 15. Comparativo del Índice de Competitividad de Viajes y Turismo en Top 15 de países de América

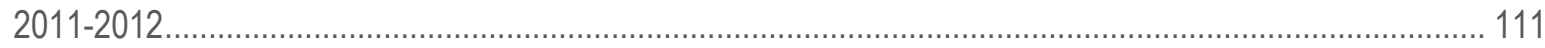

Cuadro 16. Comparativo del ranking en los diferentes atributos evaluados en el Country Brand Index 2013 de

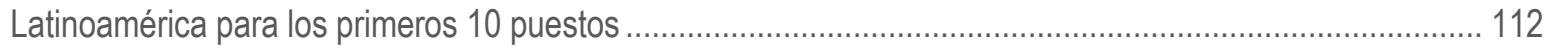

Cuadro 17. Ranking CBI categoría Autenticidad, Exótico y Estrella Emergente 2006 ................................. 115

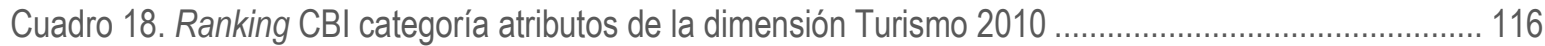

Cuadro 19. Ranking Country Brand Index América 2009-2011 ................................................................ 116

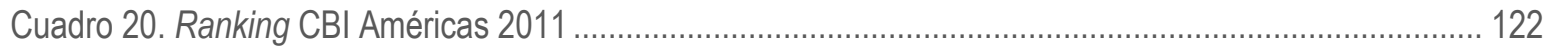

Cuadro 21. Top 5 de Visitantes por países 2011-2012 ............................................................................. 122

Cuadro 22. Country Brand Index América 2012 …............................................................................ 129

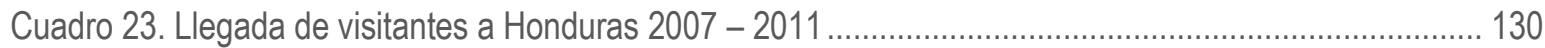

Cuadro 24. Estadía y Gasto Promedio por Estadía del Turista Receptor 2007 - 2011 .............................. 130

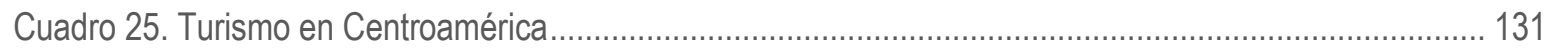

Cuadro 26. Posiciones de Brasil en el Ranking CBI 2006 por categorías ................................................. 135

Cuadro 27. Ranking de Competitividad Turística 2011-2012 ................................................................... 138

Cuadro 28. Marcas líderes del mañana: Top 15 del futuro ........................................................................ 139 


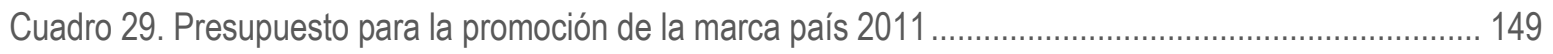

Cuadro 30. Posiciones de Brasil en el Ranking CBI 2006 por categorías ................................................... 151

Cuadro 31. Posiciones de Perú en el Ranking CBI 2012 por categorías...................................................... 154

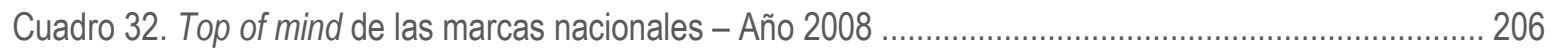

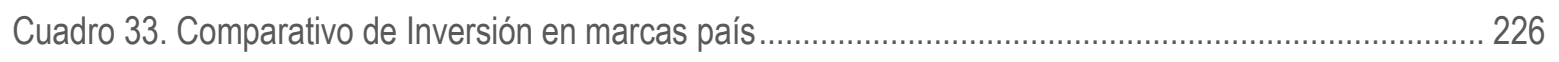

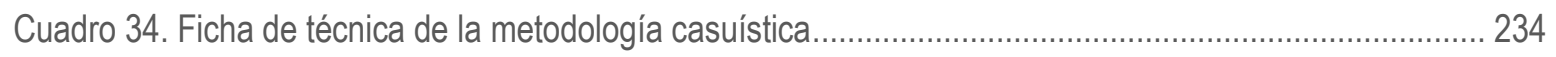

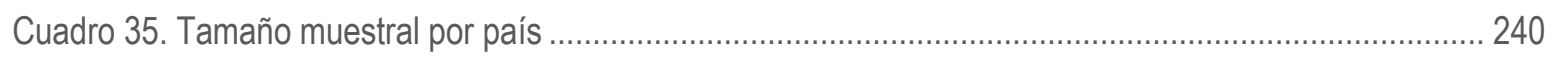

Cuadro 36. Perfil sociodemográfico de las personas encuestadas ............................................................ 241

Cuadro 37. Destino en América del Sur donde les gustaría vivir a los visitantes extranjeros ....................... 258

Cuadro 38. Destino en América del Sur que les gustaría visitar a los visitantes extranjeros ........................ 259

Cuadro 39. Test Chi Cuadrado de Imagen país de Colombia y variables demográficas de los visitantes ..... 267

Cuadro 40. Test Chi Cuadrado de Asociación Simbólica de la imagen país de Colombia y variables demográficas de los visitantes....................................................................................................... 272

Cuadro 41. Test Chi Cuadrado de Imagen país de Colombia y variables demográficas de los prospectos... 280

Cuadro 42. Test Chi Cuadrado de Asociación Simbólica de la imagen país de Colombia y variables

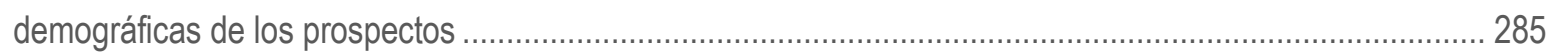

Cuadro 43. Descomposición de la inercia ..................................................................................... 291

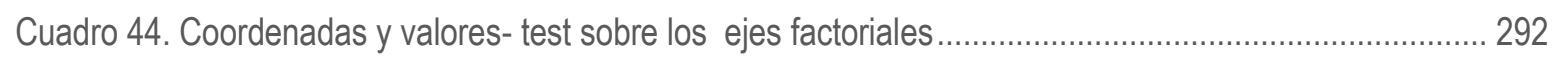

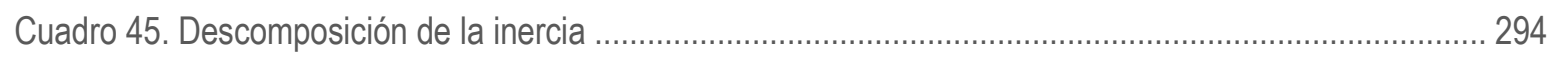

Cuadro 46. Coordenadas y valores- test sobre los ejes factoriales ............................................................. 294

Cuadro 47. Variables de los Visitantes, Prospectos y Residentes …........................................................ 310

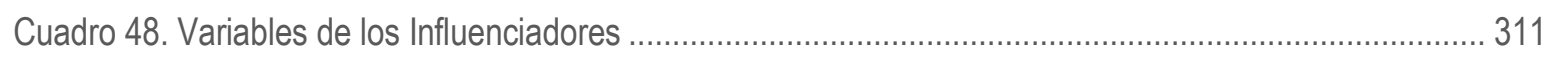




\section{Índice de Figuras}

Figura 1. Campos de estudio de Tesis Doctoral y aportaciones a través de publicaciones .............................. 4

Figura 2. Modelo para construcción de marca basado en el consumidor ...................................................... 21

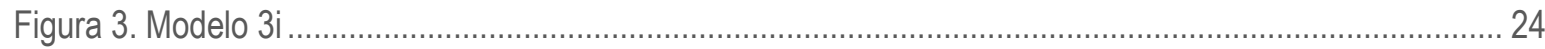

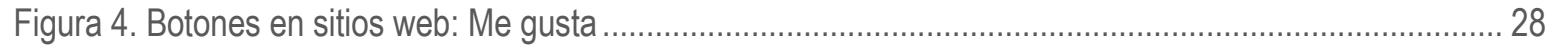

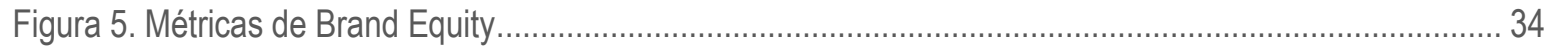

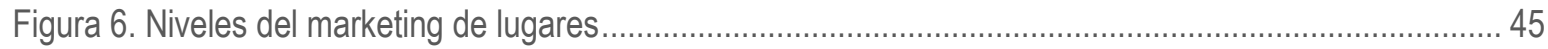

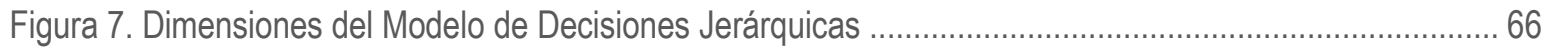

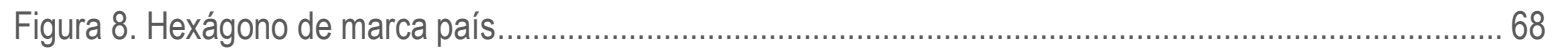

Figura 9. Logotipo de la marca país de Canadá ........................................................................................ 84

Figura 10. Etapas del antiamericanismo

Figura 11. Logotipo de la marca país de Estados Unidos ........................................................................... 97

Figura 12. Porcentaje de la población con imagen favorable sobre Estados Unidos .................................... 99

Figura 13. Porcentaje de la población con imagen desfavorable sobre Estados Unidos ............................. 100

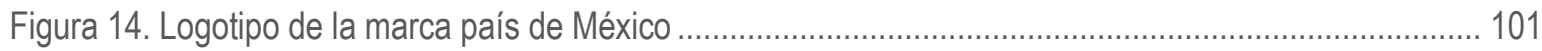

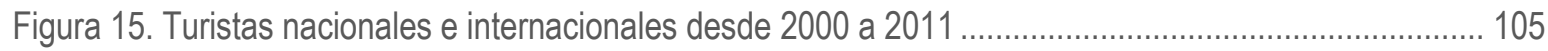

Figura 16. Percepción de los Estadounidenses hacia México 1999 a 2010 ............................................... 107

Figura 17. Logotipo de la campaña promocional de Costa Rica ................................................................ 114

Figura 18. Logotipo de la marca país de Costa Rica ................................................................................ 118

Figura 19. Logotipo de la primera marca país de Guatemala ..................................................................... 120

Figura 20. Logotipo de la segunda marca país de Guatemala .............................................................. 121

Figura 21. Logotipo de la primera marca país de Honduras ..................................................................... 126

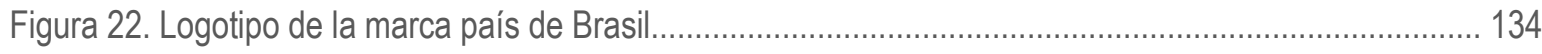

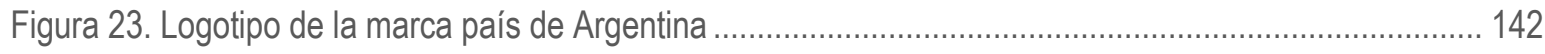

Figura 24. Renovación del logotipo de la marca país de Argentina ..................................................... 144

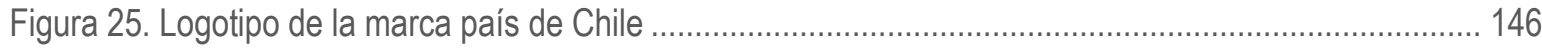

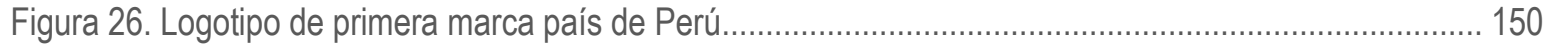

Figura 27. Logotipo de la segunda marca país de Perú …..................................................................... 153

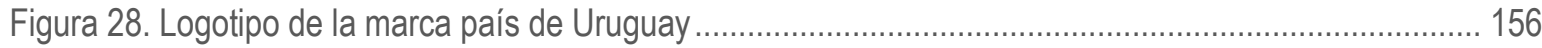

Figura 29. Logotipo de la primera marca país de Ecuador ......................................................................... 160

Figura 30. Logotipo de la segunda marca país de Ecuador ..................................................................... 161 
Figura 31. Logotipo de la primera marca país de Venezuela ................................................................. 163

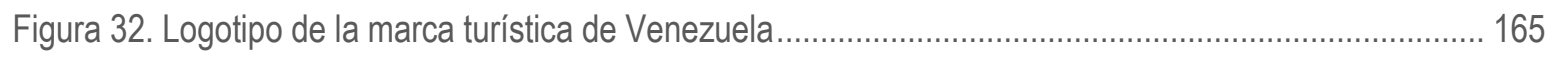

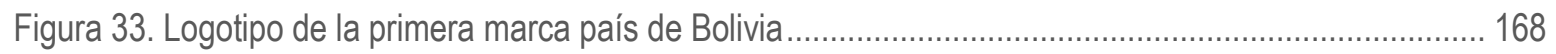

Figura 34. Logotipo de la segunda marca país de Bolivia .................................................................... 169

Figura 35. Crecimiento Económico de Colombia 2000-2012 _.................................................................... 178

Figura 36. Evolución de la posición competitiva de Colombia en el IGC (2008-2011) .................................. 180

Figura 37. Top 5 de Posicionamientos de Colombia en el ámbito regional e internacional ............................ 182

Figura 38. Logotipo de la primera marca país de Colombia ....................................................................... 192

Figura 39. Participación porcentual de las ventas de la licencia - año 2005.............................................. 197

Figura 40. Participación porcentual de las ventas de la licencia - años 2005 y 2006 .................................... 200

Figura 41. Comparativo de la participación de las ventas totales 2005, 2006 y 2007 ................................. 203

Figura 42. Ventas totales de licencias de uso de marca país Colombia es pasión al sector privado ............. 204

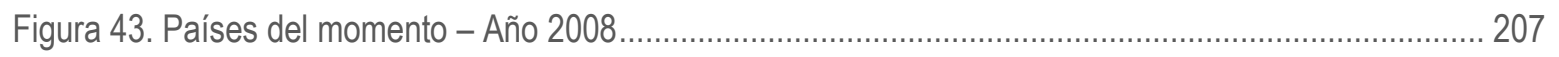

Figura 44. Estructura de vinculación administrativa de la Marca País Colombia........................................... 210

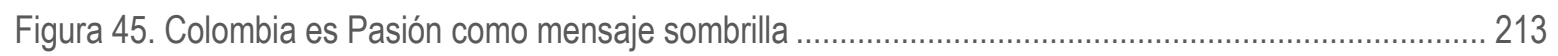

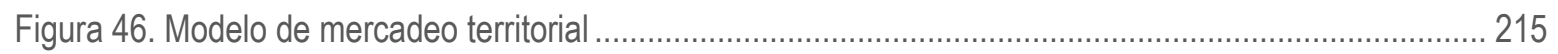

Figura 47. Logotipo de la segunda marca país de Colombia................................................................. 217

Figura 48. Potenciadores gráficos derivados de la marca país Colombia .................................................... 218

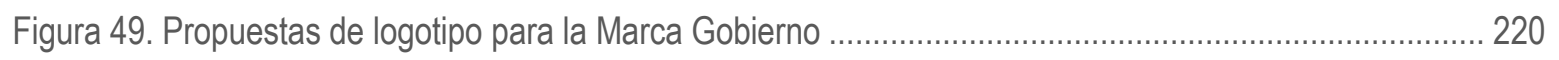

Figura 50. Identidad del Fondo de Promoción Turística de Colombia ............................................................ 220

Figura 51. Identidad del Fondo de Promoción Turística de Colombia ......................................................... 221

Figura 52. Top 10 de visitantes extranjeros que ingresaron a Colombia durante 2012 según nacionalidad .. 225

Figura 53. Modelo teórico e hipótesis de investigación ............................................................................... 230

Figura 54. Metodología para la construcción de casos............................................................................. 233

Figura 55. Top 8 de número de visitantes extranjeros procedentes del continente americano que ingresaron a

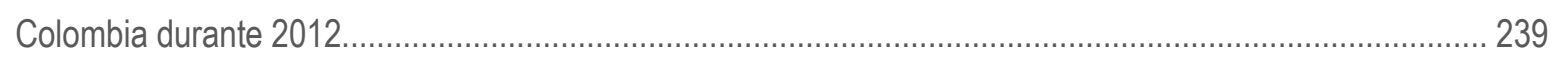

Figura 56. Top 8 de países del continente americano que registran el mayor flujo de visitantes hacia Colombia

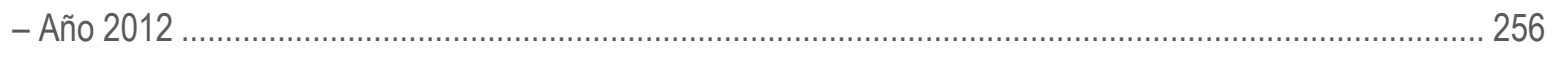

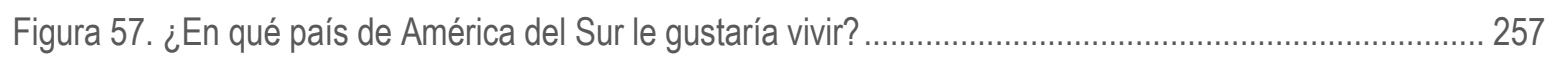

Figura 58. ¿Qué país de América del Sur le gustaría visitar? ................................................................... 259

Figura 59. ¿Qué es lo primero que piensa cuando oye la palabra Colombia? .............................................. 260

Figura 60. ¿En una sola palabra describa algo positivo de Colombia? ..................................................... 261

Figura 61. ¿En una sola palabra describa algo negativo de Colombia? ...................................................... 262 
Figura 62. ¿Qué características tienen los colombianos? .................................................................. 263

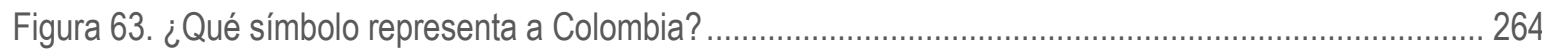

Figura 64. Cuando se menciona a Colombia, ¿con qué producto la asocia? .............................................. 265

Figura 65. Cuando se menciona a Colombia, ¿con qué persona la asocia? ............................................. 266

Figura 66. Cuando se menciona a Colombia, ¿qué ciudad se le viene a la mente? ................................... 266

Figura 67. Análisis de correspondencia entre lo que piensan los visitantes extranjeros cuando oyen la palabra

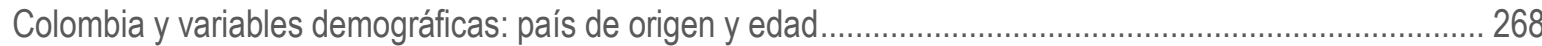

Figura 68. Análisis de correspondencia entre los aspectos positivos de Colombia y variables demográficas: país

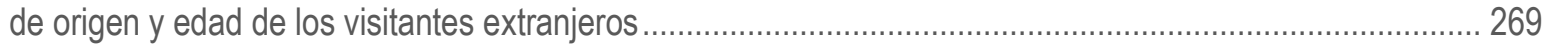

Figura 69. Análisis de correspondencia entre los aspectos negativos de Colombia y variables demográficas:

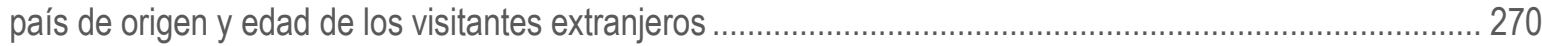
Figura 70. Análisis de correspondencia entre las características de los colombianos y país de origen de los

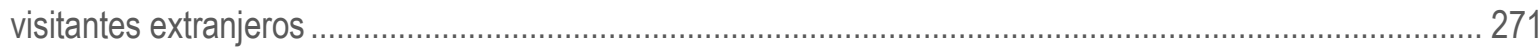

Figura 71. Análisis de correspondencia entre el color que más se asocia a Colombia y el país de origen.... 273 Figura 72. Análisis de correspondencia entre el olor que más se asocia a Colombia y variables demográficas: país de origen y edad de los visitantes 274

Figura 73. Análisis de correspondencia entre el símbolo que representa a Colombia y variables demográficas: país de origen y edad de los visitantes 275

Figura 74. Análisis de correspondencia entre la persona que se asocia a Colombia y variables demográficas: país de origen y edad de los visitantes ........................................................................................................ 276 Figura 75. ¿En su visita que fue lo que más le gustó de Colombia? ........................................................... 277

Figura 76. ¿En su visita que fue lo que menos le gustó de Colombia? ...................................................... 278

Figura 77. Preferencias e intereses en Colombia según los extranjeros visitantes ....................................... 279

Figura 78. Análisis de correspondencia entre lo que piensan los prospectos extranjeros cuando oyen la palabra Colombia y variables demográficas: país de origen y edad..................................................................... 281 Figura 79. Análisis de correspondencia entre los aspectos positivos de Colombia y variables demográficas: país

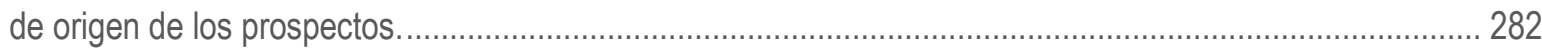
Figura 80. Análisis de correspondencia entre los aspectos negativos de Colombia y variables demográficas:

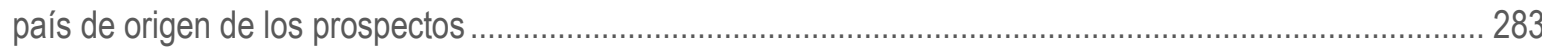
Figura 81. Análisis de correspondencia entre las características que tienen los colombianos y variables

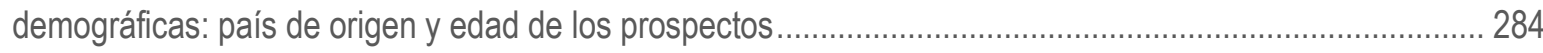
Figura 82. Análisis de correspondencia entre el símbolo que representa a Colombia y variables demográficas:

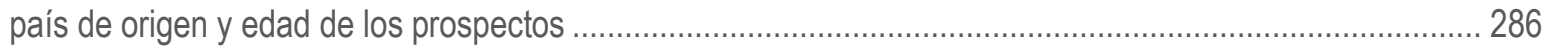


Figura 83. Análisis de correspondencia entre ciudad que representa a Colombia y variables demográficas: país

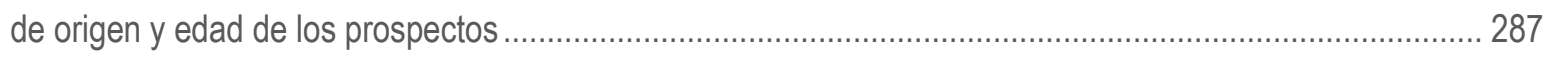

Figura 84. Análisis de correspondencia entre persona que asocia a Colombia y variables demográficas: país de

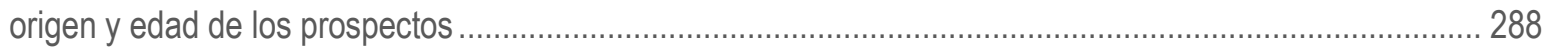

Figura 85. Preferencias e intereses en Colombia según los prospectos .................................................... 289

Figura 86. Análisis de correspondencia entre interés de visitar a Colombia y variables demográficas: país de

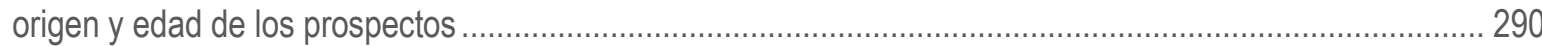

Figura 87. Dendograma del análisis clúster de los extranjeros que han visitado a Colombia ...................... 292

Figura 88. Dendograma del análisis clúster de los prospectos .................................................................. 295

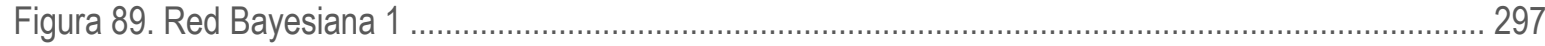

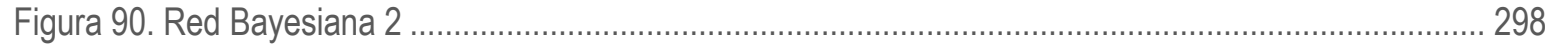

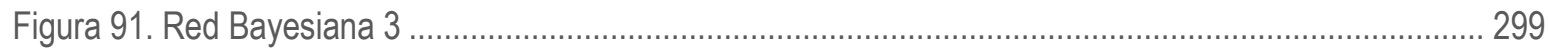

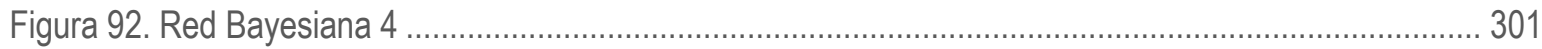

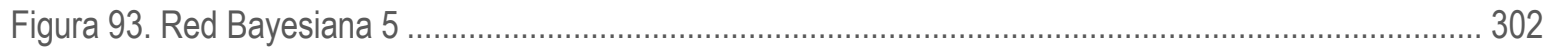

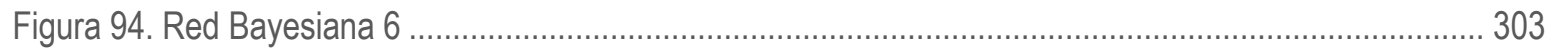

Figura 95. Modelo Estratégico de Proyección País (MEPP)..................................................................... 307

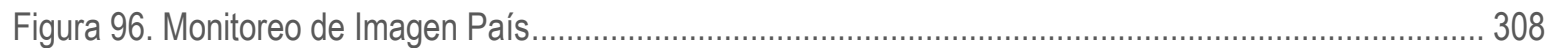

Figura 97. Indicadores del posicionamiento de un país .......................................................................... 312

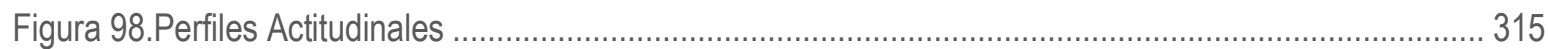

Figura 99. Territorio de marca país........................................................................................................... 316

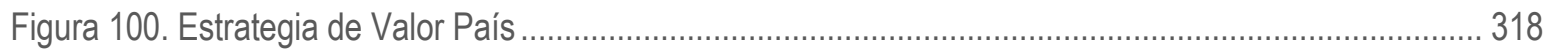

Figura 101. Componentes de la Tesis Doctoral y las publicaciones simultáneas....................................... 388 


\section{Índice de Anexos}

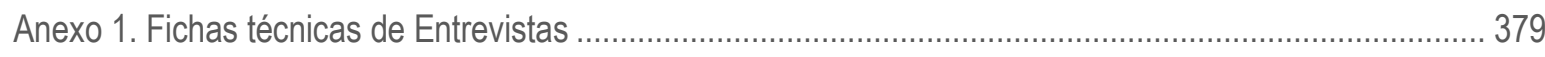

Anexo 2. Guía de preguntas para la Entrevistas Exhaustivas ............................................................... 382

Anexo 3. Cuestionario para extranjeros visitantes empleado para la investigación empírica......................... 385

Anexo 4. Cuestionario para extranjeros prospectos empleado para la investigación empírica ...................... 386

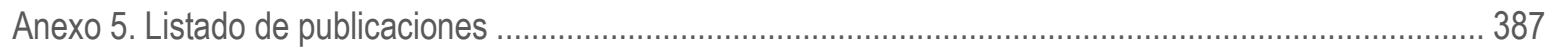

Anexo 6. Componentes de la Tesis y ubicación de las publicaciones ........................................................ 388 


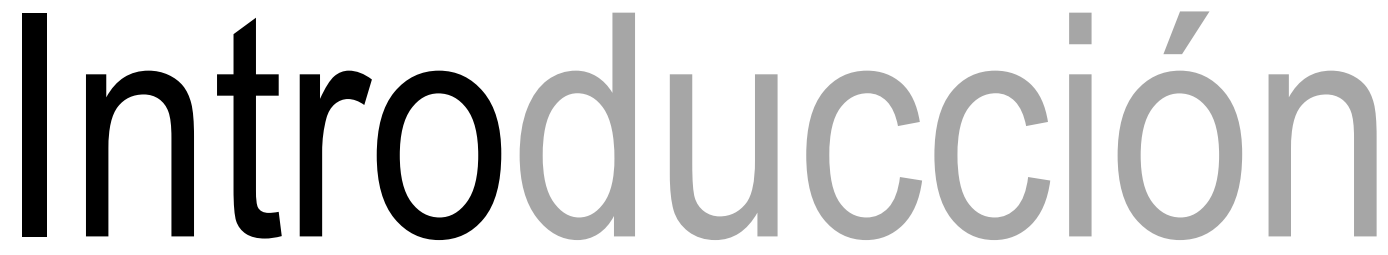




\section{Introducción}

La marca país es un campo nuevo o más bien poco trabajado como tal dentro del cuerpo de conocimiento del marketing. Pero su uso e importancia actual, muestra que es conveniente que como concepto se funde epistemológicamente desde la teoría de la marca (Olins, 2002). La teoría de la marca indica cómo se genera un producto, e indica cómo hay que generar conexiones, experiencias y promesas entre consumidor y productos, y por esto mismo aporta elementos que permiten fundar una base epistemológica para hablar con solidez teórica de marca país. La tesis, en este sentido, aporta aspectos metodológicos y prácticas acerca de cómo presentar esta fundación y en cómo analizar un caso de estudio: Colombia como marca.

Según Dinnie (2008) el concepto de marca país nace de la teoría y gestión de marca (Branding). Como una nueva área de interés de la teoría de la marca, los conceptos de imagen país (country image) y marca país han sido impulsados más por los profesionales del campo de las comunicaciones que por los investigadores académicos (Dinnie et al., 2010). El término de marca país es conocido también en el idioma inglés como nation branding (Anholt, 2002), place branding (Gertner \& Kotler, 2002) o country branding (Olins, 2006).

Desde el año 2000 se ha generado un gran interés en estudios y proyectos de consultoría en torno a imagen y marca país, sin embargo, hay una ausencia de progreso y desarrollo conceptual al respecto (Fan, 2010). Esta situación que se refleja en una necesidad conceptual y de desarrollo teórico sobre marca país e imagen país especialmente en el continente americano (Norteamérica, Centroamérica y América del Sur). Además, los conceptos y aplicaciones de imagen y marca país han sido poco estudiados para países en vía de desarrollo (Akotia et al., 2011; Jenes, 2008). 
Autores latinoamericanos como Chaves (2011), Pipoli (2009), Rojas (2013), entre otros, han aportado a la discusión académica nuevas reflexiones sobre el panorama de las marca país en América Latina, sin embargo, han sido insuficientes. Sumado a lo anterior, se ha generado una gran diversidad en las interpretaciones, que están sujetas a las perspectivas de marketing, branding o de comunicaciones que relacione cada investigador (Olins, 2002).

\section{Impacto de la tesis y caso de Estudio}

La tesis trabaja sobre un caso de estudio: Colombia. Colombia es escogido por la cercanía en datos a la autora de la tesis, y porque, tal como rescata de Moura (2011), gran gran parte de los países tienen problemas de imagen pero no saben cómo abordar y atacar adecuadamente esta problemática, y en este sentido Colombia no es una excepción.

Colombia es reconocido por la producción y comercialización de café, y recientemente por los logros en la eficacia gubernamental de aportar seguridad y estabilidad en los últimos gobiernos de los Presidentes Uribe y Santos. Pero a pesar de esta reconocimiento y logros, Colombia siempre está aún asociado a la corrupción, a la violencia, a la guerrila y, al narcotráfico o las drogas (Monroy, 2009).

Enfrentar estas situaciones, demanda esfuerzos adicionales, y como señala Moffett (2008), con la creación de una marca país se ha buscado cómo abordar y atacar adecuadamente esta problemática. Y no sólo eso, cuando las problemáticas originales ya son reducidas o eliminadas, una estrategia de marca país pasa a ser una estrategia de estado reenfocada que puede aumentar la competitividad y la proyección internacional de un país. Colombia, en este sentido como caso de estudio, es un caso adecuado para estudiar y revisar los planteamientos que hace la tesis, pues es un país con una imagen desmejorada que se puede ver revertida una imagen baja con un trabajo con bases estratégicas y en el marketing. 


\section{Contribuciones}

La Tesis Doctoral opera en base a tres campos fundamentales:

a. En la disciplina de marketing, donde subyace la teoría de la marca y a su vez gestión de la marca (Branding).

b. En la identidad nacional, donde la reputación de un país cobra relevancia.

c. En la investigación cualitativa como fuente para el monitoreo de la imagen de un país en mercados internacionales.

Estos campos definen el dominio o campo de estudio de la tesis y con relación a los cuales surgen varias aportaciones desde la Tesis Doctoral.

a. En cuanto al campo del Marketing, la tesis distingue entre marca país e imagen país. Esta distinción teórica es un aporte a la teoría de la marca país al ser un marco teórico y referencial sobre marca país, y es un aporte a la gestión de la marca al estudiar y trabajar datos empíricos sobre imagen país.

b. En cuanto al campo de la Identidad Nacional, la tesis consigue aportar ideas y contribuciones a Colombia como país, donde algunas ideas se pueden considerar válidas en otros países.

c. En cuanto al campo de la Investigación Cualitativa, la tesis se suma a otros estudios de naturaleza cualitativa que no son abundantes, pero que si permiten establecer nuevos planteamientos de observación de los países como sujetos de estudio y del branding como objeto de estudio.

A nivel de relaciones entre los campos, hay otras aportaciones y para tal efecto se muestra la Figura 1 donde los 3 campos se relacionan, y donde en la misma figura se destacan las contribuciones emanadas desde la tesis como publicaciones ${ }^{1}$.

\footnotetext{
${ }^{1}$ En la Figura 1 se incluyeron las publicaciones realizadas de manera simultánea con la Tesis Doctoral:
} 


\section{Introducción}

\section{Figura 1. Campos de estudio de Tesis Doctoral y aportaciones a través de publicaciones}

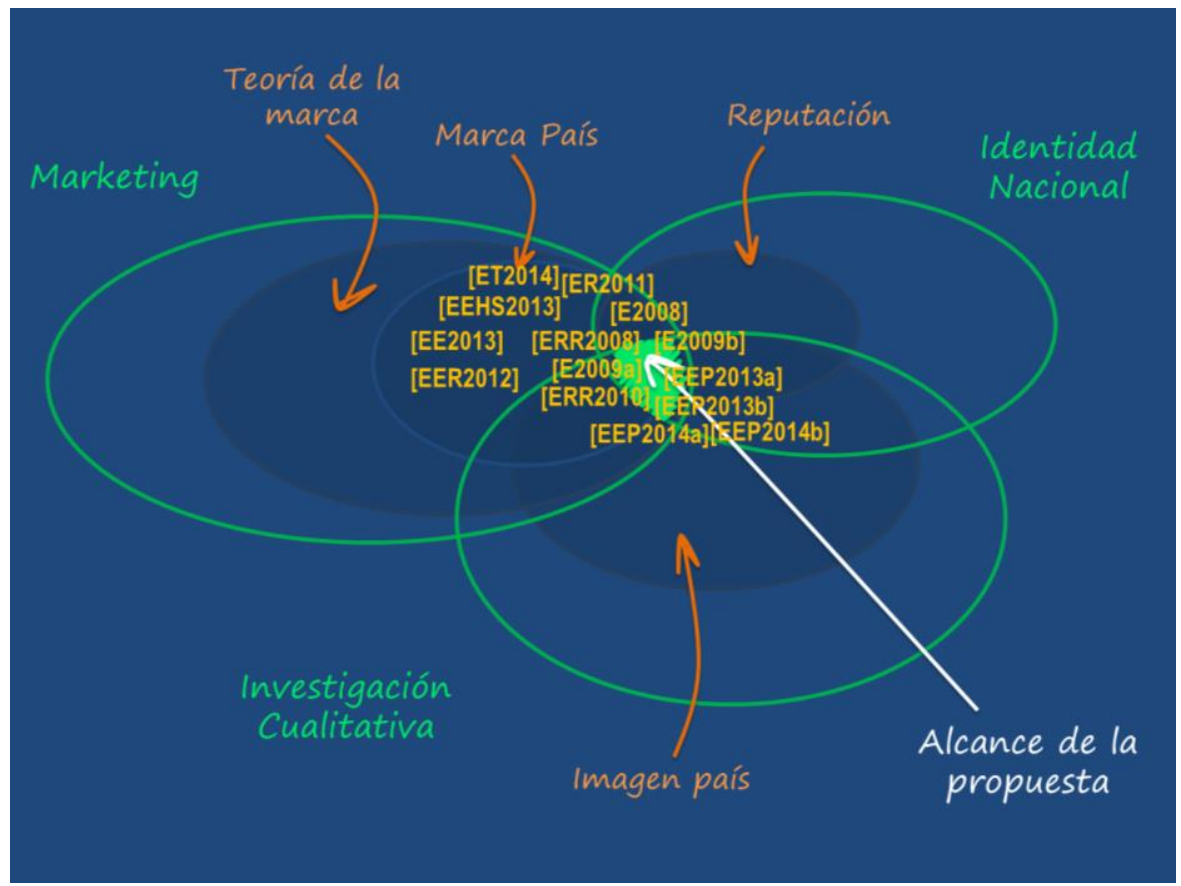

[E2008] Echeverri, L. M. (2008). El país como una marca: el caso de Colombia es pasión. XXIII Encuentro de Docentes Universitarios de Comercialización y cátedras afines de Argentina y América Latina. Paraná: EDUCAAL.

[E2009a] Echeverri, L. M. (2009a). La imagen país: ¿Cómo se aplica el marketing a una nación? XLIV Asamblea Anual CLADEA 2009. Ecuador: CLADEA.

[E2009b] Echeverri, L. M. (2009b). La marca país: el reflejo de la identidad cultural y empresarial de una Nación. Responsabilidad social de la administración en el mundo (pág. 24). Bucaramanga: ASCOLFA.

[EE2013] Echeverri, L. M., \& Estay-Niculcar, C. (2013). El rol del turismo como pilar estratégico de la marca país Argentina. Revista Científica Visión de Futuro, 186-199. [Factor de Impacto SCIELO 0.083]

[EEHS2013] Echeverri, L. M., Estay-Niculcar, C., Herrera, C., \& Santamaría, J. (2013). Desarrollo de marca país y turismo: el caso de estudio de México. Revista Estudios y Perspectivas en Turismo, 22(6), 1121-1139. [Factor de Impacto SCIELO 0.0964]

[EEP2013a] Echeverri, L., Estay-Niculcar, C., \& Parra, H. (2013a). Estudio de la imagen país de Colombia desde la perspectiva mexicana. XVIII Congreso Internacional en Contaduría, Administración e Informática. México: UNAM.

[EEP2013b] Echeverri, L., Estay-Niculcar, C., \& Parra, H. (2013b). Percepción de los visitantes estadounidenses, venezolanos y ecuatorianos sobre la imagen país de Colombia. III Encuentro Internacional de Investigadores en Administración. Bogotá: Universidad del Externado de Colombia.

[EER2012] Echeverri, L., Estay-Niculcar, C., \& Rosker, E. (2012). Estrategias y experiencias en la construcción de marca país en América del Sur. Revista Estudios y Perspectivas en Turismo, 21, 288-305. [Factor de Impacto SCIELO 0.0964]

[ERR2008] Echeverri, L. M., Restrepo, M. L., \& Rosker, E. (2008). Colombia es pasión - Caso académico. Bogotá: Universidad del Rosario-CESA.

[ERR2010] Echeverri, L. M., Restrepo, M. L., \& Rosker, E. (2010). Los orígenes de la Marca País Colombia es Pasión. Revista Estudios y Perspectivas en Turismo, 409-421. [Factor de Impacto SCIELO 0.0964]

[ER2011] Echeverri, L. M., \& Rosker, E. (2011). Diferencias en la construcción de marca país: Canadá y Colombia. Revista Virtual Universidad Católica Del Norte (33), 1-29. [Publindex Categoría B]

[ET2014] Echeverri, L. M., \& Trujillo, L. (Forthcoming-2014). Una marca país para Colombia. Bogotá: Editorial CESA.

[EEP2014a] Echeverri, L., Estay-Niculcar, C., \& Parra, H. (Forthcoming-2014a). Impresiones de los mexicanos sobre la imagen país de Colombia. Revista Clío América. [Publindex Categoría C]

[EEP2014b] Echeverri, L., Estay-Niculcar, C., \& Parra, H. (Forthcoming-2014b). Imagen país de Colombia desde la perspectiva estadounidense. Revista Hallazgos. [Publindex Categoría B] 
Fuente: Elaboración propia.

\section{Aportes de la Tesis Doctoral}

1. Se aclara cómo el concepto de marca país e imagen país deben tratarse y aplicarse diferente al desarrollo y promoción de un bien o servicio.

2. Se conceptualiza la marca país como una estrategia para capitalizar la reputación de un país, e imagen país como un conjunto de percepciones que tienen las personas (residentes, visitantes, influenciadores y prospectos ${ }^{2}$ ) sobre un país.

3. Se muestra que gracias a un buen tratamiento de la imagen país a través de la estrategia de marca país, se mejorar el posicionamiento de un país en mercados internacionales.

4. Se explora a fondo dos conceptos: marca país e imagen país.

5. Se realizan nuevas aportaciones para Colombia como un estudio empírico de país.

\section{Objetivos de la Tesis Doctoral}

Objetivo 1. Establecer los fundamentos y principios de la marca país como especialidad dentro de la teoría de la marca.

Objetivo 2. Analizar la evolución de la marca país en América

Objetivo 3. Analizar los orígenes y evolución de la marca país de Colombia.

Objetivo 4. Formular el diseño metodológico adecuado para la aplicación de técnicas instrumentos en la recolección de información

Objetivo 5. Identificar los determinantes de la percepción de la imagen país de Colombia desde la perspectiva de ocho países de América.

Objetivo 6. Enmarcar las aportaciones principales de la investigación desde lo teórico, metodológico y práctico generado por los resultados del estudio.

${ }^{2}$ Corresponde a las personas que no han visitado un determinado país. 


\section{Metodología}

A través de una investigación empírica y cualitativa se identificaron los determinantes de la percepción de la imagen país de Colombia desde la perspectiva extranjera.

Se definió el problema metodológico, buscando integrar los conocimientos cualitativos con la interpretación y significado de los datos y la palabra hablada. Se estudiaron las impresiones, percepciones y asociaciones de extranjeros mayores de 18 años que han visitado y aún no han visitado a Colombia. Este enfoque tiene como objetivo capturar la multiplicidad de perspectivas de los actores (extranjeros) y los significados de sus impresiones sobre un determinado país, en este caso Colombia.

La población de estudio corresponde a extranjeros procedentes de ocho países que registran el mayor número de visitantes en Colombia en el 2013 desde el continente americano (Proexport, 2013): Estados Unidos, Venezuela, Ecuador, Argentina, Perú, Brasil, México y Chile.

En un total de 1544 encuestas aplicadas, se encontró que la imagen de Colombia no es unidimensional, es multidimensional. Es decir, mantiene asociaciones históricas positivas y negativas enmarcadas en dos contextos: el café y el narcotráfico. Se logran identificar cinco dimensiones como: el conocimiento del país, la orientación industrial, las actitudes de los visitantes, las percepciones de los prospectos y las preferencias e intereses asociado a su imagen.

La información que integra esta investigación se obtuvo a partir del análisis de variables previamente establecidas que fueron de utilidad para identificar, clasificar y localizar socio demográficamente a la población de estudio (género, edad, estado civil y nivel de escolaridad).

La metodología de investigación integra cuatro tipos de análisis para la presentación de resultados: análisis bivariado, análisis de correspondencia simple y múltiple, análisis clúster y análisis de redes bayesianas. Estos análisis permiten conocer el comportamiento de las variables cualitativas en el estudio de la imagen país de Colombia. 


\section{Introducción}

\section{Organización del trabajo doctoral, resumen de la tesis doctoral, y estructura del}

\section{documento de tesis}

El siguiente cuadro resume la tesis doctoral mostrando cómo se han organizado sus componentes, lo cual permite tener una idea resumida de sus ideas, y de cómo se despliega el trabajo a lo largo del documento en sus capítulos. Se acota en la tabla los aportes de cada capítulo y las publicaciones emanadas.

\section{Cuadro 1. Organización de la Tesis Doctoral}

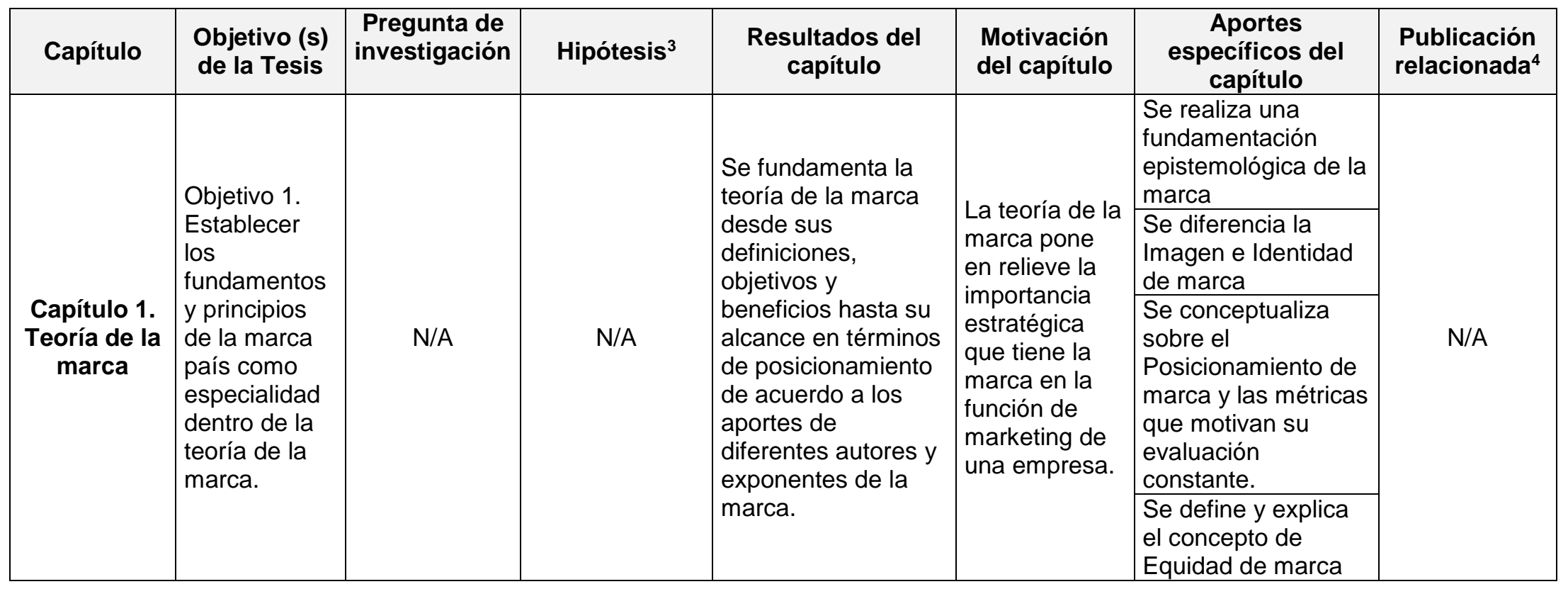

${ }^{3}$ Las hipótesis son presentadas y fundamentadas en el Capítulo 3.

${ }^{4}$ Las publicaciones son las mismas de la nota a pié número 1. 


\section{Introducción}

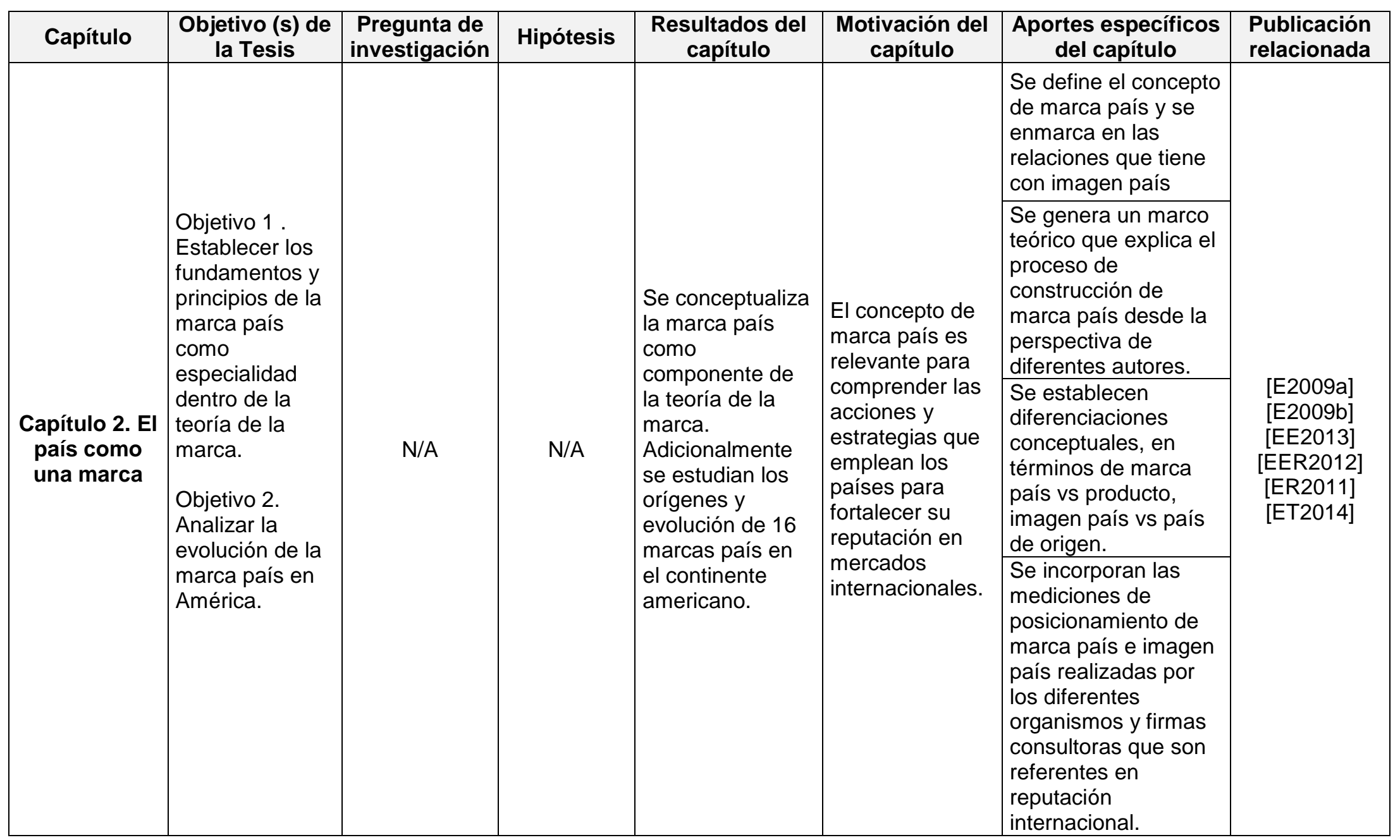




\section{Introducción}

\begin{tabular}{|c|c|c|c|c|c|c|c|}
\hline Capítulo & $\begin{array}{l}\text { Objetivo (s) } \\
\text { de la Tesis }\end{array}$ & $\begin{array}{l}\text { Pregunta de } \\
\text { investigación }\end{array}$ & Hipótesis & $\begin{array}{l}\text { Resultados } \\
\text { del capítulo }\end{array}$ & $\begin{array}{c}\text { Motivación del } \\
\text { capítulo }\end{array}$ & $\begin{array}{c}\text { Aportes específicos } \\
\text { del capítulo }\end{array}$ & $\begin{array}{l}\text { Publicación } \\
\text { relacionada }\end{array}$ \\
\hline $\begin{array}{l}\text { Capítulo } 3 . \\
\text { La marca } \\
\text { país de } \\
\text { Colombia }\end{array}$ & $\begin{array}{l}\text { Objetivo } 3 . \\
\text { Analizar los } \\
\text { orígenes y } \\
\text { evolución de } \\
\text { la marca } \\
\text { país de } \\
\text { Colombia. }\end{array}$ & $\begin{array}{c}\text { ¿Cómo es el } \\
\text { posicionamient } \\
\text { o de Colombia } \\
\text { en el continente } \\
\text { americano? }\end{array}$ & $\begin{array}{l}\text { H3: La imagen } \\
\text { de Colombia } \\
\text { ostenta, por } \\
\text { otro lado, un } \\
\text { posicionamient } \\
\text { o negativo } \\
\text { derivado de la } \\
\text { asociación } \\
\text { histórica del } \\
\text { país con las } \\
\text { drogas y la } \\
\text { guerrilla. }\end{array}$ & $\begin{array}{l}\text { Se estudia el } \\
\text { origen, } \\
\text { evolución y } \\
\text { desarrollo de } \\
\text { las dos marcas } \\
\text { país que ha } \\
\text { tenido } \\
\text { Colombia: } \\
\text { Colombia es } \\
\text { Pasión (2005- } \\
\text { 2010) y la } \\
\text { Marca País } \\
\text { Colombia } \\
\text { (2012-2013). }\end{array}$ & $\begin{array}{l}\text { Colombia es el país } \\
\text { objeto de estudio de } \\
\text { la Tesis Doctoral. Por } \\
\text { este motivo es } \\
\text { fundamental conocer } \\
\text { el proceso de } \\
\text { creación de las dos } \\
\text { marcas país que se } \\
\text { han generado desde } \\
\text { el } 2004 \text { y determinar } \\
\text { los resultados que } \\
\text { han motivado el } \\
\text { desarrollo de } \\
\text { acciones acordes a } \\
\text { mejorar el } \\
\text { posicionamiento del } \\
\text { país en el extranjero. }\end{array}$ & $\begin{array}{l}\text { Se hace el } \\
\text { levantamiento de las } \\
\text { dos marcas país de } \\
\text { Colombia, desde su } \\
\text { génesis hasta los } \\
\text { resultados y avances } \\
\text { al 2013. Este } \\
\text { contenido aporta a la } \\
\text { teoría de marca a } \\
\text { través de la } \\
\text { casuística, como } \\
\text { unos casos de } \\
\text { interés que revelan la } \\
\text { experiencia nacional } \\
\text { para ser ejemplo } \\
\text { internacional de los } \\
\text { procesos de } \\
\text { construcción de } \\
\text { marca país. }\end{array}$ & $\begin{array}{c}\text { [E2008] } \\
\text { [ERR2008] } \\
{[\text { ERR2010] }}\end{array}$ \\
\hline
\end{tabular}




\section{Introducción}

\begin{tabular}{|c|c|c|c|c|c|c|c|}
\hline Capítulo & $\begin{array}{l}\text { Objetivo (s) } \\
\text { de la Tesis }\end{array}$ & $\begin{array}{l}\text { Pregunta de } \\
\text { investigación }\end{array}$ & Hipótesis & $\begin{array}{l}\text { Resultados del } \\
\text { capítulo }\end{array}$ & $\begin{array}{l}\text { Motivación del } \\
\text { capítulo }\end{array}$ & $\begin{array}{c}\text { Aportes } \\
\text { específicos del } \\
\text { capítulo }\end{array}$ & $\begin{array}{l}\text { Publicación } \\
\text { relacionada }\end{array}$ \\
\hline $\begin{array}{c}\text { Capítulo } 4 . \\
\text { Metodología } \\
\text { de la } \\
\text { investigación }\end{array}$ & $\begin{array}{l}\text { Objetivo } 4 . \\
\text { Formular el } \\
\text { diseño } \\
\text { metodológico } \\
\text { adecuado } \\
\text { para la } \\
\text { aplicación de } \\
\text { técnicas } \\
\text { instrumentos } \\
\text { en la } \\
\text { recolección de } \\
\text { información. }\end{array}$ & $\mathrm{N} / \mathrm{A}$ & $\mathrm{N} / \mathrm{A}$ & $\begin{array}{l}\text { Se aborda el } \\
\text { problema } \\
\text { metodológico, } \\
\text { buscando integrar } \\
\text { los conocimientos } \\
\text { cualitativos con la } \\
\text { interpretación y } \\
\text { significado de los } \\
\text { datos y la palabra } \\
\text { hablada. Se } \\
\text { aplicaron dos tipos } \\
\text { de investigaciones: } \\
\text { empírica y } \\
\text { cualitativa. Para } \\
\text { efectos de la } \\
\text { investigación, se } \\
\text { denominó al objeto } \\
\text { de estudio como } \\
\text { visitante y } \\
\text { prospecto. } \\
\text { Partiendo de la } \\
\text { base que este } \\
\text { calificativo permite, } \\
\text { con mayor amplitud, } \\
\text { delinear perfiles y } \\
\text { rasgos sino también } \\
\text { la percepción de la } \\
\text { imagen país de } \\
\text { Colombia. }\end{array}$ & $\begin{array}{l}\text { El estudio de la } \\
\text { imagen país } \\
\text { exige una } \\
\text { profundización } \\
\text { sobre la } \\
\text { percepción que } \\
\text { tienen los } \\
\text { visitantes o } \\
\text { residentes sobre } \\
\text { un lugar. En este } \\
\text { caso solo se } \\
\text { analizan las } \\
\text { percepciones, } \\
\text { impresiones y } \\
\text { asociaciones de } \\
\text { los extranjeros } \\
\text { visitantes y } \\
\text { prospectos (no } \\
\text { visitantes) sobre } \\
\text { la imagen país de } \\
\text { Colombia. Se } \\
\text { eligió como } \\
\text { marco muestral a } \\
\text { ocho país que } \\
\text { presenten el } \\
\text { mayor flujo de } \\
\text { Ilegada de } \\
\text { visitantes a } \\
\text { Colombia. } \\
\end{array}$ & $\begin{array}{l}\text { La metodología } \\
\text { define un camino } \\
\text { para el desarrollo } \\
\text { de estudios futuros } \\
\text { relacionados con la } \\
\text { imagen de un país. } \\
\text { Define la } \\
\text { importancia de } \\
\text { realizar análisis } \\
\text { bivariado, de } \\
\text { correspondencia, } \\
\text { clúster y redes } \\
\text { bayesianas para } \\
\text { comprender la } \\
\text { posición de } \\
\text { variables } \\
\text { cualitativas en el } \\
\text { entorno de la } \\
\text { imagen de un país, } \\
\text { en este caso de } \\
\text { Colombia. Como } \\
\text { resultado de la } \\
\text { investigación } \\
\text { cualitativa, se } \\
\text { propone un Modelo } \\
\text { Estratégico de } \\
\text { Proyección País } \\
\text { para Colombia. }\end{array}$ & $\mathrm{N} / \mathrm{A}$ \\
\hline
\end{tabular}




\section{Introducción}

\begin{tabular}{|c|c|c|c|c|c|c|c|}
\hline Capítulo & $\begin{array}{l}\text { Objetivo (s) } \\
\text { de la Tesis }\end{array}$ & $\begin{array}{l}\text { Pregunta de } \\
\text { investigación }\end{array}$ & Hipótesis & $\begin{array}{l}\text { Resultados del } \\
\text { capítulo }\end{array}$ & $\begin{array}{l}\text { Motivación del } \\
\text { capítulo }\end{array}$ & $\begin{array}{c}\text { Aportes } \\
\text { específicos } \\
\text { del capítulo }\end{array}$ & $\begin{array}{l}\text { Publicación } \\
\text { relacionada }\end{array}$ \\
\hline $\begin{array}{c}\text { Capítulo } 5 . \\
\text { Imagen } \\
\text { país de } \\
\text { Colombia } \\
\text { desde la } \\
\text { perspectiva } \\
\text { extranjera }\end{array}$ & $\begin{array}{l}\text { Objetivo } 5 . \\
\text { Identificar los } \\
\text { determinantes } \\
\text { de la } \\
\text { percepción de } \\
\text { la imagen } \\
\text { país de } \\
\text { Colombia } \\
\text { desde la } \\
\text { perspectiva } \\
\text { de ocho } \\
\text { países de } \\
\text { América. }\end{array}$ & $\begin{array}{c}\text { ¿Con qué } \\
\text { asocian lo } \\
\text { extranjeros a } \\
\text { Colombia? } \\
\text { ¿La } \\
\text { experiencia al } \\
\text { visitar } \\
\text { Colombia } \\
\text { puede } \\
\text { modificar la } \\
\text { prcepción del } \\
\text { extranjero? } \\
\text { ¿Qué } \\
\text { impresiones } \\
\text { tienen los } \\
\text { extranjeros } \\
\text { sobre los } \\
\text { colombianos? } \\
\text { ¿Cómo es la } \\
\text { imagen país } \\
\text { de Colombia } \\
\text { para el } \\
\text { continente } \\
\text { americano? }\end{array}$ & $\begin{array}{l}\text { H1: Los visitantes han } \\
\text { dejado de asociar la } \\
\text { imagen de Colombia con } \\
\text { las drogas, el terrorismo, } \\
\text { la inseguridad y la } \\
\text { corrupción. } \\
\text { H2: Existen diferencias } \\
\text { proporcionales entre } \\
\text { visitantes y prospectos } \\
\text { cuando indican que un } \\
\text { aspecto positivo de } \\
\text { Colombia es la alegría de } \\
\text { su población. } \\
\text { H4: Los extranjeros que } \\
\text { no han visitado al país, } \\
\text { consideran que la alegría } \\
\text { y la diversión son } \\
\text { características propias de } \\
\text { los colombianos. } \\
\text { H5: La imagen de } \\
\text { Colombia es reconocida } \\
\text { en mercados } \\
\text { internacionales como } \\
\text { poseedora de un alto } \\
\text { valor agregado debido al } \\
\text { poder y notoriedad del } \\
\text { café. }\end{array}$ & $\begin{array}{l}\text { Se analizaron los } \\
\text { resultados de ocho } \\
\text { países del } \\
\text { contintente } \\
\text { americano: Estados } \\
\text { Unidos, Venezuela, } \\
\text { Ecuador, Argentina, } \\
\text { Perú, Brasil, México } \\
\text { y Chile. } \\
\text { La percepción sobre } \\
\text { Colombia está } \\
\text { condicionada por la } \\
\text { experiencia y } \\
\text { conocimiento que se } \\
\text { tiene del país. Los } \\
\text { extranjeros asocian } \\
\text { a Colombia con la } \\
\text { calidez de su gente, } \\
\text { sin embargo, se } \\
\text { mantiene un } \\
\text { posicionamiento } \\
\text { negativo } \\
\text { relacionado con el } \\
\text { narcotráfico, la } \\
\text { inseguridad, la } \\
\text { corrupción y el } \\
\text { terrorismo. }\end{array}$ & $\begin{array}{l}\text { Colombia tiene } \\
\text { dos marcas } \\
\text { país, pero no } \\
\text { tiene aún } \\
\text { identificado } \\
\text { cuál es su } \\
\text { imagen país. } \\
\text { En este } \\
\text { capítulo se } \\
\text { logra ir más allá } \\
\text { de los estudios } \\
\text { tradicionales y } \\
\text { hacia el } \\
\text { mercado } \\
\text { interno que se } \\
\text { han } \\
\text { desarrollado en } \\
\text { Colombia para } \\
\text { sustentar la } \\
\text { propuesta de } \\
\text { valor de la } \\
\text { marca país. }\end{array}$ & $\begin{array}{l}\text { Se genera } \\
\text { nuevo } \\
\text { conocimiento } \\
\text { sobre la } \\
\text { percepción que } \\
\text { tienen los } \\
\text { extranjeros } \\
\text { sobre la } \\
\text { imagen país de } \\
\text { Colombia. Se } \\
\text { obtienen } \\
\text { resultados de } \\
\text { las } \\
\text { impresiones, } \\
\text { percepciones y } \\
\text { asociaciones } \\
\text { que tienen } \\
\text { extranjeros } \\
\text { visitantes y } \\
\text { prospectos de } \\
\text { ocho países del } \\
\text { continente } \\
\text { americano. }\end{array}$ & $\begin{array}{l}\text { [EEP2013a] } \\
\text { [EEP2013b] } \\
\text { [EEP2014a] } \\
\text { [EEP2014b] }\end{array}$ \\
\hline
\end{tabular}




\section{Introducción}

\begin{tabular}{|c|c|c|c|c|c|c|c|}
\hline Capítulo & $\begin{array}{l}\text { Objetivo (s) de } \\
\text { la Tesis }\end{array}$ & $\begin{array}{l}\text { Pregunta de } \\
\text { investigación }\end{array}$ & Hipótesis & $\begin{array}{l}\text { Resultados } \\
\text { del capítulo }\end{array}$ & $\begin{array}{l}\text { Motivación del } \\
\text { capítulo }\end{array}$ & $\begin{array}{c}\text { Aportes } \\
\text { específicos del } \\
\text { capítulo }\end{array}$ & $\begin{array}{l}\text { Publicación } \\
\text { relacionada }\end{array}$ \\
\hline $\begin{array}{c}\text { Capítulo } 6 . \\
\text { Conclusiones }\end{array}$ & $\begin{array}{l}\text { Objetivo } 6 . \\
\text { Enmarcar las } \\
\text { aportaciones } \\
\text { principales de la } \\
\text { investigación } \\
\text { desde lo } \\
\text { teórico, } \\
\text { metodológico y } \\
\text { práctico } \\
\text { generado por } \\
\text { los resultados } \\
\text { del estudio. }\end{array}$ & $\mathrm{N} / \mathrm{A}$ & $\mathrm{N} / \mathrm{A}$ & $\begin{array}{l}\text { Se exponen las } \\
\text { conclusiones, } \\
\text { profundizando } \\
\text { en las hipótesis } \\
\text { planteadas en } \\
\text { el modelo } \\
\text { teórico, } \\
\text { además de } \\
\text { considerar las } \\
\text { implicaciones } \\
\text { estratégicas, } \\
\text { las limitaciones } \\
\text { del estudio y } \\
\text { las futuras } \\
\text { líneas de } \\
\text { investigación. }\end{array}$ & $\begin{array}{l}\text { La frontera del } \\
\text { conocimiento } \\
\text { de la tesis } \\
\text { doctoral } \\
\text { permite a } \\
\text { través de sus } \\
\text { conclusiones } \\
\text { replantear } \\
\text { teorías, } \\
\text { estrategias, } \\
\text { acciones o } \\
\text { modelos que } \\
\text { fundamentan el } \\
\text { concepto de } \\
\text { marca país. }\end{array}$ & $\begin{array}{l}\text { Las conclusiones de } \\
\text { la Tesis Doctoral } \\
\text { generan nuevas } \\
\text { líneas de } \\
\text { investigación sobre } \\
\text { marca país e } \\
\text { imagen país. La } \\
\text { marca país hay que } \\
\text { interpretarla desde } \\
\text { el branding y la } \\
\text { imagen país hay que } \\
\text { comprenderla desde } \\
\text { las impresiones } \\
\text { generales que tiene } \\
\text { un público sobre } \\
\text { determinado país. }\end{array}$ & $\mathrm{N} / \mathrm{A}$ \\
\hline
\end{tabular}




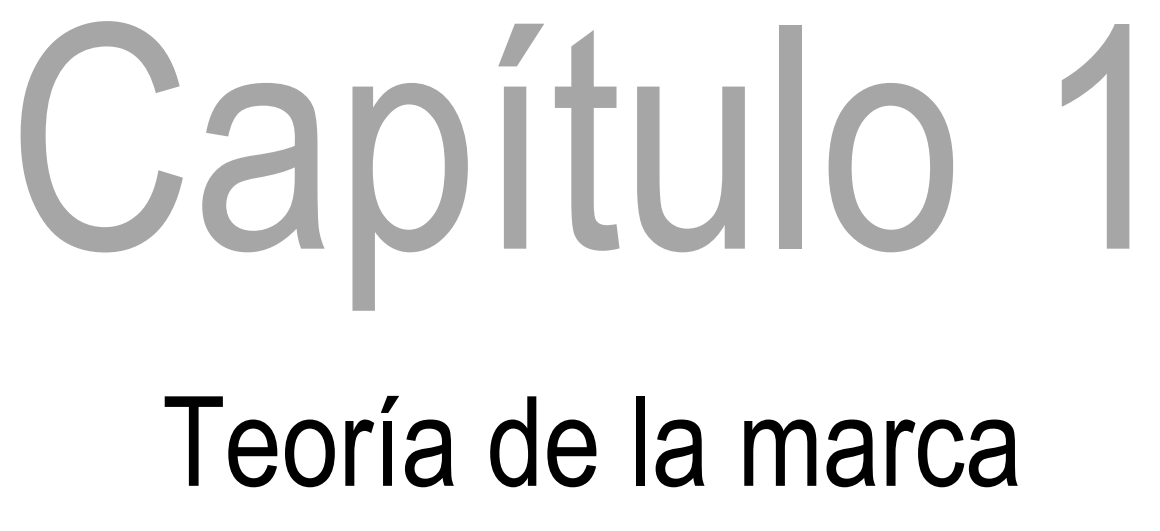




\section{Capítulo 1. Teoría de la marca}

La marca es un activo que permite diferenciar y extraer valor para las empresas en un mercado cada vez más competitivo. No obstante, el proceso de gestión y dirección de marca, es algo relativamente nuevo en la agregación de valor para los bienes y servicios que buscan generar confianza en el consumidor y crear asociaciones positivas. Esta diferenciación en el ámbito empresarial, es hoy cada vez más difícil, ya que la calidad y los costos de los productos son similares. Por ello como elemento diferenciador, la clave es la definición de marca.

El éxito o fracaso del proceso de construcción de marcas y de gestión de las mismas en las organizaciones, depende en gran medida del esfuerzo en todas sus áreas y niveles. Entonces, es necesario establecer estrategias de marca íntimamente ligadas a las estrategias organizacionales que aseguren un posicionamiento diferenciador. Posteriormente, dichas estrategias, deben plasmarse adecuadamente en documentos de consulta que especifiquen las directrices y rutas de marca donde se interactúe.

Este capítulo expone la teoría de la marca como fundamento conceptual de marca país. La primera sección del capítulo desarrolla el significado de la marca, sus objetivos y beneficios, y las diferencias entre marca y producto desde la perspectiva de autores que han contribuido a la disciplina de marketing. La segunda sección integra los conceptos de imagen, identidad y personalidad de marca. La tercera sección presenta lo referente al posicionamiento de marca y sus respectivas mediciones. Y finalmente, la cuarta sección del capítulo explica el significado de equidad de marca y las métricas empleadas para su medición.

\subsection{El significado de la marca}

Las dinámicas y tendencias del consumo cada día establecen que es necesario el posicionamiento de marcas y productos en el mercado. 


\section{Capítulo1. Teoría de la marca}

Los mercados actuales se caracterizan por una gran diversidad de modelos de negocios, una amplia variedad en la oferta de marketing y una alta complejidad de consumidores cada vez más globales (Adamson, 2007). Consumidores más informados y más selectivos donde la decisión de compra está influenciada por el poder de la marca (Aaker, 2005b). Esto muestra que el papel de la marca trasciende el rol funcional que cumple el producto a un rol emocional (Costa, 2010).

Se asevera, por tanto, que las empresas requieren de nuevas estrategias de marketing que permitan conectarse con su mercado objetivo (Kotler \& Keller, 2006a). Y dentro de las estrategias de marketing, la estrategia de marca es un elemento diferenciador no solo para productos, sino para la imagen de la compañía. Una marca genera credibilidad (Miao-Que \& Lee, 2012). Construir una marca es un factor clave para el éxito de cualquier empresa o producto (Omaniuk et al., 2012).

La marca es una estrategia de concertación entre el valor de la marca y la emoción de los compradores teniendo como sustento el impacto positivo a la sociedad (Aaker, 2011). Es una estrategia fundamentada en la construcción de relaciones con clientes importantes (Wheeler, 2012).

El concepto de marca ha evolucionado rápidamente en los últimos cincuenta años (Velilla, 2010). Inicialmente la marca era considerada como un símbolo que identificaba un producto. La marca se concebía como un nombre, una promesa, un logo o un empaque (Arnold, 1993). En años recientes, el concepto incluye el desarrollo creativo de la construcción de una identidad muy diferente a una representación gráfica (Landa, 2006; Costa, 2010)

Las marcas tienen cualidades físicas y emocionales que las hace diferente y plenamente reconocibles en el mercado objetivo (Hernández et al., 2008). La marca no identifica un producto, la marca ahora es un enlace emocional con el comprador (Roberts, 2005). Ante la dinámica del mercado y las tendencias de consumo, la marca es un factor altamente influyen en la decisión de compra. Por esto, Keller (2008), concluye que la marca crea conciencia y reputación en el mercado. 


\section{Capítulo1. Teoría de la marca}

El propósito de la marca es generar diferenciación e identidad. Estos dos atributos generen así un valor extraordinario hacia el comprador de tal manera que motive la compra o cautive su atención (Aaker, 2005a).

Según Adamson (2007) la marca es más que una identidad, es un activo de la identidad que tiene una empresa en un mercado específico. Es una idea que vive en la cabeza de quienes ejercen la compra. Por tal motivo el gran desafío de los productos en un entorno competitivo es el de lograr que los consumidores los recuerden y los prefieran sobre los demás y para lograrlo lo primero que se debe hacer es consolidar una identidad de marca. Identidad que se va moldeando y a la cual se le imprime una propuesta de valor que permita superar las expectativas de los compradores.

Al irse plasmando así la idea marca, una marca reside en la mente de los consumidores, hace parte de su idiosincrasia y modifica sus percepciones (Keller et al., 2008).

Para que una marca llegue a ser exitosa y crecer en el mercado debe ser relevante en la vida de los compradores. Las marcas pueden responder proactivamente a tendencias, entender las inquietudes de sus clientes y vincularse a la identidad corporativa (Prasad, 2011). Las organizaciones buscan desarrollar las marcas como una manera de atraer y mantener clientes mediante la promoción de valores, imagen, prestigio, o estilo de vida (Jalilvand et al., 2011)

Las marcas son un conjunto de asociaciones y de beneficios funcionales, emocionales y racionales que tienen en la mente los consumidores (Woo Jin \& Winterich, 2013). Las asociaciones no son más que las imágenes y los símbolos asociados a las ventajas de la marca.

Si bien las definiciones de marca se concentran en referenciarla desde una perspectiva simbólica perdiendo de vista que el concepto de marca es más que una identidad. Es un activo único y fuente de poder de las empresas para: a) cumplir con la promesa de valor de un bien o un servicio y b) superar las expectativas de los clientes (Morgan, 2011). 


\section{Capítulo1. Teoría de la marca}

\subsubsection{Objetivos y beneficios de la marca}

Un componente central del proceso de construcción de marca es la definición de objetivos de la marca (Aaker, 2011). Mediante el desarrollo de los objetivos de la marca - una función de gestión de marketing - se formulan las estrategias y tácticas necesarias para cautivar al consumidor.

Los objetivos para la creación de marca son los siguientes:

a. Identificar al fabricante del producto, ya que es la identidad visual, es parte integral de la estrategia de comunicación de la compañía;

b. Transmitir una información, utilizando la sencillez, un claro y definido significado respecto de aquello que representan, tener continuidad en la comunicación que se transmite;

c. Comunicar la promesa del producto y su diferenciación con respecto a sus competidores, asegurando beneficios futuros mediante un incremento de la preferencia y fidelidad del consumidor;

d. Fijar la imagen del producto en la mente del comprador, el cual es importante que no cambie y que constituya la visión de la marca (Aaker, 2011; Prasad, 2011; Velilla, 2010).

Cuando se habla de los beneficios de las marcas, se llega a un punto en común: la necesidad que tienen las compañías y las distintas instituciones para lograr competitividad. La diferenciación es la clave, y lo que da la relevancia a utilizar las marcas para generar un adicional que pueda ser valorado por el consumidor, y facilite la decisión de compra de un bien o servicio (Aaker \& Joachimsthaler, 2005b).

Un elemento importante que apoya la diferenciación de las marcas son los beneficios emocionales que transmiten las mismas. Gracias a éstos tipos de beneficios las marcas apalancan su posicionamiento en la mente de los consumidores, fortaleciendo el compromiso de los mismos hacia sus productos. 


\section{Capítulo1. Teoría de la marca}

Los beneficios emocionales generan barreras de entrada, las cuales toman mayor relevancia cuando entran nuevos competidores al mercado (Bhargava, 2009).

Cuando existe un reconocimiento relevante de la marca con asociaciones favorables en determinado contexto de la elección de compra hay un verdadero valor de marca para un consumidor (Adams, 2005).

Cuando la marca genera un valor al consumidor, ese beneficio se convierte en lealtad y a su vez se constituye en una barrera de entrada a mercados competitivos (Vera, 2008).

Para las organizaciones, poseer una marca representa la posibilidad de capitalizar diferentes ventajas, como reducción de los costos de marketing, aumento de la fidelidad del consumidor, márgenes de lucro agregado, y oportunidades de extender la marca hacia otras líneas de producto (García, 2005).

Construir valor alrededor de una marca debe ser un propósito estratégico orientado a direccionar el camino de las empresas, de acuerdo a las oportunidades que éstas puedan capturar en el mercado (Vidic \& Vadnjal, 2013).

Para las empresas éste intangible es de gran valor porque de alguna manera explica por qué un consumidor está dispuesto a pagar un mayor valor por un producto o servicio; o, por qué una empresa pueda llegar a capturar una determinada participación de mercado (Aaker \& Joachimsthaler, 2005b).

La marca genera como beneficio la reducción de costos de marketing (Barwise, 1993). Lo anterior se evidencia en que el conocimiento de marca logra convertir la transmisión del mensaje en un elemento de recordación hacia el consumidor (Stahl et al., 2012). De hecho las marcas fuertes enfocan sus esfuerzos de comunicación en reforzar su posicionamiento con valores intangibles.

Según Petroll et al. (2008) la gestión estratégica de la marca puede representar un importante diferencial competitivo, pues se busca un reconocimiento e identificación que la vuelve única en la mente del consumidor. Esta afirmación expresa un claro beneficio que facilita de alguna manera decidir escoger un bien o servicio, o decidir una compra. Hablar de reconocimiento e identificación es hablar de una labor que se encuentra detrás de una marca para facilitarle al comprador la tarea de escoger un producto (Vera, 2008). 


\section{Capítulo1. Teoría de la marca}

El reconocimiento que menciona Petroll et al. (2008), va mucho más allá del simple hecho de identificación de las marcas en el mercado. Este reconocimiento se interpreta como un diferencial por diversas variables, bien sea por la personalidad que adquiere la marca, que a su vez se identifica con un tipo de cliente en particular, o por la trayectoria que ha tenido la misma, y que genera todo un valor implícito (Shillington, 2012). Provocado por una apropiación de la marca por parte del consumidor, creando un efecto de herencia que se va legando de generación en generación (Adams, 2005).

Siendo un elemento intangible, la marca es capaz de transformar las ventajas que ofrece a una compañía, en beneficios tangibles, como una mayor recaudación de dinero, vía mayor margen sobre un producto y servicio, y por ende una generación de mayor rentabilidad y flujo de caja (Ross, 2010). Por ésta razón la gerencia de marca eventualmente mantiene un contacto directo con sus clientes, hablándole por diferentes medios de comunicación estratégicos, con el objeto de no perder vigencia en la mente de los consumidores, y continuar redituando este valor en los precios que manejan en sus productos (Shillington, 2012).

\subsubsection{Diferencias entre la marca y el producto}

La marca ha tomado protagonismo sobre el concepto de producto (Adams, 2005). Las empresas ya no pueden confiar en las estrategias de diferenciación de bienes y servicios ni convertirlos como una ventaja competitiva sostenible frente a aumento de competidores y la creciente sofisticación de los consumidores (Kapferer \& Thoenig, 1991).

La marca tiene como misión ser un hilo conductor de las mejoras del producto (Kapferer \& Thoenig, 1991). Los consumidores compran marcas no productos. La marca es un conjunto de asociaciones emocionales y funcionales (Aaker, 2011).

La marca es la promesa de que el producto funcionará de acuerdo con las expectativas del cliente (Noseworthy \& Trudel, 2011). Un producto es un conjunto de atributos tangibles e intangibles que busca satisfacer necesidades y deseos de los mercados de consumo y empresariales (Kerin et al., 2012).

En la literatura de marketing, es común encontrar que el concepto de producto incluye la marca como un elemento funcional de la estrategia. Kotler (2010), Kerin (2012), y Fischer 


\section{Capítulo1. Teoría de la marca}

(2010), mantienen un pensamiento que puede llamarse convencional, sobre el rol de la marca dependiente al producto. Sin embargo, otro grupo de escritores si establecen diferencias como se puede observar en el Cuadro 2:

Cuadro 2. Diferencias conceptuales entre marca y producto

\begin{tabular}{|l|l|l|}
\hline Criterio & \multicolumn{1}{|c|}{ Marca } & \multicolumn{1}{c|}{ Producto } \\
\hline Esencia & $\begin{array}{l}\text { Da forma a las expectativas de los } \\
\text { clientes (Aaker, 1996a) } \\
\text { Ee construye sobre los valores y } \\
\text { emociones (Aaker, 2011) }\end{array}$ & $\begin{array}{l}\text { Da forma a los beneficios que buscan } \\
\text { los clientes (Keller, 2012) }\end{array}$ \\
\hline $\begin{array}{l}\text { Se construye sobre la racionalidad y el } \\
\text { rendimiento (Narayanan et al., 2012) }\end{array}$ \\
\hline Delimitación & $\begin{array}{l}\text { Es definida por elementos } \\
\text { sensoriales que las personas } \\
\text { describen cuando interactúan con } \\
\text { ella (Adamson, 2007). }\end{array}$ & $\begin{array}{l}\text { Es definido por las necesidades y los } \\
\text { deseos de las personas (Kerin et al., } \\
\text { 2012) }\end{array}$ \\
\hline Finalidad & Cuenta historias (Godin, 2012) & $\begin{array}{l}\text { Invita a la experiencia (Kotler \& Keller, } \\
\text { 2006a) }\end{array}$ \\
\hline Conexión & $\begin{array}{l}\text { Conecta la experiencia con la } \\
\text { emoción (Lindstrom, 2011) }\end{array}$ & $\begin{array}{l}\text { Conecta la experiencia con la } \\
\text { inspiración (Cagan, 2008) }\end{array}$ \\
\hline
\end{tabular}

Fuente: Elaboración propia.

Estas diferencias se complementan con situaciones que han logrado independizar el concepto de marca del producto y que se enuncia a continuación:

a. Cambio en el enfoque de producto a marca. Las empresas hoy han incorporado el concepto de gerencia de marca (o Branding) como filosofía en la compañía, más allá de simbolismos adscritos a los productos (Ross, 2010). Se da prioridad al gerenciamiento de la marca, los productos pasan a ser una función secundaria (Wheeler, 2012).

b. Del enfoque al cliente al enfoque de los grupos de interés. Mientras que el producto se dirige a atender necesidades de los consumidores, la marca responde a los intereses de los proveedores, los socios, la comunidad, el gobierno y la industria (Kotler et al., 2010).

c. De la necesidad a la proximidad. Los productos satisfacen necesidades y deseos, las marcas generan conexiones (Healey, 2008). La marca genera cercanía y calidez al comprador (Drew, 2013). 


\section{Capítulo1. Teoría de la marca}

d. Atrás el dominio del producto ahora se promueve la integración. Los productos dejaron de dominar los departamentos de marketing. La marca se integra a la visión holística de la empresa (Adams, 2005).

Las marcas exigen el apoyo de toda la organización porque generan compromiso (Costa, 2010). La marca requiere de la alineación con la comunicación interna y externa para consolidad una imagen clara y precisa frente a la multiplicidad de mercados (Arnold, 1993).

e. Cambio en horizontes. Los productos se delimitan por sus atributos (Saavedra, 2006). Las marcas se apropian de los objetivos corporativos de las compañías (Olins, 2008). Las marcas viven el presente, pero con o sin producto tienen una característica de inmortalidad (Light, 1998).

\subsection{Imagen e identidad de marca}

Según Kotler y Keller (2006b), la imagen de marca hace referencia a las propiedades extrínsecas del producto o servicio, incluidas en la forma en que se intenta que la marca satisfaga las necesidades sociales y psicológicas del consumidor.

La marca se encuentra en un nivel simbólico. Representa un diferencial asociado a diversas variables, que muchas veces se encuentran muy lejos de evaluarse exclusivamente por el desempeño de un producto o servicio, sino por todo lo que representa para un consumidor (Signorelli, 2012). De alguna manera la marca le está hablando al consumidor de una contraprestación que puede recibir por el hecho de llevar puesto, o usar cierto producto o servicio (Roberts, 2005). Esta contraprestación debe estar dirigida conceptualmente en función de una necesidad insatisfecha, por la cual el consumidor está dispuesto a ofrecer un mayor valor, gracias a variables extrínsecas que hacen parte del desarrollo de la personalidad de cada sujeto (Kornberger, 2010).

La imagen de marca pone a prueba el posicionamiento y la identidad de la marca después de haber sido creadas (Omaniuk et al., 2012) Se puede decir que las marcas adquieren una imagen e identidad particular en la medida en que cada marca dirigida al mercado encuentra una afinidad con una necesidad del mercado, donde la persona que 


\section{Capítulo1. Teoría de la marca}

consume una marca, la traslada a su forma, estilo y personalidad propia y asumen éstas marcas como componente importante para llevar su estilo de vida (Bhargava, 2009).

La identidad de marca es el principal activo de las empresas, puesto que se convierte en el gran elemento diferenciador frente a la competencia (Trout \& Rivkin, 2010). La identidad provee direccionamiento, propósito y significado a una marca (Aaker, 1996a).

La identidad, el posicionamiento y la imagen, responden a estos tres cuestionamientos: ¿Qué características tendrá la marca? ¿Cómo quiero que se vea la marca? y ¿Cómo me percibe el público? (Wheeler, 2012).

En éste orden de ideas las marcas tienen una variable que representa parte importante de su identidad, y es el posicionamiento en la mente del consumidor. De acuerdo a éste posicionamiento, un consumidor valorará de diferente manera una marca teniendo en cuenta lo que representa la misma en su valoración personal (Trout et al., 2000).

\subsubsection{La personalidad de la marca}

Al igual que las personas, las marcas tienen personalidad propia. Los especialistas en marketing trabajan en función de la personalidad de una marca. Enfocan sus esfuerzos en desarrollar un concepto que se construye sobre insights ${ }^{5}$ que se encuentran en el subconsciente del comprador. Estos insights buscan encontrar los motivantes que hacen que el consumidor desee utilizar un producto o servicio (Bhargava, 2009). La personalidad de la marca es la forma en que una marca habla y se comporta (Aaker, 2011).

La personalidad se construye sobre una asignación de los rasgos con el fin de lograr la diferenciación. Generalmente la identidad de la marca se expresa en términos de rasgos humanos, y esto se conoce como personalidad de marca (Morgan, 2011).

La personalidad de la marca no es más que la personificación de la marca (Kotler \& Keller, 2006a). Es el resultado de todas las experiencias del consumidor con la marca. Es única y duradera. Existen diferencias entre personalidad e imagen de marca. La primera indica asociaciones emocionales de la marca (Keller, 2012). Y la segunda, hace referencia a

5 Son descubrimientos o motivaciones espontáneas asociados al comportamiento de compra y consumo de las personas. 


\section{Capítulo1. Teoría de la marca}

los beneficios tangibles (físicos y funcionales) y a los atributos de una marca (Aaker, 2005a). A través de la personalidad de la marca se desarrolla el valor de marca. Se establece la actitud hacia la marca (Rossiter \& Bellman, 2012). La personalidad de la marca indica el tipo de relación que un cliente tiene con la marca. Es un medio por el cual un cliente comunica su propia identidad (Matzler et al., 2011).

Saavedra (2006) propone un modelo para la construcción de marca basado en el consumidor donde se busca llegar a la marca ideal mediante las preguntas que usualmente se hace un consumidor al enfrentarse con una marca por primera vez (ver Figura 2):

Figura 2. Modelo para construcción de marca basado en el consumidor

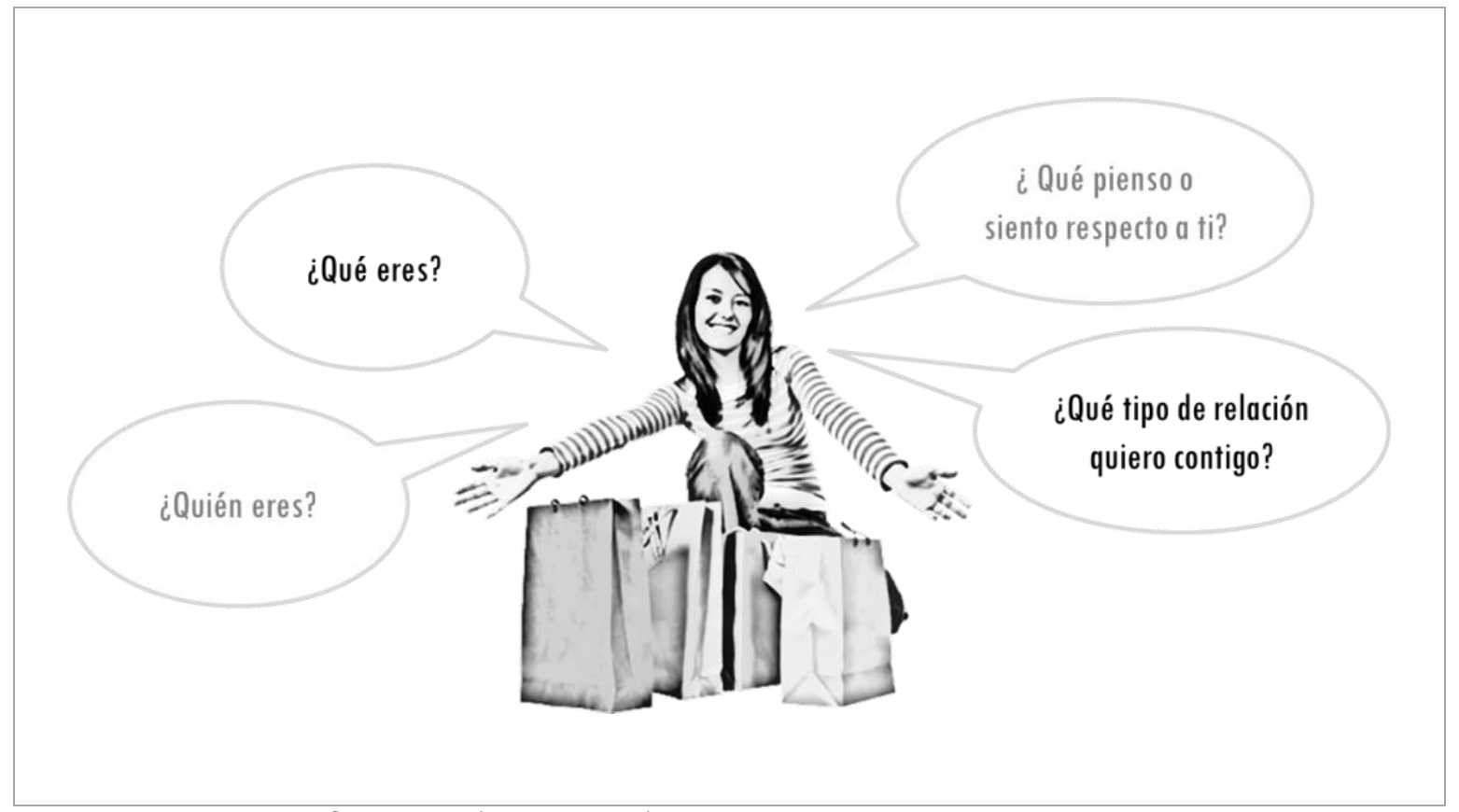

Fuente: Adaptado de Saavedra (2006, p. 84). 


\section{Capítulo1. Teoría de la marca}

El consumidor se ve enfrentado constantemente a la toma de decisiones en su proceso de compra. Situación que se convierte en un escenario interesante para potencializar y fortalecer la personalidad de la marca. Las preguntas planteadas por Saavedra (2006) ayudan a definir la personalidad de la marca. La personalidad se constituye en el eje articulador de la gerencia de marca (branding).

\subsection{Posicionamiento de marca}

La articulación de los objetivos de marketing con la filosofía empresarial lleva consigo la tarea de buscar reconocimiento de los productos o de una compañía. En este sentido el posicionamiento una estrategia de marketing (McGhie, 2012). Existen multitud de enfoques utilizados en el posicionamiento. Sin embargo, la intencionalidad de la empresa es responder a nuevas estrategias para ocupar el primer lugar en la mente de su mercado meta (Bertrán Vall, 2003). En el posicionamiento, la imagen del competidor es tan importante o más, como la propia.

En el mercado, los productos y las empresas buscan atraer la atención de los compradores a través del posicionamiento. Y para lograrlo, emplean una amplia gama de estrategias de comunicación para acercarse al comprador y lograr la venta. Sin embargo, como defensa al volumen actual de comunicaciones, la mente humana selecciona y rechaza gran parte de la información que se le ofrece (Westjohn et al., 2012). En general, únicamente acepta aquello que encaja con sus conocimientos y experiencia previos. Una empresa no intenta cambiar la opinión o confundir a su mercado real y potencial. Busca darle a su marca el lugar que merece en el mercado (Velilla, 2010).

El término Cherchez le créneau acuñado al tema de posicionamiento implica buscar el hueco en la mente del cliente y ser el primero en ocuparlo (Mora \& Schupnik, 2000). Una de las principales funciones que tienen los expertos en marketing al interior de la empresa es diseñar y proponer una acertada estrategia de posicionamiento. 


\section{Capítulo1. Teoría de la marca}

El posicionamiento es importante porque la empresa compite generando ruido para atraer la atención de los compradores potenciales (Hoskisson et al., 2013).

La empresa prioriza fortalecer su posicionamiento en el mercado (Jowitt \& Lury, 2011). Cada acción y decisión de formular una estrategia de posicionamiento debe iniciarse por determinar la ventaja competitiva de la empresa y declarar la propuesta de valor al cliente.

El posicionamiento es la manera en que el mercado meta distingue a la empresa en relación con sus competidores (Fuchs \& Diamantopoulos, 2012). Un buen posicionamiento está determinado por los beneficios generados por la oferta de valor (Blankson \& Kalafatis, 2007). Cautivar la atención del mercado meta dependerá del conocimiento que la empresa tenga acerca de los puntos de vista de sus clientes y de las acciones concernientes a la rivalidad de sus competidores (Trout et al., 2000).

La marca se hace cada vez más importante en la era del posicionamiento, ya que el contenido que lleva implícito tiene un objetivo fundamental: elevar las expectativas, es decir, crear ilusión de que el bien o el servicio cumplirá con los beneficios esperados por los clientes. El cliente compra por emoción y no tanto por la razón. Es allí donde la marca se nutre, crece y conserva la información que la empresa desea posicionar (Roberts, 2005).

El posicionamiento se integra en el proceso de construcción y fortalecimiento de la marca (Kotler et al., 2010). En este proceso intervienen las 3i: Integridad de marca, Identidad de marca, e Imagen de marca.

En la Figura 3 se explica el modelo 3i, expuesto por Kotler et al. (2010). Para los autores: la Integridad de marca logra satisfacer lo que se demanda a través del posicionamiento y la diferenciación. La identidad de marca es el posicionamiento que tiene la marca en la mente de los consumidores y la imagen de marca es la adquisición de una participación fuerte de la emociones del consumidor. 


\section{Capítulo1. Teoría de la marca}

Figura 3. Modelo 3i

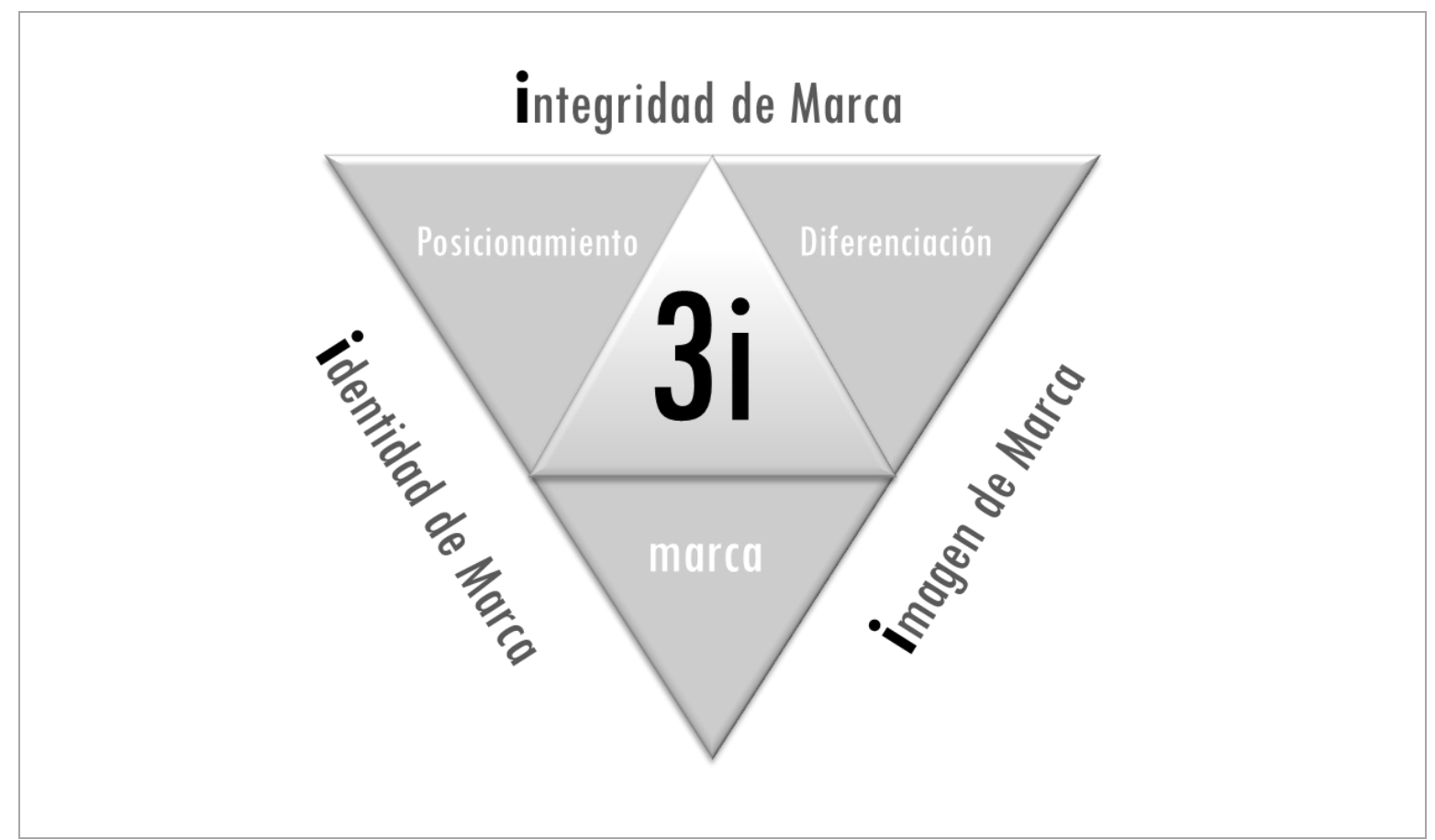

Fuente: Adaptado de Kotler, Setiawan y Kartajaya (2010).

La mente del consumidor captura imágenes de productos y ubica las marcas en relación con las demás (McGhie, 2012). Un buen posicionamiento se caracteriza porque hace que la empresa y el producto sean únicos en la mente del consumidor (Trout \& Rivkin, 2010). Esta condición se considera como un beneficio para el mercado objetivo.

El posicionamiento tiene la tarea de:

a. Fortalecer el mensaje que comunica el producto hacia los consumidores (Choi \& Myer, 2012).

b. Dirigirse a un segmento particular (Kotler \& Keller, 2006a).

c. Asegurar la diferenciación de los productos en la mente de los consumidores y decidir el terreno donde se va a competir (Trout \& Rivkin, 2010).

d. Analizar las posibilidades de reposicionamiento (Jowitt \& Lury, 2011). 


\section{Capítulo1. Teoría de la marca}

Si la empresa puede mantener una ventaja única, tiene una mayor posibilidad de captar la atención de sus compradores. Hay que entender el producto desde el punto de vista del consumidor y de la competencia (Keller, 2012).

\subsubsection{Medición de posicionamiento de marca}

El posicionamiento conduce a la asociación y lealtad a largo plazo y es el resultado de la conexión entre la marca y el consumidor (Blankson \& Kalafatis, 2007).

El consumidor logra identificar diferencias y similitudes entre las marcas, reconoce y apropia identidades, este proceso es conocido como posicionamiento de marca (Choi \& Myer, 2012). Existe una gran variedad de métricas que miden el posicionamiento de marca:

\subsubsection{Top of Mind, Top of Heart y el Top of Hand}

Ese lugar que quiere ocupar la marca en la mente del consumidor se mide a través del Top of Mind (TOM). El Top of Mind es un concepto de marketing centrado en que los consumidores van a comprar productos basados en el conocimiento deseado de una determinada marca (Cobb-Walgren et al., 1995).

El TOM es la primera marca o producto que se le viene primero a la mente de los clientes cuando se piensa en una industria en particular (Aaker, 1996b). Las empresas tratan de crear conciencia de marca a través de la exposición a los medios de comunicación en canales como internet, radio, periódicos, televisión, revistas y las redes sociales (Aaker \& Joachimsthaler, 2005b).

El TOM requiere de los esfuerzos de comunicación coherentes por parte de una empresa a través de diversos canales de comercialización. También requiere que la empresa entregue la información necesaria para ayudar en el proceso de toma de decisiones al consumidor (Aaker, 2000).

No es sencillo para todas las empresas destacarse en este tipo de mediciones. Influye el sector al que pertenecen y el mercado que atienden. Es relevante entender el proceso de compra del consumidor. 


\section{Capítulo1. Teoría de la marca}

Profundizar en cada una de sus etapas para lograr influenciar sus decisiones, dado que los compradores se toman su tiempo para tomar sus decisiones (Kornberger, 2010).

Un consumidor debe identificar fácilmente la marca (Fuchs \& Diamantopoulos, 2012). Si no lo logra, el esfuerzo de marketing hacia la marca será insuficiente. El producto entrará como un sustituto de la marca al no ser reconocida (Aaker, 1996a).

Para lograr una estrategia de posicionamiento de marca efectiva es importante identificar el consumidor objetivo y estudiar los principales competidores directos e indirectos desde sus fortalezas y debilidades (Aaker \& Joachimsthaler, 2005b).

El reconocimiento de marca cobra relevancia, en la medida que el posicionamiento de marca se convierte en un factor que influye en la compra (Adams, 2005). El TOM como métrica es considerada tradicional especialmente ahora con la digitalización del marketing (Barón, 2010).

El Top of Heart (TOH) no se aleja de la definición del Top of Mind. Hace referencia a las marcas que más aprecia el comprador, aquellas que están más cercanas a su corazón (Roldán, s.f.). Y el Top of Hand, hace referencia a aquellas marcas o productos que generan espacios de co-creación. Es decir, aquí el consumidor tiene un papel fundamental, participa en el diseño del producto y en creación de estrategias de comunicación (Isaza, s.f.).

Cuadro 3. Comparación Top of Mind, Top of Heart y Top of Hand

\begin{tabular}{|l|l|l|l|}
\hline Criterio & \multicolumn{1}{|c|}{ Top of Mind } & \multicolumn{1}{|c|}{ Top of Heart } & \multicolumn{1}{|c|}{ Top of Hand } \\
\hline ¿Qué mide? & $\begin{array}{l}\text { Primera marca en la } \\
\text { mente del comprador }\end{array}$ & $\begin{array}{l}\text { Grado de cariño hacia } \\
\text { una marca }\end{array}$ & $\begin{array}{l}\text { Participación activa del } \\
\text { consumidor en la } \\
\text { construcción de la } \\
\text { marca }\end{array}$ \\
\hline $\begin{array}{l}\text { ¿Cuál estrategia de } \\
\text { marketing aplica? }\end{array}$ & Posicionamiento & Branding & $\begin{array}{l}\text { Diseño de producto y } \\
\text { comunicación }\end{array}$ \\
\hline $\begin{array}{l}\text { ¿Qué relación genera } \\
\text { entre la marca y el } \\
\text { producto? }\end{array}$ & Emocional y racional & Emocional & Emocional y racional \\
\hline
\end{tabular}

Fuente: Elaboración propia. 


\section{Capítulo1. Teoría de la marca}

\subsubsection{Técnicas de Brand Awareness}

Brand awareness o conocimiento de marca hace referencia a la capacidad que tiene el consumidor de reconocer aspectos de la marca (Girard et al., 2013). Se utilizan dos técnicas para medir el conocimiento de marca: el recuerdo de marca y el reconocimiento de marca.

a. El recuerdo de marca, se realiza a través de una prueba de memoria, en la cual se pregunta la primera denominación de marca que recuerdan los consumidores sobre una categoría de productos específica (Aaker, 1996b). Esta técnica es importante para las empresas, dado que la marca que recuerden puede estar en las lista de las primeras alternativas que tiene el consumidor cuando toma una decisión de compra (Alba \& Chattopadhyay, 1986). Las marcas que logran esta posición tienen una fuerte ventaja competitiva (Mikhailitchenkoa et al., 2009). Los resultados de esta técnica ayuda a medir la eficacia de las acciones de marketing de la empresa (Krishnan et al., 2013).

b. El reconocimiento de marca, busca medir la efectividad de las decisiones que se han tomado en la función de marketing (Thoma \& Williams, 2013). Se les presenta unos archivos visuales a los consumidores y se les pregunta si asocian la imagen con alguna marca (Dens et al., 2012). Por ejemplo, los consumidores pueden señalar que reconocen una marca en un anuncio o una exhibición de la tienda.

El objetivo de la prueba es identificar altos niveles de reconocimiento. Los resultados

de la prueba pueden ayudar a rediseñar el contenido o las tácticas de comunicaciones para que mejore los niveles de reconocimiento y mejorar el retorno de su inversión en marketing (Sherman, 2013). 


\section{Capítulo1. Teoría de la marca}

\subsubsection{Métricas en las redes sociales}

El posicionamiento de una marca trasciende el marketing análogo y se integra al marketing digital (Bruhn et al., 2012). Un objetivo importante es incrementar el nivel de exposición de la marca en las redes sociales. Hay una gran variedad de métricas en las redes sociales (Eun Sook \& Yongjun, 2011). Ambos autores plantean que las redes sociales ayudan a medir y controlar el aumento o disminución de los niveles de interés del público. Una exposición que ayuda a construir posicionamiento de marca en ambientes virtuales, son los botones que aparecen en los sitios web denominados Me gusta (Like) como se observa en la Figura 4 (Naylor et al., 2012).

Figura 4. Botones en sitios web: Me gusta
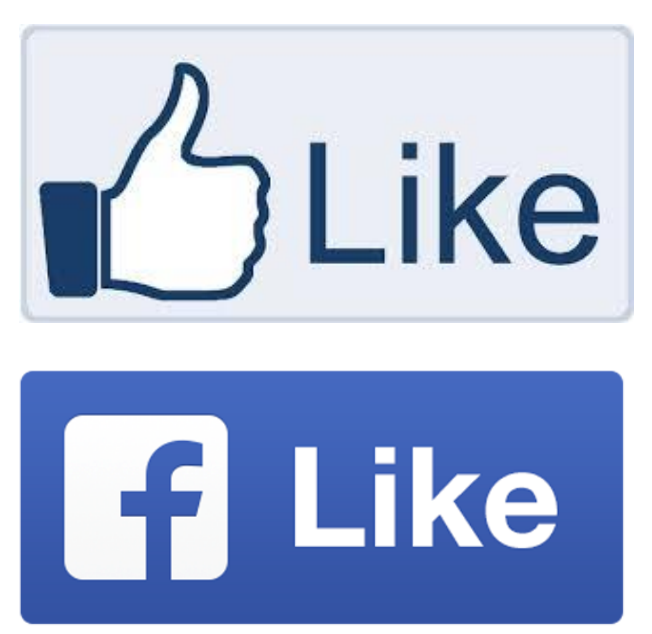

Fuente: Tomado de Naylor et al. (2012)

Las redes sociales son los medios ideales para el posicionamiento de una marca por dos razones: libertad y accesibilidad (Stieglitz \& Dang-Xuan, 2013).

Las métricas más comunes en las redes sociales para medir el posicionamiento se muestran en el Cuadro 4: 


\section{Capítulo1. Teoría de la marca}

Cuadro 4. Métricas de Posicionamiento en Redes Sociales

\begin{tabular}{|c|c|}
\hline Red Social & Métricas de Posicionamiento \\
\hline Blogs & $\begin{array}{l}\text { \# de visitantes } \\
\text { \# de visitantes que retornan } \\
\text { Ranking en buscadores } \\
\text { Top Clics }\end{array}$ \\
\hline Facebook & $\begin{array}{l}\text { \# Fans } \\
\text { \# de Me gusta } \\
\text { \# de comentarios } \\
\text { \# de Compartir }\end{array}$ \\
\hline Twitter & $\begin{array}{l}\text { \# de seguidores } \\
\text { \# de menciones } \\
\text { \# de retweets } \\
\text { \# de favoritos }\end{array}$ \\
\hline Linkedln & $\begin{array}{l}\text { \# de Me gusta } \\
\text { \# de contactos } \\
\text { \# de comentarios } \\
\text { \# de Compartir }\end{array}$ \\
\hline Google+ & $\begin{array}{l}\text { \# de Compartir } \\
\text { \# de comentarios } \\
\text { \# de post más populares }\end{array}$ \\
\hline Foursquare & $\begin{array}{l}\text { \# de comentarios } \\
\text { \# de Me gusta }\end{array}$ \\
\hline
\end{tabular}

Fuente: Elaboración propia.

La primera manera de reinventar el posicionamiento en redes sociales es saber qué atributos tiene la propuesta de valor, qué la hace única, y qué factor de compra motiva al cliente para elegir una empresa sobre su competencia (Romaniuk, 2012). Si una organización no logra identificar lo mencionado anteriormente, los clientes tampoco lo harán (Chung \& Austria, 2010).

Por esto, es necesario buscar maneras de agregar valor en las estrategias de posicionamiento de una marca (Dou et al., 2010). Situación que se convierte en oportunidad para las redes sociales, ya que ellas ayudan a colocar la marca como líder en la mente del cliente (Bertrand, 2013). En las redes sociales, el posicionamiento de la marca está condicionado por las acciones del usuario, y éstas acciones está influenciadas por las estrategias de comunicación que logran ubicar la marca como un factor determinante en las decisiones de compra (Chung \& Austria, 2010). 


\section{Capítulo1. Teoría de la marca}

Es fundamental identificar para el comprador: qué se le puede ofrecer, cómo puede hacerlo mejor y lo que siente cuando la marca interactúa con ellos (Lipsman et al., 2012).

El posicionamiento de una marca en redes sociales debe construirse bajo la figura de una marca personal y no comercial (Ridgen, 2011).

Los usuarios son más amables con marcas personales (Chase, 2011). Las personas están más dispuestas a escuchar a personas reales que llegan a través de Twitter, Google +, Facebook, y otras redes, en comparación con las marcas corporativas (Smith, 2013; Brock, 2012; Manjoo, 2011).

Las marcas están empezando a darse cuenta de esto. Algunas de las marcas más importantes están comenzando a reposicionarse como marcas personales en Internet (Gumbs, 2010). Una estrategia común es que las empresas vinculan líderes de opinión o voceros de redes sociales que se convierten en su marca personal en Internet (Chase, 2011).

La necesidad de medir y hacer seguimiento en redes sociales ha hecho surgir un sector de empresas dedicadas a monitorear las métricas que ayudan a cuantificar el posicionamiento de las marcas en términos de participación, la influencia, la experiencia y la confianza (Serrano-Puche, 2012). Por ejemplo, empresas como Kred, Empire Avenue, PeerIndex, Klout, y otras.

La mediciones han cobrado relevancia por su utilidad en el proceso de consolidación de una marca en el mundo digital (Manjoo, 2011). Sin embargo, los directores de marketing deben ser cuidadosos con el estudio de los resultados provenientes de este tipo de métricas, ya que en este escenario, el usuario es un número más dentro de unas cifras estadísticas susceptibles a ser manipuladas (Deiser \& Newton, 2013).

El posicionamiento de una marca en redes sociales se ha convertido en una práctica que está replanteando la función de marketing en una empresa (Hauptmann \& Steger, 2013). Ya no se privilegia exclusivamente el lugar que ocupa la marca en la mente del consumidor, sino la participación del usuario en la creación de contenido de una marca (Mohammadian \& Mohammadreza, 2012). 


\section{Capítulo1. Teoría de la marca}

Ahora el usuario difunde ideas, comparte experiencias y aprendizajes, y se identifica con los beneficios emocionales que le genere una marca (Campbell et al., 2013). Esta situación se evidencia en los contenidos que circulan en las redes sociales (Zingshem, 2012). El posicionamiento está en un proceso de reinvención y lo más importante, las redes sociales logran darle visibilidad y mayor relevancia (Bruhn et al., 2012).

\subsection{Equidad de marca (Brand Equity)}

Mientras las marcas ganan reconocimiento y valor en el mercado, para las compañías, poseer este intangible, representa una oportunidad estratégica latente que permite generar un crecimiento de portafolio y multiplicar los beneficios de participar en nuevas categorías o nuevas líneas de producto (Aaker, 1991). Es decir, una marca representa una oportunidad latente de multiplicar los beneficios de una compañía, en la medida en que se puedan capitalizar las oportunidades que se detecten en el mercado, donde las marcas puedan jugar un rol importante de acuerdo los beneficios que percibe el consumidor de las mismas (Wreden, 2002). Con marcas establecidas de manera importante en los mercados, se pueden ampliar horizontes de negocios, el solo hecho de tener un reconocimiento, permite generar la credibilidad suficiente, para emprender nuevos retos en la ampliación de portafolios, y de ahí apalancar un crecimiento sostenido para las organizaciones (Cobb-Walgren et al., 1995).

El Brand Equity es el valor añadido de que se dota a productos y servicios (Aaker, 1991). Éste valor se refleja en cómo piensan, sienten y actúan los consumidores respecto a la marca, o en los precios, la participación de mercado y la rentabilidad que genera la marca para la empresa (Lebar et al., 2005).

El Brand Equity, se puede entender como un efecto diferenciador que reconocen los consumidores relacionado con la marca (Farhana, 2012). De acuerdo a éste reconocimiento la respuesta del consumidor puede ser más favorable, en relación a todo lo mencionado anteriormente (Keller, 2012), como: mayor margen, mayor participación de mercado, y mayor lealtad, entre otros.

La gran asociación que tiene el Brand Equity con la identidad de marca, es el complemento que se dan en la medida en que se trabaja la identidad de la marca en función 


\section{Capítulo1. Teoría de la marca}

de su posicionamiento y reconocimiento se está trabajando el Brand Equity (Madhavaram et al., 2005).

Cuando el valor que percibe el mercado sobre una marca establecida se considera fuerte, se pueden encontrar algunos beneficios adicionales que están asociados al Brand Equity de la marca, al tamaño y tradición de las compañías, y las marcas en el mercado (Lebar et al., 2005).

Las marcas proporcionan beneficios que no necesariamente se pueden palpar. De hecho, el valor que cada persona le da a una marca va depender en gran medida de la experiencia individual que cada sujeto tiene con respecto a su producto o servicio (Stahl et al., 2012). Valor que ayuda a que la decisión de compra se facilite. Las marcas generan valor porque se convierten en señales que ayudan a identificar el producto y ayudan a reducir el proceso de compra (Saavedra, 2007). Lo importante en éste punto es lograr que lo que realmente conozcan los consumidores de una marca, sea lo que desean las compañías que asocien con la identidad que se quiere desarrollar, y por ende se fortalezca el Brand Equity (Cobb-Walgren et al., 1995).

Una marca fuerte genera lealtad lo que incide en la decisión de compra del consumidor, debido a que en el largo plazo, puede volver a las empresas estables, independientemente a las condiciones que varíen en el entorno de las mismas (García, 2005).

Lo anterior dará como resultado, una menor vulnerabilidad a la competencia, a pesar de que la competencia haga un gran esfuerzo por cautivar clientes de la categoría o segmento donde participe ésta marca fuerte, será muy difícil encontrar herramientas válidas, para superar el intangible que logra posicionar ésta marca fuerte en la mente del consumidor (Parsa et al., 2013).

Indiscutiblemente la marca se convierte en un racional importante en la toma de decisión de compra, porque puede asociar calidad, reconocimiento, estatus, estilo de vida, emociones y diversos intangibles que no tienen mucho que ver con el precio (Aaker, 2005a).

Si bien algunas marcas fuertes sean sustancialmente más costosas que otras, los consumidores logran mantener cierta constancia ante las acciones de la competencia en precio, mientras que por el contario si la marca fuerte reduce el precio, seguramente la 


\section{Capítulo1. Teoría de la marca}

respuesta de los consumidores ante éste movimiento será muy positiva (Villarejo-Ramos \& Sánchez-Franco, 2005) .

En la medida en que las marcas se vuelvan parte de la vida de los consumidores, es mucho más probable que los consumidores se conviertan en los protectores número uno de las marcas, y que las saquen a flote en momentos de crisis; una subida de precios para un producto cualquiera en situación de crisis, genera una pérdida sustancial en ventas (Ambler, 2012).

Según Kotler y Keller (2006a), el conocimiento de marca es lo que motiva las diferencias que se manifiestan en el Brand Equity. En sentido abstracto, el Brand Equity podría entenderse como un puente estratégico que se pone a disposición de los mercadólogos para conectar su pasado y su presente (Barwise, 1993).

\subsubsection{Medición de la Equidad de Marca}

El valor de una marca y por lo tanto su patrimonio, se deriva en última instancia, del comportamiento de compra de los consumidores (Aaker, 1991). El poder real de una marca está en los pensamientos, sentimientos, imágenes, creencias, actitudes y experiencias que tienen los consumidores (Thoma \& Williams, 2013).

El conocimiento que tiene el consumidor sobre una marca afecta su comportamiento y la manera cómo responderá frente a los productos, los precios, las comunicaciones y las estrategias de comercialización que diseñen las empresas (Lindstrom, 2011). La medición de la Equidad de Marca hay que entenderla desde tres perspectivas, tal como se muestra en la Figura 5: métricas financieras, métricas del poder de la marca y métricas de la experiencia del consumidor. 


\section{Capítulo1. Teoría de la marca}

Figura 5. Métricas de Brand Equity

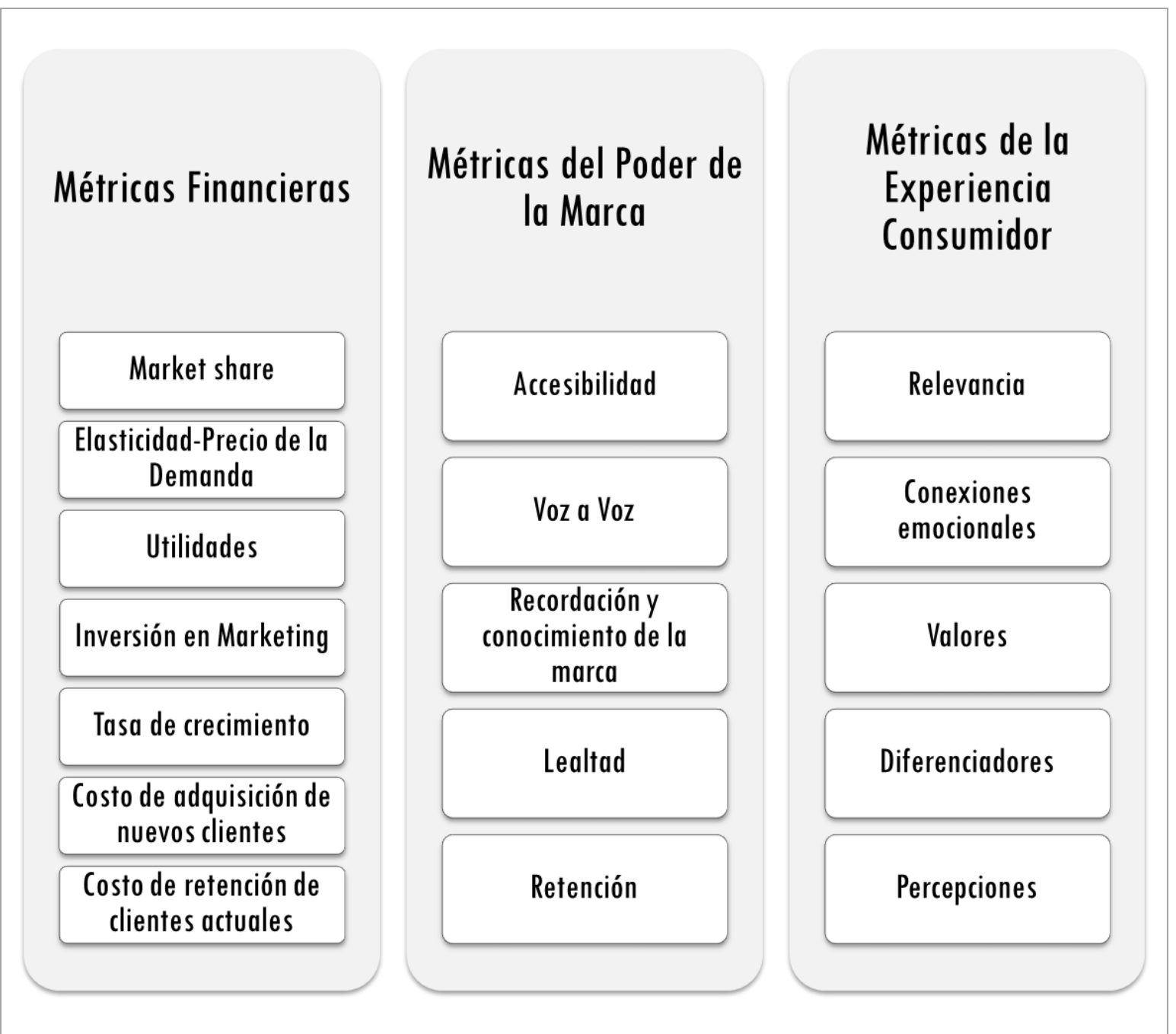

Fuente: Adaptado de Rafi et al. (2011).

Se consideran como métricas financieras de la Equidad de Marca: Market Share, la sensibilidad del precio, las utilidades, la inversión en marketing, la tasa de crecimiento periódico en el mercado y en el consumo, el costo de adquisición de clientes potenciales y el costo de la retención de clientes actuales (Reynolds \& Phillips, 2005; Aaker, 1996; CobbWalgren et al., 1995). Las métricas financieras rescatan la importancia de ver la marca como un activo (Morgan, 2011) y ayudan al empresario a confirmar si una marca es rentable. Sin embargo, su estudio debería ser la última parte del proceso en la medición del Brand Equity (Haigh, 2009). 


\section{Capítulo1. Teoría de la marca}

Las métricas del poder de una marca son un factor clave en el valor de la marca (Aaker, 1991). Medir la fuerza que tiene una marca, es evaluar su accesibilidad, el impacto del marketing viral, el nivel de recuerdo y de conocimiento de una marca, la lealtad y la retención en clientes y consumidores (Rafi et al., 2011). Esta medición debe hacerse permanente y ayuda a demostrar la fortaleza que tiene una marca en un mercado específico (Haigh, 2009).

Las métricas fundadas en la experiencia del consumidor ayudan a construir el valor de las marcas, no de las empresas (Aaker, 1991). Por lo tanto, es esencial hacer seguimiento a la confianza del consumidor y a sus conductas relacionadas con la marca (Strauss \& Neal, 2008). Si los consumidores creen en una marca, eso aumenta el capital de marca sobre aquellas que no creen o no son importantes para ellos (Zingshem, 2012). Para medir la experiencia se deben considerar las siguientes métricas: relevancia, conexiones emocionales, diferenciadores, valores y percepciones (Mirzaei et al., 2011). El resultado de esta medición ayuda a profundizar sobre cómo las personas se sienten frente a una marca y cómo se tomas las decisiones de compra (Buil et al., 2013). 


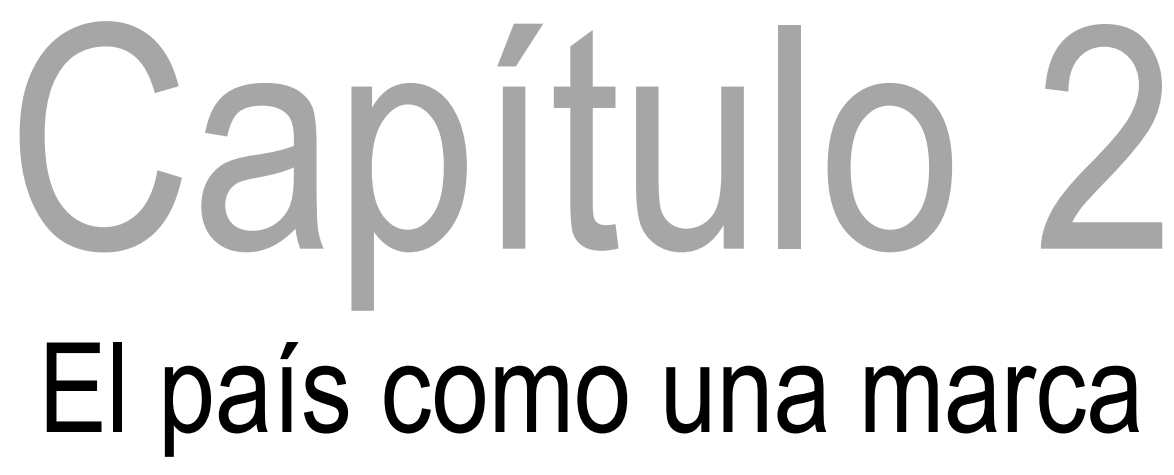




\section{Capítulo 2. El país como una marca}

Los avances en las comunicaciones, el desarrollo de una nueva cultura empresarial propia de los efectos de la globalización y los cambios en los modelos de negocio, están propiciando un fenómeno cada vez más fuerte, relacionado con el descubrimiento de una identidad propia y única de los países en el entorno empresarial (Negrea, 2012).

Una marca país es un proceso con múltiples facetas, hay críticos de marca país, que ya admiten su significado y su aplicabilidad en todas las naciones (Fan, 2010). El concepto de marca país ha sido objeto de un amplio uso y popularidad, sin embargo pocos autores han intentado definirlo con claridad. Eso ha llevado a una variedad de interpretaciones que han generado confusión (Szondi, 2010).

El segundo capítulo de la Tesis Doctoral se divide en dos secciones. La primera sección expone los conceptos de marca país, el proceso para construir una marca país, la relación entre imagen país y marca país, las diferencias entre imagen país y país de origen, y las métricas del posicionamiento de una marca país.

La segunda sección del capítulo complementa la conceptualización con un marco referencial de las experiencias de marca país en el continente americano. Se estudia el origen y evolución de 16 marcas de países norteamericanos, centroamericanos y suramericanos.

\subsection{Concepto de marca país}

El concepto de país hace referencia a un espacio geográfico y organización política, ocupado por un grupo de personas que comparten el mismo lenguaje, territorio y cultura. En este sentido, circunscribir a un país al concepto de marca, tiene como finalidad definir estrategias de posicionamiento y comunicación que permitan difundir una imagen positiva que sea reconocible en gran parte del mundo (Fischer et al., 2010).

El término marca país es tratado por diversos autores con distintas denominaciones pero cercanos significados.

Existen anglicismos que son homónimos al término de marca país como: Place Branding (Gertner \& Kotler, 2002), Nation Branding (Anholt, 2002); Destination Branding 


\section{Capítulo 2. El país como una marca}

(Ritchie et al., 1998); Country Branding (Olins, 2006) y Country of Origin (Papadopoulos \& Heslop, 1993). Se puede observar que existen diferencias entre los términos utilizados como homónimos de marca país. Las distintas acepciones acuñadas por los autores, además de tener propósitos diferentes, implican tipologías específicas en manejos de branding y en cuestiones legales.

Cuadro 5. Terminología en Branding

\begin{tabular}{|c|c|c|c|}
\hline Concepto & Distintivo & Propósito & Ejemplo \\
\hline $\begin{array}{c}\text { Marca País } \\
\text { (Country o Nation } \\
\text { Branding) }\end{array}$ & Imagen país & $\begin{array}{l}\text { Identidad nacional frente } \\
\text { audiencias internas y externas } \\
\text { para efectos de promoción y } \\
\text { pertenencia. }\end{array}$ & \\
\hline $\begin{array}{l}\text { Marca Destino } \\
\text { (Destination o } \\
\text { Place Branding) }\end{array}$ & $\begin{array}{l}\text { Lugar para } \\
\text { visitar }\end{array}$ & Promoción turística & \\
\hline $\begin{array}{l}\text { Hecho en } \\
\text { (Made In) }\end{array}$ & Equity de país & $\begin{array}{l}\text { Promover la capacidad del país } \\
\text { como proveedor de productos y/o } \\
\text { servicios. }\end{array}$ & MÉxICe \\
\hline $\begin{array}{l}\text { Denominación de } \\
\text { Origen } \\
\text { (Country of } \\
\text { Origin) }\end{array}$ & $\begin{array}{l}\text { Sello de } \\
\text { certificación de } \\
\text { origen de país }\end{array}$ & $\begin{array}{l}\text { Asociar un producto y/o servicio a } \\
\text { un país para efectos de } \\
\text { reconocimiento y garantía }\end{array}$ & \\
\hline
\end{tabular}

Fuente: elaboración propia. 


\section{Capítulo 2. El país como una marca}

En la teoría sobre marca país se identifican enfoques más centrados en el consumidor (Lightle, 2005) y otros en el valor de la marca (Anholt, 2002; Fan, 2010), pero algunos autores logran integrar las consideraciones relativas a las impresiones de quienes visitan y no han visitado un país (Pipoli, 2009; Papadopoulos \& Heslop, 1993).

El concepto de marca país nace de la necesidad de los sectores empresariales y los gobiernos por generar una identidad propia frente a los mercados internacionales (Gudjonsson, 2005). Marca país hace referencia a la aplicación de un marketing sofisticado combinado con técnicas del branding para cultivar el entendimiento de una nación (Pike, 2011).

El concepto de marca país se fundamenta en supuestos comunes que obligan a extraer algunas de las características principales de esta noción. Se entiende por marca país una estrategia de Estado orientada a capitalizar la reputación de un país en mercados internacionales (Jain \& Winner, 2013). Es un conjunto de actividades que contribuyen a crear la imagen de un lugar determinado (Chaves, 2011; Trajkov et al., 2012).

La marca país es una estrategia que identifica un destino, y permite a los visitantes elegir entre distintas alternativas; concepto que se ha incorporado en el campo del marketing contemporáneo (Tourist Destination Branding, 2012).

Tradicionalmente tres elementos componen el concepto de marca país: turismo, inversión extranjera y exportaciones (Harrison-Walker, 2011). Estas variables no representan sectores, por el contrario tienen un papel significativo en el mejoramiento de la reputación de un país. De acuerdo con Castrogiovanni (2007) el turismo es considerado por políticos y académicos como una solución para las economías más sensibles y que ayuda a conservar el patrimonio natural y cultural de una nación.

Para Fan (2010) la marca país es un área emergente de interés, que ha sido impulsada por profesionales ante la evidente necesidad conceptual.

Una marca país no es sinónimo de una estrategia promocional (Kaneva, 2011). La marca país refleja una visión holística de la imagen de un territorio específico que debe ser reforzada y enriquecida permanentemente por la inversión en comunicación del país de origen hacia el resto del mundo (Mihailovich, 2006). 


\section{Capítulo 2. El país como una marca}

El concepto de marca país es mucho más complejo (Chaves, 2011). El concepto de marca país se sustenta en la importancia que comienza a cobrar la percepción de los extranjeros y el país de origen en los mercados internacionales. La marca país usualmente ayuda a los gobiernos a entender el valor complejo de la reputación internacional y la cohesión interna (Anholt, 2005b). Una marca país tiene como finalidad consolidar el imaginario de los nacionales y alinear comunicaciones públicas, discursos cívicos y comportamientos sociales, todo lo anterior englobado en una cultura de marca apropiada por toda una sociedad (Anholt, 2007b). De acuerdo con lo anteriormente descrito, la marca país permite lograr un lugar en los mercados y en la mente de las personas (Fan, 2006).

La marca país es una herramienta para gestionar la competitividad de un país, en la medida que busca posicionarlo y generarle una identidad como la mejor opción para atraer a quienes buscan lugares para viajar, invertir, vivir o comprar (Fan, 2010) .

Los objetivos de la marca país son:

a. Generar una sola identidad que integre todas las actividades productivas del país (Stock, 2009).

b. Promocionar y posicionar una identidad clara, definida y unificada. Evitar los regionalismos (Dinnie, 2007).

c. Proyectar la imagen de un país productivo y exportador en el ámbito internacional (Dinnie et al., 2010).

d. Centrar en un solo concepto el esfuerzo de comunicación de un país ante los públicos nacionales e internacionales (Harrison-Walker, 2011).

e. Crear una cultura de valor nacional entre sus ciudadanos alrededor de elementos de identidad común altamente reconocidos (Foscht et al., 2008).

Una marca país ofrece diferentes beneficios como:

a. Mejora la imagen de un país (Capriotti, 2008).

b. Alinea la percepción de los ciudadanos hacia un mayor patriotismo y orgullo nacional (Van der Horst, 2010) . 


\section{Capítulo 2. El país como una marca}

c. Ofrece una ventaja competitiva a medida que los países compiten en tres indicadores específicamente: inversión, turismo y exportaciones.

d. Refuerza el concepto made in en las etiquetas de los productos que se comercializan en mercados internacionales.

La estrategia de marca país se replica en la generación de una mayor confianza interna y mejor desempeño externo del país (Szondi, 2010).

La formulación de la estrategia de marca país es tan importante como su implementación, la cual sucede cuando las personas experimentan realmente la marca permitiendo que se comiencen a formar actitudes y comportamientos positivos acerca del país (Anholt, 2007a).

La implementación de la marca país implica acciones que involucren a todos los grupos de interés en una ciudad, una región y un país con la finalidad de comprometerlos en el proceso de desarrollo y consolidación de una imagen con una fuerte proyección interna y externa (Madhavaram et al., 2005).

Anholt (s.f.) citado por Gabriel Terrés (2010) plantea que la marca de un país está sujeta a su reputación. Reputación que se sostiene si un país muestra indicadores positivos en marcas de exportación, los cambios de la política pública, la promoción turística y de inversión, la presencia de personas de ese país en el exterior y decisiones de la política pública (Terrés, 2010).

El desafío más crítico para una marca país es encontrar una estrategia que sea creíble, relevante para la audiencia de los consumidores, fiel a la realidad y a las aspiraciones del lugar, capaz de abarcar esta variedad de características sin llegar a ser un compromiso aburrido que pueda afectar la percepción de la población (Anholt, 2007a).

Otro desafío importante que enfrenta la marca de un país es la falta de unidad e integración de un propósito común, la dificultad en el establecimiento de objetivos y acciones concretas y medibles, sumado a la ausencia de conocimiento sobre marketing territorial (Anholt \& Hildreth, 2005a). 


\section{Capítulo 2. El país como una marca}

\subsubsection{Diferencias entre marca país y marca de un producto}

La construcción de marca país debe ser parte de un ciclo que se auto perpetúa, es decir, el país promueve sus marcas de bienes o servicios, y estos bienes o servicios promoverán a su vez, al país de origen (Bhakar et al., 2013). A veces funciona el ciclo, pero la relación entre marcas de productos y el país, no siempre es sencilla, debido a la similitud las marcas, los productos y los países.

Supphellen y Nygaardsvik (2002) explican que en principio diseñar un producto y diseñar una marca país es lo mismo; todo se fundamenta en identificar, desarrollar y comunicar los aspectos positivos del producto a un mercado meta específico. Sin embargo, el análisis de la identidad de un producto y de la percepción de su mercado objetivo, unido a las actividades que se involucran en la construcción de marca, es mucho más complejo para países que para productos.

La relación entre el producto y la marca país es mucho más compleja. Pueden existir similitudes entre los productos y las marca país, sin embargo, es muy distinto desarrollar una marca para un producto (marca comercial) que una marca para un país (Olins, 2006).

Como lo señala Philip Kotler (2006b), los productos, sus marcas y empaques pueden modificarse, los países no. Un país no puede cambiar sus playas o montañas, pero si puede atraer inversión extranjera, o modificar su actividad económica. Desde luego, una marca país tiene restricciones superiores y diferentes a lo que respecta el desarrollo de un producto (Kotler et al., 2007).

En su definición básica un producto es un bien físico o servicio, que satisface una necesidad. Un país tiene productos que a su vez están compuestos por bienes físicos, servicios e ideas, que combinados producen una experiencia para quien la visita, cualquiera que sea su propósito al hacerlo (Han \& Terpstra, 1988). La adecuada combinación de los bienes físicos, los servicios y la imagen de un país, es lo que hace que esta logre satisfacer las necesidades de los mercados a los que atiende, que como se verá posteriormente, son tan variados como sus componentes (Johansson et al., 1985; Maheswaran et al., 2013).

A continuación en el Cuadro 6 se explica las diferencias entre una marca país y una marca de un producto: 


\section{Capítulo 2. El país como una marca}

Cuadro 6. Diferencias entre marca país y marca de un producto

\begin{tabular}{|c|c|c|}
\hline Criterio & Marca país & Marca de un producto \\
\hline $\begin{array}{l}\text { Tipología de } \\
\text { compradores }\end{array}$ & $\begin{array}{l}\text { Residentes, turistas, inversionistas, } \\
\text { exportadores y el Gobierno }\end{array}$ & $\begin{array}{l}\text { Mercados de consumo (B2C) y } \\
\text { mercados corporativos (B2B) }\end{array}$ \\
\hline $\begin{array}{l}\text { Expectativas hacia } \\
\text { la marca }\end{array}$ & $\begin{array}{l}\text { Diferentes compradores tienen diferentes } \\
\text { expectativas de la marca país }\end{array}$ & $\begin{array}{l}\text { Las expectativas son uniformes } \\
\text { hacia la marca }\end{array}$ \\
\hline $\begin{array}{l}\text { Comparar con } \\
\text { otras marcas }\end{array}$ & Difícil & $\begin{array}{l}\text { Fácil. El comprador tiene muchas } \\
\text { posibilidades de elección entre un } \\
\text { amplia oferta }\end{array}$ \\
\hline $\begin{array}{l}\text { Estrategia de } \\
\text { Comunicación }\end{array}$ & $\begin{array}{l}\text { Diferentes mensajes para diferentes } \\
\text { segmentos del mercado }\end{array}$ & $\begin{array}{l}\text { Igual mensaje para todos los } \\
\text { segmentos del mercado }\end{array}$ \\
\hline $\begin{array}{l}\text { Estrategia de } \\
\text { Precio }\end{array}$ & No es relevante & $\begin{array}{l}\text { Puede desarrollar una estrategia de } \\
\text { precio única }\end{array}$ \\
\hline $\begin{array}{l}\text { Estrategia de } \\
\text { Posicionamiento }\end{array}$ & $\begin{array}{l}\text { Se puede formular un posicionamiento } \\
\text { integral o tres estrategias particulares } \\
\text { para turismo, inversión y exportaciones }\end{array}$ & Estrategia de posicionamiento única \\
\hline $\begin{array}{l}\text { Estrategia de } \\
\text { Distribución }\end{array}$ & $\begin{array}{l}\text { Utiliza varios canales para atraer a } \\
\text { compradores hacia la marca país }\end{array}$ & $\begin{array}{l}\text { Utiliza varios canales para la venta y } \\
\text { disponibilidad de la marca comercial }\end{array}$ \\
\hline $\begin{array}{l}\text { Asociación del } \\
\text { comprador con la } \\
\text { marca }\end{array}$ & $\begin{array}{l}\text { Es a largo plazo para todo tipo de } \\
\text { compradores. En el caso de } \\
\text { inversionistas y exportadores hay un } \\
\text { asociación financiera y para los turistas } \\
\text { hay una asociación emocional y } \\
\text { experiencial }\end{array}$ & $\begin{array}{l}\text { La asociación está sujeta a múltiples } \\
\text { factores: momento de la compra, } \\
\text { lealtad a la marca, calidad, atención } \\
\text { al cliente, competencia, necesidad } \\
\text { percibida, entre otros. }\end{array}$ \\
\hline
\end{tabular}

Fuente: Adaptado de Khanna (2011).

Es más complejo obtener una mezcla de comunicación integrada de la marca país debido a que los países tienen un poder limitado para alterar sus propias marcas (Pucci et al., 2013). Un país no puede reemplazar sus playas con montañas, ni cultivar plátanos si su clima favorece la nieve (Supphellen \& Nygaardsvik, 2002). Los productos se pueden modificar, se pueden mejorar o reemplazar, los países no tienen estas opciones (Kotler et al., 2007; Ritson, 2010). Distintos países o regiones siempre han sido asociados con una competencia específica: Chile y sus vinos, Francia y sus quesos, Suiza y sus relojes, Italia y su pasta, Australia con turismo, entre otros (Uddin et al., 2013). 


\section{Capítulo 2. El país como una marca}

Pero en años recientes se ha observado una abundante investigación que señala que los consumidores en distintos países responden de maneras diferentes a las características del país de origen, y que estas respuestas pueden variar en el tiempo (Deshpandé, 2007).

\subsubsection{Proceso de construcción de la marca país}

Una marca país, implica una filosofía de desarrollo urbano y regional, que hace parte de un proceso de planeación estratégica en el que el país complementa sus programas económicos tradicionales, con estrategias de marketing para conseguir ventajas competitivas (Nikolova \& Hassan, 2013). Los constructores de la marca país son empresas, marcas líderes y referentes de la sociedad civil. A continuación se explican los pasos para desarrollar la marca país (Mukoma, 2008):

a. Involucre al gobierno, a las empresas, a los medios, las artes y la educación.

b. Consulte a los ciudadanos y a los líderes de opinión para conocer la percepción sobre su país a nivel interno y externo.

c. Establezca una idea clara y positiva de marca y de su posicionamiento.

Una marca país no se utiliza reducir la brecha entre percepción y realidad, sino para representar el elemento diferenciador de un país con respecto a otro. Tampoco se construye sobre las características de su población, sino por el contrario, por las características del país (Anholt, 2007b).

La marca país se construye a partir de tres definidos para el marketing de lugares: grupo de planeación, factores de mercado y mercados meta (Ver Figura 7) (Kotler et al., 2007).

En el nivel inicial, es decir, grupo de planeación, es donde se define la oferta de un país. En él se cumplen tres funciones primordiales: hacer el diagnóstico de la comunidad, construir su visión a largo plazo y desarrollar planes de acción (García et al., 2012).

En el segundo nivel, se encuentran los factores de mercadeo donde se definen los atributos que son más sensibles para el mercado al que se dirige. 


\section{Capítulo 2. El país como una marca}

A través de la infraestructura, la estrategia de marca país se asegura de proveer todos los servicios básicos para los diferentes grupos de demanda (Haven-Tang et al., 2007). A través de las atracciones, el país eleva el nivel de calidad de vida de sus residentes, visitantes y se hace más atractiva para los inversionistas y empresarios (Olins, 2006).

La marca país necesita comunicar a través de una poderosa imagen su oferta y sus ventajas; y además busca garantizar que todos los demás elementos funcionen a través de su gente, sus líderes y sus instituciones (Ren \& Blichfeldt, 2011).

En el tercer nivel se encuentran los mercados meta hacia los cuales se dirigen todos los esfuerzos anteriores: Los turistas que asisten motivados la recreación, los eventos y convenciones, los exportadores, los inversionistas y las empresas que buscan locaciones para sus capitales y finalmente las grandes corporaciones que buscan lugares para instalar su casa matriz (Kotler, Haider, Gertner, \& Rein, 2007).

Figura 6. Niveles del marketing de lugares

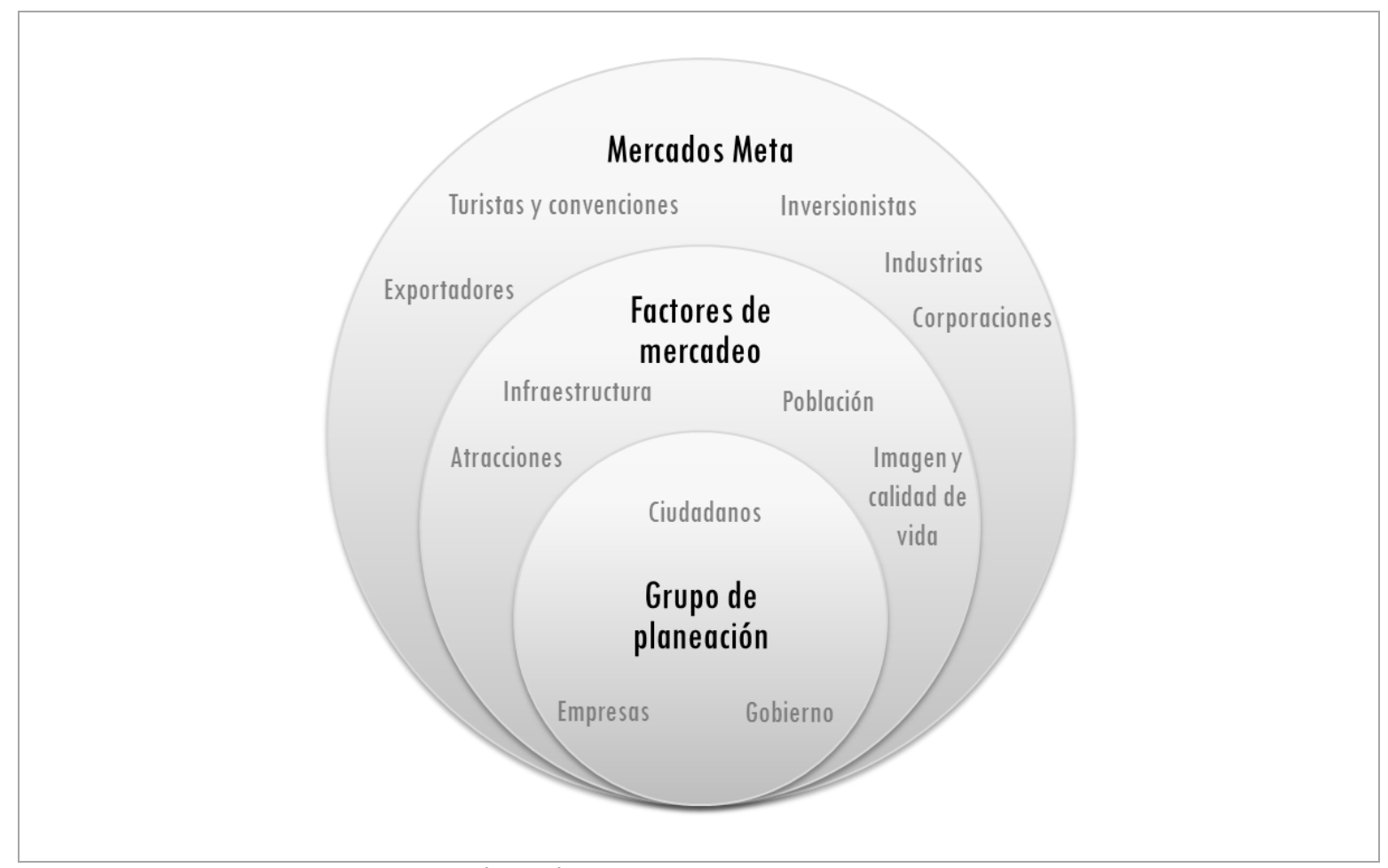

Fuente: Adaptado de Kotler et al. (2007). 


\section{Capítulo 2. El país como una marca}

Una estrategia de marketing aplicada a un país se considera exitosa en la medida en que permita que esta satisfaga las necesidades de su comunidad permanente (residentes, trabajadores, empresas) y cumpla con las expectativas de sus nuevos visitantes, inversionistas o compradores (Gudjonsson, 2005). El país debe garantizar una oferta de productos y servicios que mantenga satisfechos a sus ciudadanos, empresarios y visitantes actuales y que ayude a mostrarse atractivo ante los nuevos o potenciales (Żemła, 2012).

La construcción de la marca país debe iniciar con un diagnóstico como punto de partida tanto en el ámbito interno como externo. Este diagnóstico tiene por objetivo entender qué está ocurriendo, cómo es percibida la imagen y la marca de un país (Prebežac \& Mikulić, 2008). En este diagnóstico se determinan también los contenidos culturales e históricos y los valores que fundamentarán la marca (Bai \& Hu, 2013). Dentro del diagnóstico hay que incluir un objetivo adicional: entender las necesidades, deseos y expectativas de los actores vinculados al proceso, tanto los internos como los externos (Mukoma, 2008). Esta información permite evaluar las condiciones en que es percibida la imagen lo que ayudará a diseñar la promesa de la marca o el valor agregado de un país determinado (Lee et al., 2010). Es posible identificar que hace al país único y valioso para sus mercados (Terrés, 2010).

La participación del sector público, privado y académico es esencial en el proceso de construcción de marca (Raharjo, 2012). Esta participación se logra a través de campañas de sensibilización que articulen los intereses de estos tres sectores en un proyecto viable y de largo plazo que defina en qué lugar del mapa competitivo se desea ubicar al país (Hankinson, 2012).

El paso a seguir es definir los grupos de interés a los cuáles se pretende mercadear un país para posteriormente diseñar estrategias de comunicación en función de cada uno de ellos: turistas, inversionistas, compradores, de interés táctico, coyuntural o estratégico (Sartori et al., 2012). Los grupos de interés cumplen un rol fundamental en el proceso de creación de una marca país. Conformados por residentes, exportadores, turistas, inversionistas, empresarios, organizaciones culturales y Gobierno, entre otros; son los elementos que caracterizan una marca país (García et al., 2012; Kemp \& Williams, 2012).

Convocar y sensibilizar a los grupos interés en la generación y consolidación de una marca país es una acción compleja (García et al., 2012). 


\section{Capítulo 2. El país como una marca}

La complejidad aumenta si se tiene en cuenta que los procesos de cambio de un lugar obedecen a ajustes culturales y de valores que toman amplios periodos de tiempo para sufrir modificaciones de fondo (Kemp \& Williams, 2012). Otra particularidad es que los grupos de interés que construyen la marca país son a su vez clientes de la misma (Morgan et al., 2003).

Los creadores de la marca país se vuelven usuarios de la misma (Olins, 2006). Por esta razón, lo más importante es determinar los valores emocionales y racionales de la marca en función de los mercados objetivo (Denman, 2012). Es necesario ir más allá de una propuesta gráfica, hay que construir la personalidad de la marca a partir de los valores e historia de un país (Fan, 2010).

En el proceso de construcción de una marca país hay que definir con claridad a qué mercados se dirige (Melewar et al., 2013). El Cuadro 7 resume los mercados que debe atender una marca país. Se identifican los diferentes interrogantes a los que la marca debe responder, así como sus objetivos para cada mercado.

\section{Cuadro 7. Mercados para una marca país}

\begin{tabular}{|l|c|c|c|}
\hline Mercado objetivo & Sector & $\begin{array}{c}\text { Decisiones influenciadas } \\
\text { por la marca país }\end{array}$ & Objetivo de la marca \\
\hline $\begin{array}{l}\text { Inversionistas, } \\
\text { empresarios }\end{array}$ & $\begin{array}{c}\text { Inversión, } \\
\text { empresariado }\end{array}$ & $\begin{array}{c}\text { ¿Dónde ubicar inversiones } \\
\text { de capital, oficinas y } \\
\text { plantas? }\end{array}$ & Atraer recursos a largo plazo \\
\hline $\begin{array}{l}\text { Turistas y visitantes } \\
\text { temporales }\end{array}$ & $\begin{array}{c}\text { Turismo y } \\
\text { eventos }\end{array}$ & $\begin{array}{c}\text { ¿A dónde ir de vacaciones? } \\
\text { ¿Dónde asistir a eventos y } \\
\text { convenciones? }\end{array}$ & Atraer visitantes temporales \\
\hline Compradores & Comercio & $\begin{array}{c}\text { ¿Dónde comprar productos } \\
\text { y servicios? }\end{array}$ & $\begin{array}{c}\text { Aumentar las ventas de la } \\
\text { producción local }\end{array}$ \\
\hline $\begin{array}{l}\text { Residentes y } \\
\text { trabajadores }\end{array}$ & $\begin{array}{c}\text { Comunidad } \\
\text { local y } \\
\text { mercado } \\
\text { laboral }\end{array}$ & ¿Dónde vivir y trabajar? & $\begin{array}{c}\text { Llenar las expectativas de la } \\
\text { población natural y captar } \\
\text { mano de obra calificada }\end{array}$ \\
\hline
\end{tabular}

Fuente: Adaptado de Morgan (2011).

Una vez definido el mercado para la proyección de una marca país se formulan estrategias de marketing con fines específicos. Estas estrategias de marketing tienen como finalidad promover una marca país y varían considerando cuáles se van a utilizar para turismo, exportaciones o inversión (Martínez, 2007). Para turismo y exportaciones a menudo 


\section{Capítulo 2. El país como una marca}

se emplea una segmentación diferenciada de carácter masivo, y se utilizan estrategias de comunicación como: relaciones públicas, marketing directo y publicidad (Rasmussen \& Merkelsen, 2012). Mientras que para la variable de inversión la estrategia de segmentación es concentrada, y se utilizan las ventas personales y relaciones públicas para atraer a los mercados internacionales (Jain \& Winner, 2013).

La construcción de una marca país requiere del diseño de herramientas de comunicación efectivas que permitan fortalecer las relaciones internacionales en sectores como el turismo, la inversión, las exportaciones, y auspiciar encuentros oficiales entre los países, la proyección nacional, la estandarización de los símbolos patrios y la promoción de conciencia ciudadana (Dinnie, 2008).

El objetivo principal del proceso de construcción de marca es atraer a un gran número de prospectos en turismo, inversiones y exportaciones (Muñiz \& Cervantes, 2010).

Con el propósito de atraerlos, es esencial construir una plataforma estratégica de marcas, en ámbitos tanto externos como internos que incida en el proceso de toma de decisiones de la población objetivo (Żemła, 2012). Widler (2007) citado por Tatevossian (2008) plantea que si la marca de un país está destinada a ser una estrategia nacional, deberá ser promovida por líderes de opinión y expertos, constituida en un punto de referencia para el mercado interno y externo, convertida en un imán para las inversiones y el turismo, y principalmente por involucrar a los ciudadanos.

Un país necesita promocionarse a través de una imagen fuerte y un adecuado plan de comunicación articulado a un plan de seguimiento, ya que la ejecución de la marca país logrará materializar los intereses propios de la marca y de la imagen país (Madhavaram et al., 2005). Si bien la imagen y el mensaje central deben tener unidad en el fondo de la comunicación de los países, es necesario realizar adaptaciones en función del grupo al cual se dirige (Robichaud et al., 2012). En el Cuadro 8 se puede observar los grupos de interés a los que se orienta una estrategia de comunicación de un país:

Cuadro 8. Principales grupos de interés a los que se orientan la estrategia de comunicación de un país

\begin{tabular}{|l|l|}
\hline Grupo & Objetivo de Comunicación \\
\hline Residentes & Atraer nuevos residentes que aumenten la fuente de ingresos del país \\
\hline
\end{tabular}




\section{Capítulo 2. El país como una marca}

\begin{tabular}{|l|l|}
\hline Visitantes & Atraer nuevos visitantes y conocer la percepción de los actuales \\
\hline Gerentes & $\begin{array}{l}\text { Atraer nuevas compañías y conocer la percepción de las que actualmente } \\
\text { tienen sede en el país }\end{array}$ \\
\hline Inversionistas & $\begin{array}{l}\text { Atraer sectores puntuales de inversionistas del mismo país o grupos } \\
\text { financieros que faciliten la obtención de recursos }\end{array}$ \\
\hline
\end{tabular}

Fuente: Adaptado de Kotler et al. (2007).

Los residentes por ejemplo, construyen la marca a través de su cotidianidad (Kemp $\&$ Williams, 2012). Son ellos quienes a diario evidencian el carácter de un país (Zouganeli et al., 2012). Igualmente son clientes, ya que demandan productos y servicios del país que busca satisfacerlos para asegurar que permanezcan en él y que además sean vehículos para promocionarlo (Pipoli \& Flores, 2006).

La creación de una marca país en función de los grupos de interés, es uno de los mayores retos ya que debe envolver todo lo que el país representa para los mercados, crear un vínculo de identidad con ellos, pero al mismo tiempo mostrarse fácil de entender (Harrison-Walker, 2011). La importancia de la marca radica en que esta es la síntesis de un país, lo que muestra su esencia y lo que comunica qué la diferencia de otros países (Kavaratzis \& Hatch, 2013).

Una vez definida la marca, la audiencia y el mensaje de acuerdo con el objetivo, se definen las herramientas a través de las cuales se interactuará con el mercado. Dichas herramientas son muy variadas y van desde la publicidad tradicional en medios como la televisión, el radio y la prensa, hasta la generación de comunidades virtuales en Internet, pasando por la realización de eventos y actividades de relaciones públicas (Dinnie, 2008). 


\section{Capítulo 2. El país como una marca}

En algunos países, los ministerios y las agencias se encargan de comunicar coherentemente la marca país, con el fin de evitar confusiones e interpretaciones diferentes sobre su significado y cómo éste se relaciona con su imagen ante el mundo (Sartori et al., 2012). Por esta razón, el proceso debe ser dirigido por el nivel más alto del gobierno, como un Alcalde, Ministro o Presidente (Morgan et al., 2003).

El siguiente paso en la construcción de una marca país es determinar cuál es su propuesta de valor. Propuesta que se sustenta en su misión, la cual se basa en un acto de reputación sobre el desempeño de un país, ahora y en el futuro, en la cual se incluye:

a. Los productos que se exportan (Aitken \& Campelo, 2011).

b. La manera en que se promueve al país en el comercio internacional en términos de turismo, inversión y contratación interna (Govers \& Go, 2009).

c. El comportamiento de la economía y la política exterior, y la manera en que esta información está siendo comunicada (Kemp \& Williams, 2012).

d. La manera en que promueve, representa y comparte su cultura en el exterior (YoungA \& Yongjun, 2013).

e. El comportamiento de sus ciudadanos en el extranjero y su trato con visitantes por dentro y por fuera del país (Yang et al., 2008).

f. La promoción de la imagen país en los medios internacionales (Valls, 1992).

g. Los gremios y asociaciones a las que pertenece la marca (Sartori, et al., 2012).

h. La manera en que compite con otros países en deporte y entretenimiento (Lubowiecki-Vikuk \& Basiñska-Zych, 2011).

i. Lo que le da al mundo y lo que recibe a cambio (Fan, 2010).

Cada país decide cómo formulará la estrategia de marca país (Anholt, 2010). Independiente de la decisión que se tome debe tener una visión holística, que integre a los agentes internos y externos necesarios para sensibilizar su implementación y esperar resultados acordes a la realidad de su territorio (Dinnie, 2008). 


\section{Capítulo 2. El país como una marca}

\subsubsection{La marca país desde la perspectiva del marketing territorial y del marketing turístico}

El término de marketing territorial comúnmente se ha referido a un marcado esfuerzo de los gobiernos de países, regiones y ciudades y de los grupos industriales que le apuntan al mercadeo de territorios y sectores que estos representaban (Rector et al., 2013).

El intento de estos esfuerzos consiste en lograr varios objetivos tales como incrementar las exportaciones, proteger los negocios y el comercio local de los competidores extranjeros (inclusive dentro del mismo país se busca la protección entre regiones y ciudades), atraer y retener factores de desarrollo que logran posicionar a un territorio en su economía local y de exportación y en sus lineamientos políticos y sociales (Gertner \& Kotler, 2002) .

La globalización ha sido el punto de partida frente a la creciente rivalidad y competencia que se ha evidenciado en los últimos años entre los territorios (regiones, ciudades y países), generando como resultados la adopción e implementación de estrategias de diferenciación para estimular el turismo y la inversión económica (Clifton, 2011). En este sentido, una estrategia de marketing territorial se convierte en un propósito nacional de capitalización de reputación en el exterior (Ferraz Sexto, 2001).

El concepto de marketing territorial surge de la necesidad de diferenciación de los territorios a través de la identificación de las características propias, creando incentivos para los ciudadanos y residentes, comunicando de manera correcta una imagen de territorio que sea consecuente con la realidad y exhibiendo las ventajas competitivas de los territorios (Meyronin, 2009).

En los años 70 se comienza a evidenciar las primeras prácticas del marketing territorial en Estados Unidos, especialmente en ciudades como New York y Los Ángeles. En la década de los 80 llegó a Europa (Flipo \& Texier, 1992). De esta manera se comenzó a dar respuesta a nuevas necesidades de diferenciación y reconocimiento, que surgen con el fin de lograr desarrollo territorial (Benko, 2000). 


\section{Capítulo 2. El país como una marca}

El marketing territorial cobra relevancia a partir de la década de los 80 's, dado que su práctica ha presentado cierta intensificación y ha incrementado el nivel de importancia acerca del origen de los productos y de las empresas (Āzena \& Keišs, 2009). El conocido made in o hecho en rescata los valores regionales a través de un producto o una marca en un contexto globalizado (Suri \& Thakor, 2013).

El marketing territorial, inicialmente se crea para promover únicamente el turismo, las inversiones y los grandes acontecimientos deportivos y culturales (Hatem, 2007).

Fue más adelante que se comenzó a incluir el estudio de las percepciones de los visitantes y residentes hacia un territorio (Fernández \& Paz, 2005). Siendo esta última variable el eje central del marketing territorial.

Los cambios en el mercado le han dado un sustento a la ejecución del marketing territorial como una actividad para vender los atributos de una determinada región, sustentada especialmente en acciones de comunicación (Benko, 2000).

Factores como la globalización, el progreso de los mercados, las nuevas ofertas y competidores han jugado un papel importante en el marketing territorial y en lo que se refiere a marca país, no solo en su creación sino también en su propagación (Le marketing territorial, 2009). Son estos factores los que han generado las condiciones adecuadas para interpretar un territorio como un producto promocionable en mercados internacionales.

La estrategia de marketing territorial es la base de todas las estrategias de mercadeo que se realicen a nivel de país, y que integra regiones y ciudades (Flipo \& Texier, 1992). Estrategias todas debidamente alineadas para ser consecuentes con lo que se quiere comunicar y con la imagen que se desea proyectar (Boisier, 2010).

La finalidad de una estrategia de marketing territorial pretende posicionar la imagen de un país a nivel internacional para lograr diferenciación y reconocimiento, y así desarrollar el turismo, la economía y la inversión de un territorio (Proulx \& Tremblay, 2006). 


\section{Capítulo 2. El país como una marca}

El principal objetivo del marketing territorial es, por un lado, responder a las necesidades y expectativas de los individuos y organizaciones del territorio y, por otro, mejorar a corto plazo la calidad y la competitividad global de la ciudad en su ambiente (López, 2006). La clave para la sostenibilidad de las regiones se encuentra en el desarrollo de una perspectiva independiente y el descubrimiento de su potencial endógeno (European Commission, 1999).

El marketing territorial surge como el mecanismo para gestionar la competitividad de los países con la finalidad de aplicar las herramientas de mercadeo a la construcción de su posicionamiento, entendido como el lugar que el país quiere ocupar en las mentes de quienes conforman sus mercados (Meyronin, 2009).

Similar al concepto de marca país, el marketing territorial pretende posicionar la imagen de un territorio a nivel internacional para lograr diferenciación y reconocimiento, y así desarrollar el turismo, la economía y la inversión de un territorio (Muñiz \& Cervantes, 2010). El marketing territorial fortalece a las ciudades y territorios como centros políticos, económicos, sociales y culturales, haciéndolos ver como lugares de preferencia tanto para inversionistas como para turistas; proporcionándoles valor e identidad frente a otros territorios (Hansen, 2010).

La relación entre el marketing territorial y la marca país se fundamenta en cuatro factores fundamentales (Valls, 1992): a) la internacionalización de las economías, b) el nuevo papel de los Estados y de las administraciones públicas en la promoción de la economía, c) la audio visualización de la sociedad y d) la proliferación de nuevos productos.

El marketing territorial abarca todo tipo de territorios como ciudades, regiones, lugares y países. La marca país se concentra en un solo territorio, el país. Sin embargo, hay un tercer concepto que motiva su estudio y que entra en la tríada: el marketing turístico. El cual consiste en un conjunto de acciones de marketing que promocionan un lugar desde la perspectiva del turismo (Kotler et al., 2003). 


\section{Capítulo 2. El país como una marca}

El concepto de marca país va más allá de crear una imagen o de atraer turistas a una nación, está más relacionada a las relaciones políticas de un país y es un punto de partida para negociaciones internacionales, es una fotografía del entorno completo de un país (Moilanen \& Rainisto, 2009). Este concepto se deriva de la teoría del marketing territorial (Dinnie, 2008).

Una vez conceptualizado el marketing territorial y la marca país, entra en el estudio un tercer protagonista: el marketing turístico. El marketing como un concepto está evolucionando rápidamente y con gran proyección para el turismo (Gustavo, 2013). Como actividad productiva, el turismo genera crecimiento económico y bienestar a una población (Mei et al., 2012).

El marketing turístico es una actividad que reduce la pobreza, genera empleos y proporciona calidad de vida (Kotler et al., 2007). Para que un país se desarrolle turísticamente, su geografía, su población e infraestructura deben contar con elementos que alcancen niveles de cierta calidad y singularidad como para despertar el interés de viajar o hacer negocios en personas no residentes (Serra Cantallops, 2002).

El marketing turístico es un proceso sistemático de actividades de negocio que tiene como propósito atraer y fidelizar a turistas hacia un destino específico (Roche, 2012). Su propósito está orientado a la promoción de un lugar turístico, centrando su intención en una actividad económica (Borma, 2012).

La marca país y el marketing turístico coinciden en el impulso que quieren otorgarle al sector turístico, sin embargo, la marca país involucra la inversión extranjera directa y las exportaciones en la construcción de una reputación de un país en mercados internacionales (Dinnie, 2008). Se diferencia de una marca turística porque integra todos los atributos de un país. La marca turística es excluyente, solo pretende institucionalizar a un lugar como destino turístico (Servicio Nacional de Turismo, 2008). En este punto converge un igual propósito para el marketing territorial, la marca país y el marketing turístico, como se puede observar en el Cuadro 9: 


\section{Capítulo 2. El país como una marca}

Cuadro 9. Comparativo de conceptos de marca país, marketing turístico y marketing territorial

\begin{tabular}{|c|c|c|c|}
\hline Criterio & Marca país & Marketing Turístico & Marketing Territorial \\
\hline Objetivo principal & $\begin{array}{l}\text { Lograr buena } \\
\text { reputación de un país }\end{array}$ & $\begin{array}{l}\text { Promoción del destino, } \\
\text { satisfacción de las } \\
\text { necesidades de los } \\
\text { turistas y comunidad } \\
\text { local }\end{array}$ & $\begin{array}{l}\text { Creación de imagen y } \\
\text { percepción de un } \\
\text { territorio con el fin de } \\
\text { lograr una } \\
\text { diferenciación }\end{array}$ \\
\hline Fundamentación & $\begin{array}{l}\text { Se basa en los } \\
\text { objetivos políticos y } \\
\text { económicos logrados } \\
\text { en una país }\end{array}$ & $\begin{array}{l}\text { Se basa en las } \\
\text { experiencias de los } \\
\text { turistas }\end{array}$ & $\begin{array}{l}\text { Se basa en las } \\
\text { características } \\
\text { diferenciadoras de un } \\
\text { territorio y en las } \\
\text { percepciones }\end{array}$ \\
\hline Consecuencias & $\begin{array}{ll}\text { - } & \text { Genera inversión } \\
\text { extranjera } \\
\text { - } & \text { Credibilidad del } \\
\text { desarrollo de un } \\
\text { país } \\
\text { - } \quad \text { Confianza en un } \\
\text { país } \\
\text { - } \quad \text { Posicionamiento de } \\
\text { un país }\end{array}$ & $\begin{array}{ll}\text { - } & \text { Genera impactos } \\
\text { económicos } \\
\text { - } \quad \text { Facilita objetivos de } \\
\text { desarrollo regional } \\
\text { - } & \text { Satisface tanto a } \\
\text { turistas como a } \\
\text { residentes locales }\end{array}$ & $\begin{array}{ll}\text { - } & \text { Genera impactos } \\
\text { económicos y } \\
\text { políticos } \\
\text { - } \quad \text { Ayuda al desarrollo } \\
\text { de un país } \\
\text { - Satisface las } \\
\text { necesidades de } \\
\text { personas y } \\
\text { empresas locales } \\
\text { - Posiciona un } \\
\text { territorio y da bases } \\
\text { para estrategias } \\
\text { posteriores }\end{array}$ \\
\hline
\end{tabular}

Fuente: Adaptado de Fan (2010).

Un elemento que es transversal a los tres conceptos abordados es la reputación (Anholt, 2005b). Los territorios, los destinos turísticos y los países tienen como propósito misional cuidar su reputación en mercados internacionales.

La reputación juega un papel muy importante para la inversión extranjera, ya que de ella depende muchas veces el desarrollo económico de un país (Prado, 2007; Stock, 2009). La marca país es un instrumento de gestión territorial, que media por lograr unir la oferta con la demanda de una país (Żemła, 2012).

La marca país logra hacer visible el marketing territorial, integra los productos, las organizaciones y la imagen que representa un país (Anholt, 2008a). La marca refleja una identidad, que se convierte en la esencia de la existencia de la empresa o producto y enmarca de principio a fin todos los objetivos y las metas, tratando de crear un estilo propio que le permita posicionar su nombre en el mercado, consolidando una reputación y reconocimiento a partir de características propias e inconfundibles (Robles, 1996). 


\section{Capítulo 2. El país como una marca}

El marketing territorial está sustentado en las imágenes de lugares, que es a su vez el sujeto de estudio de la noción de imagen de producto de un país; ambas nociones están enfocadas en cómo las imágenes de territorios pueden ser utilizadas para hacer mercadeo en otros lugares o en ellos mismos (Meyronin, 2009). Esto significa que la convergencia entre estas dos áreas representa un importante desarrollo el cual es posible que genere un gran impacto a corto y largo plazo, en mercados y en sistemas de mercadeo a nivel global y en cómo los dirigentes de empresas y gobiernos perciben sus roles en los contextos globales y locales (Laxe \& Palmero, 2009).

Un error muy común se da por la falta de conocimiento por parte de las compañías, que no entienden el efecto real de la imagen de un territorio en sus negocios, y esto se da a su vez porque muchas compañías aun ven su mercado netamente nacional y tratan a su mercado como único (Morgan et al., 2003).

Otro error es el hecho de creer que la imagen de un territorio o país es completamente independiente de los productos que se producen en este. El hecho de tener una buena reputación en un territorio específico ayuda a respaldar a los productos que se producen o fabrican en ese lugar. Así mismo una experiencia desfavorable con los productos de un territorio afecta de manera negativa la imagen de un destino (Anholt, 2007a).

Los países y territorios deben cuidar la calidad de sus productos, claramente esta es una carta de presentación frente a los demás territorios (Suri \& Thakor, 2013). Hay países que sus productos no gozan de un buen prestigio por su baja calidad, este factor afecta directamente la percepción de un lugar y perjudica su productividad (Wang et al., 2012).

El desarrollo y la evolución son conceptos que evidentemente no son estáticos. Los territorios se encuentran inmersos en este tipo de conceptos, no por el hecho de que un lugar haya implementado una estrategia de marketing exitosa en determinado tiempo significa que la estrategia tenga una duración infinita (Āzena \& Keišs, 2009).

Siempre se debe buscar la evolución y el cambio adaptado a las necesidades que surgen día a día. 


\section{Capítulo 2. El país como una marca}

El éxito de que un territorio obtenga beneficios tangibles a través de sus estrategias de marketing implica una observación permanente de su capacidad de adaptación con el fin de posicionarse frente a los demás territorios de una manera diferente y sobresaliente (Boisier, 2010).

Muchas veces esta práctica se puede confundir con el proceso desarrollado por el marketing territorial. Aunque la esencia del resultado sea el mismo, el enfoque es diferente.

Tanto la marca país como el marketing territorial tienen como objetivo aplicar estrategias del marketing convencional con el interés de mercadear un espacio como un producto, el posicionamiento y la experiencia serán diferentes (Paz, 2006).

La diferenciación está en que mientras una marca país promueve a una nación, el marketing territorial hace referencia a espacios más reducidos, tales como ciudades y barrios (Proulx \& Tremblay, 2006).

\subsubsection{Relación entre imagen país y marca país}

Un elemento relevante en el desarrollo de la competitividad de un país es la construcción y consolidación de su imagen en mercados nacionales e internacionales (Yang et al., 008).

La imagen de un país es la percepción que tienen los consumidores directos, indirectos, reales y potenciales de los países (Valls, 1992). Esta percepción de los consumidores es equivalente a la suma de todos los elementos que componen el país, más los elementos que se generan para comunicar las características del país (Hildreth, 2008). La percepción de un país contiene connotaciones diferenciadoras (Jetter \& Chen, 2011).

El concepto de imagen país surge de la necesidad de diferenciación de los territorios a través de la identificación de las características propias de cada territorio. Lo anterior permitiré crear incentivos para los ciudadanos y residentes del territorio, comunicar de manera correcta una imagen de territorio que sea consecuente con la realidad y mostrar las ventajas competitivas de los territorios (Souiden et al., 2011).

El concepto de imagen país ha estado asociado al conjunto de percepciones que tienen las personas sobre los atributos originarios de un país determinado (Madichie \& Yamoah, 2006). 


\section{Capítulo 2. El país como una marca}

Entendiendo la percepción como la forma que un individuo entiende al mundo, es la manera cómo interpreta estímulos (Arellano, 2002). Los estímulos que los consumidores reciben, no siempre se perciben en forma real. Cada persona ajusta la información que recibe de acuerdo a un marco mental de referencia (Solé, 2003).

Mazzarol et al. (2007) citados por Hanna y Rowley (2011) indican que el voz a voz. sigue siendo una poderosa forma de comunicación y que afecta directamente la percepción.

La imagen país es un conjunto de percepciones, imágenes mentales o impresiones que tiene un público sobre un país (Balabanis \& Diamantopoulos, 2011). Percepción que se construye desde tres fuentes: la experiencia, medios y líderes de opinión, y los grupos de referencia. Los consumidores construyen una percepción global de un país en función de la experiencia positiva o negativa previa con la comercialización de sus productos (Roth \& Romeo, 1992).

La imagen un país está representada por un conjunto de creencias, mitos, historia y cultura (Gertner \& Kotler, 2002). La imagen de país es la representación o asociación mental de un determinado país, más allá si son atributos reales o ficticios de la nación en cuestión (Capriotti, 2008).

La imagen país es un estado mental compuesto de una red de asociaciones afectivas y cognitivas que se conectan cuando se piensa en un país (Verlegh, 2001).

En este caso, la imagen país se compone de nodos enlazados que conforman una red asociativa que se almacena en la memoria de las personas con respecto a un país determinado (Anderson, 1983). La imagen de un país se deriva de la estructura cognoscitiva y afectiva del individuo. De acuerdo con Villar (2010), la imagen país es un conjunto de ideas racionales y emocionales que se asocian de un país.

Las imágenes que se tiene sobre un país generalmente están relacionadas con la manera en que se perciben como destinos turísticos, lugares para invertir o lugares para comprar las marcas preferidas por los clientes (Wang et al., 2012). El turismo es el vínculo más directo entre la imagen positiva y el crecimiento económico de un país (Stock, 2009).

El turismo es un escenario de experiencias que ayudan a modificar de manera positiva o negativa la imagen de un lugar y por ende afecta directamente la reputación de un país en el mundo. 


\section{Capítulo 2. El país como una marca}

La percepción de los turistas es un elemento clave en la construcción de la imagen país y debe convertirse en una nueva perspectiva en el estudio de la planificación de marca país (Mei et al., 2012). Vanella (2000) expresa que la imagen de un país incide directamente en el comportamiento del cliente extranjero: los consumidores finales y los inversores.

La imagen de un país puede estar influenciada por factores exógenos como el desarrollo económico, la identidad nacional, la política, la economía, la cultura y los valores personales (de Tavares Canto Guina \& de Moura Engracia Giraldi, 2012). Varios estudios sobre la imagen del país que se han llevado a cabo desde la década de 1960, indican que la percepción difiere y se generaliza según la experiencia que tenga el visitante en un país o con los productos de otros países (Usunier, 2006).

Las percepciones de un país tienen un efecto significativo sobre las actitudes de visitantes y prospectos frente a las marcas, líderes de opinión o productos procedentes de otros países. Si un país tiene desarrollo en tecnologías de punta, las percepciones positivas son mayores hacia su imagen (Gotsi et al., 2011; Rojas et al., 2013).

Para construir una imagen de un país, hay que construir sobre algo que une a la gente del país; no puede ser solamente el logotipo, no puede ser solamente la palabra, tiene que estar basado en los valores que representa una nación (Nordstróm, 2008).

La formación de la imagen país es por naturaleza un proceso subjetivo y está expuesta a cambios a lo largo del tiempo (Dikčius \& Stankevičienè, 2010). Diferente al concepto de marca país, que busca materializar el proceso subjetivo hacia un aprendizaje experiencial de un visitante o un inversionista (de Moura Engracia Giraldi et al., 2011).

La imagen no es ajena al concepto de la marca país. La primera, depende de las percepciones populares y la segunda es una estrategia que permite consolidar una imagen deseada de un país en mercados internos y externos (Bhakar et al., 2013).

Las características de la imagen país son atributos percibidos por los visitantes al país, que son aquellos individuos que a partir de la percepción y su posterior experimentación en el lugar, pueden definir su impresión y comprensión por medio de palabras y símbolos que trasmitan su sentimiento (Balabanis \& Diamantopoulos, 2011).

Son ellos quienes al regresar a sus lugares de origen, trasmitirán su sentimiento y experiencia vivida del país visitado. Estas experiencias pueden ser los paisajes, la 


\section{Capítulo 2. El país como una marca}

infraestructura, la modernidad, lo clásico, la historia y cultura, el trato recibido de los ciudadanos del país, o empresas y/o productos que hayan marcado un diferencial en sus mentes (Martínez \& Alvarez, 2010).

La imagen de un país puede ser expresada a través de percepciones generalizadas y también puede reducirse a una serie de actitudes positivas y negativas dependiendo de las impresiones que tenga un visitante, inversionista o habitante sobre un país (Martínez \& Alvarez, 2010).

De una manera más precisa se refuerzan los estereotipos se articulan con los juicios de valor y con las asociaciones mentales que tengan las personas frente a un destino determinado (Diamantopoulos et al., 2011).

La imagen de una marca país se construye sobre la realidad del país, el mensaje que se comunica y la influencia de hechos históricos más destacados (Bertrán Vall, 2003).

La marca país va más allá de la identidad visual o los elementos asociados a un país como escudos, banderas e himnos. La marca país también sobrepasa la promoción de los lugares que normalmente se ha enfocado en la difusión de una oferta turística a través de folletos, videos, páginas de Internet, entre otros (Jain \& Winner, 2013).

La diferenciación, es un requisito permanente en la construcción de una identidad de marca, y su forma es la imagen misma de una empresa, producto o país que se expone ante un mercado determinado (Gertner \& Kotler, 2002). Para un país, su imagen implica considerar el conjunto de características, valores y creencias con las que la sociedad se auto identifica y se auto diferencia de las demás (Jetter \& Chen, 2011).

\subsubsection{Diferencia entre imagen país y país de origen}

Con relativa frecuencia se confunden los conceptos de imagen país y país de origen. Pero entre ambos hay grandes diferencias. Si la imagen país recoge las impresiones, ideas y percepciones de los visitantes y residentes sobre un país, el país de origen hace referencia al lugar donde se fabrica un producto (Jenes, 2008).

País de origen (country of origin) es un término internacional que indica donde se fabrica, se cultiva y produce un producto. Este concepto se ha convertido en una certificación 


\section{Capítulo 2. El país como una marca}

para los procesos de importación y exportación. El término de país de origen ha sido objeto de estudio de investigadores en comercio exterior.

Autores como Bilkey y Nes (1982), Maheswaran (1994) y Najafizadeh et al. (2013) encontraron que el país de origen se ha consolidado en un criterio de evaluación de productos por parte de los consumidores.

\subsubsection{El posicionamiento de la marca país}

Algunos países padecen problemas de imagen pero no tienen una idea clara de cómo abordarlos. La marca país puede dar la solución a estos problemas. La marca país significa gestionar la imagen y el prestigio de un país (Dinnie, 2007). La imagen es lo que se proyecta al mundo, mientras que el prestigio es la información recibida dada por la experiencia del visitante o inversionista.

Un país tiene múltiples identidades, lo que implica que tiene que decidir cuál es la imagen que quiere proyectar en mercados internacionales (Gotsi et al., 2011). La imagen de un país está condicionada al público objetivo (Madichie \& Yamoah, 2006; Raharjo, 2012). No es lo mismo posicionar una imagen que comunique la solidez de la economía y estabilidad política para inversionistas o para turistas (Robles, 1996).

La estrategia de posicionamiento de un país en particular se enmarca en el objetivo de capitalizar el origen de los productos, las empresas y las personas en los mercados globales (Akotia et al., 2011).

El objetivo principal es posicionar la imagen de un país a nivel internacional para lograr diferenciación y reconocimiento, y así desarrollar el turismo, la economía y la inversión de un territorio (Anholt, 2007b). Todos los países son diferentes, así compartan elementos comunes.

La diferenciación, es un requisito permanente en la construcción de una imagen país, y su forma es la que se expone ante un mercado determinado (Dinnie, 2008). 


\section{Capítulo 2. El país como una marca}

Para un país, su imagen implica considerar el conjunto de características, valores y creencias con las que la sociedad se identifica y se diferencia de las demás (Passow et al., 2005).

La imagen se construye según la reputación que tenga un país. En este sentido, la imagen y la reputación son dos componentes interrelacionados, es decir, la imagen es lo que se proyecta al mundo, mientras que la reputación es la información recibida dada por la experiencia del visitante o inversionista (Whetten \& Mackey, 2001; White, 2012).

Existe una estrecha relación entre la imagen de un país y su reputación internacional. La imagen de un país hace referencia a las representaciones mentales que tienen residentes, visitantes e inversionistas sobre el destino, y la reputación complementa la percepción de imagen con las asociaciones que tienen otros grupos de interés como líderes de opinión, medios, y gremios, entre otros (Yang, et al., 2008).

La reputación de un país depende principalmente del comportamiento de sus marcas comerciales y de sus productos (país de origen), los cuales son indicadores de progreso, de prosperidad y de óptima gestión administrativa (Jain, \& Winner, 2013). Por este motivo los países han formulado su estrategia de marca país para mejorar su posicionamiento en mercados internacionales (Anholt, 2005b).

Un objetivo de posicionamiento de una marca país es promocionar y posicionar una identidad clara, definida y unificada evitando los regionalismos (Harrison-Walker, 2011).

Se espera que el posicionamiento no solo mejore la imagen de un país, sino que además refuerce el concepto del made in en las etiquetas de los productos que se comercializan en mercados internacionales (Gertner \& Kotler, 2002; Gilmore, 2002). De esta

forma la estrategia de marca país se replica en la generación de una mayor confianza interna y mejor desempeño externo del país (Anholt, 2005b).

El posicionamiento inicia con un trabajo investigativo, es decir, cada país debe preguntarse permanentemente cuál es la percepción que tienen los ciudadanos, visitantes y prospectos sobre el país en términos de productos, atractivos turísticos, servicios y la confianza de los gobiernos (Fantoni, 2008). 


\section{Capítulo 2. El país como una marca}

Como se ha mencionado, el concepto de marca país integra tres sectores: turismo, exportaciones e inversión directa. Sin embargo, el turismo es la variable que se ha convertido en el eje central de la estrategia de construcción de marca país (Borma, 2012). Los gobiernos promueven su imagen y marca país a través del turismo y sus canales de comunicación son las embajadas alrededor del mundo (Lichrou et al., 2010).

El posicionamiento de un país está determinado por la percepción y experiencia de sus turistas. Kerr (2006), citado por Lichroy et al. (2010) indica que construir una marca país sólo con fines turísticos es una decisión limitada.

El objetivo de la marca país no es sólo atraer a los turistas, sino además cautivar a los inversionistas y ayudar en la exportación de las marcas nacionales (Gudjonsson, 2005; Anholt, 2010; Dinnie, 2008). No obstante, teniendo en cuenta la importancia económica que genera el turismo hoy en día para los países, estos están cada vez más interesados en trabajar para fortalecer su marca país y así hacerla conocer alrededor del mundo resaltando cinco factores claves para el turista como: turismo, patrimonio y cultura, aptitud para negocios, calidad de vida y sistema de valores (Moilanen \& Rainisto, 2009).

Estos son los factores más importantes que diferencian a una marca país y que permiten que las personas identifiquen a través de asociaciones, atributos lo que piensan al escuchar el nombre del país, o mirar una fotografía o programa de viaje (Laxe \& Palmero, 2009).

Los cambios en el entorno de marketing de un país representan importantes amenazas en el mercado turístico, pero al mismo tiempo ofrecen oportunidades.

El turismo necesita adoptar estrategias de marketing en el largo plazo, que incluya una oferta micro-segmentada de destinos turísticos y con unas estrategias de comunicación directa con el propósito de alcanzar el posicionamiento de la marca país (Djurica \& Djurica, 2010).

La finalidad de una marca país es alcanzar y mantener el posicionamiento. Para medir la imagen de marca país, se puede considerar el modelo matemático que presenta JosepFrancesc Valls (1992) en su libro La imagen de marca de los países en la cual hace una abstracción ideal del posicionamiento de un país: 


\title{
Capítulo 2. El país como una marca
}

$$
\mathbf{I M}=\mathbf{P}+\mathbf{C}=\mathbf{P E}
$$

Donde,

\author{
IM Imagen País \\ P Todo lo que ofrece un país (productos, turismo, \\ tecnología, etc.) \\ C Plan de Comunicaciones \\ PE Percepción de clientes y prescriptores
}

A través de investigaciones de mercados, se analizan indicadores que componen las variables P, C y PE. El objetivo es comparar estas variables con otros países para identificar donde se están presentando debilidades y oportunidades. Por ejemplo, si dos países, como Colombia y Perú que tienen un turismo similar $(\mathrm{P})$, pero la percepción $(\mathrm{PE})$ sobre la imagen de Colombia es menor o es negativa en comparación con Perú, indicaría que la estrategia de comunicación (C) de Colombia está mal diseñada o mal ejecutada.

Josep Bertrán Vall (2003) plantea el modelo matemático para el análisis de la marca país:

$$
\mathbf{I M P}=\mathbf{P}+\mathbf{P A C}+\mathbf{H H}
$$

Donde,

IMP Imagen de marca país

P El país como producto real, auténtico, sin la influencia de imagen. Su identidad concreta

PAC Política de comunicación realizadas durante la historia

HH Hechos históricos con influencia de la comunicación 


\section{Capítulo 2. El país como una marca}

Existen mediciones de marca país que se realizan con el análisis de seis variables: turismo, inversión e inmigración, producto y exportaciones, gobierno, cultura y patrimonio, y población de un país (Harrison-Walker, 2011).

Por otro lado, hay países que planifican una estrategia para realizar un seguimiento y medir lo que está ocurriendo en el país versus a lo que se quiere llegar para determinar en qué medida se están alcanzando los objetivos planteados (Zenker \& Martin, 2011). A continuación se presentan cuatro mediciones de posicionamiento de marca país de consulta permanente:

\subsubsection{Country Brand Index CBI}

FutureBrand es una compañía líder en investigación sobre el ranking de marca país. Tiene a su cargo las mediciones del Country Brand Index. Este índice, creado en el 2005, construye un ranking de 118 países el cual surge de la realización de encuestas a 3600 líderes de opinión, al igual que un panel de expertos en política pública, globalización y disciplinas relacionadas con los medios en 18 países (FutureBrand, 2012a).

Para la organización, los enfoques tradicionales de marketing aplicados a los productos no se pueden implementar en los países (FutureBrand, 2007).

La puntuación que otorga cada encuestado a un país se construye a través del Modelo de Decisiones Jerárquicas (HDM por sus siglas en inglés). Este modelo indaga a los encuestados sobre las variables de conocimiento, familiaridad, preferencia, consideración y propensión a visitar y recomendar.

FutureBrand (2012b) hace un énfasis especial a las asociaciones que tiene cada encuestado frente a las dimensiones que se presentan en la Figura 7: 


\section{Capítulo 2. El país como una marca}

Figura 7. Dimensiones del Modelo de Decisiones Jerárquicas

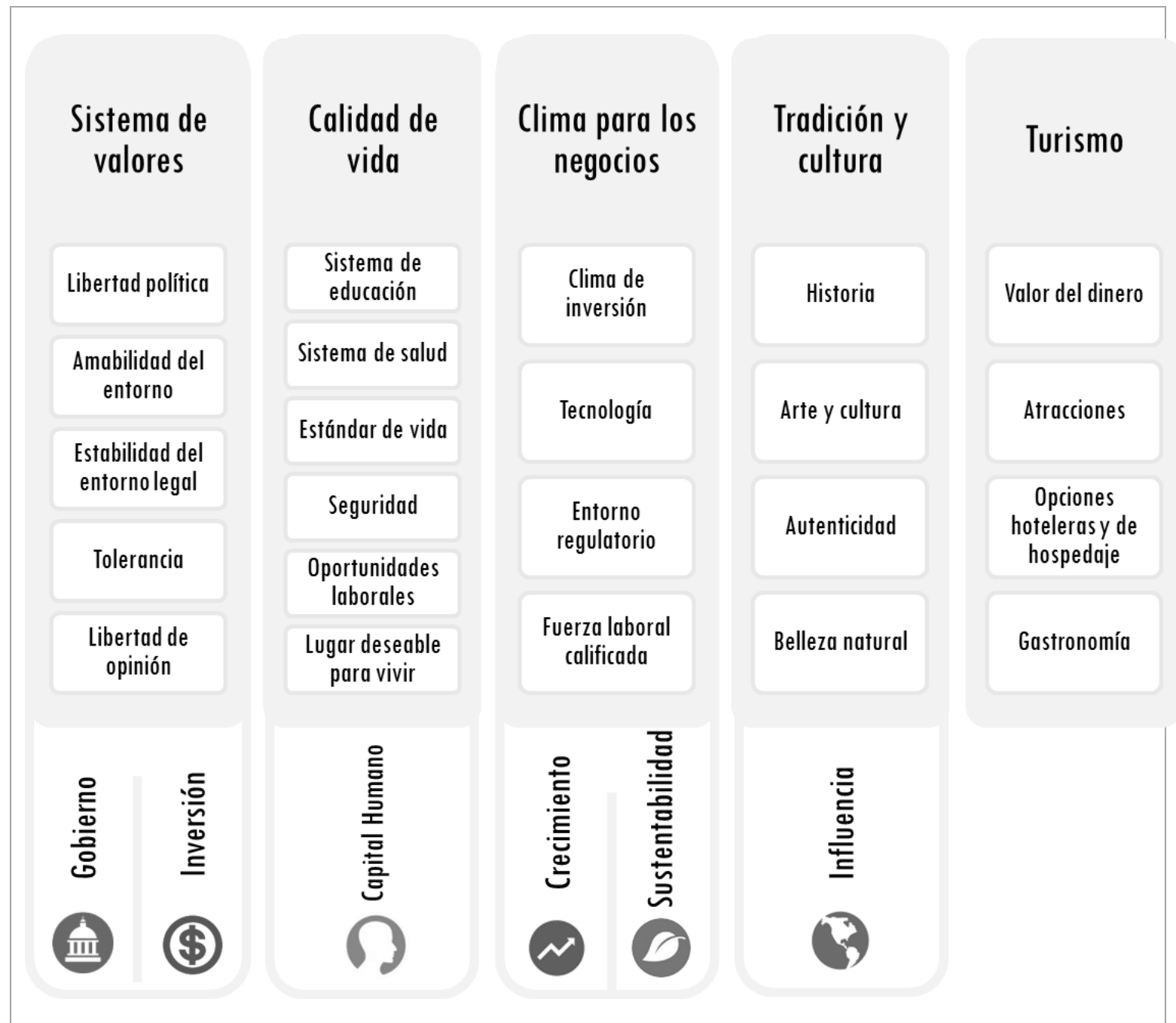

Fuente: Adaptado de FutureBrand (2012b).

Las marca país pueden orientarse hacia las preferencias o hacia las necesidades. Si una marca país se orienta hacia las preferencias, es porque busca fortalecer sus atractivos (lugares), autenticidad (gente, rituales, eventos), cultura (artes, creatividad) y valores (costumbres, creencias e historia) (FutureBrand, 2007). Si una marca país se orienta hacia las necesidades, sus fortalezas están en la geografía (recursos naturales, paisajes), infraestructura (tecnología, comunicaciones), gobierno (eficacia en la gestión) y en la economía (riqueza, calidad de vida) (FutureBrand, 2007). Variables como los atractivos, geografía, infraestructura, autenticidad entre otros, permiten ubicar a los países en aquellos puntos donde son más fuertes o representan una ventaja competitiva (FutureBrand, 2012a). 


\section{Capítulo 2. El país como una marca}

\subsubsection{Nation Brand Index NBI}

Simon Anholt, experto británico en medición de la reputación internacional de países, es el creador del Ranking Anholt de marca país (también conocido como Nation Brands Index), el cual se ejecuta en más de treinta y cinco países del mundo con el objetivo de conocer la percepción de los productos, la población, la cultura, los gobiernos, la economía y el turismo de los países (Anholt \& GfK Custom Research, s.f.).

La metodología de Anholt se basa en el diseño de una encuesta que integra diferentes variables y a su vez permite realizar análisis comparativo de un país con otro; por consiguiente, al Nation Brands Index se le atribuye el conocimiento de las marcas país dependiendo de la imagen percibida por millones de personas de diferentes lugares del mundo. Los países deben distinguir sus reputaciones de uno a otro y evitar identidades generalistas (Anholt, 2008).

El Nation Brands Index mide seis dimensiones diferentes y que le permite tener a los países una noción de lo que realmente es importante al momento de evaluar un país como una marca y de esta manera conseguir mejorar la reputación del país y su perfil frente a los consumidores mundiales (GfK Roper Public Affairs \& Media, 2009).

Como se puede observar en la Figura 8, la medición incluye la potencia y la calidad de la imagen de marca de cada país combinando las dimensiones del hexágono de marca país: exportaciones, gobernabilidad, cultura y patrimonio, personas, turismo, inversión e inmigración (Denman, 2012). 


\section{Capítulo 2. El país como una marca}

Figura 8. Hexágono de marca país

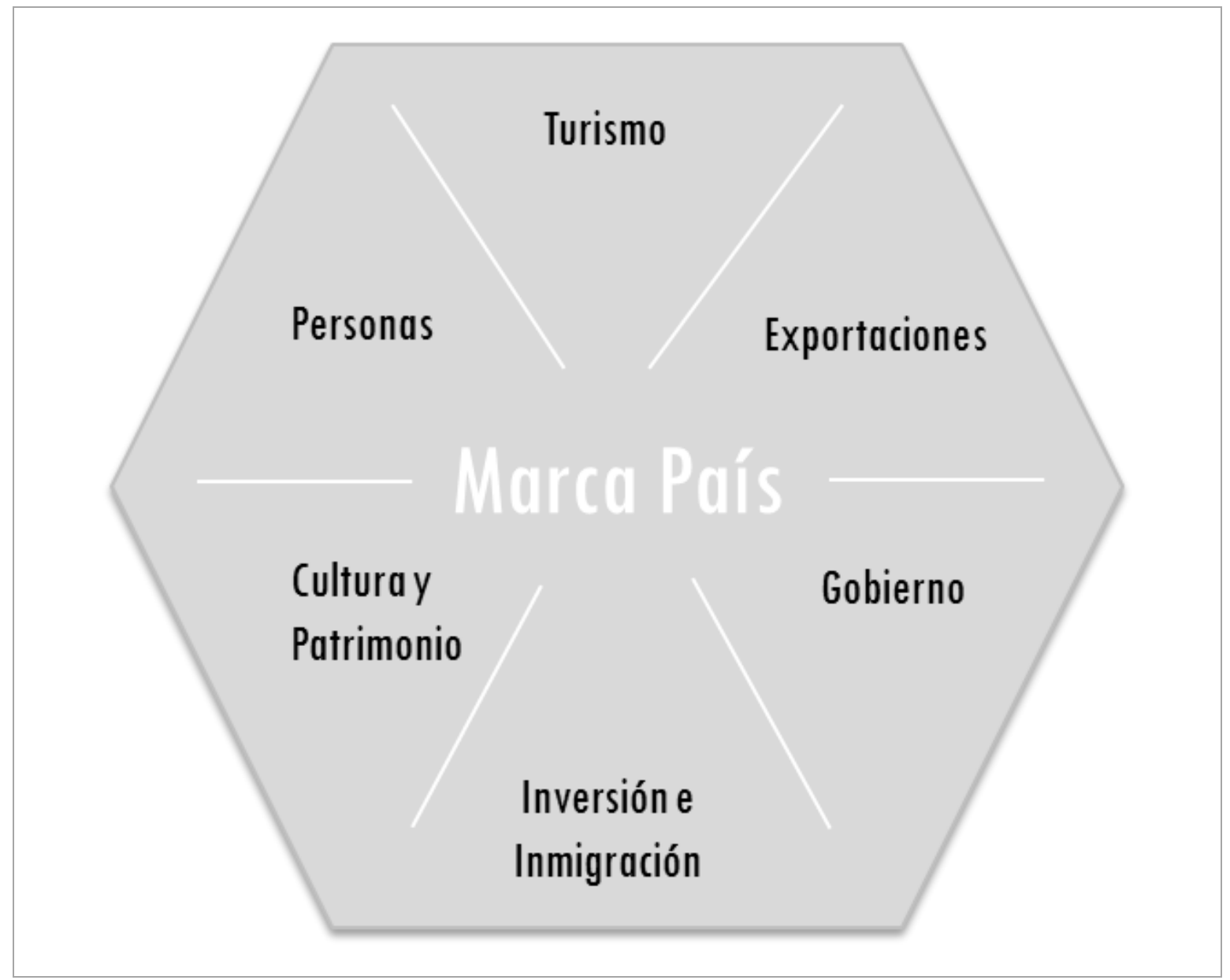

Fuente: Adaptado de GfK Roper Public Affairs \& Media (2009).

En el hexágono de marca país, la dimensión de turismo captura el nivel de interés en visitar un país y la variedad de atractivos turísticos naturales y artificiales. La dimensión de personas mide la reputación de la población y su competencia, en cuanto a la educación, la apertura y la amabilidad, entre otras cualidades. Así mismo, mide los posibles niveles de percepción de la hostilidad y discriminación (Denman, 2012).

A través de las exportaciones, se determina la imagen pública de productos y servicios de cada país y la medida en que los consumidores de forma proactiva buscan o evitan los productos de cada país de origen. 


\section{Capítulo 2. El país como una marca}

La dimensión de gobierno se estudia la opinión pública en relación con el nivel de competencia del gobierno nacional y la justicia, y describe las creencias de los individuos sobre el gobierno de cada país, así como la percepción de compromiso que tienen los países frente a los problemas globales como la democracia, la justicia, la pobreza y el medio ambiente.

La cultura y el patrimonio, revelan la percepción global del patrimonio de cada nación y el aprecio por la cultura contemporánea, incluyendo el cine, la música, el arte, el deporte y la literatura. Y la dimensión de inversión e inmigración determina el poder de atraer a la gente para vivir, trabajar o estudiar en cada país y revela la percepción de las personas frente a la situación económica y social de un país (GfK Roper Public Affairs \& Media, 2009).

\subsubsection{The Pew Global Attitudes Project}

Este es un proyecto de investigación creado en 2001 por The Pew Research Center, una entidad independiente con sede en Washington que fue creada con el propósito de informar al público sobre los problemas, actitudes y tendencias que se dan en América y el mundo (Pew Research Center, 2013). El proyecto de medición de actitudes realiza encuestas de opinión en 59 países sobre una variada gama de temas que incluyen desde temas de percepción personal hasta de temas de política.

\subsubsection{GAP's de la marca país}

En el modelo conceptual Dinnie (2007) precisa las variables que componen la identidad e imagen de un país. Además explica que la identidad de marca contiene una serie de componentes críticos no controlables y que reflejan rápidamente la imagen del país. El Cuadro 10 expone el modelo conceptual del posicionamiento de una marca país propuesto por Dinnie (2007): 


\section{Capítulo 2. El país como una marca}

Cuadro 10. Componentes del posicionamiento de la marca país

\begin{tabular}{|l|l|}
\hline Identidad de la marca país & $\begin{array}{l}\text { Componentes críticos } \\
\text { Historia, lenguajes, territorio, régimen político, arquitectura, } \\
\text { deportes, literatura, arte, religión, sistema educativo, iconos, } \\
\text { paisajes, música, comida y bebida, folclore }\end{array}$ \\
\hline $\begin{array}{l}\text { Vectores de la identidad de la } \\
\text { marca país }\end{array}$ & $\begin{array}{l}\text { Exportaciones, logros deportivos, estrategias de } \\
\text { comunicación, embajadores de marca, aspectos culturales, } \\
\text { política exterior, experiencia en turismo, personajes } \\
\text { reconocidos }\end{array}$ \\
\hline Imagen de la marca país & $\begin{array}{l}\text { Mercado de consumo doméstico y externo, empresas } \\
\text { nacionales e internacionales, inversión extranjera, gobierno y } \\
\text { medios }\end{array}$ \\
\hline
\end{tabular}

Fuente: Adaptado de Dinnie (2007).

Son varias las alternativas de medición de una marca país. Independientemente de la opción escogida, lo elemental es que los países puedan conocer qué tan posicionada está su imagen ante el mundo y verificar si la estrategia implementada es la más adecuada para dar a conocer lo que realmente se quiere trasmitir.

Dinnie (2007) sustenta su propuesta señalando que los indicadores en términos de exportaciones y turismo son los más importantes. Los vectores si son controlables y pueden ser modificables en el corto plazo diferente a los componentes críticos que pueden sufrir variaciones pero en el largo plazo. El autor, plantea que la imagen de una marca país se construye sobre las percepciones que tienen las personas, empresas, el gobierno y los medios acerca de los componentes críticos y vectores de la identidad de marca nacional.

Cuando se evalúan las percepciones en términos de imagen país, se considera importante aplicar un análisis que permita identificar el Gap (percepción-expectativa) a través de la comparación de una situación actual con el contexto a futuro.

Existen cuatro gaps que deben ser examinados: a) percepción propia y externa del país vs imagen actual, b) imagen construida vs imagen actual, c) imagen proyectada vs imagen actual y d) imagen actual vs imagen a futuro (Fan, 2006). 


\section{Capítulo 2. El país como una marca}

Hay dos tipos de posicionamiento: a) aquel en el cual un país tiene un posicionamiento por asociación productiva, por ejemplo, se asocia a China con la producción de arroz; y b) aquel en el cual un país tiene un posicionamiento por asociación de marca, es decir cuando una marca comercial logra hacer visible un país, por ejemplo Nokia con Finlandia (Echeverri et al., 2012).

Este modelo proporciona investigadores y profesionales una herramienta útil para entender las complejas relaciones entre las diferentes perspectivas en la construcción de imagen país. Ante esto la tarea de la marca país es identificar y analizar los gaps, y en lo posible reducir estas diferencias a través de nuevas y extensivas comunicaciones (Yang et al., 2008).

\subsubsection{Country RepTrak}

Las medidas adoptadas en el posicionamiento de la marca influyen pero no controlan la percepción que tenga el público sobre un determinado país (Zenker \& Martin, 2011). La consideración más importante en la marca país es mantener la reputación de la marca, es decir, el objetivo es comunicar hechos reales y consecuentes de la imagen que proyecta un país (Laxe \& Palmero, 2009).

La reputación se ha consolidado como una fuente para generar posicionamiento. El Country RepTrak de Reputation Institute ayuda a los gobiernos y al sector privado a monitorear la reputación de un país frente a su desempeño económico. Es un estudio que se aplica a más de 27.000 usuarios en los países que están vinculados al G8 ${ }^{6}$. Emplea una metodología que consiste en el análisis de las percepciones de un país desde la perspectiva de los grupos de interés (Reputation Institute, n.d.).

${ }^{6}$ Foro de países industrializados conformado por: Estados Unidos, Gran Bretaña, Italia, Francia, Alemania, Japón, Canadá y Rusia. 


\section{Capítulo 2. El país como una marca}

\subsubsection{East West Nation Brand Perception Indexes}

Es un conjunto de índices que clasifican a los países según como son percibidos por los medios de comunicación internacionales. Los índices se construyen sobre el análisis de millones de menciones que figuran artículos de noticias. El estudio considera 193 países miembros de la ONU y siete territorios. Los datos se encuentran ordenados por volumen de menciones, por orden alfabético y en índices regionales (East West Nation Brand Perception Indexes, 2013).

\subsubsection{Bloom Consulting Country Brand Ranking}

Bloom Consulting, firma fundada por José Filipe Torres y especializada en marcas país, publica el Country Brand Ranking. Este índice anuncia tres variantes principales de evaluación: Turismo (Attraction of Tourism), Comercio (Attraction of Trade), y Talento (Attraction of Talent). Bloom Consulting considera que es necesario valorar estas líneas de atracción hacia un país de manera separada, pues por sus propias naturalezas no se pueden combinar bajo un solo sistema de medición integrado. La metodología de evaluación se basa en un ejercicio cuantitativo de carácter algorítmico y de análisis de datos. No considera información proveniente de opiniones ni encuestas. Basándose en cifras económicas, el ranking se hizo público por primera vez en el año 2011 arrojando resultados para 144 países en la variante de comercio y 157 en turismo respectivamente. Entre más alto figure un país en el ranking, mejor está posicionado ante la competencia en materia de atraer inversión extranjera directa y turistas (Bloom Consulting, 2012).

\subsubsection{Monocle Soft Power Survey}

La revista inglesa Monocle se centra en la evaluación del poder blando para valorar los países del mundo. Poder blando (Soft Power) es un concepto desarrollado por Joseph Nye de la Universidad de Harvard y se identifica con la habilidad que tiene un país para atraer e influir en el mundo sin recurrir a la cohesión, ni a la intervención militar ni a la persuasión a través del dinero. 


\section{Capítulo 2. El país como una marca}

En el estudio, se consideran unas 50 variables de poder blando que consideran factores como: los estándares de gobierno, la infraestructura diplomática, la producción cultural, la cantidad de eventos internacionales celebrados en el territorio, la capacidad educativa, la atractividad para los negocios, las misiones culturales del país en el extranjero, el número de medallas olímpicas obtenidas, la calidad de la arquitectura en el país y el reconocimiento de sus marcas privadas (Monocle, 2012).

\subsubsection{Gallup Country Ratings}

Gallup evalúa las percepciones favorables o desfavorables que tienen los residentes sobre un país o sobre personas procedentes de un lugar. Se aplican encuestas telefónicas a una muestra aleatoria de adultos mayores de 18 años. Para los resultados basados en la muestra total de adultos nacionales, el nivel de confianza es de $95 \%$ y el margen de error es de \pm 4 puntos porcentuales.

Las encuestas se realizan a través de teléfonos fijos y teléfonos celulares. Cada muestra de adultos nacionales incluye una cuota mínima del 50\% de los encuestados de teléfonos celulares y el $50 \%$ de los encuestados fijos, con cuotas mínimas adicionales por región.

Las muestras se ponderaron para corregir la desigual probabilidad de selección, la falta de respuesta, y la doble cobertura de los usuarios fijos y móviles en los dos marcos de muestreo. También se ponderan para que coincida con los datos demográficos nacionales de género, edad, raza, origen hispano, la educación, la región, la densidad de población y el tipo de teléfono (teléfono móvil, red fija, ambos). Además del error de muestreo, la redacción de las preguntas y dificultades prácticas en la realización de encuestas pueden introducir errores o sesgos en los resultados de encuestas de opinión pública (Gallup, 2013).

\subsection{Experiencias de marca país en América}

Considerar que un país o una región constituyen una marca, se ha convertido en uno de los objetivos estratégicos en términos de competitividad para algunos países, lo cual motiva a 


\section{Capítulo 2. El país como una marca}

los gobiernos y empresarios a formular estrategias que ayuden a mejorar su imagen en el mundo (Akotia et al., 2011). Si un país es reconocido mundialmente por la calidad de sus productos, seguramente buscará orientar su estrategia competitiva hacia el rubro de exportaciones (Dikčius \& Stankevičienè, 2010).

De allí que la creación y conceptualizacion de una marca país involucre la participación de multiples actores que serán quienes la representarán, al igual que un programa estrategico de visibilidad que permita su adecuado posicionamiento con un horizonte de largo plazo (Sartori et al., 2012). Con base en lo anterior, los desafíos más importantes a los que se ven enfrentada una marca país son: a) la falta de unificar un propósito, b) la dificultad de establecer objetivos medibles y alcanzables, c) la flexibilidad restringida y d) la ausencia de conocimientos en marketing (Ferraz Sexto, 2001).

Para Healey (2008), el enfoque diferenciador que tiene una marca país, puede surgir de distintos patrones, lo importante es que permitan lograr una identidad nacional extraordinaria. En el caso de España, este país ha conseguido posicionarse como una nación moderna y desarrollada, mientras que Dinamarca ha fortalecido exitosamente sus ministerios y departamentos del gobierno (Gilmore, 2002). Croacia por su parte, ha estado trabajando en reformar su imagen hacia deporte y turismo; y Polonia ha comenzado a afirmarse en términos de política exterior (Šeric, 2011; Lubowiecki-Vikuk \& Basiñska-Zych, 2011).

La marca país es susceptible a los cambios o manifestaciones que se experimentan por los países, es decir, una imagen de un país evoluciona, puede ser controlada o no (Wang et al., 2012). Por ejemplo, lo que sucede en India en la actualidad y las percepciones alrededor de este país, son muy diferentes (Farooqi, 2009). La imagen de la India hoy es totalmente diferente de la manera en que era percibida hace quince años; antes era la espiritualidad y la pobreza, ahora es el desarrollo de software (Kerrigan et al., 2012). 


\section{Capítulo 2. El país como una marca}

El gobierno Hindú se ha enfocado en diseñar programas de educación con altos estándares de calidad, y en algunos países, los textiles y tejidos hindúes son los más demandados por los talleres de diseño (Anholt, 2008b). Todos estos sucesos han sido naturales, no han sido controlados. Además del enfoque diferenciador, la promoción de un país está relacionada con identificar a los prescriptores, es decir, hacer difusión de las marcas de los productos o divulgar acontecimientos de dicho país que puedan influir favorablemente la opinión pública en otros países (Anholt, 2003).

En el caso de los países del continente americano, especialmente centro y sur, tienen un problema común de imagen que no es sólo económico, sino fundamentalmente político, de desconfianza generada por la corrupción y la inseguridad de las instituciones (Ramos \& Noya, 2006). Las marcas países de las naciones latinoamericanas fueron diseñadas con una estructura similar al concepto de marcas blancas (Anholt \& Hildreth, 2005a).

Las experiencias de marca país en el continente americano son diversas y con desarrollos en algunos casos discontinuos (Pipoli \& Flores, 2006). Se destacan Estados Unidos y Canadá, como los países que han estructurado sus marcas país fundamentadas en los valores de su identidad nacional. Sin embargo, en los países latinoamericanos, la creación de la marca país se dio en la mayoría con el cambio de milenio, ante una necesidad de replicar el modelo estratégico exitoso de países como Australia, Canadá, España y Nueva Zelanda, entre otros (Anholt, s.f.; Lightle, 2005; FutureBrand, 2012).

El posicionamiento de la imagen país en América es heterogéneo. Algunas marcas país que se caracterizan por su liderazgo, como Estados Unidos y Canadá, otras que sobresalen por su enfoque turístico como Costa Rica y Perú, y marcas emergentes como México, Brasil y Colombia (FutureBrand, 2012a).

Países como México, Chile, Argentina, Costa Rica, Brasil y Perú han conseguido fortalecer su imagen en el campo del turismo y la inversión. El desarrollo de su marca país ha sido un proceso planeado y sistemático, que no responde a gobiernos de turno. En el caso de Colombia, Venezuela, Guatemala y Honduras, sus marcas están en una fase introductoria y sus propuestas se reinventan con los cambios de gobierno.

En el Cuadro 11 se puede observar las posiciones que han ocupado las marcas país de América desde el 2009: 


\section{Capítulo 2. El país como una marca}

Cuadro 11. Posiciones que han ocupado las marca país en el Country Brand Index América 2009-2012

\begin{tabular}{|c|c|c|c|c|}
\hline Posición & 2009 & 2010 & 2011 & 2012 \\
\hline 1 & Estados Unidos & Canadá & Canadá & Canadá \\
\hline 2 & Canadá & Estados Unidos & Estados Unidos & Estados Unidos \\
\hline 3 & México & Costa Rica & Costa Rica & Costa Rica \\
\hline 4 & Costa Rica & Argentina & Brasil & Brasil \\
\hline 5 & Brasil & Chile & Argentina & Argentina \\
\hline 6 & Argentina & Brasil & Chile & Chile \\
\hline 7 & Belice & Belice & Perú & Perú \\
\hline 8 & Uruguay & Perú & México & México \\
\hline 9 & Perú & México & Uruguay & Uruguay \\
\hline 10 & Chile & Uruguay & Rep. Dominicana & Cuba \\
\hline 11 & Panamá & Panamá & Cuba & Ecuador \\
\hline 12 & Venezuela & Ecuador & Panamá & Colombia \\
\hline 13 & Ecuador & Venezuela & Ecuador & Venezuela \\
\hline 14 & Colombia & Colombia & Guatemala & Bolivia \\
\hline 15 & Nicaragua & Guatemala & Venezuela & Guatemala \\
\hline 16 & Guatemala & Nicaraqua & Colombia & Honduras \\
\hline
\end{tabular}

Fuente: Adaptado de FutureBrand (2012).

En el caso latinoamericano, la construcción y permanencia de la marca país ha sido a través del apoyo de firmas consultoras y expertos conocedores del marketing territorial (Echeverri et al., 2012). Cada país en Latinoamérica ha desarrollado su propia marca en un entorno de contrastes (Anholt \& Hildreth, 2005a). La situación política y socioeconómica no favorece la imagen en algunos países, como el caso de Colombia, Venezuela, Ecuador y Nicaragua (FutureBrand, 2012a).

Anholt y Hildtreh (2005) señalan que América Latina tiene una marca blanca, es decir, está en una fase introductoria carente de estrategias que capitalicen la reputación. Por este motivo, hay una necesidad emergente de estudiar el modelo de construcción, las experiencias y los resultados en la implementación de marca país en países de América Latina.

En el continente americano se evidencia recientes avances en el proceso de construcción de una marca país. Las propuestas ejecutadas por la mayoría de los países carecen de estudios a profundidad sobre la imagen de un país en mercados internacionales.

América Latina tiene problemas de identidad e imagen porque las características de los países están cambiando. 


\section{Capítulo 2. El país como una marca}

Los países latinoamericanos tienen un problema común de imagen que no es sólo económico, sino fundamentalmente político, de desconfianza generada por la corrupción y la inseguridad de las instituciones (Ramos \& Noya, 2006).

Las democracias están siendo reemplazadas por dictaduras, las tasas de inflación son cada vez más bajas, los déficit fiscales se reducen, los déficits en cuenta corriente son el resultado de la apertura de los mercados, y la corrección de los desequilibrios estructurales en sus economías permiten una recuperación más rápida de las crisis financieras.

Sin embargo, la región sigue siendo muy dependiente del capital extranjero (Sánchez E. , 1999). Dado por el aumento en las exportaciones e inversiones en el campo de la agricultura, la minería y el petróleo. Tres renglones productivos que se han convertido en fuentes de resistencia de gobiernos de turno (Blanco \& Grier, 2013).

A continuación se realizará a través de la casuística una descripción de la situación real de las marcas países de los países americanos considerados en el Ranking del Country Brand Index 2012. El caso de Colombia es abordado a profundidad en el capítulo 3 del documento.

\subsubsection{Marca país en América del Norte}

Los países, así como los productos y servicios, tienen características propias que responden a sus más intrínsecas particularidades (Anholt, 2002). La cultura, su gente, los recursos naturales, sus características socioeconómicas y políticas, y su inserción en el mundo (Szondi, 2010; Fan, 2010).

Cada país tiene un importante caudal de cualidades que los hacen diferentes unos a otros, que los distinguen, que deberían servirles como diferenciadores en la oferta que proyecten al mercado (Gudjonsson, 2005). Los países han identificado la necesidad de construir una marca que trascienda la descripción de características físicas de un territorio y se oriente a la generación de experiencias para sus visitantes (Hudson \& Ritchie, 2009). 


\section{Capítulo 2. El país como una marca}

Así como las organizaciones, los países deberían salir a identificar, en sus correspondientes segmentos, cuáles son los principales atributos percibidos por la gente, cuál es la imagen que tienen sobre ellos para poder insertarse en la oferta global, para posicionarse o reposicionarse (Denman, 2012). Canadá y Estados Unidos son dos experiencias disimiles y destacadas en el proceso de construcción de marca país.

Dos países, que advirtieron su necesidad de diseñar y desarrollar estrategias que les permitieran reposicionar su imagen. Ambos partían de situaciones iniciales diferentes, con percepciones internacionales muy distintas pero con un objetivo común, aumentar su visibilidad en el exterior que significara mejorar sus ingresos turísticos y aumentar sus inversiones y exportaciones (Gallup, 2010).

\subsubsection{Canadá}

La marca país Canadá se ha mantenido en los cinco primeros lugares del Country Brand Index desde el año 2008, demostrado por el desarrollo de una marca que se fundamenta en ser el primer país del G8 que superó la recesión internacional por el conservadurismo fiscal. Para el año 2010, según el Country Brand Index de la firma consultora FutureBrand, Canadá se posicionó como la Marca País \#1 en el mundo. No obstante haber mejorado en 7 atributos turísticos, en el informe 2012-2013 la marca país Canadá cae al lugar \#2 superada por Suiza principalmente debido a una caída en el atributo de sistema de valores.

En el 2004, las investigaciones realizadas por el gobierno mostraban que Canadá era visto en términos muy positivos por el público pero no era un Top of Mind en cuanto a destino de viaje (Echeverri \& Rosker, 2011).

De hecho, el desempeño competitivo de Canadá entre 1980 y 2005 fue débil, los viajeros veían a Canadá como un punto de conexión en medio de sus países de origen o sus destinos de viaje. Hasta entonces, la imagen de Canadá era antigua y aburrida: nieve, alces y montañas. Faltaba un mensaje que creara una conexión emocional, invitando a los ciudadanos del mundo a querer vivenciar la unicidad que ofrecía Canadá. 


\section{Capítulo 2. El país como una marca}

Según la Canadian Tourism Committee para el 2005, tres eran los factores principales que influenciaban fuertemente al viajero entre países: la globalización, ya que cuando los individuos se descubren e interactúan en el mundo virtual entonces aumentan sus deseos de encontrarse, intercambiar y negociar personalmente; las elecciones del consumidor y sus fuentes de influencia, que les permiten acceder a infinitas fuentes de información acerca de productos, lugares y destinos, en apenas un instante y así poder comparar, evaluar, seleccionar o rechazar, y la volatilidad e incertidumbre, ya que los lugares y sectores industriales son cada vez más interdependientes con la complejidad que eso trae aparejado.

En octubre de 2005, la Comisión de Turismo de Canadá planteó una innovadora estrategia de marketing global bajo la marca Canada - Keep Exploring, para lograr un mejor posicionamiento del país como un destino donde los viajeros pudieran crear experiencias personales extraordinarias. El objetivo principal de la campaña era invitar al mundo a explorar Canadá.

Lo importante para la marca era dar a conocer a los viajeros la posibilidad de crear su propia experiencia, de sentir y formar vivencias, probar cosas nuevas, conocer gente amable y descubrir nuevas perspectivas del país (Echeverri \& Rosker, 2011).

La Comisión de Turismo de Canadá (CTC) se propuso firmemente en buscar nuevas formas de promocionar y reforzar rápidamente la industria del turismo dentro de la oferta del mercado global. Las ideas iniciales buscaban extender una invitación a los viajeros que quisieran satisfacer su curiosidad y buscar nuevas experiencias visitando Canadá.

La marca Canada - Keep Exploring impulsaba a todos los miembros de la industria del turismo de Canadá a buscar y descubrir nuevas maneras de deleitar a los visitantes y convertirlos en celosos embajadores (Echeverri \& Rosker, 2011).

Los primeros pasos fueron reconvertir la visión, la misión y escribir sus preceptos principales:

a. Visión: impulsar al mundo a explorar Canadá.

b. Misión: aprovechar la voz colectiva de Canadá para incrementar los ingresos por exportaciones.

c. Principios fundamentales: 


\section{Capítulo 2. El país como una marca}

- Sostener una vibrante y redituable industria del turismo en Canadá.

- Vender Canadá como un destino turístico deseable.

- Sustentar una relación cooperativa entre el sector privado y el gobierno de Canadá, sus provincias y territorios, para el turismo canadiense.

- Proveer de información relacionada al turismo canadiense al sector privado y a los gobiernos provinciales y territoriales de Canadá.

Lanzar esta nueva marca país significó un proceso intensivo, exhaustivo y esencial. Los ejercicios realizados por la CTC para el diseño de la marca fortalecieron los lazos entre la industria de turismo canadiense y la misma CTC.

A pesar de que la CTC fue quien inició este proceso el resultado final Canada - Keep Exploring fue producto de un pensamiento colectivo, puesto que la estrategia también fue desarrollada con el apoyo de organizaciones que pertenecen al sector turístico. Se contrataron profesionales con la experiencia y habilidad para llevar adelante la estrategia de marketing.

El plan estratégico hasta el 2011 tenía como meta principal el crecimiento de los ingresos por exportaciones de turismo (Echeverri \& Rosker, 2011). De esta forma se plantearon los objetivos y prioridades que se convertirían en el eje central de la consolidación de la marca país.

Los objetivos que se plantearon fueron (Canadian Tourism Commission, 2010):

a. Convertir a los clientes altamente potenciales a comprar productos canadienses.

b. Enfocar en los mercados de alto retorno a la inversión.

c. Consistencia de marca.

d. Investigar nuevas oportunidades de mercado.

Las prioridades de la marca país fueron:

a. Desarrollar relaciones uno a uno con los clientes.

b. Alinear las asignaciones de mercado para una maximización del retorno de la inversión. 


\section{Capítulo 2. El país como una marca}

c. Diferenciar a Canadá.

d. Apalancar la inversión de los socios (empresas y agencias de turismo canadienses).

e. Apalancar la exposición realizada con los medios para los Juegos Olímpicos de Vancouver 2010.

f. Crear demanda para los crecientes accesos aéreos.

g. Excelencia organizacional.

Para alcanzar un posicionamiento de marca que reconociera las realidades competitivas que ofrecía Canadá en el sector la CTC analizó datos correspondientes a diez años de historia turística canadiense y tuvo en cuenta el comportamiento de competidores claves, mercados turísticos y consumidores.

La Comisión sostuvo consultas con cerca de 450 profesionales del sector turístico y desarrolló 24 grupos foco en seis países para probar sus hallazgos (Echeverri \& Rosker, 2011).

La marca invita a los viajeros a proyectar sus propias expectativas y deseos, sugiriendo que cualquier tipo de experiencias que pudieran estar buscando, las encontrarán en Canadá (Echeverri \& Rosker, 2011).

Pretende alimentar el impulso inherente de explorar y mostrar a Canadá como un lugar que vale la pena visitar, así como renovar la emoción de descubrir y alentar a los consumidores a que se asombren como cuando eran niños (Canadian Tourism Commission, 2005).

Según el informe CTC de 2006, los cinco conceptos principales respecto a la marca país Canada - Keep Exploring, eran:

a. La promesa de marca: Visite a Canadá y cree sus propias extraordinarias historias.

b. La declaración de marca: Canadá es un catalizador para la propia expresión.

c. Los pilares de marca: cultura, geografía, gente.

d. La personalidad de la marca: confiable, joven, informal, cálida, ingeniosa, intrigante, abierta, auténtica.

e. Recompensa: pruebe una vida menos común. 


\section{Capítulo 2. El país como una marca}

Según la CTC, la marca país Canadá transmite los atributos únicos del país: la cultura, la gente y la geografía. El punto en dónde estos tres factores se interceptan, representa lo que verdaderamente significa Canadá: una experiencia que no puede ser replicada en ningún otro lugar del planeta (Canada Tourism Commission, 2011).

Con el objetivo de mantener una voz colectiva para Canadá, la CTC desarrolló una estrategia de comunicaciones basada en tres lineamientos para transmitir la marca:

a. Crear conciencia sobre Canadá como un destino vacacional a través de medios y mensajes influenciados por la marca Canadá. Esto se realiza insertando la marca en momentos inesperados de rutina para inspirar a los consumidores a ejercitar su curiosidad natural.

b. Lograr comunicar localmente que Canadá es un destino de vacaciones que permite a los consumidores internos experimentar el país sin irse de casa.

c. Crear oportunidades destinadas para los consumidores, de tal forma que realicen compras de ofertas desarrolladas por los socios de la CTC.

A lo largo de dos años, el plan de la Comisión consistió en capacitar para construir conciencia, buscar alianzas y asociaciones globales para apoyar las mejores prácticas de la marca y alcanzar participación a través de los mercados (Canadian Tourism Commission, 2008).

Los diez mercados globales hacia los cuales enfocarían su estrategia eran: Australia, China, Francia, Alemania, Japón, México, Corea del Sur, Reino Unido, el mercado de placer y el mercado de negocios de Estados Unidos y, por supuesto, a su mercado interno, la propia Canadá. Este target surgió de investigaciones de mercados realizadas por la CTC en distintos mercados externos tales como Estados Unidos, Europa, Japón y China, midiendo potencialidad de los mismos en cuanto a su interés en Canadá (Canadian Tourism Commission, 2008).

La decisión fue tomada en el año 2004 y todos los esfuerzos de promoción de la marca debían enfocarse en estos países, puesto que generan los más altos retornos en consumo por 


\section{Capítulo 2. El país como una marca}

turismo (Canadian Tourism Commission, 2010). Algunas consideraciones de las estrategias en cada país se relacionan a continuación:

a. Canadá: el mercado doméstico era el que más aportaba a la cifra global de ingresos percibidos por turismo en Canadá.

b. Estados Unidos: la CTC se embarcó en un programa de marketing diseñado para apelar a los prospectos urbanos más accesibles, (por ejemplo, New York, Boston y Los Ángeles). El programa, lanzado en la primavera del 2005, costó 11 millones de dólares trabajándose sobre cuatro componentes básicos: creación de conciencia, estimulación, nichos de mercado y negociación con agentes. Algunos de los nichos de mercado establecidos fueron: pesca sofisticada, aventura soft, mercado de esquí, mercado gay, y el mercado de convenciones y eventos, en el cual CTC invirtió 4.6 millones de dólares.

c. China: Canadá logró obtener el Estatus de Destino Aprobado (ADS) por el gobierno chino para facilitar los viajes en grupo hacia Canadá. La CTC abrió una oficina permanente en Beijing desde enero de 2005 con el objetivo de promover a Canadá como destino turístico mediante prensa y actividades en muestras comerciales. El objetivo era crear conciencia sobre Canadá como un preferido destino turístico para lo cual se invirtieron poco más de medio millón de dólares en el 2005.

d. Japón: la CTC invirtió 5.8 millones de dólares durante el 2005. En alianza con una empresa japonesa desarrollaron e implementaron una promoción de las Montañas Rocosas de Canadá.

e. Reino Unido: durante el 2005, la CTC invirtió aproximadamente 2.2 millones de dólares en el mercado del Reino Unido.

f. Alemania: en el mercado alemán la CTC invirtió para el 2005, 1.8 millones de dólares.

g. Francia: el programa de inversiones en el mercado francés, para el 2005, fue de 2.2 millones de dólares.

h. Corea del Sur: las inversiones en el programa de marketing en este país fueron de 670 mil dólares. 


\section{Capítulo 2. El país como una marca}

i. Australia: el programa en el mercado australiano significó 830 mil dólares para el 2005.

Esto significó una inversión total, en esta primera etapa del plan estratégico, de más de 26 millones de dólares, buscando realizar su promoción en los mercados target que habían seleccionado.

El logo como elemento principal de la identidad de la marca; se apoya en la hoja de maple, la cual es respetada y reconocida alrededor del mundo como un ícono nacional canadiense (ver Figura 9). La marca también incorpora el slogan Keep Exploring tanto en inglés como en francés Explorez sans fin, idiomas oficiales de Canadá.

Figura 9. Logotipo de la marca país de Canadá

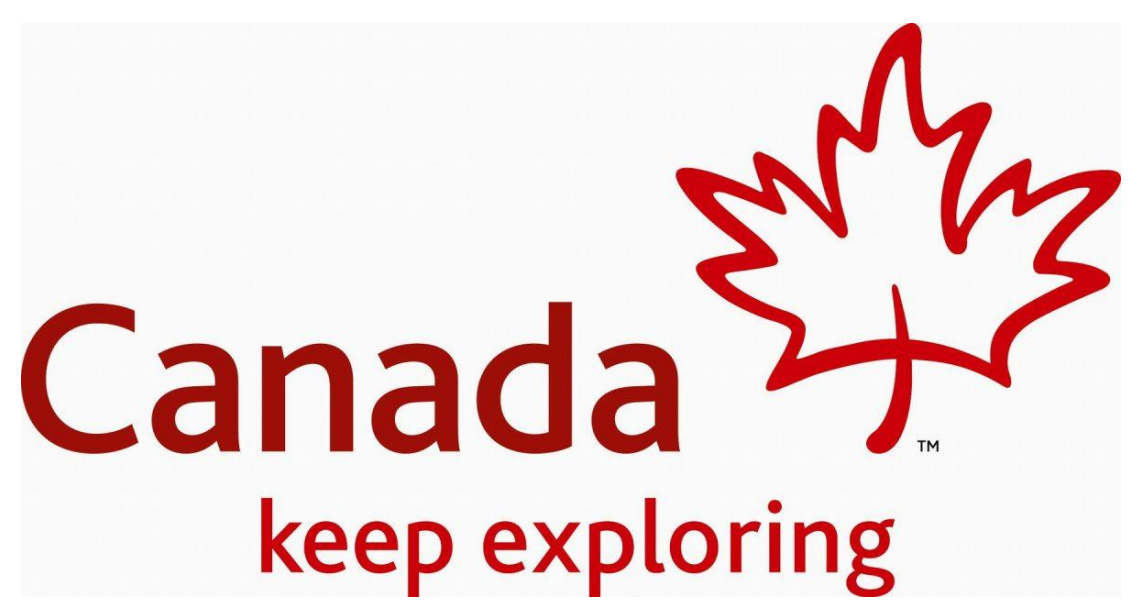

Fuente: Adaptado de Canadian Tourism Comission (2013). 


\section{Capítulo 2. El país como una marca}

Para lograr articular mejor la estrategia de marca país de Canadá, la CTC diseñó un $\mathrm{EQ}^{\mathrm{TM}}$ o Explorer Quotient ${ }^{\mathrm{TM}}$, (Coeficiente del explorador), con el propósito de identificar mejor a los clientes viajeros de Canadá a través de insights, puesto que se consideró que las metodologías métricas tradicionales, limitaban la segmentación (Echeverri \& Rosker, 2011).

Para diseñar el coeficiente EQ ${ }^{\mathrm{TM}}$, la CTC se apoyó en el modelo de valores sociales de Environics Research Group, firma reconocida por sus encuestas de opinión pública e investigación de mercados relacionadas con estudios sobre valores humanos y cambio social (Canadian Tourism Commission, 2006).

Este coeficiente se basa principalmente en identificar: valores sociales, motivaciones y conductas del viajero, qué busca el viajero en sus vacaciones, estilo de vida, hábitos de compra, investigación. Bajo este modelo, la CTC identificó tres prospectos objetivo de viajeros para Canadá: el Experimentador Auténtico (Authentic Experiencer), el Explorador Cultural (Cultural Explorer) y el de Espíritu Libre (Free Spirit). Son ellos los que mayores niveles de utilidad ofrecen, son los que muestran el interés más entusiasta por las experiencias ofrecidas por Canadá.

Mientras se trabajaba en el lanzamiento global de la nueva identidad visual de la marca, fueron lanzadas varias campañas de promoción de Canadá: Keep Exploring en los mercados de Latinoamérica, Europa y Asia, a principios de 2007.

Igualmente, la CTC mejoró la plataforma web, mediante la creación de sitios web para consumidores ubicados en cada uno de los mercados objetivos mencionados previamente, así como un sitio web para el mercado norteamericano relacionado con las conferencias y ferias internacionales (Canadian Tourism Commission, 2007).

El año 2008 puede considerarse como el año en el que la marca país de Canadá se consolidó completamente. Principalmente, los esfuerzos de la Comisión se enfocaron en integrar los elementos de la marca en todas las actividades turísticas y comerciales del país, mediante planes de relaciones públicas y marketing digital (Echeverri \& Rosker, 2011).

La CTC desarrolló una iniciativa para valorar la marca país de Canadá para tener un punto de referencia ante la inminente inversión que iba a realizar como parte del proceso de planeación estratégica para el período 2009-2023, especialmente, para medir el crecimiento 


\section{Capítulo 2. El país como una marca}

de la marca a lo largo del periodo relacionado con la estrategia de los Juegos Olímpicos de Invierno que se desarrollarían en Canadá en el 2010.

Para desarrollar esta tarea fue contratada Interbrand, líder en valoración y administración de marcas y que cuenta con una metodología propia que es aceptada a nivel mundial por analistas, bancos, autoridades de impuestos, consultores del mercado accionario y altas cortes. Esta iniciativa midió el impacto de las actividades de la CTC sobre la marca.

Interbrand determinó que el valor de la marca país de Canadá era de \$123.8 billones de dólares (Echeverri \& Rosker, 2011).

Como parte del proceso de planeación estratégica de la Comisión Canadiense de Turismo para el período 2009-2013 se establecieron cuatro objetivos estratégicos y seis prioridades para incrementar los ingresos por concepto de turismo extranjero para Canadá.

Varios de estos elementos se apoyan en el fortalecimiento, desarrollo y aprovechamiento de las características de la marca Canadá. Los objetivos estratégicos que se establecieron fueron los siguientes:

a. Influir en las decisiones de viaje y compra de consumidores de alto perfil para aumentar los ingresos por exportación de servicios mediante la consolidación de las relaciones.

b. Enfocar los esfuerzos de marketing en los mercados globales o segmentos de mercado donde se percibe que está el más alto potencial de retorno de inversión.

c. Conducir la industria dando relevancia y consistencia a la marca.

d. Responder a las dinámicas cambiantes de los mercados.

Las prioridades que tiene la organización de la marca país de Canadá con fecha límite de 2013 son las siguientes (Echeverri \& Rosker, 2011):

a. Enfocarse en las necesidades relevantes de los viajeros. En este sentido, el equipo de e-marketing de la marca implantó una herramienta de CRM (Customer Relationship Management) para identificar clientes, recolectar y analizar datos relacionados con sus preferencias de viajes y patrones de consumo. Utilizando esta herramienta, la 


\section{Capítulo 2. El país como una marca}

CTC pudo desarrollar y mantener una comunicación con targets de clientes potenciales para asegurar que los mensajes de marketing que recibieran, fueran acordes con sus intereses y expectativas.

b. Comprometerse más con las pequeñas y medianas empresas. La CTC trabajaría de la mano con las pequeñas y medianas empresas para que piensen en promocionar a Canadá como una experiencia más que un producto. Para ayudar a estos negociantes a desarrollar mensajes consistentes y poderosos para el mercado, la CTC había identificado cinco factores diferenciadores:

- Ciudades al límite.

- Posibilidades de viaje por tierra, mar o aire.

- Aventuras inspiradoras entre maravillas naturales.

- Cocina ampliamente ganadora de premios.

- Conexión con la comunidad canadiense, una de las más amables del mundo.

c. Diferenciar a Canadá. Considerando lo anterior, la CTC trabajaría en el período mencionado con sus asociados para crear o renovar productos que puedan extender y fortalecer la marca, siempre respondiendo a las expectativas de los potenciales consumidores. Así como:

- La incorporación de ventajas competitivas en los planes de marketing y ventas de la marca, así como la implementación de un esquema de administración de la crisis, aseguraría la proyección del plan.

- Dentro del plan, se identificaban ciertos elementos fundamentales.

- Marca: posicionamiento de marca consistente y poderoso que se consolidara durante la preparación y ejecución de los Juegos Olímpicos de Invierno de Vancouver 2010.

- Explorer Quotient (EQ $\left.{ }^{\mathrm{TM}}\right)$ : coeficiente del explorador que permite conocer los intereses particulares de los viajeros internacionales para enfocar la oferta hacia cada cliente.

- Factores diferenciadores de Canadá (USP): define los atributos que hacen de Canadá un destino de viaje con experiencias únicas para los viajeros. 


\section{Capítulo 2. El país como una marca}

- Contenido enfocado en lo experiencial: capturando y creando historias emocionantes y llamativas en Canadá.

- Plataforma global: construida en asocio con la industria turística para convencer al mundo de viajar y explorar Canadá.

d. Apoyar la estrategia de marca país de Canadá en el desarrollo de los Juegos Olímpicos y Paralímpicos de Invierno Vancouver 2010. La Comisión se apoyará en los Juegos Olímpicos de Invierno 2010 para cambiar las percepciones que tiene el mundo sobre Canadá. La estrategia sería ejecutada en 3 fases:

Fase 1. Antes de los juegos: la Comisión pretende dar una personalidad a Canadá como destino turístico, fortaleciendo la promoción de la marca en los medios y las relaciones con nuevos socios de negocio.

Fase 2. Durante los juegos: en el período activo de los juegos 2010, se aprovecharán las relaciones establecidas con los medios para mostrar al mundo la renovada experiencia canadiense a través de imágenes cautivadoras y dinámicas. Fase 3. Después de los juegos: entre los visitantes del evento, la organización promocionará nuevas experiencias en Canadá.

e. Adoptar excelencia organizacional. Esta prioridad se relaciona con capacitar y fortalecer el equipo humano que interactúa en la Comisión Canadiense de Turismo para que se convierta en una organización enfocada en la estrategia.

f. Fortalecer el compromiso con accionistas y partes interesadas. La Comisión mantendrá y fortalecerá su comunicación con los departamentos y agencias del gobierno federal, incluyendo Industry Canada y la Oficina de la Secretaría del Estado, para temas relacionados con los pequeños negocios y el turismo.

Adicional a los puntos anteriores y con el fin de promover el turismo, el gobierno federal de Canadá también se ha enfocado en facilitar el acceso de los viajeros al país a través de las siguientes acciones: 


\section{Capítulo 2. El país como una marca}

- Facilitar los viajes aéreos internacionales: actualmente se tiene un total de 39 acuerdos con diferentes países en Europa, Asia y Latinoamérica lo cual permite normas más laxas entre estos países para el tráfico aéreo.

- Mejorar la experiencia del viajero: se implementaron estrategias para agilizar los procesos de seguridad en aeropuertos y se alinearon a normas internacionales las prohibiciones sobre elementos peligrosos.

- Agilizar los procesos de visado: se incrementó el número de centros de aplicación para visa canadiense y se extendió, para algunos países, el tiempo de vigencia de la visa de 5 a 10 años.

- Movilizar turistas a través de la frontera: se hicieron inversiones significativas en la optimización de procesos de inmigración en los puntos de acceso a Canadá desde los Estados Unidos mejorando la experiencia de los turistas. También se hicieron inversiones importantes en obras de infraestructura vial con el fin de incrementar el flujo de viajeros.

Como complemento a estas estrategias, también se han enfocado en el desarrollo de productos y en el estímulo a la inversión en los activos turísticos del país. Dicha propuesta se basa en los siguientes puntos:

- Mejorar los parques nacionales

- Incentivar el turismo cultural y deportivo

- Apoyar a los negocios turísticos

- Invertir en infraestructura turística y cultural

Canadá ha trabajado fuertemente en distintos eventos y acciones promocionales en el exterior, con un fuerte compromiso y apoyo de los distintos sectores del turismo y mediante alianzas comerciales.

En el 2010, Canadá mostró que, comparativamente con el 2005, ha mejorado el ingreso relativo, en divisas por turismo en $43 \%$, a pesar de haber disminuido el número de 


\section{Capítulo 2. El país como una marca}

visitantes en un $10 \%$. Esto significa una mejora en la calidad de los ingresos en divisas por concepto de turismo para Canadá (Echeverri \& Rosker, 2011).

A diciembre de 2012 Canadá recibió 16 millones de visitantes en el año, creciendo $1,7 \%$ con respecto al año 2011. Sin embargo, es importante tener en cuenta que históricamente el número de turistas que ingresan a Canadá, como se puede ver en el Cuadro 12, viene disminuyendo en comparación con años anteriores.

Cuadro 12. Llegadas internacionales de turistas a Canadá

\begin{tabular}{|c|l|c|l|c|l|c|}
\hline \multicolumn{5}{|c|}{$\begin{array}{l}\text { Llegadas Internacionales de Turistas } \\
\text { (Top 20 de países en millones) }\end{array}$} \\
\hline Puesto & \multicolumn{2}{|c|}{2008} \\
\hline 1 & Francia & 77.0 & Francia & 79.2 & Francia & 2012 \\
\hline 2 & España & 52.3 & Estados Unidos & 57.9 & Estados Unidos & n/a \\
\hline 3 & Estados Unidos & 43.6 & España & 57.2 & China & 57.7 \\
\hline 4 & Italia & 39.8 & China & 53.0 & España & 57.7 \\
\hline 5 & China & 36.8 & Italia & 42.7 & Italia & 46.4 \\
\hline 6 & Reino Unido & 24.2 & Reino Unido & 30.1 & Turquía & 35.7 \\
\hline 7 & Canadá & 20.1 & Ucrania & 25.4 & Alemania & 30.4 \\
\hline 8 & México & 19.7 & Turquía & 25.0 & Reino Unido & 29.3 \\
\hline 9 & Austria & 18.6 & Alemania & 24.9 & Rusia & 25.7 \\
\hline 10 & Alemania & 18.0 & México & 22.6 & Malasia & 25.0 \\
\hline 11 & Hong Kong & 16.6 & Malasia & 22.1 & Austria & 24.2 \\
\hline 12 & Hungría & 15.9 & Austria & 21.9 & Hong Kong & 23.8 \\
\hline 13 & Grecia & 14.2 & Rusia & 21.6 & México & 23.1 \\
\hline 14 & Polonia & 14.0 & Hong Kong & 17.3 & Ucrania & 23.0 \\
\hline 15 & Malasia & 13.3 & Canadá & 17.1 & Tailandia & 22.4 \\
\hline 16 & Turquía & 12.8 & Grecia & 15.9 & Canadá & 16.3 \\
\hline 17 & Portugal & 11.6 & Arabia Saudita & 14.8 & Grecia & 15.5 \\
\hline 18 & Tailandia & 10.9 & Tailandia & 14.6 & Polonia & 14.8 \\
\hline 19 & Ucrania & 10.5 & Polonia & 13.0 & Arabia Saudita & 13.7 \\
\hline 20 & Holanda & 9.6 & Egipto & 12.3 & Macao(China) & 13.6 \\
\hline
\end{tabular}

Fuente: Adaptado de Canadian Tourism Comission (2013). 


\section{Capítulo 2. El país como una marca}

Mientras Canadá disminuye en número de turistas, otras naciones como Francia presentan cada vez mejores cifras en este aspecto. Esto quiere decir que el total de personas con intención y posibilidad de viajar en el mundo se está redistribuyendo hacia nuevos rumbos. Una de las posibles explicaciones de esta dramática caída en las cifras canadienses se debe a los altos costos de los tiquetes aéreos para llegar a Canadá (Canandian Tourism Comission, 2013).

Si bien Canadá cuenta con una de las mejores infraestructuras aeroportuarias del mundo, los múltiples impuestos hacen que el costo de un tiquete aéreo sea mucho más alto en comparación con otros destinos turísticos como por ejemplo, Estados Unidos.

Si bien se están creando y ejecutando tareas de promoción de la marca país, esto parece no ser suficiente en términos de presupuesto destinado al marketing de la marca. Mientras otros países invierten altas cifras en la promoción del país, el gobierno canadiense reduce cada vez más el monto destinado a este rubro (Canandian Tourism Comission, 2013). Lo anterior es una posible causa más de la disminución en las cifras de turismo.

El camino de Canadá y su marca país permanece y es consistente en el tiempo, sus objetivos están delimitados y la realidad les ha permitido mantenerse como país líder entre los rankings que miden estas marcas en sus diferentes espectros, y particularmente este país continua firme y su gobierno pese a los cambios de administración crece en su aporte al país en términos económicos, sociales y culturales.

\subsubsection{Estados Unidos}

Estados Unidos parece ser un país que no requiere ser promocionado, y mucho menos en mercados internacionales (O’Shaughnessy \& O’Shaughnessy, 2000). Sin embargo, es un país que no ha realizado mayores esfuerzos en desarrollar una marca país como tal (oficialmente inició en 2010) con el propósito de ofrecer una amplia gama de destinos y experiencias que no tienen paralelo en el mercado mundial. 


\section{Capítulo 2. El país como una marca}

Pero independiente de la estrategia, es un país que ha construido una fuerte imagen hacia el exterior gracias a su cultura, el poder de sus medios, su economía y a su papel en la historia del último siglo. Si bien es cierto que la imagen es fuerte, esta varía según la región del mundo (Bush, 2009).

Como toda potencia mundial, Estados Unidos tiene sus partidarios y contradictores; en especial, teniendo en cuenta que es un país que ha participado en varias guerras en el último siglo y que por el apoyo político que le ha dado al estado de Israel, tiene poca su popularidad en el mundo musulmán.

En el 2009, el presidente Obama dio un discurso donde propuso cambiar la percepción de Estados Unidos en el mundo musulmán, lo que hasta la fecha no ha sucedido pues la guerra se mantiene en Oriente y la pacificación que se prometió entre israelíes y palestinos aún no ha llegado (Ramírez, 2013).

Uno de los términos que se encuentran al revisar sobre los estudios al respecto de la imagen de estados unidos es el antiamericanismo, término que hace referencia a una corriente que promulga el desacuerdo frente a la política exterior, sociedad, cultura o valores de los Estados Unidos. Para O’Connor (2007) el antiamericanismo se puede clasificar en cuatro etapas (ver Figura 10):

Figura 10. Etapas del antiamericanismo

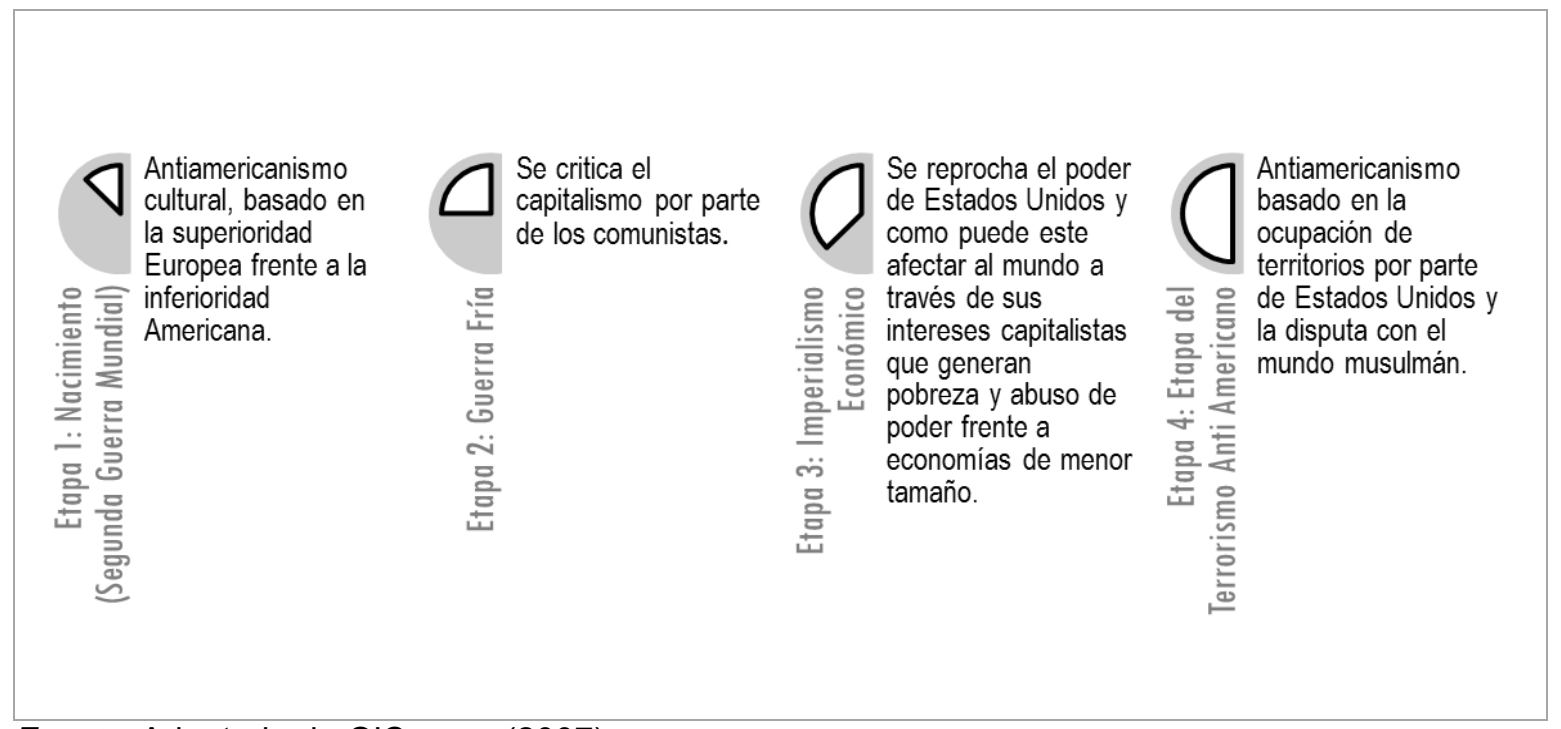

Fuente: Adaptado de O'Connor (2007). 


\section{Capítulo 2. El país como una marca}

Sobre el antiamericanismo la literatura ha aportado bastante y se ha tratado de justificar de diversas formas (Chiozza, Anti-Americanism and the American world order, 2010). Sin embargo, también existe la corriente inversa: El pro-americanismo y agrupa a todas aquellas personas que están de acuerdo, y en algunos casos admiran, las políticas estadounidenses, su cultura, su sociedad y sus valores (Chiozza \& Choi , 2012).

Independiente de la posición política o situación económica, Estados Unidos seguirá representando el sueño americano (FutureBrand, 2007).

Es el segundo país más visitado del mundo, después de Francia (Murphy, 2013). Sin embargo, entre los años 2000 y 2010, los gastos en viajes internacionales hacia Estados Unidos se redujeron notablemente, pasado de un 17,2\% al 11,6\% (Milken Institute, 2010). Una de las causas en la reducción del número de visitantes se debió a lo ocurrido con los ataques terroristas del 2001 (Morgan \& Pritchard, 2004). Ante este acontecimiento, se incrementó la seguridad restringiendo el ingreso de visitantes extranjeros.

La incertidumbre que se generó por esta situación, llevo a los principales bancos internacionales a bajar las tasas de interés para incentivar el consumo, principal factor en la generación de la crisis económica que junto con el crecimiento de los valores de los bienes inmuebles, la posterior subida de las tasas de interés y las impagables deudas hipotecarias generaron la burbuja inmobiliaria. Pero esto, no fue lo único que desató la crisis también se redujeron las inversiones, se presentó una desaceleración en los consumidores, en las exportaciones y en el gasto público (Delgado, 2009).

Esta crisis ha traído consecuencias en la economía mundial, los impactos negativos van desde pérdidas financieras en sus sistemas bancarios, hasta efectos en la actividad económica de los países que tenían relaciones comerciales con Estados Unidos. Según el McKinsey Global Institute (2010), el número de visitantes extranjeros a los Estados Unidos (excluyendo a Canadá y México) se redujo en 2 millones en el 2009. Para ese periodo se esperaban USD 214 millones en ingresos adicionales.

Estados Unidos facturó 134.400 millones de dólares gracias al turismo internacional en el año 2010, cuando un máximo histórico de 60 millones de personas visitaron el país, según datos del departamento de Comercio (McKinsey Global Institute, 2010). 


\section{Capítulo 2. El país como una marca}

Sin embargo, la mayoría de estos visitantes provienen de países fronterizos, incluyendo los viajes de menos de un día. Sólo un 6\% llegaron desde Reino Unido, un 5\% desde Japón, un 3\% de Alemania y un 2\% desde Francia (The Brand USA, 2012b). Considerando que el turismo supone un 2,8\% del PIB y que aporta 7,52 millones de empleos, Washington apuesta a que esta industria sea una forma fácil y rápida de sacar a la economía del pozo de la recesión (The Brand USA, 2012a).

Los Estados Unidos sigue siendo uno de los principales destinos turísticos en el mundo, pero se enfrenta a una fuerte competencia. La Unión Europea gasta USD 800 millones al año para la promoción del turismo receptivo, México destina USD 187 millones, Australia, USD 113 millones, el Reino Unido, USD 200 millones (The Brand USA, 2012a).

Mientras que Estados Unidos no ha destinado recursos para atraer turísticas en los últimos 10 años. En el 2009 era el único país industrializado sin una estrategia de marca país para incentivar el turismo (The Brand USA, 2012a).

Si bien, Estados Unidos no ha destinado recursos para su estrategia de marca país, desde el 2005, el Ranking Country Brand Index CBI ubica en las dos primeras posiciones a la marca país de Estados Unidos junto con la de Canadá en el continente americano (FutureBrand, 2005; FutureBrand, 2006; FutureBrand, 2007; FutureBrand, 2008; FutureBrand, 2009; FutureBrand, 2010; FutureBrand, 2012a).

La imagen país de Estados Unidos ha pasado por varios momentos. Posterior a 2001, en el gobierno Bush, con las medidas impopulares para luchar contra el terrorismo la marca se vio afectada negativamente.

En 2007 y 2008, durante el segundo mandato de George Bush, Estados Unidos ocupó el séptimo lugar en la lista de los 50 países más admirados del mundo (GFK Group, 2009).

La elección de Barack Obama en el 2008, representó una mejoría en el indicador en lo que se conoció como el efecto Obama que renovó la credibilidad y la atención sobre las ideologías americanas tradicionales (FutureBrand, 2012a). 


\section{Capítulo 2. El país como una marca}

La marca continuó viéndose afectada, esta vez por las crisis fiscales y las incertidumbres en la economía del país, así como por las percepciones generadas por temas polémicos como la legislación migratoria, los matrimonios entre personas del mismo sexo y el desempleo (Hoefer, Rytina, \& Baker, 2011; Pew Research Center, 2013).

A partir del 2010, se creó la Corporación para la Promoción de Viajes, organización encargada de promocionar al país como destino turístico y de inversión dirigido al público internacional. Esta organización es la responsable de la gestión de marca país en los Estados Unidos pasa a denominarse Brand USA.

Organización está liderada por la industria privada con la supervisión del Departamento de Comercio de Estados Unidos y el Congreso (Daily Travelling News, 2011).

La creación de la nueva marca país de Estados Unidos es el primer paso crítico en el desarrollo del primer esfuerzo de marketing que expone un país unificado. El propósito misional de la marca es invitar a los extranjeros a visitar a Estados Unidos para fines de ocio, negocios y académicos (Corporation for Travel Promotion, 2013).

La marca país de Estados Unidos es un organismo sin Animo de Lucro, apoyada por la inversión privada y por el fondo del Electronic System for Travel Authorization (ESTA). En el 2012 recibió cerca de 110 mil dólares para financiarse, de los cuáles un 10\% corresponde a los aportes de las empresas contribuyentes y el 90\% son ingresos generados por los visitantes internacionales de países donde hay exención de visas (Corporation for Travel Promotion, 2012).

Para el 2012, la marca país de Estados Unidos determinó un presupuesto de 70 mil dólares para gastos en marketing, investigaciones de mercados, eventos, comunicaciones y salarios, entre otros (Corporation for Travel Promotion, 2012). La esencia de esta nueva marca país subyace en ser un lugar con posibilidades ilimitadas. Tienen claro que cada visitante y cada experiencia ayudan a crear la estructura de la cultura americana, sus audiencias son ilimitadas y tienen como finalidad mostrar lo mejor de América en el ámbito internacional. 


\section{Capítulo 2. El país como una marca}

Para el 2012, la marca país de Estados Unidos determinó un presupuesto de 70 mil dólares para gastos en marketing, investigaciones de mercados, eventos, comunicaciones y salarios, entre otros (Corporation for Travel Promotion, 2012).

La esencia de la nueva marca país subyace en ser un lugar con posibilidades ilimitadas. Tienen claro que cada visitante y cada experiencia ayudan a crear la estructura de la cultura americana, sus audiencias son ilimitadas y tienen como finalidad mostrar lo mejor de América en el ámbito internacional.

Por primera vez los Estados Unidos tiene un programa de capitalización de imagen país orientado al marketing turístico. La misión de la marca país es fomentar las visitas internacionales hacia los Estados Unidos y aumentar su participación en el mercado global de viajes (Corporation for Travel Promotion, 2013). De este modo, el objetivo es atraer a nuevos visitantes internacionales a los Estados Unidos, y generar nuevos empleos en el mercado interno.

En el 2012 se incrementó el número de visitantes procedentes de Japón, Brasil, China y Korea del Sur a Estados Unidos en un $7 \%$ con respecto al año (US Department of Commerce, 2013).

Entre las funciones de la marca país, tal como se establece en la Ley de Promoción de Viajes aprobada por el Congreso en 2010, están: identificar, corregir y minimizar las percepciones erróneas sobre las políticas de admisión a los Estados Unidos (Corporation for Travel Promotion, 2013).

El mensaje de la nueva marca tiene tres elementos que se asocian a la imagen país estadounidense: fresco, acogedor e inclusivo (Ver Figura 11). Pretende recordar al mundo que los Estados Unidos es un país incluyente, y que mantiene la idea del sueño americano en gran parte de los países hispanoamericanos (FutureBrand, 2010). 


\section{Capítulo 2. El país como una marca}

Figura 11. Logotipo de la marca país de Estados Unidos

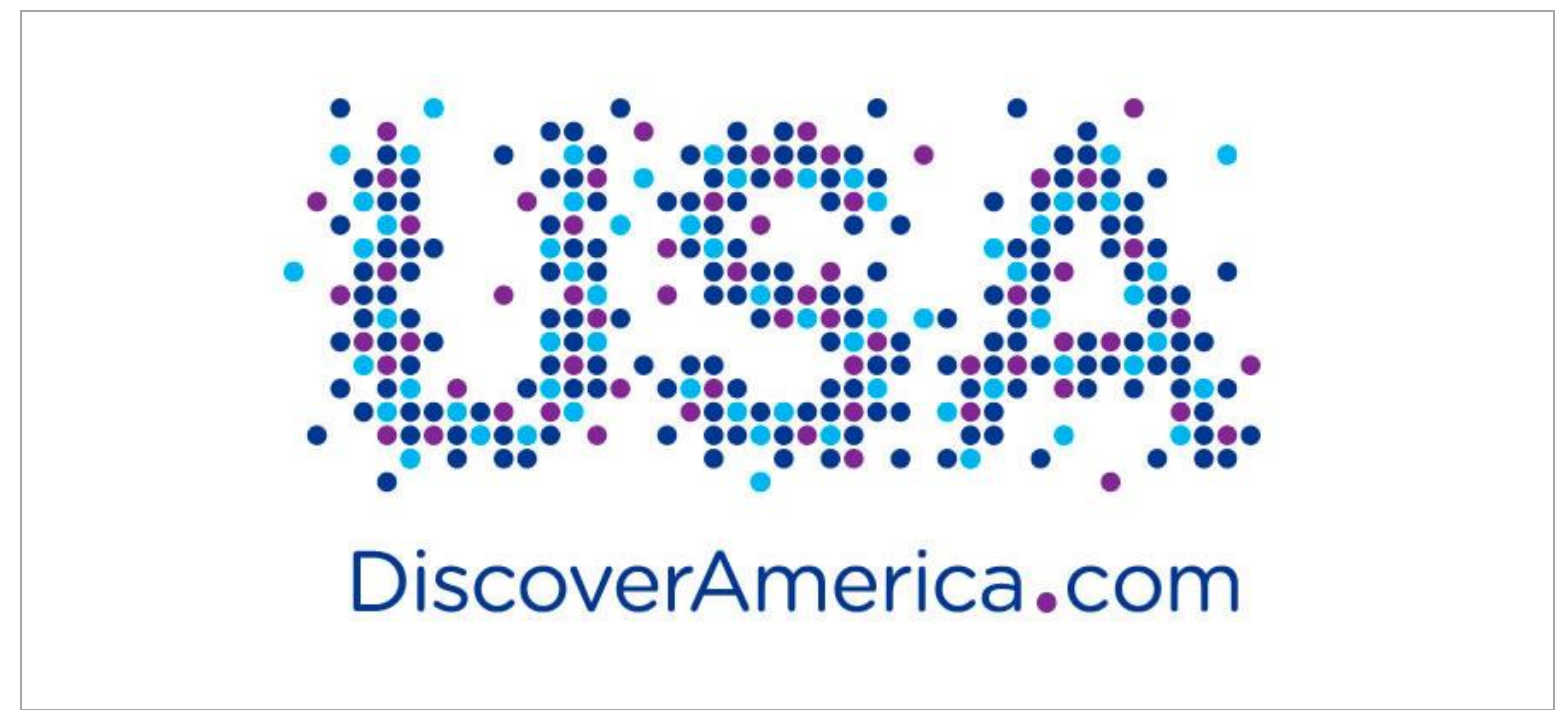

Fuente: Adaptado de Corporation for Travel Promotion (2013).

A inicios del 2012, el Gobierno de Obama anunció nuevas iniciativas administrativas para aumentar considerablemente los viajes y el turismo en y hacia los Estados Unidos (The Brand USA, 2012b). La intencionalidad del gobierno norteamericano se vincula con las acciones que está ejecutando su nueva marca país. Sin embargo, cabe señalar que los resultados en términos de posicionamiento pueden o no coincidir con las acciones de la marca país.

La estrategia nacional de turismo y viajes para el 2012, se fundamenta en el hecho de que los Estados Unidos se están quedando atrás en la promoción de su marca frente a otros competidores. Esta estrategia busca principalmente (Task Force on Travel \& Competitiveness, 2012):

a. Promover a los Estados Unidos con ayuda de la marca país Estados Unidos a través de la creación de un mensaje positivo de bienvenida para los visitantes internacionales. 


\section{Capítulo 2. El país como una marca}

b. Habilitar e incentivar los viajes y el turismo hacia y dentro de los Estados Unidos por medio de la reducción de las barreras de entrada como visados y renovación de los mismos. Adicionalmente, se harán mejoras a los procesos tecnológicos para optimizar los circuitos de seguridad en inmigración en los puntos de entrada a Estados Unidos.

c. Proveer servicio de primera clase y mejorar la experiencia del turista. Para esto, el gobierno apoyará financieramente a las grandes y medianas empresas que implementen programas para la mejora de atención a turistas. Hacer estudios e implementar métricas. Se debe contar con la información real y actualizada sobre las estadísticas de turismo con base en las cuales se tomarán decisiones de inversión y de implementación de programas para la mejora del turismo en Estados Unidos.

De acuerdo con el Cuadro 13, el Nation Brand Index 2012, muestra que la marca país de Estados Unidos ha mejorado su posicionamiento, y llegando a ocupar el primer puesto en el Top 10.

Cuadro 13. Posicionamiento de las marcas país según Nation Brand Index NBI 2012

\begin{tabular}{|c|l|c|c|}
\hline Posición & \multicolumn{1}{|c|}{ País } & Puntaje NBI 2012 & Diferencia 2012/2011 \\
\hline 1 & Estados Unidos & 69.09 & +0.21 \\
\hline 2 & Alemania & 67.72 & -0.13 \\
\hline 3 & Reino Unido & 67.14 & -0.25 \\
\hline 4 & Francia & 66.58 & -0.38 \\
\hline 5 & Canadá & 65.90 & -0.54 \\
\hline 6 & Japón & 65.87 & -0.85 \\
\hline 7 & Italia & 65.08 & -0.50 \\
\hline 8 & Suiza & 64.61 & -0.25 \\
\hline 9 & Australia & 64.36 & -0.53 \\
\hline 10 & Suecia & 63.49 & -0.38 \\
\hline
\end{tabular}

Fuente: Adaptado de Anholt (2012). 


\section{Capítulo 2. El país como una marca}

Estados Unidos continúa siendo el país con mayor consideración y preferencia por parte de los extranjeros, al igual que el país con la mayor familiaridad (Pew Research Center, 2013). En el estudio en el 2012, se preguntó a personas de 59 países sobre su percepción favorable o desfavorable frente a los Estados Unidos, sin tener que dar mayores especificaciones.

Los resultados fueron favorables entre personas procedentes de países americanos y europeos como se observa en la Figura 12.

Figura 12. Porcentaje de la población con imagen favorable sobre Estados Unidos

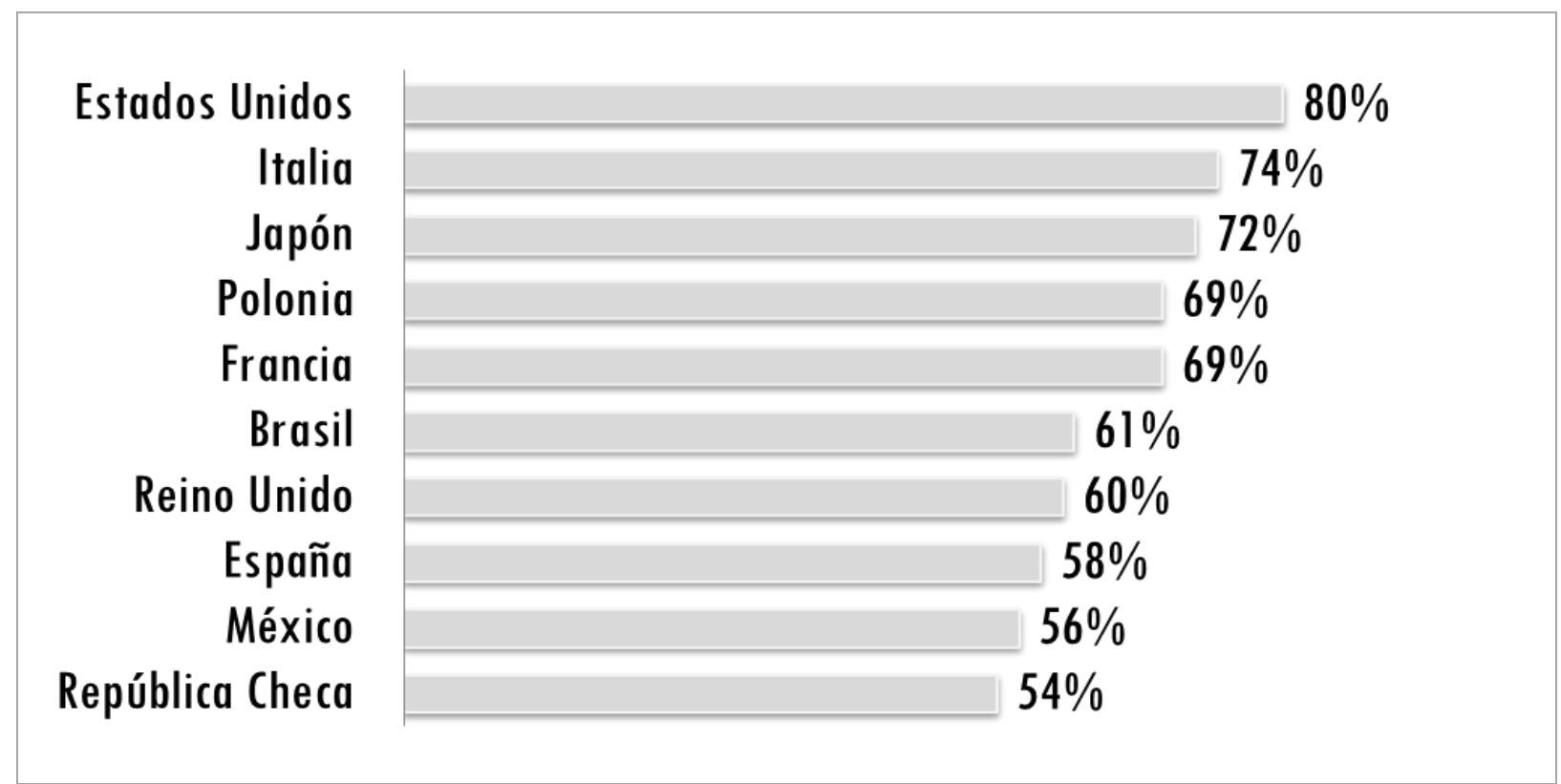

Fuente: Adaptado de The Pew Global Attitudes Project (2012).

Las personas procedentes de Jordania, Pakistán, Egipto y Turquía indicaron que tenían una percepción desfavorable de la imagen de Estados Unidos (Ver Figura 13). 


\section{Capítulo 2. El país como una marca}

Figura 13. Porcentaje de la población con imagen desfavorable sobre Estados Unidos

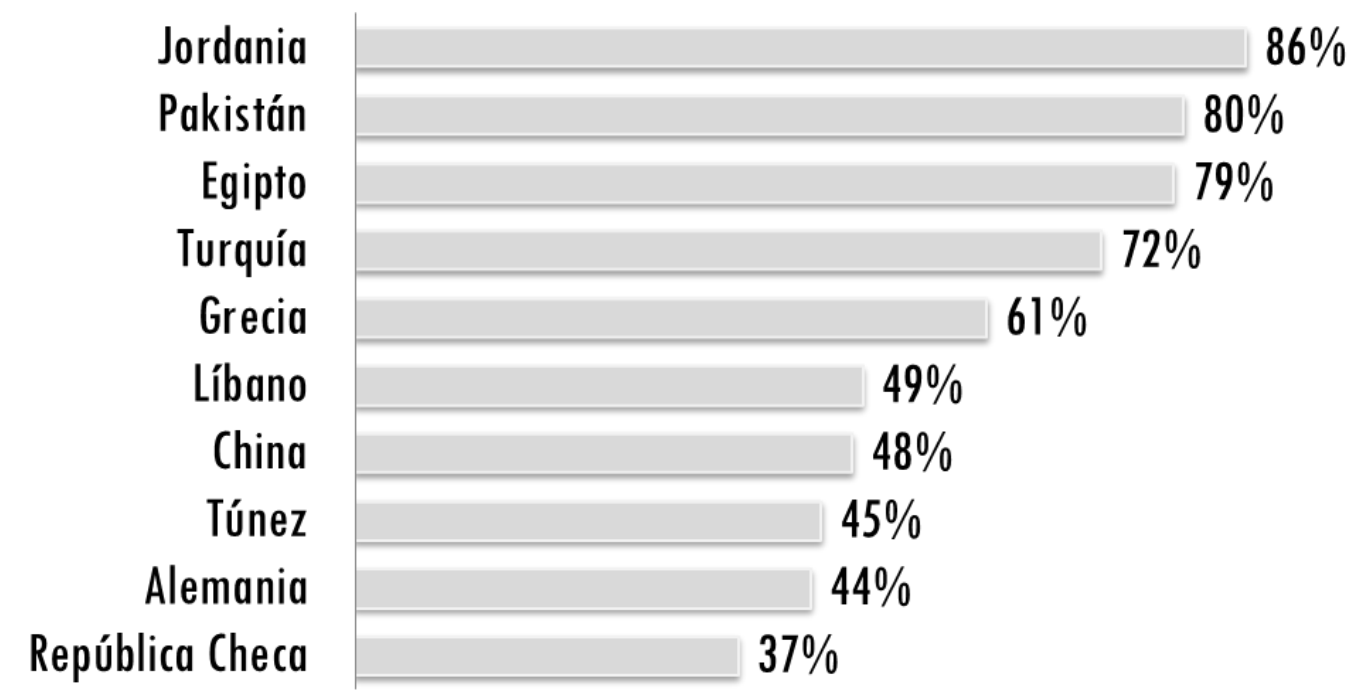

Fuente: Elaboración propia con datos de The Pew Global Attitudes Project (2012).

Como puede notarse la reputación de Estados Unidos en los países que se ven afectados por el conflicto con Israel como lo son Pakistán y Jordania es negativa mientras que la percepción que tienen los estadounidenses de sí mismo es positiva, mientras que los países europeos y latinoamericanos se mantienen divididos.

Conforme a los resultados, The Pew Research Center (2013) indica que Estados Unidos es un país al que se le reconoce por ser un importante atractivo turístico y de buen clima para los negocios. Sin embargo, puede mejorar en los aspectos que tienen que ver con la economía, como lo son la calidad de vida y el sistema de valores. La economía de Estados Unido ha pasado por un crisis reciente fuerte y que dejo algunos rezagos en la economía del país, sin embargo esto no fue impedimento para que la marca país se siguiera potencializando con el fin de traer beneficios vía exportaciones, ingreso de turismo e inversión extranjera directa, variables que aportan al crecimiento del país y a estimular la economía.

\subsubsection{México}

La intencionalidad de crear una marca país para México se origina en el 2003 pero se materializa en el 2004. Idea fundamentada en integrar los valores culturales, productivos y 


\section{Capítulo 2. El país como una marca}

comerciales a través del Consejo de Promoción Turística de México creado desde 1999 (Urrutia, 2006).

Se creó la marca México como símbolo de unidad e integración de regiones y sectores (Barriendos, 2006). El objetivo principal era comunicar la actualidad del país por lo que a cada letra de la palabra México tenía su propio significado: M de civilización milenaria, E de nación que nace de dos mundos, X símbolo de encuentro, I de verticalidad, aspiraciones modernas, $\mathrm{C}$ de vitalidad, recursos naturales, $\mathrm{O}$ de mares y cielos, belleza natural (Urrutia, 2006).

El lema de acompañamiento de la marca fue México: único, diverso y hospitalario. Cada aspecto justificaba el propósito misional de la marca. Único por su sistema de tradiciones y costumbres, Diverso por los atractivos turísticos y Hospitalario por la calidez de su gente (Ver Figura 14).

Figura 14. Logotipo de la marca país de México

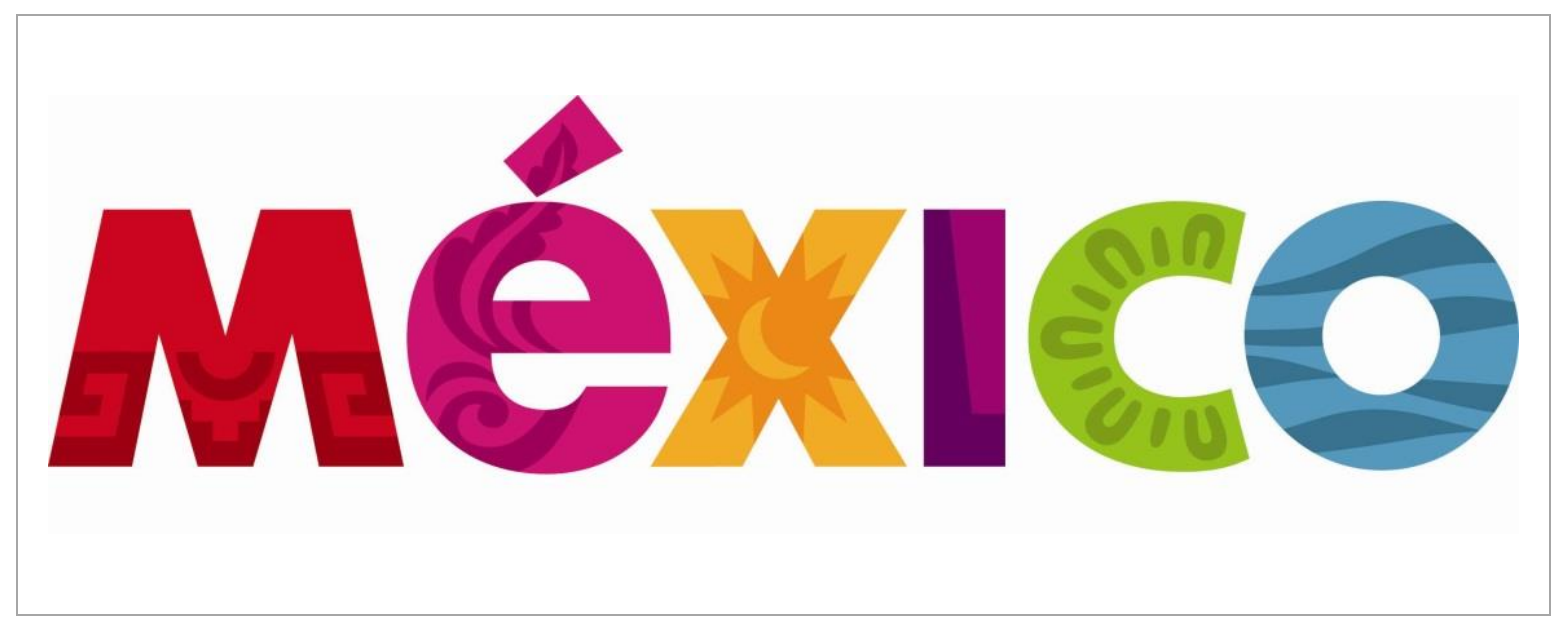

Fuente: Adaptado de Secretaría de Turismo de México (2013). 


\section{Capítulo 2. El país como una marca}

A partir del 2005, el Ranking Country Brand Índex CBI incluyó a México en sus mediciones de posicionamiento de marca país en el ámbito internacional. México llegó a ocupar el puesto \# 9 en el ranking mundial de las mejores marcas países por su cultura e historia (FutureBrand, 2005).

A partir de 2006, cuando el presidente Felipe Calderón asumió el poder, el gobierno mexicano inició un agresivo esfuerzo para acabar con los traficantes de drogas. Esto dio lugar a la escalada de la violencia del narcotráfico, que ha afectado la imagen de México como un destino turístico (Echeverri et al., 2013).

El gobierno mexicano ha hecho hincapié en el hecho de que la violencia del narcotráfico se concentra en las regiones específicas en las que los cárteles de la droga tienen sus operaciones. Sin embargo, la constante cobertura de los medios de comunicación, además de las advertencias emitidas por los Estados Unidos, restringió el flujo de turistas entrantes pero no afectó los resultados de la marca país.

En el 2006, se comparó la estrategia de posicionamiento de México con la de India y Nueva Zelandia, como el reflejo de una identidad auténtica sustentada en sus valores culturales (FutureBrand, 2006).

En el 2007, por Decreto Presidencial se crea PROMEXICO, entidad dedicada a la promoción de negocios internacionales de México (Diario Oficial de la Federación, 2007).

Para Felipe Calderón, en ese entonces, Presidente de México, la labor de promoción del país había sido insuficiente y ya era momento de convertir al país en el principal exportador de América Latina (Diario El Siglo de Torreón, 2007). Ese mismo año, México ocupó el puesto \#9 en el CBI dentro de los países preferidos por sus playas de aguas cristalinas, el puesto \#4 en el grupo de países que mejor retorno a la inversión ofrece a sus visitantes y el puesto \#8 en los destinos elegidos por la vida nocturna que ofrece a sus turistas (FutureBrand, 2007).

La estrategia de la marca país de México ha logrado la sinergia entre la asociación del nombre de un país con las características del estilo de vida de sus residentes, la calidad de sus productos, su sofisticación, la tecnología y el glamour. Considerando desde hace un tiempo México ha buscado alejarse de la sombra poderosa que proyecta Estados Unidos (Anholt \& Hildreth, 2005a). 


\section{Capítulo 2. El país como una marca}

El Consejo de Promoción Turística de México definió los siguientes mercados foco de la estrategia de promoción de la marca país México (Superbrands, 2006):

- Mercado Nacional

- Estados Unidos y Canadá

- En Latinoamérica: Argentina, Chile y Brasil

- En Europa: España, Inglaterra, Francia, Italia y Alemania

- Japón y China en Asia

En el 2008, el CBI incluyó a México en el Top 10 de países en el mundo que las personas desearían visitar sin importar que sea inseguro (FutureBrand, 2008). La imagen de México en los mercados internacionales ha estado fuertemente articulada al concepto del made in. Corona es la marca de cerveza más reconocida internacionalmente (Echeverri et al., 2013). Corona es una cerveza ligera y popular, procedente de México una tierra con riqueza cultural y atractivos turísticos de incluyen hermosas playas y ruinas de antiguas civilizaciones emblemáticas. Situación que permite a la marca país aprovecharse de la imagen y posicionamiento de la bebida.

Según FutureBrand (2009), la asociación productiva entre país y producto contribuye a mejorar la percepción que tienen los extranjeros otorgando una identidad a México de un lugar agradable que ofrece una vida nocturna y espacios de relajación.

En el 2009, ocupó el tercer puesto del Country Brand Index en América, después de Estados Unidos y Canadá. En un año de recesión económica, México sobrevivió con una marca muy fuerte posicionándose como un destino importante para el turismo receptivo. Resultados contradictorios a los que sucedía con su economía (Echeverri et al., 2013).

En enero de 2009 la economía de México se desplomó drásticamente. Descenso causado por una caída en la producción industrial, y la desaceleración de la demanda de Estados Unidos. Estos factores llevaron a la economía mexicana a generar resultados negativos en términos de salarios y empleo muy distinto a lo esperado para el 2009 (Banco de México, 2010). 


\section{Capítulo 2. El país como una marca}

En este periodo, el Presidente Calderón presentó la estrategia Vive México para reimpulsar el turismo nacional e internacional. México tuvo una lenta recuperación económica en el 2010. El sector de turismo experimentó una leve recuperación en 2010, después de ser afectado por la crisis económica mundial y el virus H1N1 en 2009. Esta mejoría si bien fue importante no fue suficiente para liberarse de la recesión. El crecimiento real del PIB fue del 5.2\% en 2010, tras un descenso del 6.1\% en 2009 (Banco de México, 2010).

Un aumento en la confianza de los consumidores, y varias estrategias de promoción del gobierno mexicano, fueron los motivos que impulsaron el turismo en México, situación demostrada por los aumentos de los niveles de ocupación y gasto en éste sector (América Economía, 2011b).

En el 2009, el sector público y privado solicitó desvincularse de la marca México por la asociación que tenía la marca país con la violencia. Se propuso crear programas de promoción turística regional en lugar de nacional (CNN Expansión, 2010).

De acuerdo con lo anterior, Vive México se ha convertido en una herramienta para la promoción del turismo nacional e internacional en el país.

Los territorios donde opera son: México, Estados Unidos, Canadá y varios países europeos y latinoamericanos. El Gobierno, junto con agencias de viajes, ha mantenido esta estrategia como parte de un esfuerzo conjunto para estimular el turismo y promover una imagen positiva del país, dado el aumento de la violencia causada por el narcotráfico en México (Echeverri et al., 2013).

Resultado de los esfuerzos por promover al país, el sector de los viajes y de turismo experimentó un lento pero positivo crecimiento durante el año 2011. Las llegadas internacionales aumentaron un $4 \%$ y los ingresos turísticos entrantes sólo generaron un ligero crecimiento (Reyna , 2012). 


\section{Capítulo 2. El país como una marca}

Durante el año 2010, año del bicentenario de la independencia, la marca país tuvo un reconocimiento del mercado, la cual fue utilizada para promover los destinos diferentes de México a través del lema Hoy más que nunca, vive México.

Para llegar este fin, el gobierno federal convocó en el 2009 a varios sectores entre ellos a medios de comunicación, empresarial, entre otros para que hicieran parte de la estrategia Vive México y así aumentar visitas de turistas extranjeros y nacionales para lo cual se destinaron USD 92.000 (Jiménez, 2009).

El mayor número de visitantes a México proviene de Estados Unidos. En un contexto de crisis económica internacional, los estadounidenses han reducido sus viajes vía área pero han aumentado sus viajes vía terrestre, favoreciendo el ingreso de turistas con su país vecino México. De acuerdo con la Figura 15, durante el 2011, México tuvo 22.67 millones de turistas internacionales (Secretaría de Turismo de México, 2012).

Figura 15. Turistas nacionales e internacionales desde 2000 a 2011

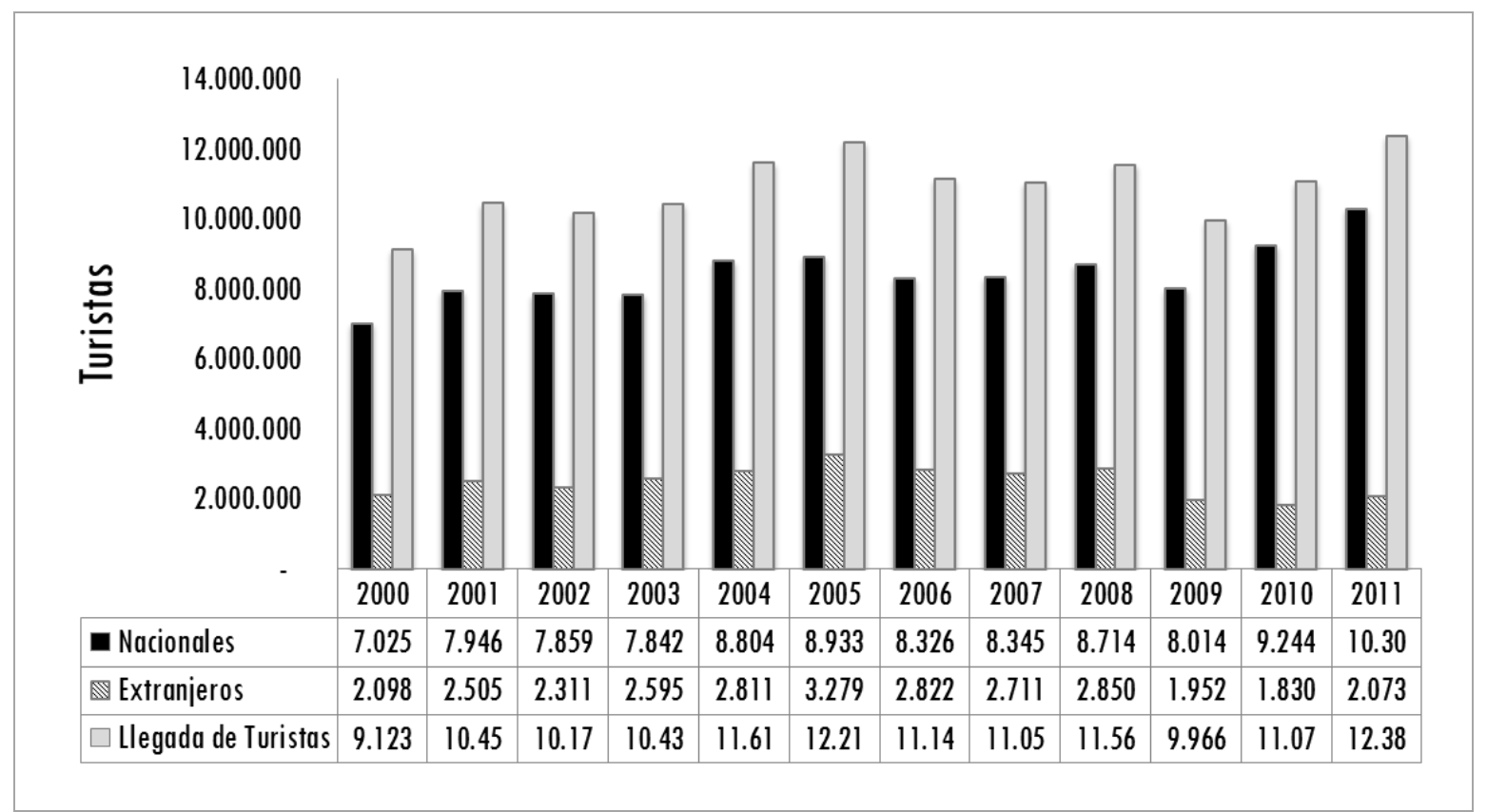

Fuente: Adaptado de Secretaría de Turismo del Gobierno del Distrito Federal (2012). 


\section{Capítulo 2. El país como una marca}

De acuerdo con el informe de Percepción de la Corrupción de Transparencia Internacional (2011), México ocupó el puesto \#100 de un total de 183 países. México obtuvo la calificación de 3 en el último índice, donde 0 representa muy corrupto y 10 significa muy transparente (Transparency International, 2011).

Durante este mismo año ocupó el puesto \#53 de 144 países en el Índice de Competitividad Global del Foro Económico Mundial, con una calificación de 4,36, donde el rango establecido es de 1 (menos competitivo) a 7 (más competitivo) lo cual representa un ascenso en 5 puestos con respecto al año anterior (World Economic Forum, 2013).

En el 2011, México ocupó el puesto \#58 de 142 países en el Índice de Competitividad Global, con una calificación de 4,3/7, donde el rango establecido es de 1 (menos competitivo) a 7 (más competitivo). (World Economic Forum, 2011). Teniendo en cuenta los indicadores anteriores, el Gobierno mexicano se ha embarcado en la tarea de luchar contra la violencia interna, situación que no favorece su imagen externa.

Un lucha contra carteles del narcotráfico, guerra entre carteles, inestabilidad gubernamental después de la salida de un partido que gobernó por 70 años, corrupción por parte de entes policiales que el presidente Calderón tuvo que lidiar cuando asumió la presidencia, delincuencia común, consumo de drogas, entre otros. Factores que contribuyeron a promover una imagen negativa del país a nivel internacional afectando el turismo y generando sensación de inseguridad entre los ciudadanos.

En la Figura 16 se puede observar la calificación de favorabilidad y no favorabilidad que le otorgan los Estadounidenses a México (Gallup, 2010). Desde 1999, la favorabilidad aumenta, sin embargo para el año 2010 se reduce. A pesar de la disminución de dos puntos porcentuales de la calificación favorables de México, no es significativa. El resultado es que, por primera vez desde 1993, menos de la mitad de los estadounidenses tiene una opinión favorable de México.

La imagen de México en los Estados Unidos por lo general ha estado en declive desde 2005. Situación que ha generado una mayor atención de los Estados Unidos a la inmigración ilegal desde México y a la intensificación de la violencia ocasionada por la guerra contra las drogas de México (Gallup, 2010). 


\section{Capítulo 2. El país como una marca}

Figura 16. Percepción de los Estadounidenses hacia México 1999 a 2010

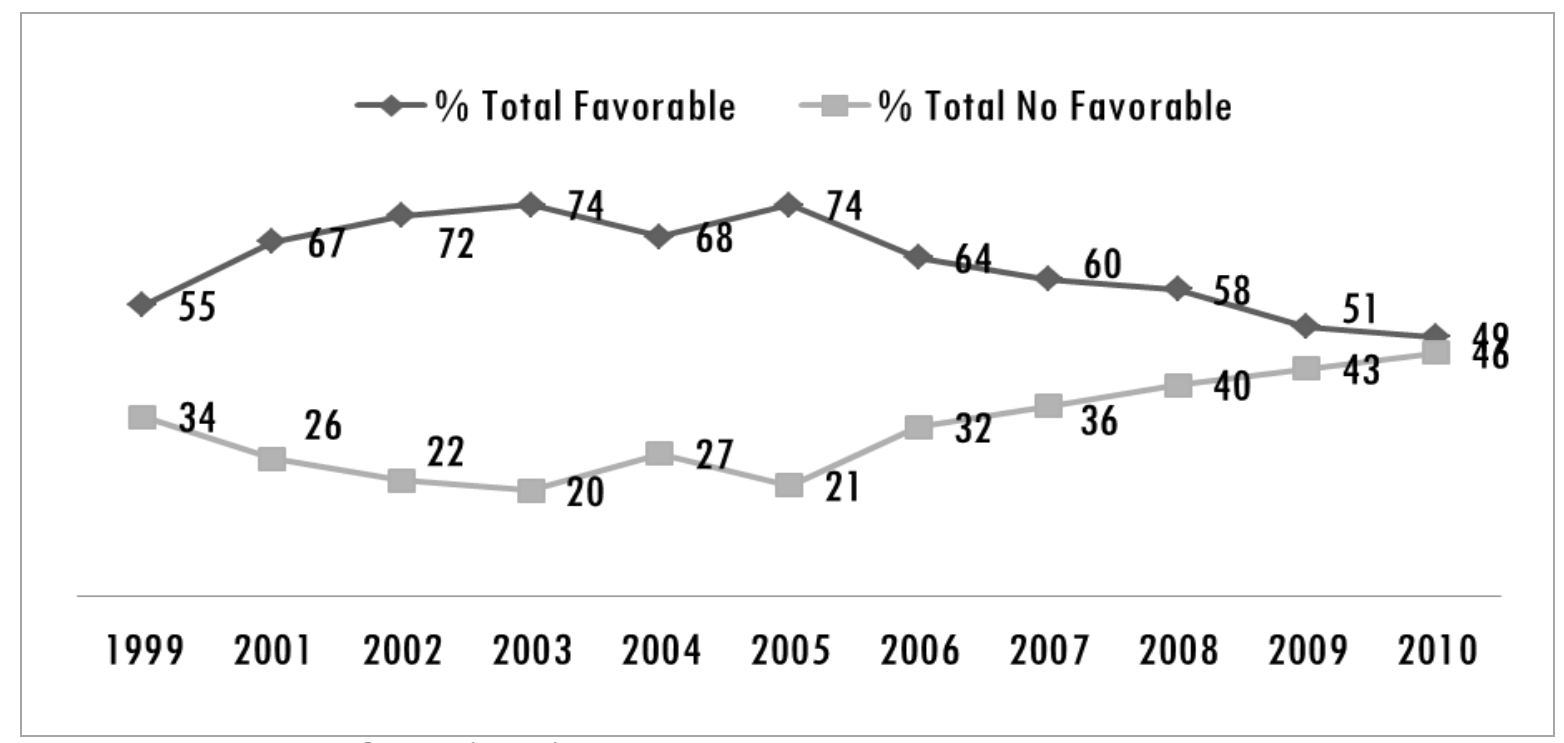

Fuente: Adaptado de Gallup (2010).

El Gobierno Mexicano estableció el 2011 como el Año Nacional de Turismo. El decreto fue acompañado por la firma de un Acuerdo Nacional para el Turismo (Secretaría de Turismo de México, 2011a), que incluía 10 objetivos estratégicos para la promoción y desarrollo de esta industria. El Acuerdo incluye, entre otros objetivos, la aceleración de los planes de infraestructura turística, con un incremento en la promoción exterior de México como destino turístico, más facilidades de crédito para los empresarios del sector y la diversificación de entradas de turistas. Los 10 puntos claves fueron:

a. Aumentar la conectividad del país, elevando la capacidad de transporte e infraestructura

b. Acelerar los planes de infraestructura turística

c. Aumentar la promoción exterior de México como destino turístico

d. Fomentar la inversión pública y privada, así como más facilidades de crédito para los agentes del sector

e. Elevar la calidad de los destinos turísticos y las empresas

f. Diversificar y aumentar la oferta turística mediante la adición de destinos, productos y servicios 


\section{Capítulo 2. El país como una marca}

g. Promover la integración de cadenas productivas nacionales (o de las industrias complementarias) con el fin de incrementar el consumo interno

h. Aumentar la sensibilización de los ciudadanos mexicanos de la importancia de la industria del turismo

i. Introducir mejoras regulatorias que favorezcan el desarrollo del sector turístico

j. Fomentar el desarrollo sostenible de todos los actores del sector con el fin de preservar el medio ambiente y hacer un mejor uso de los recursos.

Como se puede observar en el Cuadro 14, en el 2011, México ocupó el puesto \# 47 en el Ranking del Country Brand Index de 2011 y el puesto \#23 en el Top 25 del Ranking en Turismo (FutureBrand, 2012a).

Cuadro 14. Top 25 del Ranking CBI categoría Turismo 2011

\begin{tabular}{|l|c|c|}
\hline País & Ranking Turismo & Ranking General \\
\hline Japón & 1 & $\# 4$ \\
\hline Italia & 2 & $\# 10$ \\
\hline España & 3 & $\# 14$ \\
\hline Estados Unidos & 4 & $\# 6$ \\
\hline Francia & 5 & $\# 9$ \\
\hline Suiza & 6 & $\# 26$ \\
\hline Tailandia & 7 & $\# 5$ \\
\hline Australia & 8 & $\# 3$ \\
\hline Nueva Zelanda & 9 & $\# 18$ \\
\hline Maldivas & 10 & $\# 22$ \\
\hline Mauricio & 11 & $\# 11$ \\
\hline Alemania & 12 & $\# 1$ \\
\hline Canadá & 13 & $\# 31$ \\
\hline Brasil & 14 & $\# 7$ \\
\hline Suecia & 15 & $\# 29$ \\
\hline India & 16 & $\# 17$ \\
\hline Austria & 17 & $\# 16$ \\
\hline Singapur & 18 & $\# 32$ \\
\hline Argentina & 19 & $\# 48$ \\
\hline Turquía & 20 & $\# 43$ \\
\hline Malasia & 21 & $\# 34$ \\
\hline Chile & 22 & $\# 47$ \\
\hline México & 23 & $\# 8$ \\
\hline Finlandia & 24 & $\# 25$ \\
\hline Emiratos Árabes Unidos & 25 & \\
\hline Fuentadaptado & & \\
\hline
\end{tabular}

Fuente: Adaptado de FutureBrand (2012a). 


\section{Capítulo 2. El país como una marca}

El 2011 fue un año histórico en sus cifras de turismo internacional. El turismo receptivo internacional creció en un 1,9\% comparado con el 2010. Llegaron 168 millones de turistas a México, superando los 161 millones del 2010 y 150 millones de 2009 (Consejo de Promoción Turística de México, 2012).

En el 2011, los extranjeros que más ingresaron a México eran procedentes de Francia y Estados Unidos. El ingreso de estadounidenses se redujo en un $7.3 \%$ comparado en el mismo periodo con el 2010. Sin embargo, el ingreso de canadienses aumentó en un 5.3\% comparado con el 2010 (Secretaría de Turismo de México, 2011b).

El gobierno mexicano continuará con la promoción del turismo, ya que representa una de las principales fuentes de ingresos del país. En términos de turismo receptor se espera que alcance 27 millones de llegadas en el 2015, mientras que el turismo nacional representará a 182 millones de viajes en el mismo año.

Dado el gran éxito de la campaña, otros países son propensos a imitar estos esfuerzos con el fin de aumentar los flujos de turismo en sus países.

Para el 2020, la Organización Mundial de Turismo (OMT) predice un crecimiento para México de $4.1 \%$ y espera que se alcance la cifra de turistas de 1.5 billones (Ruíz O. , 2008). Para el 2020 se proyectan llegadas internacionales a México de $3.6 \%$ y nacionales de 3.9\%. Canadá seguirá siendo el mercado de mayor crecimiento y Estados Unidos será el país que aporte el mayor número de visitantes, por lo cual, se proyectan 45 millones de turistas para el 2020 (Organización Mundial del Turismo, 2000).

Con las elecciones presidenciales de 2012 se espera que la economía mexicana permanezca estable en los próximos dos años.

El turismo seguirá siendo un importante motor de la economía, y tanto el gobierno y el sector privado tienen planes de invertir considerablemente en éste sector durante los próximos años. 


\section{Capítulo 2. El país como una marca}

La Organización para la Cooperación y el Desarrollo Económico (OCDE) estima un crecimiento para el PIB de 3.8\% (Echeverri et al., 2013).

El fortalecimiento de la economía de Estados Unidos ayuda a la demanda interna de México dado por la relación que se tiene con dicho país. Adicionalmente, los planes de gobierno son mantener un presupuesto moderado y equilibrado para el 2013 lo que puede ayudar para la recuperación (Organización para la Cooperación y el Desarrollo Económico, 2012).

México se encuentra en un buen momento para el turismo y la inversión puesto que durante el 2011 se invirtieron 3.720 millones de dólares, 5,5\% más que el año anterior, unido a 1.000 proyectos de infraestructura turística se ejecutaron a través de la iniciativa privada, de los cuales 370 fueron de hospedaje.

La Secretaría de Turismo indica que los países que más invirtieron en obras de infraestructura fueron Estados Unidos, España, China y Reino Unido (Diario El Universal, 2012).

En el Índice de Competitividad en Viajes y Turismo del 2011 del Foro Económico Mundial (ver Cuadro 15), México ocupó el lugar 43 entre 139 países del ranking global y el cuarto lugar en América entre un total de 25 países.

México obtuvo estos lugares debido a sus fortalezas como sus recursos naturales, patrimonio de la humanidad, entre otros. Estas fortalezas son soportadas por la prioridad de establecer el impulso hacia el turismo (Foro Económico Mundial, 2011). 


\section{Capítulo 2. El país como una marca}

Cuadro 15. Comparativo del Índice de Competitividad de Viajes y Turismo en Top 15 de países de América 2011-2012

\begin{tabular}{|c|c|c|c|}
\hline \multirow[b]{2}{*}{ País } & \multicolumn{3}{|c|}{2011} \\
\hline & Calificación & $\begin{array}{c}\text { Top } 15 \\
\text { Ranking } \\
\underset{\star}{\text { América }} \\
\end{array}$ & $\begin{array}{c}\text { Ranking } \\
\text { General** }^{*}\end{array}$ \\
\hline $\begin{array}{l}\text { Estados } \\
\text { Unidos }\end{array}$ & 5,3 & 1 & 6 \\
\hline Canadá & 5,29 & 2 & 9 \\
\hline Barbados & 4,84 & 3 & 28 \\
\hline México & 4,43 & 4 & 43 \\
\hline Costa Rica & 4,43 & 5 & 44 \\
\hline Puerto Rico & 4,42 & 6 & 45 \\
\hline Brasil & 4,36 & 7 & 52 \\
\hline Panamá & 4,3 & 8 & 56 \\
\hline Chile & 4,27 & 9 & 57 \\
\hline Uruguay & 4,24 & 10 & 58 \\
\hline Argentina & 4,2 & 11 & 60 \\
\hline Jamaica & 4,12 & 12 & 65 \\
\hline Perú & 4,04 & 13 & 69 \\
\hline $\begin{array}{l}\text { República } \\
\text { Dominicana }\end{array}$ & 3,99 & 14 & 72 \\
\hline Colombia & 3,94 & 15 & 77 \\
\hline
\end{tabular}

\begin{tabular}{|c|c|c|c|}
\hline \multirow[b]{2}{*}{ País } & \multicolumn{3}{|c|}{2012} \\
\hline & Calificación & $\begin{array}{c}\text { Top } 15 \\
\text { Ranking } \\
\text { América* }\end{array}$ & $\begin{array}{c}\text { Ranking } \\
\text { General }^{* *}\end{array}$ \\
\hline $\begin{array}{l}\text { Estados } \\
\text { Unidos }\end{array}$ & 5,32 & 1 & 6 \\
\hline Canadá & 5,28 & 2 & 8 \\
\hline Barbados & 4,88 & 3 & 27 \\
\hline Panamá & 4,54 & 4 & 37 \\
\hline México & 4,46 & 5 & 44 \\
\hline $\begin{array}{l}\text { Costa } \\
\text { Rica }\end{array}$ & 4,44 & 6 & 47 \\
\hline Brasil & 4,37 & 7 & 51 \\
\hline $\begin{array}{l}\text { Puerto } \\
\text { Rico }\end{array}$ & 4,36 & 8 & 52 \\
\hline Chile & 4,29 & 9 & 56 \\
\hline Uruguay & 4,23 & 10 & 59 \\
\hline Argentina & 4,17 & 11 & 61 \\
\hline Jamaica & 4,08 & 12 & 67 \\
\hline Perú & 4 & 13 & 73 \\
\hline Ecuador & 3,93 & 14 & 81 \\
\hline $\begin{array}{l}\text { Trinidad y } \\
\text { Tobago }\end{array}$ & 3,93 & 15 & 83 \\
\hline
\end{tabular}

Fuente: Adaptado de Blanke y Chiesa (2012).

* Se toma los países de América con base al Travel \& Tourism Competitiveness Report 2011-2012

${ }^{* *}$ Ranking general incluye el total de países estudiados en el Travel \& Tourism Competitiveness Report 2011 y 2012

México ocupa el puesto \#4 en la región y el segundo lugar en América Latina en el Índice de Competitividad de Viajes y Turismo de 2011. Logró subir ocho puestos desde la medición de 2009. 


\section{Capítulo 2. El país como una marca}

Los activos diferenciales que logran esta mejoría en el ranking, son los recursos naturales (\#10 en el Ranking) y la cultura (\#19 en el ranking). Tiene puntos críticos en transporte terrestre (\#79), higiene insuficiente (\# 64) y salud y seguridad (\#128).

En cuanto a los rankings de posicionamiento de marca país, México se encuentra en descenso. Si bien en el 2011 este país hacía parte del Top 25 a nivel mundial en el atributo de turismo, para el año 2012 salió de este selecto grupo. A nivel global descendió tres puestos desde el año 2010. Aun así este país es considerado por FutureBrand como una de las 15 posibles marcas país líder en los próximos años.

Se destaca el hecho de que México está haciendo grandes esfuerzos por cambiar la imagen negativa que se tiene de este país a nivel mundial. Adicional a esto, México mantiene una agenda de políticas extranjeras asertiva ya demás continua con la tarea de desarrollar las diferentes sectores con el fin de diversificar la economía (FutureBrand, 2012b). En el ranking regional de FutureBrand, México ocupa el puesto \#6 dentro de las 21 naciones de Latinoamérica evaluadas. En el Cuadro 16 se muestra la ubicación de México en cada uno de los atributos evaluados en el Country Brand Index Latinoamérica 2013 de FutureBrand.

Cuadro 16. Comparativo del ranking en los diferentes atributos evaluados en el Country Brand Index 2013 de Latinoamérica para los primeros 10 puestos

\begin{tabular}{|l|l|l|l|l|l|l|}
\hline $\begin{array}{l}\text { Ranking } \\
\text { General }\end{array}$ & País & $\begin{array}{c}\text { Ranking } \\
\text { Sistema de } \\
\text { Valores }\end{array}$ & $\begin{array}{c}\text { Ranking } \\
\text { Calidad de } \\
\text { Vida }\end{array}$ & $\begin{array}{c}\text { Ranking } \\
\text { Aptitud } \\
\text { para los } \\
\text { Negocios }\end{array}$ & $\begin{array}{c}\text { Ranking } \\
\text { Patrimonio } \\
\text { y Cultura }\end{array}$ & $\begin{array}{c}\text { Ranking } \\
\text { Turismo }\end{array}$ \\
\hline 1 & Brasil & 5 & 7 & 1 & 3 & 1 \\
\hline 2 & Argentina & 3 & 2 & 4 & 4 & 2 \\
\hline 3 & Costa Rica & 2 & 4 & 6 & 6 & 3 \\
\hline 4 & Chile & 6 & 3 & 2 & 8 & 6 \\
\hline 5 & Perú & 8 & 12 & 9 & 1 & 5 \\
\hline $\mathbf{6}$ & México & $\mathbf{7}$ & $\mathbf{9}$ & $\mathbf{7}$ & $\mathbf{2}$ & $\mathbf{4}$ \\
\hline $\mathbf{7}$ & Uruguay & 1 & 1 & 3 & 11 & 8 \\
\hline 8 & Panamá & 10 & 5 & 5 & 18 & 13 \\
\hline $\mathbf{9}$ & Colombia & 11 & 6 & 8 & 7 & 7 \\
\hline 10 & Puerto Rico & 4 & 11 & 10 & 9 & 10 \\
\hline
\end{tabular}

Fuente: Adaptado de FurureBrand (2013).

México se destaca por atributos como patrimonio, cultura y turismo. Por otra parte la calidad de vida y el sistema de valores son los atributos en los que menor valoración obtiene 


\section{Capítulo 2. El país como una marca}

incluso por debajo de Colombia, país que en otra época tenía problemas similares que para el 2013 ha presentado México.

El turismo se ha consolidado como el eje central para la estrategia de marca país, diferente a la variable de inversiones extranjeras directas. Para inversionistas norteamericanos, México no es un escenario atractivo en términos de seguridad, el país ya no se percibe como un destino clave para efectuar negocios (Newell, 2011).

Se espera una captación de 19.000 millones de dólares de inversión extranjera directa, cifra similar a la ocurrida en el año 2011 (Diario El Economista, 2012).

Sin embargo, México es un destino atractivo para la inversión extranjera por su solidez macroeconómica y que ha tenido una posición sobresaliente a pesar de la crisis económica mundial (Diario El Economista, 2012). De acuerdo con el informe de la Cámara México-Alemana, el 70\% de sus miembros tienen planes de invertir en México en el 2012 siendo esto una señal positiva de confianza en el país (Agren, 2012).

La visión de la marca país para el 2018 contempla ubicar a México en el Top 5 de los países con mayor demanda turística e ingresos por concepto de divisas (Secretaría de Turismo de México, 2011c).

\subsubsection{Marca país en América Central y el Caribe}

\subsubsection{Costa Rica}

La biodiversidad un factor clave que distingue a Costa Rica sobre otras naciones. Por este motivo ha procurado su conservación a través de la creación de parques nacionales desde 1970 (Brenes, 2003). Esa fue la primera etapa para consolidar al país como un destino para el ecoturismo. Sin embargo, en la década de los 80's, el Instituto Costarricense de Turismo (ICT) definió una estrategia diferente, en la cual se posicionara a Costa Rica como un destino de sol y playa con el apoyo del sector privado. 


\section{Capítulo 2. El país como una marca}

Lo planeado no llegó a buen término, aunque el ecoturismo ha logrado conservar un rol relevante en la estrategia de marca país de Costa Rica. Sin embargo, Costa Rica no es solo ecoturismo. Este país ocupa hoy el primer lugar de América Latina en calidad del sistema educativo y el país \#5 en el mundo cuya inversión extranjera está cultivando la innovación y tecnología (World Economic Forum, 2013). En cuanto a competitividad turística, es importante anotar que Costa Rica ocupa el lugar \# 6 entre los 27 países de América dado que, en general, la infraestructura turística (hoteles, carreteras, etc.) está altamente desarrollada en comparación con otros países de América (World Economic Forum, 2013)

El ICT presentó el Plan Marco para un Mercadeo Competitivo de Costa Rica como Destino Turístico, 1995-1999, el cual ha sido la carta de navegación para la promoción turística del país en mercados internacionales (Segura, 1998).

En 1996, McCann-Erikson obtuvo la licitación para el diseño del eslogan Sin ingredientes artificiales (Segura, 1998). En esta campaña se invirtieron más de 3 millones de dólares (Alvarado, 2010). La finalidad era relacionar a Costa Rica con un producto de la naturaleza (Alvarado, 2010). El Instituto Costarricense de Turismo y la agencia McCannErickson estuvieron a cargo de su lanzamiento (Segura, 1998). La intencionalidad era mostrar a Costa Rica a través de una receta para unas vacaciones, resaltando su volcán, los parques nacionales, el ecoturismo y las playas de agua cristalina (ver Figura 17).

Figura 17. Logotipo de la campaña promocional de Costa Rica

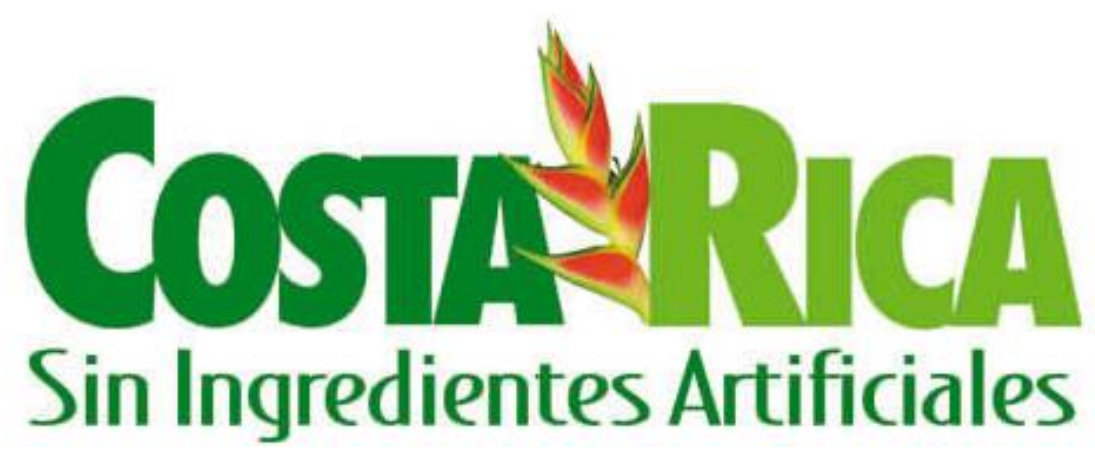

Fuente: Adaptado de Instituto Costarricense de Turismo (2013) 


\section{Capítulo 2. El país como una marca}

Costa Rica es la joya de la corona en América Latina, por ser un país sin ejército, el más seguro de América Central y con una poderosa marca país (Instituto Costarricense de Turismo, 2013). Costa Rica ha construido una imagen país sobre la base de un favorable posicionamiento internacional.

Como se puede observar en el Cuadro 17, el Ranking CBI 2006, indica que la marca país de Costa Rica ocupó la posición \#6 en la categoría de autenticidad por tener una cultura distintiva y genuina; la posición \#2 por tener una marca país exótica, con mayor oferta de excursiones no tradicionales y la posición \#8 por ser un destino preferido por parte de los turistas en los próximos cinco años (FutureBrand, 2006).

Cuadro 17. Ranking CBI categoría Autenticidad, Exótico y Estrella Emergente 2006

\begin{tabular}{|c|l|l|l|}
\hline Posición & \multicolumn{1}{|c|}{ Autenticidad } & \multicolumn{1}{|c|}{ Exótico } & Chtrella Emergente \\
\hline 1 & India & Perú & Croacia \\
\hline $\mathbf{2}$ & Nueva Zelanda & Costa Rica & Emiratos Árabes Unidos \\
\hline 3 & Egipto & Kenia & Sudáfrica \\
\hline 4 & Sudáfrica & Nueva Zelanda & Argentina \\
\hline 5 & Tailandia & Indonesia & Chile \\
\hline $\mathbf{6}$ & Costa Rica & Líbano & Vietnam \\
\hline 7 & Líbano & Sudáfrica & Costa Rica \\
\hline $\mathbf{8}$ & Italia & Tailandia & Perú \\
\hline 9 & Perú & Islandia & Turquía \\
\hline 10 & Marruecos & Fiji & \\
\hline
\end{tabular}

Nota: Fuente: Adaptado de FutureBrand (2006).

En el 2007, ocupó la posición \#10 en el Ranking CBI en la categoría de un país orientado a la protección del medio ambiente y la posición \#9 del lugar donde las personas prefieren vivir fuera de su país de origen (FutureBrand, 2007).

De acuerdo con el Ranking CBI 2008, Costa Rica ocupó la posición \#7 en la categoría de Estrella Emergente (FutureBrand, 2008).

En el 2009 se realizó el relanzamiento del eslogan Costa Rica sin ingredientes artificiales con la intencionalidad de promover al país como un destino eco turístico (Central América Data, 2009).

En el Cuadro 18 aparecen las posiciones que ha ocupado Costa Rica en el ranking de atributos en la dimensión de turismo: 


\section{Capítulo 2. El país como una marca}

Cuadro 18. Ranking CBI categoría atributos de la dimensión Turismo 2010

\begin{tabular}{|c|l|l|l|l|}
\hline Posición & \multicolumn{1}{|c|}{ Conveniencia } & \multicolumn{1}{|c|}{ Hoteles y Resorts } & \multicolumn{1}{|c|}{ Belleza Natural } & $\begin{array}{c}\text { Amigable con el } \\
\text { medio ambiente }\end{array}$ \\
\hline 1 & Tailandia & Mauricio & Noruega & Noruega \\
\hline 2 & Vietnam & Maldivas & Nueva Zelanda & Suecia \\
\hline 3 & Nueva Zelanda & Suiza & Suiza & Finlandia \\
\hline 4 & Camboya & Emiratos Árabes Unidos & Maldivas & Dinamarca \\
\hline 5 & Laos & Estados Unidos & Mauricio & Suiza \\
\hline $\mathbf{6}$ & Canadá & Costa Rica & Costa Rica & Nueva Zelanda \\
\hline 7 & Guatemala & Canadá & Islandia & Islandia \\
\hline 8 & Malasia & España & Nepal & Canadá \\
\hline 9 & Indonesia & Bahamas & Canadá & Holanda \\
\hline 10 & Uruguay & Australia & Finlandia & Australia \\
\hline 11 & México & Tailandia & Namibia & Alemania \\
\hline $\mathbf{1 2}$ & Costa Rica & Austria & Australia & Japón \\
\hline 13 & República Checa & Francia & Austria & Austria \\
\hline 14 & Botsuana & Japón & Irlanda & Singapur \\
\hline $\mathbf{1 5}$ & Australia & Barbados & Fiji & Costa Rica \\
\hline
\end{tabular}

Fuente: Adaptado de FutureBrand (2010)

Recientemente, Costa Rica viene consolidándose como la marca país más importante de América latina como se puede observar en Cuadro 19:

Cuadro 19. Ranking Country Brand Index América 2009-2011

\begin{tabular}{|c|c|c|c|}
\hline Posición & $\mathbf{2 0 0 9}$ & $\mathbf{2 0 1 0}$ & $\mathbf{2 0 1 1}$ \\
\hline 1 & Estados Unidos & Canadá & Canadá \\
\hline 2 & Canadá & Estados Unidos & Estados Unidos \\
\hline 3 & México & Costa Rica & Costa Rica \\
\hline 4 & Costa Rica & Argentina & Brasil \\
\hline 5 & Brasil & Chile & Argentina \\
\hline 6 & Argentina & Brasil & Chile \\
\hline 7 & Belice & Belice & Perú \\
\hline 8 & Uruguay & Perú & México \\
\hline 9 & Perú & México & Uruguay \\
\hline 10 & Chile & Uruguay & Rep. Dominicana \\
\hline
\end{tabular}

Fuente: Adaptado de FutureBrand (2009-2012) 


\section{Capítulo 2. El país como una marca}

Costa Rica ha hecho un excelente trabajo de posicionamiento, primero por ser un país respetuoso del medio ambiente y destino exótico. En los rankings sobresale por belleza natural, actividades y deportes al aire libre, autenticidad y sustentabilidad ambiental. Lo anterior lo consolida como un destino de primer nivel (FutureBrand, 2009).

En el 2010 y 2011, Costa Rica ha mantenido la posición \#1 como la mejor marca país de América Latina en el Ranking Regional CBI (FutureBrand, 2012a). En el ranking general del CBI 2010 ocupó la posición \#27 de un total de 110 países y en Ranking CBI 2011, ganó posición ocupando el puesto \#24 de un total de 113 países (FutureBrand, 2012a).

Dos proyectos importantes definen el posicionamiento de la marca Costa Rica: el Certificado para la Sostenibilidad Turística (CST) y la campaña de Sin ingredientes artificiales (Turismo Sostenible CST: Certificación para la Sostenibilidad Turística en Costa Rica, 2010). La visión de Costa Rica es simple, convincente y clara: ser el primer país carbono neutral en el mundo para el 2021 (FutureBrand, 2012b).

En el 2013, ocupó el puesto \#1 como el país más innovador de Latinoamérica, según el Índice Mundial de Innovación y la misma posición como el país más feliz del mundo (The New Economics Foundation, 2013).

Ese mismo año, Costa Rica lanzó una nueva marca país. El ICT, el Ministerio de Comercio Exterior, la Promotora de Comercio Exterior (Procomer) y Cinde, fueron las entidades a cargo del lanzamiento de la nueva marca país. El propósito misional de la marca es atraer más turistas hacia el país, impulsar la venta de productos locales hacia mercados extranjeros y cautivar inversionistas de todos los sectores, especialmente de tecnología. El CBI Latinoamérica 2013 ubicó a Costa Rica como la marca \#3 de América Latina principalmente debido a su patrimonio y cultura y también a su fuerte sistema de valores (FutureBrand, 2012b)

La autenticidad, la concentración, el orgullo, la democracia y ser una nación con alto talento humano son cinco atributos de la promesa de valor de la marca (Grupo Nación, 2013). La validación de la marca país a nivel internacional en los dos últimos años ha tenido un costo de USD 450.000 (González, 2013). En la Figura 18 se observa el logotipo caracterizado por el color verde, que se asocia a la biodiversidad. 


\section{Capítulo 2. El país como una marca}

Figura 18. Logotipo de la marca país de Costa Rica

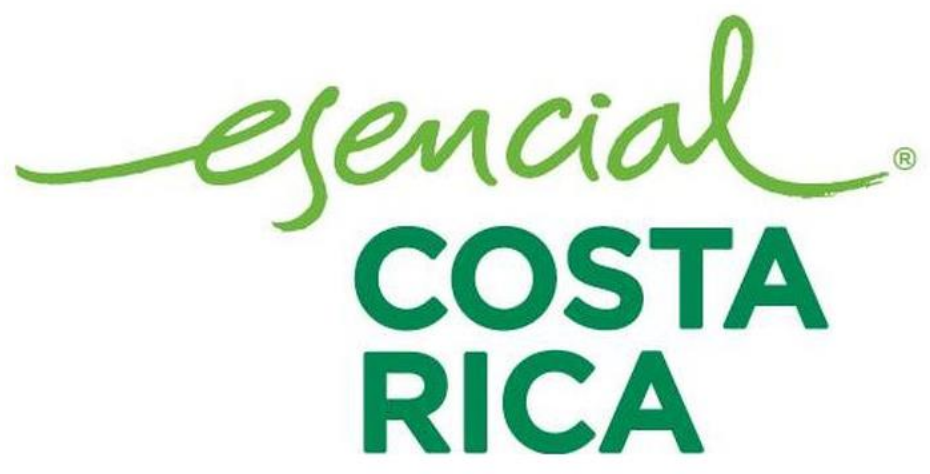

Fuente: Adaptado de Grupo Nación (2013).

Una de las ventajas claramente definidas en la estrategia de marca país de Costa Rica es la permanencia de una identidad única. No obstante, la marca se enfrenta a retos externos e internos complejos (Hill, 1990). Si bien el país sigue siendo considerado como uno de los principales destinos de turismo ecológico del mundo, la competencia se ha intensificado (Vivanco, 2012).

Países como Panamá, Brasil y Chile están apropiándose del ecoturismo como un atractivo de su marca país. Internamente, la marca país de Costa Rica se ve amenazada por los cambios en su oferta turística. Las actividades de turismo ecológico y de aventura siguen siendo el núcleo de su marca país, sin embargo existen otras formas de turismo tradicional de las zonas costeras, como turismo de sol y playa y los cruceros que si bien complementan la oferta, generan competencia (Honey, Vargas, \& Durham, 2010). Para mantener la marca país de Costa Rica, es relevante tener un equilibrio, sin dejar de destacar su principal atributo: el ecoturismo (Nost, 2013). 


\section{Capítulo 2. El país como una marca}

En el Costa Rica presenta su nueva marca país Esencial Costa Rica, diseñada por FutureBrand, la cual después de 5 años y USD \$650.000 invertidos ha generado opiniones divididas entre los expertos en marca país (El Financiero, 2013). Algunos opinan que la anterior marca comunicaba más sentimientos con respecto al país mientras otros opinan que la marca es inteligente y tiene todo lo que el país necesita. La nueva marca país busca posicionar a Costa Rica no solo como un destino conocido por la belleza de sus paisajes naturales, sino también como un país que concentra alta tecnología e innovación adicional a sus capacidades para exportar todo tipo de productos de alta calidad (Instituto Costarricense de Turismo \& Promotora del Comercio Exterior, 2013). Es por esto que el objetivo principal de la nueva marca país es atraer inversión extranjera como fuente alternativa de ingresos al país adicionales a los ingresos obtenidos por turismo.

El desarrollo la marca demandó un largo proceso de diseño e investigación en el cual no solo participó FutureBrand sino también especialistas en testeos públicos e internacionales a través de la elaboración de encuestas a diferentes públicos objetivo en países como New York, Londres y Madrid entre otros (Instituto Costarricense de Turismo \& Promotora del Comercio Exterior, 2013)

Se espera que la marca país ayude a consolidar la visión del país en el ámbito local, regional e internacional. En el proceso de construcción de la nueva marca, los resultados de los estudios se enfocaron en los valores costarricenses. Otra expectativa de la nueva marca para Costa Rica es que se potencie la gestión de atracción de inversión extranjera directa, la promoción de las exportaciones y el turismo.

\subsubsection{Guatemala}

La marca país de Guatemala se encuentra en su fase introductoria. Su imagen país tiene un posicionamiento poco favorable en mercados internacionales. El país es percibido de manera negativa por dos factores críticos: la pobreza y el deterioro ambiental (Méndez, 2003).

De acuerdo con lo anterior, en el 2005, se crea la primera marca país de Guatemala. Tres componentes ayudaron a construir la marca país: el misticismo de la cultura guatemalteca, su diversidad y autenticidad, así como la calidez de su población. 


\section{Capítulo 2. El país como una marca}

En un entorno importante para el sector de turismo, Guatemala alcanzó cifra récord en el 2005, con un 1.3 millones en visitas de turistas superando el 2004 (Banco de Guatemala, 2009). El desarrollo de la marca país estuvo a cargo de la firma consultora Interbrand (Marketing Directo, 2005).

Bajo el lema Guatemala alma de la tierra, se buscaba expresar cuatro elementos que ejercen identidad: la autenticidad, la identificación con los guatemaltecos, la credibilidad y la flexibilidad en la promoción y venta de productos de exportación como el café y el banano (ver Figura 19). El gobierno y líderes políticos querían demostrar que el país pasaba por un mejor momento, debido a la pacificación y ambiente democrático emergente.

En sus inicios se consideró una fase internacional para ejecutar la campaña promocional de la marca país. Se definieron los siguientes países: España, Estados Unidos, México, Japón, Alemania y el Reino Unido, como los destinos más relevantes para fomentar el turismo en Guatemala.

Figura 19. Logotipo de la primera marca país de Guatemala

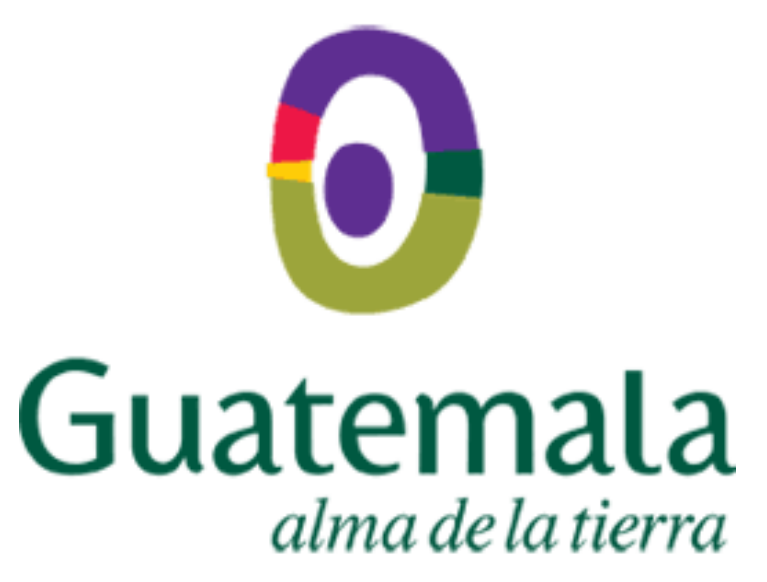

Fuente: Adaptado de Instituto Guatemalteco de Turismo (s.f.).

En el 2009 se lanzó la segunda marca país Guatemala el corazón del mundo maya cuyo propósito era promover el turismo cultural del país (ver Figura 20). 


\section{Capítulo 2. El país como una marca}

Figura 20. Logotipo de la segunda marca país de Guatemala

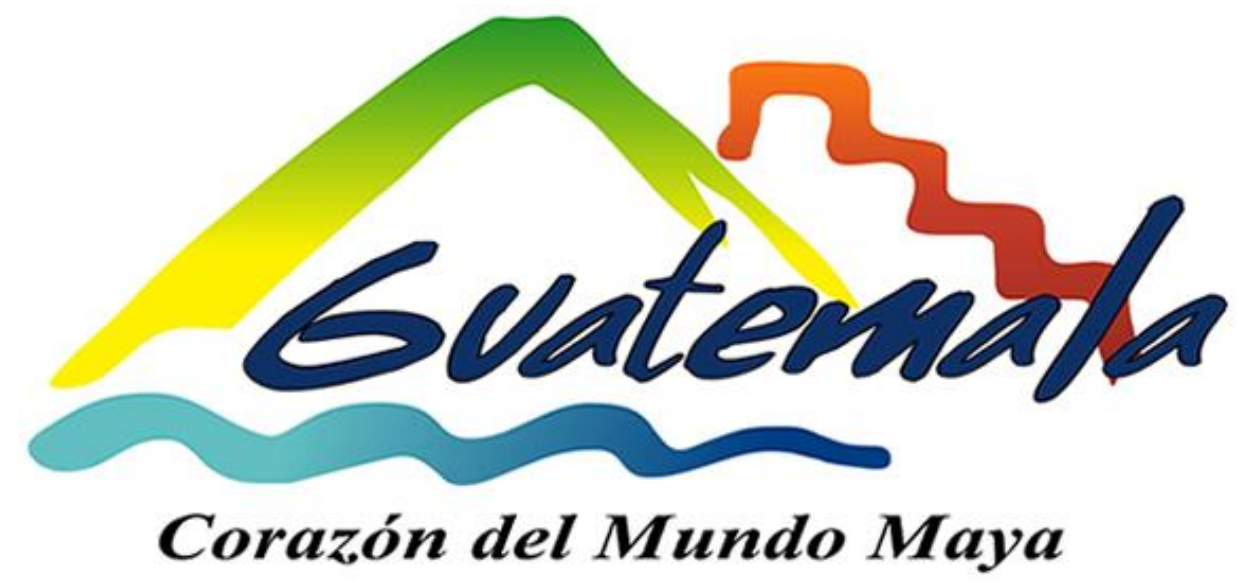

Fuente: Adaptado de Instituto Guatemalteco de Turismo (s.f.).

En el Ranking CBI Américas de 2009, los resultados para Guatemala no fueron los mejores. El país ocupó la posición \#16 de la región; y la posición \#93 (de 102 países) de los destinos que los turistas visitarían nuevamente (FutureBrand, 2009). En el ranking general llegó a la posición \#88.

Para el 2010, Guatemala mejora su posicionamiento de marca país en mercados internacionales. En el Ranking CBI 2010 de la categoría de conveniencia en la dimensión de turismo ocupó la posición \#7 y la posición \#1 (FutureBrand, 2010). En el ranking general ese mismo año ascendió en posiciones, ocupando el lugar \#86.

En el Ranking CBI 2011, Guatemala demostró resultados favorables de su marca país como se puede observar en el Cuadro 19: 


\section{Capítulo 2. El país como una marca}

Cuadro 20. Ranking CBI Américas 2011

\begin{tabular}{|l|c|c|}
\hline País & Ranking Regional & Ranking General \\
\hline Costa Rica & 1 & $\# 24$ \\
\hline Brasil & 2 & $\# 31$ \\
\hline Argentina & 3 & $\# 32$ \\
\hline Chile & 4 & $\# 34$ \\
\hline Perú & 5 & $\# 44$ \\
\hline México & 6 & $\# 47$ \\
\hline Uruguay & 7 & $\# 50$ \\
\hline República Dominicana & 8 & $\# 55$ \\
\hline Cuba & 9 & $\# 56$ \\
\hline Panamá & 10 & $\# 67$ \\
\hline Ecuador & 11 & $\# 75$ \\
\hline Guatemala & 12 & $\# 81$ \\
\hline Venezuela & 13 & $\# 84$ \\
\hline Colombia & 14 & $\# 89$ \\
\hline Honduras & 15 & $\# 90$ \\
\hline Bolivia & 16 & $\# 96$ \\
\hline Nicaragua & 17 & $\# 100$ \\
\hline Paraguay & 18 & $\# 106$ \\
\hline El Salvador & 19 & $\# 109$ \\
\hline Fuente Adaptado & & \\
\hline
\end{tabular}

Fuente: Adaptado de FutureBrand (2011).

En el 2011, el East West Global Index ubicó a Guatemala en la posición \#163 de 200 países en cuanto a las menciones que realizan los medios de comunicación (East West Nation Brand Perception Indexes, 2013).

El turismo de Guatemala ha crecido lentamente y se concentra en ser receptor de visitantes procedentes de países vecinos como se puede observar en el Cuadro 21:

Cuadro 21. Top 5 de Visitantes por países 2011-2012

\begin{tabular}{|l|c|c|c|}
\hline \multicolumn{1}{|c|}{ País } & $\mathbf{2 0 1 1}$ & $\mathbf{2 0 1 2}$ & Variación relativa (2011-2012) \\
\hline El Salvador & 542.316 & 604.871 & $11.5 \%$ \\
\hline Estados Unidos & 429.216 & 434.175 & $1.2 \%$ \\
\hline Honduras & 223.0120 & 236.680 & $5.7 \%$ \\
\hline México & 132.661 & 144.076 & $8.6 \%$ \\
\hline Nicaragua & 74.362 & 77.238 & $3.9 \%$ \\
\hline
\end{tabular}

Fuente: Adaptado de Instituto Guatemalteco de Turismo (2012). 


\section{Capítulo 2. El país como una marca}

Frente a un entorno propicio para atraer turísticas el Gobierno de Guatemala formuló la Política Nacional para el Turismo Sostenible de Guatemala 2012-2022. En esta política se plantearon metas de crecimiento esperado en ingreso de visitantes en $6.6 \%$ para 2016 y $8 \%$ para el 2022 (Presidencia de la República de Guatemala, 2012).

En el primer cuatrimestre de 2013 el número de visitantes a Guatemala creció un 6.3\% con respecto al mismo periodo del año anterior siendo los turistas provenientes de El Salvador, Estados Unidos, Honduras, México, Canadá, Nicaragua el 84\% del turismo total (Instituto Guatemalteco de Turismo, 2012). Por otra parte, el departamento de gestión y análisis (2013), identifica que algunos de los países potenciales emisores de turismo para Guatemala son Rusia, Países Bajos y los Países Nórdicos debido a que generalmente los residentes de estos países buscan destinos eco turísticos y con playas.

El Ranking CBI 2012 ubicó a Guatemala en la posición \#93 (de 118 países). Posición poco favorable, dado que descendió 12 lugares respecto al ranking general de 2011 (FutureBrand, 2012a).

El Reporte de Competitividad de Viajes y Turismo 2013 ubica a Guatemala en la posición \#97 de 144 países (Foro Económico Mundial, 2013). Según el reporte, Guatemala presentó debilidades en ambiente para los negocios, infraestructura aeroportuaria y recursos culturales, entre otros. La meta del gobierno es llegar a la posición \#70 antes del 2022.

Los esfuerzos por mejorar la imagen país han sido insuficientes. Según el Índice de Competitividad de Global 2012-2013, Guatemala es la país donde más invierte en seguridad el sector privado (World Economic Forum, 2013).

El país tiene fortalezas en términos de competitividad en lo relacionado con regulaciones laborales flexibles, marco de fijación salarial, un mercado financiero eficiente y la intensidad de la competencia local. Sin embargo la competitividad se ve obstaculizada por la debilidad de sus instituciones públicas y los altos costos de la delincuencia y la violencia.

Sumado a lo anterior, Guatemala tiene un nivel muy bajo en innovación lo que da como resultado un sistema educativo de baja calidad, escases en el uso de las TIC y la deteriorada calidad de la infraestructura en transporte (World Economic Forum, 2013). 


\section{Capítulo 2. El país como una marca}

Un elemento diferenciador de su estrategia de marca país reciente, es la inclusión digital en las acciones de comunicación de la marca. A través de aplicaciones web, el Instituto Guatemalteco de Turismo quiere ubicar al país en un destino turístico de primer orden mundial (Diario El Comercio, 2013).

Guatemala buscó eliminar las barreras de entrada para los visitantes de países de Latinoamérica omitiendo el requisito de visa a Perú y a Colombia. (Diario El Comercio, 2013).

No obstante, los esfuerzos del gobierno guatemalteco por impulsar su marca país, en el ranking de las mejores marcas de Latinoamérica (FutureBrand, 2013), Guatemala ocupa el puesto \#20 dentro de un listado de 21 Naciones. Tan solo logra ubicarse dentro de los rankings en atributos gastronómicos e históricos ocupando en ambos el puesto \#8.

No obstantes en el CBI de Latinoamérica 2013, Guatemala en la dimensión de Patrimonio y Cultura que evalúa aspectos como el arte, historia, belleza natural y autenticidad, Guatemala ocupa la posición \#9 en la variable de autenticidad y el \#8 en historia. Asimismo en la demisión de turismo que considera aspectos como hoteles, gastronomía, atracciones, conveniencia, playas, vida nocturna y compras, Guatemala ocupa el puesto \#8 en gastronomía. Estos resultados muestran un avance interesante en el reconocimiento del país por algunos ejes que la marca país está impulsando.

El Instituto Guatemalteco de Turismo se enfrenta a nuevos desafíos, contratar una empresa que apoye la gestión de imagen país, con un presupuesto aproximado de 150 mil dólares para definir una estrategia que impulse el turismo y posicione favorablemente a Guatemala en la mente de los extranjeros (Bolaños, 2013).

\subsubsection{Honduras}

Honduras es un país que al igual que Colombia ha tenido momentos difíciles en cuanto percepción por parte de los extranjeros. Los altos índices de inseguridad han hecho de Honduras uno de los países más peligrosos para los periodistas según la UNESCO y es además anfitrión de una de las ciudades más peligrosas del mundo: San Pedro Sula. 


\section{Capítulo 2. El país como una marca}

De acuerdo con la OMS la tasa promedio de homicidios de un país es de 8.8 homicidios por cada 100.000 habitantes, sin embargo en honduras se presentan en promedio 83 homicidios por habitante (UNFPA - United Nations Population Fund, 2012). Adicional a esto la complicada situación política que atraviesa el país, hace que el resto del mundo lo perciba como un país inseguro y que los turistas no se sientan atraídos a visitarlo. No obstante, Honduras se ubica en el lugar \#93 entre 140 naciones en cuanto competitividad de turismo y viajes por encima de otros países latinoamericanos como Paraguay, Bolivia y Venezuela (World Economic Forum, 2013). En este sentido, uno de los factores que requiere de mayor atención para mejorar en el índice, según el Foro Económico mundial, es el costo que tiene la violencia y la inseguridad sobre el ambiente de negocios y del turismo pues en este atributo se ubica en el puesto \#138 de los 140 países evaluados.

Desde el 2006, el Banco Mundial aprobó un fondo inicial para comenzar el proceso de construcción de la marca país de Honduras por un valor 170 mil dólares (Hondudiario, 2008). En 2008 nació la marca Honduras con el propósito de posicionar a Centro América como un destino emergente entre viajeros estadounidenses. Honduras es la conexión que sustenta la región y trata unir relaciones que se cultiven a través de la comunidad, la región, y el mundo.

La marca Honduras comparte la responsabilidad por la creación, construcción, promoción, y el bien estar de la imagen de Centro América. Entre las ilustraciones y la tipografía Warnock pro, la identidad intenta reivindicar su ubicación como pieza central en la zona y su condición de país emergente, genuino, vibrante y conectando a las personas porque tiene de todo para ellas y lo recuerdan con su promesa de marca: Todo está aquí (Galgo, 2012).

Para el desarrollo inicial de la marca país se realizaron estudios de mercado donde se encontraron que los extranjeros asocian a Honduras con el istmo, la historia, mares cristalinos, montañas, arqueología, y la calidez y hospitalidad de su población (Instituto Hondureño de Turismo, 2013). 


\section{Capítulo 2. El país como una marca}

En el 2008 se creó la marca país para Honduras con el eslogan Todo está aquí (ver Figura 21). Adicional a este planteamiento, se propuso otro eslogan dirigido a los estadounidenses denominado Honduras, la Centroamérica que tú conoces, el país que tu amas. Estados Unidos es el principal emisor para Honduras (Hondudiario, 2008).

\section{Figura 21. Logotipo de la primera marca país de Honduras}

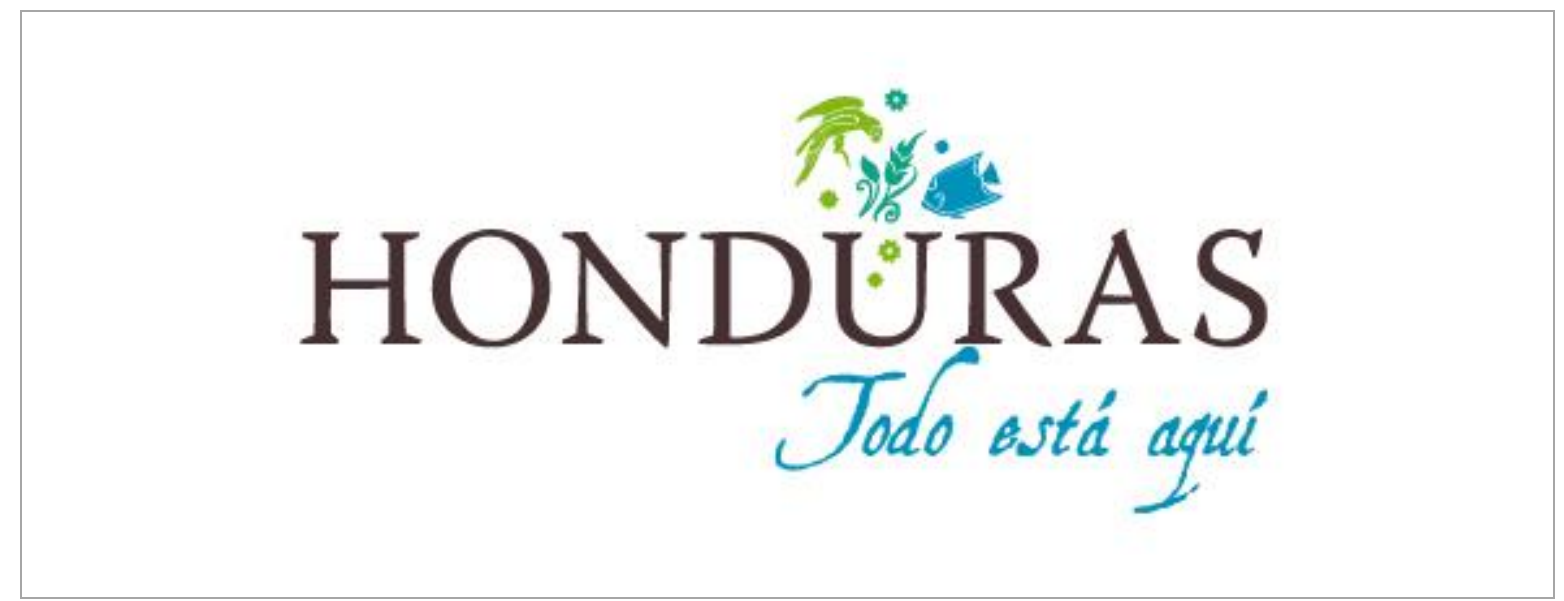

Fuente: Adaptado de Instituto Hondureño de Turismo (2011)

La misión de la marca país es consolidar a Honduras como destino vital de vacaciones (Instituto Hondureño de Turismo, 2008). En los inicios de la marca país, la intencionalidad fue claramente mejorar la asociación de Honduras con sus productos.

Utilizando el turismo como imán, se ha impulsado un marca de país centrada en transmitir un territorio con diversidad de productos de destino, con actividades de entretenimiento y diversión como posibilidades alcanzables sin la necesidad de recorrer grandes distancias. De ahí el eslogan Todo está aquí.

La marca país nació en un contexto en el cual, el país lideraba en desarrollo y seguimiento turístico, sin embargo, la crisis financiera generó efectos negativos en la economía política del país (Diario El Heraldo, 2013).

La marca Honduras tiene el propósito de conectar a Centro América como un destino emergente entre viajeros estadounidenses. Honduras es la conexión que sustenta la región. Se trata sobre unir relaciones que se cultivan a través de la comunidad, la región, y el mundo. 


\section{Capítulo 2. El país como una marca}

La marca Honduras comparte la responsabilidad por la creación, construcción, promoción, y el bien estar de la imagen de Centro América. (Instituto Hondureño de Turismo, 2008)

El mensaje clave detrás de esta marca señala que Honduras tiene el rol indispensable en el desarrollo de Centro América como un destino vital de vacaciones. Es la pieza central de esta parte del mundo. (Instituto Hondureño de Turismo, 2008). Entre los atributos que exploraron con la marca país están:
a. Ubicación $=$ Pieza central
b. Emergente
c. Orgullo Silencioso
d. Sustentable
e. Genuino/ Auténtico
f. Vibrante
g. Conectando a las personas
h. Un lugar para nosotros
i. Experiencial
j. Recuerdos de por vida

El Instituto Hondureño de Turismo es el órgano encargado de potenciar el desarrollo del turismo con base en una estrategia nacional con vista a impulsar el crecimiento del sector en forma equilibrada, sostenible y responsable, a fin de coadyuvar en la creación de empleos, la captación de divisas y el desarrollo local/regional (Instituto Hondureño de Turismo, 2008). Entre sus objetivos específicos esta:

- Impulsar el desarrollo y diversificación de productos turísticos competitivos y de alto valor agregado.

- Lograr una promoción efectiva de nuestros productos en el mercado nacional, regional e internacional. 


\section{Capítulo 2. El país como una marca}

- Propiciar el desarrollo de programas dirigidos a la capacitación del recurso humano para elevar la productividad y competitividad del sector.

- Impulsar el desarrollo de infraestructura y servicios básicos en las zonas con alto potencial turístico.

- Fomentar la incorporación de la dimensión ambiental en la planeación y ordenamiento de proyectos de desarrollo turístico.

- Incentivar el desarrollo de servicios de seguridad, facilitación, información y asistencia al turista.

- Fomentar la inversión nacional y extranjera del sector, en proyectos de alta rentabilidad y rápida implantación así como en apoyo a la pymes del sector.

Los esfuerzos por desarrollar una marca consistente y reconocida hasta ahora está iniciando y la estrategia de su desarrollo está en los primeros pasos teniendo en cuenta que los temas políticos influencian fuertemente el interés por incentivar y desarrollar más el mercado interno atrayendo turistas e inversión que permitan al país centroamericano crecer de una manera más acelerada.

Es por ello que las cifras que miden los indicadores de turismo más actualizados son al año 2011 donde se evidencia que al país ingresaron 1,8 millones de personas representando una caída de 5,8\% con respecto al mismo periodo de 2010. De igual forma el ingreso de divisas creció $1,8 \%$ representado en 638.800 millones de dólares y finalmente un gasto promedio de 645 dólares por estadía promedio de 10 días (FutureBrand, 2012b).

La marca país Honduras cuenta con el reto de fortalecerse entre sus homólogas del continente americano. Como aparece en el Cuadro 22, la marca país de Honduras aparece en la posición \#16 del CBI en el continente americano en el 2012. Ocupa la última posición, sin embargo en los últimos tres años no figuraba en el ranking y para el 2012 se hace visible. 


\section{Capítulo 2. El país como una marca}

Cuadro 22. Country Brand Index América 2012

\begin{tabular}{|c|c|}
\hline Posición & Co12 \\
\hline 1 & Canadá \\
\hline 2 & Estados Unidos \\
\hline 3 & Costa Rica \\
\hline 4 & Brasil \\
\hline 5 & Argentina \\
\hline 6 & Chile \\
\hline 8 & Perú \\
\hline 9 & México \\
\hline 10 & Uruguay \\
\hline 11 & Cuba \\
\hline 13 & Ecuador \\
\hline 14 & Colombia \\
\hline 15 & Venezuela \\
\hline 16 & Bolivia \\
\hline
\end{tabular}

Fuente: Adaptado de FutureBrand (2012).

La economía seguirá creciendo a un ritmo moderado en 2013. Se espera un crecimiento del PIB real del 3,3\% en 2013. La minería y los servicios financieros proporcionan la mayor parte del apoyo a la economía. La caída en la producción de café, debido a la roya y la debilidad de la demanda en los mercados de exportación son un obstáculo para el crecimiento (Palencia \& Barera, 2013) .

En lo referente a turismo, el país permanece de cuarto entre sus vecinos centroamericanos como receptor de turistas. Como se puede observar en el Cuadro 23 y 24 , aunque el flujo de visitantes pueda considerarse como alto (1.921.584 visitantes anuales), no ocurre así con las divisas que genera el sector (660 millones de dólares), que se consideran bajas para la región (Revista Summa, 2013). 


\section{Capítulo 2. El país como una marca}

Cuadro 23. Llegada de visitantes a Honduras 2007 - 2011

\begin{tabular}{|l|c|c|c|c|c|}
\hline Clasificación & 2007 & $\mathbf{2 0 0 8}$ & $\mathbf{2 0 0 9}$ & $\mathbf{2 0 1 0}$ & $\mathbf{2 0 1 1 p}$ \\
\hline $\begin{array}{l}\text { Total Visitantes } \\
\text { (Suma de Turistas más Excursionistas) }\end{array}$ & $\mathbf{1 , 3 0 8 . 8}$ & $\mathbf{1 , 5 6 2 . 0}$ & $\mathbf{1 , 5 8 9 . 4}$ & $\mathbf{1 , 9 6 5 . 1}$ & $\mathbf{1 , 8 5 1 . 8}$ \\
\hline $\begin{array}{l}\text { Turistas } \\
\text { (Visitantes que pernoctan) }\end{array}$ & 803.6 & 868.5 & 835.5 & 862.5 & 871.5 \\
\hline $\begin{array}{l}\text { Excursionistas } \\
\text { (Cruceristas más visitantes del día) }\end{array}$ & $\mathbf{5 0 5 . 2}$ & $\mathbf{6 9 2 . 5}$ & $\mathbf{7 5 3 . 9}$ & $\mathbf{1 , 1 0 2 . 6}$ & $\mathbf{9 8 0 . 3}$ \\
\hline$\quad-\quad$ Cruceristas & 297.4 & 434.2 & 429.8 & 803.1 & 787.0 \\
\hline$\quad$ Visitantes del día & 207.8 & 258.3 & 324.1 & 299.5 & 193.3 \\
\hline
\end{tabular}

Fuente: Adaptado de Instituto Hondureño de Turismo (2011).

Cuadro 24. Estadía y Gasto Promedio por Estadía del Turista Receptor 2007 - 2011

\begin{tabular}{|c|c|c|}
\hline Año & Estadía Promedio (noches) & Gasto Promedio por estadía (Dólares) \\
\hline 2007 & 12,7 & $\$ 623.4$ \\
\hline 2008 & 12,8 & $\$ 651.2$ \\
\hline 2009 & 11,1 & $\$ 656.3$ \\
\hline 2010 & 9,9 & $\$ 632.9$ \\
\hline 2011 & 10,4 & $\$ 645.8$ \\
\hline
\end{tabular}

Fuente: Adaptado de Instituto Hondureño de Turismo (2011).

Con el fin de incentivar el turismo en el país y además lograr un posicionamiento y recordación de la marca, Honduras lanza al mercado la tarjeta de crédito Honduras todo está aquí en maca compartida con Visa, a través de la cual se ofrecen beneficios adicionales a las personas que la usen para financiar sus viajes y eventos turísticos. Las ganancias del uso de esta tarjeta son una contribución al desarrollo del turismo sostenible en Honduras. Esta es quizá la primera tarjeta de este tipo en Latinoamérica, con lo cual se demuestra el interés que tiene este país por emprender el camino del reconocimiento de su marca país (FutureBrand, 2012b).

En el 2012, la marca país de Costa Rica logra ocupar el primer lugar en el ranking de países amigables con el medio ambiente, según FutureBrand. 


\section{Capítulo 2. El país como una marca}

Si se evalúa los rankings internacionales, la posición que ocupa Honduras sigue estando al final de las listas, lo cual indica que aún se requiere recorrer un camino largo en el desarrollo y posicionamiento de su marca país potencializando aquellos valores que ya se han identificado pero que se muestran al mundo con esfuerzos tímidos y presupuestos reducidos que lamentablemente no generan ningún efecto en la recordación de los turistas.

Adicionalmente, fue necesario contar con el respaldo del gobierno, empresarios y los mismos ciudadanos para que sea una estrategia de país contundente apoyado en estudios y una órgano encargado de la puesta en marcha de la marca país, que lidere este proceso y sea transversal a los objetivos de generar ingresos por turismo, inversión extranjera directa y exportaciones.

Pese a estos resultados no tan positivos, es importante reconocer los esfuerzos que ha hecho el gobierno con el Instituto Hondureño de Turismo para centralizar las estadísticas, información de marca país y documentos de interés, con el fin de tener un espacio que reúna la información básica de su marca país.

Cuadro 25. Turismo en Centroamérica

\begin{tabular}{|c|c|c|c|c|}
\hline Posición & País & Visitantes & $\begin{array}{c}\text { Divisas por Turismo } \\
\text { (USD millones) }\end{array}$ & $\begin{array}{c}\text { Competitividad } \\
\text { turística }\end{array}$ \\
\hline 1 & Costa Rica & 2.343 .213 & $2.219,2$ & 47 \\
\hline 2 & Panamá & 2.086 .007 & $2.261,9$ & 37 \\
\hline 3 & Guatemala & 1.951 .173 & $1.418,9$ & 97 \\
\hline 4 & Honduras & $\mathbf{1 . 9 2 1 . 5 8 4}$ & $\mathbf{6 6 0}$ & 93 \\
\hline 5 & El Salvador & 1.738 .317 & 730,2 & 104 \\
\hline 6 & Nicaragua & 1.232 .896 & 421,8 & 95 \\
\hline
\end{tabular}

Fuente: Adaptado de World Economic Forum (2013). 


\section{Capítulo 2. El país como una marca}

Honduras debe encontrar cómo posicionar sus ventajas competitivas, que realmente lo diferencien de otros países en Centroamérica. Especialmente por el contexto histórico vigente presenta indicadores de narcotráfico y violencia que poco favorecen el posicionamiento de imagen país en mercados internacionales (Grupo de Estudios Estratégicos, 2012)

\subsubsection{Marca país en América del Sur}

La aplicación de la marca país es un fenómeno relativamente nuevo para los países sudamericanos. Sin embargo, está aumentando el volumen de países que buscan consolidar una marca territorial dado por el gran número de competidores que hay en los mercados nacionales e internacionales.

Los países de América del Sur están haciendo esfuerzos por perfeccionar su marca país con la intención de cumplir tres grandes objetivos: atraer turistas, estimular la inversión interna e impulsar las exportaciones. Un cuarto objetivo para algunos países es atraer talento humano. Este nuevo objetivo permite a los países competir entre sí por atraer a estudiantes de educación superior y a empleados calificados.

Vale la pena incluir más objetivos adicionales como que la marca país contribuye a la estabilidad de la moneda ya que ayuda a restaurar credibilidad internacional y confianza en los inversores, aumentar la influencia de las políticas internacionales, estimular el fortalecimiento de las asociaciones internacionales y promover las ventajas competitivas de un país. El logro de esos objetivos requiere que los países adopten de manera consciente y responsable su marca país para que puedan competir eficazmente en el escenario global.

Los países compiten en el mercado global para ser elegidos por inversionistas, turistas, residentes y compradores.

Algunas economías dependen casi exclusivamente de los ingresos por turismo, y otras lo ven como un sector más que aporta a la balanza de pagos (Santana, 2001). En esa medida, los países se esfuerzan para ser más atractivos y lo hacen a través de la construcción de sus propias marcas. 


\section{Capítulo 2. El país como una marca}

Los países más demandados, con mejor reputación, más ricos y poderosos tienen marcas fuertes que son el resultado de coordinar los programas de gobierno con la cultura de sus habitantes, el comercio, el desarrollo urbano y la administración de su imagen.

En América del Sur se evidencia un escenario optimista para sus economías, pero no están preparadas para su futuro (Oppenheimer, 2011).

América del Sur no ha sido un mercado internacional representativo, pero es ahora el nuevo mercado para las operadoras turísticas por el potencial crecimiento de sus economías (The Caims Post, 2010: 12). El turismo es uno de los principales motores de cualquier economía, ya que representa en la mayoría de países entre el 2\% y el 10\% del PIB, siendo este el caso de los países desarrollados o de las islas que dedican la mayoría de sus actividades económicas al turismo.

El turismo genera cerca de 919 millones de dólares en ingresos anuales y el porcentaje de llegadas de turistas internacionales en países en vía de desarrollo ha aumentado de un 32\% en 1990 a un 47\% en 2010 (Organización Mundial del Turismo, 2010). En la mayoría de los países de américa del sur se evidencia el fuerte apalancamiento entre la marca país y el turismo. De continuar así, la marca país deberá orientarse a aumentar el turismo nacional con el fin de descentralizar el desarrollo local causado por esta actividad, sin descuidar las exportaciones y las inversiones (Brida \& Risso, 2009).

Las mediciones de posicionamiento de marca país ubican a los países de américa del sur en lugares distantes al conteo general como ocurre en el ranking de Future Brand (2012a).

\subsubsection{Brasil}

La imagen país de Brasil ha logrado superar las fronteras culturales y de lenguaje para posicionarse favorablemente en mercados internacionales.

En el año 2003, el Gobierno Brasileño creó el Ministerio de Turismo, entidad que sería la piedra angular en el proceso de construcción de una marca país. Se definió en sus inicios que Brasil requería una identidad visual para promocionarla en mercados externos (Nicolau \& Aires, 2010). 


\section{Capítulo 2. El país como una marca}

La agencia McCann-Erickson fue la encargada del diseño de la campaña promocional que acompañaría la nueva marca país. Se realizó un estudio con turistas extranjeros procedentes de 18 países que habían visitado a Brasil. De acuerdo a los resultados, la imagen de Brasil se asocia con la naturaleza, su cultura, la variedad de escenarios y playas, así como la alegría del pueblo y el patrimonio natural (Ramos \& Noya, 2006).

Fue en el 2005 cuando se lanzó la marca país de Brasil (Nicolau \& Aires, 2010). Este lanzamiento estuvo acompañado de la apertura de la Oficina Brasileñas de Turismo que tenían como tarea posicionar al país como destino turístico.

La marca como símbolo está representada por el multicolor, que refleja la alegría, luminosidad y modernidad, aspectos presentes en el subconsciente del turista (IProfesional, 2005).

El logotipo fue diseñado por el Kiko Farkas de Máquina Estudio basado en la obra de arte Jardín Acuarela del paisajista Roberto Burle Marx creada para el Palacio de Capanema de Río de Janeiro en 1938 porque refleja la alegría del pueblo brasileño (ver Figura 22).

Figura 22. Logotipo de la marca país de Brasil

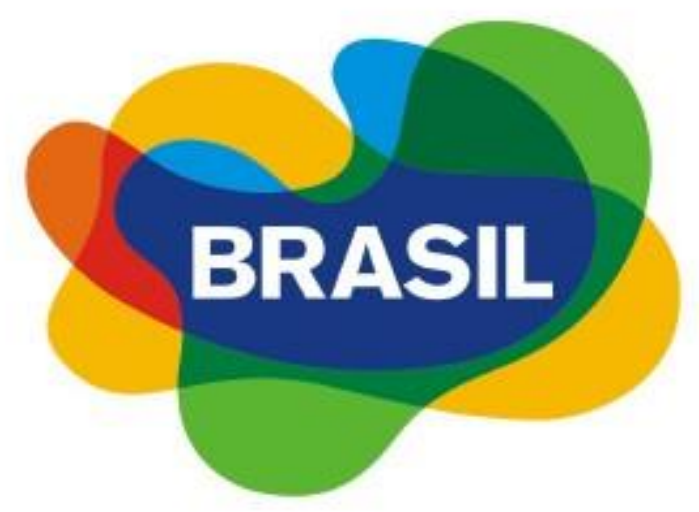

Fuente: Adaptado de EMBRATUR (s.f.).

Los colores tienen diferentes significados que rescatan la esencia de la identidad nacional (Ministério do Turismo Governo Federal do Brasil, s.f.): 


\section{Capítulo 2. El país como una marca}
a. Verde: florestas
b. Amarillo: sol y luminosidad
c. Rojo y naranja: fiestas populares
d. Azul: cielo y agua
e. Blanco: manifestaciones religiosas

Todo esto enmarcado en la búsqueda de generar un reconocimiento diferente a la de samba, café y Pelé. La marca país está acompañada de un eslogan Brasil Sensacional que tiene como finalidad posicionar al país como destino competitivo, atraer turistas que mejoren el flujo de ingreso de divisas, generar empleo en las regiones y contribuir a mejorar la calidad de vida de la población. El mismo año que se lanzó la marca país, Brasil ocupó dos posiciones en el Ranking CBI 2005: a) posición \#8 de marca país como Estrella Emergente y b) posición \#3 de mejor marca país en la categoría de vida nocturna (FutureBrand, 2005). Desde sus inicios, el sector empresarial ha apoyado la estrategia de marca país. La primera empresa en utilizarlo, fue la Aerolínea Varig, exponiendo la imagen en sus aviones con destinos nacionales e internacionales (Diario El Mundo, 2009). El Ranking CBI 2006 ubicó a Brasil en varias posiciones como se puede observar en el Cuadro 26:

Cuadro 26. Posiciones de Brasil en el Ranking CBI 2006 por categorías

\begin{tabular}{|l|l|c|}
\hline \multicolumn{1}{|c|}{ Categorías } & \multicolumn{1}{|c|}{ Descripción } & $\begin{array}{c}\text { Posición en el } \\
\text { Ranking CBI 2006 }\end{array}$ \\
\hline Playa & Destino donde el visitante encuentra aguas cristalinas & $\# \mathbf{\# 4}$ \\
\hline $\begin{array}{l}\text { Actividades } \\
\text { Outdoor }\end{array}$ & País atractivo para actividades outdoor y deportes & $\# 10$ \\
\hline $\begin{array}{l}\text { Viaje de negocios } \\
\text { extendido }\end{array}$ & $\begin{array}{l}\text { Destino donde los viajeros por negocios quieren pasar } \\
\text { sus vacaciones }\end{array}$ & $\# 10$ \\
\hline Convenciones & Sitio preferido para convenciones y eventos & $\# 10$ \\
\hline Vida nocturna & $\begin{array}{l}\text { Destino gastronómico y primera clase de clubes y } \\
\text { bares de la vida nocturna }\end{array}$ & $\# 10$ \\
\hline
\end{tabular}

Fuente: Adaptado de FutureBrand (2006).

Expertos en marca país, señalan que Brasil es un país que no se promueve lo suficiente, considerando la magnitud de la imagen país que tiene en el mercado internacional (FutureBrand, 2007). 


\section{Capítulo 2. El país como una marca}

En el 2007 ocupó la tercera posición en el Ranking CBI de mejor marca país en la categoría de vida nocturna, después de España y Estados Unidos (FutureBrand, 2007).

Los expertos en marca país volvieron a insistir en el 2008, que Brasil, Estados Unidos y China son países que no se promocionan tan bien como podrían (FutureBrand, 2008). Ese mismo año, los expertos señalaron que Brasil es un país sobre calificado y en alza.

En el Ranking CBI 2008 aparece en el Top 10 de países que tienen una positiva relación entre dos variables: deseo de visitar y seguridad. Ocupó la posición \#10 en la categoría de playas flamantes y la posición \#2 en la categoría de vida nocturna, por notables bares, clubes nocturnos y escenarios hasta altas horas de la noche (FutureBrand, 2008).

La firma consultora FutureBrand (2009) destaca que el ícono que representa a Brasil es el Carnaval. En el Ranking CBI 2009, Brasil predominó en las categorías de: vida nocturna (posición \#4), Arte y cultura (\#23) y Autenticidad (\#3) (FutureBrand, 2009).

El Country Brand Index 2009 ubica a Brasil en la posición \#5 en el continente americano (FutureBrand, 2009).

Brasil ha ocupado posiciones importantes en el ranking $\mathrm{CBI}$ en los últimos años, pero en la categoría de seguridad se ubica en los últimos puestos (FutureBrand, 2010). En el Ranking CBI 2010 de las Américas, Brasil desciende una posición (\#6), sin embargo ser la sede de la Copa Mundial 2014 y los Juegos Olímpicos 2016 pueden ayudarle a mejorar su

posicionamiento que viene descendiendo en categorías como conveniencia, seguridad y amigable con el medio ambiente (FutureBrand, 2010).

En el Ranking CBI 2010 descendió posiciones, pasando del puesto \#35 en el 2009 al puesto \#41 en el 2010 (FutureBrand, 2010).

En el 2011, la marca país de Brasil presenta avances importantes en términos de seguridad, destino para negocios, calidad de vida y amigable con el medio ambiente (FutureBrand, 2012a).

Brasil es un gigante económico y líder en la región. Ocupó el segundo puesto después de Costa Rica en el Ranking CBI 2011 de mejor marca país de América Latina. La intencionalidad de su marca es concentrar sus esfuerzos para promover una imagen de un sector económico que no coincida necesariamente con los estereotipos existentes (Dinnie K. , 2008). 


\section{Capítulo 2. El país como una marca}

Ser parte de grupo BRICS ${ }^{7}$ le da una ventaja competitiva, por la influencia que puede generar en asuntos y la economía mundial. Brasil es la Estrella Emergente de este grupo, abre sus puertas para mejorar su posicionamiento como destino apto para los negocios (FutureBrand, 2012a).

De acuerdo con el Country Brand Index 2012, Brasil ocupó la posición \#28 en el ranking general, la posición \#4 en la categoría de playa y la posición \#2 en la categoría de vida nocturna (FutureBrand, 2012b).

En el CBI Latinoamérica, Brasil ocupó la primera posición (FutureBrand, 2013). La imagen de Brasil se asocia con el turismo, el arte y la cultura. De igual forma entre los indicadores que son determinantes para evidenciar la eficacia de las acciones en marca país están las estadísticas de ingreso de turistas. Se evidencia una tendencia creciente importante tanto en el número de extranjeros que entran al país con 5,4 millones de personas como en el ingreso que para el año 2012 fue aproximadamente de 6,6 billones de dólares (Banco Mundial, 2013).

Según el Ministerio de Turismo de Brasil, en el 2012, el número de visitantes internacionales fue de 5.676 millones de turistas provenientes principalmente de Suramérica encabezado por Argentina y de Europa liderado por Alemania. Esta cifra representa un incremento del 4.3\% con respecto a la cifra del 2011 en dónde los principales puntos de entrada al país son Sao Paulo y Rio de Janeiro con mayor afluencia de turistas en los meses de Diciembre, Enero y Febrero (Ministerio de Turismo República de Brasil, s.f.).

${ }^{7}$ Grupo de países conformado por Brasil, Rusia, India, China y Sudáfrica. 


\section{Capítulo 2. El país como una marca}

El Informe de Competitividad Turística (World Economic Forum, 2013) sitúa a Brasil como el país \#1 en competitividad turística en el pilar de recursos naturales debido a que alberga una gran número de lugares considerados por la UNESCO como patrimonios de la humanidad al igual que extensas porciones de tierra protegida gracias a la riqueza de sus ecosistemas (World Economic Forum, 2013). Estas características hacen que Brasil sea el país más atractivo para aquellos turistas que buscan experiencias cercanas a la naturaleza.

Por otra parte, Brasil ocupa el puesto 126 en competitividad de precio para los turistas, es decir, Brasil contempla precios más elevados para el visitante diferente a otras naciones de América como Estados Unidos, Canadá, Costa Rica y Panamá (World Economic Forum, 2013). El Foro Económico Mundial clasifica a Brasil en el puesto \#51 de competitividad turística dentro de un listado de 140 naciones a nivel mundial. A nivel América, Brasil se mantiene en el puesto \#7 en índice de competitividad turística por encima de naciones tradicionalmente turísticas como República Dominicana y Jamaica (World Economic Forum, 2013)

Cuadro 27. Ranking de Competitividad Turística 2011-2012

\begin{tabular}{|l|c|c|}
\hline \multicolumn{1}{|c|}{ País } & Posición $\mathbf{2 0 1 2}$ & Posición $\mathbf{2 0 1 1}$ \\
\hline Estados Unidos & 1 & 1 \\
\hline Canadá & 2 & 2 \\
\hline Barbados & 3 & 3 \\
\hline Panamá & 4 & 8 \\
\hline México & 5 & 4 \\
\hline Costa Rica & 6 & 5 \\
\hline Brasil & $\mathbf{7}$ & $\mathbf{7}$ \\
\hline Puerto Rico & 8 & 6 \\
\hline Chile & 9 & 9 \\
\hline Uruguay & 10 & 10 \\
\hline Argentina & 11 & 11 \\
\hline Jamaica & 12 & 12 \\
\hline Perú & 13 & 13 \\
\hline Ecuador & 14 & 18 \\
\hline Trinidad y Tobago & 15 & 16 \\
\hline Colombia & 16 & 15 \\
\hline República Dominicana & 17 & 14 \\
\hline Honduras & 18 & 19 \\
\hline Nicaragua & 19 & 22 \\
\hline Guatemala & 20 & 17 \\
\hline
\end{tabular}

Fuente: Adaptado de World Economic Forum (2013). 


\section{Capítulo 2. El país como una marca}

Grandes desafíos en un entorno de oportunidades será el escenario para consolidar la marca país de Brasil como una de las más fuertes de América Latina y del mundo. En el Reporte de Country Brand Index 2012-2013, figura Brasil en la posición \#9 de las marca país del futuro (ver Cuadro 28). Según los expertos de marca país, Brasil está en la mente de muchos inversionistas, políticos y turistas por muy buenas razones (FutureBrand, 2012b).

Brasil presenta un crecimiento económico constante, tiene una creciente clase media, una amplia demanda de consumidores, una geografía rica en recursos naturales y cuenta con un gobierno que tiene un rol de liderazgo en el ámbito regional e internacional (Gertner, Berger, \& Gertner, 2007; Mariutti \& Giraldi, 2010; Niesing, 2013).

\section{Cuadro 28. Marcas líderes del mañana: Top 15 del futuro}

\begin{tabular}{|c||l|l|}
\hline Posición & \multicolumn{2}{|c|}{ País } \\
\hline 1 & & Emiratos Árabes Unidos \\
\hline 2 & & Chile \\
\hline 3 & Malasia \\
\hline 4 & & Qatar \\
\hline 5 & & Estonia \\
\hline 6 & & China \\
\hline 7 & & Islandia \\
\hline 8 & & México \\
\hline 9 & & Brasil \\
\hline 10 & & Turquía \\
\hline 11 & & Tailandia \\
\hline 12 & & Colombia \\
\hline 13 & & India \\
\hline 14 & & Kazajistán \\
\hline 15 & & Vietnam \\
\hline
\end{tabular}

Fuente: Adaptado de FutureBrand (2012b). 


\section{Capítulo 2. El país como una marca}

Brasil ha pasado de ser una economía emergente a ser una de las 10 economías más potentes del mundo marcando el pulso de toda la región (FutureBrand, 2013), por lo tanto la promoción y fortalecimiento de su marca país es una tarea obligada para seguir en el camino del reconocimiento como una de las grandes potencias turísticas del mundo. Asimismo para el próximo 2014 se espera que la economía brasilera se dinamice aún más con el evento futbolístico más grande del mundo, el Mundial pues esto incentivara el ingreso por concepto del turismo.

\subsubsection{Argentina}

La experiencia en el proceso de creación y gestión de la estrategia de marca país Argentina nació en un contexto nacional marcado por una profunda crisis económica, social y política entre 2001 y 2002 (Echeverri et al., 2011). Para ese período, Argentina ocupó el primer puesto del ranking de mayor riesgo país en el mundo (Diario Clarín, 2001). Pese a que algunos escépticos afirmaran que cualquier esfuerzo por mejorar la imagen de Argentina y potenciar sus productos y servicios en el mundo no era factible en un país en quiebra, el gobierno de Néstor Kirchner puso en marcha la Estrategia Marca País EMP en manos de un equipo cuyos responsables técnicos fueron Roberto Occhipinti por parte del área de turismo y Luis Rosales del lado de la Secretaría de Comunicaciones (Echeverri et al., 2011).

A inicios de 2004 se anunció que la estrategia de los siguientes dos años era constituir una propuesta de valor agregado a todo lo que se hace y produce en el país, impulsando diferentes áreas del país como lo es la cultura, turismo, y empresas entre otros (Echeverri \& Estay-Niculcar, 2013). Adicionalmente esta estrategia inició con la constitución del equipo compuesto por técnicos de la Secretaría de Medios de Comunicación, Secretaría de Turismo y la Fundación Exportar (Instituto Nacional de Promoción Turística, 2010).

Antes de que se concretara esta iniciativa en 2004, existieron algunos proyectos de marca país que hasta ese momento no pasaron de la etapa embrionaria o expositiva porque se asociaba y limitaba el tema al desarrollo de una imagen visual o campaña publicitaria (Echeverri et al., 2011). 


\section{Capítulo 2. El país como una marca}

Sin embargo, luego de la crisis de 2001 todos los esfuerzos realizados hasta ese momento para posicionar a Argentina fueron desvirtuados por la inestabilidad económica del país provocando una imagen negativa frente al mundo. De acuerdo con Hidalgo (2008) durante un periodo, el país gozó de una imagen internacional positiva que se expresaba en $E l$ Granero del Mundo por ser el primer exportador mundial de alimentos.

En el 2006, Argentina ocupó la posición \#5 en el Ranking CBI en categoría de Estrella Emergente (FutureBrand, 2006). Un año después ocuparía la posición \#10 en la misma categoría. En el Ranking CBI 2007 en la categoría de gastronomía de lujo, el país ocupó el puesto \#10.

La marca país de Argentina fue creada en el 2008 dando respuesta a una situación coyuntural en el sector turístico. En ese mismo periodo, la coyuntura económica de Argentina fue susceptible a la recesión (Echeverri et al., 2011).

De acuerdo con De Luca y Malamud (2010) Argentina había pasado de ser el país que crecía más rápido a uno de los que evolucionaba más lentamente. En ese entonces el Secretario de Turismo, Enrique Meyer, señaló que la creación de la marca país coincidía con la consolidación del turismo receptivo que venía creciendo desde el año 2007, ubicando a Argentina en el segundo país de la región con cuatro millones y medio de turistas (Echeverri \& Estay-Niculcar, 2013).

La marca país de Argentina se institucionalizó a través del Decreto 1372 de 2008 con el propósito de homogenizar la imagen nacional en el mundo (Portal público de noticias de la República Argentina, 2008). En la Figura 23 se puede observar que los colores que se incluyeron en el logo hacen referencia a los colores de la bandera nacional (Instituto Nacional de Promoción Turística, 2010). Y el lema de acompañamiento fue Argentina late con vos. 


\section{Capítulo 2. El país como una marca}

Figura 23. Logotipo de la marca país de Argentina

\section{Argentina}

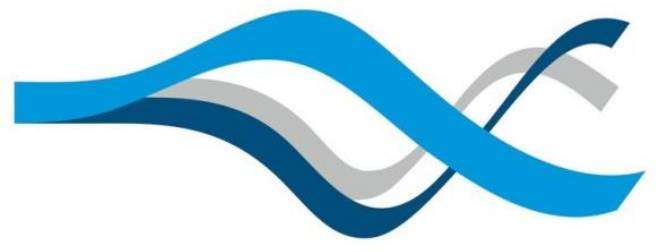

Fuente: Adaptado de Instituto Nacional de Promoción Turística (2010).

La participación de todos los sectores en el proceso de construcción de marca país fue fundamental. En el estudio Marca País: Introducción a la problemática desde los ejecutivos de compañías top de la Argentina, el Gobierno Nacional es percibido como el principal impulsor de la Marca País Argentina, a la vez que es visto como el organismo que más colabora en definir su construcción e implementación (Peña, 2007).

La marca país tenía como propósito difundir la imagen de Argentina en el exterior. Este objetivo no se cumplió como se esperaba, según la Revista Container (2009) Argentina tiene un proyecto sobre marca país que pocos conocen. Si un programa de promoción es escasamente reconocido, tal vez signifique que muy bien no está funcionando (Revista Container, 2009). Sin embargo, la marca país logró posicionarse entre los mejores destinos del mundo, ubicándose en el puesto 43 de un total de 102 países en el año 2009 y en el puesto 33 de un total de 110 países en 2010.

En el Ranking del Country Brand Index CBI 2009, Argentina se ubicó en el puesto número 10 de los países que ofrecen mejor vida nocturna. En ese mismo periodo ocupó el puesto número 4 como destino gastronómico después de Francia, Italia y Japón (FutureBrand, 2009). 


\section{Capítulo 2. El país como una marca}

El estudio realizado por Gina Pipoli (2009) sobre la percepción que tienen los estadounidenses y franceses acerca de la imagen país de Argentina señala que todavía se evidencia un alto posicionamiento de la carne argentina siendo el tango, los deportes y el fútbol los exponentes del talento argentino en mercados internacionales. De acuerdo con lo anterior, la imagen de Argentina se circunscribe al tango y al fútbol, lo cual coincide con los resultados obtenidos del Ranking CBI 2010.

Para el año 2010, Argentina asciende 10 puestos en el ranking por atributos distintivos como paisajes, diversidad cultural, turismo y aventura (FutureBrand, 2010; Echeverri \& Estay-Niculcar, 2013). Los factores que más influyeron en este indicador fueron dos

fundamentales: la economía creció en un 9,2\% y en ese mismo período logró el tercer puesto en la Copa Mundial de Fútbol (América Economía, 2011a).

En el 2013, Argentina le apostó a renovar la imagen de su marca país, cuya estrategia se basó en los conceptos de imaginación, química y capacidad de superación con el fin de trasladar su esencia, su promesa y su target conceptual (Diaz, 2013). Para lograrlo, se incorpora el color amarillo como símbolo de energía y contraste (ver Figura 24), se incrementa el tamaño de la letra y se le da más relevancia al movimiento de las cintas ondulantes.

Según FutureBrand (2013), quién apoyó en el desarrollo de esta nueva imagen, el reto principal era capturar la esencia que define a los argentinos, capturar su pasión, dedicación y profesionalismo en una propuesta de valor que diferenciara y potenciara los diversos segmentos de inversión, exportación, cultura y turismo. La marca anterior carecía de elementos que permitieran reforzar el verdadero sentir de los argentinos. 


\section{Capítulo 2. El país como una marca}

Figura 24. Renovación del logotipo de la marca país de Argentina

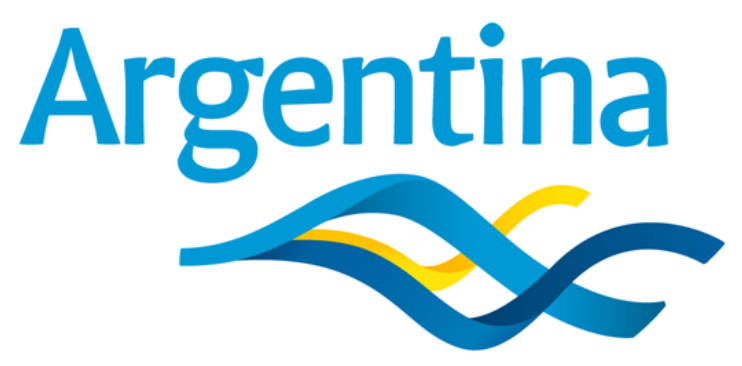

Fuente: Adaptado de Instituto Nacional de Promoción Turística (2013).

Esta nueva estrategia de marca país, recalca los esfuerzos que se han venido haciendo a lo largo de los años en el área de marca país y que le han permitido a Argentina ocupar el puesto \#2 en el Country Brand Index CBI 2013 de Latinoamérica, después de Brasil, entre las 10 marcas país más fuertes en América latina (FutureBrand, 2013). En el índice general del Country Brand Index 2013, Argentina ocupó el lugar \# 30 entre 118 países del mundo tan solo a pocos pasos de Brasil y Costa Rica.

El interés de Argentina por gestionar su marca país es notable. Es quizá una de las marcas de Latinoamérica que más información ha consolidado sobre su país. Gracias a que ha desarrollado portales informativos robustos que ayuda a las industrias a proyectar la visibilidad de la marca país argentina hacia el mundo (Echeverri et al., 2011).

La experiencia de la marca Argentina no sólo se evidencia con las decisiones y resultados producidos hasta el momento actual, sino en la particularidad del proceso que, sin dejar de capitalizar las experiencias de otros países, define la gestión integral de la imagen país mediante un plan maestro de marketing, comunicaciones, prensa y relaciones públicas. Cabe señalar que Argentina se ha consolidado históricamente en un centro de atracción turística para Brasil, Uruguay, Paraguay y Chile; logrando convertirse en un país que promueve el turismo intrarregional (Gardella et al., 2005). 


\section{Capítulo 2. El país como una marca}

\subsubsection{Chile}

Chile es el país de Latinoamérica en cuanto a marca país que ha trabajado con éxito en su proyección de su identidad. Su estrategia ha sido combinar los esfuerzos y recursos tanto del sector privado como del estatal. Sumado a que éste país cuenta con un gobierno democrático y una economía abierta, competitiva, orientada al libre comercio y con una fuerte política exportadora.

La economía chilena sigue siendo considerada una de las más estables y dinámicas de Latinoamérica, basado en el crecimiento sostenido entre los años 2000 y 2013, gracias a la baja deuda pública y un presupuesto gubernamental en superávit. Adicionalmente la transparencia que caracteriza a sus instituciones públicas y la avanzada infraestructura de transporte hacen de Chile un país atractivo para la inversión extranjera (Echeverri et al., 2012).

La economía chilena es considerada una de las más estables y dinámicas de Latinoamérica, esto basado en el crecimiento sostenido entre los años 2000 y 2010. Según el Comité de Inversiones Extranjeras del Gobierno de Chile (s.f.) el posicionamiento del país estaba asociado a la confianza. Con estabilidad política, logros en lo social y austeridad en el manejo de políticas públicas, Chile ha logrado fortalecer su imagen frente a inversionistas internacionales (Gobierno de Chile, s.f.).En el año 2004, ProChile determinó que la responsabilidad de la creación de marca estaría a cargo de un comité compuesto por organizaciones del sector público y la firma Interbrand Chile, entre otros. Según Gómez (2007) en el año 2004, por medio de una licitación pública, la empresa internacional Interbrand se adjudicó inicialmente US\$150.000 (al proyecto total se destinarían un total de US\$25.000.000) para diseñar la estrategia comunicacional de la Marca País Chile.

Chile no tenía una imagen negativa sino que había un desconocimiento de su industria y de su potencial económico. Luego de un año y medio de trabajo se hizo el lanzamiento de Chile sorprende siempre con un propósito integral de marca país: promover las exportaciones, el turismo y la inversión extranjera. Para Interbrand, Chile una marca país no es un logo o una campaña publicitaria, es un conjunto de emociones, asociaciones positivas y percepciones que se desarrollan a través de la experiencia (ver Figura 25). 


\section{Capítulo 2. El país como una marca}

Figura 25. Logotipo de la marca país de Chile

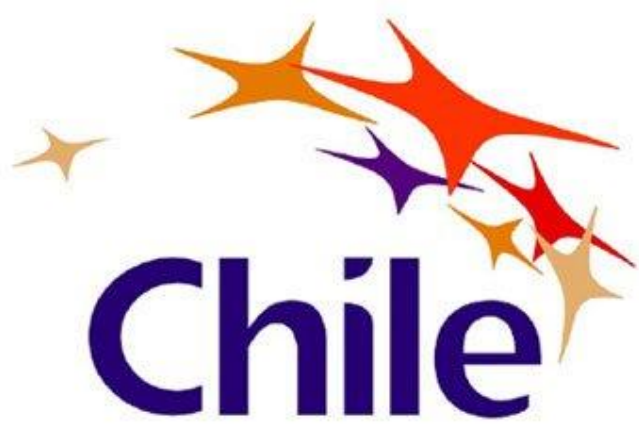

Fuente: Adaptado de Servicio Nacional de Turismo de Chile (s.f.).

La creación de la nueva marca era parte de todo un concepto estratégico que en ese momento llevaba adelante el país. Chile buscaba insertarse en los mercados globales mediante estrategias que incluían acuerdos comerciales, intercambios científicos y tecnológicos, atracción de inversiones extranjeras y promoción de la cultura con un apoyo concreto de distintos sectores públicos y privados. Puntualmente el objetivo de la creación de la marca país era impulsar, desarrollar, patrocinar, promover y ejecutar la difusión de la imagen de Chile en el exterior, contribuyendo a la competitividad mediante la coordinación con el sector público y privado (Chadwick, 2013). Los tres ejes de posicionamiento de la marca fueron (Noya \& Prado, 2012):

a. Geografía diversa: se busca resaltar el hecho de que chile es un país con una geografía diversa que goza de tener desiertos, glaciares y mares.

b. Gente: destacar las grandes cualidades de los chilenos quienes son vistos como gente amable calidad y eficiente.

c. Estabilidad del país: promover la imagen de chile como país estable, con calidad democrática y con un clima atractivo para inversionistas. 


\section{Capítulo 2. El país como una marca}

El camino de la construcción del logotipo de la marca país llevó a la idea central de que el principal atributo de Chile además de su geografía y de la calidez de su gente es el ser un país que sorprende (Echeverri et al., 2011). Con base en esta idea se definió la imagen de la marca en dónde a través de la elección de las estrellas de colores ocre se muestra que la sorpresa es abstracta. Se parte de la base de la estrella solitaria que representa a chile y se modifican sus puntas de tal forma que sugieren humanidad y diversidad (Prochile, s.f)

El mercado al cual se dirigía la estrategia eran, en principio, ejecutivos de los máximos niveles de empresas multinacionales de Europa, Estados Unidos y Asía-Pacífico. Se lanzó una campaña para crear una imagen turística de Santiago destacando los atributos como centro turístico de negocios, buscando un liderazgo regional en ese sentido y logrando alianzas estratégicas con el Ministerio de relaciones Exteriores, el Instituto Nacional de Deportes y el Consejo Nacional de la Cultura y las Artes. Dentro de las cualidades que se destacaban estaban los estándares de seguridad de la ciudad, su infraestructura, las comunicaciones, su modernidad, su cercanía a los centros de esquí, a rutas del vino y la costa. Santiago también destacaba su variedad de buen vino y una importante oferta gastronómica (Echeverri et al., 2012).

El propósito del plan estratégico de esta marca país era que debería ser coherente y alienado con todas las campañas que se estaban llevando a cabo por distintos sectores en el exterior.

Esto significaba que todo el desarrollo de la marca, tanto en diseño como en concepto, debería poder reforzar e integrar todos los esfuerzos realizados hasta el momento.

La idea que buscó Interbrand fue transmitir la naturaleza de sus paisajes, sus frutos, su población y sus valores, con el propósito que fuera única y atractiva y a su vez expresara su diversidad con una perspectiva diferente y sorprendente. La marca país en Chile no fue establecida como una estrategia promocional sino como una política, puesto que se involucraron todos los sectores lo que sirvió para conseguir recursos para su financiación. El $60 \%$ de sus recursos provienen del Estado y el excedente del sector privado (Echeverri et al., 2012). 


\section{Capítulo 2. El país como una marca}

Entre las organizaciones participantes del esfuerzo chileno por desarrollar su marca país se encuentran por el sector público: Comité de Inversiones Extranjeras, Corfo Corporación de Fomento de la Producción, ProChile, Servicio Nacional de Turismo; y por el sector privado Asoex - Asociación de Exportadores de Chile, Asociación de Productores Avícolas, Asexma - Asociación de Exportadores de Manufacturas-, Cámara de Comercio de Santiago, Cámara Nacional de Comercio, ChileAlimentos, Corporación de Promoción Turística, Fedefruta - Federación Gremial Nacional de Productores de Fruta, SalmonChile, Sonapesca - Sociedad Nacional de Pesca -, Sociedad de Fomento Fabril, Wines of Chile.

Las altas inversiones en campañas publicitarias, superiores a 3 millones de dólares desde el año 2007, han estado alineadas con el crecimiento del turismo para el mismo período. Sumado esto a su estabilidad económica que ha logrado ubicar a Chile como el primer país en América del Sur al ingresar en el puesto 31 del ranking de los países más ricos del mundo en el 2010 (Cámara de Diputados de Chile, s.f.).

Chile ha mantenido un bajo perfil con esta nominación, fundamentado en los hechos políticos y económicos que han logrado posicionar a este país como un lugar atractivo para la inversión y el turismo y, especialmente, como un modelo de crecimiento para América Latina al lograr reducir la pobreza de un 38.6\%, en 1990; a un 13,7\%, en 2006 (UNICEF Chile, 2006).

Para el año 2009 el gobierno chileno creó la Fundación Imagen de Chile, para velar por la promoción genérica de Chile y darle valor y prestigio al origen, convirtiendo esta tarea en una misión país, que recoja la diversidad de visiones y trascienda las coyunturas; siendo financiada con recursos públicos. (Fundación Imagen de Chile, 2013)

En el 2011 se destinaron 44,6 millones de dólares a la promoción de la marca país siendo esta cifra un aporte de varias instituciones como se ve en el Cuadro 29. De este presupuesto se estima que al menos el $50 \%$ tuvo una incidencia importante en el turismo del país. 


\section{Capítulo 2. El país como una marca}

Cuadro 29. Presupuesto para la promoción de la marca país 2011

\begin{tabular}{|l|c|}
\hline \multicolumn{1}{|c|}{ Institución } & Inversión (USD) \\
\hline PRO CHILE & $24 \mathrm{MM}$ \\
\hline TURISMO CHILE + SENATUR & $6.5 \mathrm{MM}$ \\
\hline FUNDACIÓN IMAGEN DE CHILE & $6 \mathrm{MM}$ \\
\hline SUBSECRETARÍA DE DESARROLLO REGIONAL & $7 \mathrm{MM}$ \\
\hline INVEST CHILE - CORFO & $0.5 \mathrm{MM}$ \\
\hline COMITÉ DE INVERSIONES EXTRANJERAS & $0.5 \mathrm{MM}$ \\
\hline DIRECCIÓN DE ASUNTOS CULTURALES + CONSEJO NACIONAL & $0.1 \mathrm{MM}$ \\
\hline DE LA CULTURA Y LAS ARTES & $\$ 44.6 \mathrm{MM}$ \\
\hline TOTAL & $\$$ \\
\hline
\end{tabular}

Fuente: Adaptado de Gobierno de Chile (2012).

La Estrategia Nacional de Turismo de Chile 2012-2020 plantea que a 2020, Chile sea reconocido como un destino turístico de clase mundial, siendo admirado y conocido por poseer una oferta atractiva, variada, sustentable y de alta calidad (Gobierno de Chile, 2012). Para tal fin busca cumplir con los siguientes objetivos:

a. Lograr 4 millones de turistas extranjeros al 2014 y 5.4 millones a 2020 .

b. Duplicar los ingresos generados por el turismo.

c. Generar 40.000 empleos directos y 160.000 indirectos

Dichos objetivos se basan en los siguientes pilares: promoción, sustentabilidad, inteligencia de mercado, inversión y competitividad y calidad del turismo. El desarrollo de la marca país Chile se encuentra presente en dos de los pilares mencionados:

- Promoción: a través del posicionamiento de la marca Chile basado en experiencias atractivas para los viajeros. El indicador de cumplimiento de esta línea de acción será el tener a Chile dentro de los 25 primeros puestos del Country Brand Index en los próximos años.

- Inteligencia de mercado: a través del seguimiento del reconocimiento de la marca país en los mercados objetivo. 


\section{Capítulo 2. El país como una marca}

Teniendo en cuenta los grandes esfuerzos del país para posicionar su marca en el mundo, para el año 2013 los resultados comienzan a evidenciarse pues en el ranking del Country Brand Index para Latinoamérica de FutureBrand, Chile se ubicó en la posición \#4 de un total de 21 naciones, antecedida por Brasil, Argentina y Costa Rica. Donde las percepciones sobre el país están enfocadas a un país ordenado y estable, con aptitud para los negocios (FutureBrand, 2012b). Por otra parte, en el Country Brand Ranking de Bloom Consulting 2013, Chile ocupa el puesto \#54, manteniéndose en la misma posición que ocupó en el 2012. Se espera que con el incremento constante en el número de visitantes extranjeros a Chile, al igual que con la alta competitividad turística que tiene el país actualmente, se pueda dar a conocer cada vez más la marca país de chile.

\subsubsection{Perú}

Pensar en Perú es pensar en la cultura Inca. Una cultura ancestral que es el cimiento de la imagen país moderna que se conoce en mercados internacionales. Es inevitable mencionar a Machu Picchu, las tradiciones indígenas y la autenticidad de su cultura, la cual se complementa de referencias a su comida de mar, el pisco, la Inca Kola y los caballos de paso peruanos. El camino en la construcción de marca país de Perú inició con una serie de campañas promocionales hasta llegar y consolidar en el 2011 lo que para ellos se constituiría en marca país. Donde los principales pilares a trabajar y fomentar en el país son las exportaciones, la inversión extranjera directa y el turismo. Entre 2001 a 2006, el gobierno de Toledo marcó el comienzo de la recuperación económica del país sobre la base de lo ejecutado durante el gobierno de Fujimori (Fuller, 2009). De acuerdo con Fuller (2009) el gobierno se propuso incentivar el turismo, por lo cual se establecieron días feriados y se otorgaron beneficios tributarios a los servicios de hospedaje y alimentación.

Ejercicios iniciales estuvieron motivados por promocionar los monumentos arqueológicos, la naturaleza, las costumbres y festividades peruanas. En el año 2002 se lanzó la marca país Perú, donde la historia vive con el propósito de fortalecer el posicionamiento del país a partir de la historia, diversidad cultural y riqueza natural de Perú (ver Figura 26).

Figura 26. Logotipo de primera marca país de Perú 


\section{Capítulo 2. El país como una marca}

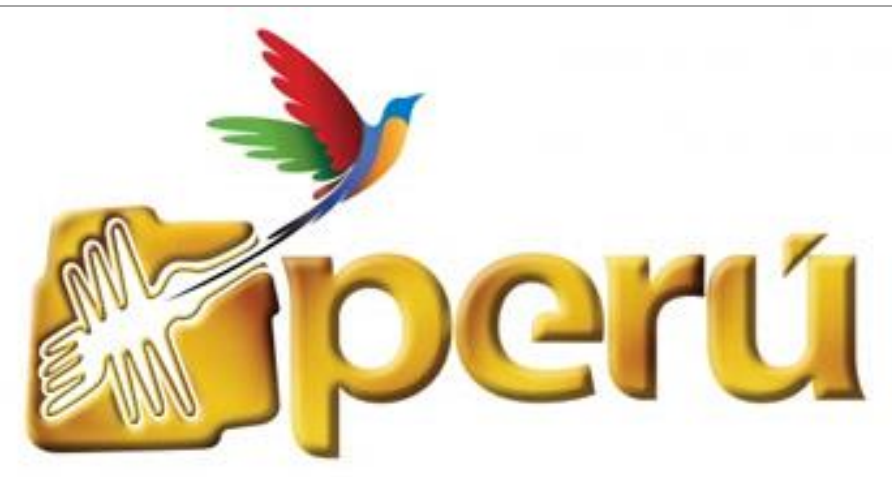

Fuente: Adaptado de PromPerú (s.f.).

El diseño gráfico estuvo a cargo del ecuatoriano Raúl Jaramillo (Rodríguez, 2010). Cortés (2007) citado por Fuller (2009) indica que la imagen está representada por un ave que resalta la exuberante belleza de la tierra.

En el 2003 se modificó el eslogan por Perú el país de los incas. La intencionalidad era concentrar esfuerzos promocionales para resaltar la cultura incaica porque era la imagen con la que más se asociaba a Perú en el extranjero.

El Ranking CBI 2006 ubicó a Perú en varias posiciones como se puede observar en el Cuadro 30:

Cuadro 30. Posiciones de Brasil en el Ranking CBI 2006 por categorías

\begin{tabular}{|l|l|c|}
\hline \multicolumn{1}{|c|}{ Categorías } & \multicolumn{1}{|c|}{ Descripción } & $\begin{array}{c}\text { Posición en el } \\
\text { Ranking CBI 2006 }\end{array}$ \\
\hline Autenticidad & Destino con culturas distintivas, genuinas y únicas & $\# 9$ \\
\hline Belleza Natural & $\begin{array}{l}\text { Geografía y topografía idílica } \\
\text { Destino Exótico }\end{array}$ & $\begin{array}{l}\text { Menos ofertas en turismo tradicional y más excursiones } \\
\text { inusuales }\end{array}$ \\
\hline $\begin{array}{l}\text { Estrella } \\
\text { Emergente }\end{array}$ & $\begin{array}{l}\text { En los próximos cinco años será uno de los destino } \\
\text { preferidos por los turistas }\end{array}$ & $\# 1$ \\
\hline
\end{tabular}

Fuente: Adaptado de FutureBrand (2006).

El reconocimiento de su cultura no es un mito y ha permanecido en el imaginario colectivo. El Country Brand Index 2007 otorgó a Perú el noveno lugar en dos de sus categorías: autenticidad e historia (FutureBrand, 2007). 


\section{Capítulo 2. El país como una marca}

Entre 2008 y 2009, se evidenció descenso en la actividad turística debido a la recesión económica mundial (Fuller, 2009).

En el 2008 se mantuvo, pero en autenticidad mejoró, escalando al séptimo puesto, superando a países tan fuertes en el ranking como Australia y China. Sin embargo, diversos especialistas coinciden en que la identidad Peruana se ha vendido equivocadamente en el exterior porque se destaca únicamente la dimensión histórica, dado que cualquier mensaje visto del país en el exterior hace exclusiva referencia al país de los incas, la existencia de la riqueza cultural de Cuzco y los imperios milenarios del pasado (FutureBrand, 2008).

Según el reporte de FutureBrand en el 2009, Perú mejorar posiciones en el Ranking CBI logrando ubicarse en tres categorías: historia (\#3), arte y cultura (\#7), belleza natural (\#9) y autenticidad (\#3). En Ranking CBI de las Américas ocupó la novena posición de un total de 17 país latinoamericanos (FutureBrand, 2009).

Para el 2010, Perú ascendió una posición en el ranking regional y subió dos posiciones ocupando el lugar \#47 en el ranking general del Country Brand Index.

La Comisión de Promoción del Perú para la Exportación y el Turismo (PromPerú) lanzó en el 2011 la Marca País Perú como parte de su nueva estrategia para acceder a más turismo, exportaciones y atracción de nuevos inversionistas (ver Figura 27). El desarrollo de esta nueva marca estuvo a cargo de FutureBrand quienes se fundamentaron en la percepción de Perú como país multifacético especial y cautivador. 


\section{Capítulo 2. El país como una marca}

Figura 27. Logotipo de la segunda marca país de Perú

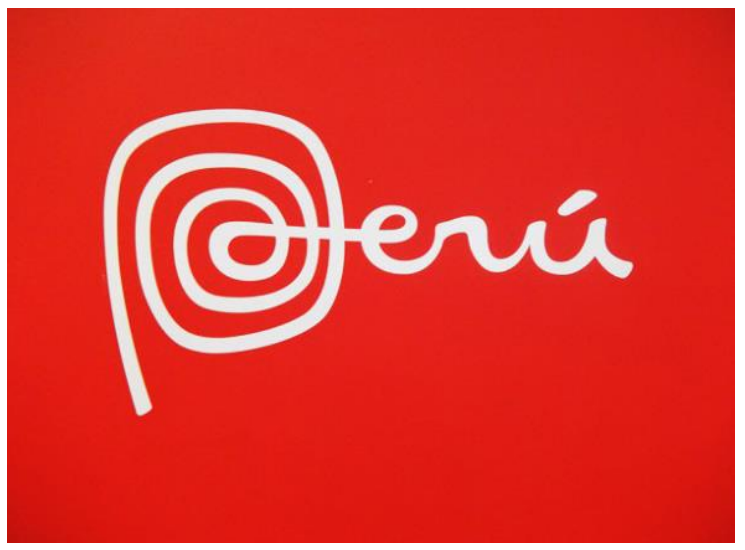

Fuente: Adaptado de PromPerú (s.f.)

Este nuevo logo tenía un enfoque diferente y buscaba comunicar nuevas dimensiones del país, por ello, El foco de la identidad está centrado en la palabra Perú, un nombre inclusivo, que no le pertenece ninguna cultura específica, sino que es el producto de una experiencia de cruces, mezclas y deseos. Por tratarse de una marca que deberá servir a diversos sectores, la marca no incorpora ningún complemento verbal adicional a su nombre: se propone como el núcleo de un ecosistema comunicacional amplio, que admite múltiples mensajes, imágenes, conceptos, paisajes, culturas, permitiendo así que cada uno de los sectores decida en cada comunicación (PromPerú, s.f.).

El espiral de la letra $P$ representa la evolución, el cambio y la transformación presente en todas las culturas peruanas. El espiral se prolonga sin interrupción para luego formar la palabra Perú con el fin de demostrar que en Perú cada quién se traza su propio camino basado en sus propios intereses (PromPerú, s.f.).

La nueva marca país Perú ha tenido aceptación en todos los mercados. Perú se ha consolidado como polo de desarrollo y destino turístico preferente, razón por la cual no solo deberá invertir en infraestructura turística (servicios básicos, hoteles, carreteras y restaurantes), sino también en buscar el consenso entre el Gobierno Central, los gobiernos regionales, el sector privado y los ciudadanos, para que todos se pongan de acuerdo en cómo quieren vender al país. 


\section{Capítulo 2. El país como una marca}

El Ranking CBI 2012-2013 ubicó a Perú en varias posiciones como se puede observar en el Cuadro 31:

Cuadro 31. Posiciones de Perú en el Ranking CBI 2012 por categorías

\begin{tabular}{|l|c|c|}
\hline \multicolumn{1}{|c|}{ Categorías } & Descripción & $\begin{array}{c}\text { Posición en el } \\
\text { Ranking CBI 2012 }\end{array}$ \\
\hline Autenticidad & Destino con culturas distintivas, genuinas y únicas & $\# 14$ \\
\hline Arte y Cultura & Destino con riqueza artística y cultural & $\# 8$ \\
\hline Historia & Riqueza histórica & $\# 9$ \\
\hline
\end{tabular}

Fuente: Adaptado de FutureBrand (2013).

Perú es un país que ha presentado mejora en los índices de competitividad. Desde el 2011 ha pasado de ocupar el puesto \#73 a ocupar el puesto \#67 en el 2012 para finalmente situarse en el puesto \#61 en el Índice de Competitividad del Foro Económico Mundial en el año 2013 (World Economic Forum, 2013).

Dicho índice califica a Perú como un país con un ambiente macroeconómico favorable con una considerable eficiencia en el mercado laboral y con un alto desarrollo del mercado financiero. Todos estos factores son motivantes para estimular el posicionamiento del país a través de una marca país que se encargue de dar a conocer estos atributos al mundo.

Según el reporte de FutureBrand en el 2012, Perú ocupa el puesto \#40 mejorando posiciones en el Ranking CBI logrando ascender siete posiciones desde el 2010.

En Ranking CBI de las Américas 2013, ocupó el quinto lugar frente al puesto número nueve en el 2009 (FutureBrand, 2013). En el 2012 Perú ocupó el puesto \#52 en el Country Brand Ranking de Bloom Consulting, mientras que en el año 2013 desciende al Puesto\# 64 dentro de un total de 161 países.

Perú es sin duda un país privilegiado por poseer una gran diversidad de riquezas culturales, naturales y humanas. En los próximos años, se augura que Perú tendrá la oportunidad de alcanzar un crecimiento económico elevado y sostenido, así como un importante desarrollo social (Centro Nacional de Planeamiento Estratégico, 2011). 


\section{Capítulo 2. El país como una marca}

\subsubsection{Uruguay}

Un país pequeño con una gran marca país. Son notables los esfuerzos que ha hecho el Ministerio de Turismo y Deporte por fortalecer su imagen país a través de la consolidación de una marca país.

La marca país de Uruguay fue creada en el 2001 y comenzó a utilizarse en el 2003 a través del Ministerio de Turismo y Deporte. Se creó el Programa Conjunto de Fortalecimiento Institucional para la construcción de la Imagen País con la finalidad de mejorar el posicionamiento de Uruguay en el mundo. Durante el proceso de construcción de la marca país se definió que la naturaleza de la marca sería la calidad de vida (Marca País Uruguay, 2013).

Durante el proceso de creación se tuvo en cuenta que la Marca Uruguay no tiene el reconocimiento a nivel mundial que le podría permitir tener un alcance mayor al regional, por tal razón tuvieron que incorporar otros valores que le aportaran a la marca en su objetivo.

El logotipo es una forma simbólica mixta verbal e icónica que alude al nombre del país por la inicial $U$ y al contexto institucional hace referencia al Pabellón Nacional. Se puede interpretar como una persona con los brazos en alto. Los colores representan la bandera nacional (ver Figura 28).

Con relación a la palabra Natural se entiende y pronuncia de forma parecida en varios idiomas, tiene connotaciones positivas y simboliza lo más destacable del país y su gente: Un medio ambiente limpio y cuidado, junto a la naturalidad en el trato de los uruguayos. 


\section{Capítulo 2. El país como una marca}

Figura 28. Logotipo de la marca país de Uruguay

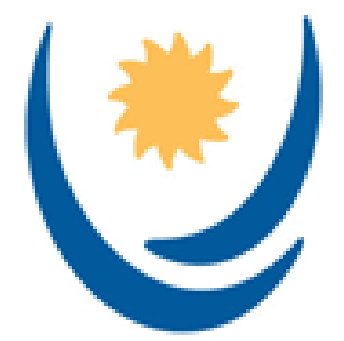

UruguayNatural

Fuente: Adaptado de Marca País Uruguay (2013).

La marca país de Uruguay se orientó a fortalecer las exportaciones, el turismo, la inversión extranjera y la segunda residencia.

En el 2005, se firmó un convenio entre el Ministerio de Turismo y Deporte, Instituto Nacional de Carnes y el Instituto Nacional de Vitivinicultura, para fortalecer el posicionamiento de la marca país en cada una de sus dimensiones. Los objetivos particulares de esta alianza son:

a. Elaborar una metodología común para la promoción de la marca país que sea compartida por las entidades aliadas con el fin de estandarizar el mensaje de la marca.

b. Aportar a la construcción de la marca país Uruguay Natural

c. Difundir la cultura uruguaya, desde las exportaciones hasta el turismo.

El Plan Nacional de Turismo 2009-2020 contempla el desarrollo de la imagen turística y nacional a través de la marca país Uruguay Natural con el fin de tener posicionamiento a nivel internacional como uno de los mejores destinos turísticos a 2020. 


\section{Capítulo 2. El país como una marca}

Para lograrlo, Uruguay no solo debe fortalecer su marca país, también debe trabajar en mejorar sus índices de competitividad turística pues actualmente ocupa el puesto \#59 dentro de 140 naciones del mundo (World Economic Forum, 2013). Sin embargo, a nivel regional Uruguay ocupa el lugar \#10 en índice de competitividad turística por encima de naciones tradicionalmente turísticas como República Dominicana y Jamaica.

En el Ranking CBI 2009, Uruguay ocupó la posición \#8 en la región, y la misma posición en la categoría de país amigable del ranking general (FutureBrand, 2009). En el 2010, Uruguay ocupó el octavo lugar en la categoría de conveniencia y la posición \#15 en tolerancia del Ranking CBI (FutureBrand, 2010).Ese mismo año descendió dos lugares en el Ranking CBI de América pero subió dos puestos en el ranking general, ubicándose en la posición \#53 de un total de 110 países.

Para el 2011, mejoró el posicionamiento de Uruguay en mercados internacionales, especialmente en dos categorías: sistema de valores y calidad de vida (FutureBrand, 2012a). En el ranking general y regional subió tres lugares posición \#50 y \#7 respectivamente.

La Comisión Interministerial para el Comercio Exterior (CIACEX) continuó con el proyecto de fortalecer la marca país a partir de 2011. Se conformó un grupo de trabajo apoyado por el Ministerio de Turismo y Deporte y el Instituto de Promoción Uruguay XXI (Marca País Uruguay, 2013)

Desde 2012, la gestión de Marca País Uruguay está a cargo CIACEX, que a partir de un préstamo del BID viene desarrollando talleres con organismos públicos y privados para concientizar sobre la importancia del uso de la marca país.

Ese mismo año, Uruguay consolida una imagen positiva demostrado como el país más próspero de América del Sur (Legatum Institute, 2012). En el 2012, el Country Brand Index de Latinoamérica clasifica a Uruguay en el puesto \#7 dentro de 21 naciones analizadas. Sus principales fortalezas son la percepción del alto índice de calidad de vida al igual que el acceso a la educación y las bajas tasas de desempleo. 


\section{Capítulo 2. El país como una marca}

Uruguay ha cuidado de su imagen país en mercados internacionales, según el Barómetro Global de Corrupción de Transparencia Internacional, es el país menos corrupto de América Latina 2013. De acuerdo al Índice Global de Paz, Uruguay figura como el país menos violento de la región (Global Peace Index 2013, 2013).

En general Uruguay goza de una imagen positiva frente a aspectos que no necesariamente son los más atractivos para el turismo, como por ejemplo, la calidad de vida o la libertad política, por lo tanto el gran trabajo que tiene el país para lograr posicionarse como destino turístico es fortalecer su imagen en este aspecto. Se deben destinar más recursos para buscar formas alternativas de turismo teniendo en cuenta que el país no cuenta con atractivos naturales suficientes para ser su mayor atractivo turístico.

En el 2013, el Ministerio de Industria, Energía y Minería de Uruguay recibió la licencia de uso de la marca Uruguay Natural con lo cual se busca promover al interior y en el exterior con el fin de promover exportaciones y de generar oportunidades de inversión (Ministerio de Turismo y Deporte - República de Uruguay, s.f.). Con esto se pretende extender el uso de la marca país hacia otros sectores con el objetivo de posicionar una sola marca a través de la cual se reconozcan todo lo que cada uno de los sectores de la economía tiene para ofrecer a nivel nacional e internacional.

Para el 2013, está en desarrollo una auditoría de la imagen de marca país, que cuenta con el apoyo del BID a través de su programa Apoyo a la Gestión del Comercio Exterior y que tiene entre sus cometidos, evaluar la percepción de Uruguay Natural en el mundo en cuanto a una marca que atraiga inversión extranjera, turismo y que agregue valor a las actividades económicas y culturales del país.

Esta auditoría, permitirá evaluar el comportamiento de la marca y su potencialidad, para transformarse en una imagen paraguas, que permita comunicar las ventajas comparativas y competitivas del país para atraer turistas, inversores y compradores de productos uruguayos, figuras claves en el proceso de crecimiento y desarrollo del país (Ministerio de Turismo y Deporte - República de Uruguay, s.f.). 


\section{Capítulo 2. El país como una marca}

Uruguay disfruta de un crecimiento económico constante, con fuertes lazos con Europa a través de numerosos tratados de libre comercio. Un entorno propicio para posicionar una marca país que ha ido ganando un lugar importante como referente internacional.

\subsubsection{Ecuador}

Ecuador es un país de tradiciones, costumbres y valores que los une como nación y crea un sentido de pertenencia, tienen la responsabilidad de fomentar la cultura de las comunidades indígenas y afro ecuatorianas.

Con una gran esencia exportadora, Ecuador llega a más de 150 países, concentrándose principalmente en Estados Unidos, Panamá, Perú y Venezuela (Revista Emprende, s.f.). Es uno de los países que posee mayor diversidad en las flores que ofrece al mundo, entre ellas la Rosa. La Gypsophila ha convertido al Ecuador en el principal productor mundial (Dirección de Inteligencia Comercial e Inversiones, 2011).

En el 2001 el Ministerio de Turismo crea la primera marca país para Ecuador. Su propósito era posicional los productos tipo exportación como el banano, camarón, flores y turismo en el extranjero.

El informe Racional creativo de la marca país del Ministerio de Turismo precisó que el país tenía la necesidad de posicionar a Ecuador desde la perspectiva interna y externa (Ramos \& Noya, 2006).

El diseño gráfico propuesto tenía la intención de exponer a través de símbolos la diversidad, la posibilidad de realizar múltiples actividades en un territorio pequeño y el factor humano positivo (ver Figura 29). El Ministerio de Turismo propuso que la vigencia de la marca país sería de 10 años lo que le permitiría consolidarse en mercados internacionales (Trujillo, 2003).

Adicionalmente, el presidente de la República de esa época, Lució Gutiérrez firmo un decreto a través del cual se obligaba a todas las entidades públicas a usar el logotipo de marca país en todas sus comunicaciones oficiales con esto se buscaba contarle al mundo quién es Ecuador, en dónde está y qué ofrece (Andrade et al., 2012). 


\section{Capítulo 2. El país como una marca}

Figura 29. Logotipo de la primera marca país de Ecuador

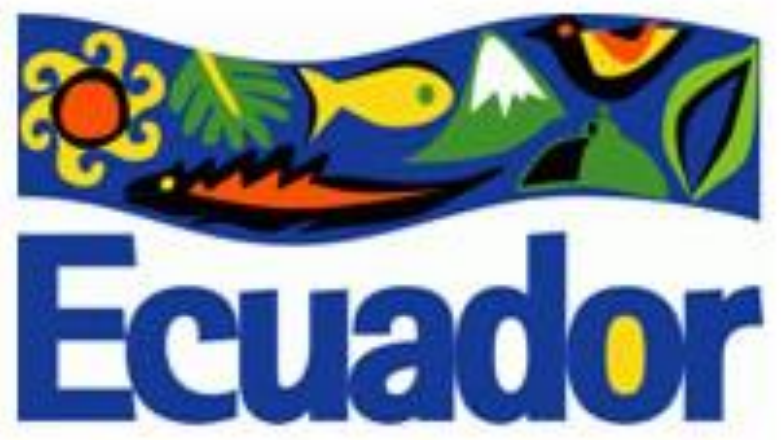

Fuente: Adaptado de Ministerio de Turismo República de Ecuador (2001).

El Ranking CBI 2008 ubicó a Ecuador en el Top 10 de países preferidos para visitar. Un años después se mantuvo en la categoría, pero descendió en temas de seguridad (FutureBrand, 2009).

En el 2009, ocupó la posición \#13 en el Ranking CBI de las Américas, superando a Colombia, Nicaragua, Guatemala y El Salvador. En el 2010, Ecuador subió una posición en el Country Brand Index, ubicándose en el puesto \#12 en ranking regional. Sin embargo, descendió tres posiciones en el ranking general, ubicándose en el puesto \#74 (FutureBrand, 2010).

En el 2011 el Ministerio de Turismo de Ecuador lanzó la que sería segunda marca país bajo el lema Ecuador ama la vida con el propósito de posicionar los paisajes, microclimas y la biodiversidad del país (Marca País Ecuador, 2013). Como se aprecia en la Figura 30 el diseño gráfico está representado por una variedad de colores relacionados con la diversidad cultural y de sus paisajes (Padilla, 2013). El diseño está creado con un modelo matemático que consta de siete círculos y siete espirales, ciento cuarenta cuadros que representan la diversidad de la flora y la fauna ecuatoriana, además de una variedad de colores que rescatan los matices de todas las artesanías del país (Andrade et al., 2012). Las texturas presentes en el símbolo son rectas que simulan movimiento y dinamismo utilizando el criterio radial utilizado por los antepasados y los colores representan el colorido de todas las regiones del país y de las etnias ecuatorianas. 


\section{Capítulo 2. El país como una marca}

Figura 30. Logotipo de la segunda marca país de Ecuador

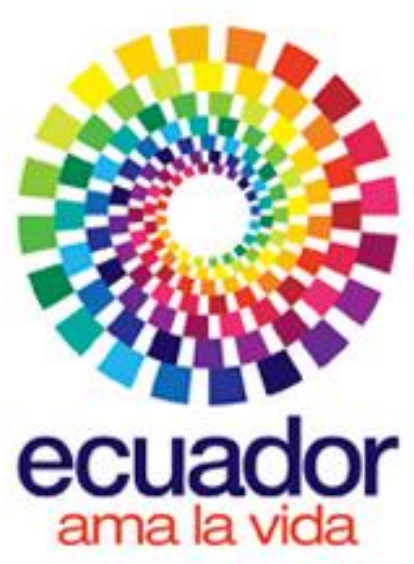

Fuente: Adaptado de Marca País Ecuador (2013)

Esta nueva marca tenía como objetivo posicionar un país donde encontramos paisajes, aventura, microclimas, biodiversidad. Un país de aromas, sabores, y que une a los mejores seres humanos: gente cálida y emprendedora, que enfrenta las adversidades. Adicional a este racional, se enfocó en comercializarse por medio de licencias de uso para asociar a bienes o servicios que se producen en el país, quienes más lo han explotado son las artesanías, ornamentales y textiles.

En el Ranking CBI 2011 descendió un puesto, ubicándose en la posición \#75 de un total de 113 países y en el 2012 los resultados o fueron mejores, ocupó la posición \#77 (FutureBrand, 2012a; FutureBrand, 2012b).

El posicionamiento de su marca país no ha sido el mejor, pero su imagen país ha demostrado resultados favorables. Entre el 2007 y 2012 mejoró en el Índice de Desarrollo Humano, ubicándose en el tercer lugar de América Latina y el Caribe (Aguilar, 2013). Aunque Ecuador ha venido en descenso en los índices del CBI, en el Country Brand Ranking de Bloom Consulting Ecuador ascendió 6 puestos, pasando de la posición \#83 en el 2012 a la posición \#77 en el 2013. Lo anterior refleja el efecto que tiene el hecho de que los diferentes índices de marca país midan entre ellos atributos diferentes de los países en cuestión. 


\section{Capítulo 2. El país como una marca}

La marca país de Ecuador se enfrenta a un entorno competitivo de alto nivel, las marcas país se orientan a los valores, aspecto que generaría diferenciación en mercados internacionales, si concentrara esfuerzos resaltando los valores de su cultura indígena. Es un proceso que ha tomado varios años para generar una estrategia de país y de gobierno que vincule los diferentes valores y características del país, para llevarlos a una marca país y poderlos explotar a nivel mundial para generar un mayor reconocimiento de Ecuador como destino, incentivando variables económicas de país que tienen alta injerencia en el resultado del país tales como el ingreso de divisas por turismo, exportaciones e inversión extranjera.

El camino que está construyendo Ecuador con su marca país, ha logrado resultados positivos tanto en su posicionamiento frente al mundo, como en su imagen y los valores que quiere que el mundo conozca de una cultura tan rica en costumbres, lugares y gastronomía. Aún falta potencializar más su marca, y darle un apoyo de gobierno mucho más visible para que las iniciativas no sean aisladas, sino que esto redunde en ingresos para el país que se puedan reinvertir en la marca para sostenerla y mejorarla teniendo en cuenta la evolución de Ecuador.

\subsubsection{Venezuela}

Como cualquier otro país, la nación venezolana ha experimentado importantes cambios a lo largo de la última década. Sin embargo, vistos desde el plano internacional estos han venido acompañados de alta agitación e inestabilidad política y económica.

Las asociaciones más frecuentes que hacen referencia a Venezuela difícilmente dejan de lado temas como revolución y socialismo, crisis económica y tensas relaciones internacionales y un controvertido liderazgo del Presidente Hugo Chávez. Es evidente que el proyecto de marca país que ha experimentado Venezuela se ha visto centrado en el gobierno mismo donde la promoción en turismo ha tenido mucho que ver mediante la exaltación de sus riquezas naturales, exceptuando el petróleo, la calidez de la gente y la igualdad social pero sobre el que prima consolidar internacionalmente un proyecto político para expandir la Revolución Bolivariana hacia el resto del continente. 


\section{Capítulo 2. El país como una marca}

Aún no ha sido declarada oficial la marca del país Venezuela ahora es de todos (Ver Figura 31).

Figura 31. Logotipo de la primera marca país de Venezuela

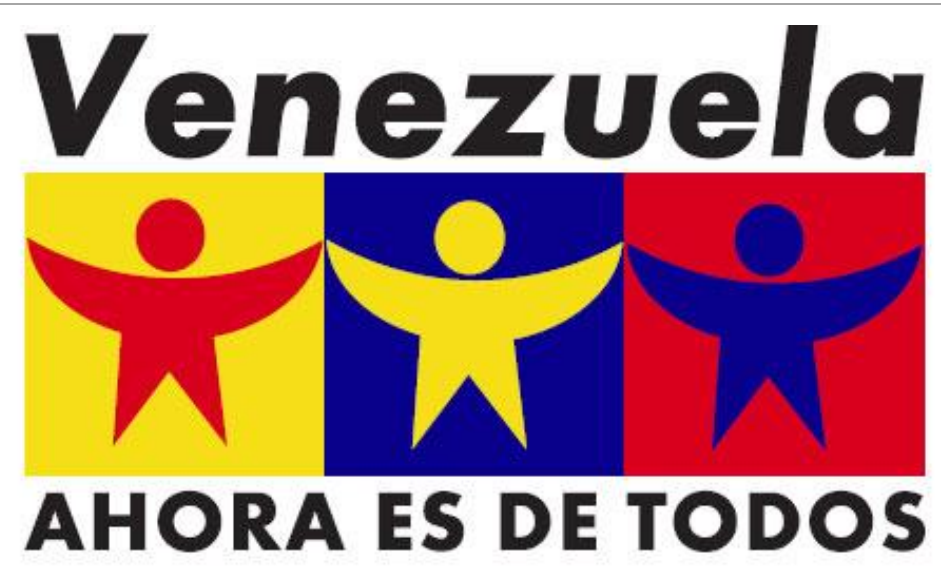

Fuente: Adaptado de Ministerio de Poder Popular para la Comunicación y la Información (2004).

De acuerdo con lo planteado por el Ministerio del Poder Popular para la Comunicación y la Información (2004) la imagen de la marca país es un símbolo de la determinación del Gobierno Bolivariano en hacer de Venezuela un país donde todos tengan las mismas oportunidades y derechos.

Conceptualmente busca demostrar que solo con una justa distribución de la riqueza se logrará el bienestar social de todos los venezolanos (Ministerio del Poder Popular para la Comunicación y la Información República Bolivariana de Venezuela, 2004)La marca país nace como una herramienta dentro del programa de unificación de la imagen del Estado con el propósito de consolidar un mensaje para llegarle a los sectores que desconfiaban mayoritariamente del proyecto bolivariano, como la clase media, que temía por la pérdida de sus pertenencias durante la implementación del modelo socialista.

La utilización del mensaje se ha dado en los periódicos nacionales, en los tanques de guerra de la Guardia Nacional y en los envases de arroz de los supermercados que el Presidente Chávez ha determinado. 


\section{Capítulo 2. El país como una marca}

Incluso, en las alocuciones del Presidente la frase que incluye el mensaje de marca país es:

El destino de los venezolanos está en manos de los venezolanos. Venezuela vive un momento estelar para la consolidación y el fortalecimiento de la democracia, la democracia participativa que hoy es ejemplo a seguir por Latinoamérica y el mundo. Venezuela ahora es de todos. (Chávez, 2003:15)

Los países harían bien en vigilar constantemente lo que la prensa extranjera escribe acerca de ellos. El informe del Pew Reserch Center Project. (2009) demuestra cómo la percepción de los venezolanos hacia Estados Unidos en el año 2002 tenía un 82\% de favorabilidad, ya para el año 2007 llegó a tener un 56\% de favorabilidad. Según un reporte de la Embajada de Venezuela en Estados Unidos (2007): el total de las exportaciones venezolanas a los Estados Unidos durante el 2007 experimentó un descenso de \$1.610,4 millones, pasando de 8.703,7 millones de dólares en el primer trimestre de 2006 a 7.093,3 millones de dólares en el mismo lapso de 2007, lo que significa una caída de 18,5\%.

Conforme al Reporte de FutureBrand (2009), Venezuela no ha generado un ambiente favorable para los negocios, motivado por la inestabilidad política, la escasa o nula protección para inversionistas y una exagerada tasa impositiva. En el Ranking CBI 2009, Venezuela ocupó la posición \#12 en el continente americano y la posición \#63 de un total de 102 países en el ranking general.

Para el 2010 su posicionamiento no fue favorable. En el Ranking CBI 2010 descendió 14 lugares motivado por factores como corrupción, inestabilidad política e inseguridad (FutureBrand, 2010). Un año después, Venezuela ocupó la posición \#84, descendiendo siete posiciones con relación al 2010 del ranking general.

En el 2011, Venezuela descendió una posición en el ranking CBI de la región, motivado por un entorno político que genera percepciones polarizadas (FutureBrand, 2012a). Ese mismo año, el Ministerio del Poder Popular para el Turismo lanzó la campaña turística Venezuela conocerla es tu destino con el propósito de promocionar al país en más de 50 países del mundo (ver Figura 32). 


\section{Capítulo 2. El país como una marca}

Figura 32. Logotipo de la marca turística de Venezuela

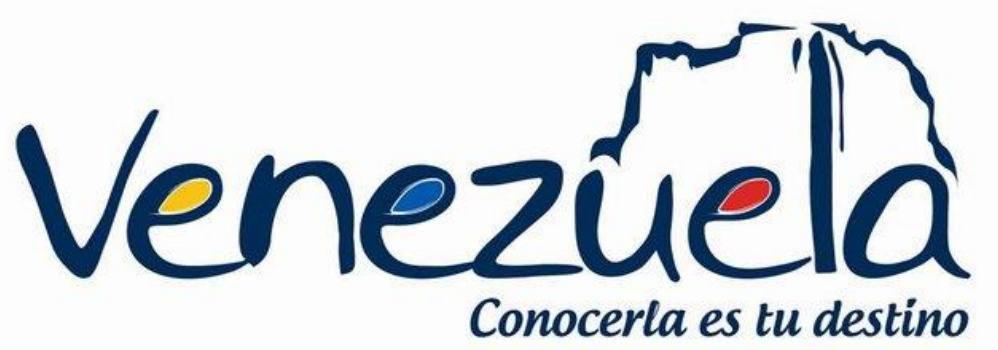

Fuente: Adaptado de Ministerio del Poder Popular para el Turismo (s.f.).

Esta marca no ha logrado posicionarse como se esperaba debido a que muchas empresas siguen utilizando versiones anteriores a causa de los altos costos que implica cambiar los impresos. A lo anterior se le suma el hecho de que con cada nueva administración llega un nuevo logo, esto ha llevado a Venezuela a tener múltiples slogans en los últimos años dentro de los cuales se destacan: Elige tú, Venezuela, donde renacen tus sueños, Venezuela de Corazón, Venezuela, un país 8 estrellas.

Como uno de los medios para promover el turismo y la marca país, el gobierno venezolano propuso el Plan Estratégico Nacional de Turismo con vigencia de 4 años (20092013). El objetivo del plan es contribuir al crecimiento social, económico y político del país a través del desarrollo del turismo a través de los siguientes objetivos específicos (Ministerio del Poder Popular para el Turismo República Bolivariana de Venezuela, s.f.)

- Desarrollo Económico Sostenible y Sustentable

- Participación e inclusión Social

- Infraestructura y Servicios

- Formación y capacitación

- Promoción y comercialización

De acuerdo con el plan se estima incrementar a 5.8\% en la participación del turismo en el PIB. En el 2012 la participación del turismo en el PIB fue del 3.6\%, aun considerablemente lejos del objetivo (World Economic Forum, 2013). 


\section{Capítulo 2. El país como una marca}

El Plan Estratégico también busca incrementar el turismo receptivo a través de la promoción estratégica del patrimonio turístico al igual que incrementar el número de empleos relacionados con el sector. Dentro de las estrategias del plan, no se visualiza ninguna estrategia orientada a la consolidación y fortalecimiento de la marca país como mecanismo para lograr las metas establecidas en el plan. Esto probablemente indica que la marca turística de Venezuela está empezando a ser considerada como una herramienta que ayuda a potencializar el turismo al igual que otros sectores de la economía.

Venezuela sigue siendo un país con grandes debilidades en aspectos de seguridad y con un nivel de interés muy bajo por la priorización de la industria turística (World Economic Forum, 2013). Adicionalmente se requieren inversiones en infraestructura de transporte para que los turistas puedan explotar al máximo la riqueza en fauna y flora, elementos a través de los cuales logra ocupar el puesto \#24 a nivel mundial en abundancia de recursos naturales.

Venezuela necesita un modelo de proyección-país que rescate las riquezas petroleras y valores culturales de su gente. El país descendió nuevamente una posición en el Ranking CBI 2012-2013 ubicándose en puesto \#86 de 118 países (FutureBrand, 2012b).

En el 2012, Venezuela ocupó el primer lugar de países más corruptos de América Latina (Transparency International, 2012). Sumado a esto Venezuela es el país de América menos competitivo y el \#126 del mundo (World Economic Forum, 2013). Esto debido a si inestabilidad macroeconómica pues es un país en donde las tasas de inflación son superiores al 20\%. Adicionalmente la poca confianza en las instituciones gubernamentales al igual que la baja calidad de la educación hace de Venezuela un país poco competitivo.

En el Country Brand Ranking de Bloom Consulting, Venezuela se ubicó en el lugar \#21 dentro de 44 países de América Latina y el Caribe (Bloom Consulting, 2012). En el 2013, Venezuela repitió el liderazgo de países más corruptos de América Latina (Transparency International, 2012).

Venezuela es de los pocos países en América Latina que se encuentra en su fase introductoria en la construcción de una estrategia de marca país. 


\section{Capítulo 2. El país como una marca}

Adicionalmente los factores políticos de este país, han provocado grandes cambios en la visitas de turistas extranjero e inclusive en el impacto de las exportaciones de este país, teniendo en cuenta el ambiente político que se vivió durante un gran periodo de tiempo con El ex presidente fallecido Hugo Chávez y actualmente con el gobierno de Nicolás Maduro. Esto tendrá grandes implicaciones en la estrategia y forma como se quiere comunicar el mundo el país, adicional a los objetivos que este gobierno quiera trabajar para exponer en su marca país.

Teniendo en cuentas los factores antes mencionados y el hermetismo que existe para poder conocer estadísticas certeras sobre variables como exportaciones, ingreso de turistas e inversión extranjera directa, es muy difícil interpretar cual es la situación actual de Venezuela frente a diferentes países de la región y del mundo.

\subsubsection{Bolivia}

La multiculturalidad de Bolivia es uno de los valores diferenciales del país frente a otros de la región. Además, sus riquezas geográficas e históricas lo convierten en uno de los países con mayor diversidad arqueológica de Suramérica.

En materia de exportaciones, se destaca por su producción de hidrocarburos y minerales (principalmente zinc y estaño), de gas natural, de soya y productos de soya, de madera y productos de madera. El gran reto en la promoción de su marca país, sin embargo, se encuentra en comunicarlo.

Bolivia es un país relacionado tradicionalmente al altiplano andino, con una precepción ante el mundo que pasa por alto la importancia de su región amazónica, de sus tradiciones variopintas y de su economía. Para atender la necesidad de ilustrar un mundo que desconoce la variedad de su oferta, el país ha venido adelantando esfuerzos importantes para promover su marca. En particular, se ha recurrido al turismo como el eje de construcción de la misma.

Tomando en cuenta la necesidad de fortalecerse para atraer el interés de los visitantes, el Plan Nacional de Desarrollo de Bolivia en el 2006 contempló una estrategia de consolidación y ampliación de los destinos turísticos. 


\section{Capítulo 2. El país como una marca}

El principal objetivo es ampliar de forma gradual la infraestructura vial, cobertura de servicios básicos, energía eléctrica y comunicaciones, para consolidar e incrementar los destinos turísticos, garantizando la conservación y uso racional de los recursos naturales, históricos, culturales y arqueológicos, los cuales tienen un amplio valor patrimonial para el país; destacando la frase bandera Lo auténtico aún existe (Ministerio de Planificación del Desarrollo República de Bolivia, 2006) .

La identidad del país junto al eslogan Lo auténtico aún existe (ver Figura 33) se venía promocionando desde principios del milenio, y generó discordia desde su lanzamiento por carecer de consenso. Sin embargo, esta imagen no pudo cumplir exitosamente con su fin último de promocionar al país en términos de turismo debido a que no representa la verdadera identidad del boliviano.

Figura 33. Logotipo de la primera marca país de Bolivia

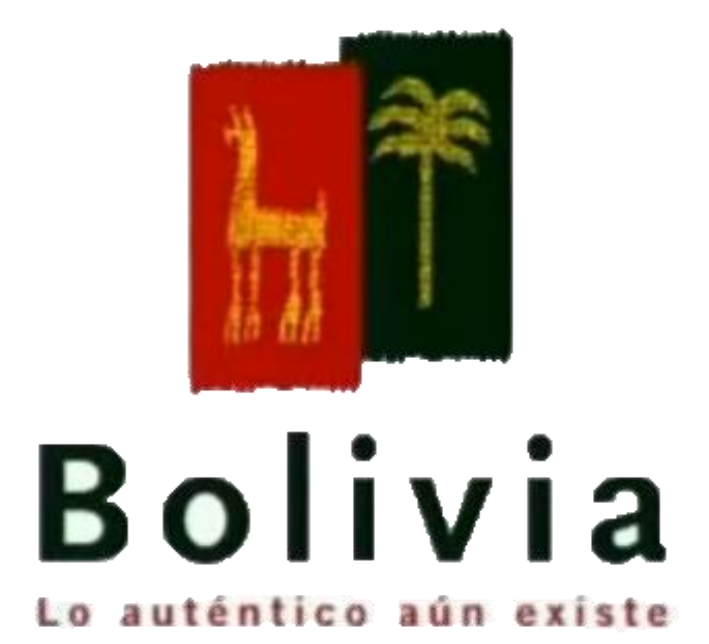

Fuente: Adaptado de Ministerio de Planificación de Desarrollo (2006). 


\section{Capítulo 2. El país como una marca}

La principal característica de los bolivianos es su respeto por las tradiciones en términos de folclor, vestido, y todas las tradiciones ancestrales de orígenes nativos (Dinnie, 2008). Ni en la imagen ni en la estrategia se identificaban ninguno de estos atributos, y pese a que el ministerio de turismo de Bolivia diseñó una página web para acompañarlas no se tuvo éxito en su promoción. Al cabo de unos meses y después de un cambio de administración, el mantenimiento y administración de la página, al igual que las labores de promoción de la marca, se abandonaron.

Bolivia podría vivir del sector del turismo basándose en sus atractivos naturales, culturales y turísticos, pero aun así esta industria sigue sin desarrollarse (Dinnie, 2008). Seguramente, consciente de esto, desde el momento de su lanzamiento y a la fecha, el gobierno Boliviano se ha preocupado por impulsar la marca país en los escenarios más importantes y de mayor visibilidad para el mundo entero.

Para diciembre de 2011, después de varios años reconsiderando la imagen promocional de Bolivia, las autoridades del país lanzaron la nueva identidad para la marca país Bolivia te espera acompañada del eslogan Donde lo fantástico es real (ver Figura 34). Para su ejecución, se recibieron fondos de cooperación internacional española, cerca de USD130.000 que fueron canalizados a través del Ministerio de Culturas y Turismo (2013). La finalidad de la segunda marca país es lograr un posicionamiento para Bolivia como un destino propicio para jóvenes turistas atraídos por conocer la cultura y la naturaleza.

Figura 34. Logotipo de la segunda marca país de Bolivia

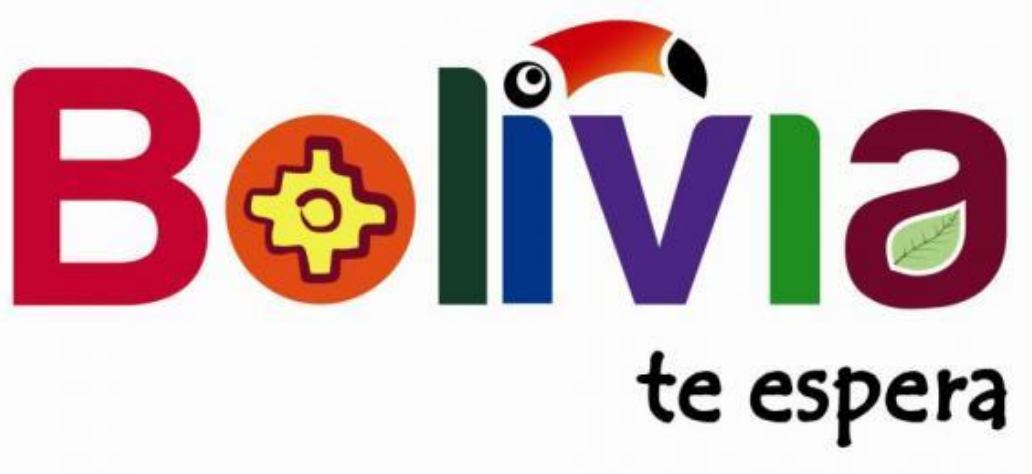

Fuente: Adaptado de Ministerio de Culturas y Turismo - República de Bolivia (2013). 


\section{Capítulo 2. El país como una marca}

Con la nueva identidad de marca país se buscó llegar a un consenso representativo de todo lo que es Bolivia. Se incluyeron elementos gráficos alusivos a la riqueza de las tradiciones y regiones del país. Es así como la $O$ incluye la cruz andina o Chacana, tomada de la iconografía de los pueblos originarios como símbolo de la cultura del altiplano andino. La $I$ incluye el tucán para expresar la biodiversidad y riqueza de la región amazónica. La $A$ incluye la hoja de coca, identifica al sector rural y la tradición milenaria de la hoja de coca. Y el colorido de las letras refleja las 36 naciones del país y sus cualidades pluriculturales (Ministerio de Culturas y Turismo República de Bolivia, 2013).

El lanzamiento de la marca país Bolivia, le ha permitido a esta nación tener mayor visibilidad dentro de los ranking de las marcas país de Latinoamérica y el mundo, el Country Brand Index de FutureBrand, por ejemplo, ya contempla a Bolivia en el lugar \#92 dentro de las 118 naciones que hacen parte del ranking, lo cual representa un ascenso de cuatro puestos con respecto al año anterior y además le permite ingresar al Top 15 de América (FutureBrand, 2012b).

En CBI Latinoamérica, Bolivia ocupa el puesto \# 18 por encima de naciones con índices de competitividad turística más altos como El Salvador y Guatemala (FutureBrand, 2013).

Las críticas alrededor de la identidad reciente de Bolivia han gravitado alrededor de que hace énfasis sobre lo turístico y cultural desconociendo una imagen que proyecte al país de manera integrada. Al revisar los resultados de los rankings de marca país, Bolivia presenta debilidades en temas de salud, educación, seguridad, marco regulatorio, entre otros, lo que influye en un desfavorable posicionamiento de marca país y en un reto para el fortalecimiento de su imagen país.

A pesar de los esfuerzos realizados en la materia, Bolivia continúa con el reto de proyectarse con una imagen holística que represente el potencial del país. Aún en el estudio más reciente del Country Brand Index Latam 2013 de FutureBrand, la marca de su país sigue siendo calificada por la comunidad internacional por debajo de sus vecinos. 


\section{Capítulo 2. El país como una marca}

Bolivia es uno de los tesoros escondidos de América del Sur. Es un país lleno de maravillas naturales y culturales aun esperando a ser exploradas por turistas de todos los países. Sin embargo, Bolivia no goza de un reconocimiento a nivel mundial como un destino turístico preferido, incluso lo ratifica el reporte de Competitividad en Viajes y Turismo (2013) en donde le otorga a Bolivia el primer lugar dentro de los 10 países menos amigables para los turistas en el mundo (World Economic Forum, 2013). 

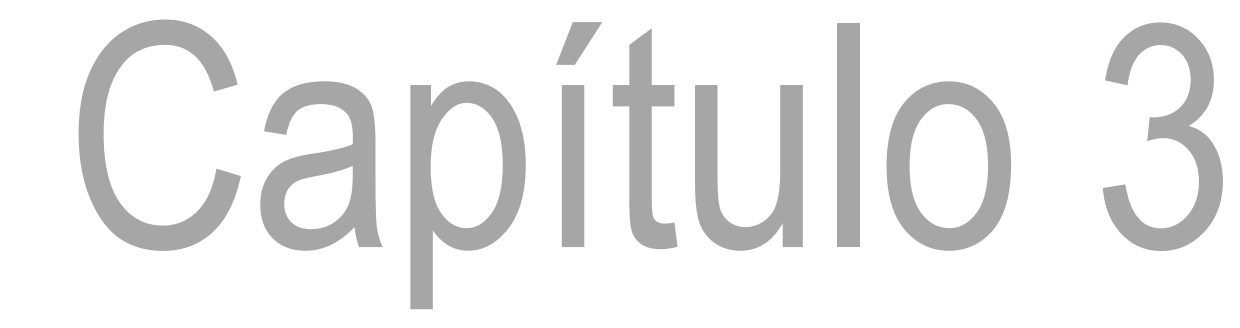

\section{La marca país de Colombia}




\section{Capítulo 3. La marca país de Colombia}

Colombia, así como otras naciones en el mundo, tiene problemas de imagen, y con la creación de una marca país se ha buscado cómo abordar y atacar adecuadamente esta problemática (OMT, 2009). No se debe olvidar que en el proceso de consolidación de la marca país, el pasado, el presente y el futuro rodean la imagen de Colombia. Sin importar las múltiples campañas y acciones que se desarrollen, siempre permanece en la mente de los visitantes una asociación histórica negativa que contrasta cuando el visitante la conoce y la experimenta.

Hay una necesidad emergente de posicionar a Colombia de forma diferencial y preferencial en la mente de los visitantes, bloquear a los competidores la posibilidad de vincularse a la misma idea o concepto, reposicionar a la competencia en la mente en beneficio propio y hacer los cambios internos necesarios para que la idea/concepto sea creíble y sostenible a largo plazo. Hay que promocionar el país, no las regiones. Las regiones deben integrar, no disgregar.

Aún no se ha llegado a un consenso sobre cuáles son los elementos, las características o los rasgos que deben destacarse para fortalecer la imagen país que se proyecta en el extranjero, lo que genera una opinión difusa en cuanto al posicionamiento del país.

Resulta crítico y complejo crear un programa ejecutable para promover una marca, a través de muchos mercados y para múltiples audiencias, y este es el desafío para la nueva organización de Marca País en Colombia.

El presente capítulo hace un recorrido sobre el entorno y evolución del contexto colombiano desde la apertura económica y los resultados de su plataforma estratégica para construir y consolidar una marca país. El capítulo se divide en cuatro secciones: hitos económicos y sociales de Colombia, los orígenes de la marca país Colombia es Pasión, el desarrollo de la Marca País Colombia, y el modelo teórico e hipótesis de estudio.

Para el desarrollo del presente capítulo, se aplicó la metodología casuística. Un estudio de caso es la descripción redactada en algún tipo de formato, de una situación real que incluye un problema, una oportunidad, un desafío, o la toma de una decisión de una 


\section{Capítulo 3. La marca país de Colombia}

persona dentro de una organización. Los componentes de la metodología aplicada se explican en el Capítulo 4 de la Tesis Doctoral.

\subsection{Hitos económicos y sociales de Colombia (1991-2013)}

Colombia se encuentra localizada al noroeste de América del Sur, limita al norte con el Mar Caribe y al occidente con el Océano Pacífico. Tiene como vecinos fronterizos a Brasil, Ecuador, Perú, Venezuela y Panamá. Colombia es considerado como uno de los 12 países mega diversos del mundo. Con un territorio que representa el 0,7\% de la superficie del planeta, Colombia posee alrededor del 10\% de la flora y fauna del mundo (Instituto Humbolt Colombia, 2001).

El país cuenta con importantes recursos naturales y su diversidad cultural refleja los orígenes indígenas, españoles y africanos de su población. Sin embargo, es un país que ha sido devastado por un violento conflicto interno de más de cuatro décadas causado por grupos armados, los carteles de la droga y las violaciones de los derechos humanos.

Colombia es el cuarto país más grande de América del Sur y uno de los países más poblados del continente. Su población asciende a más de 46 millones de habitantes, con un 49\% de hombres y el 51\% mujeres (Departamento Administrativo Nacional de Estadística DANE, 2012a).

A diferencia de la mayoría de países de la región, Colombia se caracteriza por tener ciudades que son ejes poblacionales y de desarrollo lo que le ha permitido distribuir el ingreso y el desarrollo de una forma más equitativa.

De acuerdo con el Censo del 2005, las ciudades que tienen cerca de un millón de habitantes son: Bogotá, Medellín, Cali, Barranquilla y Cartagena. Cada ciudad presenta un dinamismo económico y social diferente: 


\section{Capítulo 3. La marca país de Colombia}

a. Bogotá. Distrito Capital de Colombia (6’776.009 hab.), está estratégicamente ubicada en el centro del país y del continente, a cinco horas de vuelo desde ciudades como Nueva York, Sao Pablo y Buenos Aires y a cuatro de Ciudad de México. Bogotá ha sido elegida por muchas compañías como sede regional y centro logístico para atender el mercado latino. De acuerdo con América Economía (2011), Bogotá ocupa el octavo lugar entre las mejores ciudades para hacer negocios en Latinoamérica.

b. Medellín. La ciudad de la eterna primavera (2’223.078 hab.), es la segunda ciudad del país, caracterizada por ser epicentro industrial, también tiene un marcado pasado negativo por haber sido escenario para el desarrollo del narcotráfico y la violencia en Colombia. Para el 2012, esta ciudad ha logrado transformar su imagen y reputación, y gracias al empuje de su gente y su sentido de pertenencia, ha logrado convertirse en protagonista del desarrollo del país y proyectarse al mundo como una ciudad moderna y emprendedora, ideal para vivir, hacer turismo y consolidar negocios. Se ha convertido en la capital financiera, comercial e industrial del país, así como sede de numerosas empresas locales que mueven la economía nacional. Medellín, es igualmente sede de múltiples eventos de moda y cultura. En el 2013, recibió el premio a la ciudad más innovadora.

c. Cali. Conocida como la sultana del valle (2’068.386 hab.), es el tercer centro económico de Colombia. Es la capital del departamento del Valle de Cauca, una de las regiones más ricas y de mayor desarrollo de Colombia y eje de progreso del sur del país. Se perfila como una ciudad con alta concentración de empresas multinacionales en textiles, consumo masivo y agroindustria. 


\section{Capítulo 3. La marca país de Colombia}

d. Barranquilla. Es la principal ciudad y eje industrial, académico y cultural de la Costa Caribe Colombiana (1’380.437 hab.). Conocida nacional e internacionalmente por su Carnaval, declarado en 2003 patrimonio oral e inmaterial de la Humanidad por la Unesco, y en 2001 patrimonio cultural de Colombia. Desde finales del siglo XIX se caracterizó por ser el principal puerto del país por donde llegaban y salían viajeros y mercancías, razón por la cual se dio a conocer como el puerto de oro de Colombia.

e. Cartagena de Indias. Ciudad turística por naturaleza (900.000 hab.). En 1984 fue declarada por la UNESCO como Patrimonio Cultural de la Humanidad. Ha ganado reconocimiento por su centro histórico, por ser un lugar de eventos, congresos y festivales internacionales. Su arquitectura colonial, de estilo republicano, su vida nocturna, sus festivales culturales, sus exóticos paisajes y su amplia oferta gastronómica y su infraestructura hotelera y turística, la han convertido en uno de los referentes más visitados de América.

Según los cálculos del FMI (Fondo Monetario Internacional) en el 2012 Colombia fue la quinta economía más grande de América Latina después de Brasil, México, Argentina y Venezuela. Posición que espera se continúe y se mejore hasta lograr un tercer puesto para el 2014 (Ministerio de Hacienda y Crédito Público, 2012). Lo anterior se fundamenta principalmente en dos acontecimientos económicos y políticos que sucedieron en 1991: la globalización económica y la nueva Constitución Nacional.

El gobierno colombiano ha buscado facilitar la transición gradual de una economía altamente regulada a una economía de libre mercado. Este nuevo escenario se ha generado por la inclusión de medidas como: la desregulación financiera, la privatización de las empresas estatales y la adopción de una tasa de cambio más flexible, entre otras.

Entre 1998 y 1999 el país se vio afectado en sus indicadores macroeconómicos por una fuerte recesión económica resultado de una baja inflación, una caída en la producción nacional y un alto índice de desempleo (Banco de la República de Colombia, 2000). 


\section{Capítulo 3. La marca país de Colombia}

Para el 2003, el país recuperó confianza en las políticas económicas del presidente Álvaro Uribe Vélez. Políticas que giraron en torno a la creación de una confianza inversionista, el impulso al sector minero y petrolero. Este último registró una transformación muy importante con la creación de la Agencia Nacional de Hidrocarburos, encargada de administrar las áreas con potencial hidrocarburíferas del país y promover la exploración de las mismas (Diario el País, 2010).

En materia de exportaciones, el país también logró un incremento importante, al alcanzar los US $\$ 32.000$ millones, cifra récord en Colombia, pues en 2002 ese índice estaba alrededor de los US\$11.000 millones (Diario el País, 2010).

Un hito importante en este periodo fue la implementación de la Política de Seguridad Democrática en el primer mandato del Presidente Álvaro Uribe, su propósito misional era incrementar los índices de seguridad y confianza tanto en los ciudadanos como en los inversionistas; de esta manera se lograría reactivar el crecimiento económico.

Como resultado de la implementación de la política se logró fortalecer el crecimiento sostenido, y un avance en la reducción de la pobreza y en la generación de bienestar y la mejora de la calidad de vida de la población colombiana.

En el 2005 la recuperación en el PIB y una reducción general de la violencia criminal y política contribuyeron a generar condiciones favorables que permitieron la reelección de Uribe en el 2006 reforzando su mandato popular.

Un resultado en la implementación de la política fue el notable incremento de turistas extranjeros que visitaron al país. Adicionalmente, aumentó el número de turistas que llegan a los puertos de Santa Marta y Cartagena.

Los cruceros se han convertido en un atractivo turístico, con un crecimiento de un $0.6 \%$ en el 2006 al 13,9\% en el 2012. Lo anterior causado por la fácil consecución de la visa americana y el ingreso de diferentes navieras (Fernández R. , 2012). 


\section{Capítulo 3. La marca país de Colombia}

Para el 2010 asume la presidencia Juan Manuel Santos, focalizando sus esfuerzos en consolidar una política exterior cercana a países vecinos y la búsqueda de una paz definitiva para Colombia.

Colombia se quiere convertir en el milagro latinoamericano, sustentado en una mejoría de las condiciones de seguridad que justifica la estimulación de sus exportaciones, inversión extranjera directa y turismo (Periódico El País, 2012).

El Presidente Juan Manuel Santos a través de su Plan Nacional de Desarrollo 20102014 Prosperidad para todos pretende darle continuidad a la Política de Seguridad Democrática implementada por el gobierno anterior. Por lo anterior, se estableció dentro de los objetivos fundamentales del Plan de Desarrollo, lograr que Colombia ocupe un papel relevante en los nuevos espacios globales (Ministerio de Relaciones Exteriores República de Colombia, 2013).

El PIB real creció un 5,9\% en 2011 y se espera un aumento del 4,8\% para el 2012 (CEPAL, 2012). En la Figura 35 se observa como ha sido crecimiento económico de Colombia desde el año 2000:

Figura 35. Crecimiento Económico de Colombia 2000-2012

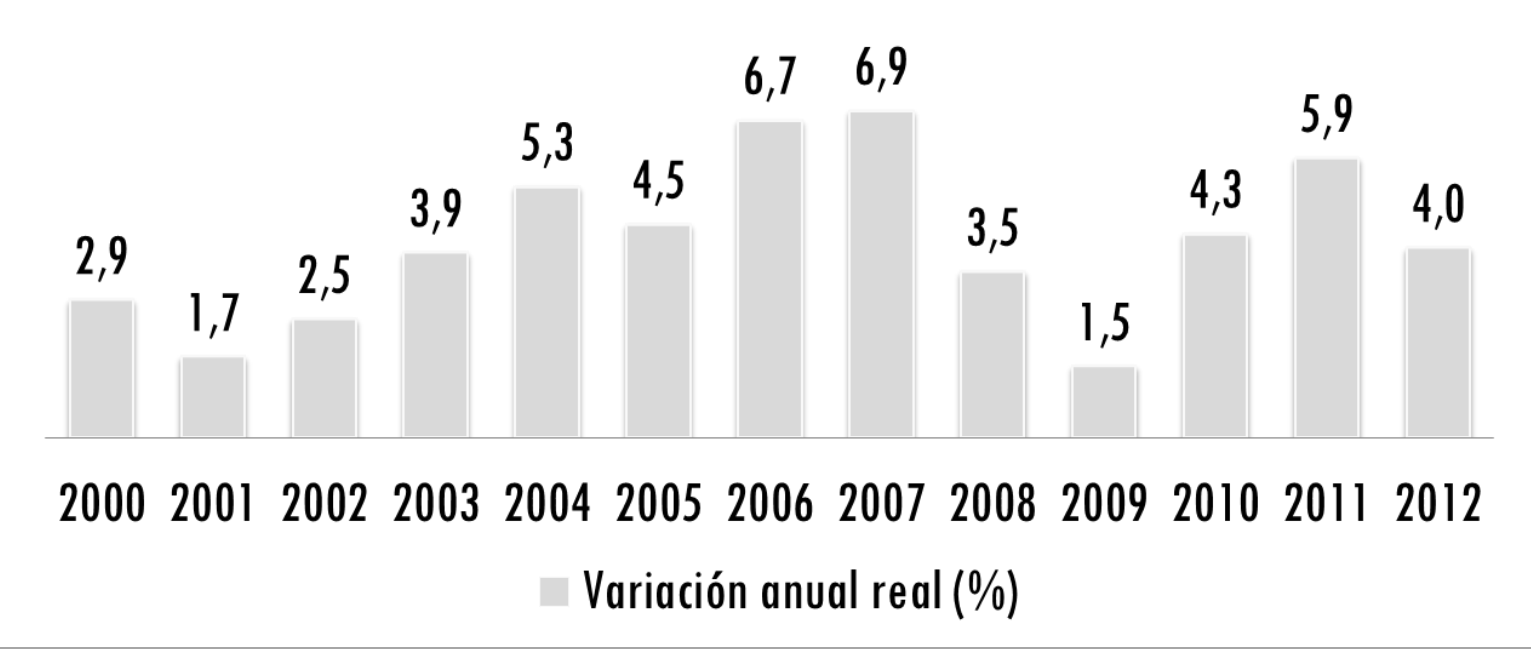

Fuente: Adaptado de DANE (2013). 


\section{Capítulo 3. La marca país de Colombia}

El gasto en infraestructura y la generación de mayores niveles de inversión extranjera directa son los dos pilares económicos del gobierno Santos. El reciente ambiente favorable de negociación con la guerrilla ha mejorado los índices de seguridad y ha atraído a más inversionistas internacionales hacia Colombia.

El Gobierno espera aumentar la participación de las exportaciones con valor agregado (en oposición a las materias primas) del 29\% en 2009 al 40\% en 2014 (Ministerio de Comercio, Industria y Turismo de la República de Colombia, 2010). Para fomentar esta transformación, las leyes que supervisan las zonas francas se han modificado para atraer empresas que apliquen modelos de innovación en sus procesos productivos.

En 2011, México, Chile, Perú y Colombia firmaron un acuerdo comercial para impulsar el crecimiento regional (Ministerio de Relaciones Exteriores de la República de Colombia, s.f.). Conocido como Alianza del Pacífico, el acuerdo tiene como objetivo

impulsar el comercio mediante la reducción de los aranceles de importación. No sólo las exportaciones han representado resultados significativos.

El turismo cobra vida como uno de los sectores productivos con mayor potencial, que contribuye a la generación de empleo, mejora de infraestructura y desarrollo de bienestar social. De acuerdo con el informe de la Asociación Colombiana de Agencias de Viaje y Turismo (ANATO) ingresaron en el 2011 un total de 1.581 .914 visitantes extranjeros a Colombia, en su mayoría procedentes de Estados Unidos. Igualmente ocurre en el año 2012.

Conforme al Índice Global de Competitividad (IGC) del Foro Económico Mundial (FEM) para el año 2011, Colombia se ubicó en el puesto 68 entre 142 países, igual posición en 2010. El IGC considera en su medición variables como instituciones, infraestructura, ambiente macroeconómico, salud y educación básica, educación superior y capacitación, eficiencia del mercado de bienes, del mercado laboral, desarrollo financiero, preparación tecnológica, entre otros. 


\section{Capítulo 3. La marca país de Colombia}

Según la medición de 2011, Colombia y la región en general, deben mejorar los problemas de inseguridad y de infraestructura, y especialmente dedicar presupuestos importantes para invertir más y mejor en educación con la finalidad de responder a las demandas de $\mathrm{I}+\mathrm{D}$, lo que multiplicaría los niveles de competitividad y llevaría al país a obtener mejores resultados económicos y comerciales.

De acuerdo con los resultados globales, Colombia fue superada por Sri Lanka, quien pasó del puesto 79 al 62 y Vietnam, del 75 al 59, mientras que logró superar a Kazajistán, Botsuana y Letonia que cedieron posiciones en su situación competitiva. Como resultado de lo anterior, Colombia supera ahora al $51 \%$ de los países incluidos en el estudio (ver Figura 36).

Figura 36. Evolución de la posición competitiva de Colombia en el IGC (2008-2011)

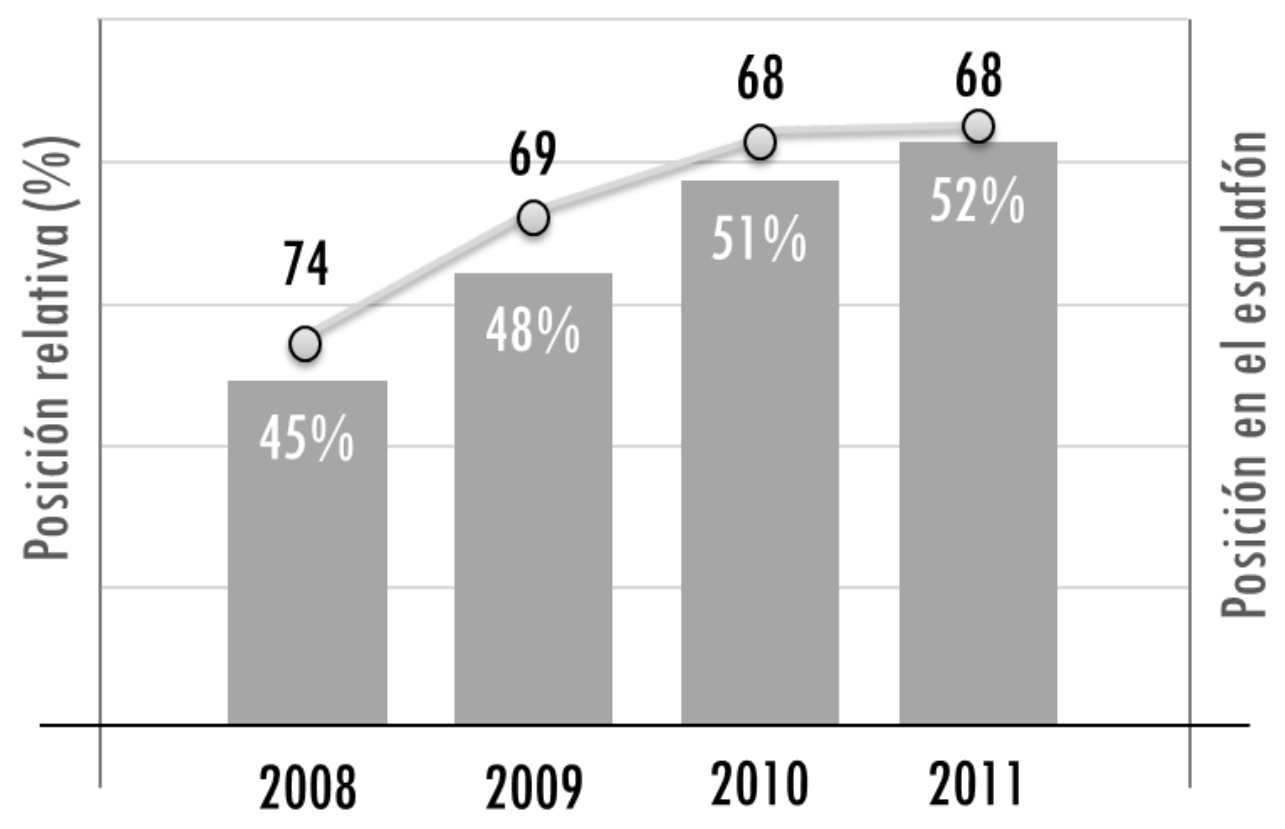

Fuente: Adaptado Departamento Nacional de Planeación (2012). 


\section{Capítulo 3. La marca país de Colombia}

En el 2012, se firmó el Acuerdo de Promoción Comercial entre la República de Colombia y los Estados Unidos de América. El Gobierno colombiano espera que el acuerdo sume un $10 \%$ de las exportaciones y un punto porcentual al crecimiento económico.

Mientras un gran número de países desarrollados siguen recuperándose de la crisis crediticia y de la recesión subsiguiente, los Civets están en la mira de algunos de los países más propensos a lograr un crecimiento sostenido.

El término Civets (Colombia, Indonesia, Vietnam, Egipto, Turquía y Sudáfrica) fue acuñado en el 2010 por el ex presidente ejecutivo de HSBC, Michael Geoghegan, con el propósito de agrupar los mercados emergentes que le apuestan al crecimiento económico. Estos países comparten una serie de similitudes, especialmente en poblaciones jóvenes. Sus economías se componen de sistemas financieros relativamente sofisticados y que no hay una dependencia de la economía hacia un solo sector (América Economía, 2010).

Colombia como mercado emergente, es un escenario atractivo para la inversión extranjera. Especialmente la inversión en el sector petrolero convierte al país en el tercer mayor exportador hacia Estados Unidos.

Colombia es un país lleno de contrastes. Las principales industrias del país, aparte de aceite son los textiles, alimentos procesados, ropa, calzado, bebidas, productos químicos, cemento, carbón, oro, y esmeraldas.

Colombia es el primer exportador mundial de esmeraldas y el segundo país exportador de flores en el mundo, después de Holanda (Marca Colombia, 2012). Es el segundo país más rico en biodiversidad a nivel mundial (Diario Portafolio, 2012a).

El país ha logrado destacarse en mercados internacionales en el campo económico, político, comercial y social. A continuación la Figura 37 expone el Top 5 de los posicionamientos que tuvo Colombia en el ámbito internacional y latinoamericano durante el 2012: 


\section{Capítulo 3. La marca país de Colombia}

Figura 37. Top 5 de Posicionamientos de Colombia en el ámbito regional e internacional

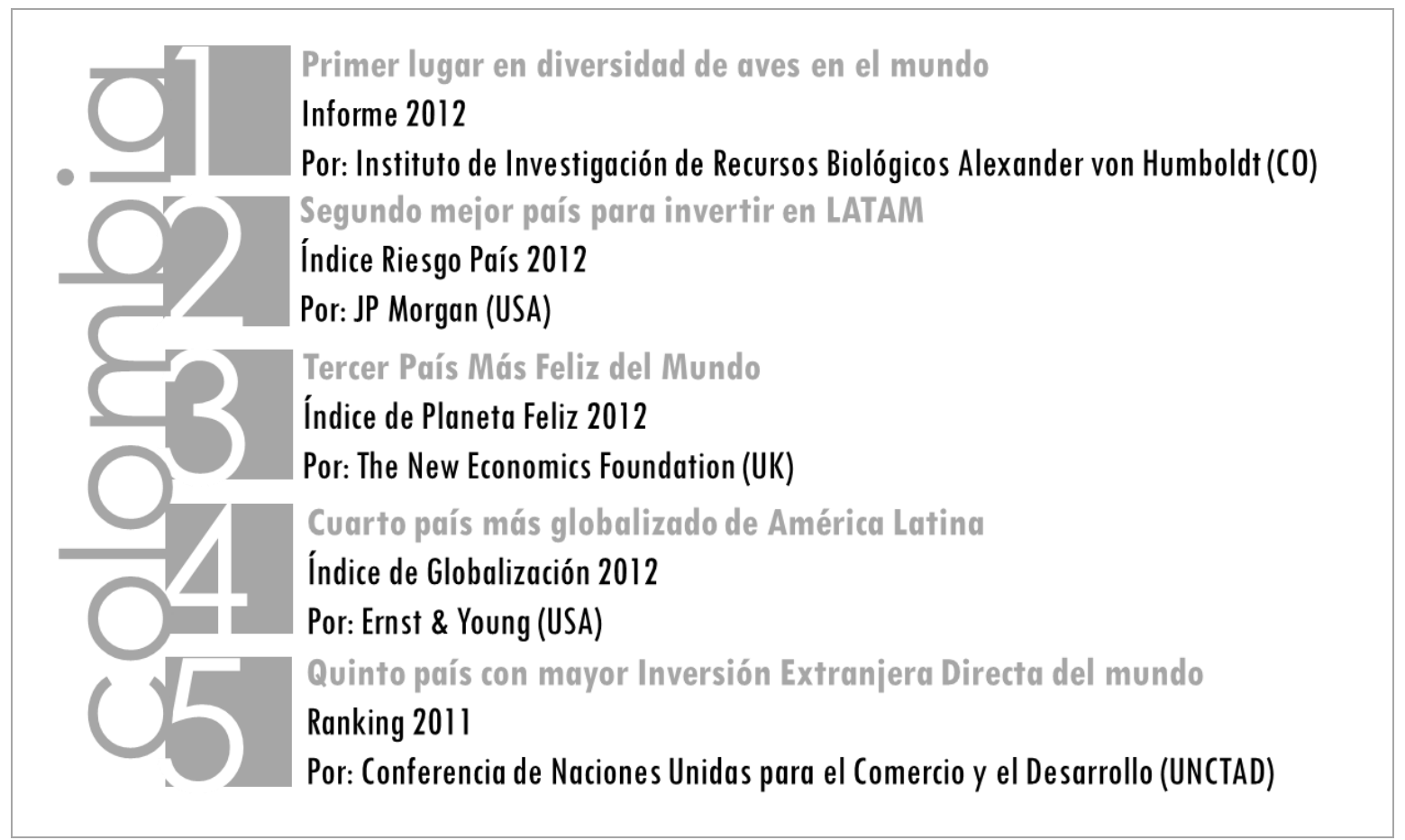

Fuente: Adaptado de Instituto Humboldt, JP Morgan, NEF, E\&Y e UNCTAD (2012).

Es un hecho que lograr mayores niveles de competitividad es y será un reto prioritario

para el Gobierno de turno. Alcanzar mayores índices de equidad social y educativa mejorando la calidad de vida, y promover una mayor penetración de bienes y servicios en los mercados internacionales, son los propósitos principales del sector público y privado actual.

En las últimas décadas, Colombia ha iniciado un camino hacia la competitividad cuyos resultados varían dependiendo de las variables a considerar. Como ya se mencionó, el proceso de apertura económica fue uno de los puntos de inflexión para dar este paso de integrarse al mundo.

Sin duda, el puesto 68 entre 144 países no es una posición privilegiada pero si se compara con el resto de países de Suramérica, solo lo supera Chile en el puesto 39, Brasil en el 48 y Perú en el 61 y todos los demás países de la región están por debajo del puesto 68. 


\section{Capítulo 3. La marca país de Colombia}

El Gobierno Santos reconoce que la innovación es el pilar fundamental para impulsar el crecimiento y desarrollo económico. En este sentido, es relevante que tres elementos se conjuguen y participen en este proceso: la educación, la ciencia y la tecnología,

Al respecto, el presidente Juan Manuel Santos ha enfatizado que la reducción de la inflación, del desempleo y la apertura de mercados son tres factores que han contribuido a mejorar la competitividad de Colombia.

Santos reconoce que la situación de Colombia al 2012 es muy distinta a la del año 2002. Con una confianza crediticia, un riesgo país más bajo y la accesibilidad de las empresas colombianas a mercados internacionales, el entorno se convierte en un escenario atractivo para turistas, visitantes e inversionistas extranjeros.

La estabilidad económica ha hecho de Colombia un destino privilegiado para los inversionistas extranjeros. El Gobierno Colombiano ha introducido reformas que han logrado mejorar el ambiente de los negocios durante el periodo 2006 al 2011.

Las políticas favorables hacia el libre comercio y la inversión extranjera, así como una notable reducción de trámites burocráticos han mejorado la competitividad del país.

Sumado a otros factores, como tener un mercado de consumo importante y un mercado laboral relativamente flexible. Todavía persisten áreas que el Gobierno debe mejorar frente a la inclusión de altas tasas impositivas, la infraestructura deficiente y los niveles de violencia.

La economía colombiana fue la menos afectada en América del Sur por la reciente crisis económica mundial. Sin embargo, la crisis tuvo un impacto negativo en el ingreso disponible y, a su vez, en el gasto del consumidor. Otro factor fue la menor demanda de las exportaciones colombianas por parte de países en recesión, como Estados Unidos.

A continuación se presentan los sectores productivos que muestran óptimos indicadores de crecimiento: 


\section{Capítulo 3. La marca país de Colombia}

Sector Agroindustrial. La agricultura es el pilar de la economía colombiana. El 69\% de las exportaciones corresponden a café, flores, banano y azúcar (Proexport Colombia, 2012). La falta de infraestructura en algunas zonas rurales sigue ralentizar el progreso agrícola. El gobierno está apoyando el desarrollo de la producción de etanol y ha introducido políticas que requieren las compañías de combustible para mezclarlo con la gasolina. La producción de etanol se espera que se duplique, alcanzando los 2,2 mil millones de litros por año para el 2014 (Federación Nacional de Biocombustibles de Colombia, 2012). Gran parte de las operaciones industriales se concentran alrededor de las ciudades de Medellín, Bogotá, Cali y Barranquilla. El sector está dominado por grandes conglomerados privados. Las industrias principales incluyen la industria textil (con algodón local y lanas), prendas de vestir y calzado, industria de alimentos, el tabaco, el hierro y el acero (en parte con carbón local y mineral de hierro), productos de metal, ensamblaje de automóviles, productos químicos, refinación de petróleo y petroquímicos. En 2011, la producción industrial aumentó en $4.9 \%$ frente al 2010 (Departamento Administrativo Nacional de Estadística DANE, 2012a). Cabe anotar que el sector agroindustrial aporta el $9 \%$ del PIB y un $21 \%$ en exportaciones (Proexport Colombia, 2012)

Sector Manufacturero. El sector manufacturero constituye el 13,4\% del PIB y emplea a 13,8\% de la fuerza laboral constituyéndose en la tercera más importante de país con un valor de US\$ 41.035 millones. Sus exportaciones totales entre 2002 y 2011 se cuadruplicaron pasando de 13 mil millones a 57 mil millones de dólares (Proexport Colombia, 2012). La mayoría de las operaciones de manufactura se concentran alrededor de las ciudades de Medellín, Bogotá, Cali y Barranquilla. El sector está dominado por grandes conglomerados privados. Las industrias principales incluyen la industria textil, prendas de vestir y calzado, industria de alimentos, el tabaco, el hierro, el acero, productos de metal, ensamblaje de automóviles, productos químicos, refinación de petróleo y petroquímicos. El PIB del sector creció en 11,4\% en 2011. Este sector es el tercero más importante del país, representa un 13\% del PIB Nacional (Invierta en Colombia, 2012). 


\section{Capítulo 3. La marca país de Colombia}

Sector Servicios. El sector servicios representa más del 50\% del PIB (Illán, 2011). En el sistema bancario a la consolidación de la banca a través de fusiones y adquisiciones que se espera. En el sector minorista, la creciente demanda interna, junto con un mayor poder adquisitivo logra estimular el crecimiento. El Gobierno Santos ha ejecutado un plan de modernización de las terminales aéreas. La industria turística es pequeña pero está creciendo rápidamente. El número de visitantes extranjeros a Colombia en 2011 presentó un crecimiento del 7.3\% (Asociación Colombia de Agencias de Viaje y Turismo ANATO, 2012),

Sectores de Minería, Petróleo y Energía. La minería es una de las fuentes más importantes del país de exportación. El país es fuente de reservas de petróleo y productor de oro, plata, esmeraldas, platino y carbón (Otero, 2012). Colombia es el quinto exportador mundial de carbón y es considerado la nueva estrella petrolera. Las políticas comerciales han favorecido la inversión extranjera directa, evidenciando un aumento en la minería entre el 2000 y 2011. A inicios del 2012, las exportaciones de petróleo y sus derivados aumentaron un 44,4\% en relación al 2011. El mercado objetivo de las exportaciones fueron países como: China (216,2\%), Panamá (88,9\%), Venezuela $(62,7 \%)$, Perú $(54,1 \%)$, Unión Europea (49,5\%), Chile (44,9\%) y Estados Unidos $(17,6 \%)$ (Departamento Administrativo Nacional de Estadística DANE, 2012b). La exportación de petróleo representa alrededor del 25\% de los ingresos del gobierno (Ruíz, 2012).

\subsection{Los orígenes de la marca país Colombia es pasión}

En 1992, el gobierno y el sector privado de Colombia invitó a Michael Porter y a su firma Monitor a evaluar las condiciones del sector productivo con el propósito de identificar las ventajas competitivas que ayudarían a Colombia a constituirse en un referente en mercados internacionales (Echeverri, 2008). 


\section{Capítulo 3. La marca país de Colombia}

El análisis del Informe Monitor se basaba en cuatro elementos que conformaban lo que Michael Porter ha llamado el Diamante de la competitividad:

a. Recursos humanos y de producción.

b. Proveedores de insumos y distribuidores.

c. Demanda nacional por los bienes y servicios producidos por las empresas.

d. Condiciones de competencia que estimulen la innovación empresarial.

A través del estudio, se examinaron sectores específicos de la economía colombiana, lo que permitió determinar el estado en que se encontraba el país en términos de competitividad. Para Porter (1994), la competitividad es un proceso innovación continua que exige precisión en la planeación, con estrategias de alcance y medibles, y en un escenario que permita adoptar la innovación basada en el conocimiento. El país debía comenzar a reestructurar su economía considerando uno de los diez imperativos estratégicos: vender o promocionar a Colombia (Porter, 1994). Para el autor, Colombia tiene una necesidad inminente de elevar la reputación internacional acorde a la oferta de productos, que demuestre calidad y servicio. Y que ésta oferta no solo genere identidad sino que también motive a la compra de productos colombianos.

El estudio presentó los imperativos estratégicos que aportarían al crecimiento económico de Colombia y a su vez a contextualizar al país en un entorno globalizado. Uno de los imperativos hacía referencia a que había que vender o promocionar a Colombia (Porter, 1994). Colombia necesita obtener un reconocimiento internacional de sus productos mediante una imagen que se sustente en la calidad y el servicio (Echeverri, 2008).

En este contexto, la preocupación por modificar el posicionamiento del país en mercados internacionales se fue consolidando como uno de los objetivos gubernamentales más relevantes para la construcción de una imagen país (Echeverri et. al., 2010).

Para dar cumplimiento al pilar estratégico propuesto por Porter, se crea Proexport Colombia, entidad que promueve la inversión extranjera, el turismo y las exportaciones en Colombia. (Porter, 1994). 


\section{Capítulo 3. La marca país de Colombia}

La implementación de la marca país no se hizo de inmediato, tardó por lo menos 12 años, en los que se retomó la inclusión del concepto de marca país, sin embargo no se evidenciaron avances en este frente, y de manera tímida solo se reforzó la labor de promoción turística a través de medios impresos en el ámbito mundial (Ramos \& Noya, 2006).

Además de las actividades de promoción, la política de Seguridad Democrática en el 2001, fue un factor clave para la campaña Vive Colombia, viaja por ella que tenía como propósito incentivar el turismo interno, generar empleo y crecimiento en las regiones de Colombia (Ministerio de Defensa Nacional República de Colombia, 2003). Esta campaña buscaba motivar la seguridad y la recuperación económica del país al inicio del mandato presidencial de Álvaro Uribe.

La misión principal era reactivar el turismo, ofreciendo seguridad en rutas terrestres nacionales, lo cual permitió que colombianos y extranjeros circularan por el país con mayor confianza y libertad (Echeverri et. al., 2010). Para el 2004, se habían recuperado espacios y el turismo comenzó a ser un sector económico de gran potencial para cada región de Colombia (Ministerio de Comercio, Industria y Turismo República de Colombia, 2009). Ese

mismo año se materializó la idea de crear marca país, iniciativa del Gobierno Nacional y Proexport Colombia.

En 2004, Artesanías de Colombia, Proexport Colombia y el Instituto para la Exportación y Moda (Inexmoda), crearon el proyecto Identidad Colombia, con el propósito de posicionar a Colombia como un país reconocido en el mundo por el tema moda. Identidad Colombia tenía dos ejes centrales: generar un alto impacto social en el sector artesanal y provocar un impacto cultural: proyectar a Colombia (Proexport Colombia, 2005).

Según Ramos y Noya (2006) el programa Identidad Colombia, basado en artesanías, cultura y moda en Milán causó un gran impacto por el despliegue de creatividad lo que evidenció la necesidad de construir una marca país que no se concentrara en artesanías o textiles, sino que involucrara otros sectores productivos de Colombia. 


\section{Capítulo 3. La marca país de Colombia}

De acuerdo a Jaime Bermúdez, Embajador de Colombia en Argentina (2008): “Muy recién llegada al Palacio de Nariño, doña Lina Moreno sugirió que buscáramos alguna forma de ayudar a las comunidades artesanales a trabajar con diseñadores colombianos; hacerlo muy chiquitico, pero se hizo un proyecto muy grande que se llamó Identidad Colombia".

Permanecía la necesidad y urgencia de proyectar a Colombia a los mercados internacionales mostrando una imagen de país que no se asociara a aspectos negativos como la corrupción, el narcotráfico o el terrorismo (Echeverri et. al., 2010).

En marzo de 2005, la Junta Asesora estaba conformada por Luis Guillermo Plata, presidente de Proexport Colombia; Pilar Lozano Ramírez, asesora de la Presidencia de Proexport Colombia; Jorge Humberto Botero, ministro de Comercio; Gustavo Ardila, presidente de Bancoldex; Martín Echavarría, delegado del presidente de la República; Juan Alfredo Pinto, Hernán Puyo, Jaime Díaz Molina y Eduardo Visbal, representantes del sector privado; Alberto Velásquez, Jaime Bermúdez y Luis Fernando Andrade, representantes de la Presidencia de la República, y Eduardo Muñoz, viceministro de Comercio Exterior (Proexport Colombia, 2008).

Es así como la Junta Asesora, atendiendo al trabajo que ya venían realizando en la Presidencia de la República, la Cancillería y Proexport Colombia, decidió iniciar el camino hacia Colombia es pasión. De esta forma se comenzó la tarea de construir una marca país única para Colombia (Echeverri et. al., 2010).

Proexport Colombia es una entidad pública, cuya función principal es fomentar las exportaciones no tradicionales, la inversión extranjera, el turismo y la imagen del país.

La relación con Proexport Colombia se da a través de la integración, dado que Colombia es pasión es el elemento integrador de las estrategias de turismo, inversión extranjera y exportaciones. 


\section{Capítulo 3. La marca país de Colombia}

De este modo, se reestructuró la nueva organización y se conformaron dos gerencias: Mercadeo y Comunicaciones y Comercial (esta última rearmada con personal de la estructura anterior) y que serían dependientes de la Vicepresidencia de Imagen País.

Según Alicia Mejía, Directora de Inexmoda (2008) se buscaba una imagen que permitiera reducir la brecha entre percepción y realidad de un país como Colombia. Una imagen que lograra reacomodar ese imaginario que existe en otros países sobre los colombianos y que se orientara a promover el turismo y la inversión.

Se conformó un Consejo Asesor compuesto por representantes de diferentes sectores de la economía nacional para que participaran en la estructura, concepto y diseño de imagen país (Proexport Colombia, 2006). El equipo de trabajo coincidió desde sus inicios en la necesidad y urgencia de proyectar a Colombia a los mercados internacionales mostrando una imagen de país que no se asociara a aspectos negativos como la corrupción, el narcotráfico o el terrorismo (Mejía, 2008).

De esta forma en el 2005 se dio inicio a la tarea de construir una marca país única para Colombia. En primer lugar se constituyó un Comité Académico donde se invitaron a líderes de opinión nacional, con la finalidad de conocer su percepción y argumentos sobre la idea de crear una marca país (Lacouture, 2008).

En el 2009, la campaña del Ministerio de Comercio, Industria y Turismo denominada El riesgo es que te quieras quedar generó un impacto muy positivo, convirtiéndose en uno de los responsables del incremento del 9,3\% en turismo internacional (Santamaría, 2010). Cabe anotar que esta campaña para promocionar el país fue desarrollada por Proexport Colombia, no era una segunda marca país como se pensó en su momento (Proexport Colombia, 2010b).

La génesis de la campaña fue el resultado de las promociones turísticas anteriores que limitaban al turista a destinos específicos y que no contemplaban la permanencia del turista ya bajo la figura de residente (Guilland, 2012). Además la necesidad de modificar en el imaginario colectivo las implicaciones de la palabra riesgo cuando se mencionaba a Colombia en medios internacionales (Arango, 2013). 


\section{Capítulo 3. La marca país de Colombia}

La prevención y el temor eran señales que permanentemente expresaban los operadores turísticos internacionales cuando se pensaba en Colombia como destino turístico o de inversión (Lacouture, 2008). La solución ante esto, fue ver el riesgo como oportunidad.

La denominación fue utilizada de manera positiva para crear el lema que acompañó la campaña. Su enfoque estaba relacionado con incentivar el deseo y voluntad del visitante extranjero por permanecer en el país (Proexport Colombia, 2010b).

Los efectos de la política de seguridad y de promoción mostraron resultados positivos pero no suficientes, que lograron que Colombia retornara al mapa de turismo mundial (Organización Mundial del Turismo, 2012).

La Vicepresidencia de Imagen País de Proexport Colombia ejecutaba acciones para promover y vender la marca país, articulado a los esfuerzos del Ministerio de Comercio, Industria y Turismo, que desarrollaba estrategias para incentivar el turismo en Colombia. Ambos organismos, se apoyaron programas en conjunto con el mismo propósito: capitalizar la reputación de Colombia en mercados internacionales (Proexport Colombia, 2010a) .

La marca país se creó con una intencionalidad de promoción internacional. Para la Directora de la marca país, María Claudia Lacouture (2008) había que reducir la brecha entre la percepción y la realidad. Según Lacouture, una marca país no puede trabajarse internacionalmente si no tiene un espejo nacional (Echeverri, 2008).

Para el desarrollo del concepto de marca país se invitó a varias firmas internacionales expertas en el tema de imagen país, pero el alto costo de las propuestas y la falta de consenso en el Consejo respecto a cuáles debían ser los temas prioritarios impidieron seguir adelante con el proceso. Sin embargo, Proexport Colombia, el Despacho de la Primera Dama, el asesor presidencial para las comunicaciones e Inexmoda decidieron contratar al experto David Lightle, consultor internacional de la empresa Visual Marketing Associates (VMA), quien había asesorado en el diseño de campañas a distintos países, entre ellos Nueva Zelanda, Australia y Taiwán. También había participado activamente en los Consejos de Competitividad organizados por el Ministerio de Defensa de Colombia (Proexport Colombia, 2005)

El consultor resaltó el hecho de que el país tenía una mala imagen internacional, pero que existía una amplia brecha entre el país y la realidad. La guerrilla y el narcotráfico eran 


\section{Capítulo 3. La marca país de Colombia}

problemas que le daban una imagen muy dura que distorsionaba la realidad del país (Lightle, 2005).

David Lightle (2005) determinó que para entender la imagen país que Colombia proyectaba al mundo había que considerar dos situaciones: una negativa planteada por el narcotráfico y la violencia, y una positiva creada por la campaña de Juan Valdez de Café de Colombia.

El consultor viajó por 14 ciudades y otros 131 municipios del país, conociendo la cultura, la gastronomía, la música y la población colombiana; recolectando datos, analizándolos y estructurando la información.

Para el desarrollo de esta investigación se aplicaron técnicas como la encuesta y la observación no estructurada, dirigida a diversos grupos de interés, como académicos, políticos, empresarios, periodistas y obreros, entre otros.

La pregunta de inicio en la investigación fue: Ustedes ¿qué son?, y las respuestas a esta pregunta se concentraron en frases como: somos personas con talento, comprometidos, creativos, apasionados, emprendedores, confiados, felices, entre otros.

Se llegó a la conclusión de que el empuje y la amabilidad eran ese elemento diferenciador del país, y que todas estas características se conjugaban en la palabra pasión.

A partir de estos conceptos, obtenidos en su recorrido por el país, David Lightle (2005) determinó que había un elemento común que identificaba a los colombianos: la pasión.

Ejercicios iniciales permitieron identificar el concepto central de la campaña y sentaron las bases para desarrollar la imagen gráfica a partir de la pregunta ¿Cómo visualiza la pasión?, las respuestas más recurrentes, en su respectivo orden, fueron: corazones, colores llamativos (en particular el rojo), silueta femenina, fuego y flores (ver Figura 38). 


\section{Capítulo 3. La marca país de Colombia}

Figura 38. Logotipo de la primera marca país de Colombia

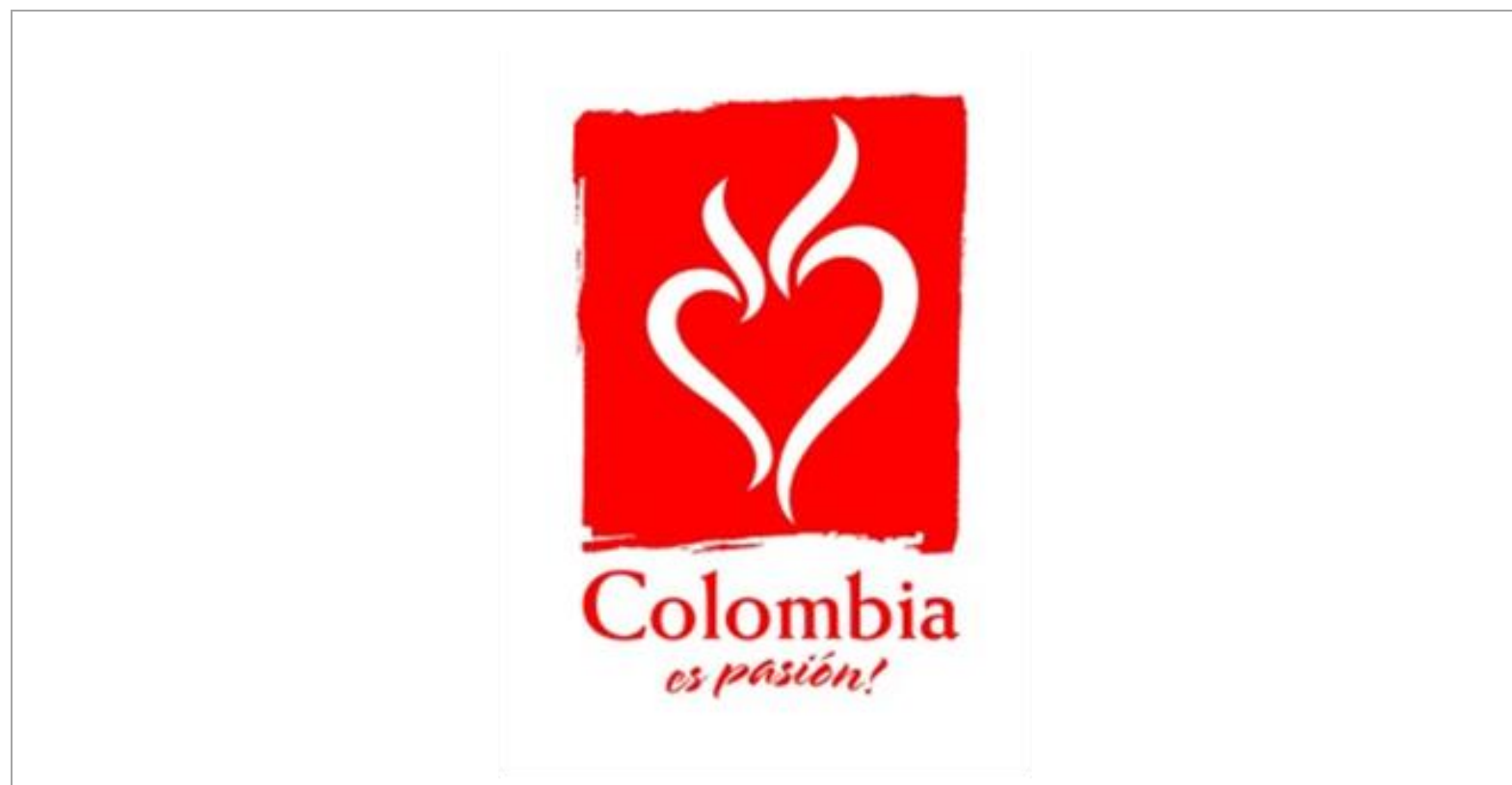

Fuente: Adaptado de Proexport Colombia (2008).

El logo símbolo fue diseñado por la firma estadounidense Visual Marketing Associates (VMA), contratada para garantizar que se cumpliera con los estándares internacionales requeridos, en asociación con los diseñadores del Comité de Expertos.

El logo con el corazón produjo fuertes discusiones en la sociedad colombiana, con ataques y defensas por igual, con fuertes críticas en las que se planteaba la falta de relación entre el logo y Colombia; incluso se habló de la irreverencia en relación con un elemento tan significativo para el pueblo colombiano: el Sagrado Corazón.

El Consejo Asesor propuso, entonces, un plan de visibilidad de la marca país (Echeverri, 2009a). En dicho proceso se incorporó Alexandra Torres como la primera directora de Imagen País, en marzo de 2005 (Proexport Colombia, 2005).

El objetivo inicial de la marca país era posicionar y consolidar una imagen positiva del país. Para Saúl Cardozo, director de capacitación de Imagen País (2008): “Imagen País es una estrategia de competitividad diseñada para mostrar la otra cara de Colombia, esa que no se conoce". 


\section{Capítulo 3. La marca país de Colombia}

\subsubsection{El camino hacia la construcción de un símbolo nacional}

En el 2005, Lightle comentó al respecto: "No fui yo quien les dijo a los colombianos qué sentir o ser. Al contrario, fueron los colombianos quienes a través de mi investigación hablaron de su identidad, su forma de sentir. La campaña es un reflejo del sentir de la colectividad, de su esencia”.

Una vez finalizado el estudio, el consultor viajó a Estados Unidos para analizar los resultados y diseñar una propuesta inicial que sería presentada ante el Consejo Asesor. Con el lema Colombia es pasión comenzó el proyecto de marca país en Colombia (Echeverri et al., 2008).

Según Cardozo (2008) antes de Colombia es pasión, no había realmente una marca país como tal; teníamos una marca comercial, que era Juan Valdez. Para Bermúdez (2008): "Hemos logrado un avance en el mundo con la marca Juan Valdez. En ocasiones nos preguntamos ¿cuál debía ser la marca de Colombia? Y frente al tema de Juan Valdez, la respuesta de alguna forma es muy simple: Juan Valdez representa un sólo sector en Colombia, el sector cafetero".

El Consejo Asesor planteó dos etapas para la implementación de la marca país. La primera etapa fue interna, con el objetivo de lograr que un alto porcentaje de colombianos se convirtieran en embajadores de su país, que empezaran a actuar por Colombia, generando compromiso en la población (Echeverri, 2009a). Lo anterior convocaba a la vinculación de empresas colombianas y la obtención de los recursos para la consecución del proceso.

Una segunda etapa, externa o de internacionalización, incluía una campaña que permitiría cerrar la brecha entre percepción y realidad de país, concientizando a la comunidad internacional de las crecientes oportunidades de Colombia, para generar más exportaciones, más turismo y más inversión extranjera (Echeverri et al., 2008).

La estrategia sugerida fue de aplicar marketing directo, orientado hacia Estados Unidos, Europa, Japón y China para el primer año de creación de la marca país. Al respecto, Porter (2005) señaló que la pasión es un atributo muy comercializable. 


\section{Capítulo 3. La marca país de Colombia}

Especialmente cuando se trata de temas de negocios, la pasión del pueblo puede demostrar un trabajo duro y resultados positivos.

Porter precisó en su consultoría que Colombia tiene que ser experimentado sensorialmente. Es un país que permite crear un vínculo emocional rápidamente (Porter, 1994).

El proyecto sería administrado por Proexport Colombia, con un centro de costos propio, donde el aporte de la entidad será para cubrir los desembolsos operativos como honorarios y gastos administrativos, y se buscarán los recursos del sector privado para cubrir los costos de promoción (Proexport Colombia, 2005).

El funcionamiento de Colombia es pasión estuvo a cargo de un Consejo Asesor presidido por Lina Moreno de Uribe e integrado por 15 miembros provenientes del sector privado, público y de la academia. Adicionalmente, se cuenta con un grupo operativo compuesto por Jaime Bermúdez, Fabio Valencia, Alicia Mejía, José Pérez, Rosario Ballesteros, David Lightle y Luis Guillermo Plata, quienes se reúnen mensualmente. La dirección ejecutiva está a cargo de Proexport Colombia, en cabeza de Alexandra Torres.

El proyecto original contó con un presupuesto inicial de USD\$429.700, de los cuales USD\$297.700 provendrían del sector privado y USD\$132.000 de Proexport Colombia. Se decidió, en ese momento, no dar inicio a la campaña de promoción interna hasta haber recaudado el $50 \%$ de los recursos del sector privado.

Los ingresos del sector privado (70\% del total de los ingresos propuestos) se originarían de la venta de la licencia de uso de marca país con valores que dependerían del tamaño de la empresa, siendo la más económica del orden USD\$431 (Proexport Colombia, 2005).

El presupuesto de la marca país se distribuye de la siguiente manera: el $87 \%$ se destina a esfuerzos promocionales, y el 13\%, a funcionamiento. La promoción de la marca requiere una estrategia de comunicación permanente y distinta. Un $20 \%$ de los gastos totales en promoción se destina para publicidad, un $16 \%$ se dirige a eventos y un $14 \%$ corresponde a merchandising ${ }^{8}$.

\footnotetext{
${ }^{8}$ Exhibición en el punto de venta.
} 
Capítulo 3. La marca país de Colombia 


\section{Capítulo 3. La marca país de Colombia}

La mayor parte de los ingresos de la marca Colombia es pasión proviene de la venta de licencias. Los valores de las licencia varían dependiendo de los activos fijos de la empresa y el tipo de inversión publicitaria. Los clientes de la marca país han sido empresas de diferentes sectores económicos.

Las empresas adquirieron la licencia para usar como parte de su campaña publicitaria. Algunas de las grandes empresas que utilizaron la licencia de la marca país son: FritoLay, BBVA, Sofasa, Bancolombia, Avianca, Americana de Colchones, Bolivariano, Carrefour, entre otros.

Empresas como BBVA, Avianca, Grupo Aval y Kokoriko dieron el impulso inicial en la promoción de la marca país. En un comienzo, el panorama era positivo, por las donaciones que recibían por parte de las empresas; sin embargo, las decisiones de adquisición de la licencia se fueron modificando hacia la formulación de estrategias de cobranding (Trujillo, 2012). Lo anterior apalancó la marca a través de la asociación de marcas con una ventaja competitiva frente a la de sus competidores (Echeverri et al., 2008).

Los usos que las empresas le dieron a la marca país variaban de acuerdo con su inversión publicitaria, entre los que se encuentran:
a. Desarrollo de productos asociados a la marca país.
b. Inserción del logotipo en las etiquetas y empaque.
c. Inserción del logotipo en catálogos, folletos, sitios web, publicidad fija y móvil.
d. Inserción del logo en la imagen corporativa de las empresas.
e. Campañas de sensibilización a empleados de empresas.

Durante el 2005 se vendieron licencias de uso de marca a 39 empresas, lo cual representó ingresos de USD\$1.693.186. Cuatro empresas (Compañía Nacional de Chocolates, Bancolombia, Grupo Aval Acciones y Valores y Empresas Públicas de Medellín) participaron con el equivalente al 51\% de las ventas (ver Figura 39). 


\section{Capítulo 3. La marca país de Colombia}

Figura 39. Participación porcentual de las ventas de la licencia - año 2005

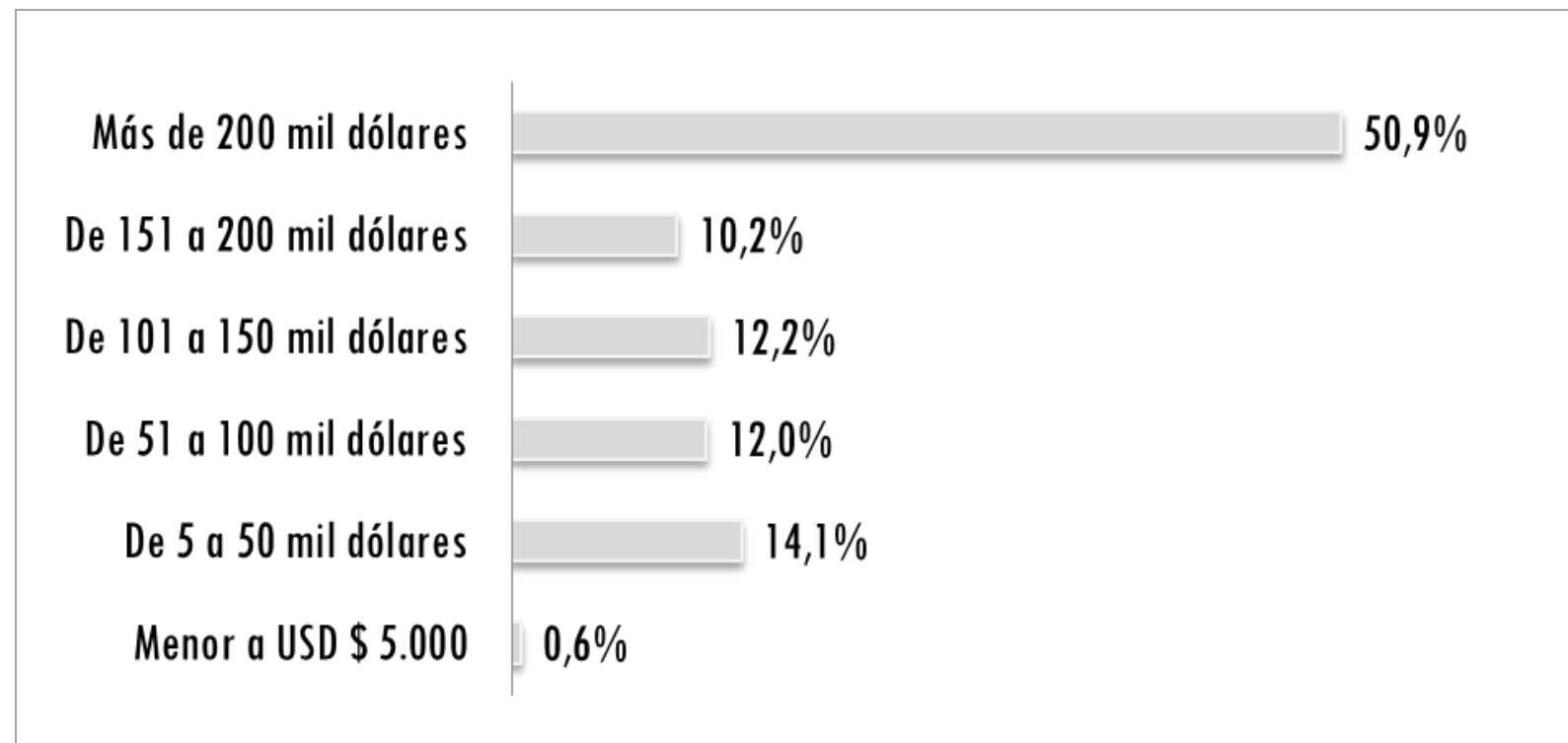

Fuente: Adaptado de Proexport Colombia (2008).

Vale la pena señalar que el mayor número de empresas que han adquirido la licencia (aproximadamente 19 de ellas) son las que menor inversión publicitaria han realizado, sólo 0,6\% del total de las ventas corresponde a una inversión menor de USD\$5.000. Lo anterior se debe al tamaño de este grupo de empresas (en gran parte, pequeñas) y al uso que le dan a la licencia.

\subsubsection{Año 2006: los primeros pasos}

En marzo de 2006 se presenta un cambio en la gerencia general de la marca país. La nueva dirección se orientó a construir y mantener las relaciones públicas con gremios, entidades y gobierno (Proexport Colombia, 2006).

El Comité Asesor decidió la desvinculación de la agencia de publicidad TBWA/Colombo - Suiza que hasta el momento tenía a su cargo la publicidad del proyecto, y contrató a la empresa Sancho BBDO, por su calidad creativa merecedora de premios internacionales y nacionales, su relación comercial con clientes considerados potenciales para el programa marca país y por la estrecha relación de los socios con esta agencia (Proexport Colombia, 2006). 


\section{Capítulo 3. La marca país de Colombia}

Los avances en la promoción de la marca país estaban demostrados en algunos puntos básicos:

a. La campaña publicitaria compuesta por un comercial de lanzamiento emitido en canales de televisión nacionales, regionales, municipales; cuñas para radio emitidas en cadenas nacionales, regionales y municipales; impresos en todos los periódicos nacionales y en las principales revistas del país, así como en vallas.

b. Aliados (socios de la campaña) multiplicadores del mensaje, free press $^{9}$, proyectos especiales y eventos.

c. Proyectos especiales plasmados en la constitución de un equipo de ciclismo nacional llamado Colombia es pasión-Coldeportes.

d. El lanzamiento de la canción Somos pasión, que originalmente iba a ser interpretada por Juanes y Shakira, pero que finalmente fue grabada por 15 artistas de nueva generación; fue lanzada a mediados de mayo en 300 emisoras de todo el país.

e. Los eventos realizados incluyeron la participación en el Festival Internacional de Teatro de Cartagena y la Feria Internacional del Libro (Hyannis Port, Estados Unidos).

En sus inicios, los empresarios no le veían el uso a la marca país y algunos optaban por registrar su aporte como una donación bajo la filosofía de apoyar al país. Mora (2008), gerente financiera de Colombia es pasión, señaló que: "Bancolombia fue una de las empresas que nos dio al principio, renovó usa el logo, lo utilizó en su página web”.

Para el 2006, los ingresos fueron de USD\$2.590.000, por concepto de ventas de licencias a empresas colombianas (con la incorporación de Almacenes Éxito como empresa de importancia en el mercado colombiano); se capacitó a 42.783 colombianos por medio de 354 charlas puntuales (100 maleteros del aeropuerto de Bogotá; funcionarios del DAS; 200 taxistas de Bogotá, empresas, gobierno, entre otros), se hizo una fuerte presencia en medios

9 Táctica de Relaciones Públicas que pretende proteger y mejorar la imagen corporativa. 


\section{Capítulo 3. La marca país de Colombia}

por medio de free press, especialmente en radio y televisión, y se estructuró el diseño de la página web (Echeverri et al., 2008).

Se inició la segunda etapa del programa original de Colombia es pasión, mediante el lanzamiento de la estrategia internacional, lo cual requeriría el apoyo del gobierno para encontrar los recursos adicionales que permitieran el desarrollo de esta etapa (Proexport Colombia, 2008).

Los resultados para del año 2006 mostraron ingresos de US $\$ 1.704 .900$ originados por 107 empresas, seis de las cuales —Caracol (canje), Postobón, Energía Y \& R (Telecom), Autosnack (canje), Almacenes Éxito y Comunicación Celular Comcel- registraban US\$807.965, que representaron el 57,4\% de los ingresos de Colombia es pasión.

El 37,4\% de las ventas de 2006 corresponden a ingresos entre 151 y 200 mil dólares. Como se aprecia en la Figura 40, el incremento en las ventas de la licencia de marca se debe a una mayor vinculación comercial (nuevas empresas) y a nuevas modalidades del uso de la marca.

El caso de Petrobras - empresa extranjera que lleva más de 20 años en Colombia y que hasta 2005 sólo estaba en el sector de exploración y producción - demuestra la oportunidad de hacer una introducción fuerte en el mercado por medio de la adquisición por una sola vez de la licencia de Colombia es pasión.

En la Figura 40, también se puede observar la comparación de las ventas totales de los años 2005 y 2006. En 2005, el 51\% de las ventas de la licencia se concentró en empresas que invirtieron una cifra mayor a 200 mil dólares.

Para 2006, la vinculación comercial de las empresas que invirtieron cifras superiores a 200 mil dólares corresponde al 12,5\%. Cabe señalar que las ventas totales de 2005 suceden en un período menor al de 2006. En 2005 ocurre el lanzamiento de la marca país y las organizaciones que más apoyaron la iniciativa fueron grandes empresas. 


\section{Capítulo 3. La marca país de Colombia}

Figura 40. Participación porcentual de las ventas de la licencia - años 2005 y 2006

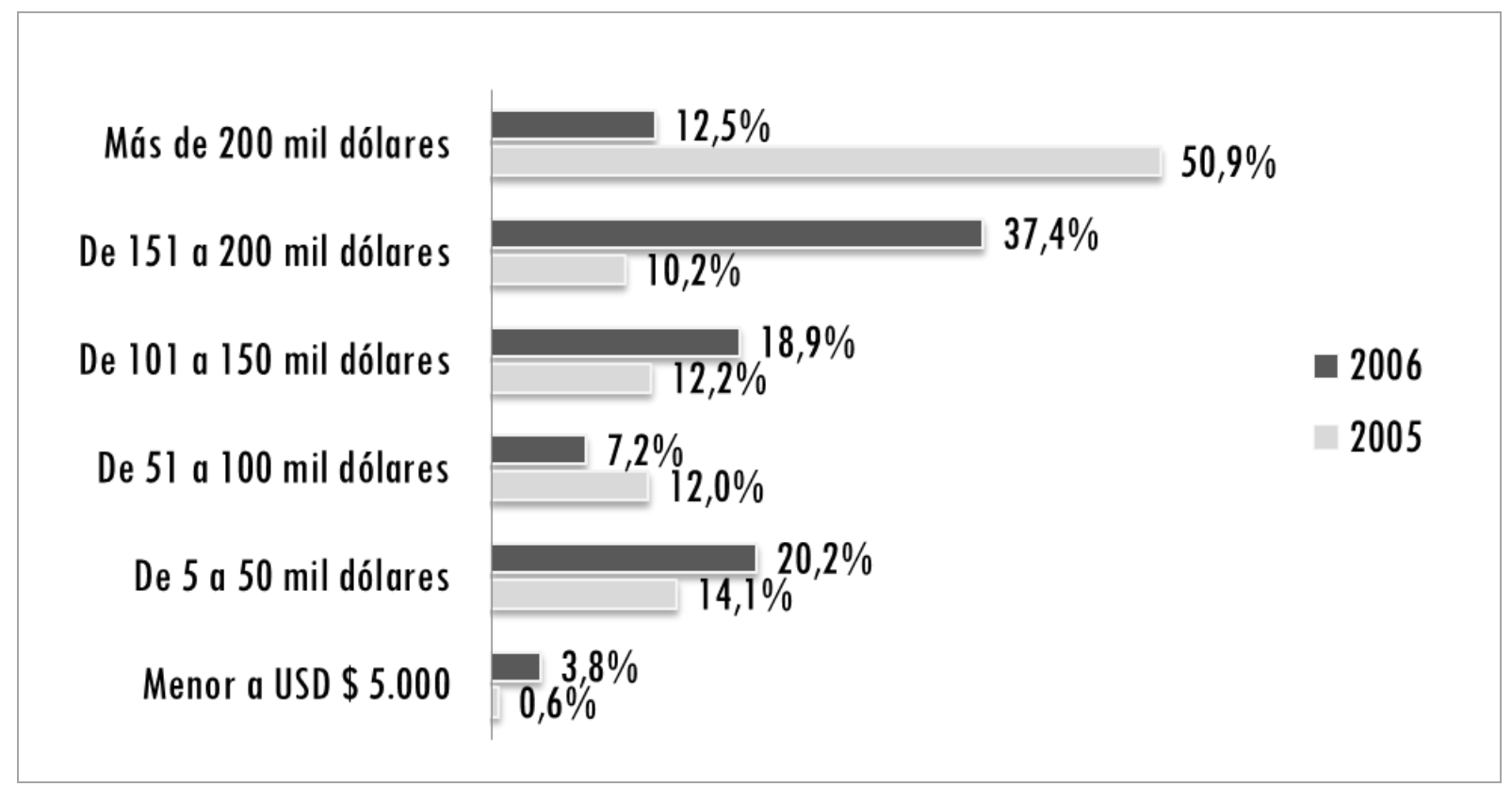

Fuente: Adaptado de Proexport Colombia (2008).

En 2006 comienzan a vincularse medios de comunicación, así como empresas medianas y pequeñas. Adicionalmente, en ese mismo año se ejecutaron estrategias de comunicación para cautivar el público en general, turistas e inversionistas, como free press, publicidad impresa y audiovisual, creación de la primera tienda, conformación del equipo de ciclismo y encuentros con empresarios.

\subsubsection{El crecimiento y evolución de la marca país Colombia es pasión}

En la primera reunión del 2007, el Consejo Asesor decidió la contratación de un consultor externo experto en planeación estratégica, para buscar la alineación de las distintas propuestas estratégicas y así facilitar el proceso de planeación del proyecto, definiendo los pilares estratégicos y el diseño de las acciones prioritarias para 2007.

Como actividades, propuso continuar con la estrategia de marca país con la intención de llegar a todos los colombianos con los valores principales identificados en Colombia es pasión, y a mercados internacionales principalmente en los mercados de Estados Unidos, 


\section{Capítulo 3. La marca país de Colombia}

España, Brasil, Chile y México, prioritarios para Proexport Colombia en lo referente a turismo e inversión (Proexport Colombia, 2008).

En la reunión del Consejo Asesor se realizó una simulación de venta de la licencia de Colombia es pasión y se invitó a visitar la tienda de la marca país, que sería abierta al público en el 2007 (Proexport Colombia, 2008). En esta se discutieron algunos temas de las gestiones realizadas anteriormente:

a. La imagen país dentro de las acciones de gobierno no tuvo respuesta positiva en cuanto a la inclusión del programa en el Plan de Desarrollo, cuestión que no sería tratada durante los próximos cuatro años.

b. Quinientas emisoras comunitarias de todo el país habían accedido a la inclusión de cuñas y una parrilla de contenido en sus programas, a fin de lograr sensibilización de los ciudadanos de las distintas regiones.

c. Se planteó la posibilidad de una estrategia de articulación con la Cancillería, proveyendo a los embajadores o cónsules con maletas que incluyeran videos, carpetas informativas, un pendón y material ilustrativo. Esto sería de utilidad para que los embajadores pudieran tener elementos de la imagen país cada vez que tuvieran una intervención pública.

d. Se fijó como meta para el año la invitación a Colombia de aproximadamente 16 periodistas extranjeros.

e. Se acordó continuar con la estrategia de free press, que estaba dando resultados positivos.

Un hecho importante se plasmó en junio de 2007, cuando se inauguró la tienda de Colombia es pasión y luego de 14 días de inaugurada, se calculó un flujo de 280 personas que ingresaron con intenciones de comprar.

El monto vendido durante ese periodo fue de USD\$20.700. En este sentido, se desarrolló una segunda etapa, con la instalación de carritos de Colombia es pasión en el aeropuerto de Bogotá. Además, se deberían de analizar las posibilidades de los productos de Colombia es pasión: franquicia, tiendas propias, puntos de venta, almacenes en todo el país, etc. 


\section{Capítulo 3. La marca país de Colombia}

A partir de esto, lanzaron 750 referencias y 290 productos de material de merchandising. En lo que corresponde a la estrategia internacional, se planteó la posibilidad de estar presentes en las 25 ciudades de Estados Unidos, donde el Gobierno colombiano haría cabildeo en relación con el TLC.

Para Mauricio Rodríguez (2012), embajador de Colombia en Inglaterra: “Colombia, hoy en día, tiene ante la comunidad internacional un mensaje, tiene una marca, tiene un posicionamiento que por supuesto, no es solamente producto de Colombia es pasión, es producto de muchas cosas; pero Colombia es pasión ha hecho una labor sobresaliente".

En su momento se mostró cierta preocupación por los fondos del programa. Era importante contar con mejores recursos por parte del Gobierno, pues poco a poco se podían ir agotando las empresas que estaban dispuestas a ayudar al país.

Empresas como Gatorade, Sofasa, Tigo, Nestlé, Bayana, entre otras, eran potenciales socios, pero a partir de las visitas realizadas, excepto Gatorade y Sofasa, las demás ya habían dado respuesta negativa. El objetivo principal planteado fue la autonomía presupuestal de Colombia es pasión (Proexport Colombia, 2008). De las cinco grandes empresas que dieron los mayores aportes en la fase introductoria de la marca, sólo se mantuvo Bancolombia.

Respecto a los contratos, solo 14 empresas con un ingreso estimado de USD \$1.663.000 renovaron la licencia. Esta situación generó discusiones internas en el Consejo Asesor sobre los comentarios realizados por esas empresas a algunos de los miembros del Consejo.

La discusión que se dio fue por el concepto que implica Colombia es pasión para las empresas: si es simplemente un aporte solidario al programa, una estrategia de marketing o una estrategia de branding. En ese mismo momento también se presentó un monto negativo de USD\$666.000, que lo estaba financiando Fiducoldex (Proexport Colombia, 2007).

Los ingresos del 2007 habían sido por un valor de USD\$1.244.576, producidos por 65 empresas, de los cuales resultaba que sólo tres empresas: Carrefour (canje), Bancolombia y Aerovías del Continente Americano S.A. (Avianca), registraban compras por USD\$585.260, equivalentes al 47\% de los ingresos.

En el periodo 2005-2007, un grupo de 211 empresas participaron del proyecto, con ingresos totales de USD\$4.782.408, donde 12 empresas —Bancolombia, Caracol (canje), 


\section{Capítulo 3. La marca país de Colombia}

Compañía Nacional de Chocolates 5. A., Empresas Públicas de Medellín 5. A. E. S. P. (EPM), Grupo Aval Acciones y Valores, Aerovías del Continente Americano S. A. (Avianca), Energía Y \& R (Telecom), Postobón 5. A., Productora Tabacalera de Colombia S. A. (Protabaco), Autosnack (canje), Almacenes Éxito y Comunicación Celular Comcelsignificaron el 55,7\% (USD\$2.667.514).

En la Figura 41 se puede observar cómo el comportamiento de las ventas de la licencia del 2007 es similar al del 2005. El 48,6\% de las ventas totales de la licencia de marca país corresponden a cifras superiores a 200 mil dólares.

Un elemento importante es la vinculación comercial de grandes superficies, como es el caso de Carrefour, que utilizó la marca país para promocionar sus puntos de ventas y generar un sentido de pertenencia de sus empleados con Colombia. Así lo afirmó Lucelly Mora (2008), gerente financiera de Colombia es pasión: "En Carrefour se puede observar a todos los trabajadores con el tema del corazón”.

Figura 41. Comparativo de la participación de las ventas totales 2005, 2006 y 2007

\begin{tabular}{|c|c|c|}
\hline \multirow{3}{*}{ Más de 200 mil dólares } & \multicolumn{2}{|c|}{$48,6 \%$} \\
\hline & $\begin{array}{l}12,3 \% \\
\end{array}$ & \\
\hline & $0,0 \%$ & \\
\hline De 101 a 150 mil dólares & $18,9 \%$ & 2007 \\
\hline & & 2006 \\
\hline De 51 a 100 mil dólares & $\begin{array}{cc}19,9 \% \\
12,2 \%\end{array}$ & 2005 \\
\hline De 5 a 50 mil dólares & $\begin{array}{l}15,2 \% \\
14,1 \%\end{array}$ & \\
\hline Menor a USD $\$ 5.000$ & $\begin{aligned} & 5,1 \% \\
& 3,8 \% \\
& 0,6 \%\end{aligned}$ & \\
\hline
\end{tabular}

Fuente: Adaptado de Proexport Colombia (2008).

Para el 2008 la organización Colombia es pasión fue liderada por una tercera dirección en la gerencia general de Imagen País de Proexport. La nueva dirección tenía como 


\section{Capítulo 3. La marca país de Colombia}

prioridad seguir con las estrategias propuestas por la anterior directora, además de enfocar sus esfuerzos en desarrollar actividades de inclusión empresarial y sinergia con medios de comunicación dentro del programa de imagen país.

El principal propósito de la dirección era ampliar las actividades de divulgación de la marca en los mercados internacionales, así lo menciona María Claudia Lacouture (2008), directora de Imagen País: “La marca es el vínculo que conecta a los colombianos, ahora hay que generar identidad con el colombiano a través de sin común denominador: ¿cómo se refleja la pasión en el colombiano?”.

Frente a las circunstancias de una marca país joven y que se encontraba perdiendo credibilidad, la directora de la organización tenía el reto de consolidar una marca y masificarla aún más porque en sus inicios por las direcciones de entonces se había focalizado en segmentos de altos ingresos. De acuerdo con Lacouture (2008): “La marca país Colombia es pasión es una estrategia de Estado, no de Gobierno. Por ahora, el reto principal es fortalecer la imagen de un país con un enfoque más de mercadeo, en lugar de ventas; evitar la sectorización exclusividad de la marca, y buscar sostenibilidad en el la plato, independientemente del gobierno de turno".

En cuanto a la estructura organizacional de Colombia es pasión al momento contaban con un área de mercadeo, administrativa, comercial, de comunicaciones, de capacitación y de divulgación (Echeverri, 2009b).

El presupuesto de la primera marca país estaba compuesto por dos aportes principales: un aporte que hacen las empresas públicas y uno de las empresas privadas después de las ventas, en una relación 30/70. Proexport Colombia fue aumentando su aporte a la marca país hasta el año 2011. En el 2006 dio un aporte de 1,2 millones de dólares, el año 2007 de 1,8 millones de dólares, y para el 2008 de 2,15 millones de dólares.

Para el año 2009, Colombia recibió recursos por un valor de 6,8 millones de dólares de los cuales, el 70\% son aportes de Proexport Colombia (Proexport Colombia, 2010a). Las ventas de licencias de uso de marca al sector privado descendieron como se puede observar en la Figura 42:

Figura 42. Ventas totales de licencias de uso de marca país Colombia es pasión al sector privado 


\section{Capítulo 3. La marca país de Colombia}

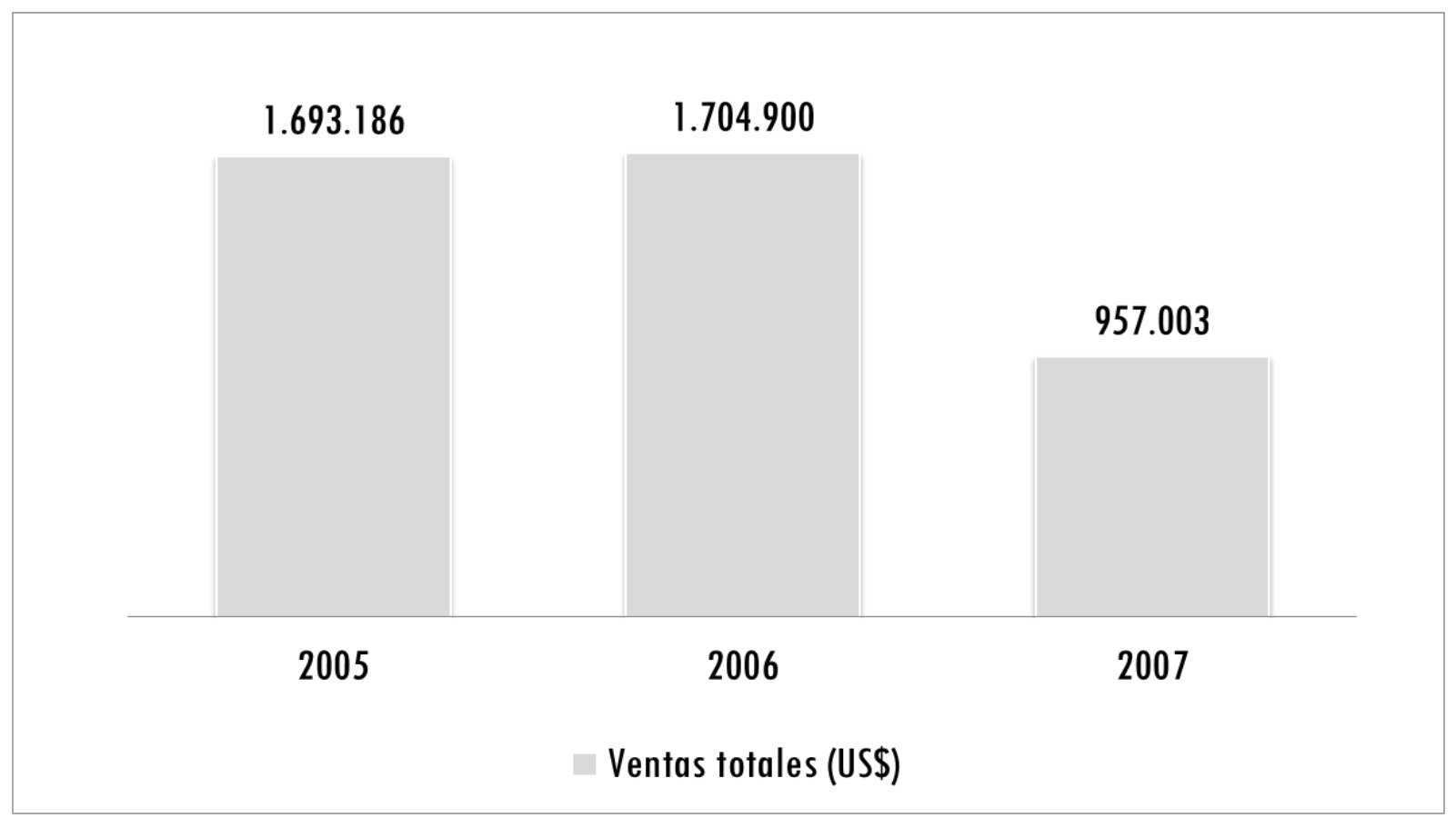

Fuente: Adaptado de Proexport Colombia (2008).

Para Lacouture (2008): “La marca país Colombia es pasión se ha convertido en un modelo a imitar. Países como Perú y Paraguay han invitado en repetidas ocasiones al equipo de marca país para que apoyen y asesoren el diseño y construcción de sus marcas territoriales”. El diseño de la nueva estrategia para 2008 incluía:

a. Fortalecer la imagen y posicionar la marca con el propósito de generar sentido de pertenencia de los colombianos.

b. Lograr que los colombianos y el mundo sepan que el motor que los impulsa y que llevan adentro es la pasión, que el símbolo de Colombia es pasión representa orgullo, nacionalismo, identidad y afecto. 


\section{Capítulo 3. La marca país de Colombia}

Los pilares sobre los cuales se planteaba la estrategia eran: a) la masificación, que los colombianos entiendan y actúen acorde al significado de la marca, en proyectos puntuales, como capacitación, comunicación, mercadeo y la parte internacional, y b) auto sostenibilidad, mediante el financiamiento del programa con proyectos en el área comercial y el desarrollo de merchandising. El presupuesto del 2008 estaba conformado por gastos de USD $\$ 2.170 .000$ e ingresos esperados por USD\$ 3.562.000.

En el estudio de mercados realizado por la empresa Datexco Company y presentada al Consejo Asesor en el 2008, se destacaron los siguientes resultados (ver Cuadro 32). Se puede observar que Juan Valdez era la marca por excelencia que mayor representatividad tiene para los colombianos (Datexco Company S.A, 2008). En el estudio se identificó que el $60 \%$ de los encuestados si han escuchado sobre la marca país Colombia es pasión, y la asocian con una campaña publicitaria de Proexport Colombia.

\section{Cuadro 32. Top of mind de las marcas nacionales - Año 2008}

\begin{tabular}{|l|c|c|c|}
\hline \multicolumn{1}{|c|}{ Marca } & Top of mind (\%) & Otras menciones (\%) & Mención inducida (\%) \\
\hline Juan Valdez & 35,1 & 8,8 & 25,3 \\
\hline Cerveza Águila & 13,3 & 13,3 & 6,5 \\
\hline Postobón & 10,5 & 16,3 & 14 \\
\hline Éxito & 9,5 & 13,5 & 10 \\
\hline Bavaria & 8 & 10,8 & 12,5 \\
\hline Colombiana & 7,8 & 10,3 & 9,8 \\
\hline Colombia es Pasión & 4,5 & 6,3 & 7,5 \\
\hline Alpina & 1,8 & 5,3 & 1,5 \\
\hline Crepes and Waffles & 1 & 1,3 & 0 \\
\hline Avianca & 0,5 & 0,3 & \\
\hline
\end{tabular}

Fuente: Adaptado de Datexto Company (2008).

En el 2008, la firma consultora FutureBrand incluyó a Colombia en el Country Brand Index, en un capítulo sobre países del momento. Se veía como un país emergente porque tiene una esencia única que al comunicarla atrae la atención (ver Figura 43). 


\section{Capítulo 3. La marca país de Colombia}

Figura 43. Países del momento - Año 2008

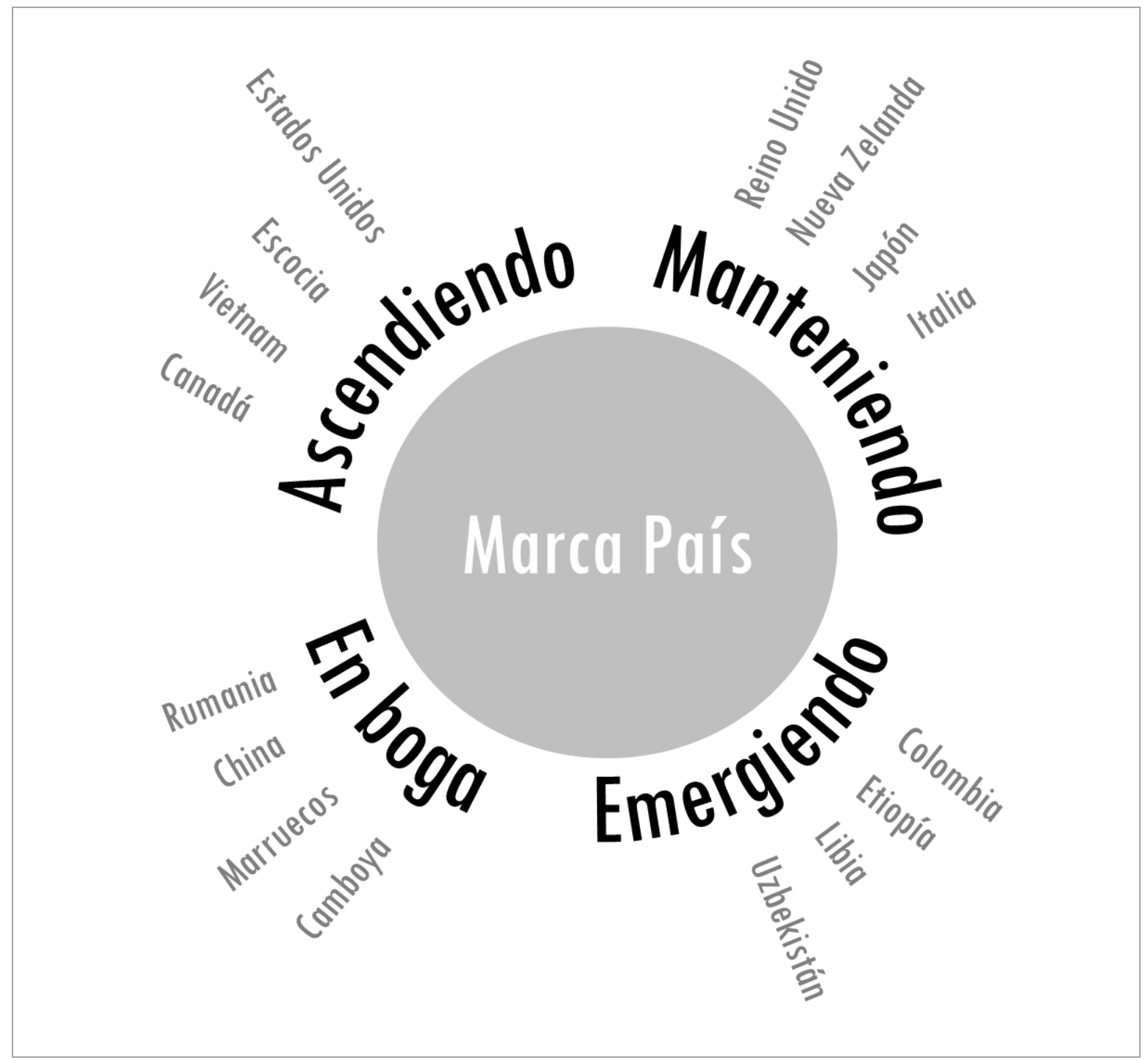

Fuente: Adaptado de FutureBrand (2008).

En el Ranking CBI 2009, Colombia aparece en la posición \#14 entre 17 países de la región (FutureBrand, 2009). Una posición poco alentadora considerando que comparado con otros países del continente americano llevaba cuatros de trayectoria en el desarrollo de una marca país.

Durante el 2010, la estrategia de imagen país redefinió su visión y misión (Proexport Colombia, 2010a): 


\section{Capítulo 3. La marca país de Colombia}

a. Visión de imagen país: Colombia es pasión será un referente mundial, ubicándose en los primeros lugares de los índices más representativos del mercadeo territorial; gracias al posicionamiento de Colombia como país de oportunidades en inversión, un destino de clase mundial, generador de productos y servicios de calidad.

b. Misión de imagen país: Colombia es pasión es una estrategia de competitividad, que busca posicionar a Colombia como un país de oportunidades en inversión, un destino de clase mundial y un generador de productos y servicios de calidad, a través de la generación de la opinión positiva sobre el país, sensibilización y transformación

cultural, del fortalecimiento de la marca y convirtiendo la estrategia de imagen país tangible y auto en el tiempo.

Los objetivos se centraron en dos proyectos: masificación y auto sostenibilidad. Cada uno de estos incorporó un conjunto de tácticas específicas como la promoción de la marca país en medios tradicionales con los cuales se han logrado acuerdos significativos para descuentos en pautas publicitarias (Proexport Colombia, 2010a).

Según Arango (2009), Vicepresidente de la Agencia de Publicidad Sancho/BBDO: "El principal problema es la falta de presupuesto. No tienen dinero disponible para publicidad, entonces hacen lo que pueden".

A nivel interno, es se evidenció una alta la dependencia de la imagen del programa con la administración del Presidente Álvaro Uribe. Esta situación fue favorable por el alto grado de imagen positiva del presidente, pero también fue negativa al momento de cambiar la administración en el año 2010. 


\section{Capítulo 3. La marca país de Colombia}

\subsection{Una nueva narrativa en imagen país: Marca país Colombia}

Finalizando el periodo presidencial de Álvaro Uribe, se generó expectativas sobre la continuidad de la estrategia de marca país lanzada en el 2005. Empresarios, académicos, miembros del Consejo, publicistas y aquellas personas que estuvieron directa o indirectamente relacionadas a Colombia es pasión coincidieron en que el año 2012 sería un momento de decisión. Según León Trujillo, Gerente Comercial y de Marketing de la Marca País en Colombia (2012) la marca Colombia es pasión desaparecería gradualmente.

En el año 2010, asume la presidencia Juan Manuel Santos discípulo y ex Ministro de Defensa del Gobierno de Uribe. Ese mismo año renuncia la tercera directora de Colombia es pasión, y la marca país se sumerge en un estado incertidumbre por el cambio de gobierno. En el 2010, Colombia mantuvo su posición en el Ranking CBI de las Américas. Sin embargo mejoró dos posiciones en ranking general, ocupando la posición \#85 entre un total de 110 países (FutureBrand, 2010).

Colombia se ha caracterizado por ser un país donde los extranjeros tienen percepciones polarizadas. Entre la riqueza de sus recursos naturales, su cultura cafetera y la gastronomía figuran también una imagen país negativa asociada al narcotráfico y la inseguridad (Echeverri et al., 2013b).

Según el Ranking CBI 2011, Colombia permanece en la posición \#14 en el índice regional, descendiendo cuatro posiciones en el general (lugar \#89). Ese año, Colombia destinó 15 millones de dólares en turismo, un valor muy inferior a lo que invirtió España (cerca de 200 millones) y Argentina (aproximadamente 100 millones) ese mismo periodo (Diario La República, 2012). El 2011 fue un año de transición. La primera marca país cerró su ciclo de vida, después de seis años de funcionamiento para darle paso a la segunda marca país. En un entorno de contrastes, se inició una nueva etapa en la formulación de una estrategia de marca país en septiembre de 2011. 


\section{Capítulo 3. La marca país de Colombia}

El Gobierno Santos autorizó la creación de la organización Marca País, como entidad independiente de Proexport Colombia y vinculada al Ministerio de Comercio, Industria y Turismo y a la Alta Consejería Presidencial para las Comunicaciones (Garbrecht, 2013).

Hasta el 2010, la marca país Colombia es pasión dependía de la vicepresidencia de Imagen País, una división adicional de Proexport Colombia. Con la Marca País Colombia, esta división adquiere autonomía, siguiendo los lineamientos presidenciales para dedicarse a profundizar en la estrategia de capitalizar la reputación del país en mercados internacionales (Garbrecht, 2013). Proexport Colombia y Marca País son un patrimonio autónomo administrado por FIDUCOLDEX ${ }^{10}$. Esta entidad de economía mixta indirecta se encuentra vinculada al Ministerio de Comercio, Industria y Turismo de Colombia, y fue creada para prestar servicios fiduciarios con énfasis en comercio exterior (Ministerio de Comercio, Industria y Turismo República de Colombia, 2008).

En la Figura 44 se puede observar la estructura de la cual depende la marca país:

Figura 44. Estructura de vinculación administrativa de la Marca País Colombia

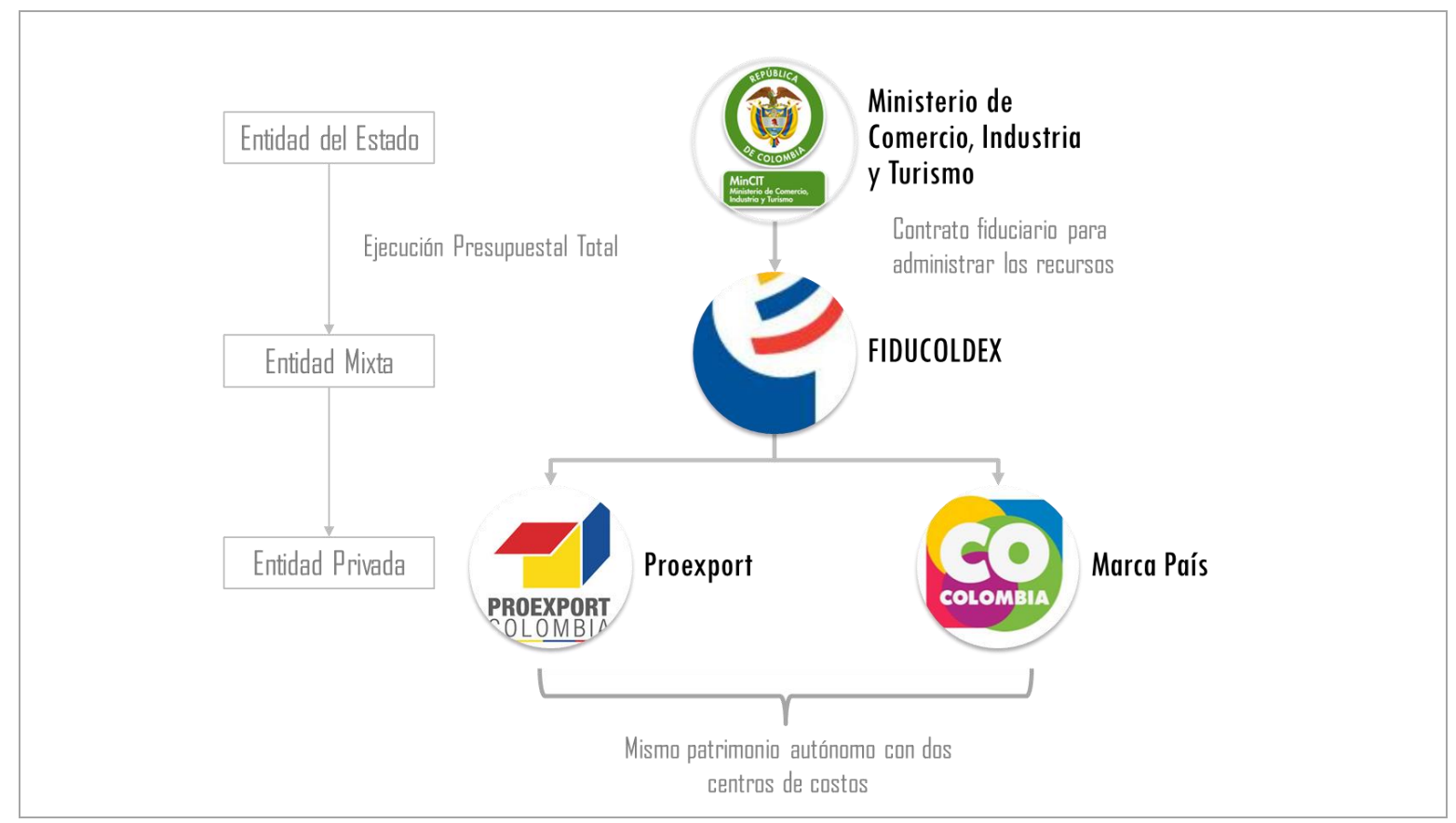

Fuente: Adaptado de Marca País Colombia (2013).

${ }^{10}$ Fiduciaria Colombiana de Comercio Exterior. 


\section{Capítulo 3. La marca país de Colombia}

De acuerdo con lo anterior, la Dirección de Marca País debe reportar a una junta directiva conformada por el Ministro de Comercio, quien a su vez encabeza la presidencia de la junta, y miembros representantes de Proexport Colombia, ANDI y FENALCO.

La Dirección de Marca País, en cabeza de Claudia Hoyos (2013), se propuso en sus inicios crear una marca sombrilla, para que agrupara no solo el turismo sino lo cultural, deportivo, económico, relaciones diplomáticas, entre otros.

En el proceso de planeación de la nueva estrategia de marca país, se decidió que la esencia de la futura marca debería desvincularse a la imagen del corazón que había proyectado Colombia es pasión. El estudio y proposición de lo que sería la segunda marca país duró cerca de cuatro meses, proceso que generalmente dura dos años (Hoyos, 013).

Se destinó un presupuesto de 3.7 millones de dólares para el diseño y desarrollo de la nueva imagen. Se abrió entonces una convocatoria que ayudara a vincular una agencia de publicidad de carácter internacional, para que ofreciera respaldo frente a los desafíos que había con la marca proponente. En el logro de este propósito, se unieron temporalmente dos agencias: WPP Colombia (representada por REP Grey, JWT y MEC) y Omnicom Solutions (representada por Sancho BBDO y el grupo DDB). Esta última se apoyó en su empresa de branding conocida como Señor López para el desarrollo de la marca país.

En palabras de Claudia Hoyos (2013), la directora general de la segunda marca país: "Colombia es un país que se caracteriza por su megadiversidad y precisamente eso fue lo que quisimos plasmar en la expresión visual de la nueva marca país Colombia. Para complementarlo y reforzarlo utilizamos un lenguaje cálido y progresista basado en cuatro principios fundamentales: Flexible, Afectivo, Colorido, y Fáctico”.

El eje central fue entonces la megadiversidad, la cual no solo tenía un significado asociado a la fauna y flora, sino megadiversidad cultural, económica, geográfica y productiva (Trujillo, 2012a). Colombia estuvo asociada por más de 30 años con la marca comercial Juan Valdés, de la Federación Nacional de Cafeteros (Reyes, 2013). 


\section{Capítulo 3. La marca país de Colombia}

Una de las grandes diferencias con la marca país anterior, es que la nueva marca está soportada por una Política Comercial definida por el Gobierno Santos (Trujillo, 2012a). Según Hoyos (2013): “Colombia ha dejado de ser un país interrogante, a convertirse en un país solución, que le está dando respuesta al mundo".

Para José Pablo Arango, el ahora encargado de la marca país, ante la renuncia de Hoyos en diciembre de 2013: La marca país es una iniciativa de Estado que pretende trabajar para mejorar, orientar y construir reputación de país tanto interna como externa".

Cuando se iniciaron labores en la organización de Marca País, permanecía en el imaginario colectivo la marca Colombia es pasión, y la campaña turística El riesgo es que te quieras quedar (Trujillo, 2012a). Trujillo señala que en el exterior la marca país Colombia es pasión era desconocida, situación muy diferente en el mercado doméstico.

No hubo transición de una marca a otra. La iniciativa de la segunda marca país partió de precisar que la marca país es Colombia, sin apellidos, sin eslogan, para darle más libertad a la marca.

Se hizo el ejercicio de identificar el código genético de la marca país. Y como resultado se encontró que era la megadiversidad. Para León Trujillo (2013), ex gerente de marketing de la marca país, y ahora consultor senior de FutureBrand Colombia: "El proceso creativo para identificar el ADN de la marca de Colombia fue auténtico".

En el proceso de construcción de la estrategia de marca país se definieron cuatro ejes: la cultura, el turismo, la inversión extranjera y las exportaciones. Para Hoyos (2013) pensar en el símbolo que representaría la imagen de la marca país no fue una tarea sencilla.

Colombia es un país enriquecido de símbolos: el sombrero vueltiao ${ }^{11}$, el café, la palma de cera, la orquídea, el cóndor, las montañas, entre otros. Sin embargo, era claro que un símbolo por sí solo no integraba una identidad única del país y que fuera coherente con los ejes planteados (Trujillo, 2012a).

${ }^{11}$ Es un sombrero típico de los departamentos de Córdoba, Sucre y Bolívar, y una de las principales piezas de artesanía de Colombia. 


\section{Capítulo 3. La marca país de Colombia}

Como símbolo per se, fue considerado como limitado para construir la imagen del país. La respuesta estaba en una re-arquitectura de la estrategia. Para desarrollarla, se evaluaron los alcances del proyecto de Colombia es pasión y se cotejaron con los nuevos objetivos trazados por Marca País.

El esquema original de Colombia es pasión como mensaje sombrilla se concibió de la siguiente manera:

\section{Figura 45. Colombia es Pasión como mensaje sombrilla}

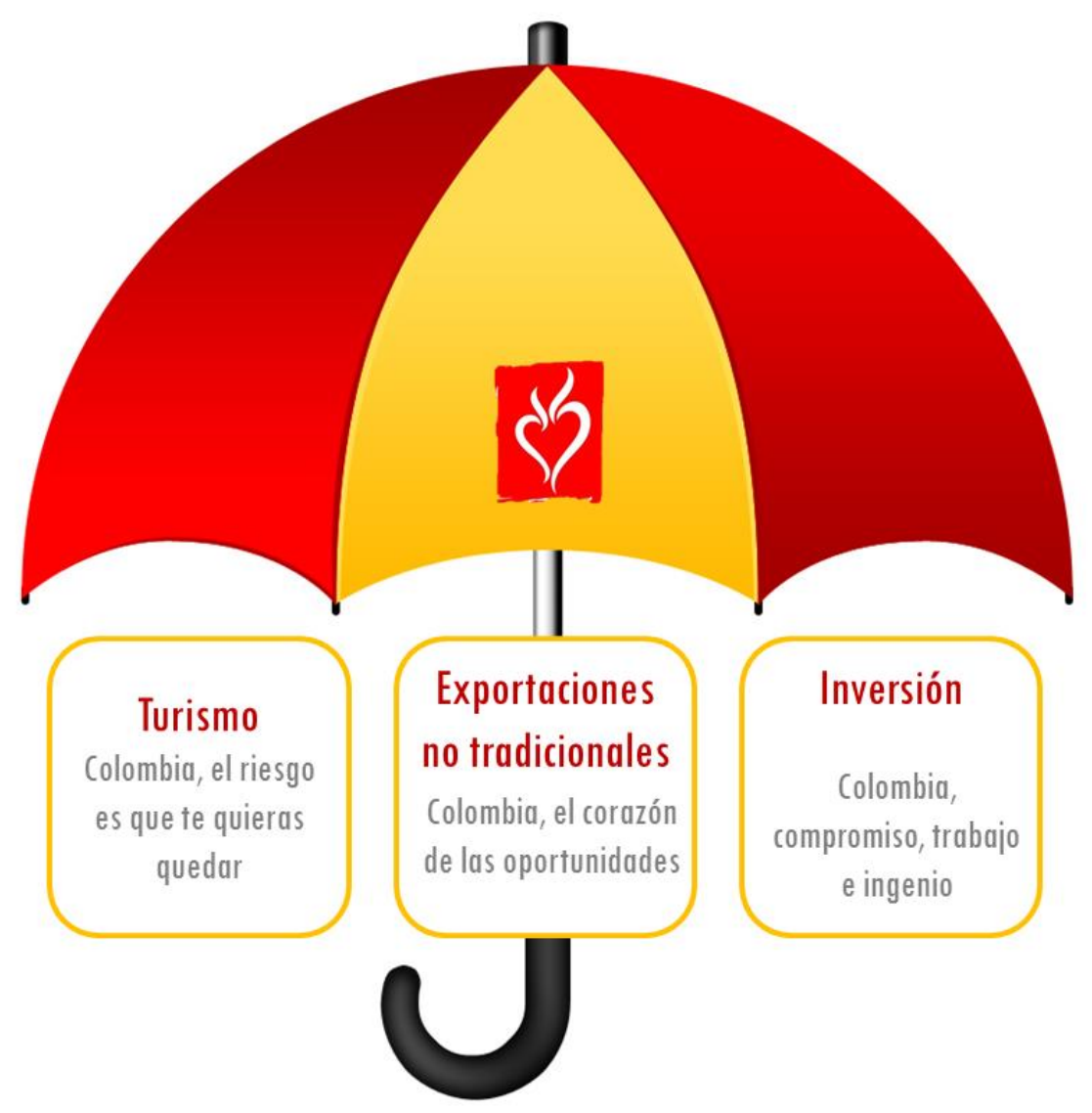

Fuente: Adaptado de Marca País Colombia (2013). 


\section{Capítulo 3. La marca país de Colombia}

Si bien como estrategia fue un paso evolutivo importante en el manejo de la imagen del país, su fortaleza siempre radicó en atender los objetivos de fomentar la colombianidad entre la población en el mercado doméstico para luego trabajar la confianza y el conocimiento sobre el país en el exterior.

Después de la etapa de Colombia es pasión, el reto fue es diseñar una estrategia de mercadeo territorial que cubriría las necesidades integrales de promoción para la nación, más allá del turismo y las características de la gente colombiana.

Es así como se replanteó una estrategia de marketing territorial para el país partiendo con la definición de los objetivos basada en: divulgar en el exterior los atributos que tiene Colombia en distintos sectores, mostrando sus ventajas comparativas frente a otros países geográficamente similares, y mejorar la percepción para que coincida con su realidad, generando un mayor conocimiento y confianza.

Se redefinieron propósitos para alcanzar más y mejores oportunidades reflejadas en:

a. La atracción de la inversión extranjera

b. El fomento del turismo

c. El incremento de las exportaciones

d. La difusión de la identidad y cultura

e. El reconocimiento del privilegiado capital medioambiental

f. La celebración del capital humano competente

g. La reafirmación de una institucionalidad seria y moderna

La magnitud que arroja el redimensionamiento de la promoción territorial y las especificidades que debe atender, requirió un modelo más ambicioso, incluyente, transversal e integrado.

Los atributos del país deben sentar las bases de la oferta para satisfacer la demanda internacional en varios frentes. 


\section{Capítulo 3. La marca país de Colombia}

Es así como, bajo la óptica del marketing internacional (entendido como el proceso de planeación y realización de transacciones a través de las fronteras nacionales con el fin de crear intercambios que satisfagan los objetivos de los individuos y las organizaciones) y del marketing territorial (entendido como el proceso mediante el cual se establecen estrategias en busca de generar posicionamiento, a nivel interno, fortaleciendo la identidad de los habitantes del territorio, y a nivel externo, atrayendo inversionistas, turistas y visitantes a la región), se llegó a la siguiente propuesta:

Figura 46. Modelo de mercadeo territorial

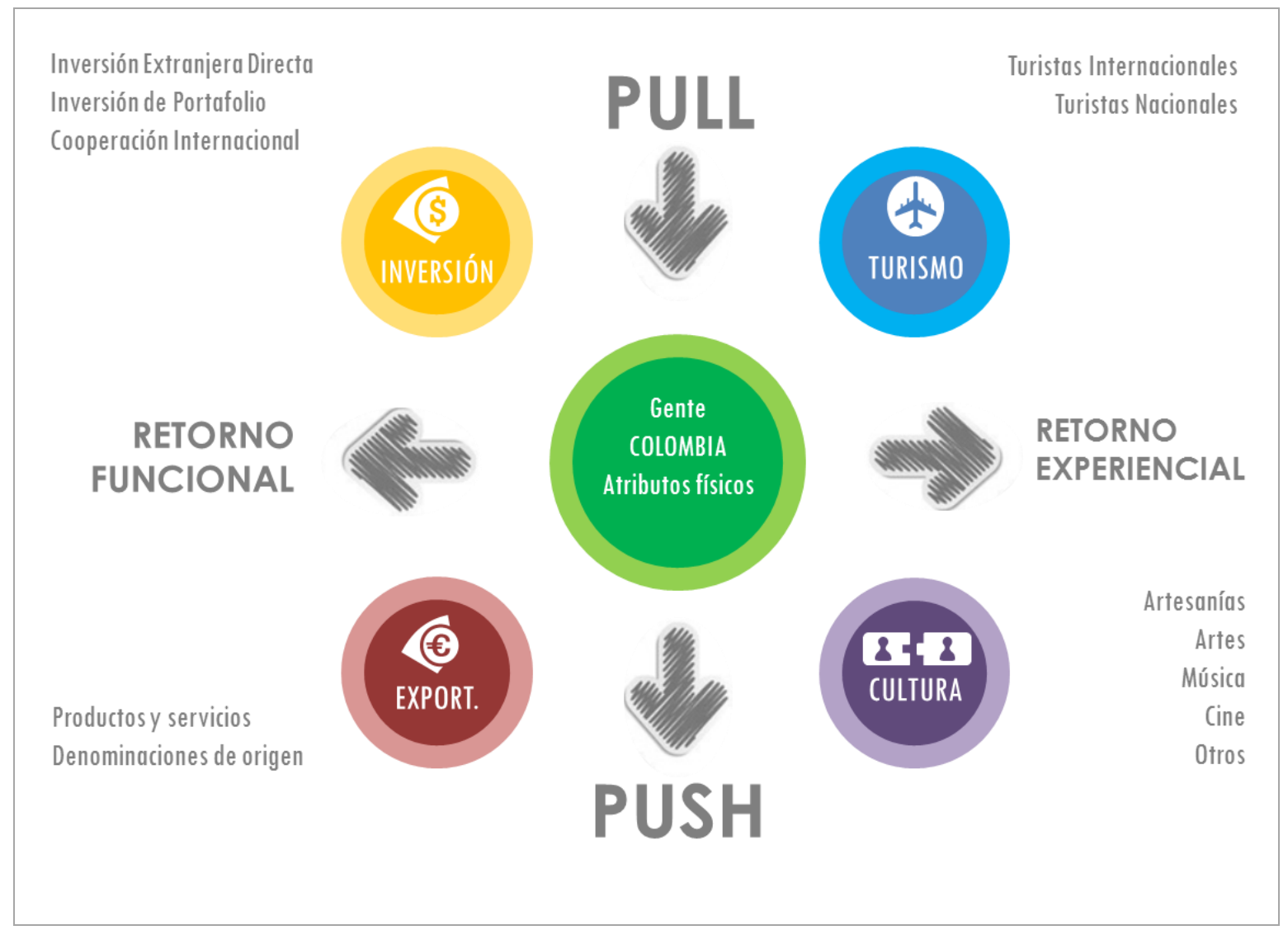

Fuente: Adaptado de Trujillo (2012). 


\section{Capítulo 3. La marca país de Colombia}

El modelo se explica con los siguientes elementos:

- Centro: Está Colombia como una nación/territorio con atributos para atender las necesidades de los demás países del mundo.

- Eje X: Se basa en los tipos de retorno que puede obtener un extranjero al relacionarse con la nación/territorio. En el lado izquierdo hay un Retorno Funcional (o transacción económica) y en el lado derecho está un Retorno Experiencial (o transacción vivencial).

- Eje Y: Describe en la parte superior una acción de Pull (o de halar interés hacia la nación/territorio) y en la parte inferior una acción de Push (o de empujar la oferta de la nación/territorio hacia los demás países).

Tomando en cuenta lo anterior se describen los campos de acción de la siguiente manera.

- Cuadrante superior izquierdo: Inversión, lo que hala el país de tal manera que tanto éste como los extranjeros obtengan un retorno funcional. Incluye: IED (Inversión Extranjera Directa), inversión de portafolio y cooperación internacional.

- Cuadrante superior derecho: Turismo, en la acción de atraer a los visitantes para que éstos vivan experiencias inolvidables en Colombia. Incluye: viajeros de negocios y/o placer tanto nacionales y extranjeros.

- Cuadrante inferior izquierdo: Exportaciones, refiriéndose a la promoción de los bienes y servicios colombianos en el exterior. Incluye: Tradicionales, no tradicionales y de todos los sectores de la economía.

- Cuadrante inferior derecho: Cultura, las intervenciones, creaciones y acciones desplegadas por el talento colombiano. Incluye: deportes, ferias y festividades, música, audiovisuales, artes plásticas y escénicas, artesanías, etc. 


\section{Capítulo 3. La marca país de Colombia}

El nuevo modelo buscaba catapultar las cualidades del país para jugar ante un nuevo orden mundial caracterizado por el colapso de las fronteras comerciales y las comunicaciones ubicuas. Aplicándolo en los procesos de marketing territorial y en lo pertinente a las herramientas que ofrece la comunicación de una marcas país, se acentúa naturalmente la nación/territorio como destino turístico y además se despliegan los demás frentes de atributos que tiene el país con mayor protagonismo y ecuanimidad. Una vez establecida la estrategia, se abordó el proceso definitivo para desarrollar el sistema de marca y logotipo. El logotipo de la Marca País Colombia fue diseñado bajo el concepto de geometría creativa (ver Figura 47). La idea era diseñar una imagen dinámica y flexible que tuviera infinitas aplicaciones para atender las necesidades de comunicar la megadiversidad del país.

Las formas que tiene el logotipo de la marca están asociadas a las regiones y los colores tienen los siguientes significados (Marca País Colombia, 2013):

a. El amarillo representa el sol y los minerales

b. El azul representa la riqueza en ríos y mares

c. El rojo representa el talento, la calidez y la pasión de la gente

d. El violeta evoca la variedad de las flores, especialmente la orquídea, que es símbolo nacional.

e. El verde representa las montañas, valles y llanos

Figura 47. Logotipo de la segunda marca país de Colombia

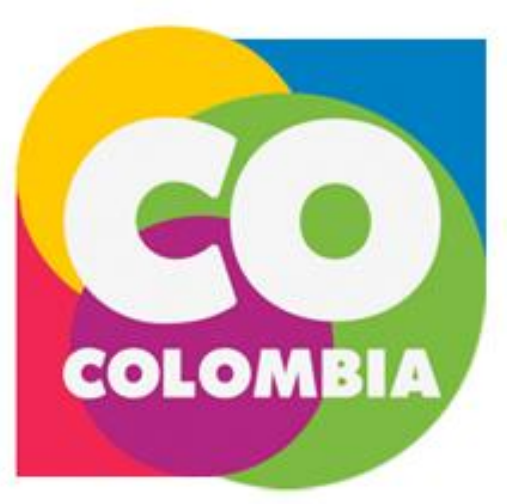

Fuente: Adaptado de Marca País Colombia (2013) 


\section{Capítulo 3. La marca país de Colombia}

Durante el proceso de diseño de la imagen de la marca país, se propuso el eslogan La respuesta es Colombia que acompañaría la campaña promocional. El logotipo fue pensado para que tuviera un ciclo de vida de 10 años, a diferencia de su eslogan que se caracteriza por la temporalidad.

Para la Dirección de Marca País, la imagen país es integral, estaba representada por la megadiversidad. Entendida como la riqueza natural, humana, cultural y ambiental (Marca País Colombia, 2012). Marcelo Arango, VP Planeación Estratégica en Sancho BBDO, consideraba evidente que un país que renace, necesita una imagen que renazca con él (Marca País Colombia, 2012).

Se propuso entonces una marca flexible, que facilitar la creación de potenciadores que se adaptaran a las necesidades que se iban presentando y a solicitud de los grupos de interés.

El logotipo propuesto cumple doble propósito: reflejar la imagen de la nueva marca y derivar potenciadores gráficos que representen sectores productivos, símbolos y regiones como se puede observar en la Figura 48:

Figura 48. Potenciadores gráficos derivados de la marca país Colombia
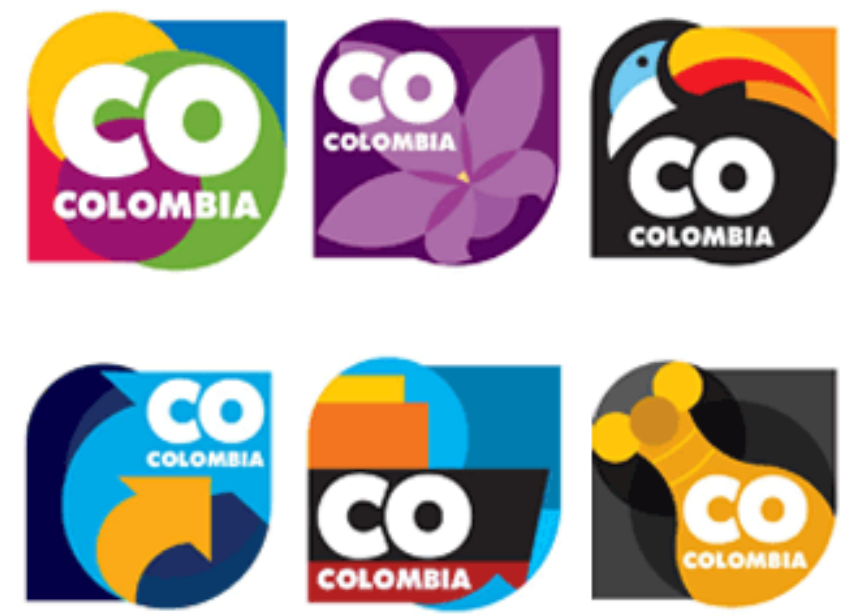

Fuente: Adaptado de Marca País Colombia (2013). 


\section{Capítulo 3. La marca país de Colombia}

Para Trujillo (2013): "El uso de los potenciadores es muy fuerte, es decir, todas las representaciones visuales que se generan exponen la multiplicidad y la diversidad de la marca país".

En el diseño gráfico se incorporó un elemento adicional el $C O$, el cual representa la síntesis de Colombia según el código de la International Standardization Organization ISO 3166-1 alpha-2, establecido en 1974 (Asociación Latinoamericana de Integración, 2002). El mismo código corresponde al dominio de internet asociado a Colombia. Con intencionalidad colateral, este atributo ayuda a que la marca país le apueste al entorno digital (Marca País Colombia, 2013).

Para la ex directora de la Marca País, Claudia Hoyos (2013) este nuevo símbolo no estuvo expuesto a la temporalidad, su misión era acompañar a los gobiernos sim estar adscrito a filosofías políticas de turno. La marca país fue evaluada por 400 turistas y más de 100 empresarios de compañías nacionales y multinacionales y líderes de opinión (Trujillo, 2012a).

El nuevo símbolo alimentó a su vez un sistema de arquitectura de marcas. Tomando en cuenta el carácter comercial de la Marca País, se buscaron denominadores comunes tipográficos para que existiera una relación con otras marcas administradas desde el gobierno basándose en el mismo manejo tipográfico presente en la identidad $C O$.

Es así como la oficina de Marca País realizó un acompañamiento al Departamento Administrativo de la Presidencia de la República para el desarrollo y diseño de la Marca Gobierno (ver Figura 49). 


\section{Capítulo 3. La marca país de Colombia}

Figura 49. Propuestas de logotipo para la Marca Gobierno

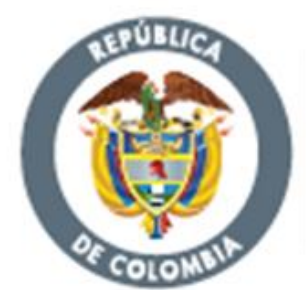

\section{Gobierno de colomila}

\section{Presidencia de la República}

Fuente: Adaptado de Marca País Colombia (2013).

Igualmente Marca País Colombia se unió a Fontur (Fondo de Promoción Turística de Colombia) para desarrollar la nueva identidad de dicha organización (ver Figura 50).

Figura 50. Identidad del Fondo de Promoción Turística de Colombia

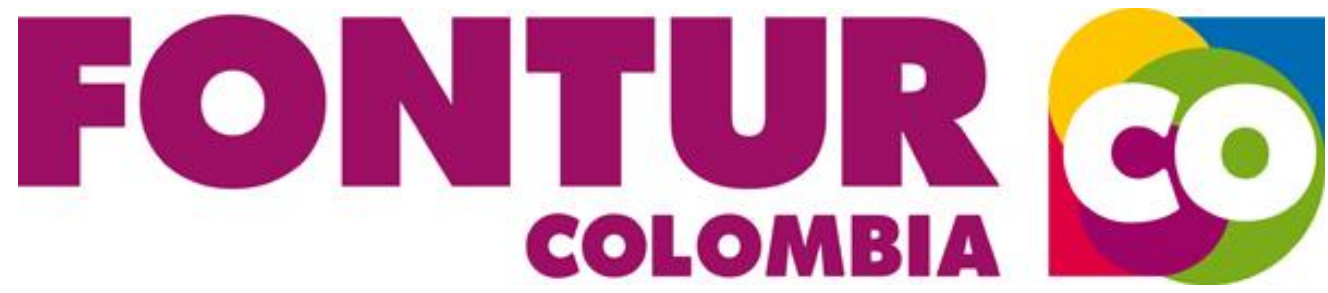

Fuente: Adaptado de Marca País Colombia (2013). 


\section{Capítulo 3. La marca país de Colombia}

La Marca País Colombia se vinculó a la Superintendencia de Industria y Comercio (SIC) para desarrollar el primer Sello de Denominación de Origen Protegida del país.

El objetivo del Sello de Denominación de Origen es resaltar valores colombianos. Su naturaleza jurídica y a su aplicación está restringida a productos agroalimentarios y artesanales con una serie de características únicas provenientes de su vínculo con una zona geográfica nacional (ver Figura 51).

El sello se diseñó para resaltar las calidades particulares ligadas al origen geográfico, tales como tradición, factores naturales y humanos, climatológicos, localización y demás factores que influyen en la calidad específica de los productos, que incluye toda nuestra riqueza natural y cultural.

Figura 51. Identidad del Fondo de Promoción Turística de Colombia

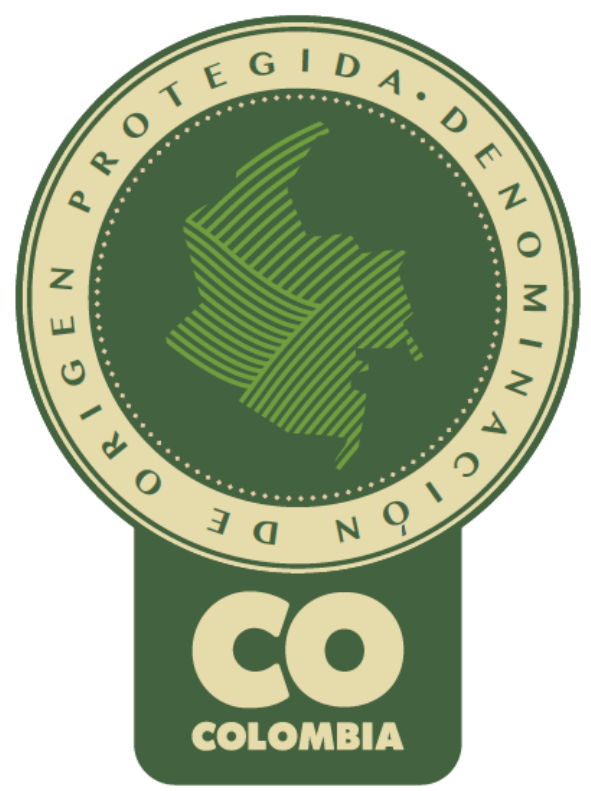

Fuente: Adaptado de Marca País Colombia (2013) 


\section{Capítulo 3. La marca país de Colombia}

Con el sistema de identidad ya establecido, se procedió a desplegar la comunicación de la marca país con una ejecución prevista en dos etapas: doméstica e internacional.

La primera etapa tenía como finalidad cautivar al público nacional a través de medios tradicionales con el apoyo de iniciativas que dieran visibilidad a lo largo y ancho del país. Para tales efectos se planificó un lanzamiento de la identidad evolucionada de marca país. El 7 de septiembre de 2012, se reveló la identidad visual y su campaña se decidió hacerla en el marco del partido de eliminatorias de la Copa Mundo FIFA Brasil 2014, Colombia vs. Uruguay en el Estadio Metropolitano de Barranquilla al norte del país. Una alianza firmada entre la Federación Colombiana de Fútbol y Marca País que permitió tener acceso al certamen donde se develó la nueva identidad visual y se realizaron actividades con las tribunas.

A través del cobranding y la inversión propia, la Marca País alcanzó 1.6 millones de dólares, pagando solo $\$ 778.191 .027$ con sus recursos, lo que representó un ahorro del $77 \%$ del valor total (Trujillo, 2013).

Después del lanzamiento se pasó a una etapa de sostenimiento a nivel nacional que implicó alianzas sistemáticas con empresas del sector privado y alianzas con entidades públicas.

Para incentivar el compromiso de las empresas y prescriptores con la marca, se establecieron una tarifas en el uso de la licencia por valores de USD\$1000, USD\$ 2500 y USD\$ 5000 para un periodo de un año dependiendo si eran micro, pequeña, mediana o gran empresa (Hoyos, 2013). Posteriormente se cambió de decisión, y con la finalidad de masificar y consolidar la marca país se determinó que no se cobrarían tarifas por el uso de la marca. Esta accesibilidad al uso de la marca requería de un acompañamiento a quien la solicitara (Hoyos, 2013).

En la fase inicial de la marca se recibieron USD\$ 250 mil por concepto de la venta de la licencia (Garbrecht, 2013). Luego que se determinó no cobrar por el uso de la marca, el Ministerio de Comercio, Industria y Turismo de Colombia, pasó a ser el aportante principal de los ingresos de la marca. Colombia es pasión, en su fase de declive cedió 300 mil dólares a la Marca País Colombia (Garbrecht, 2013). 


\section{Capítulo 3. La marca país de Colombia}

Para Garbrecht (2013), gerente de planeación en Marca País Colombia: “El tema de presupuesto es complejo, dado que se depende de un solo ministerio. Se solicitó un presupuesto para el 2012 cercano a los 18 millones de dólares, y se recibieron solo USD\$ 3 millones de dólares. Se deberían generar inercias con otros organismos o ministerios, dado que es un tema transversal. En otros países, como el caso de México invirtió cerca de 200 millones de dólares, Ecuador invirtió USD\$40 millones, mientras en Colombia la inversión fue de 3 mil dólares. Esta situación es compleja, y hace que la creatividad nuestra se imponga ante restricciones presupuestarias, pero no siempre es la mejor opción”.

Si bien la primera etapa se concentró en un despliegue a nivel nacional, la segunda etapa abordó el escenario internacional.

En la primera etapa, en el lanzamiento, la publicidad no fue asumida por la marca país, sino por empresas como Bavaria, Avianca, Pacific Rubiales, entre otras. La función de la marca país en ese momento fue revisar que las estrategias publicitarias fueran coherentes con la naturaleza y manifiesto de la Marca País Colombia (Garbrecht, 2013). Para el primer año de su lanzamiento, la marca país vinculó 50 empresas de todos los sectores como: FONTUR, Coldeportes, Instituto Caro y Cuervo, para la promoción de Colombia, así como la Federación Nacional de Cafeteros con la marca comercial Juan Valdez, Bavaria, Americana de Colchones, entre otras. Un año después de su lanzamiento, la marca país cuenta con 300 aliados (Arango, 2013). Según Garbrecht (2013): “Conseguir un cliente, explicarle cómo funciona la marca país, no es suficiente para vincularlo. Requerimos de más personas que se encarguen del marketing de la marca, es decir, necesitamos de más presupuesto”.

El presupuesto de la marca país está compuesto por un $80 \%$ de gastos de inversión y un $20 \%$ de gastos de funcionamiento. Para el 2013, el presupuesto fue de 4.3 millones de dólares. Según Hoyos (2013): “Con una marca no mejoras la reputación de un país, tampoco significa lo contrario, pero una marca debe reflejar los buenos momentos que vive el país". 


\section{Capítulo 3. La marca país de Colombia}

La marca país de Colombia tiene un retraso de 10 años en el imaginario colectivo (Hoyos, 2013). Aún para las personas mayores de 50 años, Colombia es el país de la violencia, de la drogadicción, del café y de las esmeraldas. Para Juliana Lora (2013), ejecutiva comercial de la organización de marca país: Colombia se caracterizaba por su mala imagen en el exterior. Se habla de narcotráfico e inseguridad, poco de experiencias positivas. Había una necesidad de reducir la brecha entre percepción y realidad".

Para las personas menores de 50 años y mayores de 30, que reconocen que hay un posicionamiento favorable pero no logra hacer conexiones, como que Shakira, Sofía Vergara, Falcao y el petróleo son de un mismo país (Hoyos, 2013). Y los más jóvenes, nativos de redes sociales, crecieron en un entorno de violencia, tienen percepciones polarizadas influenciadas por los medios. Para Hoyos (2013) Colombia es un país que ha cambiado su composición productiva, antes el 54\% de las exportaciones correspondían al Café, ahora este sector representa el 3\%. Era un país donde no existía la minería y el petróleo, y hoy son el primer renglón en la economía (Hoyos, 2013).

Los destinos elegidos para la promoción de la marca país son Estados Unidos, Reino Unido, Canadá, Corea del Sur, Brasil, Chile, México, Perú, Turquía, la Unión Europea y Suiza (Marca País Colombia, 2013). Adicional a lo mencionado, Colombia está mostrando una vocación en temas culturales. Si bien es un país con violencia e inseguridad, los gobiernos han dedicado esfuerzos por lograr la paz para Colombia (Departamento Nacional de Planeación, 2003).

El éxito de la estrategia de marca país está sujeto al mejoramiento de la infraestructura, al fortalecimiento del sistema educativo regido por estándares internacionales y a la generación de crecimiento económico.

Durante el 2012, ingresaron 1.698.366 extranjeros a Colombia, es decir un 7\% superior al 2011 (Migración Colombia, 2013). Según el Boletín Migratorio, el número de visitantes extranjeros por nacionalidad que ingresaron a Colombia en su mayoría fueron procedentes de Estados Unidos con 325.802 registros de entrada (Migración Colombia, 2013). En la Figura 52 se puede observar los registros de entrada según nacionalidad: 


\section{Capítulo 3. La marca país de Colombia}

Figura 52. Top 10 de visitantes extranjeros que ingresaron a Colombia durante 2012 según nacionalidad

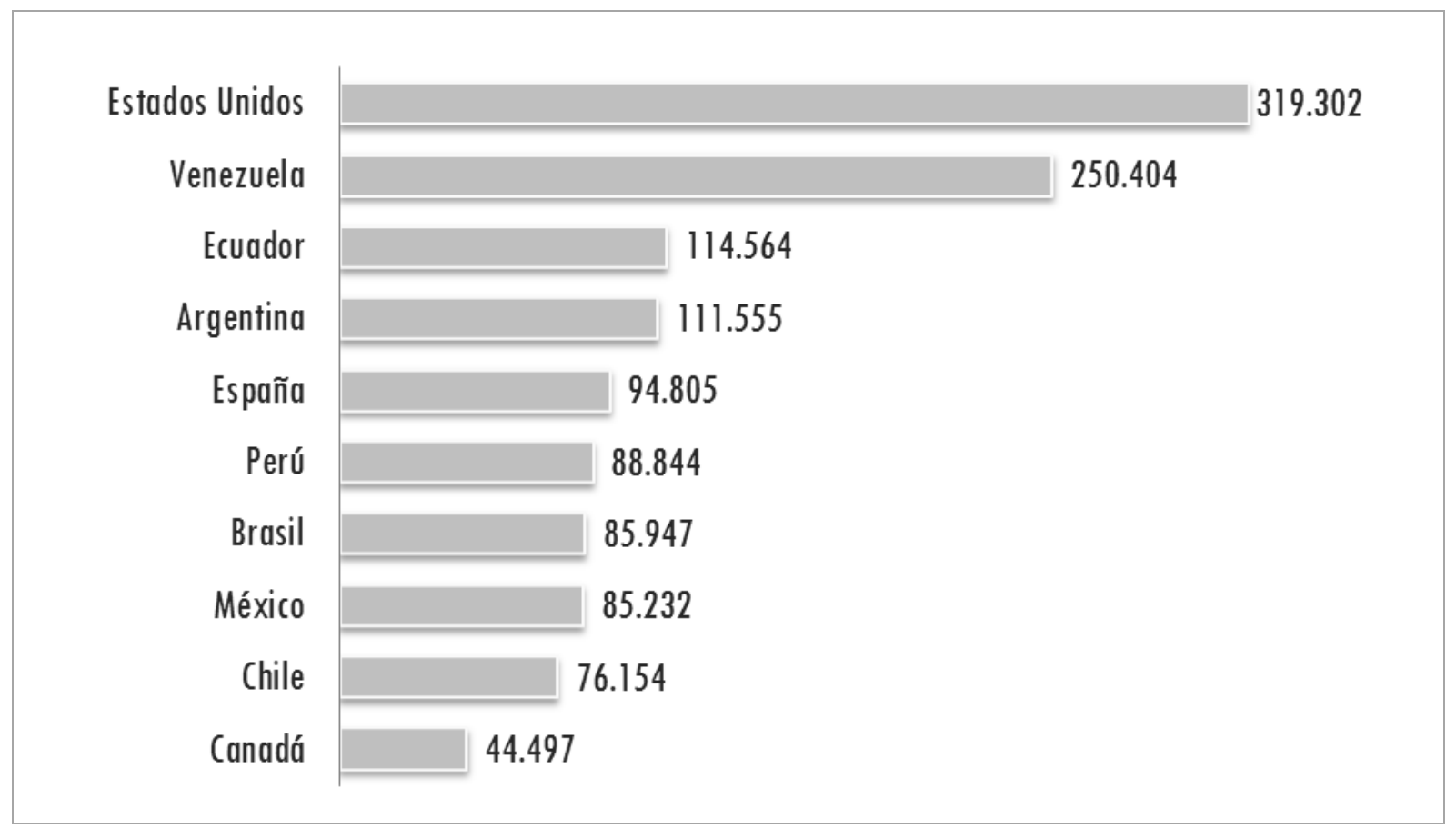

Fuente: Adaptado de Migración Colombia (2013).

No solo en turismo creció el país. En inversión extranjera directa, Colombia tuvo un récord histórico en crecimiento de un 16\%, es decir, se recibieron 15.823 millones de dólares (Diario Portafolio, 2013).

Se espera así mismo, que la inversión en los proyectos de marca país vaya aumentando junto a los resultados de una buena gestión. Colombia presenta una inversión baja en relación a los esfuerzos en este tipo de proyectos promocionales en términos per cápita como se puede observar en el Cuadro 33: 


\section{Capítulo 3. La marca país de Colombia}

Cuadro 33. Comparativo de Inversión en marcas país

\begin{tabular}{|c|c|c|c|c|}
\hline & $\begin{array}{c}\text { INVERSION } \\
\text { ANUAL } \\
\text { APROXIMADA } \\
\text { EN } \\
\text { PROYECTOS } \\
\text { DE MARCA } \\
\text { PAIS }\end{array}$ & $\begin{array}{c}\text { POBLACION } \\
\text { (Fuente CIA } \\
\text { World Factbook } \\
\text { 01/2011) }\end{array}$ & $\begin{array}{l}\text { FONDOS } \\
\text { PUBLICOS vs. } \\
\text { PRIVADOS }\end{array}$ & $\begin{array}{c}\text { INVERSION } \\
\text { PER CAPITA EN } \\
\text { PROYECTOS } \\
\text { DE } \\
\text { MARCA PAIS }\end{array}$ \\
\hline CANADA & $\$ 91.900 .000$ & 34.030 .588 & $50 \% / 50 \%$ & $\$ 2,70$ \\
\hline AUSTRALIA & $\$ 106.700 .000$ & 21.766 .712 & $100 \%$ & $\$ 4,90$ \\
\hline ESPAÑA & $\$ 199.000 .000$ & 46.754 .784 & $100 \%$ & $\$ 4,26$ \\
\hline PERU & $\$ 20.000 .000$ & 29.248 .944 & $100 \%$ & $\$ 0,68$ \\
\hline ARGENTINA & $\$ 90.000 .000$ & 41.769 .728 & $100 \%$ & $\$ 2,15$ \\
\hline ECUADOR & $\$ 40.000 .000$ & 15.007 .343 & $100 \%$ & $\$ 2,67$ \\
\hline MEXICO & $\$ 173.800 .000$ & 113.724 .224 & $100 \%$ & $\$ 1,53$ \\
\hline COSTA RICA & $\mathrm{N} / \mathrm{D}$ & 4.576 .562 & $100 \%$ & \\
\hline USA & $\$ 110.000 .000$ & 313.232 .032 & $90 \% / 10 \%$ & $\$ 0,35$ \\
\hline CHILE & $\$ 25.000 .000$ & 16.888 .760 & N/D & $\$ 1,48$ \\
\hline BRASIL & $\$ 30.000 .000$ & 203.429.776 & N/D & $\$ 0,15$ \\
\hline SUIZA & $\$ 7.600 .000$ & 7.639 .961 & N/D & $\$ 0,99$ \\
\hline GRAN BRETAÑA & $\$ 44.928 .000$ & 62.698 .360 & $50 \% / 50 \%$ & $\$ 0,72$ \\
\hline COLOMBIA & $\$ 4.444 .444$ & 46.737 .814 & $100 \%$ & $\$ 0,10$ \\
\hline
\end{tabular}

Fuente: Adaptado de Marca País Colombia (2013)

En la segunda etapa se hizo en lanzamiento de la marca país en New York. Se realizó una actividad promocional en abril de 2013 que duró 11 días, con resultados satisfactorios en la experiencia internacional.

La consultora internacional Porer Novelli, mostró que se evidenciaron 654 notas de prensa, que valorizadas en el sistema de comunicación habitual, la inversión hubiese sido por un monto de 69 millones de dólares (Arango J. P., 2013).

Se prevé que el panorama mejore sobre el posicionamiento que tendrá Colombia en el Futuro. La firma FutureBrand (2012b) incluyó a Colombia entre las 15 marca país que liderarán en el futuro (posición \#13).

Para Lora (2013): “La marca país debe contar los hechos positivos de Colombia, de la mano del sector privado, de la mano del gobierno, de la mano de los medios, de todos los que quieran que Colombia crezca como nación en la región y en el mundo". 


\section{Capítulo 3. La marca país de Colombia}

Uno de los principales retos presentes y futuros de la marca país de Colombia es la limitación presupuestaria. Para crecer y fortalecer la marca hay que invertir. La reputación internacional de un país depende de la consolidación de su posicionamiento.

Un posicionamiento no se construye sin inversión, sin recursos y menos sin la participación de los grupos de interés.

Para Arango (2013), una marca país es un bien público, como puede ser una autopista o un electrificadora y como tal le pertenece a todos los colombianos y se nutre de todo lo que los colombianos le aportan, por esta razón, se constituye en un bien que es de todos y en el cual hay que trabajar en función de esa realidad.

Colombia al igual que otros países necesita de una marca país (Arango, 2013). Es una estrategia de integrar, concentrar y actuar de manera colectiva a favor de la imagen, el turismo, la inversión y las exportaciones del país en mercados internacionales.

Arango señala: El reto más grande tiene que ver con ¿qué estas administrando y a qué estás haciendo mercadeo? ¿A qué y cómo estas tratando de construir reputación y preferencia? Estás desarrollando un producto que no manejas. Hay cosas que no controla nadie y esas son las variables que tú tienes para vender el país”.

De acuerdo con lo anterior, Cesar Trujillo (2013), Vicepresidente de Marketing Digital de la Agencia de Publicidad JWT indicó que: “Otro reto importante, es que la marca país todavía tiene un potencial inexplorado en temas digitales creo que ahí es donde veo la mayor oportunidad, creo que la marca se ha enfocado en las audiencias locales y debe pensar ahora en audiencias globales".

\subsection{Modelo teórico e hipótesis de investigación}

El posicionamiento de la marca país de Colombia no ha logrado ser una estrategia competitiva que transporte la identidad y los valores de Colombia como una forma consistente de la marca. Este es el punto de partida de la Tesis Doctoral, se hace necesario crear un modelo estratégico que proyecte la imagen y la marca país de Colombia. Para la investigación se definieron las siguientes hipótesis: 


\section{Capítulo 3. La marca país de Colombia}

- La experiencia del visitante logra modificar su percepción sobre la imagen de Colombia (Echeverri et. al., 2013b). Sin embargo, los extranjeros (prospectos) aún conservan una percepción negativa de Colombia asociada a las drogas y el terrorismo. Por este motivo la estrategia de marca país debe enfocarse en identificar estas percepciones para mejorar la imagen que proyecta Colombia en mercados internacionales.

$\boldsymbol{H}_{1}$ : Los visitantes han dejado de asociar la imagen de Colombia con las drogas, el terrorismo, la inseguridad y la corrupción.

- El posicionamiento de una marca país se construye sobre la percepción de la imagen país (Echeverri et. al., 2013b). Existen diferencias entre las percepciones de un visitante y de quienes aún no han visitado un país. Los extranjeros que han visitado a Colombia consideran que un aspecto positivo del país es la alegría de su población.

$\boldsymbol{H}_{2}: \quad$ Existen diferencias proporcionales entre visitantes y prospectos cuando indican que un aspecto positivo de Colombia es la alegría de su población.

- El posicionamiento de una marca país mide el grado de conocimiento y recordación de un lugar en la mente de los visitantes o inversionistas (Dinnie, 2007). Las drogas y la guerrilla se han constituido en dos sombras del pasado que afectan negativamente la imagen de Colombia en mercados internacionales.

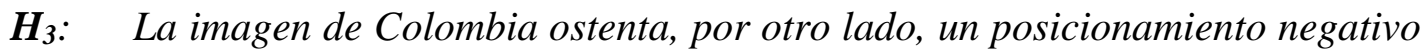
derivado de la asociación histórica del país con las drogas y la guerrilla. 


\section{Capítulo 3. La marca país de Colombia}

- La imagen país refleja el prestigio de su población, de sus empresas y de sus atributos naturales (Echeverri, 2009b). Las características de una población definen la personalidad de una marca país.

H. $\quad$ Los extranjeros que no han visitado al país, consideran que la alegría y la diversión son características propias de los colombianos.

- Colombia es reconocida internacionalmente por la producción y comercialización de café. En este sentido, el país tiene un fuerte posicionamiento por asociación productiva.

H5: La imagen de Colombia es reconocida en mercados internacionales como poseedora de un alto valor agregado debido al poder y notoriedad del café.

En el tercer capítulo se profundiza sobre la experiencia de marca país de Colombia desde la perspectiva estratégica, pero es en los siguientes capítulos donde se profundiza sobre su imagen país, en términos de impresiones sobre la imagen país, asociación positiva y negativa, características de los colombianos, asociación simbólica, asociación productiva y persona asociada a la imagen país.

En la Figura 53 se puede observar cómo se integran las hipótesis en el desarrollo de los resultados de investigación. Los temas centrales que se exponen en los siguientes capítulos hacen referencia al concepto de imagen país. Especialmente a los resultados obtenidos en la investigación cualitativa, y que se desagregan en temas referentes al posicionamiento que tiene Colombia en mercados internacionales. 


\section{Capítulo 3. La marca país de Colombia}

Figura 53. Modelo teórico e hipótesis de investigación

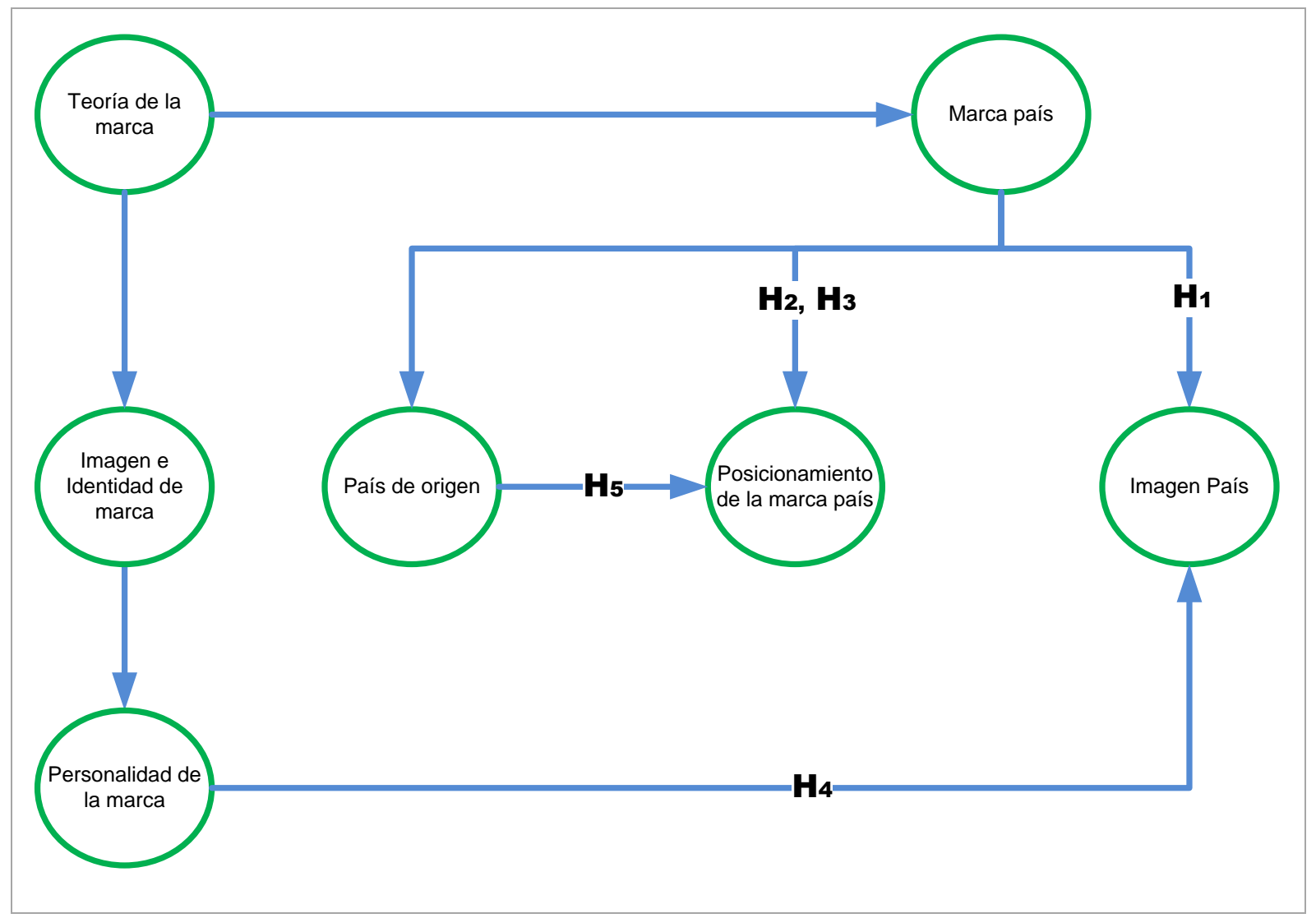

Fuente: Elaboración propia.

Las hipótesis de investigación se resumen a continuación:

H1: Los visitantes han dejado de asociar la imagen de Colombia con las drogas, el terrorismo, la inseguridad y la corrupción.

$\mathbf{H}_{2}$ : Existen diferencias proporcionales entre visitantes y prospectos cuando indican que un aspecto positivo de Colombia es la alegría de su población.

H3: La imagen de Colombia ostenta, por otro lado, un posicionamiento negativo derivado de la asociación histórica del país con las drogas y la guerrilla.

H4: Los extranjeros que no han visitado al país, consideran que la alegría y la diversión son características propias de los colombianos.

H5: La imagen de Colombia es reconocida en mercados internacionales como poseedora de un alto valor agregado debido al poder y notoriedad del café. 


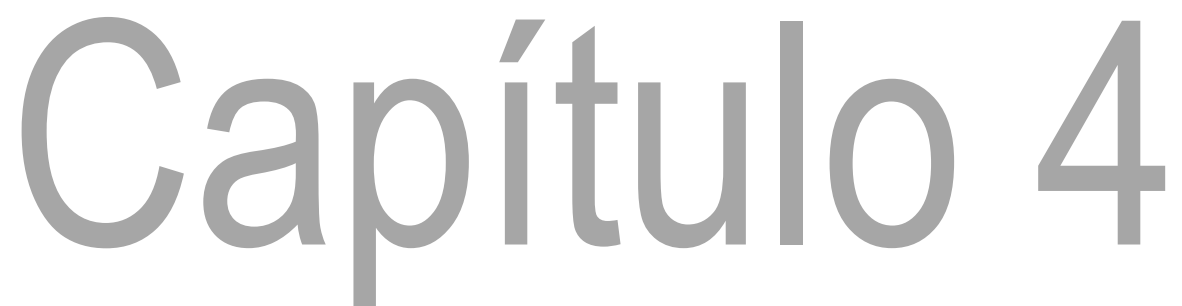

Metodología de la Investigación 


\section{Capítulo 4. Metodología de la Investigación}

La metodología de la investigación permite abordar con claridad y precisión el estudio propuesto. Es un componente esencial en el desarrollo de la investigación de la Tesis Doctoral, especialmente en este caso por su carácter empírico y cualitativo.

La investigación empírica se fundamenta en la observación y en la experimentación. Se utiliza para comprobar hipótesis que se plantean en el proceso investigativo (MacNealy, 1998). Es un tipo de investigación se basa en la evidencia (Dendaluze, 1997).

Su naturaleza permite ir más allá de describir observaciones, utiliza el estudio de caso como fuente para describir una situación real de un fenómeno y demuestra la relevancia del marco teórico mediante la aplicación en un entorno real (Laughlin, 2012).

La investigación empírica ayuda a entender y responder adecuadamente la dinámica de una realidad (Bravo et al., 1998). Proporciona respeto en el análisis de diferencias contextuales y se orienta a la generación de nuevo conocimiento para dar cumplimiento a los estándares de la investigación profesional (Ander-Egg, 1995; Fernández, 2006). Este tipo de investigación se utiliza principalmente en la investigación académica, porque es bastante útil para responder a preguntas prácticas.

En la disertación de la Tesis Doctoral, los resultados de la investigación empírica se encuentran en la revisión de la literatura sobre la teoría de la marca y marca país que se expone el primer y segundo capítulo del documento final.

En el tercer capítulo se explica la metodología casuística que termina de complementar la investigación empírica aplicada. La metodología casuística permite utilizar casos reales que puedan generar debates, aprendizaje y aplicabilidad en investigación y en docencia. Los métodos de caso son una fuente para investigaciones empíricas debido a que se focalizan en estudios de la complejidad de fenómenos organizativos. 


\section{Capítulo 4. Metodología de la Investigación}

La investigación empírica permite un acercamiento científico a un problema, especialmente cuando éste aún no ha sido abordado o suficientemente estudiado (Tamayo, 2004). En este contexto, Aaker et al. (2001, p. 73) plantea que: "se emplea este tipo de investigación cuando se está buscando un conocimiento más profundo sobre la naturaleza general de un problema, las posibles alternativas de decisión y las variables pertinentes que necesitan considerarse". Los métodos empleados incluyen estudios que describen la situación actual y el desarrollo que tratan de determinar los cambios en el tiempo.

La esencia del estudio de caso es tratar de responder en relación a una situación o un evento, las decisiones tomadas, el porqué de esas decisiones, como fueron implementadas y con qué resultados. Su mayor fortaleza radica en que a través del mismo se mide y registra la conducta de las personas involucradas en el fenómeno estudiado, mientras que los métodos cuantitativos sólo se centran en información verbal obtenida a través de encuestas por cuestionarios (Yin, 2011). En el método de estudio de caso los datos pueden ser obtenidos desde una variedad de fuentes, tanto cualitativas como cuantitativas: documentos, registros de archivos, encuestas directas, observación directa, observación de los participantes e instalaciones u objetos físicos (Vissak, 2010).

Para la Tesis Doctoral se ha desarrollado una metodología propia para construcción de casos. Para construir los dos casos de estudio que se evidencian en el capítulo se desarrollaron los siguientes pasos:

a. Elaboración del protocolo. se definieron los propósitos de investigación, el contexto de la problemática y las fuentes de información.

b. Conducción del estudio. Se definieron los roles del investigador para la planeación de cada caso, el diseño del cuestionario de preguntas para la aplicación de las encuestas propuestas y el cronograma de ejecución de la investigación.

c. Análisis de la evidencia. Con la información obtenida por fuentes primarias y secundarias se procede a documentar el caso. 


\section{Capítulo 4. Metodología de la Investigación}

d. Conclusiones y recomendaciones. Al cierre del caso, se derivan unas conclusiones que motivaron a definir que estos casos podrían ser resultado de la investigación y efectivamente aplicados en la docencia.

Figura 54. Metodología para la construcción de casos

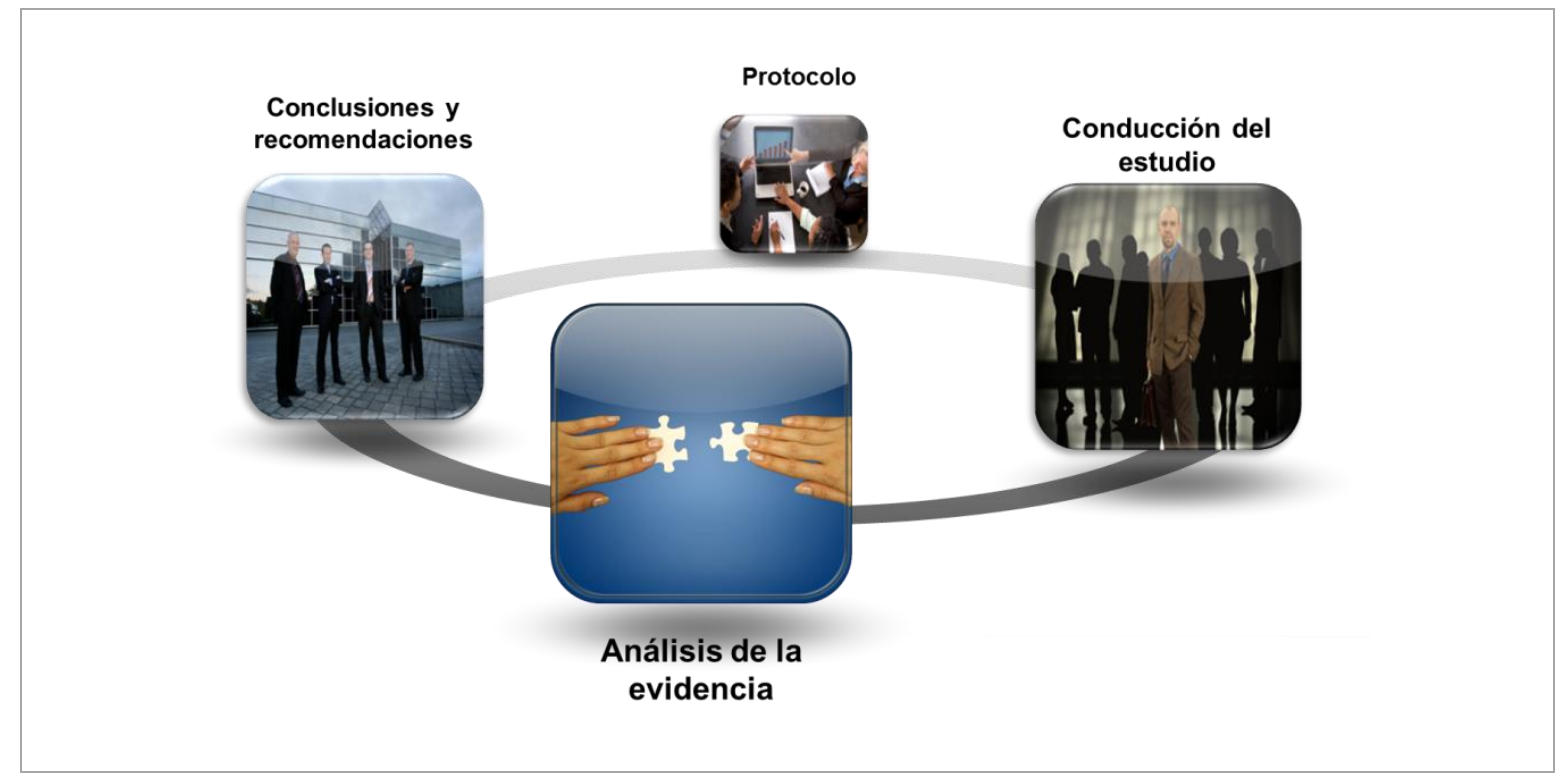

Fuente: Adaptado de Yin (2011).

La literatura de la mercadotecnia contiene ejemplos basados en la metodología del estudio de caso. El uso de esta técnica está determinado por la intencionalidad del docente de incentivar la reflexión del estudiante, la evaluación de conocimientos adquiridos o la aplicación de conceptos a realidades y prácticas empresariales.

Un caso se redacta en forma neutral, no incluye análisis, ni juicios de valor por parte de los autores y se construye a partir de la investigación basada en datos primarios (encuestas personales de las personas relacionadas interna y externamente con la organización) y secundarios (documentos de la organización, medios e información pública). Se redacta la historia de la marca país, con la finalidad de registrar sus inicios, su crecimiento, hechos puntuales, estrategias exitosas o no, sus experiencias de las distintas áreas o direcciones de las mismas.

El método de análisis fue de carácter cualitativo. Las fuentes secundarias consultadas corresponden a documentos e informes de dirección de la organización a cargo de la marca 


\section{Capítulo 4. Metodología de la Investigación}

país de Colombia. La siguiente ficha técnica que se observa en el Cuadro 34 resume el diseño metodológico empleado.

Cuadro 34. Ficha de técnica de la metodología casuística

\begin{tabular}{|l|l|}
\hline Unidad de análisis & Marca país de Colombia \\
\hline Ámbito geográfico & Colombia \\
\hline Tipo de muestra & $\begin{array}{l}\text { Muestra lógica y teórica (capacidad de generalización } \\
\text { analítica del fenómeno estudiado), no de forma aleatoria }\end{array}$ \\
\hline Fuentes de Información & $\begin{array}{l}\text { Organización a cargo de la gestión de la marca país } \\
\text { Colombia }\end{array}$ \\
\hline $\begin{array}{l}\text { Interna: documentación (memorias, informes y estudios } \\
\text { internos), archivos (páginas web, archivos de presentaciones, } \\
\text { archivos de imagen y sonido), entrevistas en profundidad, } \\
\text { cuestionarios, contexto físico real. } \\
\text { Externa: publicaciones especializadas, informes de } \\
\text { organismos oficiales y medios de comunicación. }\end{array}$ \\
\hline $\begin{array}{l}\text { Informadores clave } \\
\text { Evidencia }\end{array}$ & $\begin{array}{l}\text { Pioneros y ejecutivos de la marca país. Académicos. } \\
\text { Revisión documental (documentación y archivos). } \\
\text { Observación directa. }\end{array}$ \\
\hline
\end{tabular}

Fuente: Elaboración Propia

El propósito fue explorar las acciones, intereses y opiniones de personas vinculadas de manera directa e indirecta en el proceso de construcción y evolución de la marca país.

La exploración tuvo dos momentos. Un primer momento ocurre entre el 2008 al 2010, durante la vigencia de la primera marca país y un segundo momento entre 2012 y 2013, con el inicio de la segunda marca país.

El periodo entre 2010 al 2011, es un periodo de pausa para la marca país de Colombia, dado que inicia el declive la primera marca país, y ocurre cambio presidencial. Los componentes de la aplicación del método de caso fueron:

a. Acercamiento institucional. En los dos momentos investigativos explicados, el investigador realizó un acercamiento institucional con las organizaciones donde se encuentra adscrita la marca país. 


\section{Capítulo 4. Metodología de la Investigación}

b. Fuentes primarias. Se determinaron tres tipos de grupos, sujetos de análisis: i) Grupo Pioneros, conformado por los fundadores y personas que estuvieron vinculadas en la generación de la idea de marca país. Para el primer momento, se encuestaron 18 personas, y para el segundo momento se encuestaron 7 personas; ii) Grupo Ejecutivo, conformado por los empleados de la organización de Marca País en Colombia. En el primer momento se encuestaron ocho personas, y en el segundo momento se encuestaron cinco personas; iii) Grupo Cliente y Prescriptor, conformado por clientes y líderes de opinión. En el primer momento se encuestaron ocho personas y en el segundo momento se encuestaron dos personas. En el Apéndice A se registran una ficha técnica de las encuestas realizadas en los dos momentos mencionados.

c. Fuentes secundarias. Las fuentes secundarias fueron bases de datos como:

i. EBSCO: 10 bases de datos especializadas en negocios, periódicos de todo el mundo, gráficas y mucho más, con más de 10.000 títulos.

ii. EBRARY - NETLIBRARY: Base de datos de libros electrónicos en todas las áreas del conocimiento incluyendo administración, finanzas, mercadeo, y afines.

iii. EUROMONITOR: Euromonitor International es una compañía de investigación de mercado global que se especializa en suministrar información sobre las industrias, países y consumidores.

iv. REPNET: Base de datos Diario La República organizada por sectores de la economía colombiana. 


\section{Capítulo 4. Metodología de la Investigación}

d. Técnica de recolección de información. Se aplicó la técnica de entrevista estructurada. Esta técnica está orientada a establecer contacto directo con personas que se consideran fuente de información. La entrevista aplicada se soporta en un cuestionario flexible que tiene como propósito obtener información más espontánea y abierta. Durante las entrevistas realizadas se profundizó en información de interés para el estudio. Se diseñó una guía de preguntas que permitieran recoger con precisión la información histórica y evolutiva sobre la marca país de Colombia.

La guía de preguntas permitió conocer las acciones, intereses y opiniones sobre la imagen y marca país de Colombia de la población objeto de estudio de la investigación empírica. En el Anexo 2 se expone la guía de preguntas utilizada en las entrevistas.

e. Análisis. Los resultados obtenidos de las entrevistas, se transcribieron y luego se adaptaron a la narrativa escrita como aparece en el Capítulo 3 de la Tesis Doctoral. Esta adaptación se hizo siguiendo acuerdos de confidencialidad con algunos encuestados y siendo fiel a los comentarios realizados por la población de estudio.

f. Duración. La duración de la metodología casuística se divide en dos momentos. El primer momento tuvo una duración de nueve meses, iniciando en febrero y finalizando en octubre de 2008. El segundo momento inició en enero de 2012 y finalizó en octubre de 2013.

La investigación cualitativa tiene que ver con el desarrollo de las explicaciones de los fenómenos sociales. Tiene como objetivo ayudar a comprender el mundo en que vivimos y por qué las cosas son como son (Bernal, 2006). En la investigación cualitativa el propósito de la investigación es presentar hallazgos relevantes del posicionamiento que tiene Colombia en mercados internacionales.

La investigación, genera datos primarios de mayor significado para el análisis que permiten recoger insights que motivan la reflexión y predicción sobre la percepción que tienen los extranjeros sobre la imagen país de Colombia. 


\section{Capítulo 4. Metodología de la Investigación}

La primera aproximación importante a la investigación cualitativa es la fenomenología, es decir, el estudio descriptivo de cómo los individuos experimentan un fenómeno (Merriam, 2009). En la Tesis Doctoral, el fenómeno objeto de estudio hace referencia a las percepciones, impresiones y asociaciones que tienen los extranjeros sobre la imagen de Colombia.

La investigación de carácter cualitativo es inductiva porque permite construir abstracciones, conceptos, hipótesis y teorías desde los detalles. En la Tesis Doctoral, el investigador es el instrumento principal para la recopilación y análisis de datos (Maxwell, 2012). Los datos son originados por aplicación del instrumento a través del contacto humano, en lugar de los inventarios o máquinas. El investigador está interesado en el proceso, en el significado y en la comprensión adquirida a través de palabras o imágenes (Silverman, 2013).

La técnica cualitativa permite alimentar el trabajo investigativo a partir del análisis de variables previamente establecidas que fueron de utilidad para identificar y las percepciones sobre la imagen país de Colombia. Para efectos de la investigación, se denominó al sujeto de estudio como visitante y prospecto ${ }^{12}$, partiendo de la base que este calificativo permitirá, con mayor amplitud, delinear perfiles y rasgos sino también la percepción de la imagen país de Colombia. A continuación se explican los componentes de la investigación cualitativa:

a. Población. Para la investigación se determinó que el alcance del estudio serían los ocho países del continente americano que registran el mayor número de visitantes extranjeros que ingresaron a Colombia durante el 2012 según Proexport Colombia (2013). Los países objeto de estudio fueron:

1. Estados Unidos

2. Venezuela

3. Ecuador

4. Argentina

12 Corresponde a los extranjeros que no han visitado a Colombia. 


\section{Capítulo 4. Metodología de la Investigación}

5. Perú

6. Brasil

7. México

8. Chile

Los elementos que componen la población son todos los visitantes extranjeros. Según la Organización Mundial de Turismo (2007), visitante es la persona que viaja a un destino diferente a su lugar de procedencia por una duración inferior a un año, independiente del motivo de viaje (turismo, negocios o personal). Las unidades de muestreo, son todos los visitantes extranjeros mayores de 18 años procedentes de Estados Unidos, Venezuela, Ecuador, Argentina, Perú, Brasil, México y Chile.

a. Muestra. Para la determinación del tamaño de la muestra se aplicó una prueba piloto a personas que han visitado y no han visitado a Colombia. La muestra piloto se realizó con dos propósitos: a) probar el instrumento de recolección de información (Encuesta) y b) calcular los estimadores (p) de las variables más importantes del estudio, que permitirán calcular el error estándar de estimación, estimador básico para la determinación del tamaño de la muestra. En este caso, la variable más importante del estudio fue: posicionamiento de imagen país por asociación productiva.

El muestreo aplicado fue aleatorio simple. El muestreo aleatorio simple exige que cada unidad tenga la probabilidad equitativa de ser incluida en la muestra. (Malhotra, 2010). Para determinar la muestra se consideró el número de visitantes extranjeros procedentes del continente americano que ingresaron a Colombia durante el 2012. De acuerdo con Proexport Colombia (2013), al país ingresaron 1'132.002 extranjeros procedentes de ocho países. Estos ocho países del continente americano son los que representan el mayor flujo de llegadas a Colombia (Ver Figura 55). 


\section{Capítulo 4. Metodología de la Investigación}

Figura 55. Top 8 de número de visitantes extranjeros procedentes del continente americano que ingresaron a Colombia durante 2012

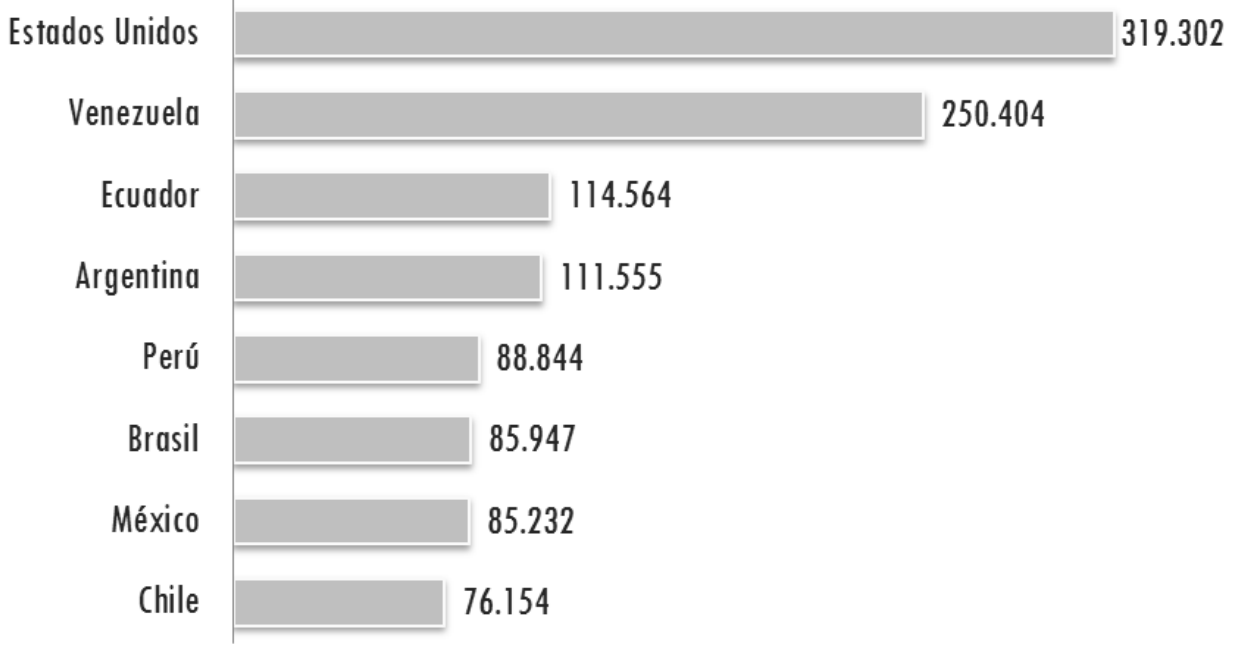

Fuente: Adaptado de Migración Colombia (2013).

Por ser una población conocida, se aplicó la siguiente formula aplicada a cada país objeto de estudio.

$$
n=\frac{N * Z^{2} * P^{*}(1-P)}{N * \varepsilon^{2}+Z^{2} * P *(1-p)}
$$

Donde,
$N$
Universo
$n$
es el tamaño necesario de la muestra
Z
margen de confiabilidad o número de unidades de desviación estándar
en la distribución normal que producirá el nivel deseado de confianza
(para un nivel de confianza de $95 \%$ o un $\alpha=0,05, \mathrm{Z}=1,96$ )
$P \quad$ proporción estimada para las variables categóricas de la población objeto de estudio $(\mathrm{P}=0,5)$.
E error estándar relativo de estimación por debajo del [7 \%]
El valor muestral fue de 188 encuestas por país. Pero se prefirió considerar 190 por destino. Con la finalidad de lograr el mayor grado de representatividad, los sujetos 


\section{Capítulo 4. Metodología de la Investigación}

fueron elegidos aleatoriamente, solo con el condicionante que fueran personas mayores de 18 años. Para balancear la muestra, se dividió en dos grupos: visitantes y prospectos.

En el Cuadro 35 se puede observar el cálculo del tamaño muestral por país y según la categoría de visitantes:

\section{Cuadro 35. Tamaño muestral por país}

\begin{tabular}{|c|c|c|c|}
\hline País & $\begin{array}{c}\text { Tamaño Muestral } \\
\text { (Visitantes) }\end{array}$ & $\begin{array}{l}\text { Tamaño Muestral } \\
\text { (Prospectos) }\end{array}$ & $\begin{array}{l}\text { Total } \\
\text { por país }\end{array}$ \\
\hline Estados Unidos & $\begin{array}{l}\mathbf{n}_{1}=95 \text { personas mayores de } 18 \\
\text { años procedentes de Estados } \\
\text { Unidos que han visitado a } \\
\text { Colombia }\end{array}$ & $\begin{array}{l}\mathbf{n}_{1}=95 \text { personas mayores de } 18 \\
\text { años procedentes de Estados } \\
\text { Unidos que no han visitado a } \\
\text { Colombia }\end{array}$ & 190 \\
\hline Venezuela & $\begin{array}{l}\mathbf{n}_{1}=95 \text { personas mayores de } 18 \\
\text { años procedentes de Venezuela } \\
\text { que han visitado a Colombia }\end{array}$ & $\begin{array}{l}\mathbf{n}_{1}=95 \text { personas mayores de } 18 \\
\text { años procedentes de Venezuela } \\
\text { que no han visitado a Colombia }\end{array}$ & 190 \\
\hline Ecuador & $\begin{array}{l}\mathbf{n}_{1}=95 \text { personas mayores de } 18 \\
\text { años procedentes de Ecuador } \\
\text { que han visitado a Colombia }\end{array}$ & $\begin{array}{l}\mathbf{n}_{1}=97 \text { personas mayores de } 18 \\
\text { años procedentes de Ecuador } \\
\text { que no han visitado a Colombia }\end{array}$ & 192 \\
\hline Argentina & $\begin{array}{l}\mathbf{n}_{1}=95 \text { personas mayores de } 18 \\
\text { años procedentes de Argentina } \\
\text { que han visitado a Colombia }\end{array}$ & $\begin{array}{l}\mathbf{n}_{1}=96 \text { personas mayores de } 18 \\
\text { años procedentes de Argentina } \\
\text { que no han visitado a Colombia }\end{array}$ & 191 \\
\hline Perú & $\begin{array}{l}\mathbf{n}_{1}=95 \text { personas mayores de } 18 \\
\text { años procedentes de Perú que } \\
\text { han visitado a Colombia }\end{array}$ & $\begin{array}{l}\mathbf{n}_{1}=95 \text { personas mayores de } 18 \\
\text { años procedentes de Perú que } \\
\text { no han visitado a Colombia }\end{array}$ & 190 \\
\hline Brasil & $\begin{array}{l}\mathbf{n}_{1}=95 \text { personas mayores de } 18 \\
\text { años procedentes de Brasil que } \\
\text { han visitado a Colombia }\end{array}$ & $\begin{array}{l}\mathbf{n}_{1}=98 \text { personas mayores de } 18 \\
\text { años procedentes de Brasil que } \\
\text { no han visitado a Colombia }\end{array}$ & 193 \\
\hline México & $\begin{array}{l}\mathbf{n}_{1}=95 \text { personas mayores de } 18 \\
\text { años procedentes de México que } \\
\text { han visitado a Colombia }\end{array}$ & $\begin{array}{l}\mathbf{n}_{1}=98 \text { personas mayores de } 18 \\
\text { años procedentes de México que } \\
\text { no han visitado a Colombia }\end{array}$ & 193 \\
\hline Chile & $\begin{array}{l}\mathbf{n}_{1}=95 \text { personas mayores de } 18 \\
\text { años procedentes de Chile que } \\
\text { han visitado a Colombia }\end{array}$ & $\begin{array}{l}\mathbf{n}_{1}=\mathbf{1 1 0} \text { personas mayores de } 18 \\
\text { años procedentes de Chile que } \\
\text { no han visitado a Colombia }\end{array}$ & 205 \\
\hline \multicolumn{3}{|c|}{ Tamaño Total de la Muestra } & 1.544 \\
\hline \multicolumn{4}{|c|}{ Fuente: Elaboración propia } \\
\hline
\end{tabular}




\section{Capítulo 4. Metodología de la Investigación}

Cuadro 36. Perfil sociodemográfico de las personas encuestadas

\begin{tabular}{|c|l|c|c|c|c|}
\cline { 3 - 5 } \multicolumn{2}{c|}{} & \multicolumn{2}{c|}{ Visitantes (n=760) } & \multicolumn{2}{c|}{ Prospectos (n=784) } \\
\cline { 3 - 6 } \multicolumn{2}{c|}{ Género } & Frecuencia & Porcentaje & Frecuencia & Porcentaje \\
\hline \multirow{5}{*}{ Edad } & Femenino & 342 & $45 \%$ & 430 & $57 \%$ \\
& Masculino & 418 & $55 \%$ & 330 & $43 \%$ \\
\hline \multirow{5}{*}{ Educación } & Entre 18 y 28 años & 165 & $22 \%$ & 309 & $41 \%$ \\
& Entre 29 y 39 años & 324 & $43 \%$ & 235 & $31 \%$ \\
& Entre 40 y 50 años & 191 & $25 \%$ & 140 & $18 \%$ \\
& Más de 50 años & 80 & $11 \%$ & 76 & $10 \%$ \\
\hline & Básica & 9 & $1 \%$ & 50 & $7 \%$ \\
& Media & 42 & $6 \%$ & 128 & $17 \%$ \\
& Técnica & 137 & $18 \%$ & 206 & $27 \%$ \\
& Pregrado & 291 & $38 \%$ & 260 & $34 \%$ \\
& Posgrado & 281 & $37 \%$ & 116 & $15 \%$ \\
\hline \multirow{5}{*}{ Estado Civilo } & Soltero & 289 & $38 \%$ & 373 & $49 \%$ \\
& Casado & 357 & $47 \%$ & 269 & $35 \%$ \\
& Unión Libre & 35 & $5 \%$ & 62 & $8 \%$ \\
& Separado & 68 & $9 \%$ & 43 & $6 \%$ \\
& Viudo & 11 & $1 \%$ & 13 & $2 \%$ \\
\hline
\end{tabular}

Fuente: elaboración propia.

Base: 1.544

b. Delimitación Espacial. La investigación empírica se realizó en Estados Unidos, Venezuela, Ecuador, Argentina, Perú, Brasil, México y Chile. Se aplicaron encuestas directas a personas mayores de 18 años nativos de los países objeto de estudio, entre ellos visitantes y prospectos de Colombia. A través de muestreo aleatorio se aplicaron 1.544 encuestas.

c. Fuentes primarias. Las fuentes primarias fueron personas mayores de 18 años procedentes de los ocho países del continente americano.

b. Técnica de recolección de información. La técnica empleada fue la encuesta estructurada. Esta técnica está orientada a establecer contacto directo con personas que se consideran fuente de información. La encuesta se soporta en un cuestionario flexible que tiene como propósito obtener información más espontánea y abierta. 


\section{Capítulo 4. Metodología de la Investigación}

Durante las encuestas realizadas se profundizó en información de interés para el estudio. Se diseñaron dos instrumentos, para visitantes y prospectos. Ambos instrumentos se sometieron al método Delphi, con la finalidad que fueran evaluados por expertos. Participaron como evaluadores investigadores en el campo de la estadística y del marketing: Hernán Parra (Profesor Universidad Nacional de Colombia), Javier Cadena (Profesor CESA), Claudia Gómez (Profesora CESA) y Carlos Osorio (Profesor Newcastle University Business School).

El instrumento se diseñó en el idioma español, inglés y portugués. En el Apéndice A y B del documento se puede consultar el formato de los instrumentos aplicados en el idioma español. En el trabajo de campo participaron 15 estudiantes de la Maestría en Dirección de Marketing del CESA bajo la figura de asistente de investigación. El instrumento diseñado tiene cerca de 20 preguntas de tipo cualitativo que permitieran recoger información en tres campos del estudio:

- Impresiones sobre la imagen de Colombia

- Asociación simbólica sobre la imagen país de Colombia

- Preferencias e intereses en Colombia

Se aplicaron los cuestionarios a través del contacto personal (ver Anexos 3 y 4). La información recopilada se tabuló los datos inicialmente en hojas de cálculo de EXCEL y una vez codificadas las bases de datos, se realizó el procesamiento estadístico de la información recogida mediante los sistemas estadísticos SPSS, SPAD.N y R.

c. Duración. La investigación tuvo una duración de 9 meses, iniciando en el mes de febrero de 2013 y finalizando en noviembre de 2013.

d. Variables de análisis. La información que integra la investigación cualitativa se obtuvo a partir del análisis de variables previamente establecidas que fueron de utilidad para identificar, clasificar y localizar a los visitantes y prospectos de nacionalidad procedentes del continente americano. A continuación se exponen las 


\section{Capítulo 4. Metodología de la Investigación}

variables que constituyeron las necesidades de información del estudio y las categorías que se identificaron como resultado del trabajo de campo del estudio:

i. Perfil sociodemográfico. Se incluyeron en el estudio las variables de tipología (visitante y no visitante), Género (femenino y masculino), Edad (entre 18 y 28 años; entre 29 y 39 años; entre 40 y 50 años; y más de 50 años), Nivel de escolaridad (Básica, Media, Técnica, Pregrado y Posgrado) y Estado civil (Soltero, Casado, Unión Libre, Separado y Viudo).

ii. País de América del Sur donde le gustaría vivir y visitar. En el estudio se indagó sobre el país en Suramérica que les gustaría para vivir o visitar. Los países que corresponden a las categorías de respuestas fueron: Argentina, Brasil, Chile, Colombia, Uruguay, Paraguay, Ecuador, Perú, Venezuela, Bolivia y Guyana.

iii. Impresiones sobre la imagen de Colombia. En este grupo de variables participan: asociación general, asociación positiva y negativa, las características de los colombianos, producto y ciudad. Cabe señalar que cobra relevancia la asociación general que tienen visitantes y prospectos sobre Colombia. Los resultados de la variable son los que permiten comprobar o rechazar las hipótesis planteadas en la investigación. Las categorías que componen la asociación general son: Arte, Cultura, Gastronomía y Deportes; Café; Drogas; Terrorismo; Inseguridad; Turismo; Gente Amable, Acogedora y Alegre; Desarrollo; Novelas; Mujeres Bellas; Negocios; y Selva, Montañas y Playas. En lo referente a la asociación positiva las categorías de análisis fueron: Alegría; Arte, Cultura y Deporte; Buen clima; Café; Cocaína, Narcotráfico; Gastronomía; Pasión; Gente amable; Naturaleza, Paisajes; Mujeres Bellas; Negocios; Turismo. Las categorías correspondientes a asociación negativa son: Crimen; Drogas; Pobreza; Guerrilla; Inseguridad; Terrorismo; Congestión Vehicular; Violencia; Narcotráfico; Corrupción. En este grupo de variables se incluyeron las características de los colombianos y 


\section{Capítulo 4. Metodología de la Investigación}

sus categorías fueron: Acogedores; Sociables; Alegres, Divertidos, Felices; La belleza de su gente; Orgullosos de su país; Trabajadores, Inteligentes, Educados; Amables; Apasionados; Creyentes. En la variable Producto, las categorías que la componen son: Café; Gastronomía; Drogas; Esmeraldas; Flores; Turismo; Textiles, Confecciones; Música; Novelas. Y en la variable ciudad, las categorías que la conforman son: Barrancabermeja; Bogotá; Cali; Cartagena; Cúcuta; Leticia; Medellín; Barranquilla; San Andrés; Pasto.

iv. Percepción de elementos sensoriales. Se incluyeron dos elementos: el color y el olor. En la variable Color, las categorías que la componen so: amarillo, azul, café, gris, blanco, rojo. En la variable Olor, las categorías son: café, flores, gastronomía, naturaleza, océanos.

v. Asociación simbólica sobre la imagen país de Colombia. Este grupo de variables está conformado por: símbolo y persona. En la variable Símbolo, las categorías son: drogas; música y cultura; bandera de Colombia; café; flores; fútbol; gente; Juan Valdés; artistas y deportistas; Pablo Escobar; Montañas, aves y ríos; piedras preciosas. Y en la variable Persona, las categorías que la conforman son: Pibe Valderrama; Álvaro Uribe; Amigos y familiares; Simón Bolívar; Hugo Chávez; Gabriel García Márquez; Juan Manuel Santos; Juan Valdés; Narcotraficantes. 


\section{Capítulo 4. Metodología de la Investigación}

vi. Preferencias e intereses en Colombia. Las variables que integran este grupo son: Frecuencia de visita, Lo que más le gustó, Lo que menos le gustó, medios de información, Recomendaría a Colombia, Interés de visita y Disposición de compra de productos colombianos. Es importante aclarar que el instrumento aplicado para visitantes y prospectos se diferencia especialmente en esta clasificación. En las variables Frecuencia de visita, las categorías que la componen son: Entre 1 y 3 veces; Entre 4 y 7 veces; Entre 8 y 11 veces; Más de 11 veces. En la variable Lo que más le gustó en su visita, las categorías son: Lugares Turísticos; Bogotá; Café; Cartagena; Negocios; Gastronomía; Cultura; Gente amable; Naturaleza; Vida Nocturna. En la variable Lo que menos le gusto, las categorías que la integran son: Clima; Gastronomía; Inseguridad; Pobreza; Ruido; Suciedad; Tráfico; Vendedores Ambulantes. En la variable Medios de Información, se encuentran las categorías de: radio, televisión, prensa e internet; en esta última categoría existen subcategorías: blogs, sitio web oficial, redes sociales y otros. En la variable de Recomendaría visitar a Colombia y si tiene Interés de visitar a Colombia, las categorías son: sí y no. Y en la variable de Disposición de Compra de Productos Colombianos, las categorías que le corresponden fueron: sí y no.

e. Análisis. En el estudio se realizaron tres tipos de análisis, Bi-variado, Análisis de Correspondencia simple (ACS), análisis de correspondencia múltiple (ACM) y análisis de conglomerados o Clúster. El Análisis Bivariado representa el cruce de dos variables, es decir, se enfrentan variables independientes con las preguntas del cuestionario. Se realizó el análisis bivariado considerando el país de origen, la edad, el género, el nivel de escolaridad y el estado civil como variables independientes. 


\section{Capítulo 4. Metodología de la Investigación}

A cada análisis se le aplicó la prueba de significación estadística basada en el coeficiente Chi Cuadrado de Pearson con la finalidad de examinar asociación entre variables nominales y ordinales (Malhotra, 2010). Para efectos del estudio, las variables independientes país de origen y edad, fueron las variables que presentaron mayor asociación con las variables nominales.

Para la prueba estadística en cuestión, si el p-valor asociado al estadístico de contraste era menor que el nivel de significación 0.05, se rechazaba la hipótesis nula H0 a un nivel de confianza del 95\%, y se aceptaba la hipótesis alternativa H1 (asociación entre la variable dependiente y la independiente).

Una vez identificadas las variables que presentaban asociación, se aplicó el Análisis de correspondencia de dos y tres dimensiones. El análisis de correspondencias es un procedimiento estadístico multivariado apropiado para la lectura y síntesis de la información contenida en una tabla de contingencia (Greenacre, 2008).

El análisis de correspondencias busca representar las interrelaciones de las categorías de las variables de fila y columna en un mapa bidimensional. Se puede pensar en cómo tratar de trazar una nube de puntos de datos (la nube que tiene altura, anchura, espesor) en un solo plano para dar un resumen razonable de las relaciones y la variación dentro de ellos. Este análisis se aplicó a variables dependientes relacionadas con la asociación de la imagen país.

Para efectos del estudio, las variables independientes país de origen y edad, fueron las variables que presentaron mayor asociación con las variables nominales. Para probar la existencia de algún tipo de asociación entre las variables X e Y se realizaron contrastes de hipótesis sobre la dependencia de dichas variables. 


\section{Capítulo 4. Metodología de la Investigación}

El test de hipótesis habitualmente utilizado es el de la $\chi 2$ (Salvador, Análisis de Correspondencias, 2003). En dicho test la hipótesis nula es $\mathrm{H}_{0}$ : X e Y son independientes o no asociación estadística y la alternativa es $\mathrm{H}_{1}$ : X e $\mathrm{Y}$ son dependientes o existe asociación estadística entre las variables. El test se basa en comparar los perfiles fila y columna con los perfiles marginales correspondientes, teniendo en cuenta que si $\mathrm{H} 0$ es cierta todos los perfiles fila (resp. columna) son iguales entre sí e iguales al perfil marginal de X (resp. de Y). El estadístico del test viene dado por la expresión:

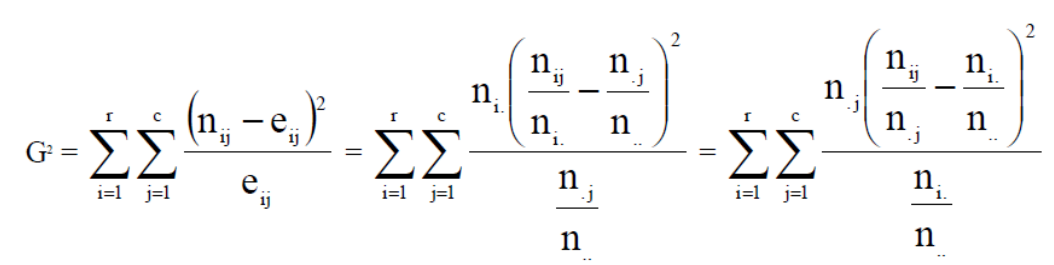

Donde $e_{i j}=E\left[n_{i j / H_{0} \text { cierta }}\right]=\frac{n_{i} n_{j}}{n}$. Valores pequeños de $\mathrm{G}^{2}$ indican que los valores de $\mathrm{n}_{\mathrm{ij}}$ $\mathrm{e}_{\mathrm{ij}}$ son cercanos y por lo tanto la hipótesis nula es cierta (independencia entre las variables). Si los valores de $\mathrm{G}^{2}$ son grandes evidencian que la hipótesis de independencia entre las variables es falsa.

Bajo la hipótesis nula, $\mathrm{G}^{2}$ se distribuye asintóticamente, según una $\chi^{2}$ y el p valor del test viene dado por: $P\left[\chi^{2}>G^{2}\right]$ donde $G^{2}$ es el valor observado del estadístico en la muestra. Para un nivel de significación $0<\alpha<1$ la hipótesis H0 se rechaza si dicho p-valor es menor o igual que $\alpha$. Si la hipótesis nula se rechaza, las variables $\mathrm{X}$ e $\mathrm{Y}$ son dependientes. En este caso conviene analizar los perfiles condicionales fila y columna así como los residuos del modelo para estudiar qué tipo de dependencia existe entre ellas.

Posteriormente se realizó el Análisis Clúster, el cual consiste en agrupar un conjunto de objetos de tal manera que los objetos en el mismo grupo (llamado clúster) son más similares (en uno u otro sentido) entre sí que a las de otros grupos (clústeres). 


\section{Capítulo 4. Metodología de la Investigación}

El análisis clúster permite conocer las características que tienen visitantes y prospectos y su percepción hacia la imagen país de Colombia. Cada clúster está representado por un grupo que tiene un determinado perfil. Este análisis es importante porque permite definir estrategias de segmentación y posicionamiento que ayudarán a mejorar la reputación de Colombia en mercados internacionales.

El objetivo del Análisis Clúster es obtener grupos de objetos de forma que, por un lado, los objetos pertenecientes a un mismo grupo sean muy semejantes entre sí, es decir, que el grupo esté cohesionado internamente y, por el otro, los objetos pertenecientes a grupos diferentes tengan un comportamiento distinto con respecto a las variables analizadas, es decir, que cada grupo esté aislado externamente de los demás grupos.

Es una técnica eminentemente exploratoria puesto que la mayor parte de las veces, no utiliza ningún tipo de modelo estadístico para llevar a cabo el proceso de clasificación. Se la podría calificar como una técnica de aprendizaje no supervisado, es decir, una técnica muy adecuada para extraer información de un conjunto de datos sin imponer restricciones previas en forma de modelos estadísticos, al menos de forma explícita y, por ello, puede llegar a ser muy útil como una herramienta de elaboración de hipótesis acerca del problema considerado sin imponer patrones o teorías previamente establecidas (Salvador, 2001).

Una vez establecidas las variables y los objetos a clasificar el siguiente paso consiste en establecer una medida de proximidad o de distancia entre los individuos que cuantifique el grado de similaridad entre cada par de objetos.

Las medidas de proximidad, similitud o semejanza miden el grado de semejanza entre dos objetos de forma que, cuanto mayor es su valor, mayor es el grado de similaridad existente entre ellos y con más probabilidad los métodos de clasificación tenderán a ponerlos en el mismo grupo.

En la literatura existe una multitud de medidas de semejanza y de distancia dependiendo del tipo de variables y datos considerados. Dado que los datos están en escala nominal, se usan medidas para este tipo de datos. 


\section{Capítulo 4. Metodología de la Investigación}

Para el análisis clúster, se aplicó el Método de Ward. Este método fue propuesto por Ward en 1963 quien argumentó que los conglomerados debían constituirse de tal manera que al fusionar dos elementos, la perdida de información producto de la fusión sea mínima. En este contexto, la cantidad de información se cuantifica como la suma de las distancias al cuadrado de cada elemento respecto al centroide del conglomerado al que pertenece ( $\mathrm{SCE}=$ suma cuadrado del error). Para ello se comienza calculando, en cada conglomerado el vector de medias de todas las variables. A continuación se calculan las distancias euclídeas al cuadrado entre cada elemento y los centroides (vector de medias) de todos los conglomerados. Por último se suman las distancias correspondientes a todos los elementos. En cada paso se unen aquellos conglomerados (o elementos) que dan lugar a un menor incremento de la SCE, es decir, la suma de cuadrados de las distancias intra-conglomerado. La SCE se define como:

$$
S C E=\sum_{j=1}^{k}\left[\sum_{i=1}^{n} X_{i j}^{2}-\frac{1}{n}\left(\sum_{i=1}^{n j} X_{i j}\right)^{2}\right.
$$

El estudio contempla los resultados de la aplicación de redes bayesianas. Una red bayesiana es un modelo gráfico que codifica relaciones probabilísticas entre variables de interés (López Puga, García García, De la Fuente Sánchez, \& De la Fuente Solana, 2007). Cuando se usa con técnicas estadísticas, el modelo gráfico tiene varias ventajas para el análisis de datos. La primera, porque el modelo codifica dependencias entre todas las variables (Birnberg, 1964; Bang-Jensen \& Gutin, 2009). Segundo, una red bayesiana se puede utilizar para aprender las relaciones causales, y por lo tanto puede ser utilizado para obtener la comprensión acerca de un dominio del problema y para predecir las consecuencias de la intervención (Turnovsky, 1969; Jensen \& Nielsen, 2007). Y tercero, porque es una representación ideal para combinar el conocimiento 


\section{Capítulo 4. Metodología de la Investigación}

previo (que a menudo viene en forma causal) con los datos (Jensen \& Nielsen, 2007; Diestel, 2005).

Un grafo es un conjunto $G=(V, A), V$ es un conjunto no vacio de nodos o vértices y $A$ un conjunto finito de pares de vértices llamados arcos, enlaces o bordes. $A$ puede ser un conjunto vacío.

Cada pareja, ordenada o no, de nodos, $a=(u, v)$, conectados, se dicen adyacentes o vecinos uno del otro. Si $(u, v)$ es una pareja ordenada $v$ se considera cabeza y $u$ la cola del arco, y se dice entonces que el arco esta dirigido de $u$ a $v$ y se representa usualmente $(u \rightarrow v)$. Si la pareja $(u, v)$ es no ordenada se dicen que u y v son incidentes, con arcos $\mathrm{n}$ dirigidos, y se nota con $(u-v)$.

La caracterización de arcos dirigidos o no dirigidos determina la caracterización del grafo en sí mismo. Si todos los arcos están dirigidos se dice que se tiene un grafo dirigido, de igual manera, si todos los arcos son no dirigidos, se tiene un grafo no dirigido, y si se tiene una combinación de arcos dirigidos y no dirigidos, se tiene entonces un grafo parcialmente dirigido. Cabe mencionar que para efecto de este trabajo se plantea la restricción de que solo puede haber a lo sumo un arco entre un par de nodos, lo que se conoce como aciclicidad. La anterior restricción también implica excluir un loop que podría ocurrir cuando $u=v$. Las abstracciones a través de grafos del mundo real generalmente pueden caer en grafos vacíos (grafos sin arcos) o en grafos densos o saturados (cada nodo está ligado a otro nodo).

Acorde con la restricción de aciclicidad u orden topológico, los primeros nodos en un grafo dirigido se le llaman nodos raíces, que no tienen arcos entrantes, y a los últimos se les llama nodos hojas, que tienen al menos un arco entrante pero no saliente. Adicionalmente, si existe un camino (secuencias de arcos que van conectando los nodos) en donde se evidencia que $u$ precede a $v$, u es llamado ancestros de $v$ y $v$ descendiente de $u$. Si este camino se compone por un solo arco se dice que $u$ es el padre y $v$ es el hijo. 


\section{Capítulo 4. Metodología de la Investigación}

Luego de haber realizado un breve esbozo de los conceptos básicos de la teoría de grafos, se procede ahora a definir una clase especial de grafos dirigidos acíclicos con los cuales se trataran las posibles relaciones, dependencia, de las variables de este proyecto, las redes bayesianas en ausencia de información temporal, dado que la información en análisis corresponde a una encuesta en un momento dado del tiempo (corte transversal).

Las redes bayesianas son una clase de modelo grafico que permite una representación concisa de la dependencia probabilística de un conjunto de variables aleatorias mediante un grafo dirigido acíclico en donde cada nodo representa una variable aleatoria. Para este caso se representa la independencia probabilística de las variables a través de la separación grafica (ausencia de un arco entre las variables). Esta correspondencia entre grafos e independencia probabilística se puede realizar gracias a lo que se conoce como mapa de independencia (Pearl, 1988).

Es decir, de acuerdo con Nagarajan et al. (2013) citando a Pearl (1988), G= $(V, A)$ representa una red Bayesiana a través de un grafo dirigido acíclico donde cada nodo $v_{i} \in V$ corresponde a una variable aleatoria $X_{i}$ de $X=\left\{X_{1}, X_{2}, \ldots, X_{p}\right\}$.

Se parte entonces de una correspondencia entre separación gráfica $\left(\perp_{G}\right)$, con ausencia de un arco, inducida por independencia probabilística $\left(\perp_{P}\right)$ entre las variables. Un grafo $G$ (es un mapa de independencia) de la estructura de dependencia probabilística $P$ de $X$ si existe una correspondencia uno a uno de las variables en $X$ y los nodos $V$ de $G$, talque para todos los subconjuntos disjuntos $A, B$ y $C$ :

$$
A \perp \perp_{P} B\left|C \Longleftarrow A \perp_{G} B\right| C
$$

Similarmente, $G$ (es un mapa de dependencia) de $P$ de $X$ si se tiene:

$$
A \perp \perp_{G} B\left|C \Longleftarrow A \perp_{P} B\right| C
$$

$G$ se dice un mapa perfecto de $\mathrm{P}$ si se cumple ambas relaciones; un isomorfismo de $P$ a $G$. 


\section{Capítulo 4. Metodología de la Investigación}

Esta relación es aclarada por el criterio de separación (independencia) dirigido $(d$ separación). Este establece que si $A, B$ y $C$ son tres subconjuntos disjuntos de nodos en $G$, entonces $C$ se dice para $d$-separar (independizar) $A$ de $B$, denotado $A \perp$ $\perp_{G} B \mid C$, si a lo largo dela secuencia de arcos entre un nodo en $A$ y un nodo en $B$ existe un nodo $v$ que satisface una de las siguientes dos condiciones:

a. $v$ presenta arcos convergentes (hay dos arcos apuntando a $v$ desde dos nodos adyacentes) y ninguno de $v$ o sus descendientes (ninguno de los que pueden ser alcanzados por $v$ ) están en $C$.

b. $v$ está en $C$ y no tiene arcos convergentes.

La propiedad de Markov de redes bayesianas, que se deriva directamente de la $d$ separación permite la representación de la distribución conjunta de probabilidad de las variables aleatorias en $X$ como un producto de las distribuciones condicionales de cada una de las variables (una aplicación directa de la regla de la cadena). Para variables aleatorias discretas está dada por:

$$
P_{X}(X)=\prod_{i=1}^{P} P_{X_{i}}\left(X_{i} \mid \prod_{X_{i}}\right)
$$

y para variables continuas expresado como:

$$
f_{X}(X)=\prod_{i=1}^{P} f_{X_{i}}\left(X_{i} \mid \prod_{X_{i}}\right)
$$

Similares resultados se cumplen para distribuciones mixtas. La inferencia de dichas densidades de probabilidad conjuntas están programadas en el paquete de R llamado bnlearn desarrollado por Nagarajan et al. (2013) y el que se utilizará en este manuscrito. 


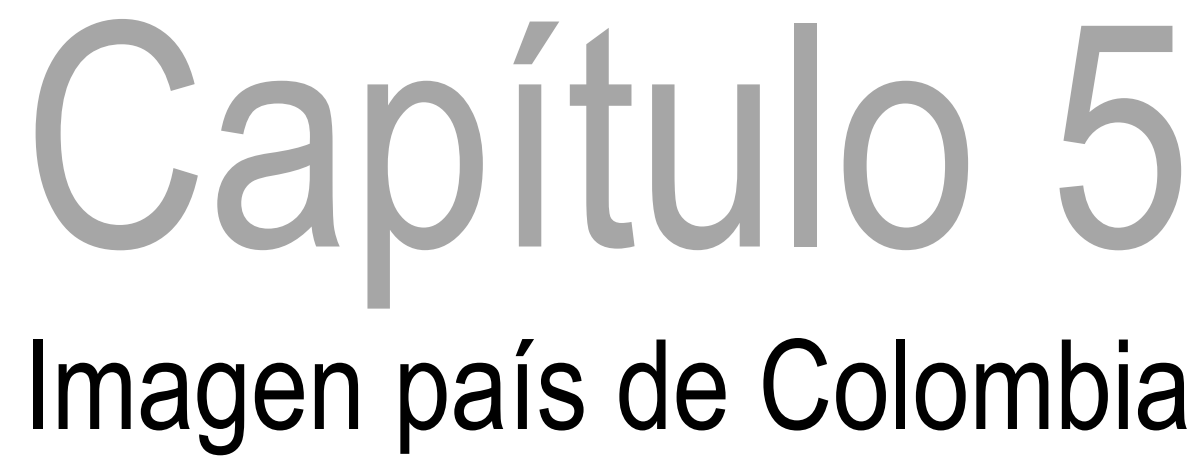




\section{Capítulo 5. Imagen país de Colombia desde la perspectiva extranjera}

La reputación de un país se construye sobre las ideas, la percepción y las experiencias que tienen los visitantes o inversionistas. Especialmente es la percepción la que recrea el concepto de imagen país, como un conjunto de creencias, ideas e impresiones que una persona tiene sobre un objeto (Kotler et al., 2003). La imagen país condiciona las actitudes y acciones de las personas (Papadopoulos \& Heslop, 1993).

Los países tienen una preocupación constante sobre la imagen que proyectan en mercados internacionales. Especialmente porque han adoptado e implementado estrategias de diferenciación para estimular el turismo y la inversión económica. En este sentido, Colombia es un país que no es ajeno a la percepción que tiene el mercado internacional.

En el posicionamiento de Colombia existen dos tipos de asociaciones: una productiva y positiva dada por los resultados del sector cafetero, y otra, negativa que recoge dos temas críticos: el narcotráfico y el terrorismo.

El proceso de mejorar la imagen país de Colombia, emerge como una búsqueda por lograr una proyección positiva al exterior, así como el gestar la reunión de los intereses e íconos que logren la construcción de la identidad nacional.

El relacionamiento con otros países ha motivado al gobierno colombiano a ser partícipe activo en los procesos de integración comercial en América y Europa. El propósito misional de las relaciones comerciales es incentivar el crecimiento económico a partir de exportaciones, inversión extranjera directa y turismo. Para cumplir este propósito, Colombia debe fortalecer su imagen país, especialmente con países del continente americano, puesto que son mercados relevantes en términos de acuerdos comerciales, y especialmente en el impacto que tienen en turismo. 


\section{Capítulo 5. Imagen país de Colombia}

La intencionalidad de la investigación subyace en el análisis de la percepción que tienen los visitantes y prospectos ${ }^{13}$ extranjeros sobre la imagen país de Colombia. Para la investigación empírica se determinó que el alcance del estudio serían los ocho países de América que registran el mayor número de visitantes extranjeros que ingresaron a Colombia durante el 2012 según Proexport Colombia (2013).

El capítulo cinco contiene los resultados del estudio que ponen en relieve la importancia de la formulación de un modelo de proyección país orientado a mejorar la imagen de Colombia en mercados internacionales. En este capítulo se verifica o se refutan las hipótesis planteadas en la Tesis Doctoral.

\subsection{Percepción de los extranjeros sobre la imagen país de Colombia}

La imagen de un país es un conjunto de creencias descriptivas, inferenciales e informativas sobre un determinado país (Martin \& Eroglu, 1993).

La percepción que tienen los extranjeros sobre la imagen país de Colombia está condicionada por diferentes factores sicológicos, como: a) las impresiones de la imagen de un país generado por la experiencia (para quienes la han visitado), b) las creencias entorno a un país (para quienes lo han visitado y no lo han visitado) y los elementos con los que se asocia a un país a través de su población, símbolos, preferencias, entre otros.

A continuación se exponen los resultados más relevantes del estudio realizado a 1.544 extranjeros.

La imagen país de Colombia es sensible a las percepciones de los extranjeros, especialmente de los países principales emisores de visitantes en el continente americano. La percepción es un elemento de comportamiento humano, y como tal, está sujeta a las influencias que dan forma a otros aspectos de la conducta.

${ }^{13}$ Corresponde a los extranjeros que no han visitado a Colombia. 


\section{Capítulo 5. Imagen país de Colombia}

La experiencia de cada individuo se combina de manera compleja para determinar su reacción a un estímulo dado. En este sentido, el estudio realizado reveló diferencias significativas entre la nacionalidad y las asociaciones sobre la imagen de Colombia.

Los países objeto de estudio fueron Estados Unidos, Venezuela, Ecuador, Argentina, Perú, Brasil, Chile y México. Ocho países que registran el mayor número de visitantes a Colombia durante el 2012 según Proexport Colombia (2013). Como se puede observar en el Figura 56, Estados Unidos representa el mayor emisor de visitantes hacia Colombia con una participación del 28\%, seguido de Venezuela.

Figura 56. Top 8 de países del continente americano que registran el mayor flujo de visitantes hacia Colombia - Año 2012

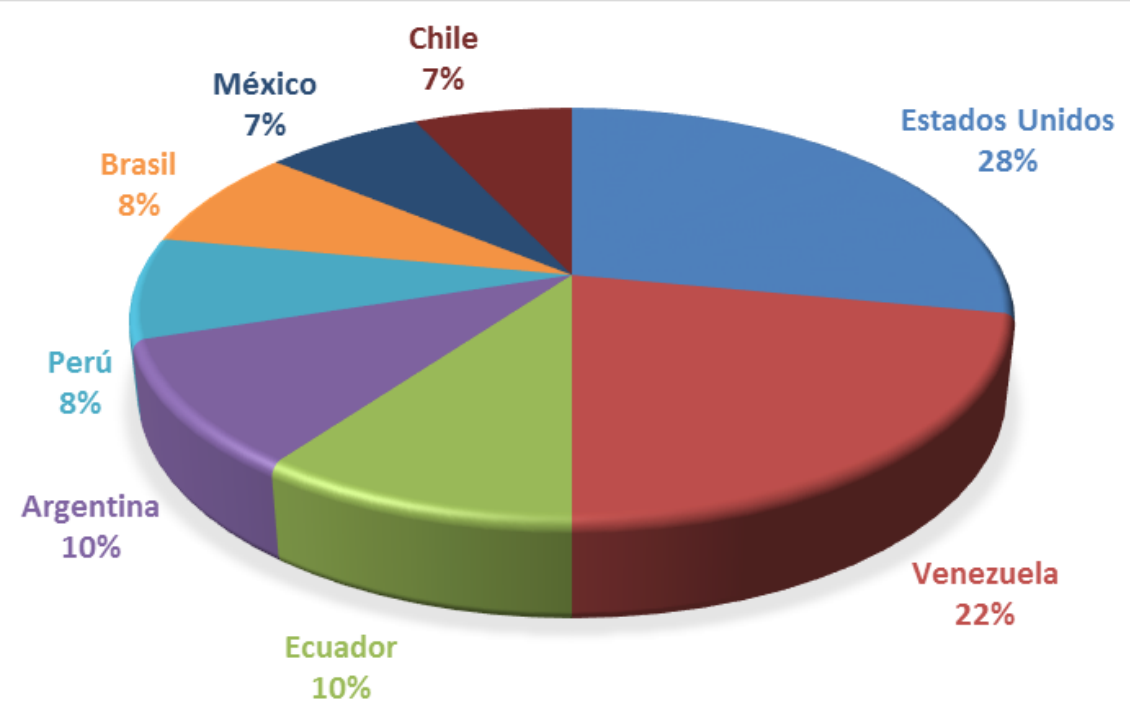

Fuente: Adaptado de Proexport Colombia (2013). 


\section{Capítulo 5. Imagen país de Colombia}

\subsubsection{Destinos para vivir y visitar en América del Sur}

La imagen de un país, motiva en las personas el deseo de visitar, vivir, trabajar o invertir en el país. Estos motivos son causados por la información y creencias que se tiene del lugar.

El 22\% de los visitantes extranjeros eligen a Colombia como el destino para vivir en América del sur. Mientras que los extranjeros que no han visitado a Colombia, indicaron que les gustaría vivir en Brasil (ver Figura 57). Agrupando las dos poblaciones estudiadas, Brasil figura en el primer puesto de lugar preferido para vivir.

Brasil ha ido consolidando su marca país gracias a la estabilidad y crecimiento económico, los indicadores de turismo de reputación, analizado en el capítulo 2 de la presente Tesis Doctoral.

Figura 57. ¿En qué país de América del Sur le gustaría vivir?

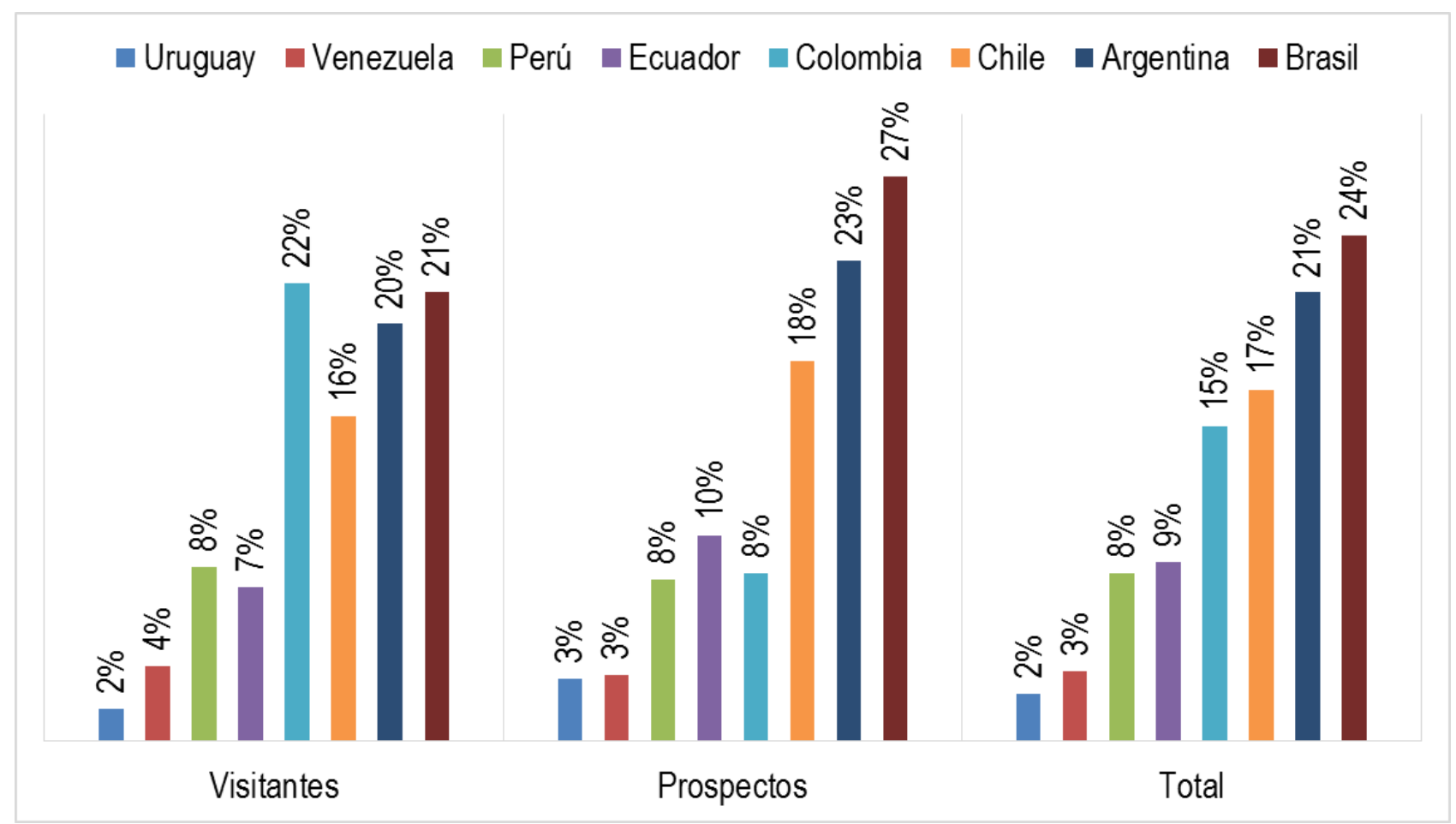

Fuente: elaboración propia.

Base: 1.544 


\section{Capítulo 5. Imagen país de Colombia}

En los resultados del estudio se encontró que la mayoría de los visitantes procedentes de Estados Unidos (44\%), Venezuela (47\%) y México (37\%) eligen a Colombia como el destino en América del Sur donde les gustaría vivir (ver Cuadro 37). El 60\% de los visitantes argentinos, el 54\% de los ecuatorianos, el 77\% de los brasileños, el $47 \%$ de los peruanos y el $57 \%$ de los chilenos prefieren residir en su país de origen.

Cuadro 37. Destino en América del Sur donde les gustaría vivir a los visitantes extranjeros

\begin{tabular}{|l|c|c|c|c|c|c|c|c|c|}
\hline \multicolumn{1}{c|}{} & \multicolumn{8}{|c|}{ Destino en América del Sur donde les gustaría vivir } \\
\hline País de Origen & Argentina & Brasil & Chile & Colombia & Uruguay & Paraguay & Ecuador & Perú & Venezuela \\
\hline Estados Unidos & $17 \%$ & $27 \%$ & $8 \%$ & $44 \%$ & $0 \%$ & $0 \%$ & $1 \%$ & $3 \%$ & $0 \%$ \\
\hline Venezuela & $6 \%$ & $0 \%$ & $22 \%$ & $47 \%$ & $0 \%$ & $0 \%$ & $0 \%$ & $0 \%$ & $26 \%$ \\
\hline Argentina & $60 \%$ & $18 \%$ & $7 \%$ & $10 \%$ & $5 \%$ & $0 \%$ & $0 \%$ & $0 \%$ & $0 \%$ \\
\hline Ecuador & $19 \%$ & $7 \%$ & $5 \%$ & $13 \%$ & $1 \%$ & $0 \%$ & $54 \%$ & $1 \%$ & $0 \%$ \\
\hline Brasil & $12 \%$ & $77 \%$ & $7 \%$ & $1 \%$ & $0 \%$ & $0 \%$ & $0 \%$ & $1 \%$ & $1 \%$ \\
\hline Perú & $6 \%$ & $17 \%$ & $4 \%$ & $23 \%$ & $2 \%$ & $0 \%$ & $0 \%$ & $47 \%$ & $1 \%$ \\
\hline México & $22 \%$ & $15 \%$ & $11 \%$ & $37 \%$ & $1 \%$ & $0 \%$ & $1 \%$ & $12 \%$ & $1 \%$ \\
\hline Chile & $18 \%$ & $12 \%$ & $57 \%$ & $7 \%$ & $2 \%$ & $1 \%$ & $0 \%$ & $3 \%$ & $0 \%$ \\
\hline
\end{tabular}

Fuente: elaboración propia

Base: 760

En cuanto al país que les gustaría visitar, los extranjeros que han visitado a Colombia eligen a Argentina, mientras quienes no han visitado prefieren a Brasil.

En los resultados generales, Colombia ocupa la tercera posición entre los destinos de América del Sur que los extranjeros prefieren para visitar. Lo anterior muestra la oportunidad que tienen las organizaciones, agencias y empresas vinculadas al sector turismo para convertir a Colombia en un destino receptor de turistas.

Países como Brasil, Argentina y Colombia, están en las cuatro primeras menciones de destinos preferidos para vivir y visitar en América del Sur. 


\section{Capítulo 5. Imagen país de Colombia}

Figura 58. ¿Qué país de América del Sur le gustaría visitar?

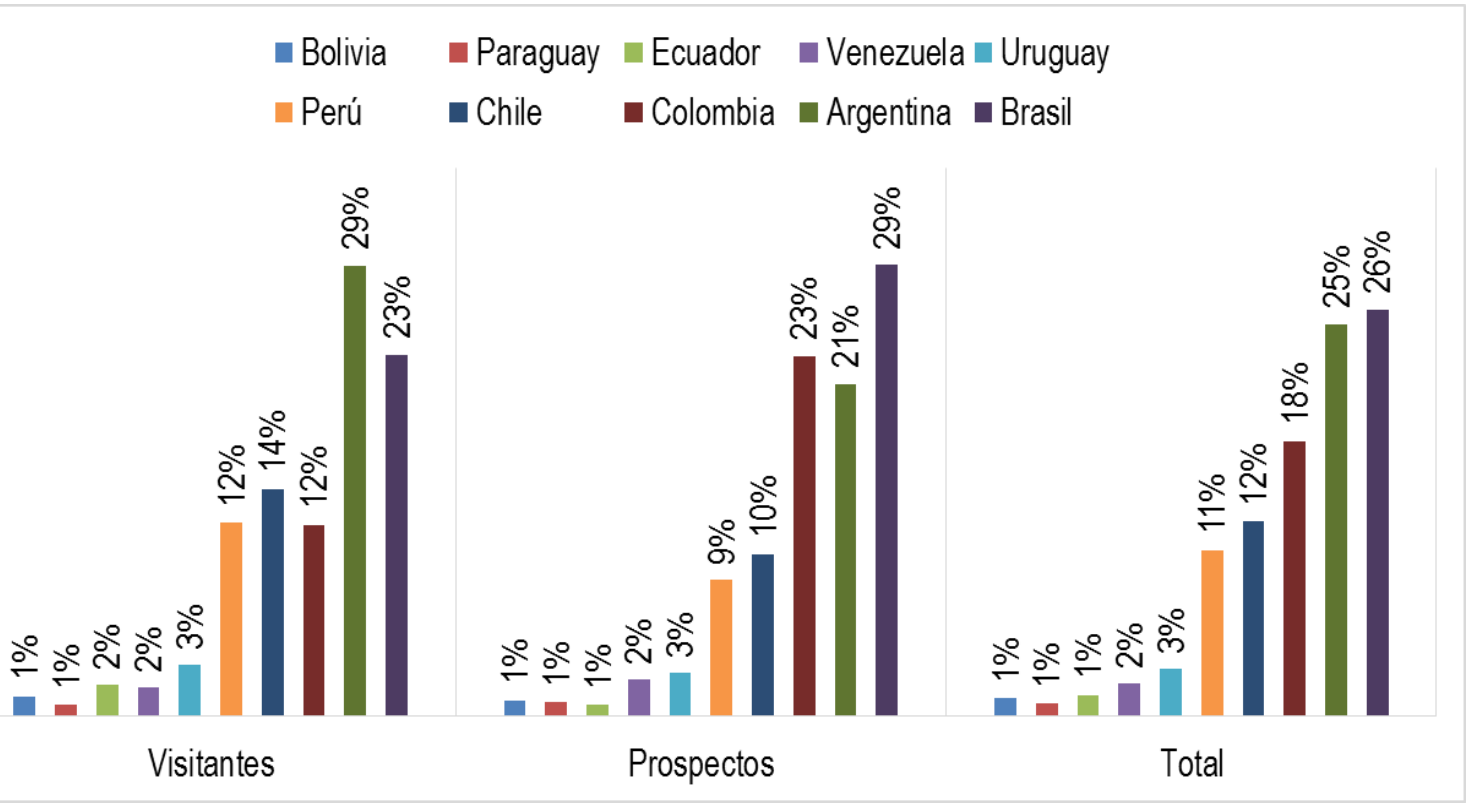

Fuente: elaboración propia.

Base: 1.544

Colombia es un destino para vivir en América del Sur, pero está entre los países que los extranjeros quieran visitar en primera instancia. Argentina y Brasil se destacan como destinos de América del Sur preferidos por los extranjeros (ver Cuadro 38). Los países que menor mención tuvieron fueron: Uruguay, Venezuela, Ecuador, Paraguay y Bolivia.

Cuadro 38. Destino en América del Sur que les gustaría visitar a los visitantes extranjeros

\begin{tabular}{|l|c|c|c|c|c|c|c|c|c|}
\cline { 2 - 11 } \multicolumn{1}{c|}{} & \multicolumn{8}{|c|}{ Destino en América del Sur que le gustaría visitar } \\
\hline País de Origen & Argentina & Brasil & Chile & Colombia & Uruguay & Ecuador & Perú & Venezuela & Bolivia \\
\hline Estados Unidos & $27 \%$ & $22 \%$ & $16 \%$ & $20 \%$ & $0 \%$ & $3 \%$ & $9 \%$ & $1 \%$ & $3 \%$ \\
\hline Venezuela & $53 \%$ & $0 \%$ & $18 \%$ & $10 \%$ & $0 \%$ & $0 \%$ & $17 \%$ & $1 \%$ & $0 \%$ \\
\hline Argentina & $17 \%$ & $16 \%$ & $21 \%$ & $15 \%$ & $9 \%$ & $2 \%$ & $15 \%$ & $5 \%$ & $0 \%$ \\
\hline Ecuador & $28 \%$ & $40 \%$ & $16 \%$ & $7 \%$ & $3 \%$ & $0 \%$ & $3 \%$ & $0 \%$ & $2 \%$ \\
\hline Brasil & $26 \%$ & $0 \%$ & $25 \%$ & $5 \%$ & $2 \%$ & $6 \%$ & $29 \%$ & $0 \%$ & $4 \%$ \\
\hline Perú & $28 \%$ & $36 \%$ & $8 \%$ & $20 \%$ & $3 \%$ & $1 \%$ & $1 \%$ & $2 \%$ & $1 \%$ \\
\hline México & $28 \%$ & $33 \%$ & $13 \%$ & $3 \%$ & $1 \%$ & $0 \%$ & $20 \%$ & $2 \%$ & $0 \%$ \\
\hline Chile & $20 \%$ & $38 \%$ & $0 \%$ & $19 \%$ & $7 \%$ & $5 \%$ & $5 \%$ & $3 \%$ & $1 \%$ \\
\hline
\end{tabular}

Fuente: elaboración propia

Base: 760 


\section{Capítulo 5. Imagen país de Colombia}

\subsubsection{La imagen de Colombia desde una perspectiva de América}

La imagen país de Colombia tiene un posicionamiento polarizado, pero que aún conserva una alta asociación histórica negativa y una asociación productiva tradicional en el continente americano.

De acuerdo con los resultados del estudio, el $27 \%$ de los visitantes y prospectos extranjeros coinciden en asociar la palabra Colombia con las drogas, el terrorismo, la inseguridad y la corrupción. Seguido de un $20 \%$ del total de los encuestados que lo asocian con el café.

Como se puede observar en la Figura 59, la palabra Colombia tiene diversas asociaciones dependiendo si es visitante o prospecto. El visitante asocia la palabra Colombia con gente amable y acogedora, mientras el prospecto la asocia con atributos negativos ya mencionados.

Figura 59. ¿Qué es lo primero que piensa cuando oye la palabra Colombia?

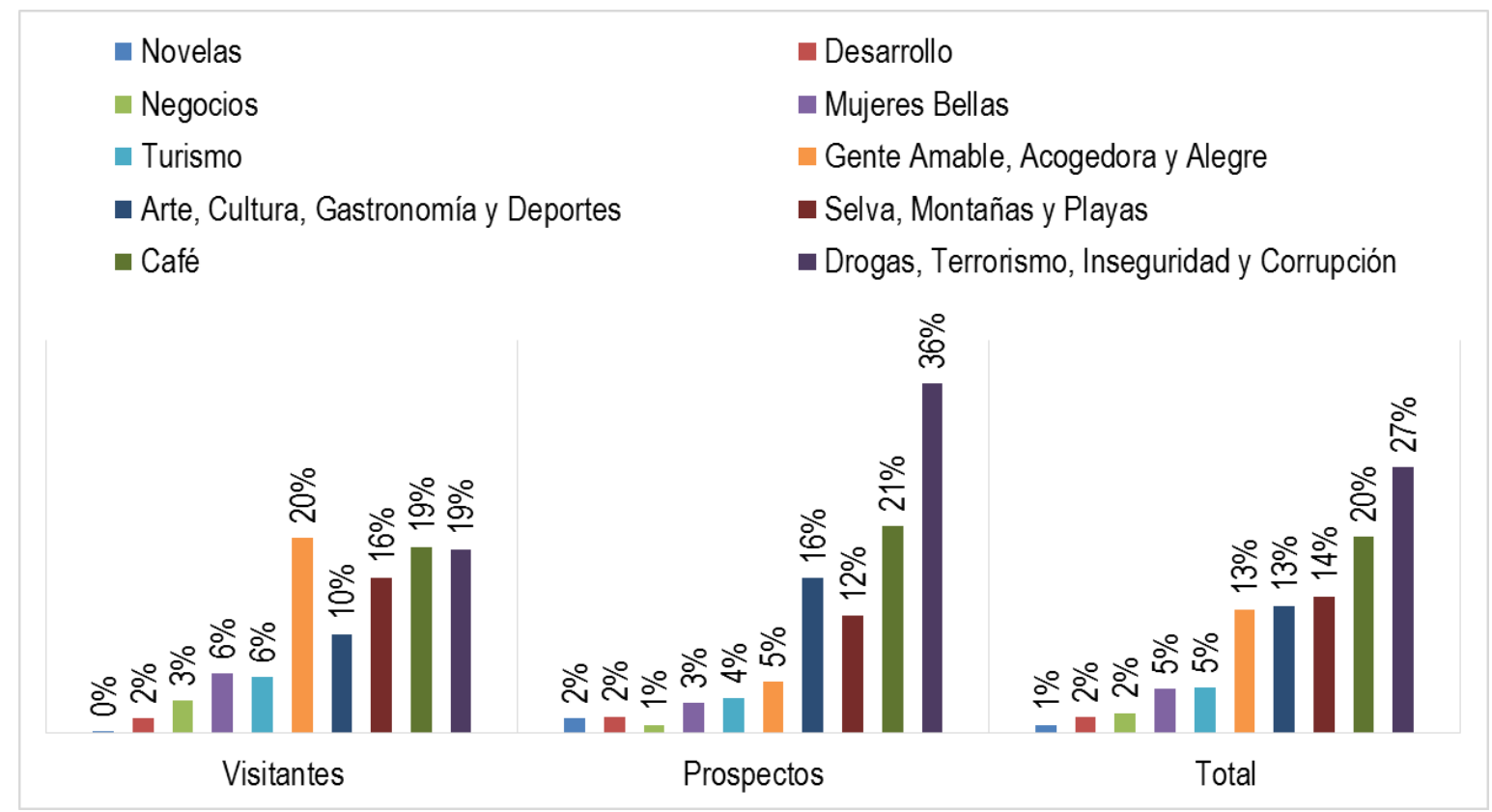

Fuente: elaboración propia.

Base: 1.544 


\section{Capítulo 5. Imagen país de Colombia}

La experiencia del visitante modifica su percepción sobre la imagen de Colombia. En base a los valores $t$ de Student significativos a un nivel de $p<0,05$, la primera hipótesis de la investigación $\left(\boldsymbol{H}_{\boldsymbol{l}}\right)$ se confirma, demostrando que la proporción de visitantes que asocian a Colombia con las drogas, el terrorismo, la inseguridad y la corrupción es significativamente inferior a la de los prospectos $(t=7,006 ; \mathrm{Sig} .=0,000)$. Lo anterior expone la necesidad de proponer un modelo de proyección país que sea incluyente, dirigido especialmente a los extranjeros del continente que no ha visitado a Colombia (prospectos), y que han mantenido en su imaginario colectivo una percepción negativa sobre el país. Atributos como la selva, montañas, playas, arte, cultura, gastronomía y deportes, fueron expuestos por los encuestados. Esto indica cómo la imagen de Colombia ha logrado explorar nuevas áreas de interés para el visitante muy diferentes a las percepciones tradicionales. Es en estos atributos que la estrategia de marca país debe enfocarse, ya que Colombia no puede concentrarse en posicionamientos de carácter productivo, sino enfocarse en otros elementos que reconoce el visitante y aún el prospecto. El total de extranjeros encuestados (visitantes y prospectos) asocian a Colombia con aspectos positivos como: la gente amable (29\%), la naturaleza y los paisajes (20\%) y la alegría (14\%).

Figura 60. ¿En una sola palabra describa algo positivo de Colombia?

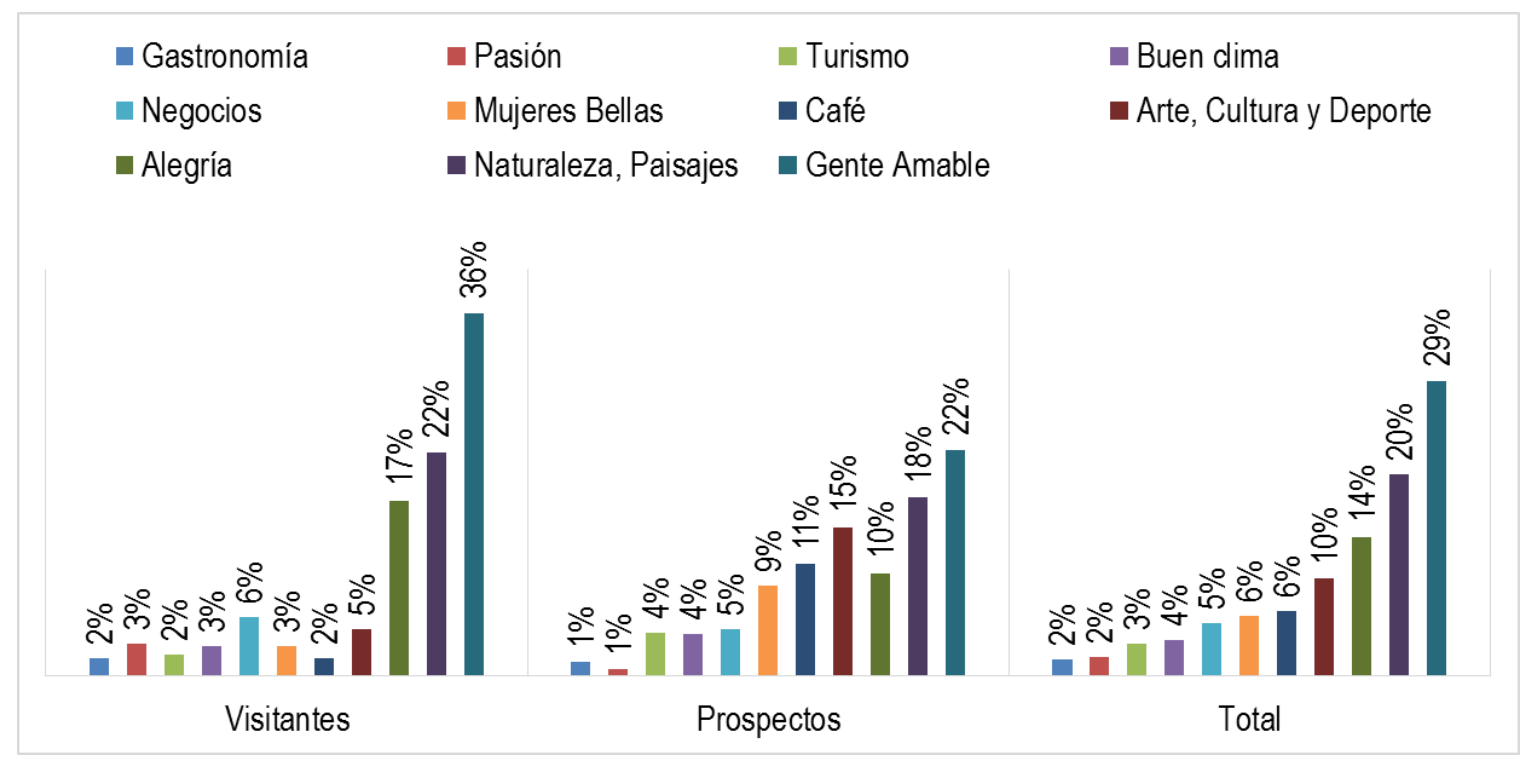

Fuente: elaboración propia.

Base: 1.544 


\section{Capítulo 5. Imagen país de Colombia}

La inspección de los valores de la $t$ de Student significativos a un nivel de $\mathrm{p}<0,05$, evidenció que se observan diferencias significativas en la proporción, es decir, el porcentaje de personas que consideran que el aspecto positivo de alegría es significativamente superior en el grupo de visitantes $(t=6,800$; Sig. $=0,000)$. De acuerdo con lo anterior se confirma la segunda hipótesis $\left(\boldsymbol{H}_{2}\right)$ de la Tesis Doctoral.

En lo referente a aspectos negativos, los extranjeros asocian la imagen del país con las drogas $(22 \%)$, la guerrilla $(21 \%)$, el narcotráfico $(21 \%)$ y la violencia (16\%). Es de notar, que Colombia mantiene una asociación histórica negativa en lo referente a las drogas y la guerrilla, es decir se confirma la tercera hipótesis $\left(\boldsymbol{H}_{3}\right)$ de investigación. De acuerdo con los

resultados de la aplicación de la prueba $t$ de Student, no existen diferencias significativas entre visitantes y prospectos sobre los aspectos negativos de drogas $(t=4,733$; $\mathrm{Sig} .=0.000)$ y guerrilla $(t=2,1240 ;$ Sig. $=0,033)$ asociados a la imagen de Colombia. Quienes han visitado a Colombia asocian su imagen con la guerrilla (23\%) y aquellos que aún no lo han visitado lo asocian con las drogas $(27 \%)$.

Figura 61. ¿En una sola palabra describa algo negativo de Colombia?

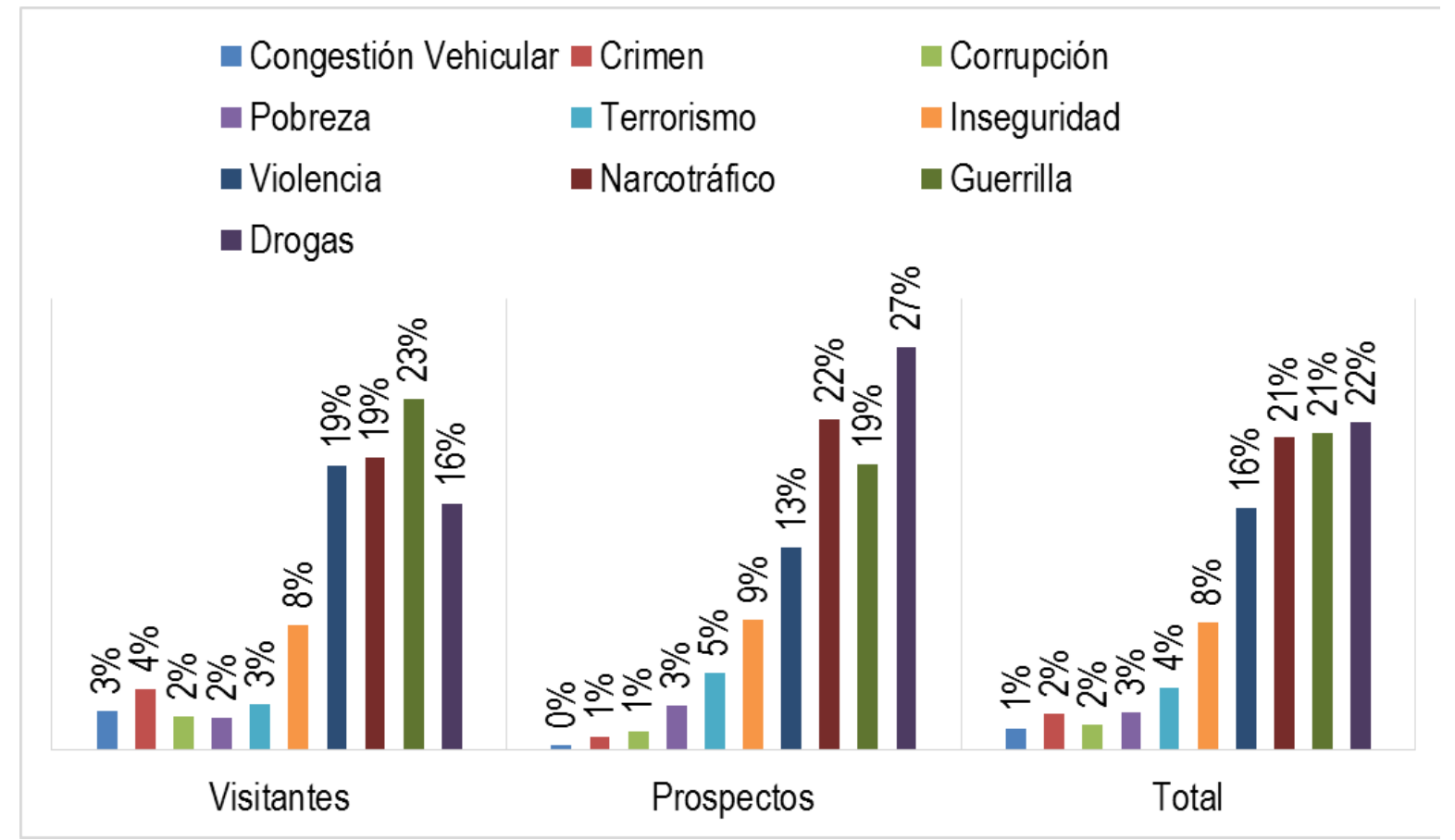

Fuente: elaboración propia.

Base: 1.544 


\section{Capítulo 5. Imagen país de Colombia}

La amabilidad es un atributo que destacan los extranjeros como aspecto positivo de Colombia. También fue considera como la primera característica de los colombianos, seguida de alegría y diversión. En los resultados del estudio cabe señalar que la característica pasión no tiene una participación notable en el análisis. Este atributo fue considerado en el 2005 como la característica que mejor representaba a los colombianos (Lightle, 2005). Sobre el elemento de la pasión se construyó la primera marca país que tuvo Colombia denominada Colombia es pasión. De acuerdo con lo anterior, se puede observar que la percepción extranjera ha cambiado sobre las características que tienen los colombianos. Para el $40 \%$ de los visitantes extranjeros, los colombianos son amables; y para el 37\% de quienes no han visitado al país, los colombianos son alegres y divertidos. De acuerdo con lo anterior, y sobre los resultados de la prueba $t$ de Student, la hipótesis de la investigación $\left(\boldsymbol{H}_{4}\right)$ se confirma, demostrando que la proporción de personas que consideran que los colombianos son alegres y divertidos es significativamente mayor en prospectos que en visitantes $(t=6,406$; Sig. $=$ 0,000).

Figura 62. ¿Qué características tienen los colombianos?

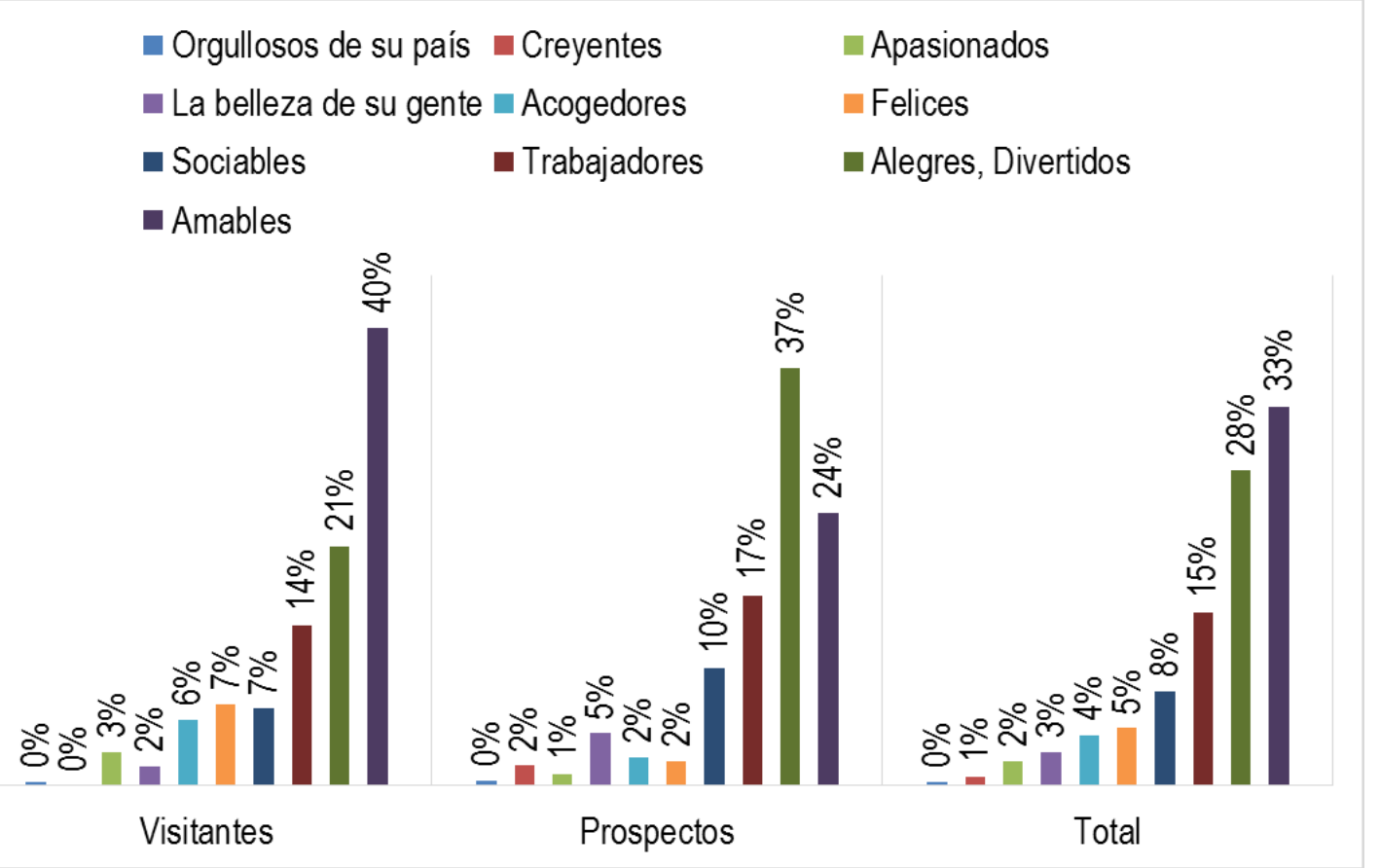

Fuente: elaboración propia.

Base: 1.544 


\section{Capítulo 5. Imagen país de Colombia}

Figura 63. ¿Qué símbolo representa a Colombia?

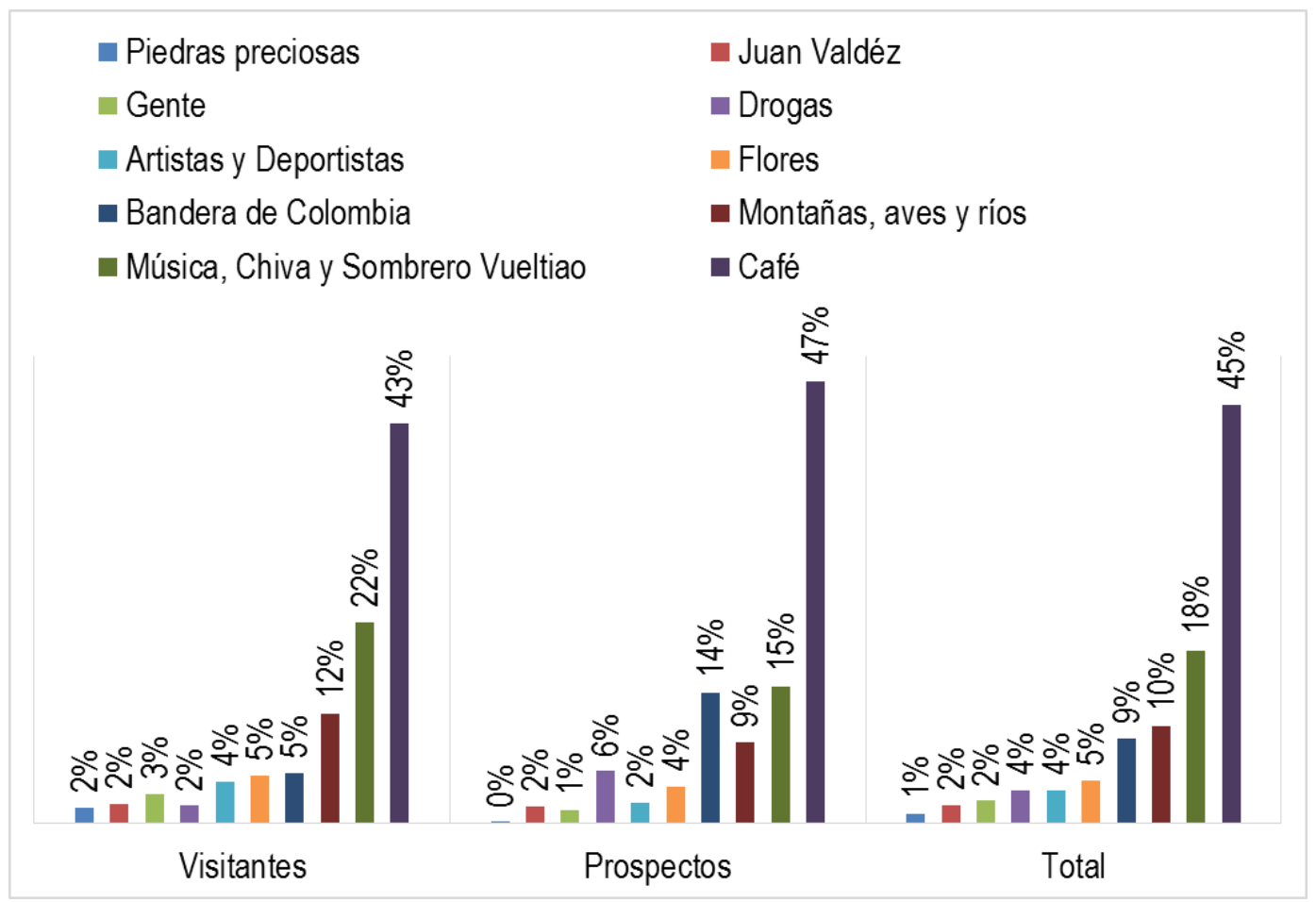

Fuente: elaboración propia.

Base: 1.544

De acuerdo con la Figura 63, el 45\% de visitantes y prospectos coinciden en que el café es el símbolo que representa a Colombia. Para el $18 \%$ de los extranjeros, hay otros símbolos asociados como la música, la chiva ${ }^{14}$ y el sombrero vueltiao.

El café es el producto que mayor recordación presenta por parte de la población de estudio (ver Figura 64). El 65\% de los extranjeros asocian a Colombia con el café. Colombia mantiene un posicionamiento histórico por actividad productiva dado por su trayectoria cafetera. Con la prueba $t$ de Student se observa que no existen diferencias significativas en la asociación con el café $(t=0,450$; Sig. $=0,652)$. Visitantes y prospectos tienen la misma percepción. De acuerdo con lo anterior se confirma la quinta hipótesis $\left(\boldsymbol{H}_{5}\right)$.

${ }^{14}$ Bus escalera típico de Colombia, Ecuador y Panamá. 


\section{Capítulo 5. Imagen país de Colombia}

Figura 64. Cuando se menciona a Colombia, ¿con qué producto la asocia?

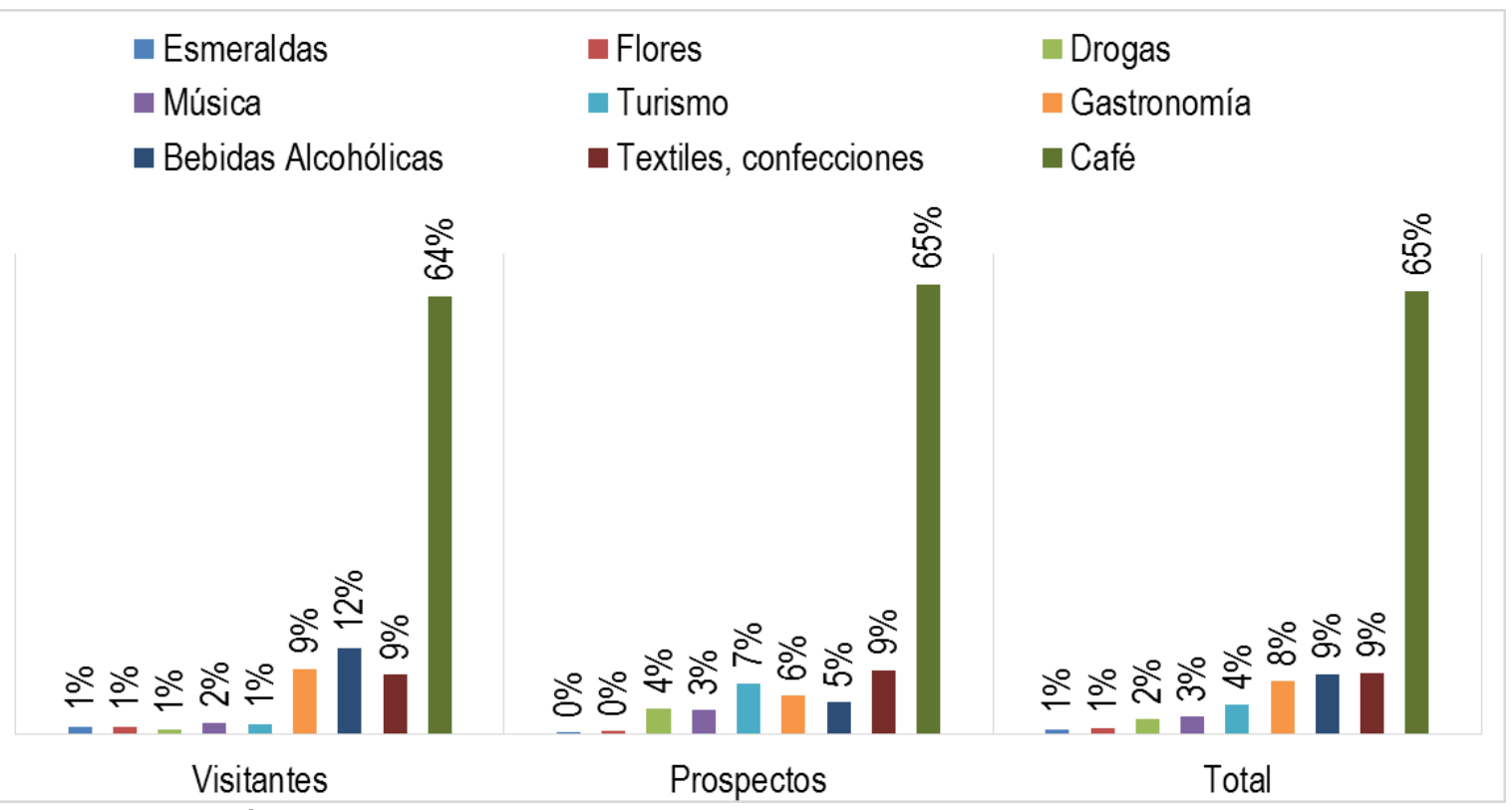

Fuente: elaboración propia.

Base: 1.544

El 22\% de los extranjeros asocian a Colombia con la cantante Shakira (ver Figura 65).

El 18\% relacional la imagen del país con amigos y familiares. Figuras presidenciales y deportistas ocupan el tercer y cuarto lugar en el total de las respuestas. Como es el caso del expresidente Álvaro Uribe, que después de cuatro años desde su presidencia, sigue manteniéndose como un líder opinión, opositor del Gobierno del presidente Juan Manuel Santos. 


\section{Capítulo 5. Imagen país de Colombia}

Figura 65. Cuando se menciona a Colombia, ¿con qué persona la asocia?

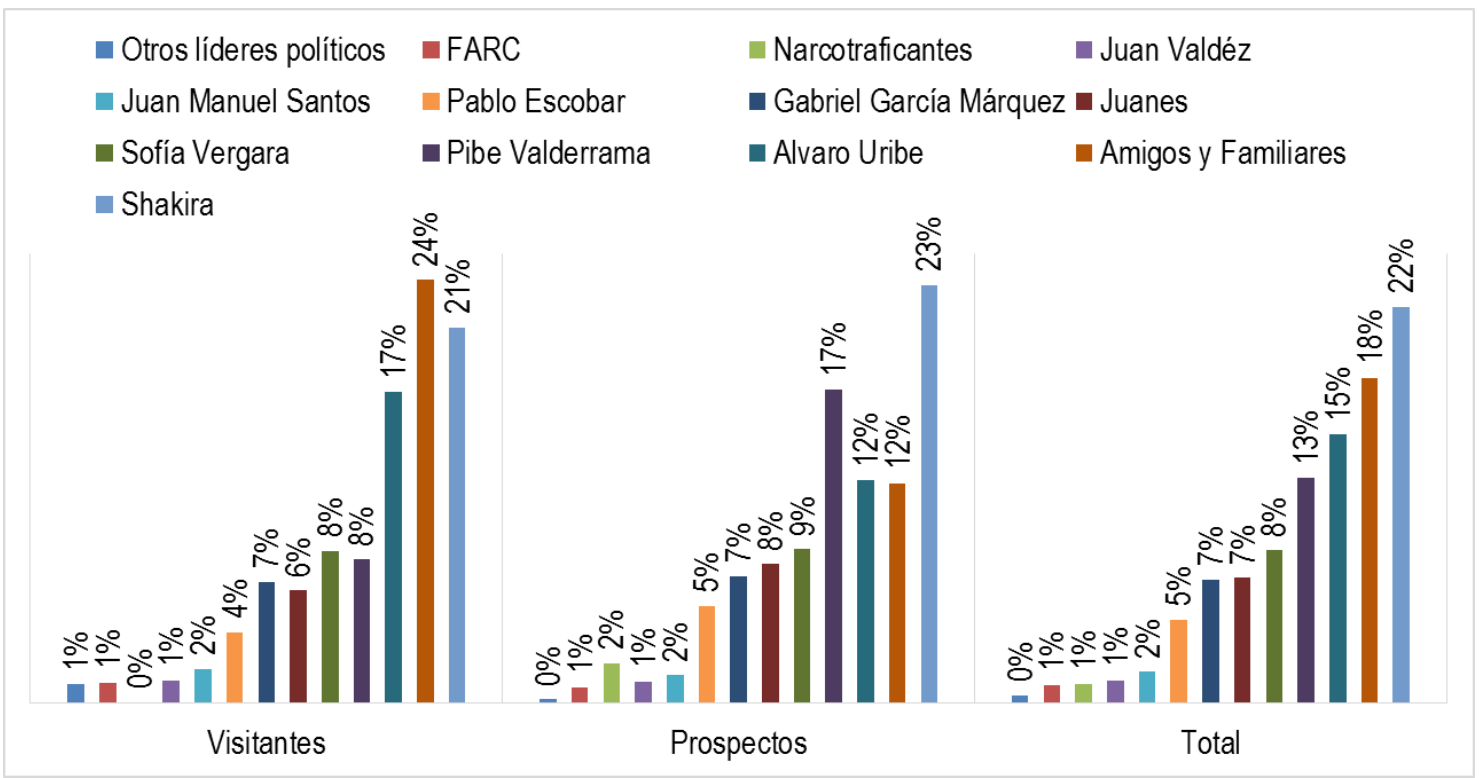

Fuente: elaboración propia.

Base: 1.544

Bogotá es la ciudad que tiene el mayor número de menciones del total de extranjeros encuestados (53\%). La capital del país se convierte en el epicentro de la imagen nacional para el extranjero (ver Figura 66).

Figura 66. Cuando se menciona a Colombia, ¿qué ciudad se le viene a la mente?

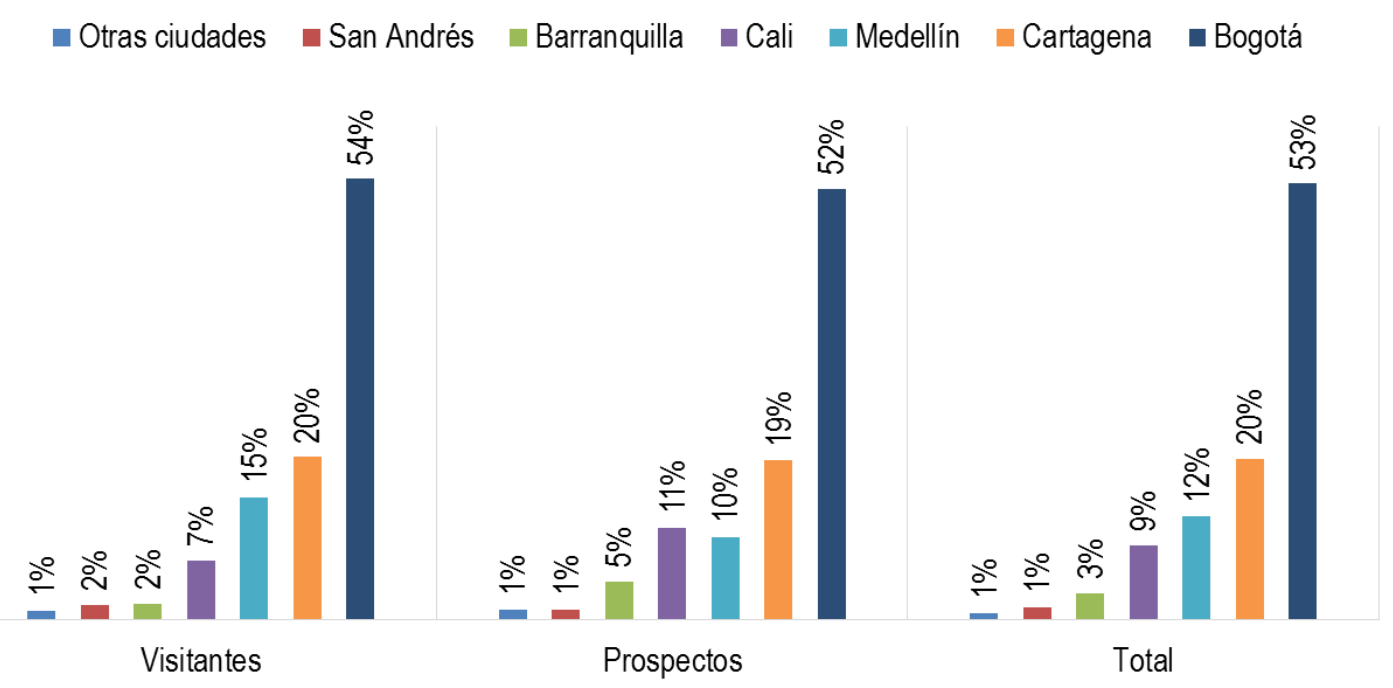

Fuente: elaboración propia.

Base: 1.544 


\section{Capítulo 5. Imagen país de Colombia}

\subsubsection{La imagen país de Colombia desde la perspectiva del visitante}

En el Análisis de Correspondencia aplicado al grupo de visitantes se consideró la relación existente entre variables demográficas (edad y país de origen) con las variables asociadas a la imagen país de Colombia. Según el Test Chi Cuadrado hay una asociación significativa (ver Cuadro 39):

Cuadro 39. Test Chi Cuadrado de Imagen país de Colombia y variables demográficas de los visitantes

\begin{tabular}{|l|c|c|c|c|}
\hline \multirow{2}{*}{ Variables } & \multicolumn{2}{|c|}{ Edad } & \multicolumn{2}{c|}{ País de Origen } \\
\cline { 2 - 5 } & $\mathbf{X}^{2}$ & Sig. & $\mathbf{X}^{2}$ & Sig. \\
\hline $\begin{array}{l}\text { ¿Qué es lo primero que piensa cuándo oye } \\
\text { la palabra Colombia? }\end{array}$ & 28,1 &, 404 & 326,9 &, 000 \\
\hline $\begin{array}{l}\text { ¿En una sola palabra describa algo positivo } \\
\text { de Colombia? }\end{array}$ & 62,2 &, 000 & 590,4 &, 000 \\
\hline $\begin{array}{l}\text { ¿En una sola palabra describa algo negativo } \\
\text { de Colombia? }\end{array}$ & 54,9 &, 001 & 666,9 &, 000 \\
\hline $\begin{array}{l}\text { ¿Qué características tienen los } \\
\text { colombianos? }\end{array}$ & 28,8 &, 227 & 432,8 &, 000 \\
\hline
\end{tabular}

Fuente: elaboración propia.

Base: 760

En la Figura 68 se observa que los visitantes más jóvenes procedentes de México y Brasil asocian a Colombia con drogas y terrorismo (Echeverri et. al., 2013a).

Los estadounidenses de 29 y 39 años asocian al país con la selva, montañas y playa, los argentinos con negocios (Echeverri et al., 2014b), los peruanos con turismo, los chilenos entre 40 y 50 años con gente amable y acogedora; y los ecuatorianos mayores de 50 años con arte, cultura, gastronomía y mujeres bellas. 


\section{Capítulo 5. Imagen país de Colombia}

Figura 67. Análisis de correspondencia entre lo que piensan los visitantes extranjeros cuando oyen la palabra Colombia y variables demográficas: país de origen y edad

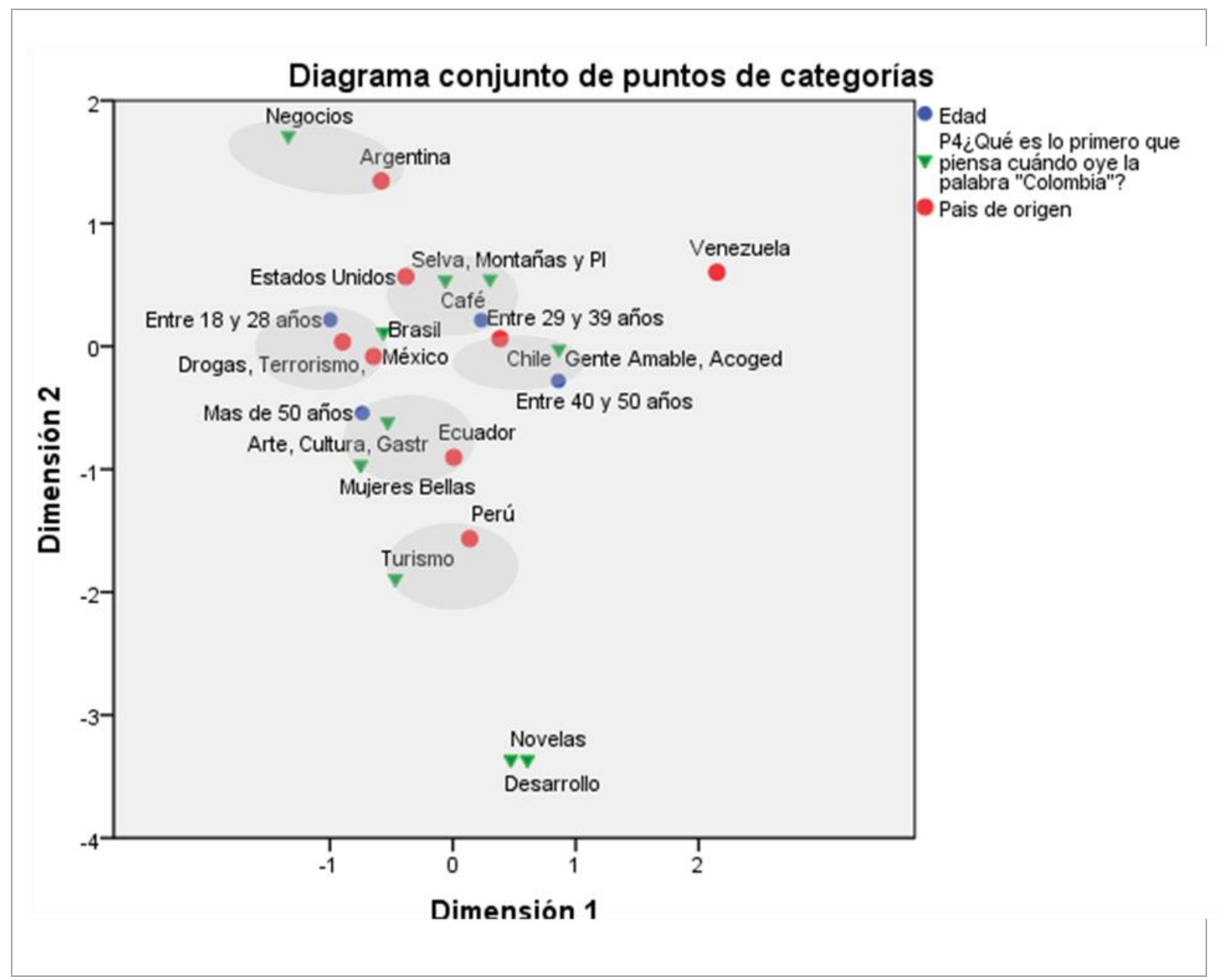

Fuente: elaboración propia.

Una vez aplicado el Análisis de Correspondencia, se encontró que existe relación entre los aspectos positivos asociados a Colombia con el perfil demográfico (edad y país de origen) de los visitantes extranjeros. 


\section{Capítulo 5. Imagen país de Colombia}

Como se aprecia en la Figura 689, los venezolanos entre 40 y 50 años asocian a Colombia con aspectos positivos como la naturaleza, las mujeres bellas y la gente amable. Los mexicanos mayores de 50 años indican que los aspectos positivos de Colombia son: el turismo, el arte, la cultura y el deporte. Para los peruanos y ecuatorianos, entre 29 y 39 años, la imagen país de Colombia se asocia con aspectos positivos como los negocios y el café. Los chilenos y argentinos por su parte, los más jóvenes de la muestra, indicaron que el buen clima y la alegría son los aspectos positivos que proyecta Colombia.

Lo anterior explica la diversidad de posicionamientos que tiene la imagen país que proyecta Colombia al mercado americano. Situación que debe evaluar la organización a cargo de la estrategia de Marca País Colombia.

Figura 68. Análisis de correspondencia entre los aspectos positivos de Colombia y variables demográficas: país de origen y edad de los visitantes extranjeros

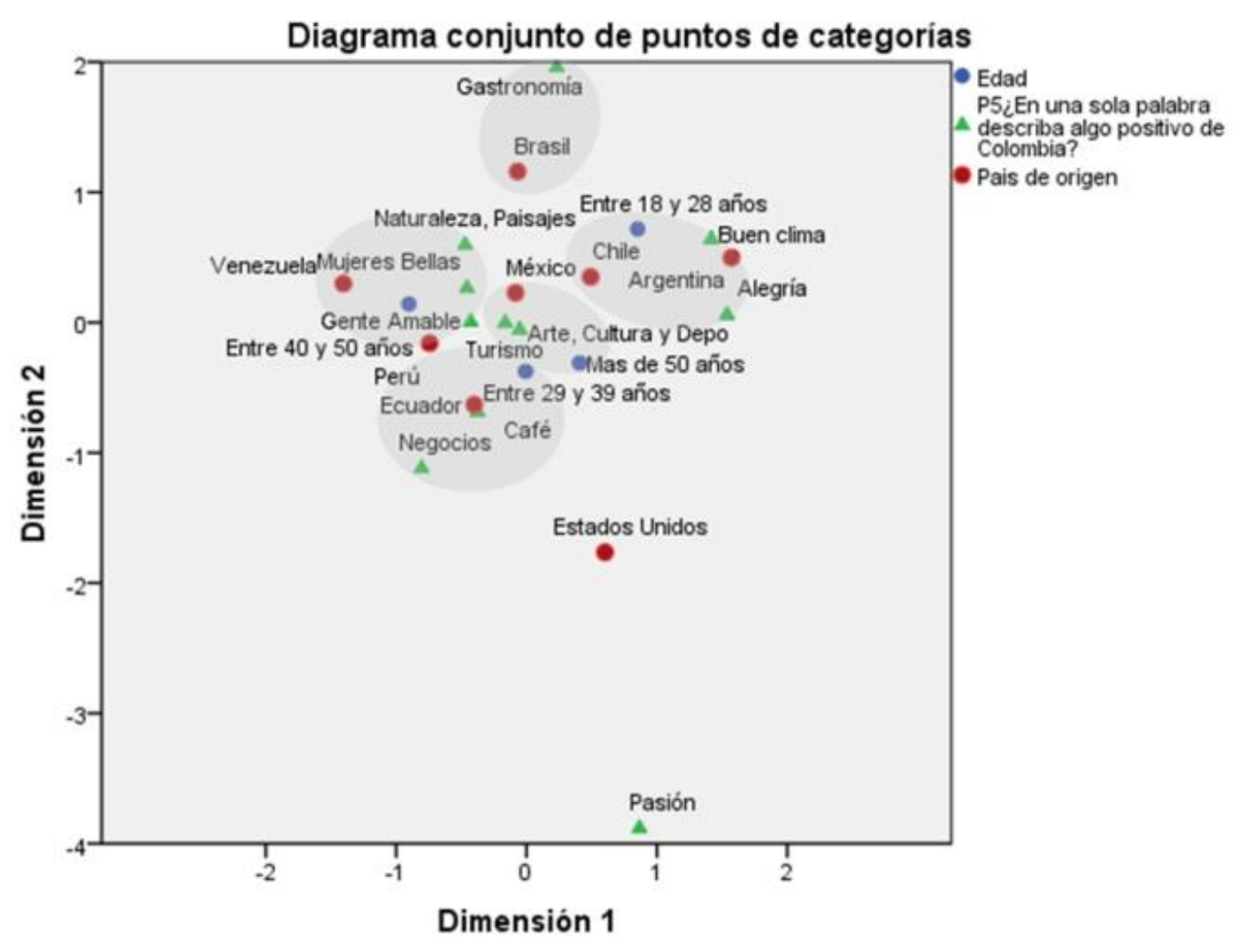

Fuente: elaboración propia. 


\section{Capítulo 5. Imagen país de Colombia}

Los visitantes más jóvenes de origen estadounidense y brasilero señalan que Colombia está asociada negativamente con las drogas, la inseguridad, el terrorismo y la congestión vehicular. Los mexicanos entre 29 y 39 años consideran que la imagen de Colombia está vinculada a la corrupción. Los chilenos, argentinos y peruanos relacionan a Colombia con el crimen y la guerrilla. Los venezolanos adultos mencionan que el narcotráfico es un aspecto negativo de Colombia. Y los ecuatorianos asocian a Colombia con la violencia. Los visitantes jóvenes y adultos coinciden en que la imagen de Colombia está relacionada con el narcotráfico.

Figura 69. Análisis de correspondencia entre los aspectos negativos de Colombia y variables demográficas: país de origen y edad de los visitantes extranjeros

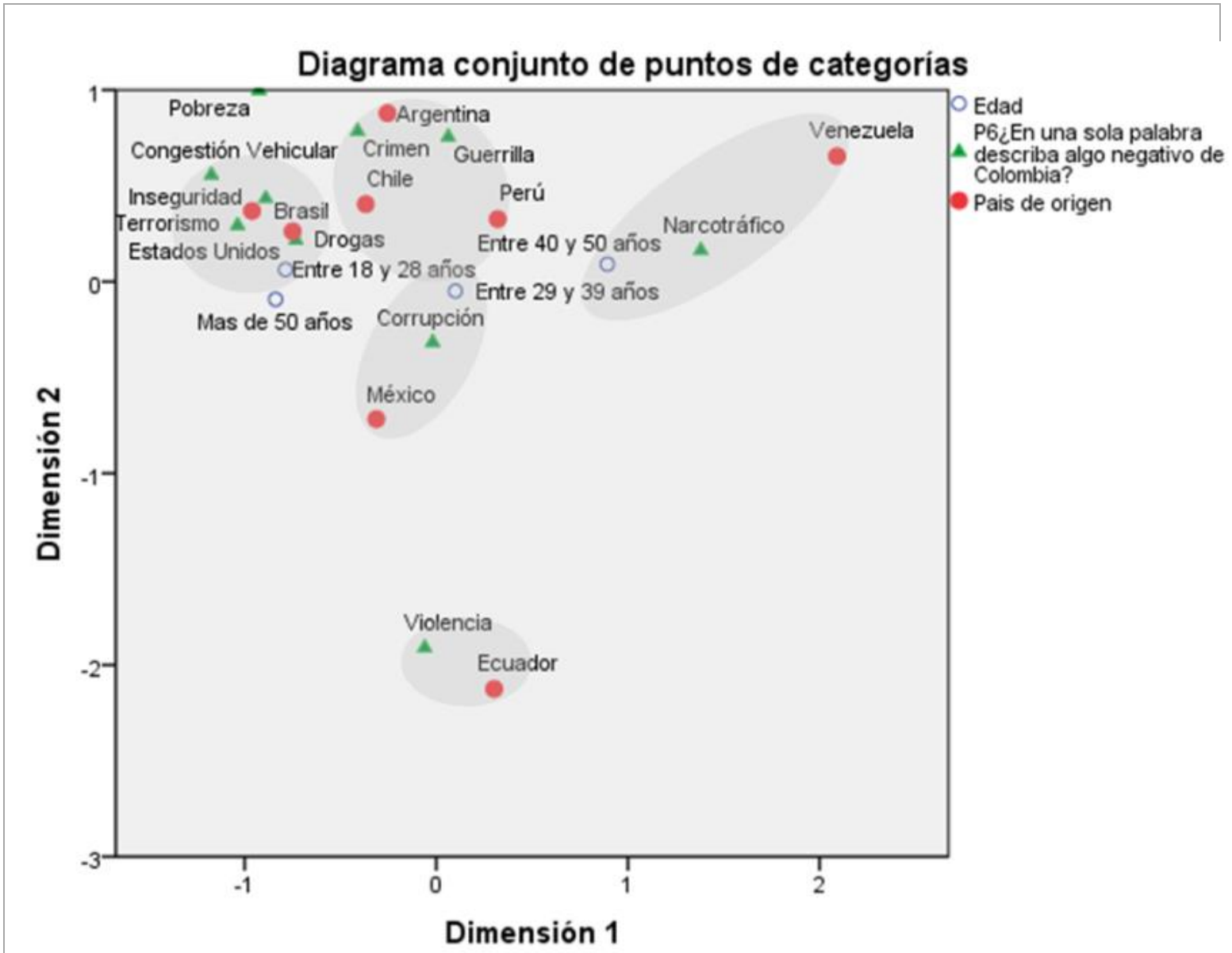

Fuente: elaboración propia. 


\section{Capítulo 5. Imagen país de Colombia}

En el plano factorial de la Figura 70, se puede observar que los peruanos y venezolanos consideran que los colombianos son acogedores, sociables y orgullosos de su país. Para los argentinos, el perfil del colombiano está estrechamente relacionado con la amabilidad. Para los estadounidenses, brasilero, ecuatoriano y chileno, el colombiano se caracteriza por ser alegre y divertido (Echeverri et al., 2014b). Y para los visitantes procedentes de México, la felicidad es una característica propia del colombiano (Echeverri et al., 2013a).

Figura 70. Análisis de correspondencia entre las características de los colombianos y país de origen de los visitantes extranjeros

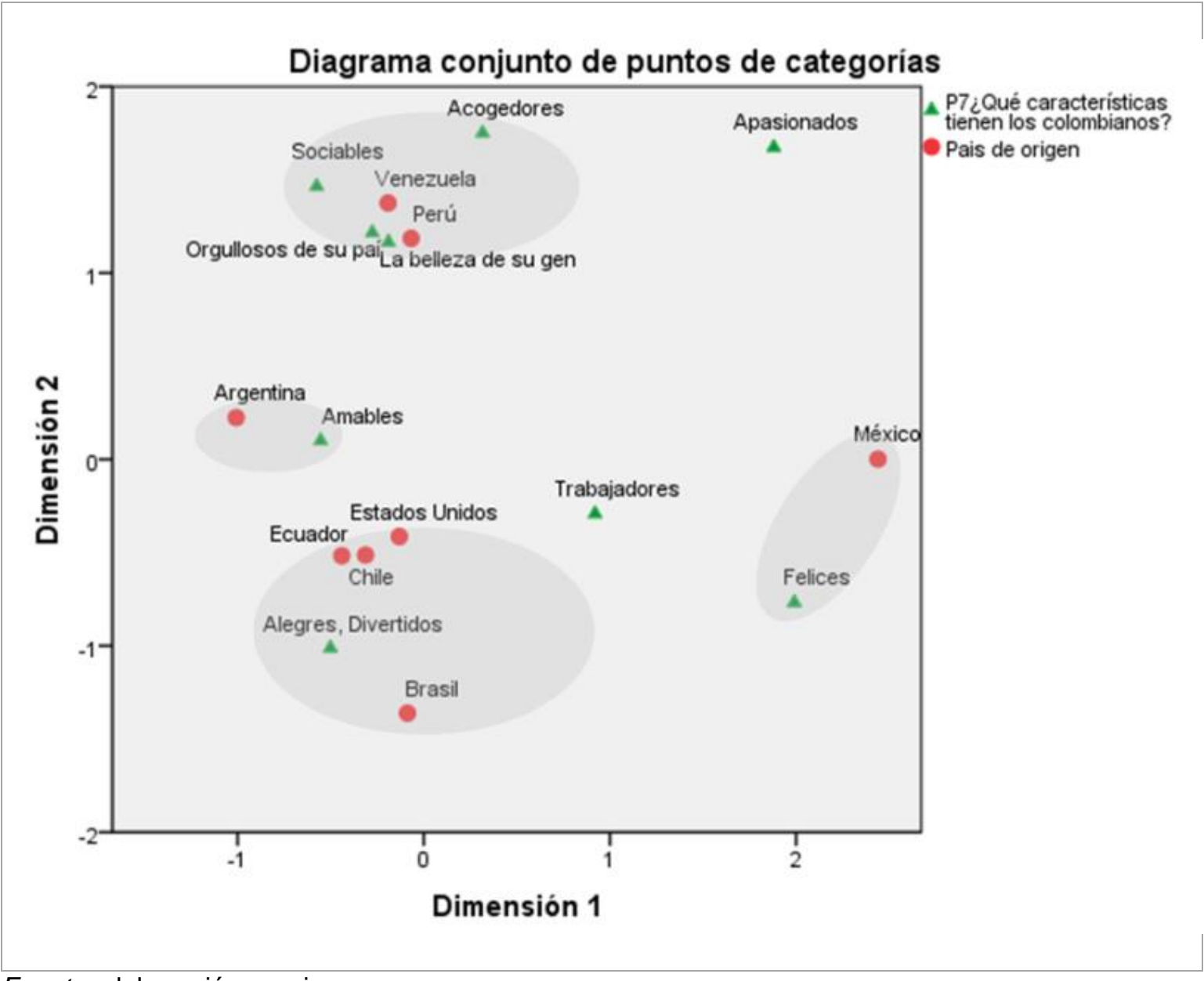

Fuente: elaboración propia. 


\section{Capítulo 5. Imagen país de Colombia}

Los resultados de la investigación presentan a continuación las apreciaciones y representaciones simbólicas que tienen los extranjeros sobre la imagen país de Colombia.

En el Análisis de Correspondencia aplicado al grupo de visitantes se consideró la relación existente entre variables demográficas (edad y país de origen) con las variables vinculadas a la asociación simbólica de la imagen país de Colombia. Según el Test Chi Cuadrado hay una asociación significativa (ver Cuadro 40):

Cuadro 40. Test Chi Cuadrado de Asociación Simbólica de la imagen país de Colombia y variables demográficas de los visitantes

\begin{tabular}{|l|c|c|c|c|}
\hline \multirow{2}{*}{\multicolumn{1}{|c|}{ Variables }} & \multicolumn{2}{c|}{ Edad } & \multicolumn{2}{c|}{ País de Origen } \\
\cline { 2 - 5 } & $\mathbf{X}^{2}$ & Sig. & $\mathbf{X}^{2}$ & Sig. \\
\hline ¿Para usted qué color tiene Colombia? & 24,8 &, 131 & 203,7 &, 000 \\
\hline ¿Para usted qué olor tiene Colombia? & 21,4 &, 045 & 189,5 &, 000 \\
\hline ¿Qué símbolo representa a Colombia? & 56,3 &, 007 & 333,8 &, 000 \\
\hline $\begin{array}{l}\text { Cuando se menciona a Colombia ¿con qué } \\
\text { persona la asocia? }\end{array}$ & 100,2 &, 000 & 548,0 &, 000 \\
\hline
\end{tabular}

Fuente: elaboración propia.

Base: 760

El color está estrechamente vinculado a los estados de ánimo, sentimientos y emociones. Al grupo de visitantes se les preguntó sobre el color y olor (aroma) que más se relaciona con el país. Los extranjeros mostraron respuestas diferentes en términos de asociación del país con el color. Los peruanos asocian a Colombia con el blanco, los brasileros con el café y el verde, los estadounidenses con el azul (Echeverri et al., 2014b), los venezolanos con el rojo; y los argentinos y ecuatorianos con el amarillo (ver Figura 72).

Mientras que la percepción de color y el olor es subjetiva, hay algunos efectos de color que tienen un significado universal. Colores en la zona roja del espectro de color se conocen como colores cálidos como el rojo, naranja y amarilla. Estos colores cálidos evocan emociones que van desde sentimientos de calidez y confort a los sentimientos de ira y hostilidad (Elliot \& Maier, 2012). Argentina Ecuador y Venezuela asocian a Colombia con estos colores. Cabe anotar que estos tres países suramericanos representan el turismo emisor más alto hacia Colombia. 


\section{Capítulo 5. Imagen país de Colombia}

Los colores en la parte azul del espectro se conocen como colores fríos e incluyen azul, púrpura y verde. Estos colores se relacionan con la calma, pero también son asociados a sentimientos de tristeza o indiferencia (Zelanski \& Fisher, 2001). En este caso, Estados Unidos y Brasil vinculan la imagen país de Colombia con estos colores (Echeverri et al., 2013).

Figura 71. Análisis de correspondencia entre el color que más se asocia a Colombia y el país de origen

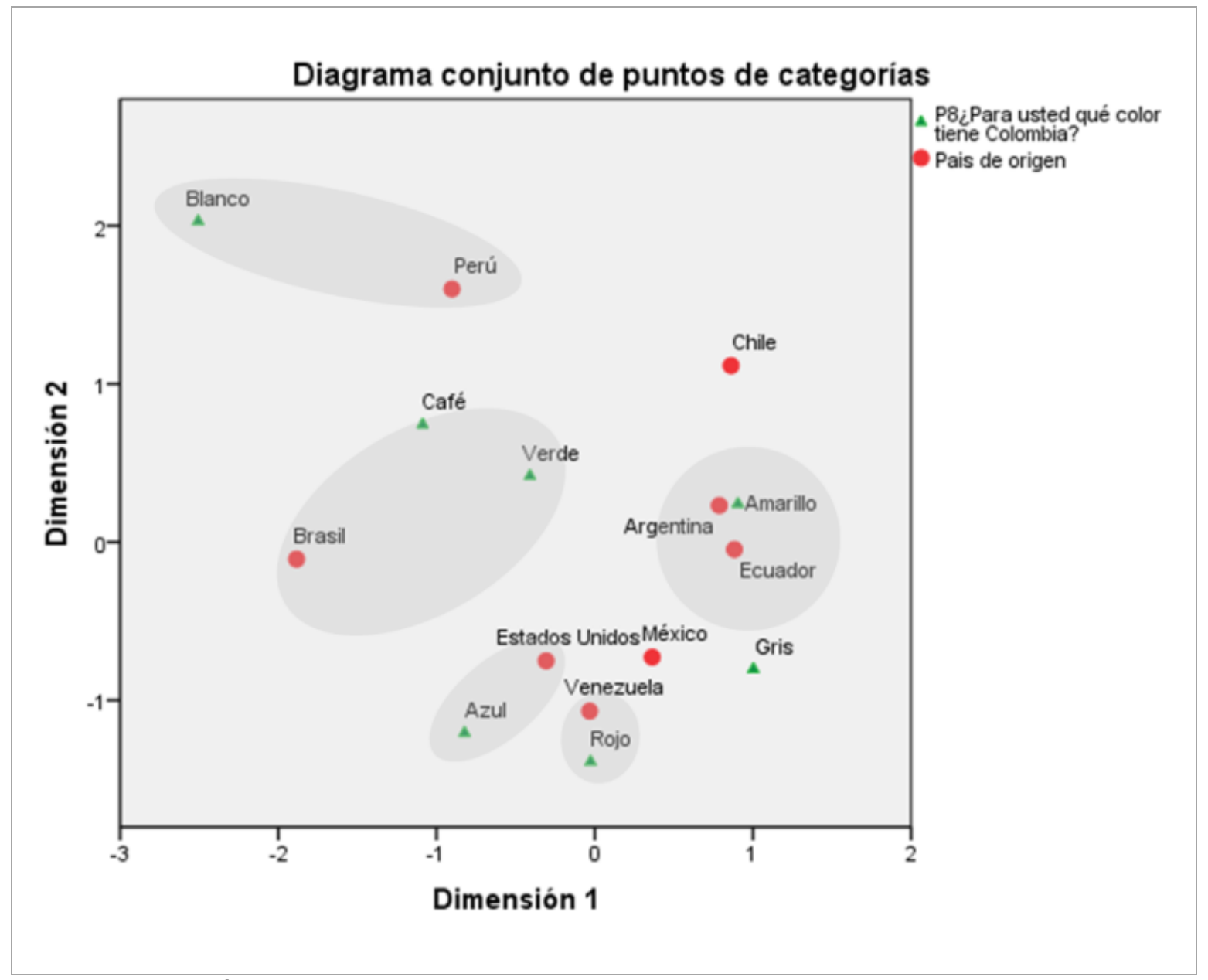

Fuente: elaboración propia. 


\section{Capítulo 5. Imagen país de Colombia}

Los expertos han encontrado que el color puede tener una influencia en los sentimientos y en las acciones de las personas, estos efectos están sujetos a factores personales, culturales y situacionales. El olfato es el sentido más complejo de estudiar. Pero también es el sentido del olfato, el que atrae la mayor parte de nuestras emociones y recuerdos (Díez López, 2013). El aroma ayuda a crear un vínculo emocional con una marca, en este caso con una marca país. Los olores se convierten en marcadores de memoria. En lo referente al olor de Colombia, también hay diferencias notables por país. Para los venezolanos, la imagen de Colombia está vinculada al aroma de la gastronomía.

Los argentinos la asocian con el aroma de los océanos, los peruanos con la naturaleza y los mexicanos mayores de 50 años la relacionan con el aroma de las flores. Para los visitantes procedentes de Brasil y Ecuador, que tienen entre 29 y 39 años, la imagen de Colombia está ligada al olor del café.

Figura 72. Análisis de correspondencia entre el olor que más se asocia a Colombia y variables demográficas: país de origen y edad de los visitantes

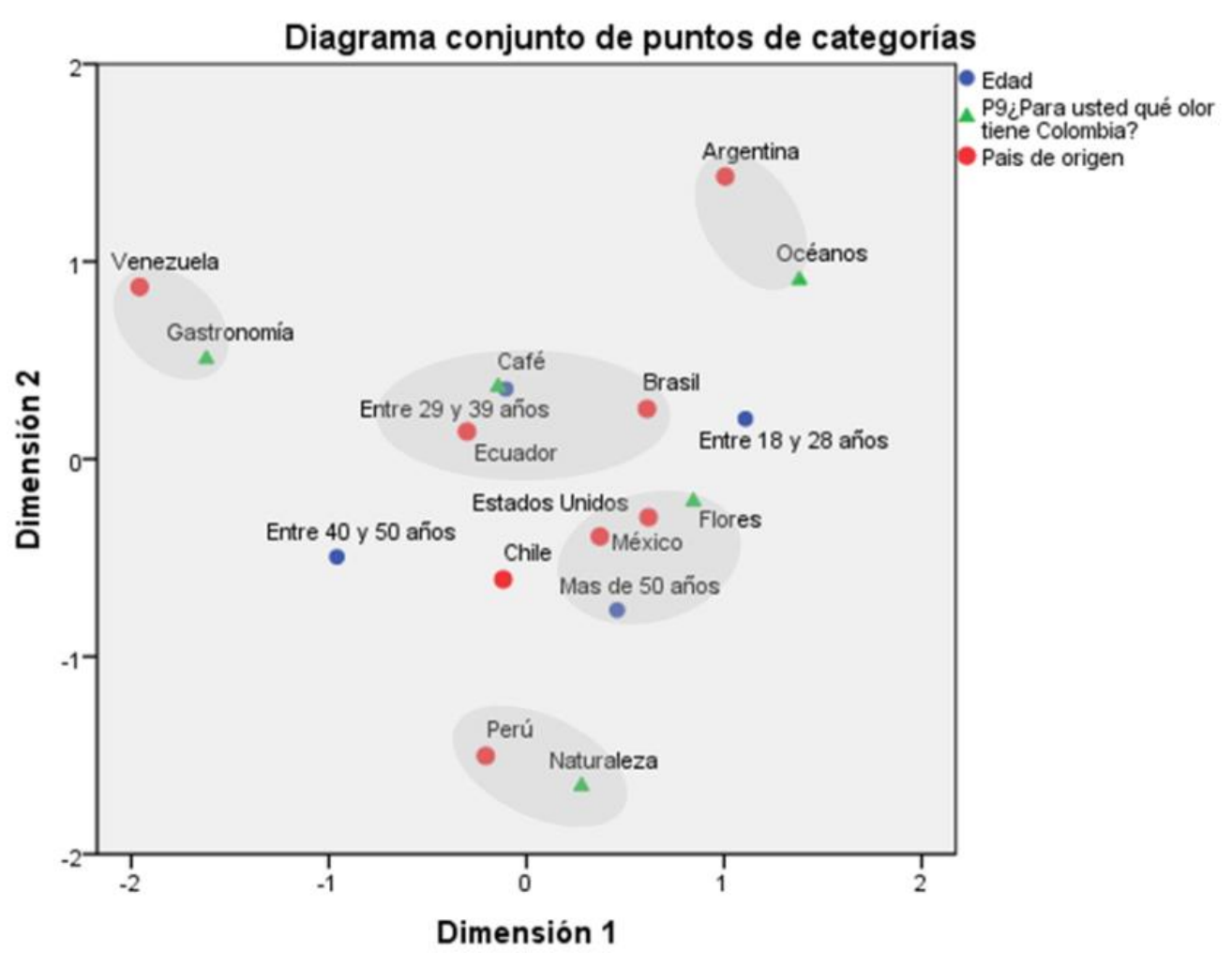

Fuente: elaboración propia. 


\section{Capítulo 5. Imagen país de Colombia}

Como se observa desde un plano factorial en la Figura 73, los visitantes más jóvenes procedentes de Brasil, México y Argentina, asocian a Colombia con el café y la bandera nacional (Echeverri et al., 2013a). Los visitantes chilenos, entre 29 y 39 años relacionan la imagen del país con la marca comercial Juan Valdez, las drogas, la música, la chiva y el sombrero vueltiao.

Los visitantes de origen peruano indicaron que las montañas, las aves, los ríos y las piedras preciosas representan Y los mayores de 40 años, como en el caso de venezolanos, asocian a Colombia con las flores; y los estadounidenses con el fútbol, artistas y deportistas (Echeverri et al., 2014b). Lo anterior refleja nuevamente un posicionamiento polarizado, en muchos campos, en diferentes símbolos. Esto motiva la necesidad de evaluar los atributos más cercanos con la imagen de Colombia que ayudarán a posicionar la estrategia de marca país.

Figura 73. Análisis de correspondencia entre el símbolo que representa a Colombia y variables demográficas: país de origen y edad de los visitantes

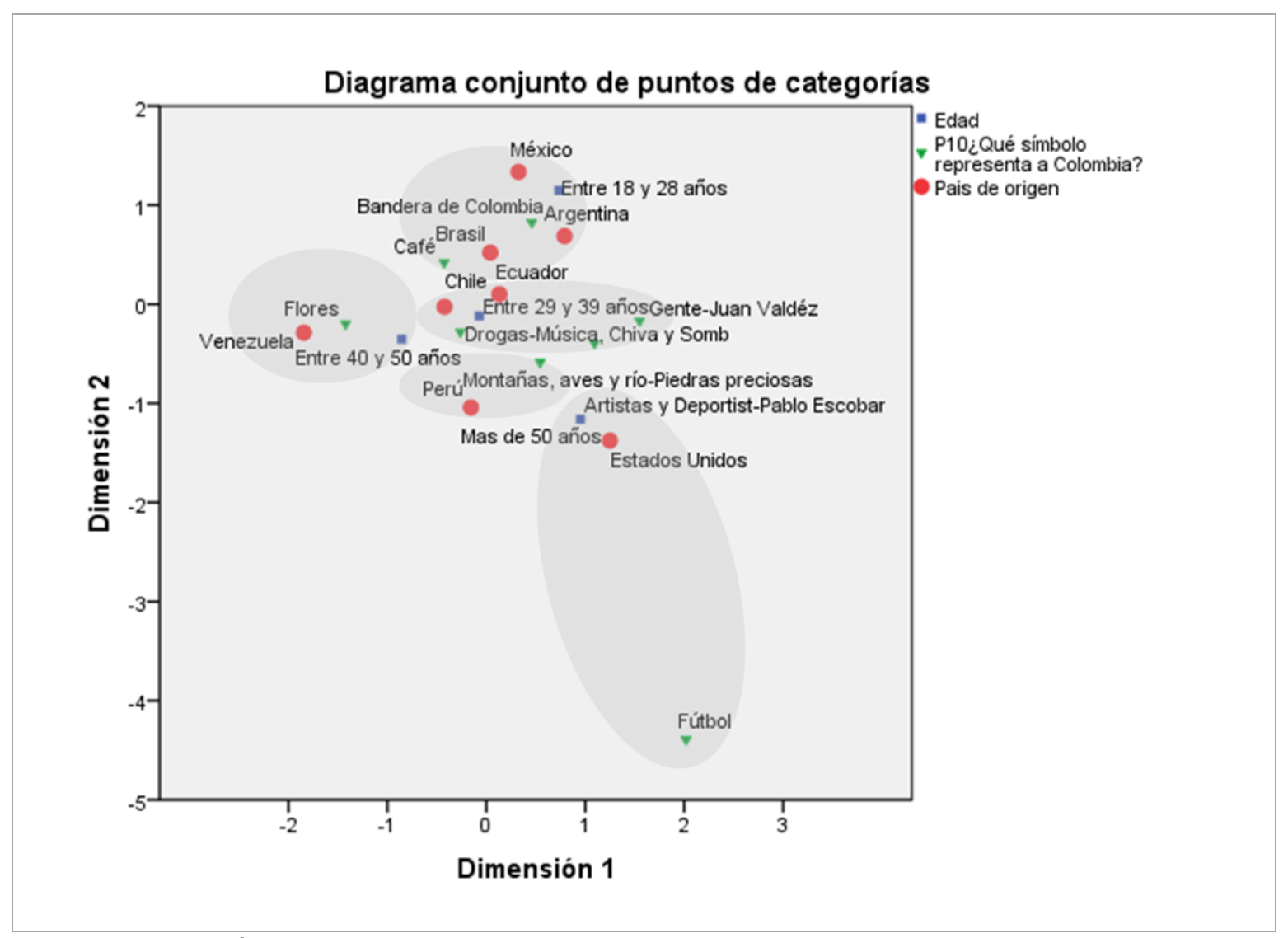

Fuente: elaboración propia. 


\section{Capítulo 5. Imagen país de Colombia}

En la Figura 74 se puede apreciar, que los visitantes de origen venezolano asocian a Colombia con amigos y familiares. Los argentinos vinculan la imagen con personajes como Hugo Chávez, Pibe Valderrama y el presidente Juan Manuel Santos. Los mexicanos más jóvenes (entre 18 y 28 años) indican que Shakira es quien representa la imagen país de Colombia (Echeverri et al., 2014a). Los visitantes peruanos entre 40 y 50 años relacionan a Colombia con el ex presidente Álvaro Uribe. Para los estadounidenses y los ecuatorianos, el narcotraficante ya fallecido Pablo Escobar, el escritor Gabriel García Márquez y el artista Juanes están estrechamente vinculados a la imagen nacional. Y en el caso de los brasileros mayores de 50 años, la marca comercial Juan Valdez, la actriz Sofía Vergara y los guerrilleros de las FARC, son los personajes que más representan a Colombia. Un aspecto en común entre los extranjeros visitantes, es que hay una notable asociación hacia líderes políticos y culturales.

Figura 74. Análisis de correspondencia entre la persona que se asocia a Colombia y variables demográficas: país de origen y edad de los visitantes

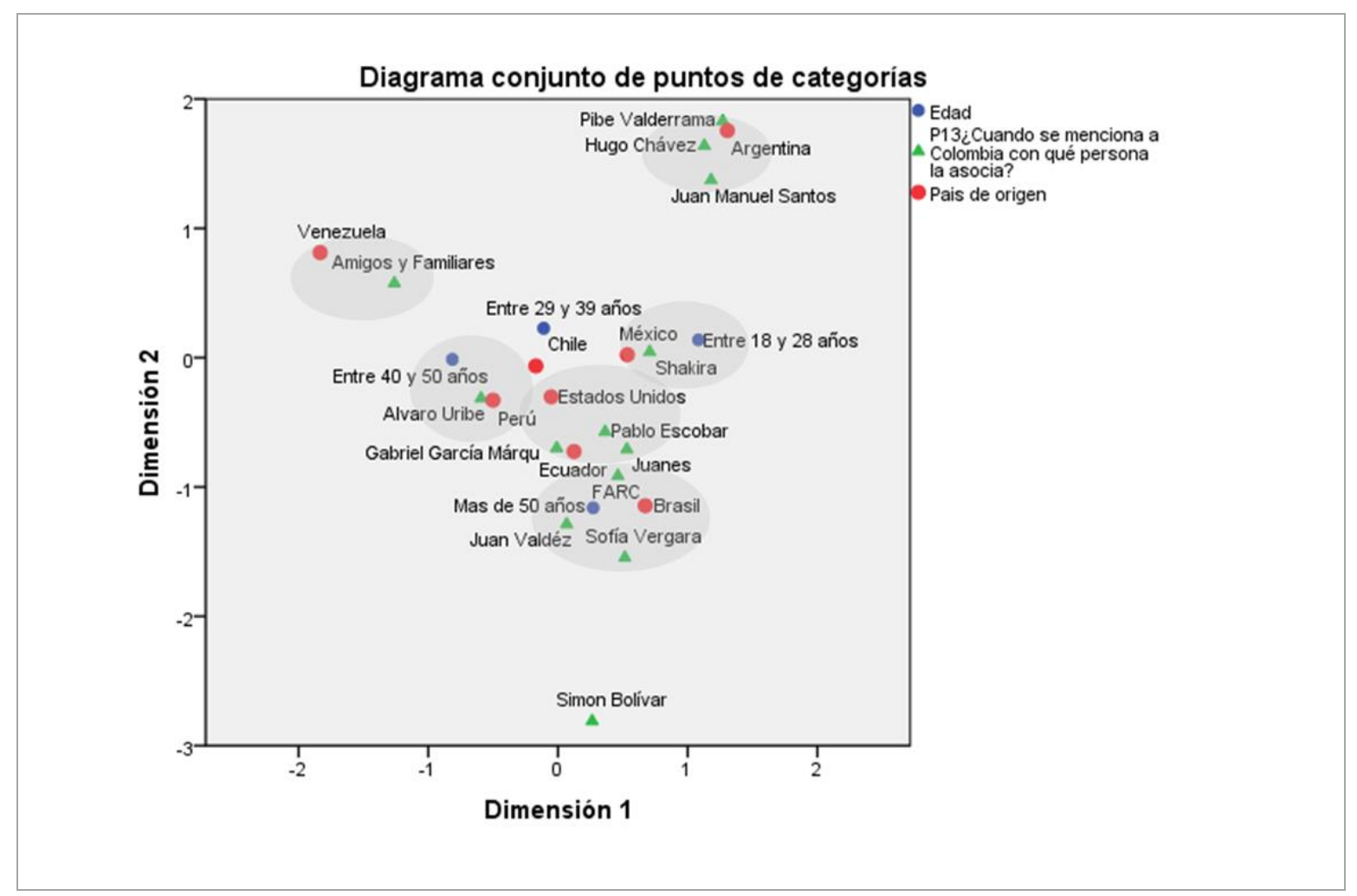

Fuente: elaboración propia. 


\section{Capítulo 5. Imagen país de Colombia}

Los extranjeros que han visitado a Colombia, señalaron que lo que más le gustó de Colombia fue la gente amable (36\%). Seguido en menor proporción de lugares turísticos (17\%), Gastronomía (15\%) y Naturaleza (13\%).

Figura 75. ¿En su visita que fue lo que más le gustó de Colombia?

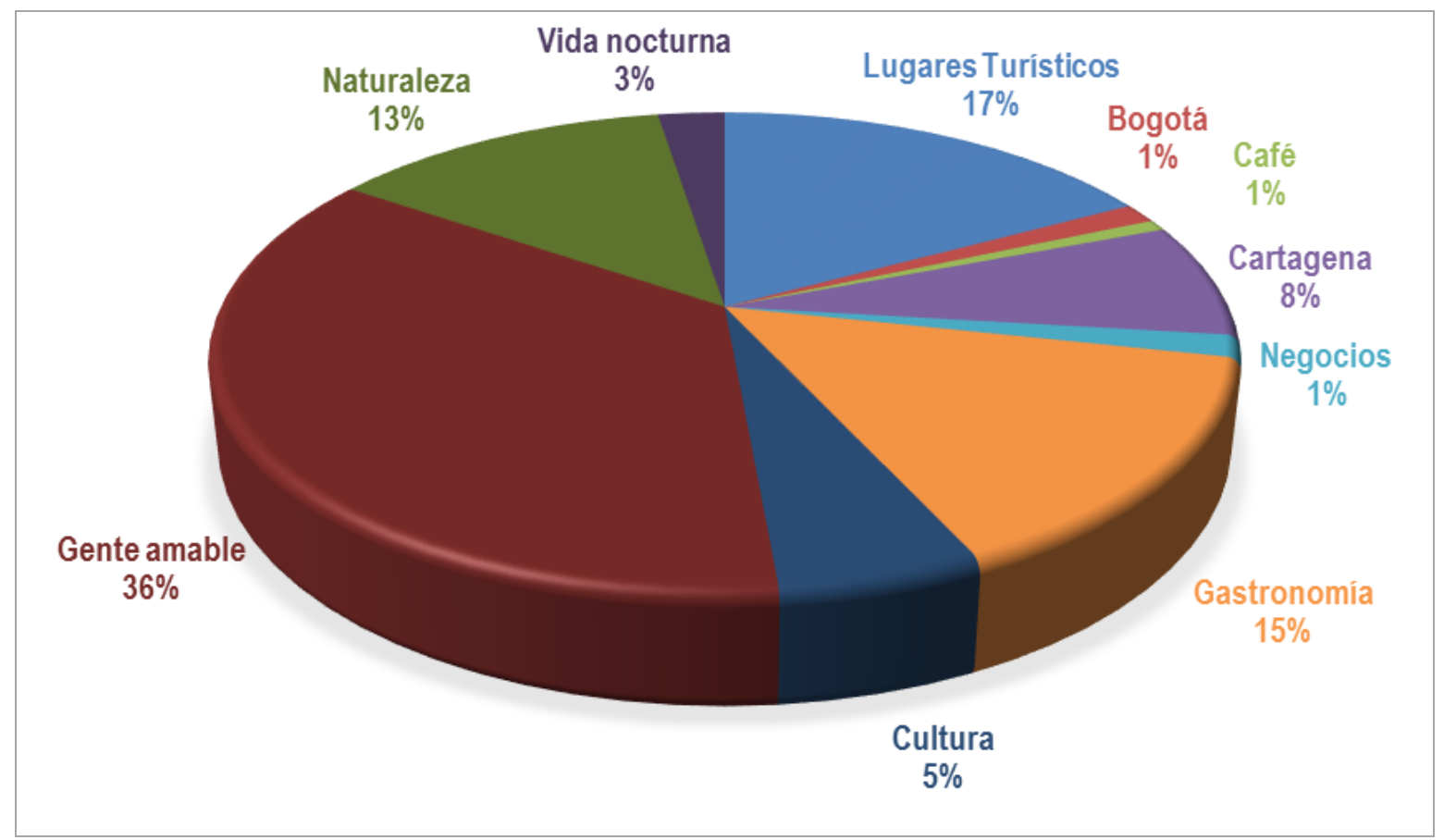

Fuente: elaboración propia.

Base: 760

Para los estadounidenses lo que más le gustó en su visita a Colombia fue la vida nocturna, la naturaleza, la cultura, el café, Cartagena y Bogotá (Echeverri et al., 2013b). Los venezolanos señalaron que los lugares turísticos y la gastronomía fueron los aspectos que más valoraron en su visita. Y para los ecuatorianos, la gente amable fue lo que más les gustó en su visita en Colombia (Echeverri et al., 2013b).

Lo que menos le gustó a los extranjeros durante su visita a Colombia fue la congestión vehicular (32\%), la inseguridad (23\%) y la pobreza (16\%). 


\section{Capítulo 5. Imagen país de Colombia}

Figura 76. ¿En su visita que fue lo que menos le gustó de Colombia?

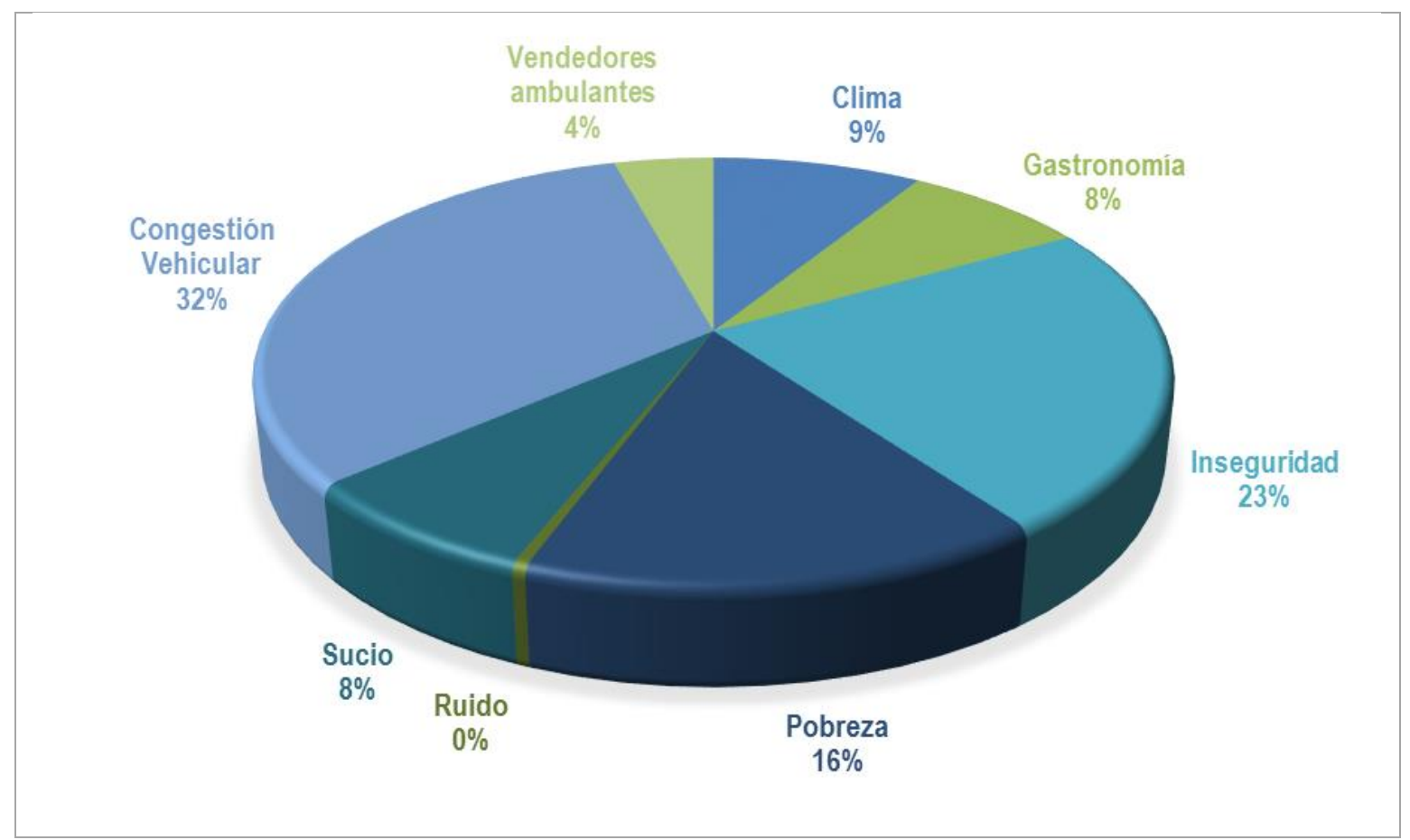

Fuente: elaboración propia.

Base: 760

Los estadounidenses calificaron el clima y la suciedad como los aspectos que menos les gustó de Colombia. Para los venezolanos la pobreza y el tráfico; y para los ecuatorianos la inseguridad (Echeverri et al., 2013b).

Del total de la muestra, la mayoría de los visitantes (97\%) señalaron que en su última visita cambió la percepción del país. Predomina el interés por regresar a Colombia por parte de los extranjeros que ya lo visitaron.

Este resultado demuestra que la experiencia del visitante en el país genera un cambio en la percepción favorable para el posicionamiento de Colombia. Y dada la experiencia positiva, el $98 \%$ de los visitantes recomendaría a un amigo visitar a Colombia. 


\section{Capítulo 5. Imagen país de Colombia}

Figura 77. Preferencias e intereses en Colombia según los extranjeros visitantes

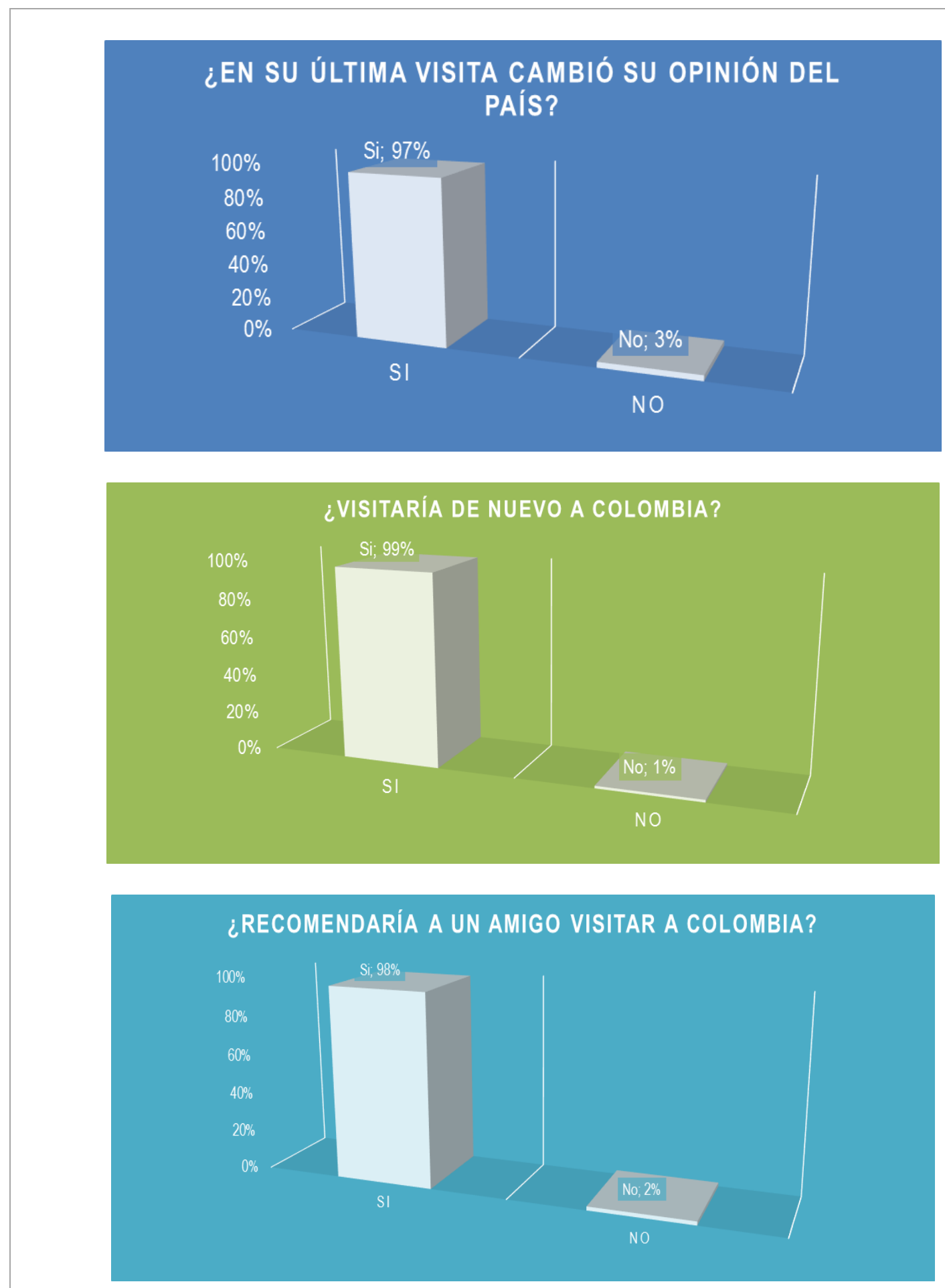

Fuente: elaboración propia.

Base: 760 


\section{Capítulo 5. Imagen país de Colombia}

\subsubsection{La imagen país de Colombia desde la perspectiva del prospecto}

En el Análisis de Correspondencia aplicado al grupo de prospectos, se consideró la relación existente entre variables demográficas (edad y país de origen) con las variables asociadas a la imagen país de Colombia. Según el Test Chi Cuadrado hay una asociación significativa (ver Cuadro 41):

Cuadro 41. Test Chi Cuadrado de Imagen país de Colombia y variables demográficas de los prospectos

\begin{tabular}{|l|c|c|c|c|}
\hline \multirow{2}{*}{ Variables } & \multicolumn{2}{c|}{ Edad } & \multicolumn{2}{c|}{ País de Origen } \\
\cline { 2 - 5 } & $\mathbf{X}^{2}$ & Sig. & $\mathbf{X}^{2}$ & Sig. \\
\hline $\begin{array}{l}\text { ¿Qué es lo primero que piensa cuándo oye } \\
\text { la palabra Colombia? }\end{array}$ & 47,558 &, 009 & 723,261 &, 000 \\
\hline $\begin{array}{l}\text { ¿En una sola palabra describa algo positivo } \\
\text { de Colombia? }\end{array}$ & 33,794 &, 429 & 695,536 &, 000 \\
\hline $\begin{array}{l}\text { ¿En una sola palabra describa algo negativo } \\
\text { de Colombia? }\end{array}$ & 33,238 &, 189 & 623,922 &, 000 \\
\hline $\begin{array}{l}\text { ¿Qué características tienen los } \\
\text { colombianos? }\end{array}$ & 41,835 &, 034 & 417,754 &, 000 \\
\hline
\end{tabular}

Fuente: elaboración propia.

Base: 784

Los extranjeros que aún no han visitado el país tienen impresiones claramente muy distintas. En la Figura 78, se puede observar que los prospectos procedentes de Argentina y Chile asocian la palabra Colombia con el café, las selvas, las montañas y las playas. Los venezolanos la asocian con arte, cultura y gastronomía. Los ecuatorianos relacionan a Colombia con turismo y desarrollo, los brasileros entre 40 y 50 años con drogas, terrorismo, inseguridad y corrupción.

Los estadounidenses y peruanos entre 29 y 39 años asocian la palabra Colombia con gente amable, acogedora, alegre y mujeres bellas. 


\section{Capítulo 5. Imagen país de Colombia}

Figura 78. Análisis de correspondencia entre lo que piensan los prospectos extranjeros cuando oyen la palabra Colombia y variables demográficas: país de origen y edad

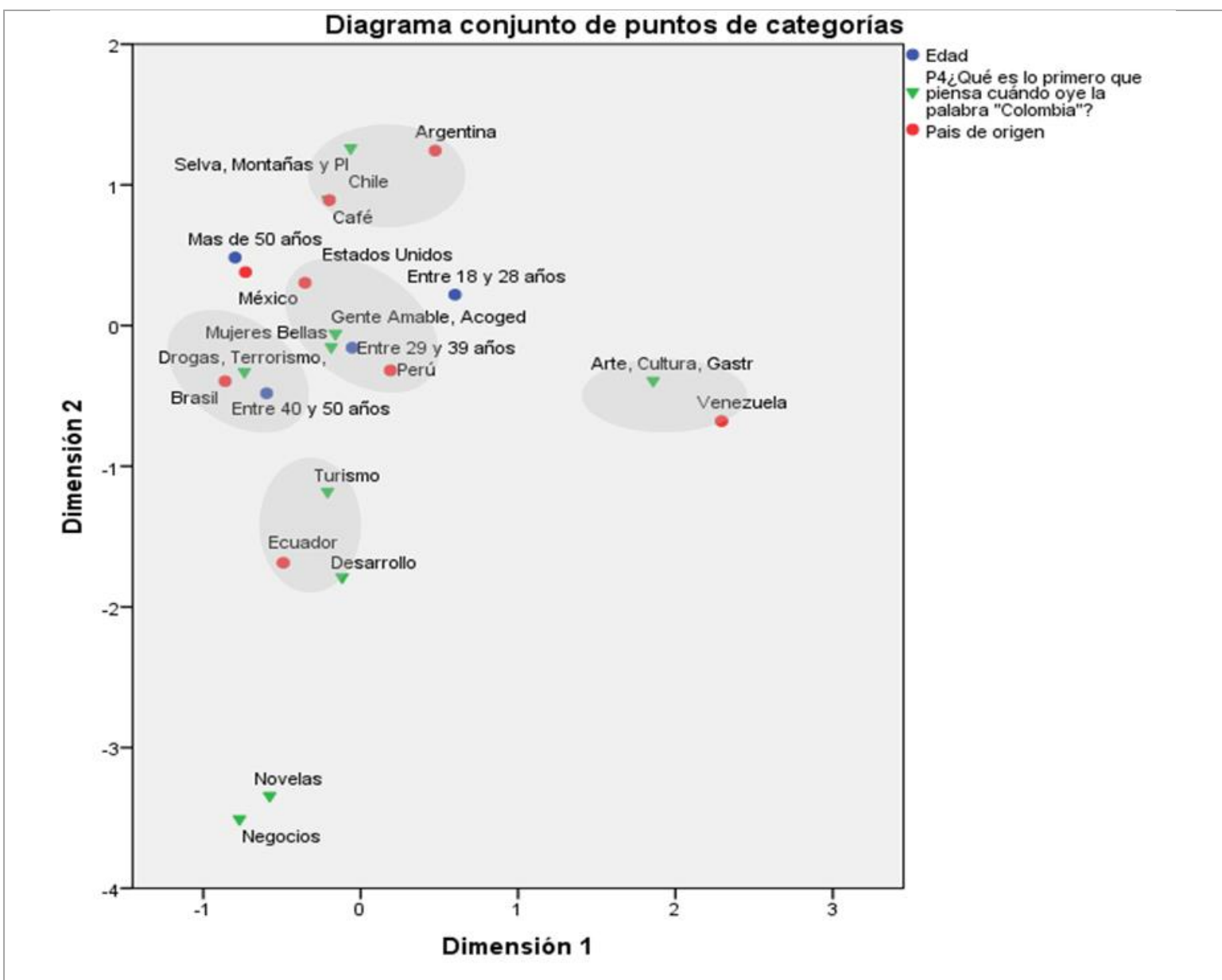

Fuente: elaboración propia.

El punto de vista positivo de la imagen de Colombia varía según el país de origen de los prospectos. Para los mexicanos y argentinos un aspecto positivo es el buen clima, para los venezolanos la gente amable y para los chilenos, la alegría del colombiano (Echeverri et al., 2014a).

Los prospectos procedentes de Brasil indicaron que la gastronomía es un aspecto positivo de Colombia. Para los estadounidenses que aún no han visitado a Colombia, las mujeres bellas y el café favorecen la imagen del país. En cuanto a los peruanos y ecuatorianos, el turismo es el aspecto positivo que más se asocia con Colombia. 


\section{Capítulo 5. Imagen país de Colombia}

Como se puede observar en la Figura 79, la imagen de Colombia es multidimensional. El país de origen de los prospectos es una dimensión que influye los puntos de vista positivos como negativos.

Figura 79. Análisis de correspondencia entre los aspectos positivos de Colombia y variables demográficas: país de origen de los prospectos.

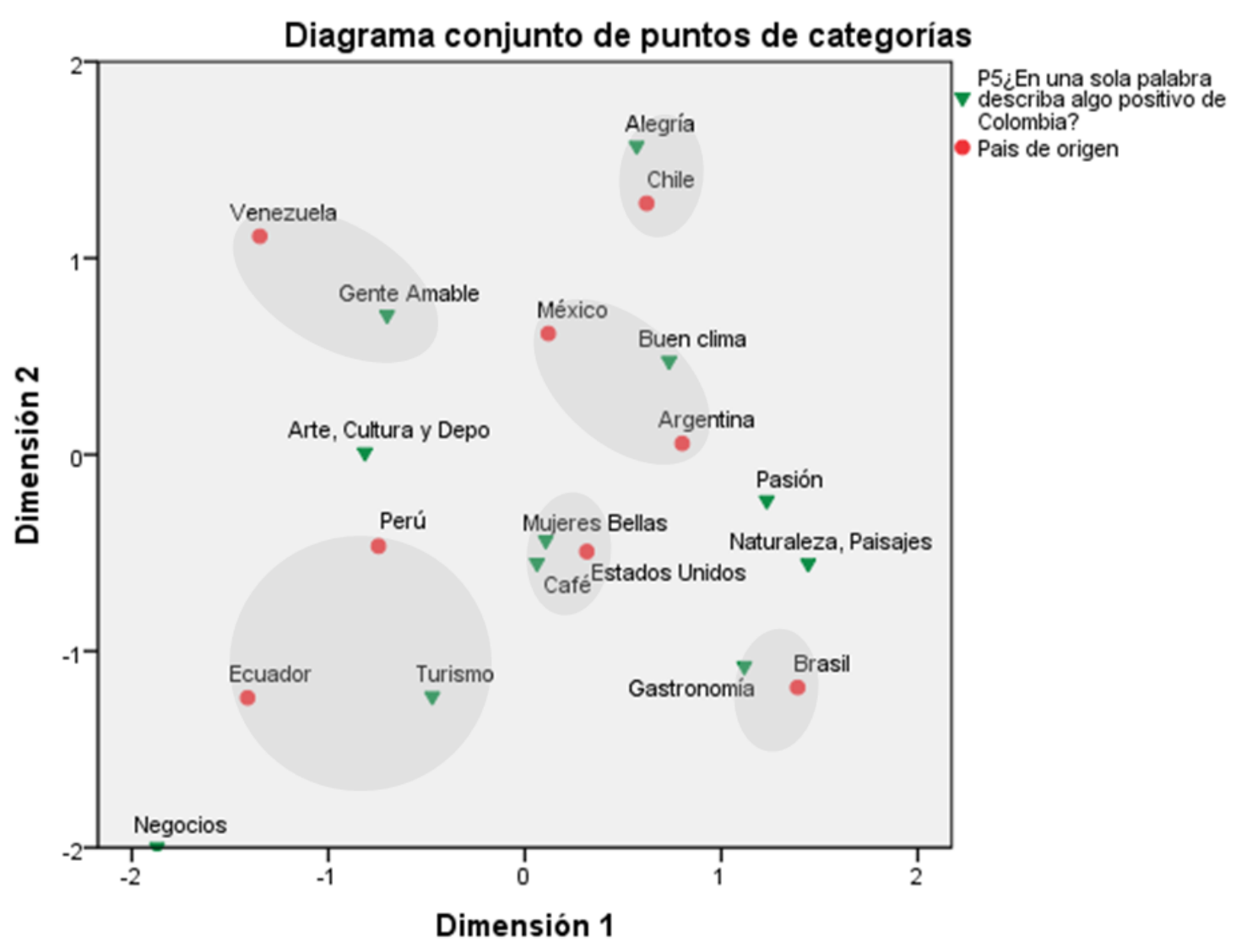

Normalización principal por variable.

Fuente: elaboración propia. 


\section{Capítulo 5. Imagen país de Colombia}

Los ecuatorianos que aún no han visitado a Colombia destacan que la violencia es un aspecto que afecta su imagen. Los peruanos relacionan a Colombia con el narcotráfico y la guerrilla. Los estadounidenses asocian al país con crimen.

Los brasileros señalaron que los aspectos negativos que perciben son: la congestión vehicular, la pobreza y las drogas. Los mexicanos, chilenos y argentinos que no han viajado a Colombia, asocian su imagen con corrupción, inseguridad y terrorismo (ver Figura 80).

Figura 80. Análisis de correspondencia entre los aspectos negativos de Colombia y variables demográficas: país de origen de los prospectos

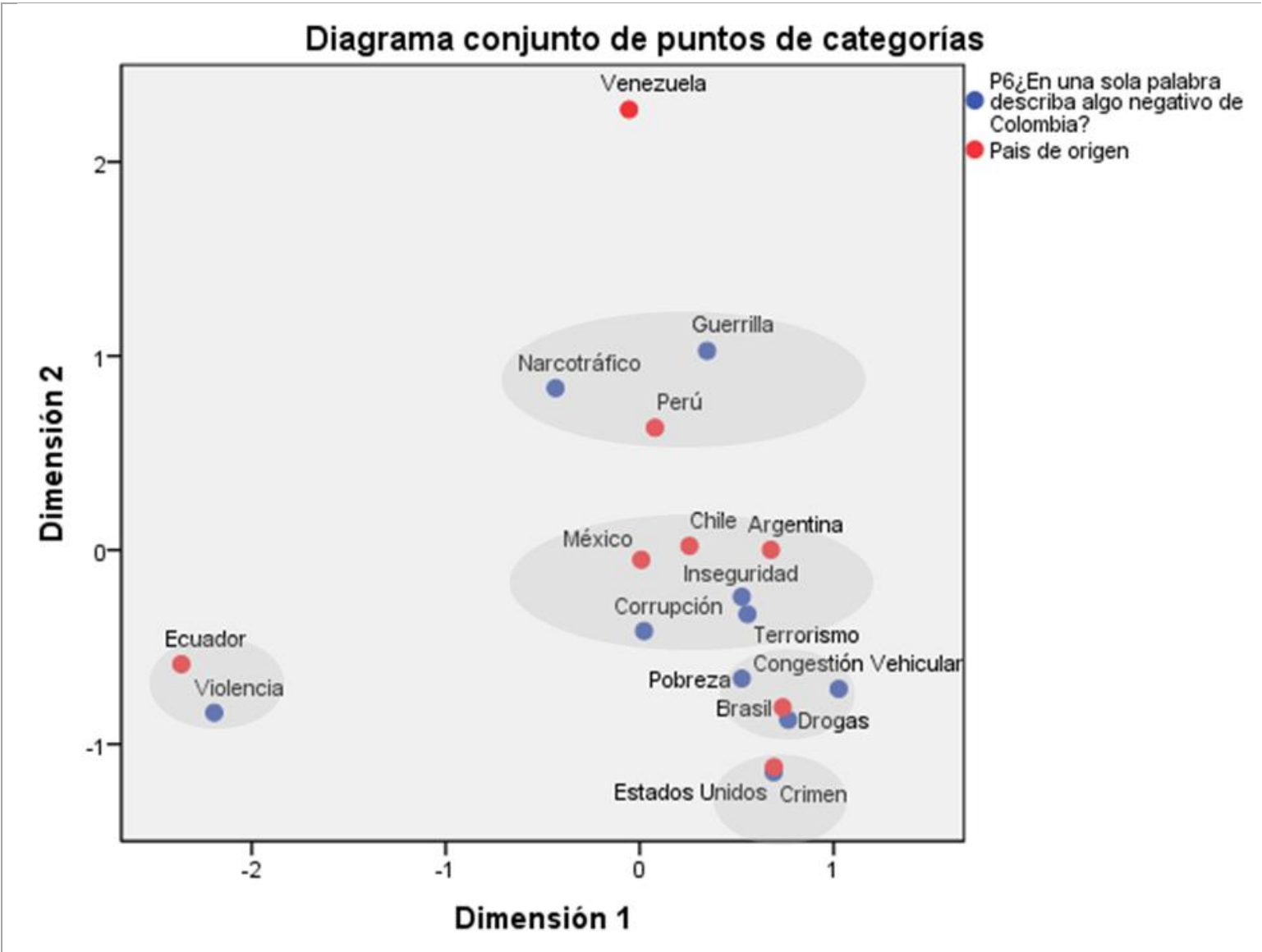

Fuente: elaboración propia. 


\section{Capítulo 5. Imagen país de Colombia}

El reto para una marca país es consolidar una imagen positiva en el mercado. Las percepciones crean un proceso consciente y deliberado mensajes y experiencias acerca de un país, situación que debe transformarse en una experiencia distintiva, convincente, memorable y lo más gratificante posible. Para los brasileros, los colombianos se caracterizan por ser creyentes y felices. Para los ecuatorianos entre 40 y 50 años, los colombianos son trabajadores (ver Figura 81).

Figura 81. Análisis de correspondencia entre las características que tienen los colombianos y variables demográficas: país de origen y edad de los prospectos

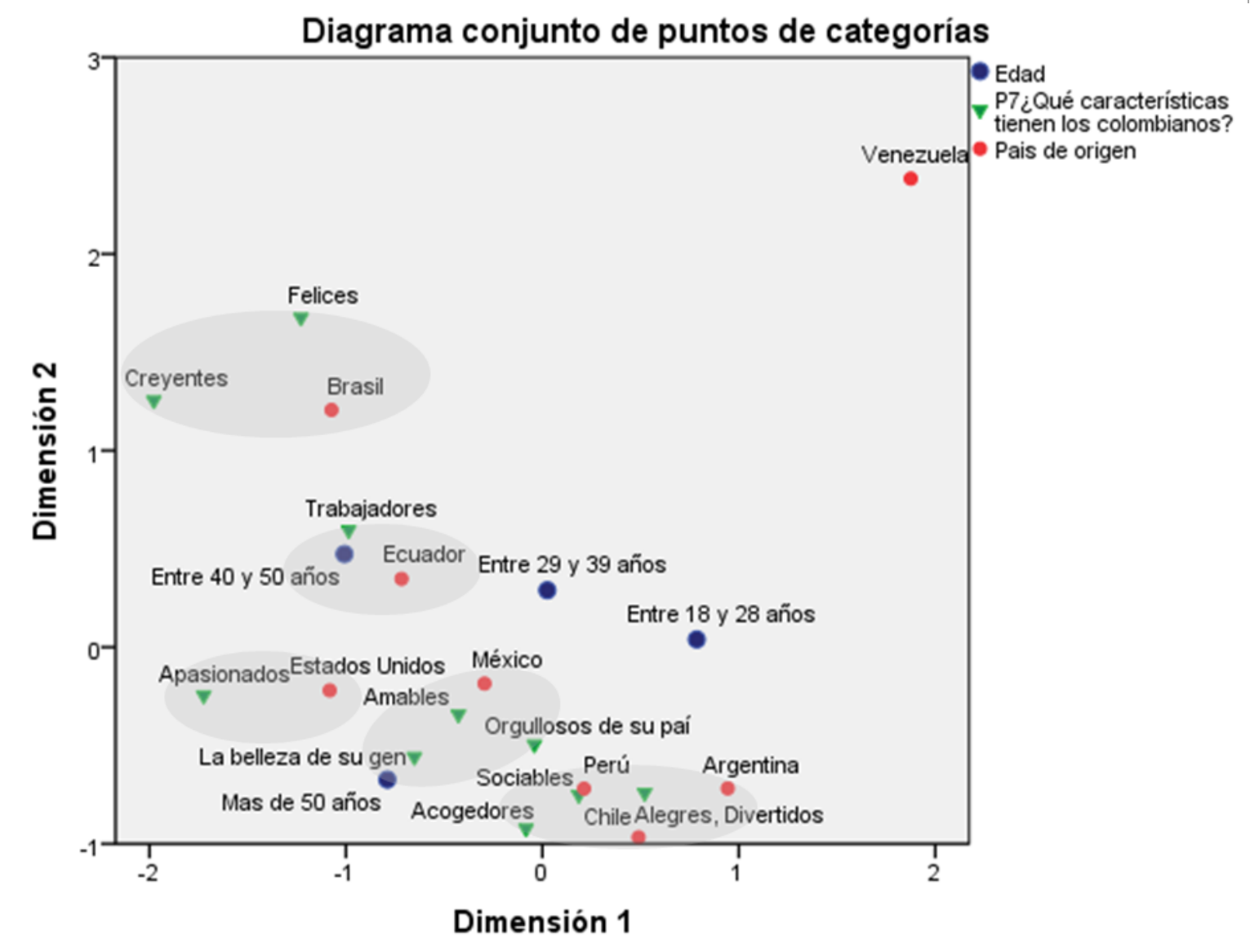

Fuente: elaboración propia. 


\section{Capítulo 5. Imagen país de Colombia}

De acuerdo a la Figura 81, los estadounidenses consideran a los colombianos apasionados. Los mexicanos que aún no han visitado a Colombia, indican que su población se caracteriza por su amabilidad, la belleza de su gente y por sus sentimientos de orgullo hacia el país (Echeverri et al., 2014a). Los chilenos, argentinos y peruanos coinciden en que el perfil del colombiano se caracteriza por ser sociable, alegre, divertido y acogedor.

En el Análisis de Correspondencia aplicado al grupo de prospectos se consideró la relación existente entre variables demográficas (edad y país de origen) con las variables vinculadas a la asociación simbólica de la imagen país de Colombia. Según el Test Chi Cuadrado hay una asociación significativa (ver Cuadro 42):

Cuadro 42. Test Chi Cuadrado de Asociación Simbólica de la imagen país de Colombia y variables demográficas de los prospectos

\begin{tabular}{|l|c|c|c|c|}
\hline \multirow{2}{*}{ Variables } & \multicolumn{2}{c|}{ Edad } & \multicolumn{2}{c|}{ País de Origen } \\
\cline { 2 - 5 } & $\mathbf{X}^{2}$ & Sig. & $\mathbf{X}^{2}$ & Sig. \\
\hline ¿Qué símbolo representa a Colombia? & 47,278 &, 051 & 259,527 &, 000 \\
\hline $\begin{array}{l}\text { Cuando se menciona a Colombia ¿qué } \\
\text { ciudad se le viene a la mente? }\end{array}$ & 37,546 &, 015 & 371,154 &, 000 \\
\hline $\begin{array}{l}\text { Cuando se menciona a Colombia ¿con qué } \\
\text { persona la asocia? }\end{array}$ & 75,133 &, 000 & 576,939 &, 000 \\
\hline ¿Estaría interesado en visitar a Colombia? & 10,704 &, 013 & 31,422 &, 000 \\
\hline
\end{tabular}

Fuente: elaboración propia.

Base: 784

Los estadounidenses mayores de 50 años asocian a Colombia con las montañas, las aves y los ríos. Los chilenos entre 40 y 50 años, que no han viajado al país, lo asocian con la Bandera Nacional y con el narcotraficante Pablo Escobar. 


\section{Capítulo 5. Imagen país de Colombia}

Los jóvenes adultos procedentes de Ecuador, Perú, México y Brasil, indicaron que los símbolos que representan a Colombia son el café, las drogas, la gente, los artistas y deportistas. Y los venezolanos, potencial visitante, consideran que las flores son el símbolo que se asocia a la imagen de Colombia.

Figura 82. Análisis de correspondencia entre el símbolo que representa a Colombia y variables demográficas: país de origen y edad de los prospectos

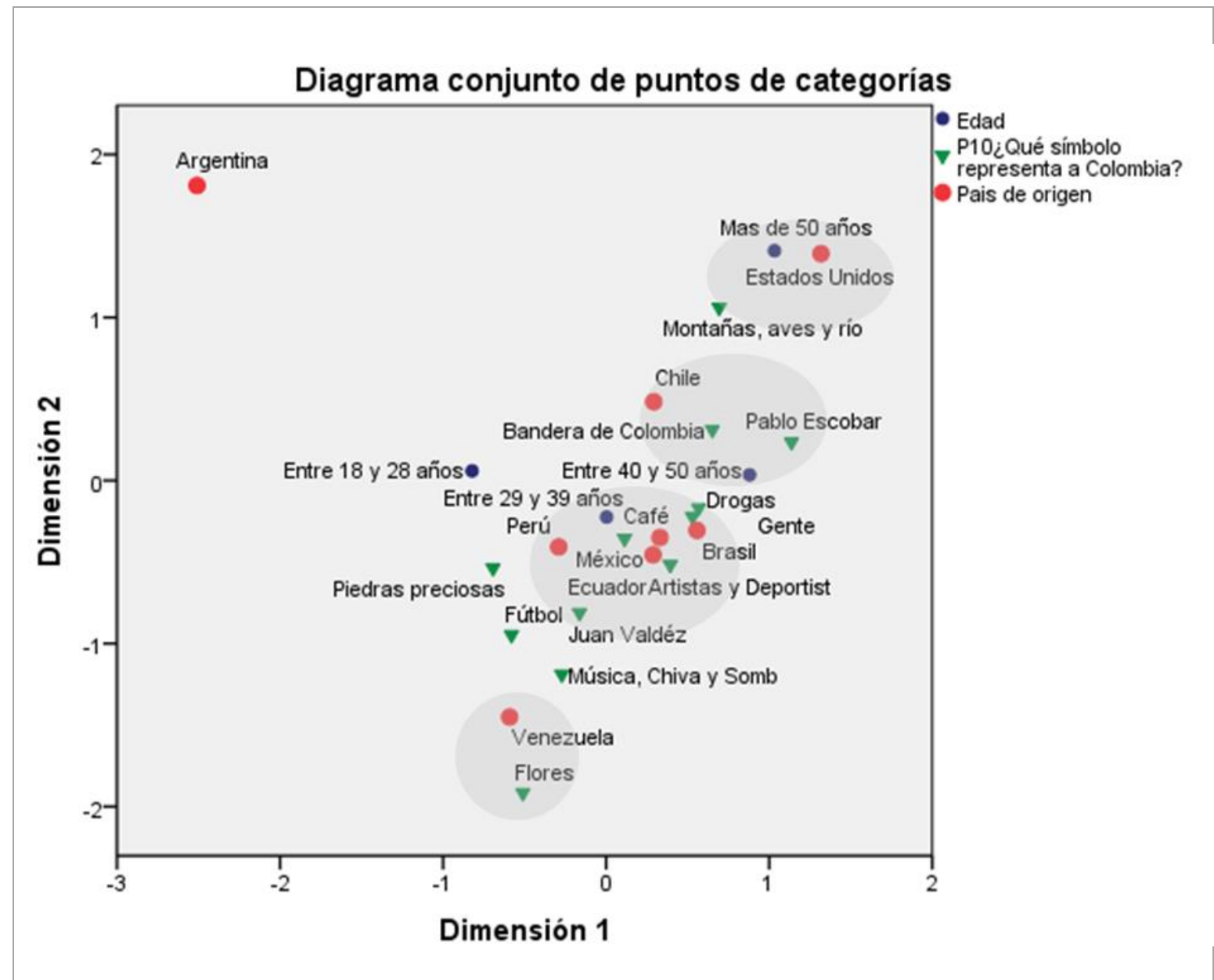

Fuente: elaboración propia. 


\section{Capítulo 5. Imagen país de Colombia}

La mayoría de los extranjeros, jóvenes y adultos, que no han visitado a Colombia, asocian al país con las ciudades de Bogotá y Medellín. Los venezolanos señalaron que Cartagena y Barranquilla son las dos ciudades que identifican la imagen de Colombia.

Figura 83. Análisis de correspondencia entre ciudad que representa a Colombia y variables demográficas: país de origen y edad de los prospectos

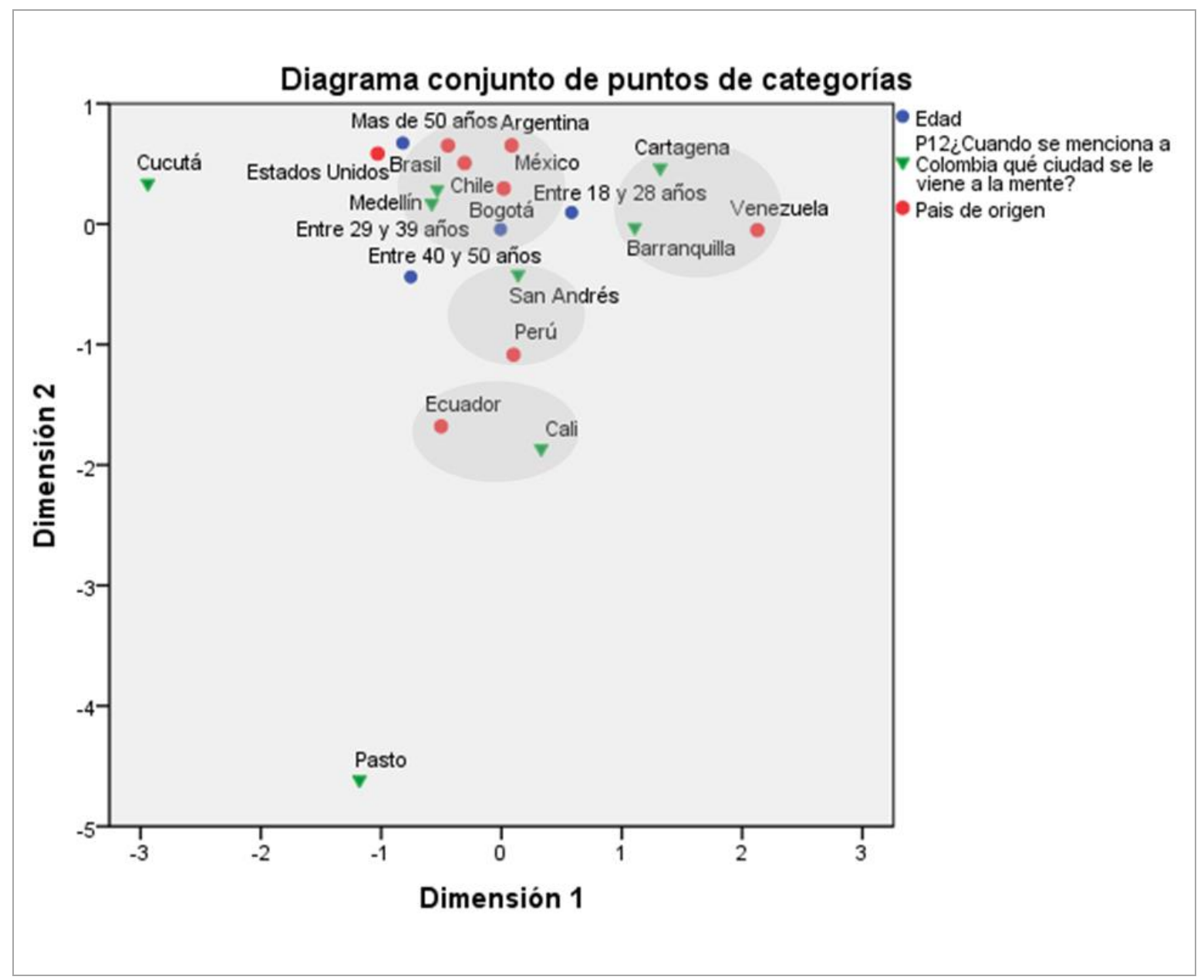

Fuente: elaboración propia. 


\section{Capítulo 5. Imagen país de Colombia}

Chilenos, peruanos, argentinos y mexicanos, entre 18 y 28 años, asocian a Colombia con el presidente Juan Manuel Santos, la actriz Sofía Vergara y los cantantes Juanes y Shakira.

Para los ecuatorianos entre 40 y 50 años, consideran que los personajes que representan la imagen de Colombia son: la guerrilla de las FARC, el escritor Gabriel García Márquez, los amigos y familiares. Para los estadounidenses mayores de 50 años, relacionan a Colombia con el libertador Simón Bolívar y la marca comercial de Juan Valdez.

Los venezolanos indicaron que el deportista Pibe Valderrama y el expresidente Álvaro Uribe son las personas que representan la imagen de Colombia.

Figura 84. Análisis de correspondencia entre persona que asocia a Colombia y variables demográficas: país de origen y edad de los prospectos

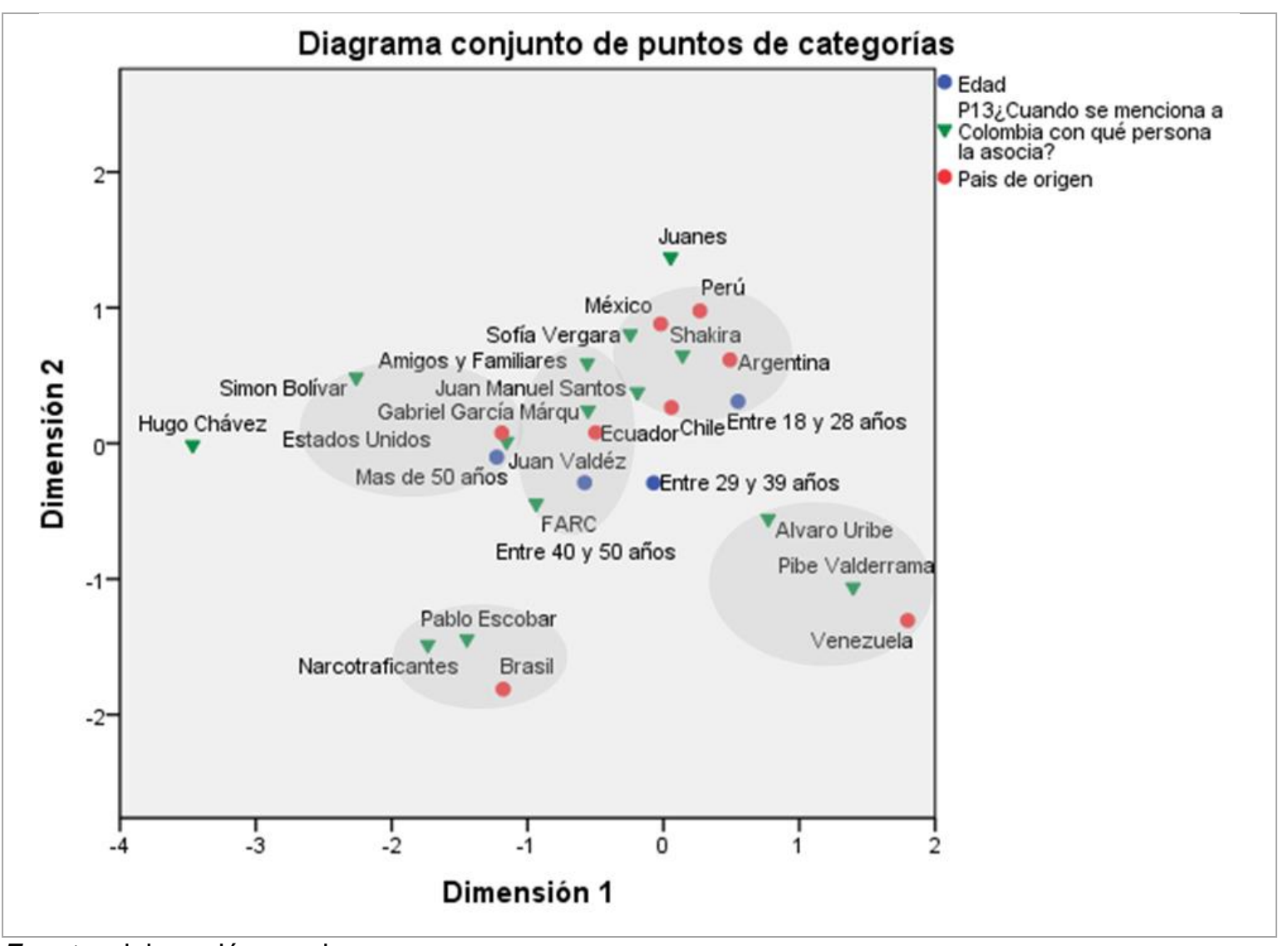

Fuente: elaboración propia. 


\section{Capítulo 5. Imagen país de Colombia}

El 90\% de las personas vinculadas al grupo de prospectos, señaló que compraría productos de origen colombiano. Este mismo grupo está interesado en visitar a Colombia $(89 \%)$.

Figura 85. Preferencias e intereses en Colombia según los prospectos

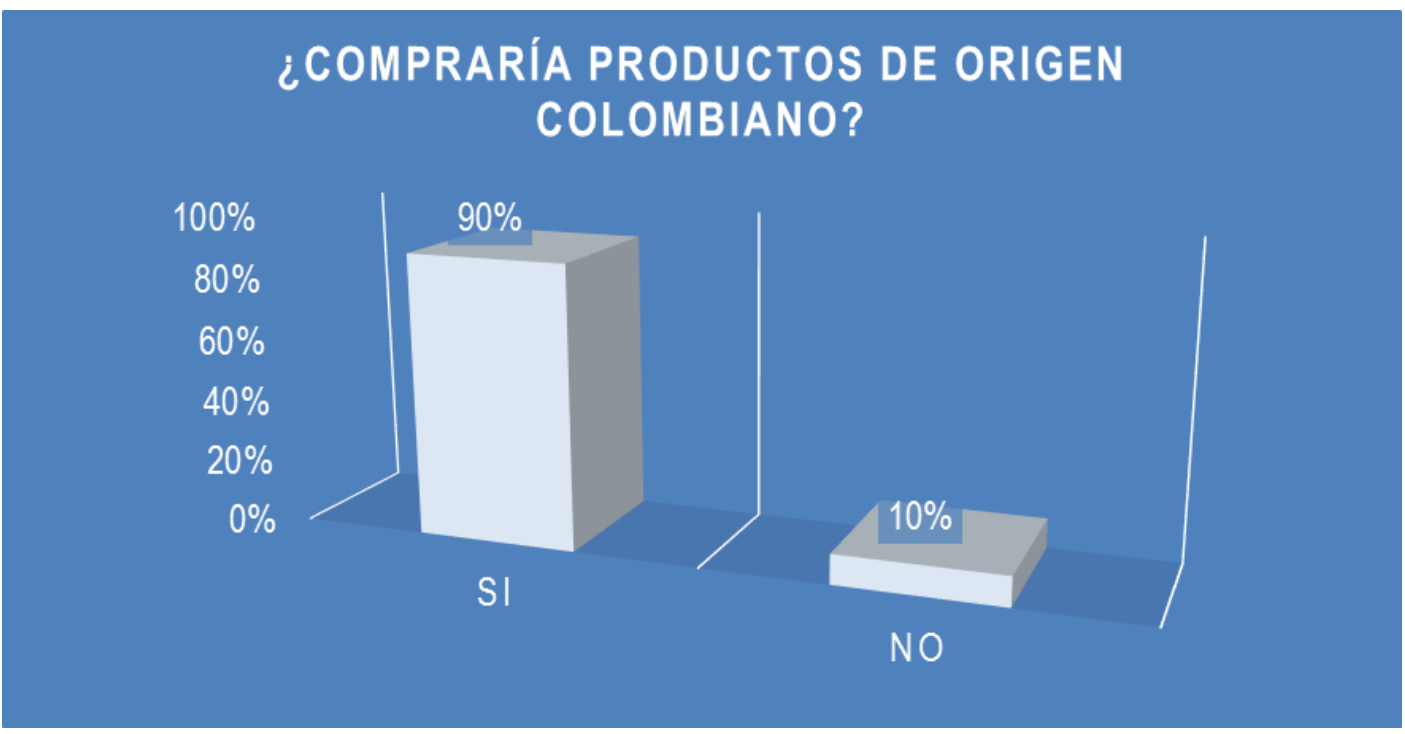

\section{¿ESTARÍA INTERESADO EN VISITAR A COLOMBIA?}
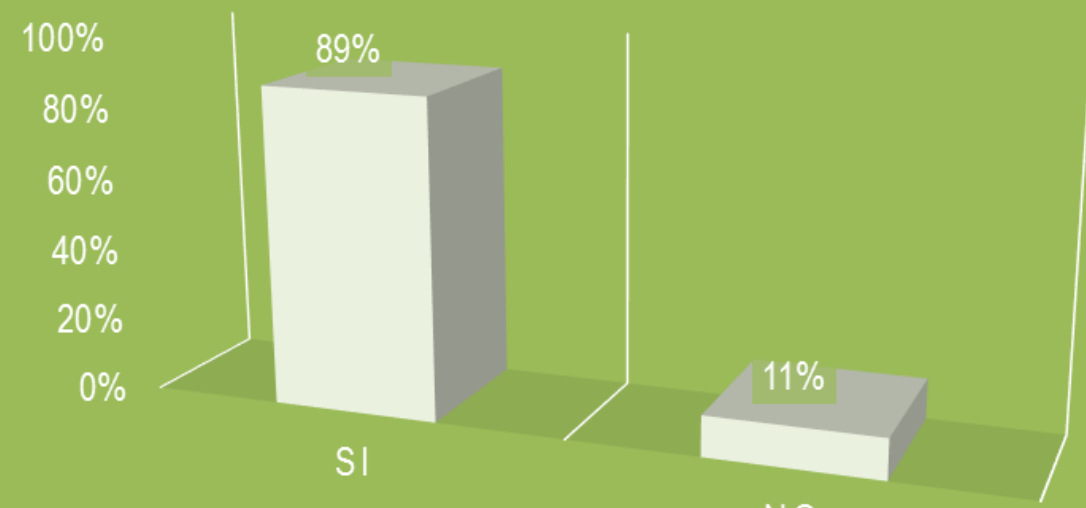

NO

Fuente: elaboración propia.

Base: 784 


\section{Capítulo 5. Imagen país de Colombia}

Como se puede observar en la Figura 86, el interés de visitar a Colombia proviene de la mayoría de los países que participaron en el estudio. Los brasileros son los que no tienen interés en visitar al país.

Figura 86. Análisis de correspondencia entre interés de visitar a Colombia y variables demográficas: país de origen y edad de los prospectos

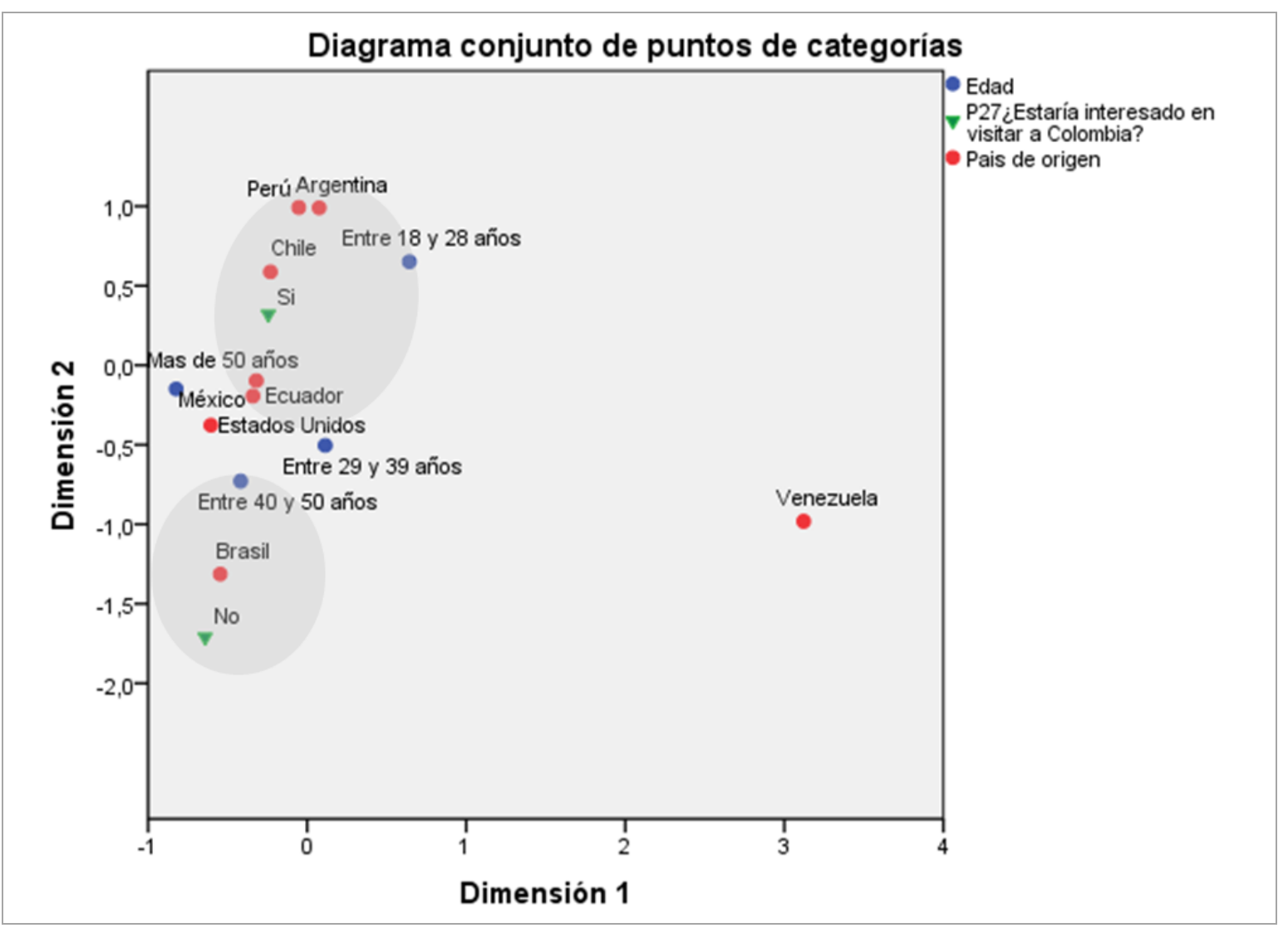

Fuente: elaboración propia. 


\section{Capítulo 5. Imagen país de Colombia}

\subsubsection{Análisis clúster sobre la imagen país de Colombia}

En el estudio se aplicó un análisis clúster o por conglomerados para visitantes y prospectos, con la finalidad de examinar el conjunto de relaciones interdependientes según la importancia declarada que asignaron los encuestados en sus respuestas. Se clasificaron los individuos en grupos relativamente homogéneos basados en el conjunto de las variables consideradas. Los individuos de un grupo son relativamente similares en términos de las variables planteadas y diferentes de los individuos de otros grupos. El método de aglomeración utilizado fue el método de Ward.

Los resultados indicaron que los visitantes podrían agruparse en tres segmentos. Las diferencias entre los segmentos fueron verificadas en forma estadística. Así, cada segmento contiene encuestados relativamente homogéneos en cuanto a sus criterios de elección. A continuación se estimó por separado un modelo de elección para visitantes y prospectos.

El análisis clúster aplicado a visitantes se detectó tres segmentos: expectantes, recurrentes y fronterizos (ver Figura 87). Y el mismo análisis aplicado a prospectos, se identificaron dos segmentos: compradores potenciales y latentes (ver Figura 88).

Una vez elegido el número de clases se obtiene la partición y los indicadores de la homogeneidad de las clases obtenidas, La clase más homogénea y pequeña es la clase 3 (inercia 0,0732), la clase 1 la más heterogénea (inercia de 0,8771) y la más grande de las tres clases.

\section{Cuadro 43. Descomposición de la inercia}

\begin{tabular}{|l|c|c|c|}
\hline \multicolumn{1}{|c|}{ Inercias } & Inercias & Efectivos & Distancias \\
\hline Inter-clases & 0,2139 & & \\
\hline Intra-clases & & & \\
\hline Clase 1 & 0,8771 & 504 & 0,0470 \\
\hline Clase 2 & 0,3776 & 168 & 0,3593 \\
\hline Clase 3 & 0,0732 & 88 & 0,8926 \\
\hline Total & 1,5418 & & \\
\hline
\end{tabular}

Fuente: elaboración propia. 


\section{Capítulo 5. Imagen país de Colombia}

En el cuadro 44 se pueden observar las coordenadas de las clases sobre los ejes factoriales y sus valores- test. Las clases se pueden interpretar al igual que la posición de los individuos sobre el primer plano factorial.

\section{Cuadro 44. Coordenadas y valores- test sobre los ejes factoriales}

\begin{tabular}{|l|c|c|c|c|}
\hline \multirow{2}{*}{ Clases } & \multicolumn{2}{|c|}{ Valores test } & \multicolumn{2}{c|}{ Coordenadas } \\
\cline { 2 - 5 } & Eje 1 & Eje2 & Eje 1 & Eje2 \\
\hline Clase 1 & $-6,2$ & $-2,4$ & $-0,09$ & $-0,03$ \\
\hline Clase 2 & $-11,2$ & 5,3 & $-0,29$ & 0,13 \\
\hline Clase 3 & 21,1 & $-3,0$ & 0,73 & $-0,10$ \\
\hline
\end{tabular}

Fuente: elaboración propia.

Según el Dendograma de Clasificación de visitantes que participaron en el estudio, se puede apreciar tres clases o grupos. La clase 1 formada por 504 visitantes, la clase 2 por 168 visitantes y la tres por 88 visitantes.

Figura 87. Dendograma del análisis clúster de los extranjeros que han visitado a Colombia

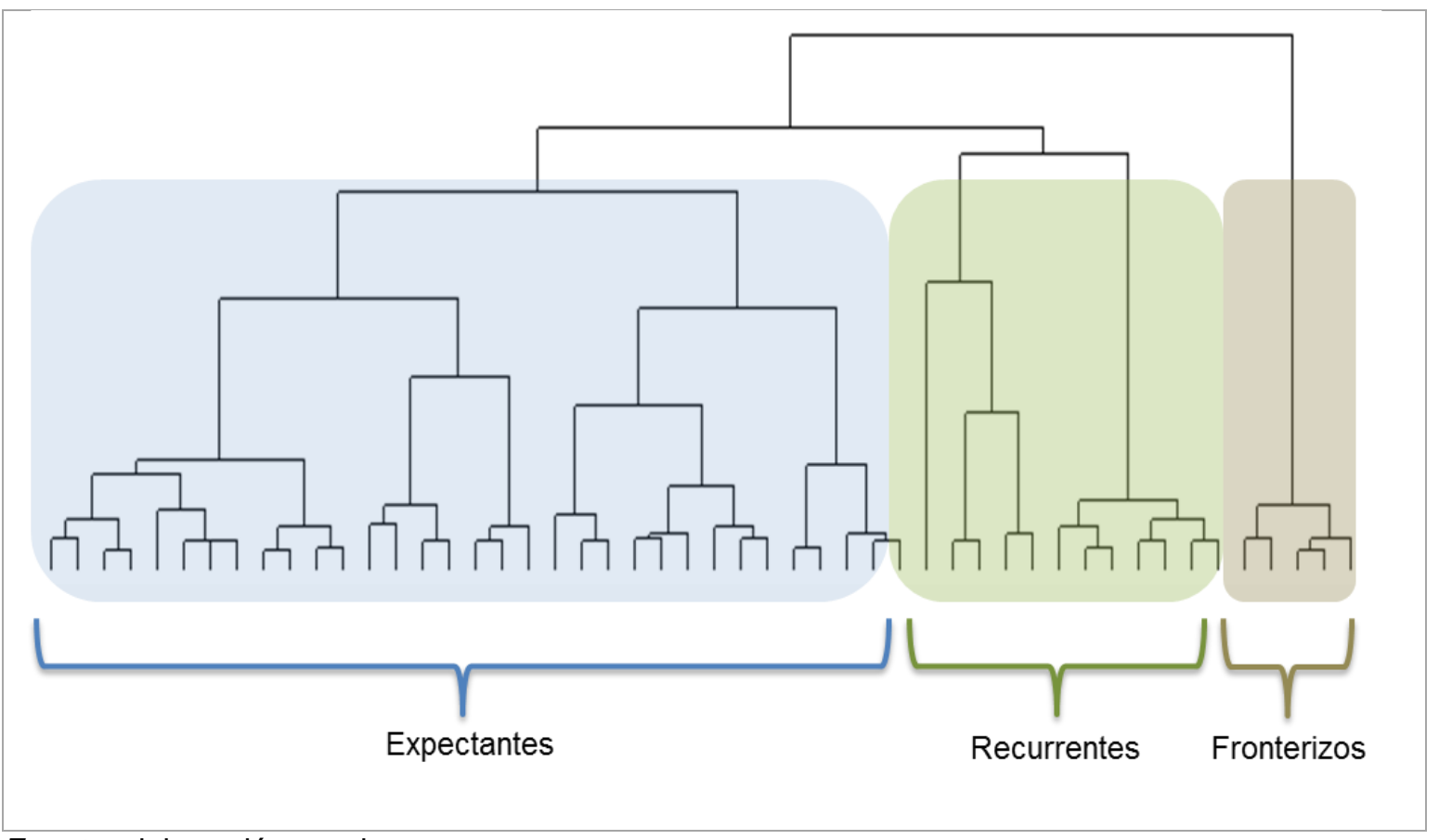

Fuente: elaboración propia. 


\section{Capítulo 5. Imagen país de Colombia}

Las características del primer clúster de visitantes estadounidenses se agrupa en este estudio bajo la denominación de Visitantes Expectantes: son visitantes procedentes de Brasil, Chile, Argentina y México. Les gustaría vivir en Brasil, Perú y Colombia. Para este grupo, Pablo Escobar, el Pibe Valderrama y Shakira son los personajes que más representan a Colombia en mercados internacionales.

En su visita lo que más le gustó fue la cultura y la ciudad de Cartagena. Lo que menos les gustó fue la suciedad, los vendedores ambulantes y la inseguridad en el país. Un aspecto negativo que se percibe de Colombia es la inseguridad, la guerrilla y las drogas. Lo primero que piensan cuando oyen la palabra Colombia es en la selva, montañas, playas, arte cultura

y gastronomía. Para los visitantes de este segmento, la amabilidad y la alegría de los colombianos son los aspectos positivos que mejor se asocian con la imagen del país. Para este grupo, los colombianos se caracterizan por ser alegres, acogedores, divertidos y felices. Para ellos el color de Colombia es el amarillo y el aroma es a café y flores.

El segundo clúster corresponde a los Visitantes Recurrentes Son visitantes frecuentes, procedentes de Ecuador y Estados Unidos (Echeverri et al., 2013b). Les gustaría vivir en Chile. Cuando se menciona a Colombia la asocian con amigos y familiares. En su visita lo que más le gustó fue la cultura y lo que menos les gustó fue el clima. Al escuchar la palabra Colombia la relacionan con negocios, drogas y terrorismo.

La pasión y los negocios son aspectos positivos de Colombia. Sin embargo, consideran que la violencia y el crimen son aspectos negativos del país. Para este grupo de visitantes, los colombianos se caracterizan por ser trabajadores. Asocian a Colombia con el color rojo y verde. Los visitantes estadounidenses y ecuatorianos relacionan a Colombia con el aroma a flores (Echeverri et al., 2014b).

El tercer grupo conformado por los Visitantes Fronterizos. Venezolanos, entre 40 y 50 años que les gustaría vivir en su país natal y en Colombia. Para estos visitantes, el café y las flores simbolizan a Colombia. Los amigos, familiares y el expresidente Álvaro Uribe son las personas con las que más asocian la imagen de Colombia. En su visita lo que más les gustó fue la gastronomía y los lugares turísticos. 


\section{Capítulo 5. Imagen país de Colombia}

Lo que menos gustó fue la pobreza y el tráfico. Al segmento de estudio, les gustaría visitar Argentina y Brasil. La imagen de Colombia está altamente asociada a las características de sus habitantes. Para estos visitantes, los colombianos son acogedores, apasionados y sociables. El color con el que más asocian a Colombia es el azul, porque representa la naturaleza y sus paisajes. En este sentido, relacionan a Colombia con el aroma a la naturaleza y a su gastronomía. Un aspecto negativo del país es el narcotráfico. Para este grupo, la naturaleza, paisajes y la amabilidad de la gente son tres aspectos positivos con los que se relaciona la imagen país de Colombia. Una vez elegido el número de clases se obtiene la partición y los indicadores de la homogeneidad de las clases obtenidas, La clase más homogénea y pequeña es la clase 2 (inercia 0,1702) con 95 personas, la clase 1 la más heterogénea (inercia de 0,8771) y la más grande de las dos clases (689 personas).

\section{Cuadro 45. Descomposición de la inercia}

\begin{tabular}{|l|c|c|c|}
\hline \multicolumn{1}{|c|}{ Inercias } & Inercias & Efectivos & Distancias \\
\hline Inter-clases & 0,3547 & & \\
\hline Intra-clases & & & \\
\hline Clase 1 & 1,3094 & 689 & 0,0489 \\
\hline Clase 2 & 0,1702 & 95 & 2,5727 \\
\hline Total & 1,8343 & & \\
\hline
\end{tabular}

Fuente: elaboración propia.

En el Cuadro 46 se pueden observar las coordenadas de las clases sobre los ejes factoriales y sus valores- test. Las clases se pueden interpretar al igual que la posición de los individuos sobre el primer plano factorial.

Cuadro 46. Coordenadas y valores- test sobre los ejes factoriales

\begin{tabular}{|l|c|c|c|c|}
\hline \multirow{2}{*}{ Clases } & \multicolumn{2}{|c|}{ Valores test } & \multicolumn{2}{c|}{ Coordenadas } \\
\cline { 2 - 5 } & Eje 1 & Eje2 & Eje 1 & Eje2 \\
\hline Clase 1 & $-26,2$ & $-1,9$ & $-0,22$ & $-0,01$ \\
\hline Clase 2 & 26,2 & 1,9 & 1,60 & 0,09 \\
\hline
\end{tabular}

Fuente: elaboración propia.

La Figura 88 expone el Dendograma de Clasificación de prospectos (visitantes potenciales) que participaron en el estudio, se puede apreciar dos clases o grupos. 


\section{Capítulo 5. Imagen país de Colombia}

Figura 88. Dendograma del análisis clúster de los prospectos

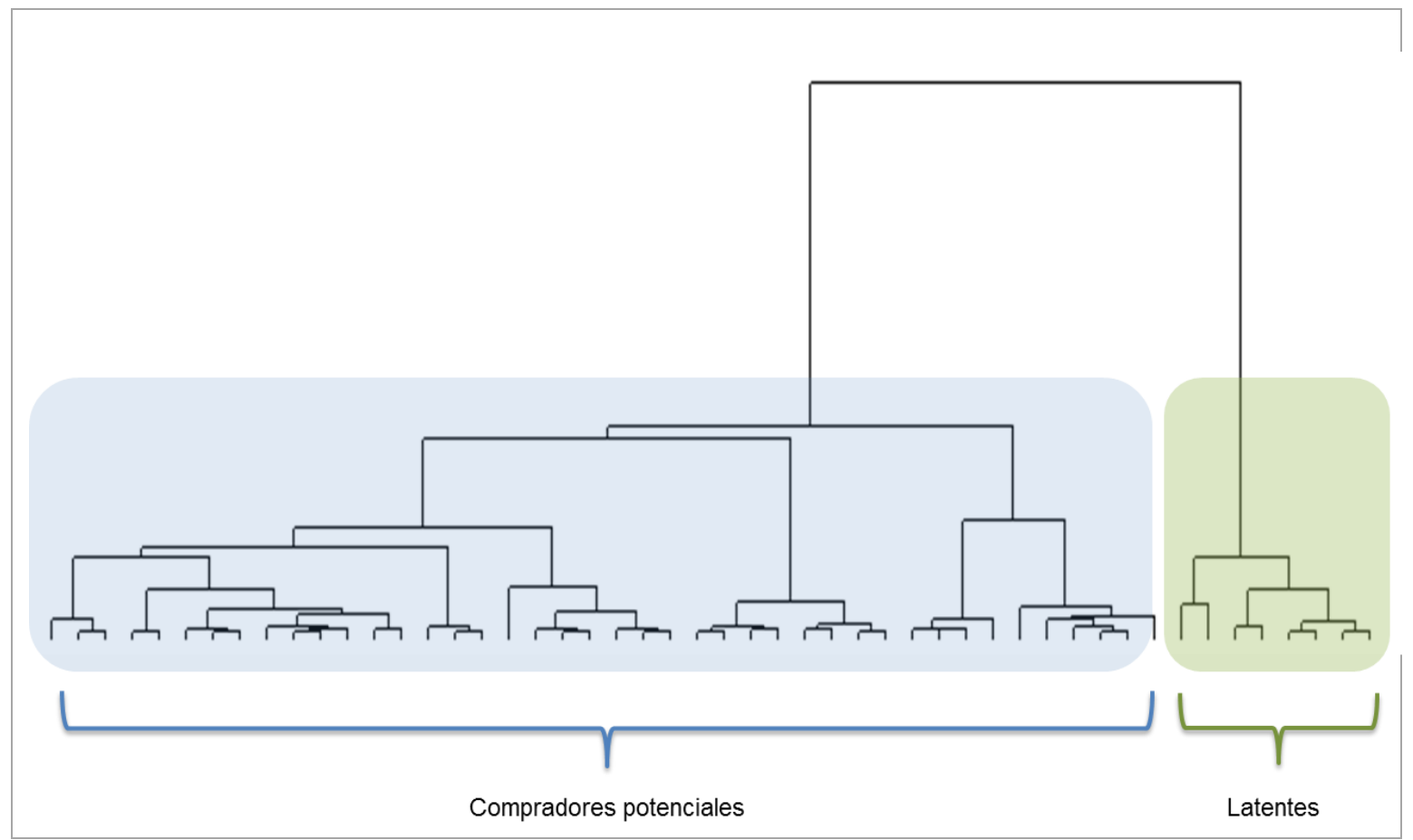

Fuente: elaboración propia.

En el estudio los prospectos cobran relevancia porque sus apreciaciones distan de una experiencia de visita. En su imaginario colectivo, los prospectos han creado una propia imagen país de Colombia, cercana o ajena a los visitantes, este grupo se convierte en objetivo de análisis, porque sobre ellos es que se deben redireccionar también las estrategias que se formulen desde marca país.

Según el análisis realizado, del grupo de prospectos se generan dos nuevos segmentos. El primer clúster denominado Compradores potenciales. Son extranjeros que les gustaría vivir en Brasil, Ecuador, Perú y Colombia. Para ellos la bandera de Colombia, las montañas, aves, ríos, el café la música, la chiva y el sombrero vueltiao son los símbolos que más representan al país. El café, los textiles y el turismo son los sectores productivos que se asocian al país. 


\section{Capítulo 5. Imagen país de Colombia}

La palabra Colombia tiene una percepción polarizada, la relacionan con las drogas y el terrorismo; pero simultáneamente la asocian con el café, la selva, las montañas, las playas, la gente amable y acogedora. Cuando se menciona a Colombia, lo asocian con ciudades como Medellín, Barranquilla, Bogotá y Cartagena. Los amigos, familiares; y artistas como Gabriel García Márquez, Juanes y Sofía Vergara son los personajes que identifican a Colombia. Para este grupo, los colombianos se caracterizan por ser: alegres, divertidos, amables, trabajadores y sociables. El primer clúster, resultado del análisis, desearía visitar en América del Sur a Brasil y Perú. Estarían interesados en comprar productos colombianos, y en visitar al país.

El segundo clúster está conformado por los Latentes. Son venezolanos que no han visitado a Colombia. Prefieren permanecer en su país de origen en lugar a de visitar Colombia. Para este segmento, las flores, el café, la música, la chiva y el sombrero vueltiao son los símbolos más representativos del país. Asocian al deportista Pibe Valderrama y al expresidente Álvaro Uribe con la imagen de Colombia. El arte, la cultura y la gastronomía son los aspectos que primero recuerdan cuando oyen la palabra Colombia. La amabilidad de la gente, el arte, la cultura y el deporte, son cuatro aspectos positivos del país. Desde el punto de vista negativo, relacionan a la guerrilla y el narcotráfico con Colombia. Las ciudades de Cartagena y Barranquilla son las que más asocian con Colombia. Este grupo de visitantes potenciales, les gustaría viajar a Perú. En los resultados del estudio, el grupo indicó que no compraría productos de origen colombiano.

\subsubsection{Análisis de redes bayesianas sobre la imagen país de Colombia}

Las redes bayesianas son una herramienta utilizada para la modelación de la toma de decisiones en condiciones de incertidumbre. Las redes bayesianas son modelos totalmente probabilísticos que se componen de variables y enlaces entre las variables (Jensen \& Nielsen, 2007). Tal y como se indicó en el Capítulo 4 de la Tesis Doctoral, cada una de las variables tiene una distribución de probabilidad que describe el grado de causalidad en los valores posibles que la variable puede tener. En una red bayesiana cada variable es tiene su función de densidad condicional en las variables que impactan e influyen sobre esta última. 


\section{Capítulo 5. Imagen país de Colombia}

Una variable se distingue por un óvalo, y los enlaces entre las variables se hacen a través de flechas (a menudo llamados arcos).

En el estudio aplicado se encontraron relaciones entre algunas variables. Como se puede observar en la Figura 89, la variable sobre el país dónde le gustaría vivir a los extranjeros en América del Sur está condicionada por el lugar de procedencia y los aspectos positivos asociados a la imagen país. Existe una relación de dependencia en la variable de País que los extranjeros quieren visitar y el país que los extranjeros quieren vivir. Es decir, la elección de un destino para vivir, impacta en la elección de un destino para visitar. Los extranjeros eligen a Brasil como el destino para vivir y visitar. Los aspectos positivos impactan sobre los aspectos negativos de la imagen país de Colombia y sobre el país que los extranjeros prefieren para vivir.

Figura 89. Red Bayesiana 1

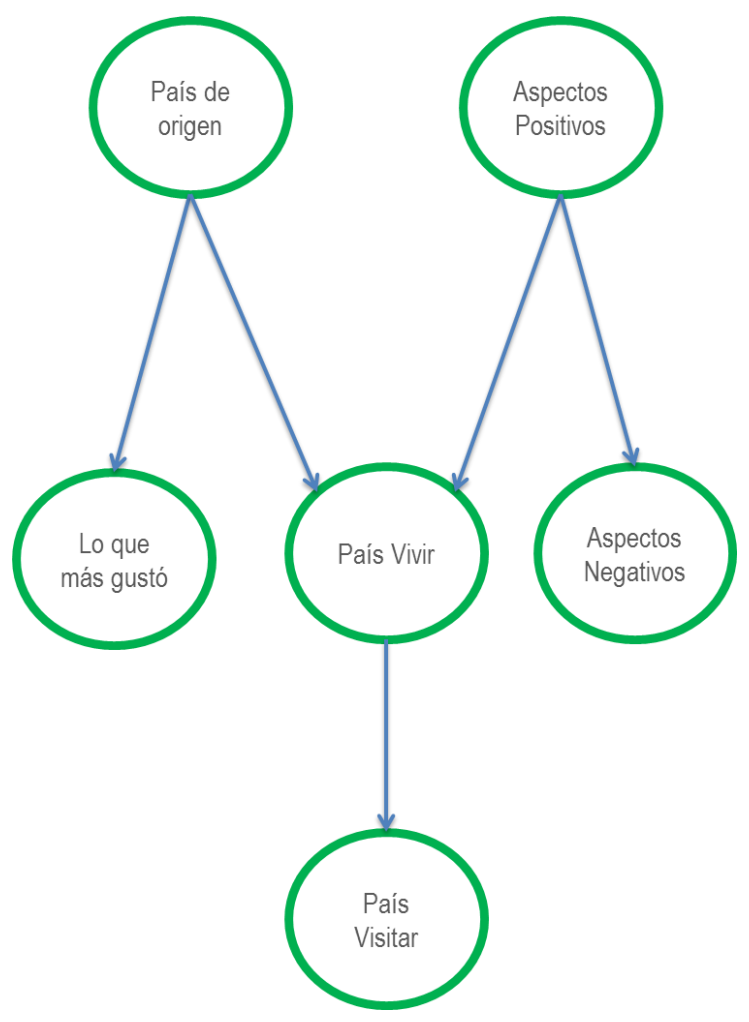

Fuente: elaboración propia. 


\section{Capítulo 5. Imagen país de Colombia}

En la Figura 90 muestra como los árboles obtenidos establecen una dependencia directa con respecto a la variable dependiente, en este caso el Color. Es decir, el color con el que se percibe un país es generado por la asociación de la imagen del país con un producto y con una ciudad. Cuando los extranjeros asocian a Colombia con un producto, esta percepción, está sujeta a dos variables: el país de origen y lo primero que piensa cuando oye la palabra Colombia.

La variable relacionada con el olor asociado a la imagen país, condiciona la variable sobre el símbolo que representa a Colombia. Y la variable sobre el símbolo genera dependencia con la variable persona que se asocia a la imagen país.

Figura 90. Red Bayesiana 2

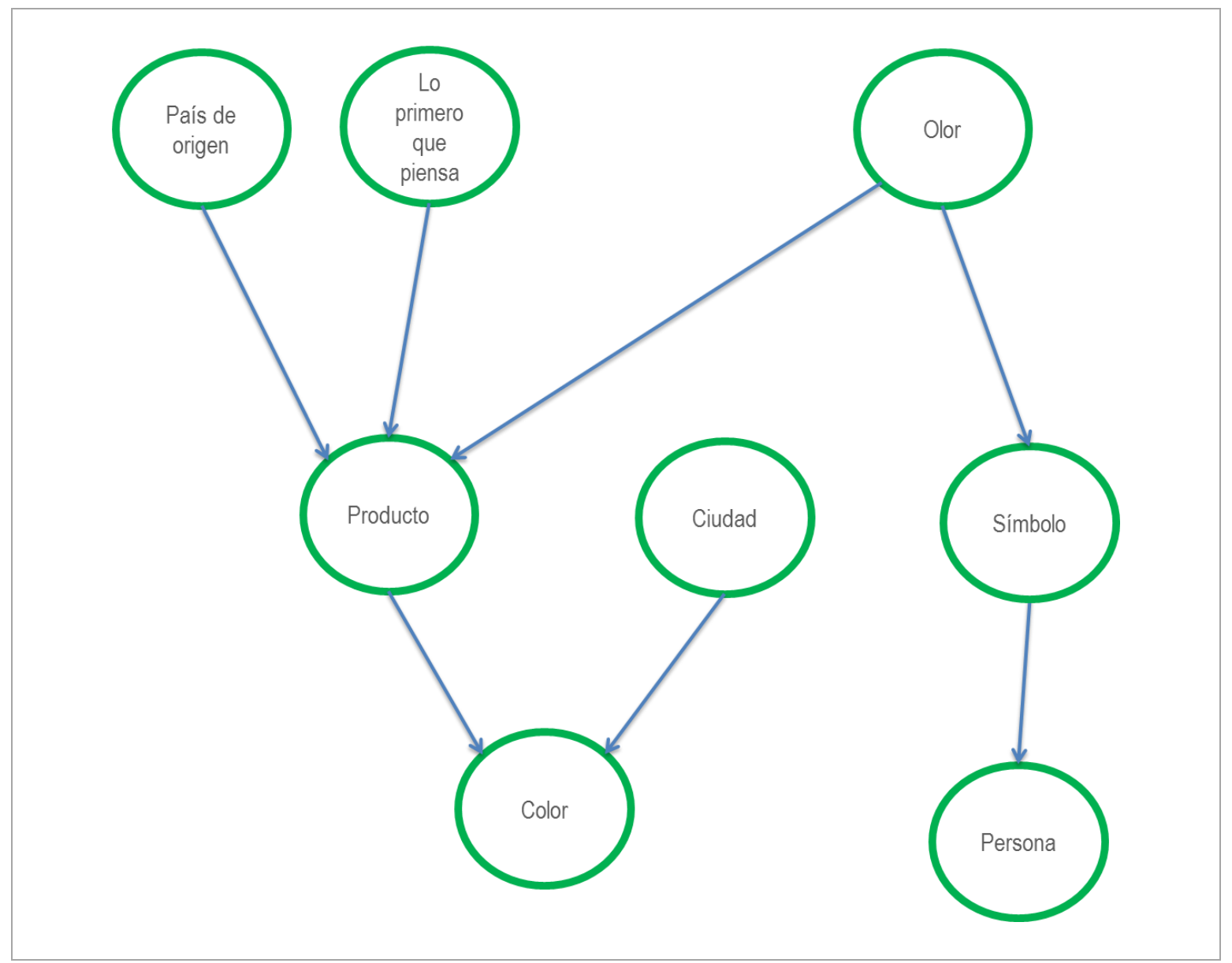

Fuente: elaboración propia. 


\section{Capítulo 5. Imagen país de Colombia}

La red bayesiana que se presenta en la Figura 91, expone cómo la variable clase, es decir, la variable sobre el cambio de opinión de los extranjeros después de una visita a un país, condiciona la variable relacionada con que lo visitaría nuevamente. Tiene sentido esta relación, dado que si se mejora la opinión que tienen los extranjeros sobre Colombia, ellos estarían dispuestos a visitarlo nuevamente.

Cuando un extranjero visita nuevamente un lugar, implica que lo recomendarían a otros extranjeros que aún no lo han visitado. La variable sobre lo que más gustó de Colombia durante su visita y la variable sobre el país de América del Sur que les gustaría vivir, ambas impactan el nodo del país de origen de los extranjeros.

\section{Figura 91. Red Bayesiana 3}

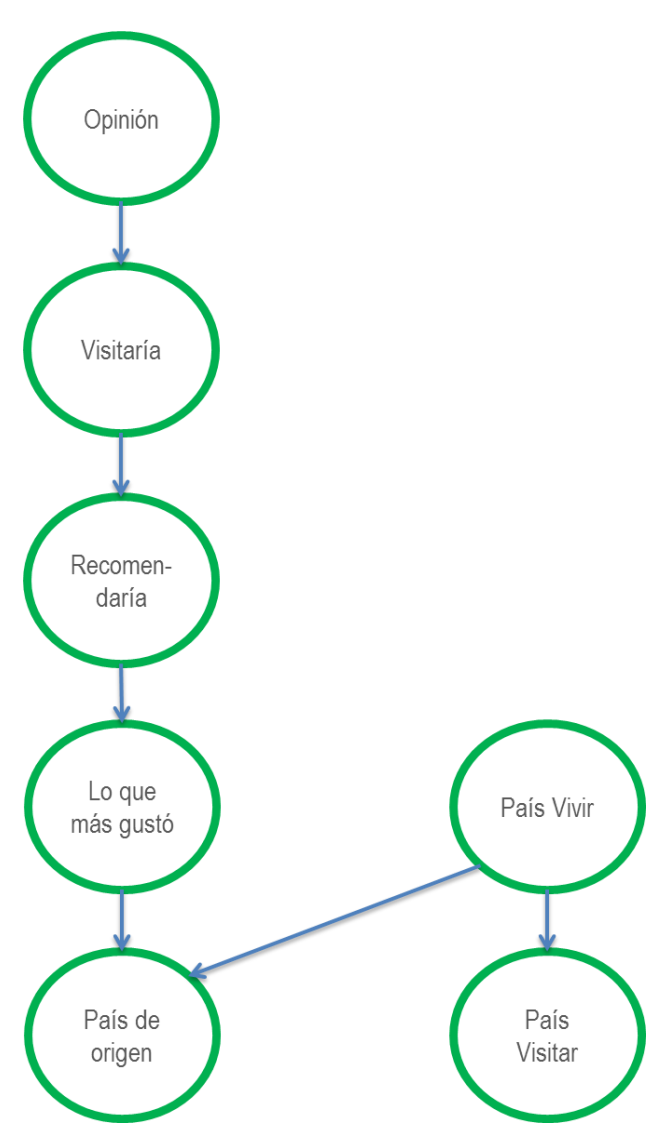

Fuente: elaboración propia. 


\section{Capítulo 5. Imagen país de Colombia}

En la Figura 92, comprende la Red Bayesiana 4, en la cual se puede observar cómo las variables relacionadas con el número de veces que ha visitado al país, lo primero que piensan los extranjeros cuando oyen la palabra Colombia; y el país de origen de los extranjeros condicionan el tipo de producto con que los extranjeros asocian al país.

Para los extranjeros decidir si visitarían de nuevo un lugar, depende de la opinión que tengan del mismo y la familiaridad con el producto (made in).

Lo que más gusta de un país está condicionado por las recomendaciones de los extranjeros, el símbolo que representa al país y su procedencia. La variable sobre el símbolo que mejor representa a un país depende del olor.

El olor es una señal de identidad. En el caso de una estrategia de marca país, se debe pensar en el odotipo, el cual consiste en una forma aromática que se registra como un elemento en la identidad de la marca territorio.

Como se puede observar, en el grafo, el olor asociado a la imagen de un país y el país donde prefieren vivir los extranjeros, son el resultado de los aspectos positivos que se tiene de un país.

En el estudio, Colombia es asociada al aroma del café, la gastronomía y la naturaleza. Las anteriores asociaciones de originan de los aspectos positivos que tienen los extranjeros sobre Colombia, entre los cuales mencionaron la naturaleza, los paisajes, el turismo, la gastronomía. 


\section{Capítulo 5. Imagen país de Colombia}

Figura 92. Red Bayesiana 4

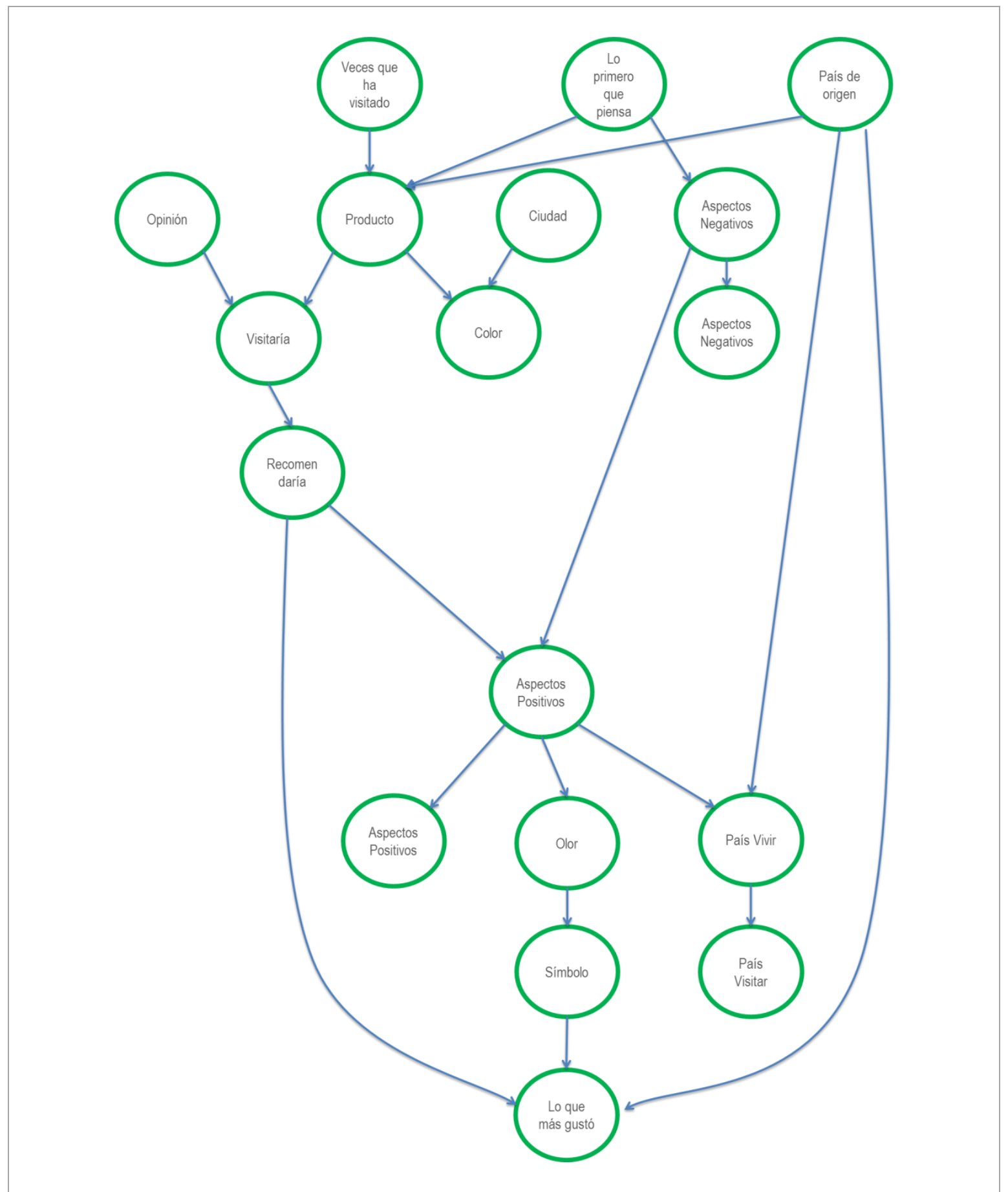

Fuente: elaboración propia.

En el siguiente grafo, es encuentra una variable nueva que no aparece en los anteriores. Y es la variable de si compraría productos de origen colombiano. Esta variable 


\section{Capítulo 5. Imagen país de Colombia}

corresponde al instrumento aplicado a los extranjeros que aún no han visitado a Colombia (prospectos). De acuerdo con lo anterior, la intención de compra de un producto de origen internacional depende de la nacionalidad del extranjero.

Figura 93. Red Bayesiana 5

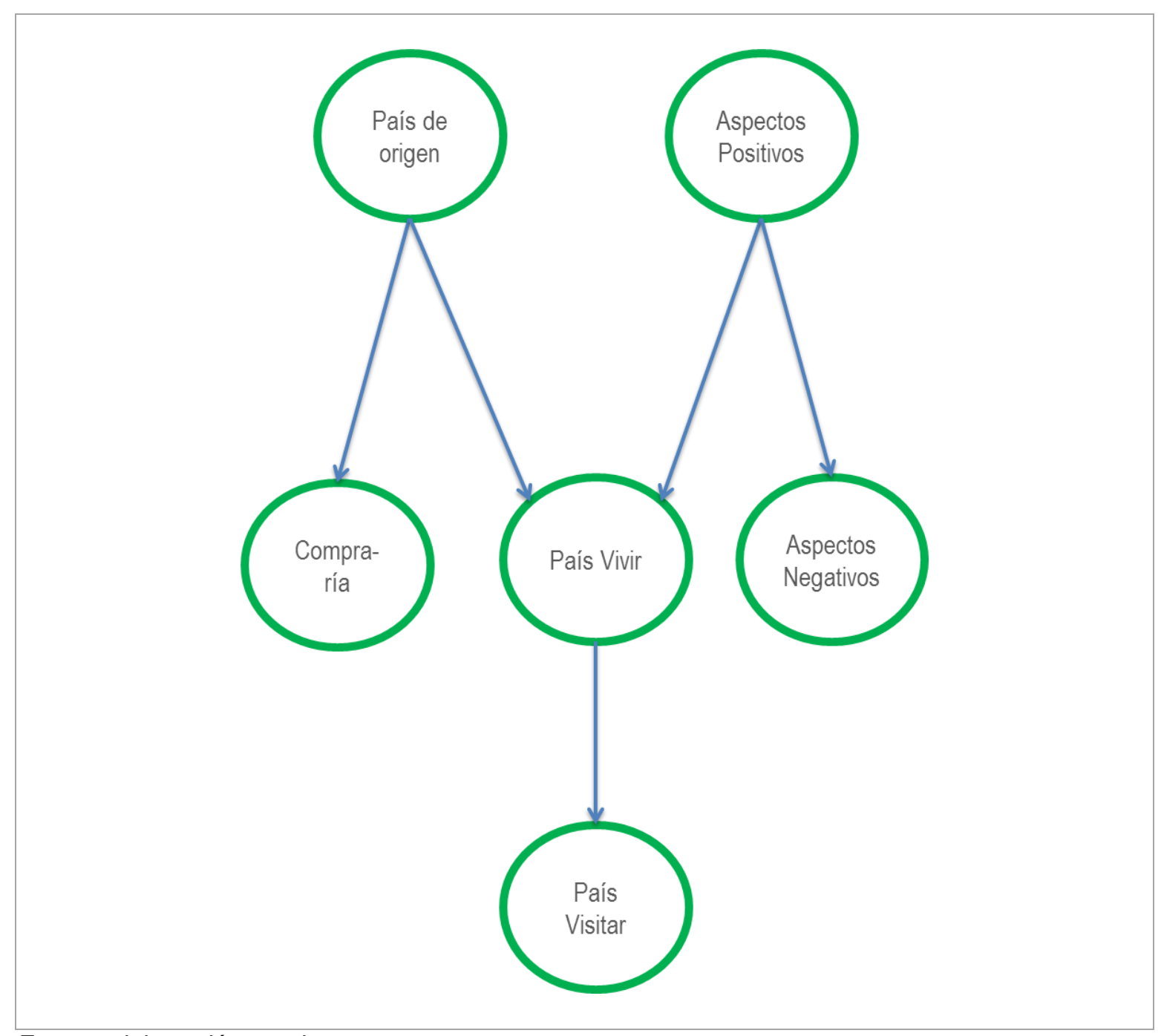

Fuente: elaboración propia. 


\section{Capítulo 5. Imagen país de Colombia}

En la Figura 94, la variable de país de origen de los extranjeros condiciona cuatro variables: el producto asociado a un país, la intención de compra de productos internacionales, el país preferido para vivir y los aspectos que más gustaron durante su visita. El producto asociado a un país está condicionado por el país de origen del extranjero, las veces que ha visitado el destino y la recordación que tienes sobre la imagen de un lugar.

Figura 94. Red Bayesiana 6

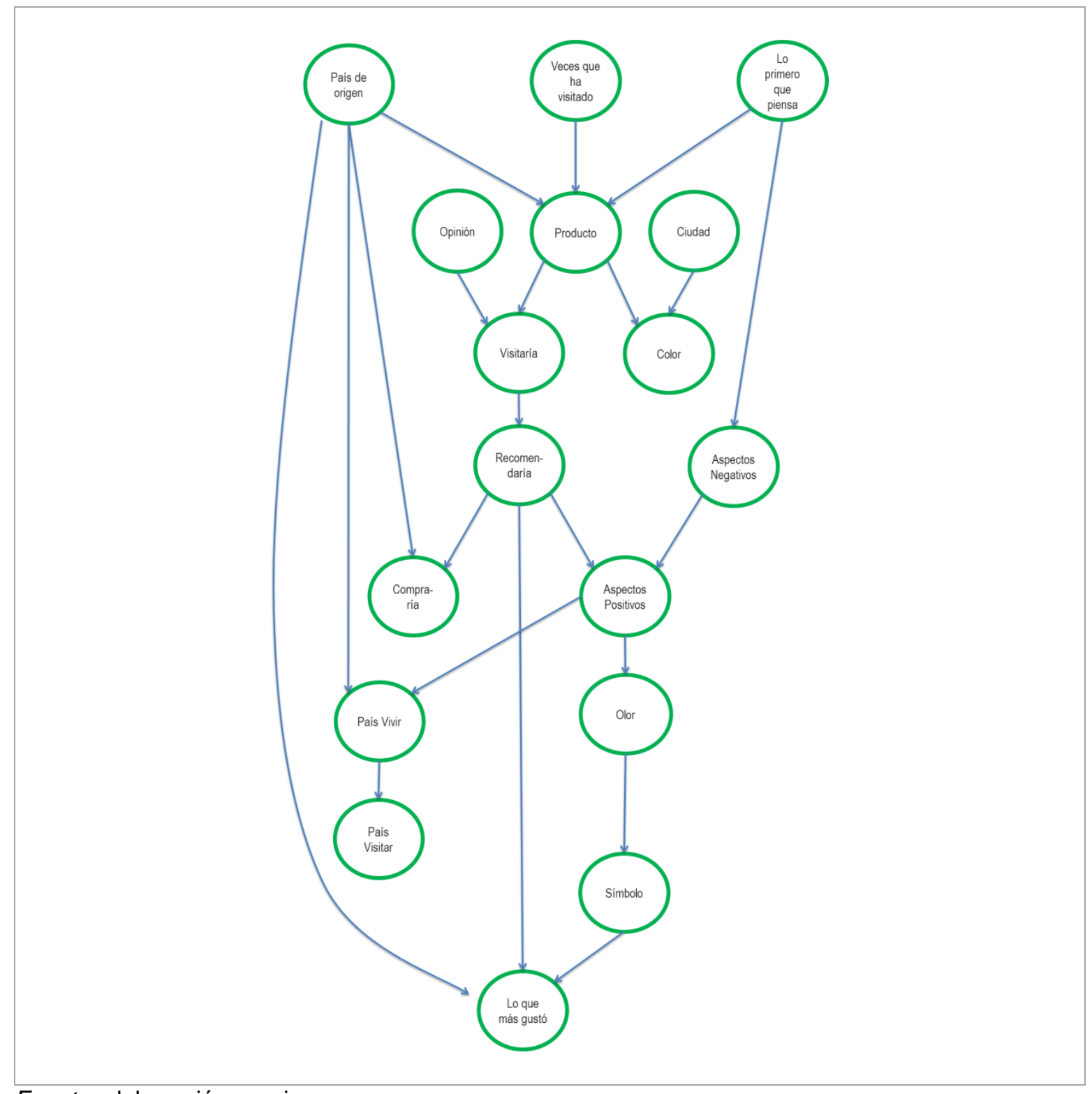

Fuente: elaboración propia. 


\section{Capítulo 5. Imagen país de Colombia}

Conforme a los resultados de la investigación, Colombia tiene un posicionamiento multidimensional, positivo y negativo. En lo positivo, una imagen país centrada en el café y las flores, y en lo negativo, manteniendo una asociación histórica con el narcotráfico. La tarea a seguir para la marca país de Colombia es concentrase en tres propósitos fundamentales:

a. Posicionar la imagen de Colombia de forma diferencial y preferencial en la mente de los visitantes y prospectos.

b. Bloquear a los competidores la posibilidad de vincularse a la misma idea o concepto.

c. Hacer los cambios internos que sean necesarios para que la idea/concepto sea creíble y sostenible a largo plazo

\subsection{Modelo Estratégico de Proyección País (MEPP)}

El MEPP tiene como propósito monitorear la imagen de un país en mercados internacionales. Por este motivo, las razones que justifican su implementación nacen de manifestaciones que se presencian diariamente:

- Cambios en los patrones de consumo. En la actualidad los países se ven enfrentados a una nueva cultura de consumo caracterizada por cambios en los estilos de vida, hábitos de consumo, roles de compra y toma de decisiones complejas. Hoy en día, las personas que visitan un destino no se conforman con tener una experiencia. El visitante del siglo XXI busca que se incremente su calidad de vida, el ahorro de tiempo y las soluciones rápidas a sus necesidades. En este sentido, se hace inminente para una marca país conseguir información oportuna acerca de las percepciones y conductas de los extranjeros. 


\section{Capítulo 5. Imagen país de Colombia}

- La urgencia por segmentar mercados. Todavía algunos países orientan sus estrategias de posicionamiento a mercados indiferenciados. Este último aspecto demuestra lo conservadores que son los países al no fragmentar su público objetivo, y considerar en sus preceptos de marketing que su mercado es una totalidad, personas o empresas con características, necesidades y comportamientos homogéneos.

- Las acciones de marketing se hacen cada vez más complicadas para los países. El paso del tiempo está poniendo de relieve que el acercamiento a los mercados internacionales es progresivamente más difícil, pues se especializan cada vez más. Esta nueva forma de personalización choca contra la suposición de mercados masivos. Por lo pronto, hay que proponer estrategias sustentadas con el made in más efectivas, dado que la irrupción de nuevas tecnologías permitirán a obtener y tratar un gran volumen de información dirigido a diferentes audiencias.

- La propuesta de valor basada en la diferenciación para el visitante. Tradicionalmente los países construían su propuesta de valor sobre sus atributos naturales y productivos. Estos elementos han cambiado y seguirán cambiando. Las nuevas generaciones de visitantes presentarán un perfil más dinámico y menos fácil de retener. Donde la experiencia será relevante, más allá de la oferta de valor que un país proponga.

- Integración en la red de Internet. Se generarán transformaciones en los agentes económicos y en las relaciones de intercambio comercial, al incorporar internet en las estrategias de marketing territorial. Internet es un elemento innovador e ilustra la posibilidad de tener un acercamiento a una amplia tipología de usuarios potenciales con una gran variedad de intereses y preferencias. 


\section{Capítulo 5. Imagen país de Colombia}

Las premisas del sustentan el modelo son:

\section{Premisa 1. Comunicar la personalidad de la marca país para crear una presencia única.}

Los procesos de comunicación en el seno de una organización son vitales para la consecución de los objetivos de la misma. Se trata de procesos que enlazan los diversos componentes que constituyen la personalidad de la marca. La marca al igual que las personas proyecta una serie de características. Estas generan sentimientos que posteriormente se traducirán en la percepción que los extranjeros tengan sobre la marca. Ante la necesidad de los países de personalizar la experiencia del visitante, se requiere identificar el atributo extraordinario para que se convierta en un elemento diferenciador. La personalidad de una marca país está formada por los comportamientos y normas establecidas por los indicadores de un país, la cual debe ser desarrollada, discutida y compartida por todos los actores (gobierno, sector público, prescriptores, visitantes, población en general).

Premisa 2. Generar una identidad fuerte de la marca país frente a la competencia. Cada país es único, y la identidad debe surgir de sus propias raíces, de su personalidad, de sus puntos fuertes y débiles. Si bien es importante que los países generen una identidad propia, también se hace importante generar valor a las audiencias internas y externas. La generación de valor se dará con la identificación de las ventajas competitivas de un país, con la finalidad de generar barreras a la competencia como estabilidad y confianza excepcional a las audiencias. La identidad de una marca país implica considerar el conjunto de características, valores y creencias con las cuales un país se auto identifica y se auto diferencia de los demás. La identidad evita la confusión de sus audiencias ya que estos están familiarizados con su propia imagen. Por lo anterior, una organización a cargo de una marca país debe precisar dos objetivos fundamentales de la Identidad, que son: finalidad y pertenencia. Finalidad, porque se explicita la razón de ser de un país, su esencia, y la pertenencia. Un país tiene un compromiso claro, y es superar las expectativas de las audiencias, antes que lo haga su competencia. 


\section{Capítulo 5. Imagen país de Colombia}

El Modelo Estratégico de Proyección País (MEPP) tiene cinco componentes como se puede apreciar en la Figura 95:

Figura 95. Modelo Estratégico de Proyección País (MEPP)

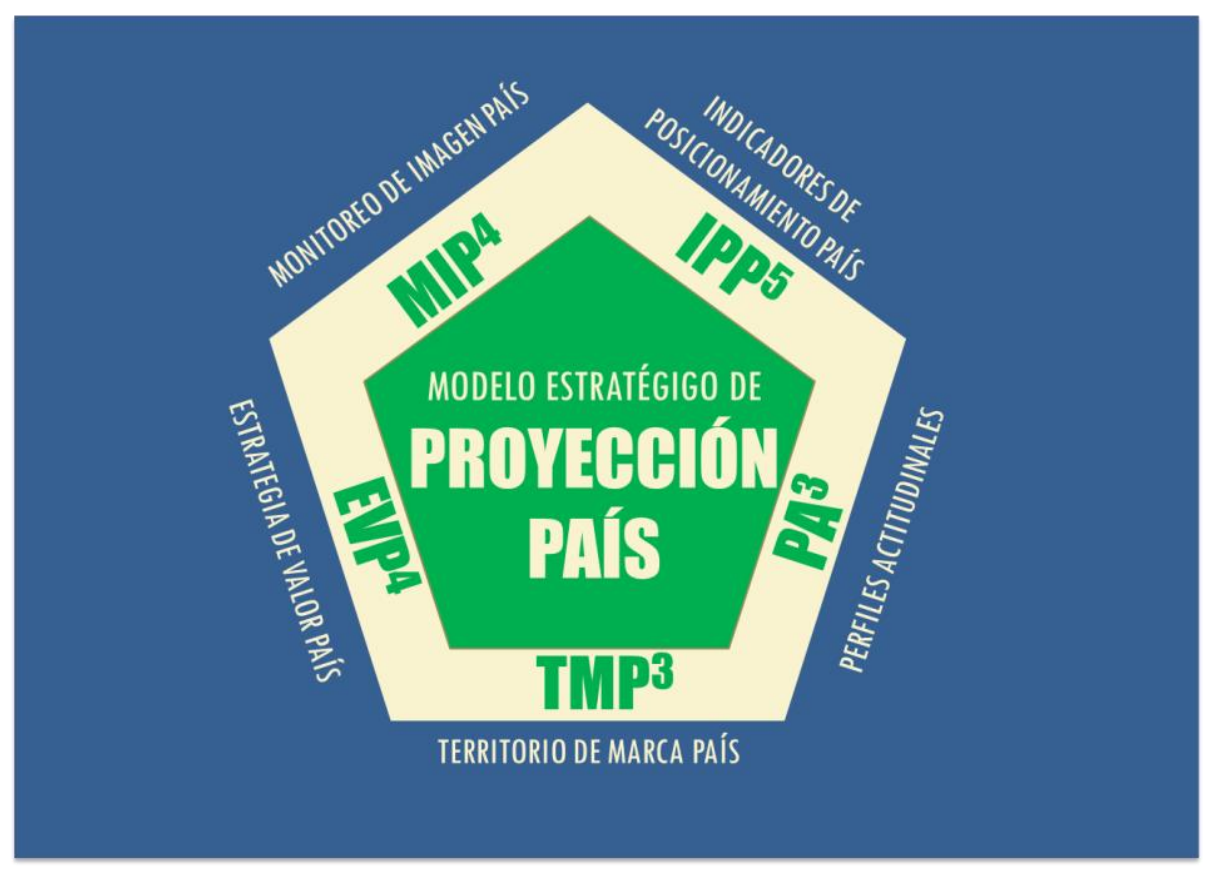

Fuente: elaboración propia.

A continuación se explica cada componente del modelo:

a. Monitoreo de Imagen País. La primera tarea es conseguir información acertada sobre el mercado. Un estudio de imagen país permitirá conocer y analizar la percepción de los extranjeros y de hecho podrá revelar problemas y áreas de interés para evaluar las estrategias de branding y de comunicación apropiadas para cada segmento.

Las audiencias son fuentes de información sobre lo que sucede con la imagen de un país. El monitoreo de imagen país contempla cuatro audiencias para medir la imagen país: los visitantes, los prospectos, los residentes, y los influenciadores (ver Figura 96). 


\section{Capítulo 5. Imagen país de Colombia}

Figura 96. Monitoreo de Imagen País

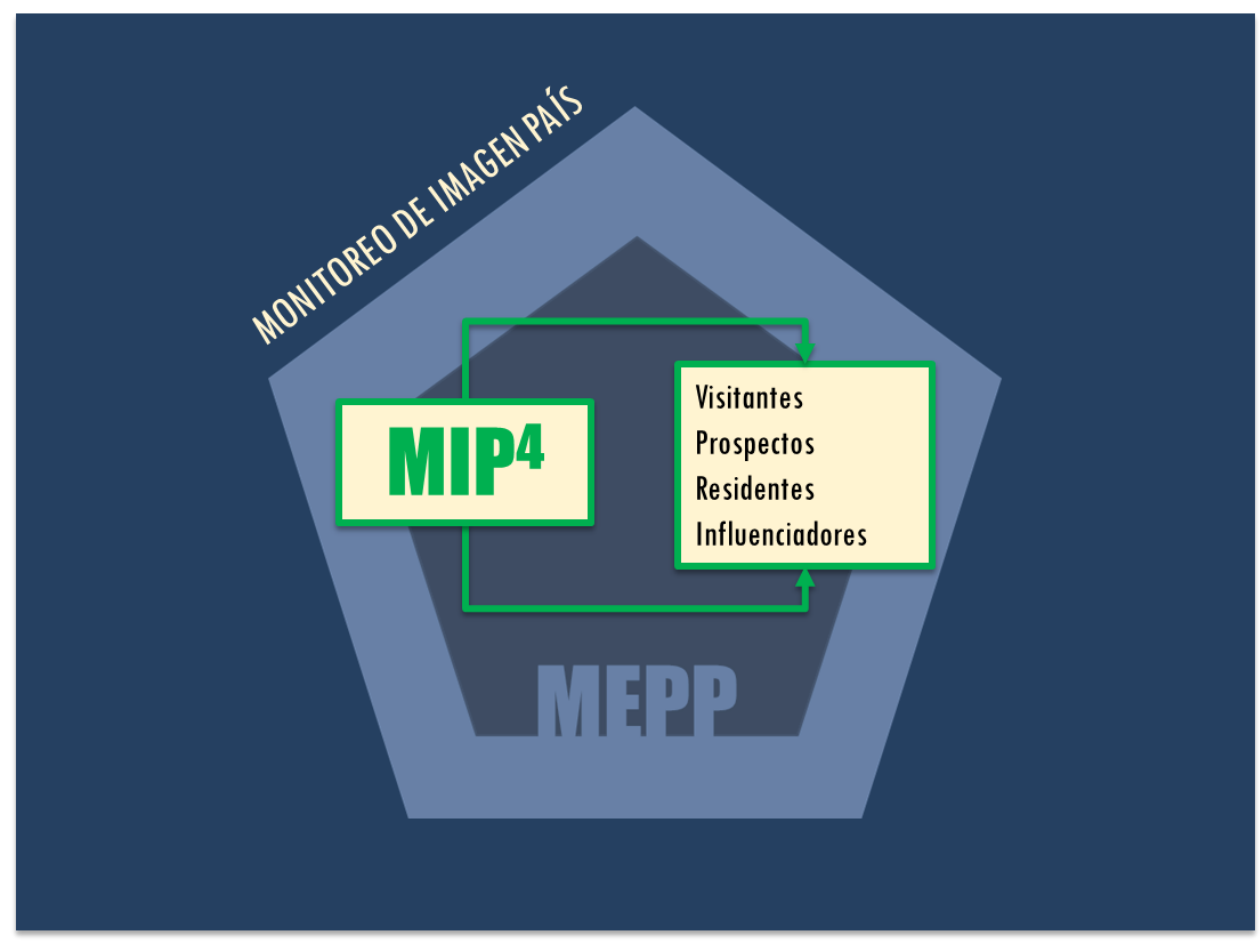

Fuente: elaboración propia.

Los visitantes son personas que viajan a un destino distinto al habitual por una duración inferior a un año. Los prospectos aquellas personas que no han viajado a un destino específico o que se encuentra en observación. Los residentes son personas naturales o jurídicas con domicilio en un país.

Y los influenciadores son personas que generan contenido y se profundizan en un tema específico, están activos en redes sociales y comunidades virtuales. Los influenciadores se clasifican en: 


\section{Capítulo 5. Imagen país de Colombia}

- Relacionista: tiene una amplia lista de contactos en plataformas como Facebook, Twitter y LinkedIn, entre las principales. Sabe sobre los demás y los demás saben sobre este influenciador.

- Líder de opinión: es el más opcional para ser embajador de marca. Es una persona del campo político, económico y social que tiene una alta reputación y credibilidad. Sus comentarios generan atención y generalmente son compartidos.

- Cazador de tendencias: es el primero en utilizar una nueva plataforma. Constantemente está en busca de nuevas tendencias que lo conviertan en el centro de atención.

- Intermediario: distribuye información a través de portales web especializados. Amplifican el mensaje.

- Usuario cotidiano: es el público en general, entraron al mundo de las redes sociales por afición en lugar de conocimiento.

El monitoreo de visitantes, prospectos y residentes debe reunir información sobre las percepciones particulares y propias en cada contexto.

Para recoger la información se recomienda elaborar encuestas estructuradas para aplicar en dos fases.

Una primera fase, de preguntas abiertas para capturar las categorías más relevantes y una segunda fase, ya con las categorías definidas, diseñar un cuestionario que permita más adelante cuantificar a través de la aplicación de escalamiento para su análisis.

Las variables de análisis para las tres audiencias son: 


\section{Capítulo 5. Imagen país de Colombia}

Cuadro 47. Variables de los Visitantes, Prospectos y Residentes

\begin{tabular}{|c|c|}
\hline Variables & Categorías \\
\hline Demográficas & $\begin{array}{ll}\text { - } & \text { Tipología (Visitante o Prospecto) } \\
\text { - } & \text { Edad } \\
\text { - } & \text { Género } \\
\text { - } & \text { País de origen }\end{array}$ \\
\hline Motivaciones del visitante & $\begin{array}{ll}\text { - } & \text { Motivos de visita } \\
\text { - } & \text { Duración de la visita } \\
\text { - } & \text { País para vivir } \\
\text { - } & \text { País para visitar }\end{array}$ \\
\hline Motivaciones del residente & $\begin{array}{ll}\text { - } & \text { Motivos de permanencia en el país } \\
\text { - } & \text { País para vivir } \\
\text { - } & \text { País para visitar }\end{array}$ \\
\hline Impresiones sobre la imagen país & $\begin{array}{ll}\text { - } & \text { Asociación general } \\
\text { - } & \text { Asociación positiva y negativa } \\
\text { - } & \text { Características de los habitantes } \\
\text { - } & \text { Asociación productiva } \\
\text { - } & \text { Asociación de ciudad } \\
\text { - } & \text { Confianza y desconfianza por país }\end{array}$ \\
\hline Asociación simbólica & $\begin{array}{ll}- & \text { Color } \\
\text { - } & \text { Aroma } \\
\text { - } & \text { Símbolo } \\
\text { - } & \text { Personaje } \\
\text { - } & \text { Animal }\end{array}$ \\
\hline Preferencias e intereses & $\begin{array}{ll}\text { - } & \text { Intención de compra de productos nacionales } \\
\text { - } & \text { Opinión del país } \\
\text { - } & \text { Interés en visitar } \\
\text { - } & \text { Recomendaciones a grupos de referencia }\end{array}$ \\
\hline Imagen del país (afectiva) & $\begin{array}{ll}\text { - } & \text { Sentimientos que despierta } \\
\text { - } & \text { Personalidad } \\
\text { - } & \text { Calificación del país } \\
\text { - } & \text { Vínculo con la marca país } \\
\text { - } & \text { Reputación de la marca país }\end{array}$ \\
\hline
\end{tabular}

Fuente: elaboración propia

El monitoreo para influenciadores requiere del diseño de una plataforma especializada que realice seguimiento a las conversaciones generadas en redes sociales. Este monitoreo agrupa las siguientes variables de análisis: 


\section{Capítulo 5. Imagen país de Colombia}

Cuadro 48. Variables de los Influenciadores

\begin{tabular}{|c|c|}
\hline Variables & Categorías \\
\hline Tipo de influenciador & $\begin{array}{ll}\text { - } & \text { Relacionista } \\
\text { - } & \text { Líder de opinión } \\
\text { - } & \text { Cazador de tendencias } \\
\text { - } & \text { Intermediario } \\
\text { - } & \text { Usuario }\end{array}$ \\
\hline Contenido & $\begin{array}{ll}\text { - } & \text { Radio de influencia } \\
\text { - } & \text { Tendencias (trending topics) } \\
\text { - } & \text { Alertas } \\
\text { - } & \text { Mensajes } \\
\text { - } & \text { Cuentas propias de marca país }\end{array}$ \\
\hline Intereses y Opiniones & $\begin{array}{ll}\text { - } & \text { Motivaciones } \\
\text { - } & \text { Opiniones } \\
\text { - } & \text { Conocimiento espontáneo } \\
\text { - } & \text { Interés sobre un destino } \\
\text { - } & \text { Recomendaciones } \\
\text { - } & \text { Menciones }\end{array}$ \\
\hline
\end{tabular}

Fuente: elaboración propia

b. Indicadores del Posicionamiento de un País. El posicionamiento es la manera en que el mercado objetivo define un país en relación con otro.

En lo referente al posicionamiento de un país, se deben considerar los índices que califican cada año en una categoría específica la posición de un país frente a otros. Hay tres categorías de posicionamiento que influyen en la imagen de un país: competitividad, marca país y reputación internacional. 


\section{Capítulo 5. Imagen país de Colombia}

Figura 97. Indicadores del posicionamiento de un país

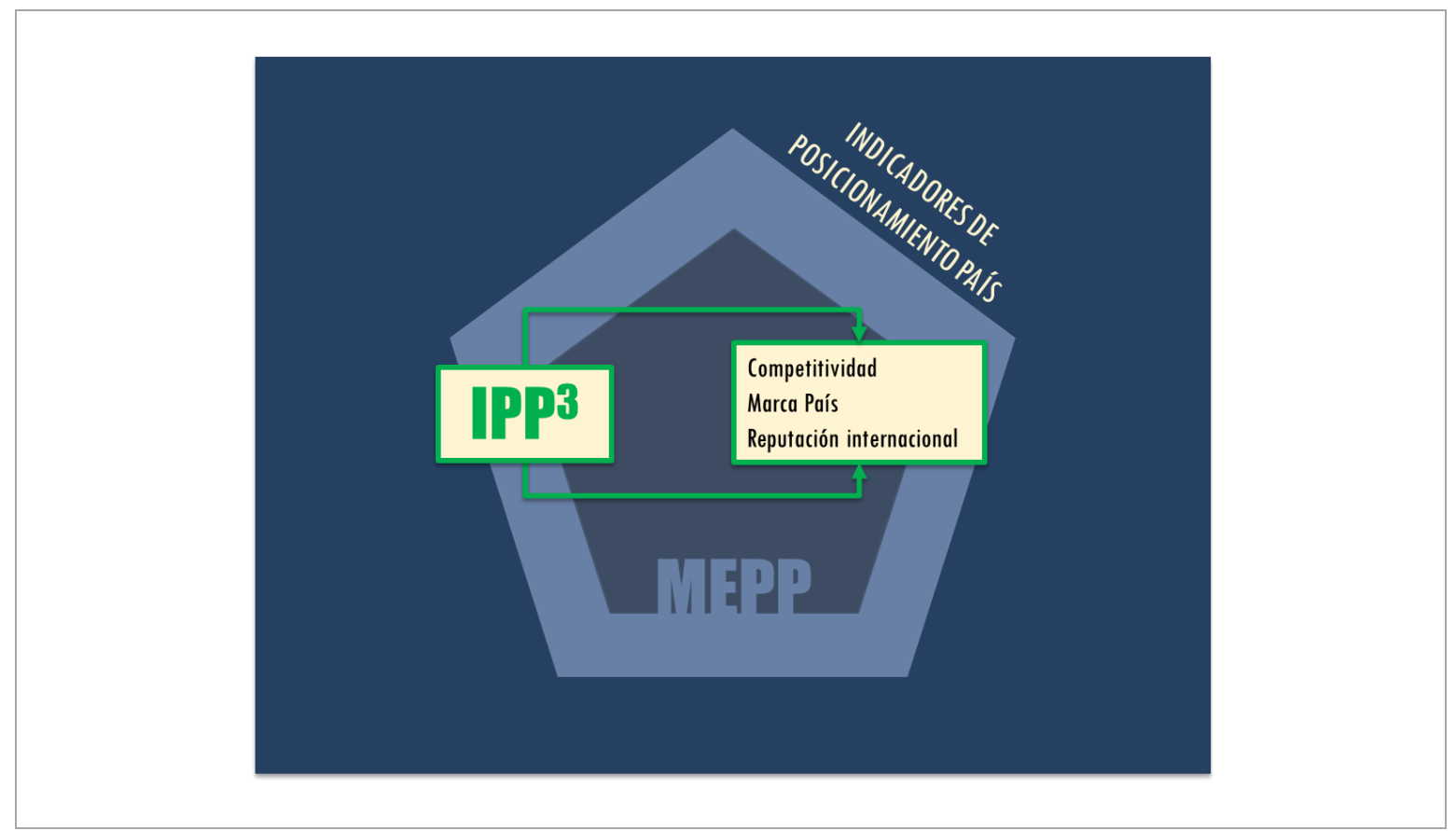

Fuente: elaboración propia.

En Competitividad se mide el posicionamiento a través de los siguientes índices:

\section{Indice}

Competitividad

Competitividad en Viajes y

Turismo

Global Innovation Index

Human Development Index

Índice de Percepción de Corrupción

Emerging Markets Bond Index Plus

Índice de Inversiones Globales

World Tourism Rankings

Índice de paz global

Índice del Desarrollo Humano

\section{Fuente}

Foro Económico Mundial

Foro Económico Mundial

Cornell University, INSEAD and WIPO

United Nations Development Programme

Transparencia Internacional

JP Morgan

Bloomberg Markets

United Nations World Tourism Organization

Institute for Economics and Peace

United Nations Development Programme 
Capítulo 5. Imagen país de Colombia 


\section{Capítulo 5. Imagen país de Colombia}

- En Marca País se mide el posicionamiento a través de los siguientes índices:

Índice

Country Brand Index

Nation Brand Index

Nation Brand Perception Indexes

Country Brand Ranking

Soft Power Survey

\section{Fuente}

FutureBrand

The Anholt-Gfk Rope

East West Communications

Bloom Consulting

Monocle

- En Reputación Internacional se mide el posicionamiento a través de los siguientes índices:

Índice

Country RepTrak

Gallup Country Ratings
Fuente

Reputation Institute

Gallup

c. Perfiles actitudinales. El objetivo de este proceso es definir el mercado objetivo y centrar las acciones que se derivan de la estrategia de marca país. Cada país y sus regiones son un mercado objetivo de otro. Los perfiles actitudinales son un conjunto de inquietudes, comportamientos y actitudes comunes de los individuos que reaccionan a los mismos estímulos. Lo anterior llevará a entender que las estrategias no pueden generalizarse, sino adaptarse un mercado específico. El MEPP requiere definir un perfil actitudinal para conocer a profundidad las características de las audiencias de una marca país. Con el entendimiento del mercado, el paso a seguir es fragmentar un mercado total en grupos que comparten necesidades, interés y comportamientos comunes. 


\section{Capítulo 5. Imagen país de Colombia}

Se hace necesario incorporar un análisis clúster que permita definir una serie de conglomerados con características homogéneas entre sí, pero diferenciales en los resultados globales. Los perfiles actitudinales son útiles para la formulación de estrategias de comunicación y branding para una marca país. Ayuda a dar prioridad a las propuestas, y luego desarrollar y entregar mensajes personalizados y pertinentes a los diferentes públicos objetivos.

Los perfiles se determinan a partir del análisis de tres categorías: a) creencias, aquello que defiende, expresa, comparte y forma parte de su filosofía de vida, b) motivaciones, lo que le mueve en sus procesos de elección, aquellos factores que despiertan su interés y preferencia $\mathrm{y}$, c) comunidad, con quien comparte sus inquietudes, en que grupo o grupos se involucra y de qué forma.

\section{Figura 98.Perfiles Actitudinales}

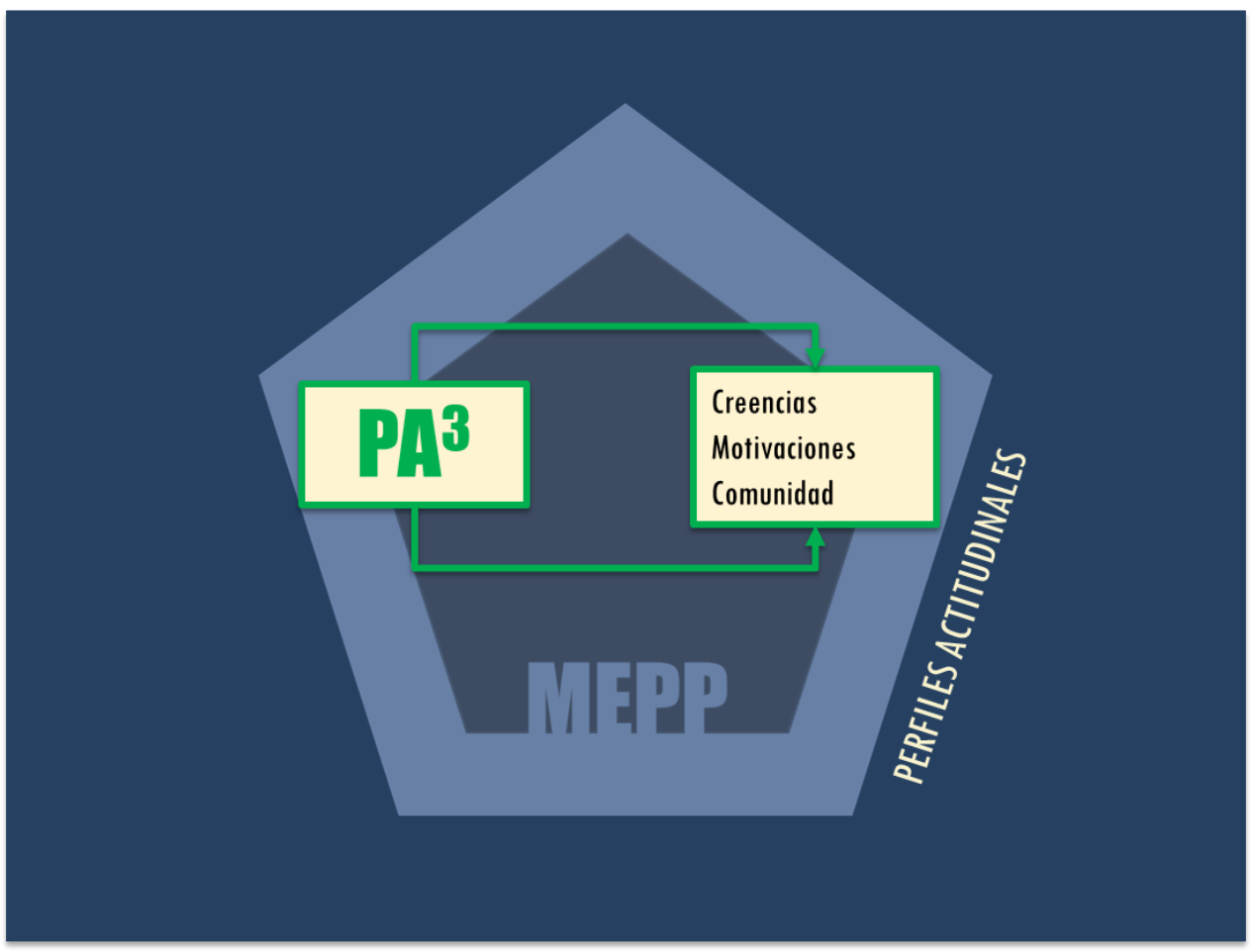

Fuente: elaboración propia. 


\section{Capítulo 5. Imagen país de Colombia}

El propósito de construir perfiles actitudinales es que esta información permite identificar: a) nichos con necesidades específicas y, b) mercados maduros para encontrar nuevos clientes, transmitir mensajes de marketing más específicas y eficaces. Las necesidades no son iguales, por lo que los mensajes de marketing deben ser diseñados para cada perfil con la finalidad de enfatizar los beneficios y características específicas. Este enfoque es más eficiente, proporcionando la combinación adecuada para el mismo grupo de personas en lugar de un enfoque disperso.

d. Territorio de marca país. Después de explorar las audiencias, evaluar los posicionamientos de un país y definir segmentos, debe precisarse cuál es el territorio de la marca país. El territorio de la marca de un país está compuesta por tres elementos: los fundamentos, las emociones y los símbolos.

Figura 99. Territorio de marca país

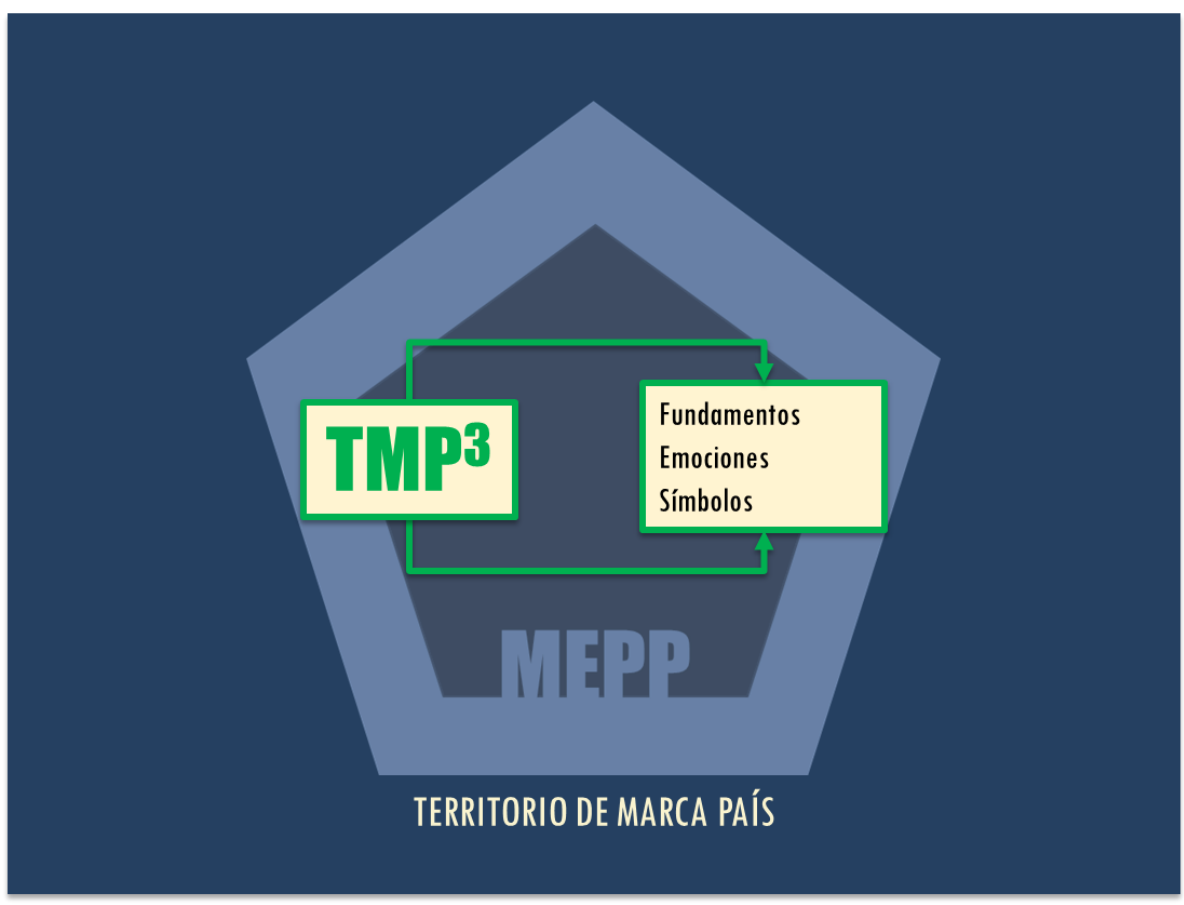

Fuente: elaboración propia. 


\section{Capítulo 5. Imagen país de Colombia}

Los fundamentos definen los vínculos entre los atributos de un país con los visitantes y residentes. Estos atributos pueden ser geográficos, climáticos, comerciales, sociales, políticos y económicos.

Debe responder a esta pregunta: ¿Qué lugar quiere el país ocupar en los mercados internacionales?

Las emociones definen la relación personal entre un país con los visitantes y residentes. Los sentimientos y percepciones sobre un destino en particular. Debe responder a esta pregunta: ¿Cómo queremos competir?

Los símbolos hacen referencia a la capacidad de distinguir estímulos y generar asociaciones semánticas sobre un destino específico. Debe responder a esta pregunta: ¿Con qué quiere un país ser asociado?

e. Estrategia de Valor País. La estrategia de valor país es una estrategia para capitalizar la reputación de un país en mercados internacional. Esta estrategia busca atraer visitantes e inversionistas hacia un país determinado con la finalidad de modificar su percepción a través de una experiencia positiva.

f. 


\section{Capítulo 5. Imagen país de Colombia}

Figura 100. Estrategia de Valor País

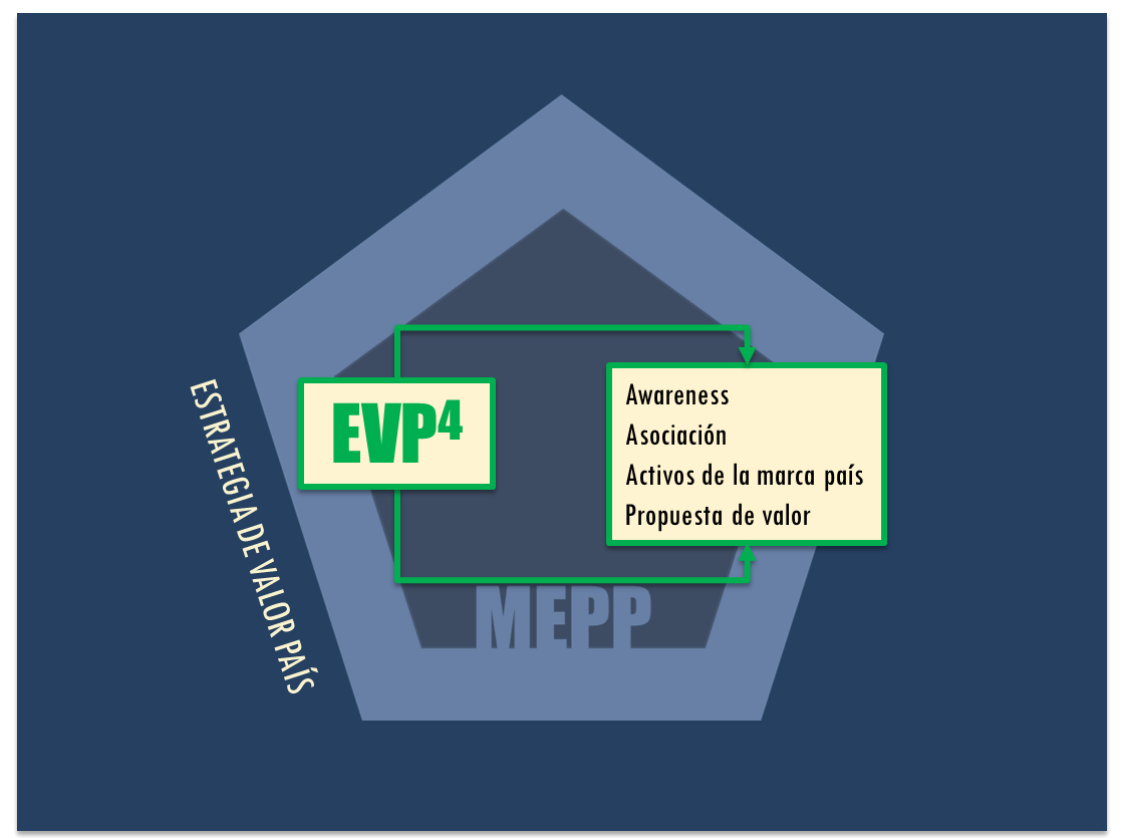

Fuente: elaboración propia.

Una marca país tiene la función principal de generar valor. Y para generar valor debe considerar tres elementos:

i. Awareness. La capacidad que tiene la persona al identificar varios aspectos de la marca país. Esta información se obtiene del Monitoreo de Imagen País del MEPP.

ii. Asociación. Las impresiones y recuerdos que tiene la audiencia sobre un país. Esta información se obtiene del Monitoreo de Imagen País del MEPP.

iii. Activos. Los atributos funcionales de un país (paisajes, clima, atracciones) y los beneficios emocionales (sentimientos, percepciones). Hacen parte de la propuesta de valor de un país. 


\section{Capítulo 5. Imagen país de Colombia}

iv. Propuesta de valor. La propuesta de valor de la marca país se construye sobre los activos que distinguen a un país con otro. En el diseño de una propuesta de valor que será el fundamento de la estrategia de valor país, suceden dos situaciones: a) generalmente los países tienen una identidad única, pero no hay claridad en la oferta de productos, y menos en la expresión de la marca país, y b) hay sesgos en la percepción de la imagen de un país. Comúnmente, la marca país se centra en elementos racionales que condicionan la conducta al elegir un destino. Pero son pocas las que incorporan elementos sensoriales que ayuden a identificar como un visitante puede tener una experiencia perceptual positiva. Cobran relevancia las percepciones afectivas en lugar de las decisiones racionales.

Lo más importante para una marca país es considerar que las audiencias perciben diferencias entre los países. El diseño de la oferta de valor dependerá del segmento a la que se encuentre dirigida. No es lo mismo diseñar una estrategia para atraer al turista que formular una para cautivar la atención de un potencial inversionista. El valor de la marca país se encuentra en la manera que los consumidores, prescriptores e inversionistas toman conciencia de la ubicación de un país y la asociación deseable de sus productos, sus empresas y su población. 


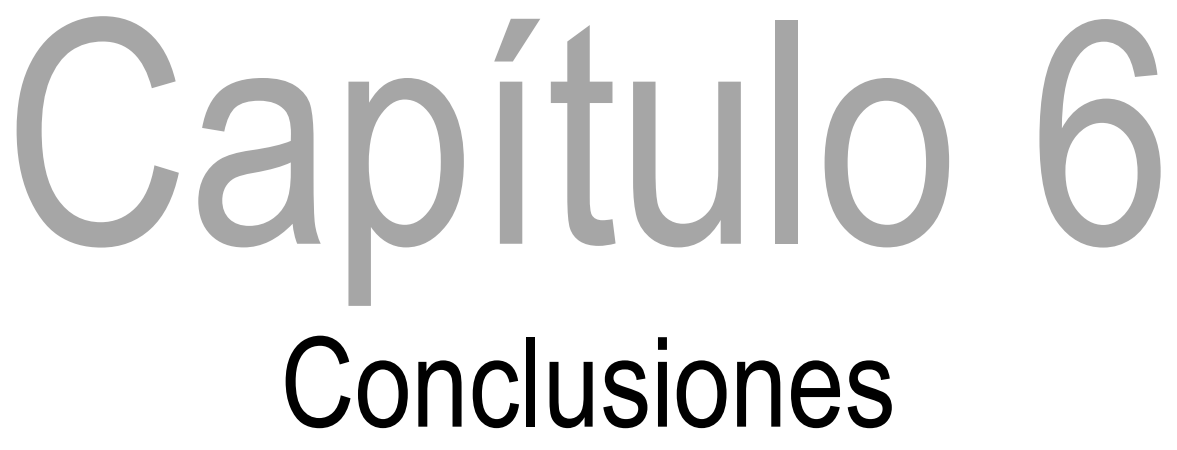




\section{Capítulo 6. Conclusiones}

El presente capítulo se organiza exponiendo las conclusiones, las implicaciones estratégicas y las futuras líneas de investigación, basadas en los objetivos y los resultados de investigación de la Tesis Doctoral.

\subsection{Conclusiones}

\subsubsection{Con relación a los objetivos}

Objetivo 1. Establecer los fundamentos y principios de la marca país como especialidad dentro de la teoría de la marca. Se han establecido los fundamentos y principios en el apartado Teoría de la Marca del Capítulo 1 y en el apartado El País como una Marca del Capítulo 2. Se conceptualizó la marca, sus objetivos y beneficios desde la perspectiva de la disciplina del marketing. Por lo anterior, se concluye que para comprender los principios de la marca país, el investigador debe estudiar y abordar la teoría de la marca por ser su fundamento epistemológico.

El contexto del estudio fue sustentado por los aportes teóricos de un creciente grupo de consultores e investigadores en los campos del conocimiento de la marca y la marca país. Una marca país debe conectarse con el visitante a través de su experiencia. Mientras que la imagen país debe conectarse a través de sus percepciones. Por este motivo, la marca país es una estrategia de Branding y de posicionamiento de un país en el extranjero. Y la imagen país, es el resultado de la percepción de los visitantes, residentes, influenciadores y prospectos sobre un país. De acuerdo con lo anterior, es relevante establecer los fundamentos y principios de una marca país como especialidad dentro de la teoría de la marca. Es decir, para comprender el concepto de marca país, hay que entender el significado de la gerencia 


\section{Capítulo 6. Conclusiones}

de marca. Y éste a su vez se debe proponer como una estrategia de marketing que se aplica para las empresas, las personas, los productos y los países.

Objetivo 2. Analizar la evolución de la marca país en América. En el Capítulo 2 se analizó y comentó la evolución de las marca país del contienente americano. El desarrollo de cada caso permitió evidenciar que cada país ha tenido una experiencia diferente en la creación, desarrollo y consolidación de su marca país. Sin embargo, un punto en común es que todos los países reconocen la relevancia que cobra la imagen país para competir en mercados internacionales.

Los países del contienente americano deben enfocarse en dos acciones: redefinir la marca país como gestión institucional y estudiar la percepción que tienen los extranjeros sobre la imagen de sus países. La experiencia de marca país en el continente americano reúne tres puntos en común en el proceso de construcción de marca: la notoriedad, la diferenciación y el prestigio.

La notoriedad dada por el posicionamiento, la diferenciación dada por la autenticidad en los atributos de un país y el prestigio originado por la reputación en mercados internacionales. Para países como Estados Unidos y Canadá la marca país es una estrategia transversal para fortalecer la imagen del país en el extranjero. Situación que no ocurre en América Latina. En los países latinoamericanos hay que fortalecer su marca país y mejorar su imagen internacional. Sin embargo, el país que pretenda construir una marca país deberá considerar una serie de condicionantes: atributos del país, características de su población, entorno socioeconómico y político, infraestructura, entre otros. Pero el condicionante principal es las impresiones sobre un país. Es la impresión la que ayuda a descubrir cuál es la identidad de un país.

Objetivo 3. Analizar los orígenes y evolución de la marca país de Colombia. Se concluyó que Colombia se encuentra en su fase introductoria en términos de gestión de marca. A través de los dos casos de estudio de la marca país de Colombia se concluye que la estrategia de marca país ha sido concebida como una política de gobierno y no como una política de Estado. Colombia carece de estrategia de marca pensada en el largo 


\section{Capítulo 6. Conclusiones}

plazo, que sea parte de una gestión institucional y articulada a las funciones de Proexport en lo referente a mejorar la reputación del país en el exterior. Ante los resultados de las dos experiencias de marca país en Colombia se logra comprender porqué en el país hay resistencia al reconocer la relevancia de la marca país.

Un aspecto común de la marca Colombia es Pasión y la Marca País Colombia es que no hay visibilidad en mercados internacionales. En los resultados expuestos en el capítulo 5 se demuesta esta afirmación. Colombia es reconocida por la marca comercial de café Juan Valdez.

\section{Objetivo 4. Formular el diseño metodológico adecuado para la aplicación de técnicas} instrumentos en la recolección de información. En apartado de Metodología de Investigación del Capítulo 4 se definieron dos tipos de de investigación empírica y cualitativa. La primera permitió realizar una descripción de la situación real de la gestión de marca país en América y en Colombia. Y la segunda ayudó a entender cómo la percepción es el punto de partida para estudiar la imagen de un país como Colombia. Por lo anterior, se identificaron las percepciones generales que los extranjeros tienen sobre la imagen país de Colombia. Se consideró pertinente abordar como población de estudio a los ocho países que registran mayor número de visitas hacia Colombia en el 2013. Los países que conformaron la población de estudio fueron: Estados Unidos, Venezuela, Ecuador, Argentina, Perú, Brasil, México y Chile.

Se realizaron cuatro análisis: a) Análisis bivariado para variables como: visitantes, prospectos, país de América del Sur donde le gustaría vivir y que prefiere visitar, b) Análisis de correspondencia, por ser una técnica descriptiva que ayuda a entender a través de mapas perceptuales las categorías de las variables analizadas; c) Análisis clúster para visitantes y prospectos americanos y d) elaboración de redes bayesianas con la finalidad de identificar qué variables pueden ser predictivas en el estudio. 


\section{Capítulo 6. Conclusiones}

Objetivo 5. Identificar los determinantes de la percepción de la imagen país de Colombia desde la perspectiva de ocho países de América. En el Capítulo 5 se identificaron los determinantes de la percepción de la imagen país de Colombia. El punto de partida de la Tesis Doctoral fue la medición de la imagen país de Colombia. Es a partir de las impresiones generales donde se identificaron los determinantes que influyen en la percepción que tienen los extranjeros sobre la imagen de Colombia. Se concluye que la percepción sobre Colombia está determinada por la experiencia en la visita, por la información que se recibe de los medios, y por la socialización con grupos de referencia que tienen conocimiento sobre un país. También se concluye que dos características del visitante y del prospecto afectan su percepción sobre Colombia:

- Característica 1. La capacidad para distinguir la imagen país de Colombia. Las variables que más se relacionan son: país de origen, el país donde le gustaría vivir y visitar, las decisiones de comprar un producto colombiano y las características de sus residentes.

- Característica 2. La generalización de la imagen país de Colombia dado por las experiencias positivas o negativas, y los jucios valorativos de los extranjeros.

La relación entre la marca país e imagen país debe ser relevante en el diseño de políticas de relaciones internacionales de los gobiernos. Para lograrlo, la gestión de la marca país de Colombia debe implementar un modelo estratégico de proyección país que permita partir del conocimiento que se tiene la imagen país de Colombia y posteriormente diseñar estrategias que fortalezcan la reputación nacional en el extranjero.

Objetivo 6. Enmarcar las aportaciones principales de la investigación desde lo teórico, metodológico y práctico generado por los resultados del estudio. En el Capítulo 6 se presentaron las conclusiones, profundizando en las hipótesis planteadas en el modelo 


\section{Capítulo 6. Conclusiones}

teórico, además de considerar las implicaciones estratégicas y las futuras líneas de investigación.

\subsubsection{Con relación a las hipótesis}

H1: Los visitantes han dejado de asociar la imagen de Colombia con las drogas, el terrorismo, la inseguridad y la corrupción. La primera hipótesis se verifica porque los extranjeros que han visitado a Colombia cambian su percepción sobre la imagen del país. Ya no se asocia a Colombia con las drogas, el terrorismo, la inseguridad y la corrupción.

H2: Existen diferencias proporcionales entre visitantes y prospectos cuando indican que un aspecto positivo de Colombia es la alegría de su población. La segunda hipótesis se confirma porque demuestra que hay diferencias proporcionales entre extranjeros visitantes y prospectos cuando asocian a Colombia con la alegría. Lo anterior es comprensible, porque es el visitante el que tiene contacto con la población colombiana.

H3: La imagen de Colombia ostenta, por otro lado, un posicionamiento negativo derivado de la asociación histórica del país con las drogas y la guerrilla. La tercera hipótesis se comprueba en los resultados relacionados con los aspectos negativos con los que se asocia a Colombia. Con la aplicación de la prueba $t$ de Student se puede observar que no hay diferencias significativas entre visitantes y prospectos sobre el posicionamiento negativo que tiene la imagen de Colombia derivado de la asociación histórica del país con las drogas y la guerrilla.

H4: Los extranjeros que no han visitado al país, consideran que la alegría y la diversión son características propias de los colombianos. La cuarta hipótesis se confirma porque los extranjeros que no han visitado aún a Colombia, consideran que los colombianos son alegres y divertidos. El posicionamiento de una marca país depende de la reputación que tenga su población, porque en el caso objeto de estudio, se exponen las características de la personalidad que refleja Colombia en mercados internacionales. 


\section{Capítulo 6. Conclusiones}

H5: La imagen de Colombia es reconocida en mercados internacionales como poseedora de un alto valor agregado debido al poder y notoriedad del café. La quinta hipótesis se verifica porque demuestra que la imagen de Colombia es reconocida en mercados internacionales como poseedora de un alto valor agregado debido al poder y notoriedad del café. En los resultados se evidencia que no hay diferencias significativas, porque que el $64 \%$ de los visitantes y el $65 \%$ de los prospectos asocian a Colombia con la actividad cafetera.

\subsubsection{Con relación a la metodología}

La Tesis Doctoral explora a fondo dos conceptos: marca país e imagen país a través de un estudio empírico y cualitativo sobre Colombia. La combinación de la metodología empírica y cualitativa permite al investigador profundizar sobre una problemática que cobra relevancia para los gobiernos y las empresas con interés en los mercados internacionales.

Para comprender las experiencias de marca país, la investigación empírica ayuda a construir los casos y entender desde su naturaleza el porqué de los resultados. Y en lo referente a la imagen país, la investigación cualitativa busca comprender los fenómenos que influyen en la percepción que tienen los extranjeros sobre un país determinado.

La aplicación de la técnica de la encuesta estructurada, propia de la investigación cualitativa, parece ser un buen método para recoger información detallada y resistir el grado de incertidumbre que surge cuando se plantean investigaciónes sobre variables perceptuales. Sin embargo, esta técnica debe mejorar el proceso de toma de decisiones cuando se convoque un nuevo estudio para comparar resultados en diferentes espacios de tiempo.

Los análisis aplicados se recomiendan en este tipo de investigaciones: (i) Análisis bivariado permite al investigador tener un panorama general del fenómeno observado; y, (ii) Análisis de Correspondencia ayuda a interpretar en un plano de dos o tres dimensiones cómo se asocian las variables sobre la percepción de Colombia. Específicamente, los análisis de correspondencia y los análisis clúster pueden ser de gran utilidad para la formulación 


\section{Capítulo 6. Conclusiones}

de estrategias de segmentación y posicionamiento para tres grupos de interés: Proexport Colombia, Marca País y el sector exportador.

La aplicación de redes bayesianas permiten centrar decisiones de acuerdo a la modelación de variables que generan dependencia. Es decir, los resultados obtenidos con el análisis expuesto por las redes bayesianas ayudan a generar inferencias y ser predictivas para la toma de decisiones de los agentes responsables de la gestión institucional de la marca país de Colombia.

\subsubsection{Con relación al Caso Colombia}

Colombia es un país que debe entender que su imagen país está evolucionando. Debe pasar de ser asociada al café y al narcotráfico, y focalizarse en promover un posicionamiento orientado a la naturaleza y los negocios.

El estudio presenta que los visitantes internacionales conservan una asociación negativa de Colombia vinculada al tema del narcotráfico y terrorismo. El $27 \%$ de los extranjeros asocian a Colombia con las drogas, el terrorismo, la inseguridad y la corrupción. La categoría de drogas sobresale en los resultados del estudio como el aspecto negativo que tiene asociación a la imagen país de Colombia. Un aspecto que aún influye en el posicionamiento del país, especialmente con países vecinos.

Contrastan los resultados con la amabilidad de los colombianos como asociación positiva a la imagen país. La experiencia hace que la percepción se modifique. Los visitantes logran reducir esa brecha entre la percepción y la realidad.

Estados Unidos es el principal emisor de visitantes hacia Colombia (Echeverri et al., 2013b). Por lo anterior, cobra relevancia la percepción que tienen los estadounidenses sobre la imagen país de Colombia. La experiencia del visitante estadounidense demuestra cómo su percepción difiere del prospecto. El estadounidense que ha visitado a Colombia, quiere regresar al país, y lo asocia con mujeres bellas y naturaleza. Sin embargo, coincide con la percepción del no visitante, al asociar a Colombia también con las drogas, el terrorismo y el café. 


\section{Capítulo 6. Conclusiones}

Una imagen país percibida como positiva es importante para Colombia. Si la imagen es positiva, los visitantes exponen todo lo que viven de manera positiva, pero si la imagen percibida es negativa, esto no solo le puede afectar la imagen al país sino a sus empresas, su población y sus productos.

En este sentido, los estadounidenses destacan como aspecto positivo del país la pasión y la alegría; y como negativo la guerrilla, el terrorismo y la congestión vehicular.

Los estadounidenses mayores de 40 años asocian a Colombia con las drogas, crimen y la inseguridad. Los visitantes más jóvenes indican que la amabilidad, la pasión y la alegría de la gente son descriptores positivos de la imagen país de Colombia. Sin embargo, los visitantes independientemente de la edad, señalaron que la violencia, la inseguridad, las drogas y la guerrilla son descriptores negativos de la imagen país.

Los jóvenes visitantes y prospectos están interesados en conocer a Colombia. Sin embargo, se mantiene una percepción negativa sobre la imagen país asociada al tema de la inseguridad. Durante el estudio, tanto para visitantes como para prospectos se encontraron importantes relaciones entre las variables con el apoyo de la metodología bayesiana.

La dependencia generada por la variable de País de Origen enmarca gran parte de las otras variables como país donde le gustaría vivir y visitar, la disposición de compra de productos nacionales y el símbolo con el que se asocia un país. Hay un efecto directo en la relación de la imagen de las personas con la imagen país.

Aún no se ha llegado a un consenso sobre cuáles son los elementos, las características o los rasgos que deben destacarse para fortalecer la imagen país que se proyecta de Colombia en el extranjero. Lo anterior genera una opinión difusa en cuanto al posicionamiento en el caso colombiano. Las asociaciones difieren entre los distintos países estudiados.

En el análisis clúster, se encontraron asociaciones compartidas. De acuerdo a lo anterior vale la pena considerar que la comunicación de una marca país depende del grupo objetivo al que planee dirigirse.

Frente a los resultados obtenidos sobre la percepción de imagen país, se propone un modelo estratégico de proyección-país para la marca país de Colombia en mercados internacionales. Lo anterior ayudará a las entidades competentes a reducir la pérdida de valor agregado en sectores de desarrollo potencial como el turismo y la inversión extranjera. En 


\section{Capítulo 6. Conclusiones}

este sentido surgen nuevas líneas de investigación relacionadas con ampliar la cobertura del estudio a otros países y realizar el mismo estudio en el mercado interno, con los colombianos como unidad de análisis.

\subsection{Implicaciones estratégicas}

Las implicaciones estratégicas corresponden a los compromisos que debe adquirir la organización que gestiona la marca país para mejorar la imagen del país en el extranjero. Las implicaciones estratégicas de la Tesis Doctoral se enuncian a continuación:

Implicación 1. Inclusión de estrategias de marketing para la marca país. La Tesis Doctoral expone que en el mercado no solo compiten los productos sino también los países. Hay una necesidad de abordar a un país de una manera muy diferente a un producto o marca comercial. El marketing deriva una especialización centrada en el territorio, donde la reputación de un país logra que sus atributos sean atractivos en mercados internacionales.

Una prioridad en la gestión de marca país es redefinr estrategias de marketing para el posiconamiento en el ámbito internacional. Estrategias que cumplan el propósito de fortalecer la reputación de un país y que dén relevancia a la denominación de origen y al posicionamiento de su imagen país en el largo plazo. La marca país debe profundizarse en los estudios académicos, para dar a concoer su importancia a los profesionales del marketing, e incorporarla como una teoría adyacente a la teoría de la marca.

Implicación 2. Monitoreo de la imagen país de Colombia. El estudio de la imagen país puede ser una fuente para la personalización de las estrategias de marketing y no pueden ser copiadas por otros países que no evocan este tipo de identidad con el país de origen. Aunque este estudio se basa en un análisis de caso de cómo se percibe un país desde diferentes mercados, los resultados tienen cualidades genéricas. 


\section{Capítulo 6. Conclusiones}

Todos los países, independientemente de su tamaño y ubicación, tienen relaciones con otros países, y la proximidad geográfica, cultural y social entre los países de origen y de destino tienen un impacto en la forma de su relación y los intereses compartidos. Lo anterior motiva a que en el caso de Colombia se debe rediseñar la estrategia de marca país.

\section{Implicación 3. Mayor conocimiento de los mercados internacionales para establecer} patrones de segmentación especializados. Un aspecto en común, destacado en el análisis clúster es que ambos grupos sujeto de estudio asocian de manera positiva a Colombia con el café. Lo más importante para un país como Colombia es considerar que los visitantes perciben diferencias entre la percepción y la realidad. Los resultados del estudio empírico y cualitativo demuestran que es con la figura del visitante donde más oportunidades se pueden identificar para mejorar la reputación de un país en el extranjero.

Referente a los resultados, la imagen positiva de Colombia tiene múltiples ventajas, dado que permite la aplicación práctica en la definición de nuevas estrategias de marketing para la organización responsable de la ejecución de la marca país. Estrategias que se sustentan en el conocimiento del mercado, en la expansión del turismo, en el aumento en el interés de los inversionistas, en mejorar la imagen de un país, y en fortalecer una posición competitiva de las marcas nacionales en el extranjero.

Implicación 3. Posicionamiento de la imagen país de Colombia. La investigación presenta como a partir de un país, se construyen creencias en el imaginario colectivo, en el cual los países parecen tener cualidades únicas en cada mercado de destino en función de la importancia de la percepción y experiencia del visitante.

En particular los intereses compartidos y las identidades colectivas parecen estar anclados en temas de relaciones históricas, económicas o geopolíticas entre países. Por lo tanto, las variables para evaluar una imagen país se deben usar con 


\section{Capítulo 6. Conclusiones}

precaución. Estas variables deben incluir cualidades relacionales, además de los rasgos descriptivos que se miden en escalas existentes en posicionamiento.

La imagen de Colombia debe reflejar el prestigio de su población, de sus empresas y de sus atributos naturales. La percepción juega un papel fundamental en la decisión de visitar o no a Colombia. El desafío para la estrategia de marca país es cautivar a los extranjeros para aumentar su radio de visita o ubicar a Colombia como destino número uno en sus planes de viajes.

De acuerdo a los hallazgos, la percepción sobre la imagen país de Colombia tiene repercusiones en el turismo, las exportaciones y la inversión extrajera. En esa perspectiva, una imagen internacional positiva se convierte en un elemento esencial para mejorar la reputación de Colombia en mercados internacionales. Se recomienda una estrategia de relaciones públicas en universidades con el propósito de promover la marca unida a la explicación académica del significado que tiene una marca país en mercados internacionales.

\section{Implicación 4. Contenido argumentativo para la estrategia de marca país de Colombia.} Un aporte logrado en el campo de la presente investigación, es argumentar la estrategia de marca país frente a grupos de interés como: sociedad civil, empresas, gobierno y prescriptores. Sumado a que permitirá definir estrategias de marketing territorial ajustadas a los segmentos (clúster) que fueron resultado del estudio.

\section{Implicación 5. Propuesta del Modelo Estratégico de Proyección País para Colombia.} Estos resultados de la investigación sobre imagen país pueden orientar el modelo de proyección país que tiene definido Colombia hacia el mercado americano. Con los hallazgos identificados en el estudio se pretende que la organización marca país rediseñe estrategias de marketing en los países de estudio considerando los siguientes aspectos: a) el cambio generacional que tiene la población, y b) la asociación positiva que tienen los extranjeros hacia Colombia en términos de la amabilidad de su gente.

El propósito del Modelo Estratégico de Proyección País es monitorear permanentemente la imagen país en mercados internacionales. El modelo se sustenta 


\section{Capítulo 6. Conclusiones}

en que la estrategia de marca país de Colombia carece de un organismo que monitoree las percepciones que tienen los extranjeros sobre la imagen país. No es suficiente aplicar estudios de mercado. Se requiere de un sistema de información que registre en la inmediatez el contenido generado a través de redes sociales, agencias de turismo, operadoras turísticas, hoteles, entre otros.

\subsection{Futuras líneas de investigación}

Se requiere de nuevas investigaciones con una comprensión más profunda sobre marca país, especialmente en la región latinoamericana. Hay escasez de conocimiento en la región, y especialmente por parte de quienes ejecutan la estrategia. Los gobiernos latinoamericanos no han logrado entender la relevancia que tiene la proyección de una imagen país.

La agenda de investigación que se deriva de la Tesis Doctoral y se propone es:

1. Profundizar en el desarrollo conceptual sobre marca país e imagen país. Es relevante diferenciar ambos conceptos, y precisar que para llegar a diseñar una estrategia de marca país se requiere del estudio detallado de la imagen país.

2. Promocionar la investigación sobre imagen país de países en América Latina. Lo anterior permitirá contribuir a definir estrategias que mejoren la reputación en lugares específicos y conocer las impresiones que tienen los extranjeros sobre un determinado destino.

3. Realizar un estudio comparativo de réplica del estudio se la imagen país de Colombia. El propósito será investigar las percepciones, impresiones y asociaciones que tienen los extranjeros para el año 2015 empleando las variables y categorías de análisis de la investigación cualitativa realizada en 2013. Lo anterior permitirá hacer comparativos de resultados en un periodo no mayor de dos años.

4. Crear un observatorio internacional de buenas y malas prácticas para el proceso de construcción y desarrollo de una estrategia de marca país. Los países que lideran en términos de marca país e imagen país, son fuente de lecciones de 


\section{Capítulo 6. Conclusiones}

aprendizaje permanente hacia otros países. Y con el apoyo de la investigación casuística se puede conocer a profundidad sus experiencias, resultados y prácticas que ayudan a mejorar el posicionamiento de un país.

5. Aumentar el uso de tecnologías sociales y las TIC avanzadas que permitan mejorar los estudios sobre imagen país, y a través del conocimiento empírico obtener información cualitativa sobre la percepción de un país por parte de visitantes, residentes prospectos e influenciadores.

6. Desarrollar un índice de imagen país que permita medir la evolución y modificaciones de las percepciones que tienen los extranjeros sobre un país, comparando un periodo con otro, en un lapso inferior a dos años. 


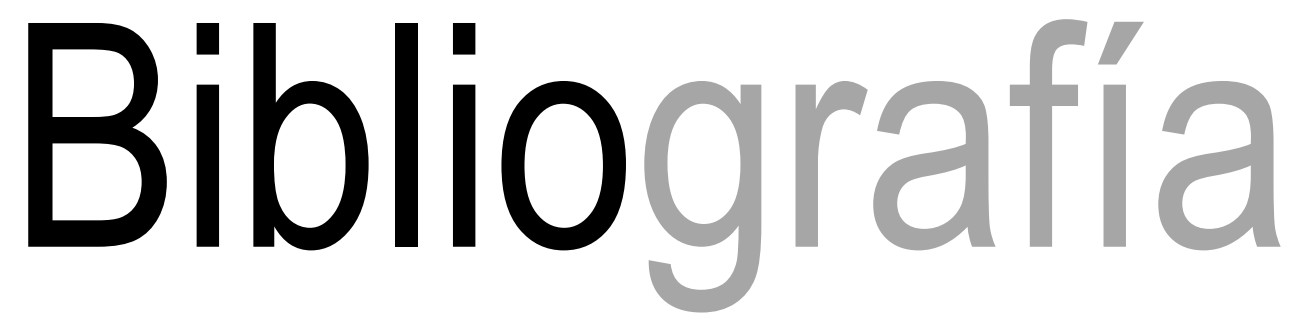




\section{Bibliografía}

Aaker, D. (1991). Managing Brand Equity. New York: The Free Press.

Aaker, D. (1996a). Building strongs brands. New York City: The Free Press.

Aaker, D. (1996b). Measuring Brand Equity Across Products and Markets. California Management Review, 38(3), 102-120.

Aaker, D. (2000). Harvard Business Review on brand management. Boston: Harvard Business School Press.

Aaker, D. (2005a). Estrategia de la Cartera de Marcas. España: Gestion 2000; 1st. edition.

Aaker, D. (2011). Brand Relevance. Making competitors irrelevant. San Francisco: JosseyBass.

Aaker, D. A., \& Joachimsthaler, E. (2005b). Liderazgo de Marca. Barcelona: DEUSTO.

Aaker, D., Kumar, V., \& Day, G. (2001). Investigación de mercados. México D.F.: Editorial Limusa Wiley.

Adams, T. (2005). How Brands Become Icons: The Principles of Cultural Branding. (J. Plummer, \& B. Woodard, Eds.) Journal of Advertising Research, 45(2), 282-283. doi: 10.1017/S0021849905000292.

Adamson, A. P. (2007). BrandSimple. United States of America: Palgrave Macmillan.

Agren, D. (2012). México la gestión de Calderón y los escollos aún por superar. Latin Trade, 20(2), 28-35.

Aguilar, S. (2013). Ecuador, el país de América Latina y el Caribe que más puestos avanzó en el Índice de Desarrollo Humano. Obtenido de Agencia Pública de Noticias del Ecuador y Suramérica: http://www.andes.info.ec/es/economia/ecuador-es-paisamerica-latina-caribe-mas-puestos-avanzo-indice-desarrollo-humano.html

Aitken, R., \& Campelo, A. (2011). The four Rs of place branding. Journal Of Marketing Management, 27(9/10), 913-933. doi:10.1080/0267257X.2011.560718.

Akotia, M., Ebow Spio, A., Frimpong, K., \& Austin, N. (2011). Country branding: a developing economy perspective. International Journal Of Business Strategy, 11(2), 123-131. 
Alba, J. W., \& Chattopadhyay, A. (1986). Salience Effects in Brand Recall. Journal Of Marketing Research, 23(4), 363-369.

Alvarado, B. (2010). Ecoturismo en Costa Rica: mito o realidad, la verdad. Obtenido de http://dspace.sunyconnect.suny.edu/bitstream/handle/1951/55354/Alvarado_grad.su nysb_0771M_10013.pdf?sequence=1

Ambler, T. (2012). Why do they still not get it? Market Leader(Q4), 12-13.

América Economía. (2010). Colombia lidera los CIVETS, el nuevo grupo de los países emergentes. Obtenido de http://www.americaeconomica.com/index.php?noticia=11457\&name=INTEGRACI $\% \mathrm{C} 3 \% 93 \mathrm{~N}$

América Economía. (2011a). PIB de Argentina creció 9,2\% en 2010. Obtenido de http://www.americaeconomia.com/economia-mercados/finanzas/pib-de-argentinacrecio-92-en-2010

América Economía. (2011b). Violencia del narcotráfico está afectando al turismo en México. Obtenido de América Economía: http://www.americaeconomia.com/negociosindustrias/violencia-del-narcotrafico-esta-afectando-al-turismo-en-mexico

Ander-Egg, E. (1995). Técnicas de investigación social. Lumen.

Anderson, J. (1983). A spreading activation theory of memory. Journal of Verbal Learning and Verbal Behavior, 22, 261-295.

Andrade, V., Melena, W., \& Silva, A. (2012). Análisis y Crítica de la Marca País en Ecuador.

Anholt, S. (2002). Nation Branding: A continuing theme. Journal of Brand Management, $10(1), 59-60$.

Anholt, S. (2003). Brand new justice: The upside of global branding. Routledge.

Anholt, S. (2005b). Nation brand as context and reputation. Place Branding, 1(3), 224-228.

Anholt, S. (2007a). Competitive identity, the new brand management for nation, cities and regions. New York: Palgrave MacMillan.

Anholt, S. (18 de Julio de 2007b). La marca país. (A. Oppenheimer, Entrevistador, \& E. Tiempo, Editor) 
Anholt, S. (2008). Chile: competitividad a prueba. Revista Capital, 16-66. Obtenido de http://74.125.45.104/search?q=cache:lgA61MsFxKUJ:www.capital.cl/reportajes-yentrevistas/edici-n-aniversario.-chile-competitividad-a-p21.html+Simon+Anholt $+\% 2 \mathrm{~B}+$ medicion + de + marca + pais $\&$ hl $=$ es $\& c t=c l n k \& c d=4 \&$ $\mathrm{gl}=\mathrm{co}$

Anholt, S. (2008a). Las marcas país. Estudios Internacionales, 41(161), 193-197.

Anholt, S. (2008b). Nation Branding in Asia. Place Branding and Public Diplomacy, 4(4), 265-269.

Anholt, S. (2010). Definitions of place branding - Working towards a resolution. Place Branding and Public Diplomacy, 6(1), 1-10. doi: 10.1057/pb.2010.3.

Anholt, S. (2011). 17. Beyond the Nation Brand: The Role of Image and Identity in International Relations. In A. Pike, Brands and Branding Geographies (p. 289.). Edward Elgar Publishing.

Anholt, S. (n.d.). The Anholt-GfK Roper Nations Brand Index. Retrieved Agosto 23, 2008, from GfK Custom Research North America: http://www.gfkamerica.com/practice_areas/roper_pam/nbi_index/index.en.html

Anholt, S., \& Hildreth, J. (2005a). Brand America: The Mother of All Brands. Cyan Communications.

Anholt, Simon \& GfK Custom Research. (s.f.). The Anholt-GfK Roper Nations Brand Index. Recuperado el 23 de Agosto de 2008, de http://www.gfkamerica.com/practice_areas/roper_pam/nbi_index/index.en.html

Arango, J. P. (2013). Gerente de Marketing de la Marca País Colombia. (A. Rodríguez, Entrevistador)

Arango, M. (2009). Vicepresidente de Sancho/BBDO. (L. Echeverri, Entrevistador)

Arango, M. (2013). Colombia, el riesgo es que te quieras quedar.... Obtenido de Latin Trade: http://es.latintrade.com/2013/02/colombia-el-riesgo-es-que-te-quieras-quedar/

Arellano, R. (2002). Comportamiento del consumidor. Enfoque América Latina. México: McGraw Hill.

Arnold, D. (1993). Manual de la gerencia de marca. Bogotá: Carvajal S.A. 
Asociación Colombia de Agencias de Viaje y Turismo ANATO. (2012). Visitantes Extranjeros que ingresan a Colombia (Migración Colombia). Obtenido de http://www.anato.org/index.php/investigaciones

Asociación Colombiana de Agencias de Viaje y Turismo ANATO. (2011). Compendio de Estadísticas Turísticas ANATO. Obtenido de http://www.anato.org/index.php?option=com_content\&view=article\&id=13\&Itemid $=20$

Asociación Latinoamericana de Integración. (2002). Evaluación de la convenienca de adpotar el código ISO para identificar a los países copartícipes. Obtenido de http://www.aladi.org/nsfaladi/reuniones.nsf/ebb78745878c4edd83256935004e82ce/ dfe0a76b80fd38ca03256fdc0059bc73/\$FILE/RecomexVIIdi4\%20\%20\%20Codigo $\%$ 20ISO.doc

Āzena, L., \& Keišs, S. (2009). Specifics of territorial marketing strategy planning. European Integration Studies, 3, 162-168.

Bai, K., \& Hu, X. (2013). Tourism Destination Brand Personality: Theoretical Sources and Relationships. (English). Tourism Tribune / Lvyou Xuekan, 28(4), 35-47. doi:10.3969/j.issn.1002-5006.2013.04.004.

Balabanis, G., \& Diamantopoulos, A. (2011). Gains and Losses from the Misperception of Brand Origin: The Role of Brand Strength and Country-of-Origin Image. Journal of International Marketing, 19(2), 95-116. doi:10.1509/jimk.19.2.95.

Banco de Guatemala. (2009). Guatemala en cifras. Obtenido de http://issuu.com/banguat/docs/guatemalaencifras

Banco de la República de Colombia. (2000). Informativo Resumen Marzo 2000. Recuperado el 29 de Octubre de 2012, de www.banrep.gov.co/documentos/junta.../resumen_marzo2000.pdf

Banco de México. (Abril de 2010). Informe Anual 2009. Obtenido de http://www.banxico.org.mx/publicaciones-y-discursos/publicaciones/informesperiodicos/anual/\%7BE1FEC59E-65CE-BF0B-CF0D-F25651B6EDBC\%7D.pdf

Banco Mundial. (2013). Turismo internacional, número de arribos. Obtenido de http://datos.bancomundial.org/indicador/ST.INT.ARVL

Bang-Jensen, J., \& Gutin, G. (2009). Digraphs: theory, algorithms and applications. Heidelberg: 2nd edn. Springer. 
Barón, A. (Septiembre de 2010). La evolución del marketing en el contexto de la revolución de las redes sociales. Obtenido de Contacforum: http://www.contactforum.com.mx/articulos/3411.html

Barriendos, J. (2006). Marca País México.Único, diverso y más allá de la hospitalidad. Obtenido de www.redibero.org/contenido/Marca_Mexico.doc

Barwise, P. (1993). Introduction to the special issue on brand equity. International Journal Of Research In Marketing, 10(1), 3-8.

Batra, R., Ahuvia, A., \& Bagozzi, R. (2012). Brand Love. Journal Of Marketing, 76(2), 116. doi:10.1509/jm.09.0339.

Benko, G. (2000). Estrategias de Comunicación y Marketing Urbano. USA: Eure Santiago.

Bermúdez, J. (2008). Embajador de Colombia en Argentina. (L. Echeverri, \& E. Rosker, Entrevistadores)

Bermúdez, J., \& Mejía, A. (15 de marzo de 2008b). Entrevista a miembros del Comité Directivo de Colombia es Pasión. (E. Rosker, \& L. Echeverri, Entrevistadores)

Bernal, C. (2006). Metodología de la Investigación. México: Pearson-Prentice Hall.

Bertrán Vall, J. (2003). Marketing en un mundo global: claves y estrategias para competir en el mercado internacional. McGraw-Hill.

Bertrand, G. (2013). Social media research: developing a trust metric in the social age. International Journal Of Market Research, 55(3), 333-335. doi:10.2501/IJMR-2013032.

Bhakar, S. S., Bhakar, S., \& Bhakar, S. (2013). Relationship between country of origin, brand image and customer purchase intention . Far East Journal Of Psychology \& Business, $11(1), 50-71$.

Bhargava, R. (2009). Personalidad de marca. México: McGraw-Hill Interamericana Editores.

Bilkey, W., \& Nes, E. (1982). Country-of-origin effects on product evaluations. Journal of international business studies, 13(1), 89-100.

Birnberg, J. (1964). Bayesian Statistics: A Review. Journal Of Accounting Research, 2(1), 108-116. 
Blanco, L., \& Grier, R. (2013). Explaining the rise of the left in Latin America. Latin American Research Review, 48(1), 68-90.

Blankson, C., \& Kalafatis, S. (2007). Congruence between Positioning and Brand Advertising. Journal Of Advertising Research, 47(1), 79-94.

Bloom Consulting. (2012). Official Website. Retrieved from http://bloomconsulting.com/en/nation-branding

Boisier, S. (2010). La imperiosa necesidad de ser diferente en la globalización: El mercadeo territorial. La experiencia de las regiones chilenas. Territorios, 15.

Bolaños, R. (2013). El Inguat contratará empresa para cambiar percepción del país. Obtenido de http://www.prensalibre.com/economia/Inguat-contratara-RelacionesPublicas-percepcion_0_847715463.html

Borma, A. (2012). Tourism - as a development strategy. Annals Of The University Of Oradea, Economic Science Series, 21(2), 332-336.

Bravo, M., Eisman, L., \& Pina, F. (1998). Métodos de investigación en psicopedagogía. McGraw-Hill.

Brenes, O. (2003). Costa Rica: una experiencia innovadora de manejo ambiental. Obtenido de http://www.undp.org.cu/eventos/aprotegidas/Biodiversidad.pdf

Brida, J. G., \& Risso, W. (2009). Tourism as a factor of long-run economic growth: An empirical analysis for Chile. European Journal of Tourism Research, 2(2), 178-185.

Bruhn, M., Schoenmueller, V., \& Schäfer, D. B. (2012). Are social media replacing traditional media in terms of brand equity creation? Management Research Review, 35(9), 770-790. doi:10.1108/01409171211255948.

Buil, I., Martínez, E., \& de Chernatony, L. (2013). The influence of brand equity on consumer responses. Journal Of Consumer Marketing, 30(1), 62-74. doi:10.1108/07363761311290849.

Bush, G. W. (2009). The national security strategy of the United States of America. Wordclay.

Cagan, M. (2008). Inspired: How To Create Products Customers Love. United States of America: SVPG Press. 
Cámara de Diputados de Chile. (s.f.). Organización para la Cooperación y el Desarrollo Económicos. Recuperado el 2 de febrero de 2011, de http://www.camara.cl/www/dai/frames/np/gen.asp?vri=79

Campbell, S., Anitsal, I., \& Anitsal, M. (2013). Social Media's key succes factor: an analysis of customer reactions. Business Studies Journal, 5(1), 43-56.

Canada Tourism Commission. (2011). Experiences. A toolkit for partners of the CTC.

Canadian Tourism Commission. (2005). Annual Report 2005: Explorations. Retrieved Febrary 2, 2011, from http://encorporate.canada.travel/sites/Corporate/images/pdf/2005_Annual_Report_en.pdf

Canadian Tourism Commission. (2006). Annual Report 2006: leading through rapid change. Retrieved March 2, 2011, from http://encorporate.canada.travel/sites/Corporate/images/pdf/2006_Annual_Report_Eng.pdf

Canadian Tourism Commission. (2007). Annual report 2007, leveraging Canada's tourism brand. Retrieved January 5, 2011, from http://www.corporate.canada.travel/docs/about_ctc/2007_Annual_Report_en.pdf

Canadian Tourism Commission. (2008). Annual Report 2008: Competing with a Strong Brand . Retrieved November 2, 2010, from http://encorporate.canada.travel/sites/Corporate/images/pdf/CTC_AR08_EN.pdf

Canadian Tourism Commission. (2008). Competing with a Strong Brand. Retrieved November 2, 2010, from http://encorporate.canada.travel/sites/Corporate/images/pdf/CTC_AR08_EN.pdf

Canadian Tourism Commission. (2010). Canadian Tourism Commission Official Website. Retrieved Febrero 2, 2011, from http://encorporate.canada.travel/?sa_campaign=domains/un/www.canadatourism.com/home

Canandian Tourism Comission. (2013). Keep Exploring. Retrieved from An official site of the Canadian Tourism Commission: http://in-keepexploring.canada.travel/

Capriotti, P. (2008). Planificación estratégica de la imagen corporativa. Barcelona: Editorial Ariel.

Cardozo, S. (18 de Marzo de 2008). Entrevista a Director de Capacitación Imagen país. (E. Rosker, M. Restrepo, \& L. Echeverri, Entrevistadores) 
Castrogiovanni, A. C. (2007). Lugar, No-lugar y Entre-lugar. Los ángulos del espacio turístico. Estudios y Perspectivas en Turismo, 16, 5-25.

Central América Data. (2009). Costa Rica quiere tener una "marca país". Obtenido de http://www.centralamericadata.com/es/article/home/Costa_Rica_quiere_tener_una_ marca_pais

Centro Nacional de Planeamiento Estratégico. (2011). Plan Bicentenario: Perú hacia el 2021. http://www.mef.gob.pe/contenidos/acerc_mins/doc_gestion/PlanBicentenarioversio nfinal.pdf

CEPAL. (Junio de 2012). Informe Macroeconómico Colombia. Obtenido de Comisión Económica para América Latina y el Caribe: www.cepal.org/publicaciones/xml/5/46985/Colombia-completo-web.pdf

Chadwick, E. (2013). La experiencia de gestión de la marca país de Chile. Foro Marca País. Experiencias de Gestión. Uruguay.

Chase, L. (2011). The Power of Personal Branding. American Salesman. 56(5), 7-9.

Chaves, N. (2011). La marca país en América Latina. Buenos Aires: La Crujía Ediciones.

Chávez, H. (2003). Aló presidente 173. Obtenido de http://www.minci.gob.ve/doc/alo173.doc

Chiozza, G. (2010). Anti-Americanism and the American world order. JHU Press.

Chiozza, G., \& Choi , A. (2012). Going the American way: the surprising case of Korean pro-Americanism. The Pacific Review, 25(2), 269-29.

Choi, J., \& Myer, D. (2012). The effect of product positioning in a comparison table on consumers' evaluation of a sponsor. Marketing Letters, 23(1), 367-380. doi:10.1007/s11002-012-9162-9.

Chung, C., \& Austria, K. (2010). Social Media Gratification and Attitude toward Social Media Marketing Messages: A Study of the Effect of Social Media Marketing Messages on Online Shopping Value. Proceedings Of The Northeast Business \& Economics Association, 581-586.

Clifton, N. (2011). Regional Culture in the Market Place: Place Branding and Product Branding as Cultural Exchange. European Planning Studies, 19(11), 1973-1994. doi:10.1080/09654313.2011.618689. 
CNN Expansión. (2010). Marca "México" en turismo: indispensable. Obtenido de http://www.cnnexpansion.com/economia/2010/10/17/marca-mexico-en-turismoindispensable

Cobb-Walgren, C., Ruble, C., \& Donthu, N. (1995). Brand Equity, Brand Preference, and Purchase Intent. Journal of Advertising, 24(3), 25-40.

Consejo de Promoción Turística de México. (2012). Sistema Integral de Información de Mercados Turísticos Obtenido de http://www.cptm.com.mx/work/sites/CPTM/resources/LocalContent/7441/32/fact_s heet_2012_enero.pdf

Corporation for Travel Promotion. (2012). Budget 2012. Retrieved from http://www.thebrandusa.com/ /media/Files/Key\%20Dox/2012/budget-presentationwebsite-03-08-2012.pdf

Corporation for Travel Promotion. (2013). The Brand USA. Retrieved from Discover America: http://www.thebrandusa.com/our-mission/

Costa, J. (2010). La marca: creación, diseño y gestión. México: Editorial Trillas.

Daily Travelling News. (2011). La Corporación para la Promoción de Viajes (CTP) nombra a JWT como Agencia Global de Marketing. Retrieved from http://www.dailyweb.com.ar/noticias/val/2455-24/la-corporaci\%C3\%B3n-para-la-promoci\%C3\%B3n-de-viajes-(ctp)-nombra-a-jwt-como-agencia-global-demarketing.html

Datexco Company S.A. (2008). Opinómetro. Percepción frente a la marca. Bogotá.

De Luca, M., \& Malamud, A. (2010). Argentina: turbulencia económica, polarización social y realineamiento político. Revista de Ciencia Política, 30(2), 173-189.

de Moura Engracia Giraldi, J., Ikeda, A., \& Campomar, M. (2011). Reasons for country image evaluation: A study on China image from a Brazilian perspective. Journal Of Database Marketing \& Customer Strategy Management, 18(2), 97-107. doi:10.1057/dbm.2011.10.

de Tavares Canto Guina, F., \& de Moura Engracia Giraldi, J. (2012). Differences on the image of Brazil in external markets according to consumers' age, gender, knowledge about the country and country of residence. International Journal Of Business Science \& Applied Management, 7(2), 13-28. 
Deiser, R., \& Newton, S. (2013). Six social-media skills every leader needs. Mckinsey Quarterly(1), 62-75.

Delgado, O. (2009). Respuestas ante la crisis: Estados Unidos, América Latina y sus gobiernos. Obtenido de http://www.economia.unam.mx/publicaciones/nueva/econunam/pdfs/21/05orlando. pdf

Dendaluze, I. (1997). La validez teórica de las investigaciones empíricas en ciencias sociales. Obtenido de http://www.euskomedia.org/PDFAnlt/riev/42/42077101.pdf

Denman, R. (2012). How to Measure A Nation's image. Site Selection, 56(6), 22-24.

Dens, N., De Pelsmacker, P., Wouters, M., \& Purnawirawan, N. (2012). Do you like What you Recognize? Journal Of Advertising, 41(3), 35-54.

Departamento Administrativo Nacional de Estadística DANE. (2012a). Boletín de Prensa No 8. Obtenido de http://www.dane.gov.co/files/investigaciones/boletines/pib/bolet_PIB_IVtrim11.pdf

Departamento Administrativo Nacional de Estadística DANE. (Octubre de 2012a). Sitio web oficial. Obtenido de http://www.dane.gov.co/\#twoj_fragment1-4

Departamento Administrativo Nacional de Estadística DANE. (2012b). Comercio Exterior Exportaciones Marzo $2012 . \quad$ Obtenido de http://lanota.com/index.php/CONFIDENCIAS/Petroleo-sigue-impulsandoexportaciones-de-Colombia.html

Departamento Administrativo Nacional de Estadística DANE. (2013). Dirección de Cuentas Nacionales. Bogotá.

Departamento Nacional de Planeación. (2003). Construcción de un futuro para Colombia desde sus territorios. Obtenido de https://www.dnp.gov.co/Portals/0/archivos/documentos/DDTS/Ordenamiento_Desa rrollo_Territorial/3a01_Mem_Sem_Const_Futuro.pdf

Deshpandé, R. (Agosto de 2007). El efecto país. (T. Stuart, Ed.) Harvard Business Review, 85(8), 22.

Diamantopoulos, A., Schlegelmilch, B., \& Palihawadana, D. (2011). The relationship between country-of-origin image and brand image as drivers of purchase intentions A test of alternative perspectives. International Marketing Review, 28(5), 508-524. doi:10.1108/02651331111167624. 
Diario Clarín. (11 de octubre de 2001). La Argentina tuvo ayer el mayor riesgo país del mundo. Recuperado el 28 de enero de 2011, de http://bit.ly/iiaLq7

Diario El Comercio. (2013). Guatemala desarrolla tecnología para aumentar el turismo. Obtenido de http://elcomercio.pe/turismo/1539196/noticia-guatemala-desarrollatecnologia-aumentar-turismo

Diario El Economista. (10 de Enero de 2012). Se confía en flujo de IED durante 2012. Obtenido de http:eleconomista.com.mx/sistema-financiero/2012/01/10/se-confiaflujo-ied-durante-2012

Diario El Heraldo. (2013). Turistas cancelan viajes a Honduras. Obtenido de http://www.elheraldo.hn/Secciones-Principales/Economia/Turistas-cancelan-viajesa-Honduras

Diario El Mundo. (2009). Se presenta "Brasil Now". Obtenido de http://www.mensajeroweb.com.ar/index.php?x=nota/21897/1/se-presenta-brasilnow

Diario el País. (2010). Relevo presidencial. Balance y proyección. Obtenido de http://www.elpais.com.co/elpais/especiales/

Diario El Siglo de Torreón. (2007). Crea Calderón ProMéxico para atraer más inversión. Obtenido de Agencias: http://www.elsiglodetorreon.com.mx/noticia/285469.creacalderon-promexico-para-atraer-mas-inver.html

Diario El Universal. (21 de Febrero de 2012). Crecio 5,5\% Inversion Privada en Turismo: SECTUR. Obtenido de La Secretaría de Turismo señala que durante 2011 se invirtieron 3 mil 720.66 millones de dólares en diversos proyectos: http://www.eluniversal.com.mx/notas/831628.html

Diario La República. (2012). Colombia, atrás en consolidación de la marca país. Obtenido de http://eleconomista.com.mx/economia-global/2012/05/23/colombia-atrasconsolidacion-marca-pais

Diario Oficial de la Federación. (13 de Junio de 2007). Decreto por el que se ordena la constitución del Fideicomiso Público considerado Entidad Paraestatal denominado ProMéxico. Recuperado el 12 de Enero de 2012, de http://www.promexico.gob.mx/work/models/promexico/Resource/85/1/images/Decr etoProMexico.pdf

Diario Portafolio. (31 de Julio de 2012a). Medio ambiente, riqueza que Colombia debe proteger. Portafolio. 
Diario Portafolio. (2012b). 'La respuesta es Colombia', es el nuevo lema del país. Obtenido de http://www.portafolio.co/economia/\%E2\%80\%98la-respuesta-escolombia\%E2\%80\%99-es-el-nuevo-lema-del-pais

Diario Portafolio. (2013). Inversión extranjera en Colombia creció 16\% en 2012. Obtenido de http://www.portafolio.co/economia/inversion-extranjera-colombia-crecio-162012

Diaz, C. (2013 йил 06-octubre). Rediseño de la Marca País Argentina: una renovación en relación con el pasado. From http://identidaddemarca.wordpress.com/2013/10/06/rediseno-de-la-marca-paisargentina-una-renovacion-en-relacion-con-el-pasado/

Diestel, R. (2005). Graph theoryg. Heidelberg: 3rd edn. Springer.

Díez López, C. M. (2013). Marketing olfativo: ¿ qué olor tienes en mente?= Olfactive marketing: what smell have you in mind? España: Universidad de León.

Dikčius, V., \& Stankevičienè, G. (2010). Perception of country brand origin and countey of product manufacturing among Lithuanians and emigrants from Lithuania. Organizations \& Markets In Emerging Economies, 1(2), 108-122.

Dincer, B., \& Dincer, C. (2010). Rethinking Brands in the Emerging Financial Markets. Journal Of Management \& Economics, 17(1), 11-22.

Dinnie, K. (2007). Nation branding. Burlington: Butterworth Heinemann.

Dinnie, K. (2008). Nation Branding: Concepts, Issues, Practice. Oxford: ButterworthHeinemann.

Dinnie, K., Melewar, T., Seidenfuss, K., \& Musa, G. (2010). Nation branding and integrated marketing communications: an ASEAN perspective. International Marketing Review, 27(4), 388-403. doi:10.1108/02651331011058572.

Dirección de Inteligencia Comercial e Inversiones. (2011). Análisis sectorial de flores. Obtenido de http://www.proecuador.gob.ec/wpcontent/uploads/downloads/2012/01/PROEC-AS2011-FLORES.pdf

Djurica, M., \& Djurica, N. (2010). Tourism destination marketing management. Tourism \& Hospitality Management, 890-901.

Dou, W., Lim, L., Su, C., Zhou, N., \& Cui, N. (2010). Brand postioning strategy using search engine marketing. MIS Quarterly, 34(2), 261-A4. 
Drew, M. (2013). Brand Strategy 101: Your Logo Is Irrelevant. Beneath the Cover Press.

East West Nation Brand Perception Indexes. (2013). Official Website. Retrieved from http://www.eastwestcoms.com/

Echeverri, L. M. (2008). El país como una marca: el caso de Colombia es pasión. XXIII Encuentro de Docentes Universitarios de Comercialización y cátedras afines de Argentina y América Latina. Paraná: EDUCAAL.

Echeverri, L. M. (2009a). La imagen país: ¿Cómo se aplica el marketing a una nación? XLIV Asamblea Anual CLADEA 2009. Ecuador: CLADEA.

Echeverri, L. M. (2009b). La marca país: el reflejo de la identidad cultural y empresarial de una Nación. Responsabilidad social de la administración en el mundo (pág. 24). Bucaramanga: ASCOLFA.

Echeverri, L. M., \& Estay-Niculcar, C. (2013). El rol del turismo como pilar estratégico de la marca país Argentina. Revista Científica Visión de Futuro, 186-199.

Echeverri, L. M., Estay-Niculcar, C., Herrera, C., \& Santamaría, J. (2013). Desarrollo de marca país y turismo: el caso de estudio de México. Revista Estudios y Perspectivas en Turismo, 22(6), 1121-1139.

Echeverri, L., Estay-Niculcar, C., \& Parra, H. (2013a). Estudio de la imagen país de Colombia desde la perspectiva mexicana. XVIII Congreso Internacional en Contaduría, Administración e Informática. México: UNAM.

Echeverri, L., Estay-Niculcar, C., \& Parra, H. (2013b). Percepción de los visitantes estadounidenses, venezolanos y ecuatorianos sobre la imagen país de Colombia. III Encuentro Internacional de Investigadores en Administración. Bogotá: Universidad del Externado de Colombia.

Echeverri, L., Estay-Niculcar, C., \& Parra, H. (Forthcoming-2014a). Impresiones de los mexicanos sobre la imagen país de Colombia. Revista Clío América.

Echeverri, L., Estay-Niculcar, C., \& Parra, H. (Forthcoming-2014b). Imagen país de Colombia desde la perspectiva estadounidense. Revista Hallazgos.

Echeverri, L., Estay-Niculcar, C., \& Rosker, E. (2012). Estrategias y experiencias en la construcción de marca país en América del Sur. Revista Estudios y Perspectivas en Turismo, 21, 288-305. 
Echeverri, L. M., Restrepo, M. L., \& Rosker, E. (2008). Colombia es pasión - Caso académico. Bogotá: Universidad del Rosario-CESA.

Echeverri, L. M., Restrepo, M. L., \& Rosker, E. (2010). Los orígenes de la Marca País Colombia es Pasión. Revista Estudios y Perspectivas en Turismo, 409-421.

Echeverri, L. M., \& Rosker, E. (2011). Diferencias en la construcción de marca país: Canadá y Colombia. Revista Virtual Universidad Católica Del Norte(33), 1-29.

El Financiero. (16 de Septiembre de 2013). Expertos en marcas critican y alaban la marca país "Esencial Costa Rica". Obtenido de González, Gilda: http://www.elfinancierocr.com/economia-y-politica/Marca_paisEsencial_Costa_Rica-Comex_0_372562764.html

Elliot, A., \& Maier, M. A. (2012). Color-in-context theory. Adv Exp Soc Psychol(45), 63125.

Embajada de Venezuela en Estados Unidos. (2007). Relación Comercial Venezuela-Estados Unidos . Obtenido de http://www.embavenezus.org/comercio_venezuela_eeuu_junio_2007.pdf

Ernst \& Young (E\&Y). (2012). 2012 Globalization Index. Retrieved from http://www.ey.com/Publication/vwLUAssets/\%C3\%8Dndice_de_Globalizaci\%C3 \%B3n_2012_de_las_60_mayores_econom\%C3\%ADas_del_mundo/\$FILE/NP_Glo balization\%20Report_2013_Spain.pdf

Eun Sook, K., \& Yongjun, S. (2011). Follow me! global marketers' twitter use. Journal Of Interactive Advertising, 12(1), 4-16.

European Commission. (1999). ESDP- European Spatial Development Perspective: Towards Balanced and Sustainable Development of the Territory of the European Union. Maio.

Fan, Y. (2006). ¿Nation branding: what is being branded? Journal of Vacation Marketing, 514.

Fan, Y. (2010). Branding the nation: Towards a better understanding. 97-103. doi:10.1057/pb.2010.16.

Fantoni, A. (2008). Comunicación total. España: ESIC.

Farhana, M. (2012). Brand Elements Lead To Brand Equity: Differentiate or Die. Information Management \& Business Review, 4(4), 223-233. 
Farooqi, R. (2009). Nation branding: a study of India's brand equity and capabilities in comparison to two other South Asian countries. Pranjana: The Journal Of Management Awareness, 12(2), 51-71.

Federación Nacional de Biocombustibles de Colombia. (2012). Biocombustibles Hoy. Bogotá: Federación Nacional de Biocombustibles de Colombia.

Fernández, G., \& Paz, S. (2005). Más allá del Marketing de ciudad. La marca territorial como herramienta para la participación ciudadana. Scripta Nova, 194.

Fernández, R. (2012). Anato: "El producto turístico de los cruceros ha sido el de más crecimiento en Colombia". Obtenido de http://www.arecoa.com/agencias/anato-elproducto-turistico-de-mayor-crecimiento-en-colombia-ha-sido-el-de-los-cruceros/

Fernández, V. (2006). Introducción a la investigación en ciencias sociales. Obtenido de http://upcommons.upc.edu/eprints/bitstream/2117/501/1/Introducci\%C3\%B3n\%20a\%20la\%20investigaci\%C3 $\%$ B3n\%20en\%20ciencias\%20sociales.pdf

Ferraz Sexto, C. (2001). El territorio como mercancía: fundamentos teóricos y metodológicos del marketing territorial. Revista de Desenvolvimento Econômico, 5, 67-78.

Fetscherin, M. (2010). The determinants and measurement of a country brand: the country brand strength index. International Marketing Review, 27(4), 466-479. doi:10.1108/02651331011058617.

Fischer, M., Völckner, F., \& Sattler, H. (2010). How Important Are Brands? A CrossCategory, Cross-Country Study. Journal Of Marketing Research, 47(5), 823-839. doi:10.1509/jmkr.47.5.823.

Flipo, J. P., \& Texier, L. (1992). Marketing territorial de la practique à la théorie. Revue française du marketing(136), 41-52.

Foro Económico Mundial. (2011). Indice de Competitividad en Viajes y Turismo 2011 (TTCI). http://www.codesin.org.mx/sites/default/files/indice_global_2011_de_competitivida d_en_turismo.pdf

Foro Económico Mundial. (2013). Reporte de Competitividad de Viajes y Turismo 2013. Obtenido de http://widgets.weforum.org/travel-and-tourism-index/ 
Foscht, T., Maloles III, C., Swoboda, B., Morschett, D., \& Sinha, I. (2008). The impact of culture on brand perceptions: a six-nation study. Journal Of Product \& Brand Management, 17(3), 131-142. doi:10.1108/10610420810875052.

Fuchs, C., \& Diamantopoulos, A. (2012). Customer-Perceived Positioning Effectiveness: Conceptualization, Operationalization, and Implications for New Product Managers. Journal Of Product Innovation Management, 29(2), 29-244. doi:10.1111/j.15405885.2011.00892.x.

Fuller, N. (2009). Turismo y cultura. Entre el entuasismo y el recelo. Lima: Fondo Editorial d ela PUCP.

Fundación Imagen de Chile. (13 de 08 de 2013). Fundación Imagen de Chile. Recuperado el 18 de 10 de 2013, de Imagen de Chile: http://www.imagendechile.cl/quienessomos/presentacion/

FutureBrand. (2005). Country Brand Index 2005. FutureBrand.

FutureBrand. (2006). Country Brand Index 2006. FutureBrand.

FutureBrand. (2007). Country Brand Index 2007. FutureBrand.

FutureBrand. (2008). Country Brand Index 2008. FutureBrand.

FutureBrand. (2009). Country Brand Index 2009. Future Brand.

FutureBrand. (2010). Country Brand Index 2010. FutureBrand.

FutureBrand. (2012a). Country Brand Index 2011-2012. FutureBrand.

FutureBrand. (2012b). Country Brand Index 2012-2013. FutureBrand.

FutureBrand. (2013). Country Brand Index Latinoamérica. FutureBrand.

FutureBrand. (2013). Country Brand Index Latinoamérica 2013.

Galgo, R. (2012). Latinoamérica en marcas. Obtenido de http://www.brandemia.org/latinoamercia-en-marcas/

Gallup. (2010, February 19). In U.S., Canada Places First in Image Contest; Iran Last. Retrieved from http://www.gallup.com/poll/126116/canada-places-first-imagecontest-iran-last.aspx

Gallup. (2013). Country Ratings. Obtenido de http://www.gallup.com/poll/1624/perceptions-foreign-countries.aspx 
Garbrecht, M. (Agosto de 2013). Gerente de Planeación en Marca País Colombia. (A. Rodríguez, Entrevistador)

García, J., Gómez, M., \& Molina, A. (2012). A destination-branding model: An empirical analysis based on stakeholders. Tourism Management, 33(3), 646-661. doi:10.1016/j.tourman.2011.07.006.

García, M. M. (2005). Arquitectura de Marcas, Modelo General de Construcción de Marcas y Gestión de sus Activos. Madrid: ESIC Editorial.

Gardella, R., Lupo, F., \& Aguayo, E. (2005). Mercado turístico argentino. Análisis de su demanda internacional. Estudios y perspectivas en turismo, 14(2), 127-138.

Gertner, D., \& Kotler, P. (22 de January de 2002). Country as brand, product, and beyond: A place marketing and brand management perspective. Journal of Brand Management, págs. 249-261.

Gertner, R. K., Berger, K. A., \& Gertner, D. (2007). Country-dot-com: marketing and branding destinations online. Journal of Travel \& Tourism Marketing, 21(2-3), 105116.

GFK Group. (2009). US Jumps to \#1 on 'Most Admired Countries' List. Retrieved from http://www.marketingcharts.com/wp/topics/asia-pacific/us-jumps-to-1-on-mostadmired-countries-list-10736/

GfK Roper Public Affairs \& Media. (2009). The Anholt-GfK Roper Nation Brands Index 2009 Highlights Report. Retrieved from http://www.simonanholt.com/Publications/publications-other-articles.aspx

Gilmore, F. (2002). A country-can it be repositioned? Spain-the success story of country branding. The Journal of Brand Management, 9(4-5), 4-5.

Girard, T., Anitsal, M., \& Anitsal, I. (2013). The role of logos in building brand awareness and perfomance: implications for entrepreneurs. Entrepreneurial Executive, 187-16.

Global Peace Index 2013. (2013). Retrieved from http://www.visionofhumanity.org/\#page/indexes/global-peace-index/2013

Gobierno de Chile. (2012). Chile: Estrategia Nacional de Turismo 2012-2020. Obtenido de http://www.chilesustentable.travel/wp-content/uploads/2013/08/ENT-2.pdf

Gobierno de Chile. (s.f.). Comité de Inversiones Extranjeras. Recuperado el 2 de febrero de 2011, de http://bit.ly/m67qEW 
Godin, S. (2012). All Marketers Are Liars: The Underground Classic That Explains How Marketing Really Works--and Why Authenticity Is the Best Marketing of All. USA: Portfolio Trade; Reprint edition .

Gómez, C. (2007). Marca país Chile All ways surprising. Obtenido de http:// wWw.tristestopicos.

González, G. (2013). Costa Rica lanzará marca país en agosto. Obtenido de http://www.elfinancierocr.com/economia-y-politica/Marca_Pais-ComexProcomer_0_338966138.html

Gotsi, M., López, C., \& Andriopoulos, C. (2011). Building country image through corporate image: exploring the factors that influence the image transfer. Journal Of Strategic Marketing, 19(3), 255-272. doi:10.1080/0965254X.2011.581387.

Govers, R., \& Go, F. (2009). Place Branding: Glocal, Virtual and Physical Identities, Constructed, Imagined and Experienced. Hampshire: Palgrave Macmillan.

Greenacre , M. (2008). La práctica del análisis de correspondencias. Obtenido de http://www.fbbva.es/TLFU/dat/greenacre_cap18.pdf

Grupo de Estudios Estratégicos. (2012). Honduras el país más peligroso del mundo. Obtenido de http://www.libertaddigital.com/opinion/gees/honduras-el-pais-maspeligroso-del-mundo-65825/

Grupo Nación. (2013). Esencial Costa Rica fue lanzada como marca país este martes. Obtenido de http://www.nacion.com/economia/Esencial-Costa-Rica-lanzadamartes_0_1363863799.html

Gudjonsson, H. (2005). Nation branding. Place Branding, 1(3), 283-298., 1(3), 283-298.

Guilland, M. (2012). "Colombia, el único riesgo es que te quieras quedar allí" De la promoción turística nacional al viaje a Sierra Nevada: usos y disuasión del riesgo. Via@ - revista internacional interdisciplinar de turismo, 2-12. Obtenido de http://www.viatourismreview.net/PDF/Article4_ES.pdf

Gumbs, A. (2010). Why We Can't Ignore Social Media. Black Enterprise, 41(5), 12.

Gustavo, N. (2013). Marketing Management Trends in Tourism and Hospitality Industry: Facing the 21st Century Environment. International Journal Of Marketing Studies, 5(3), 13-25. doi:10.5539/ijms.v5n3p13.

Haigh, D. (2009). How brand equity metrics drive brand strategy. Market Leader, 45, 40-43. 
Han, C. M., \& Terpstra, V. (1988). Country-of-origin effects for uni-national and bi-national products. Journal of International Business Studies, 235-255.

Hankinson, G. (2012). The measurement of brand orientation, its performance impact, and the role of leadership in the context of destination branding: An exploratory study. Journal Of Marketing Management, 28(7/8), 974-999. doi:10.1080/0267257X.2011.56572.

Hanna, S., \& Rowley, J. (2011). Towards a strategic place brand-management model. Journal Of Marketing Management, 458-476. doi:10.1080/02672571003683797.

Hansen, R. (2010). The narrative nature of place branding. Place Branding \& Public Diplomacy, 6(4), 268-279. doi: 10.1057/pb.2010.27.

Harrison-Walker, L. (2011). Strategic positioning of nations as brands. Journal Of International Business Research, 10(2), 135-147.

Hatem, F. (2007). Le marketing territorial: principes, méthodes et pratiques. Éd. EMS, Management \& sociétés.

Hauptmann, S., \& Steger, T. (2013). "A brave new (digital) world"? Effects of In-house Social Media on HRM. . Zeitschrift Für Personalforschung, 27(1), 26-46. doi:10.1688/1862-0000_ZfP_2013_01_Hauptmann.

Haven-Tang, C., Jones, E., \& Webb, C. (2007). Critical Success Factors for Business Tourism Destinations: Exploiting Cardiff's National Capital City Status and Shaping Its Business Tourism Offer. Journal Of Travel \& Tourism Marketing, 22(3/4), 109. doi:10.1300/J073v22n0309.

Healey, M. (2008). What is branding? Switzerland: Rotovision.

Hernández, M., Delgado, E., \& Rodríguez, H. (2008). Marketing: Fundamentos científicos y Empresariales (Primera ed.). Cali, Colombia: ECOE Ediciones - Universidad del Valle.

Hidalgo, M. (2008). La imagen nuestro futuro. Rosario: Instituto Superior de Hotelería y Restauranteur.

Hildreth, J. (2008). Chapter 3: Persuade or Perish: Brandishing Brand America. In GBS: Brand America (pp. 46-73). Marshall Cavendish Limited.

Hill, C. (1990). The paradox of tourism in Costa Rica. La paradoja del turismo en Costa Rica. CS Quarterly, 14(1), 14-19. 
Hoefer, M., Rytina, N., \& Baker, B. C. (2011). Estimates of the Unauthorized Immigrant Population Residing in the United States: January 2010. United States: Population Estimates, Office of Immigration Statistics, Department of Homeland Security.

Hondudiario. (2008). "Honduras todo está aquí", la marca que representa al país. Obtenido de http://www.hondudiariohn.com/turismo=0141.php

Honey, M., Vargas, E., \& Durham, W. H. (2010). Impact of Tourism Related Development on the Pacific Coast of Costa Rica: Summary Report. Center for Responsible Travel.

Hoskisson, R., Wei, S., Xiwei, Y., \& Jing, J. (2013). The evolution and strategic positioning of private equity firms. Academy Of Management Perspectives, 27(1), 22-38. doi:10.5465/amp.2012.0131.

Hoyos, C. (20 de Marzo de 2013). Entrevista a la Directora de la Marca País Colombia. (L. M. Echeverri, Entrevistador)

Hudson, S., \& Ritchie, B. (2009). Branding a Memorable Destination Experience. The Case of 'Brand Canada'. International Journal of Tourism Research, 217-228. doi:10.1002/jtr.720 .

Illán, A. (2011). Colombia: la migración del conflicto. Obtenido de Fundación Iberoamérica Europa: http://www.eldiarioexterior.com/imagenes\%5Cfotosdeldia\%5C35383_colombia_1 a_migracion_del_conflicto.pdf

Instituto Costarricense de Turismo \& Promotora del Comercio Exterior. (2013 йил 03Septiembre). Costa Rica Esencial. From http://www.esencialcostarica.com/sobre_lanzamiento.php

Instituto Costarricense de Turismo. (2013). Costa Rica sin ingredientes artificiales. Obtenido de http://www.visitcostarica.com/ict/paginas/home.asp?ididioma=1

Instituto Guatemalteco de Turismo. (2012). Boletín Anual de Estadísticas de Turismo. Obtenido de http://www.inguat.gob.gt/boletin-anual-2012.pdf

Instituto Hondureño de Turismo. (2008). Manual de la Marca País. Obtenido de http://www.iht.hn/files/marcapais.pdf

Instituto Hondureño de Turismo. (2011). Lets go Honduras. Obtenido de http://www.letsgohonduras.com/ 
Instituto Hondureño de Turismo. (2013). Honduras, todo está aquí. Obtenido de http://www.visitehonduras.com/

Instituto Humbolt Colombia. (2001). Biosíntesis. Obtenido de http://www.humboldt.org.co/download/bol28.pdf

Instituto Nacional de Promoción Turística. (2010). Argentina late con vos. Obtenido de http://www.argentina.travel/

Invierta en Colombia. (2012). Inversión en el sector Manufacturas en Colombia. Obtenido de http://www.inviertaencolombia.com.co/sectores/manufacturas.html

IProfesional. (2005). Brasil presentó su marca país. Obtenido de http://www.iprofesional.com/notas/13006-Brasil-present-su-marca-pas

Isaza, J. (s.f.). ¿Sabe cuál es el TOP-OF-HAND de su marca? Obtenido de MarketingDATARED: http://www.data-red.com/cgi-bin/articulos/ver.pl?id=20102110262153

Jain, R., \& Winner, L. (2013). Country reputation and performance: The role of public relations and news media. Place Branding \& Public Diplomacy, 9(2), 109-123. doi:10.1057/pb.2013.7.

Jalilvand, M., Ebrahimabadi, F., \& Samiei, N. (2011). The Impact of Branding on Customers' Attitudes toward Banking Services. International Business \& Management, 2(1), 186-197.

Jenes, B. (2008). Reconsidering the measurement of country image - theory and practice. Retrieved from FIKUSZ 2008 Business Sciences - Symposium for Young Researchers: http://kgk.uni-obuda.hu/system/files/JenesB.pdf

Jensen, F., \& Nielsen, T. (2007). Bayesian Networks and Decision Graphs. USA: Springer Science + Business Media.

Jetter, L. G., \& Chen, R. C. (2011). Destination Branding and Images: Perceptions and Practices from Tourism Industry Professionals. International Journal Of Hospitality \& Tourism Administration, 12(2), 174-187. doi:10.1080/15256480.2011.564498.

Jiménez, S. (25 de Mayo de 2009). Calderón presenta campaña Vive México. Obtenido de Diario El Universal: http://www.eluniversal.com.mx/notas/600153.html

Johansson, J., Douglas, S. P., \& Nonaka, I. (1985). Assessing the impact of country of origin on product evaluations: a new methodological perspective. Journal of Marketing Research, 388-396. 
Jowitt, H., \& Lury, G. (2011). Is it time to reposition positioning? Journal Of Brand Management, 20(2), 96-103. doi:10.1057/bm.2012.42.

JP Morgan. (2012). Emerging Markets Bond Index (EMBI+). Retrieved from http://datamarket.com/data/set/1dme/jp-morgan-emerging-markets-bond-indexembi\#!display $=$ line $\& d s=1 \mathrm{dme} ! \times 88=9$

Kaneva, N. (2011). Nation Branding: Toward an Agenda for Critical Research. International Journal of Communication, 5, 117-141.

Kang, M., \& Yang, S. (2010). Comparing Effects of Country Reputation and the Overall Corporate Reputations of a Country on International Consumers' Product Attitudes and Purchase Intentions. Corporate Reputation Review, 13(1), 52-62. doi:10.1057/crr.2010.1.

Kapferer, J.-N., \& Thoenig, J.-C. (1991). La marca: motor de competitividad de las empresas y del crecimiento de la economía. España: McGraw-Hill/Interamericana.

Kavaratzis, M., \& Hatch, M. (2013). The dynamics of place brands: An identity-based approach to place branding theory. Marketing Theory, 13(1), 69-86. doi:10.1177/1470593112467268.

Keller, K. L. (2012). Strategic Brand Management. United States of America: Prentice Hall.

Keller, K. L., Monserrat, E., Borneville, H., Mondragón, C., \& Garza, R. (2008). Administración Estratégica de Marca (Tercera ed.). México: Pearson Educación S.A.

Kemp, E., \& Williams, K. (2012). The impact of marketing on internal stakeholders in destination branding: The case of a musical city. Journal Of Vacation Marketing, 18(2),. 18(2), 121-133. doi:10.1177/1356766712443469.

Kerin, R., Hartley, S., \& Rudelius, W. (2012). Marketing. United States of America: McGraw-Hill/Irwin.

Kerrigan, F., Shivanandan, J., \& Hede, A. (2012). Nation Branding: A Critical Appraisal of Incredible India. Journal of Macromarketing, 32(3), 319-327. doi:10.1177/0276146712445788.

Khanna, M. (2011). Destination Branding: Tracking Brand India. Synergy (0973-8819), 9(1), 40-49.

Kornberger, M. (2010). Brand Society. United States of America: Cambridge University Press. 
Kotler, P. (2006b, February 16). The Brand Image of Nations: Israel. (R. Cravatts, Interviewer)

Kotler, P., \& Keller, K. (2006a). Dirección de Marketing. Madrid: Pearson Educación S.A.

Kotler, P., Bowen, J., Makens, J. C., \& Moreno, R. R. (2003). Marketing para turismo. McGraw-Hill.

Kotler, P., Haider, D., Gertner, D., \& Rein, I. (2007). Marketing internacional de lugares y destinos. Estrategias para la atracción de clientes y negocios en Latinoamérica. México: Pearson.

Kotler, P., Setiawan, I., \& Kartajaya, H. (2010). Marketing 3.0: From Products to Customers to the Human Spirit. Canada: Wiley.

Krishnan, V., Sullivan, U., Groza, M., \& Aurand, T. (2013). The brand recall index: a metric for assesing value. Journal of Consumer Marketing, 30(5).

Lacouture, M. C. (25 de mayo de 2008). Directora de Colombia es Pasión. (L. M. Echeverri, \& E. Rosker, Entrevistadores)

Landa, R. (2006). Designing Brand Experience: Creating Powerful Integrated Brand Solutions (First ed.). United States of America: Delmar Cengage Learning.

Laughlin, T. (2012). Introducción a la Metodología de La Investigación Empírica. Paidotribo Editorial.

Laxe, F., \& Palmero, F. (2009). "Atractividad" y competividad económica de los territorios. Boletín económico de ICE, Información Comercial Española.

Le marketing territorial. (2009). Decisions Marketing(54), 77.

Lebar, E., Buehler, P., Keller, K., Sawicka , M., Aksehirli , Z., \& Richey , K. (2005). Brand Equity Implications of Joint Branding Programs. (C. U. Press, Ed.) Journal of Advertising Research, 45, 413-425. doi: 10.1017/S0021849905050439.

Lee, R., Klobas, J., Tezinde, T., \& Murphy, J. (2010). The underlying social identities of a nation's brand. International Marketing Review, 27(4), 450-465. doi:10.1108/02651331011058608.

Legatum Institute. (2012). The 2012 Legatum Prosperity Index. Retrieved from http://press.prosperity.com/ 
Lichrou, M., O'Malley, L., \& Patterson, M. (2010). Narratives of a tourism destination: Local particularities and their implications for place marketing and branding. Place Branding \& Public Diplomacy, 6(2), 134-144. doi:10.1057/pb.2010.10.

Light, L. (1998). Marcas Inmortales. WOBI Magazine, 3.

Lightle, D. (2005). The Colombian brand story. Bogotá.

Lindstrom, M. (2011). Brandwashed. Bogotá: Grupo Editorial Norma.

Lipsman, A., Mud, G., Rich, M., \& Bruich, S. (2012). The Power of "Like": How Brands Reach (and Influence) Fans Through Social-Media Marketing. Journal of Advertising Research, 52(1), 40-52. doi:10.2501/JAR-52-1-040-052.

López Puga, J., García García, J., De la Fuente Sánchez, L., \& De la Fuente Solana, E. (2007). Las redes bayesianas como herramientas de modelado en psicología. 23(2).

López, M. J. (marzo de 2006). Ejes estratégicos para la planificación de una marca territorial. Recuperado el 2 de octubre de 2010, de http://nulan.mdp.edu.ar/1145/1/lopez_mj.pdf

Lora, J. (2013). Gerente Comercial de Marca País Colombia. (A. Rodríguez, Entrevistador)

Lubowiecki-Vikuk, A., \& Basiñska-Zych, A. (2011). Sport and tourism as elements of place branding a case study on Poland. Journal Of Tourism Challenges \& Trends, 4(2), 3352.

MacNealy, M. S. (1998). Strategies for Empirical Research in Writing. Longman.

Madhavaram, S., Badrinarayanan, V., \& McDonald, R. (2005). Integrated Marketing Communication (IMC) and Brand Identity as critical Components of Brand Equity Strategy. Journal Of Advertising, 34(3), 69-80.

Madichie, N., \& Yamoah, F. (2006). Country image and consumer food quality perception: a developing country perspective. Consortium Journal Of Hospitality \& Tourism, 10(2), 89-10.

Maheswaran, D. (1994). Country of origin as a stereotype: effects of consumer expertise and attribute strength on product evaluations. Journal of Consumer Research., 21(2), 354365.

Maheswaran, D., Chen, C., \& He, J. (2013). Nation Equity: Integrating the Multiple Dimensions of Country of Origin Effects. Review of Marketing Research, 153-189. 
Manjoo, F. (2011). (Like) + (Retweet $)=\$ \$$ ? Fast Company $(157), 86-117$.

Marca Colombia. (2012). Primer productor mundial de esmeraldas para exportación . Bogotá: Organización Marca País Colombia.

Marca País Colombia. (2012). Video del proceso creativo. Bogotá, Cundinamarca, Colombia.

Marca País Colombia. (2013). Informes de Dirección. Bogotá.

Marca País Ecuador. (2013). Sitio Oficial de Ecuador ama la vida. Obtenido de http://marcapaisecuador.com.ec/marca/

Marca País Uruguay. (2013). Sitio Oficial de la Marca País de Uruguay. Obtenido de http://marcapaisuruguay.gub.uy/marca-pais/

Mariutti, F. G., \& Giraldi, J. D. (2010). Análise da Imagem do Brasil por meio do Anholt Nation Branding Index: Contribuições para a Marca Brasil. VII Seminário da Associação Brasileira de Pesquisa e Pós-Graduação em Turismo.

Marketing Directo. (2005). Interbrand ha desarrollado la nueva marca e imagen estratégica de Guatemala. Obtenido de http://www.marketingdirecto.com/actualidad/agencias/interbrand-ha-desarrolladola-nueva-marca-e-imagen-estrategica-de-guatemala/

Martin, I. M., \& Eroglu, S. (1993). Measuring a Multi-Dimensional Construct. Journal of Business Research(28), 193.

Martínez, S. (7 de 1 de 2007). Sistema de gestión comunicacional para la construcción de una marca ciudad o marca país. Revista Signo y Pensamiento(51), 80-97. Recuperado el 25 de julio de $2012, \quad$ de http://web.ebscohost.com/ehost/pdfviewer/pdfviewer?sid=8b27cf06-ff6d-4db483e1-1c7da178847a\%40sessionmgr13\&vid=2\&hid=15

Martínez, S., \& Alvarez, M. D. (2010). Country Versus Destination Image in a Developing Country. Journal of Travel \& Tourism Marketing, 27(7), 748-764. doi:10.1080/10548408.2010.51968.

Matzler, K., Pichler, E., Fuller, J., \& Mooradian, T. (2011). Personality, person-brand fit, and brand community: An investigation of individuals, brands, and brand communities. Journal Of Marketing Management, 27(9/10), 874-890. doi:10.1080/0267257X.2010.543634. 
Maxwell, J. (2012). Qualitative Research Design: An Interactive Approach (Applied Social Research Methods). United States of America: SAGE Publications.

McGhie, A. (2012). Brand is a four letter word: Positioning and The Real Art of Marketing. United Stated of America: Advantage.

McKinsey Global Institute. (2010). Beyond austerity: a path to economic growth and renewal in Europe. Retrieved from http://www.mckinsey.com/

Mei, X., Chun-la, L., Jian-she, C., \& Pei-lin, L. (2012). Tourism Image Map: A New Scenic Spot Planning Idea Based on Tourists' Perception. Tourism Tribune / Lvyou Xuekan, 27(4), 21-27.

Mejía, A. (15 de marzo de 2008). Entrevista a Miembro de Comité de Dirección de Colombia es Pasión. (L. M. Echeverri, \& E. Rosker, Entrevistadores)

Melewar, T. C., Gupta, S., \& Dinnie, K. (2013). Nation Branding: Issues, Insights and Impacts. Corporate Reputation Review, 16(1), 5-6. doi:10.1057/crr.2012.21.

Méndez, J. C. (2003). Pobreza y biodiversidad. Obtenido de http://biblio3.url.edu.gt/IARNA/SERIETECNINCA/10.pdf

Merriam, S. (2009). Qualitative Research: A Guide to Design and Implementation. United States of America: Jossey-Bass.

Meyronin, B. (2009). Le marketing territorial. Enjeux et pratiques.

Miao-Que, L., \& Lee, B. Y. (2012). The influence of website environment on brand loyalty: brand trust and brand affect as mediators. International Journal Of Electronic Business Management, 10(4), 308-321.

Migración Colombia. (2013). Boletín Migratorio. Bogotá.

Mihailovich, P. (2006). Kinship branding: A concept of holism and evolution for the nation brand. Place Branding, 2(3), 229-247.

Mikhailitchenkoa, A., Javalgib, R., Mikhailitchenkoc, G., \& Laroched, M. (2009). Crosscultural advertising communication: Visual imagery, brand familiarity, and brand recall. Journal of Business Research, 62(10), 931-938.

Milken Institute. (2010). Travel and tourism direct contribution to GDP. Retrieved from http://www.milkeninstitute.org/presentations/slides/2697GC11.pdf 
Ministerio de Comercio, Industria y Turismo de la República de Colombia. (2010). Emprendimiento, Formalización e Innovación. Obtenido de http://www.confecamaras.org.co/Documentos/Asambleas/MemoriasAsamblea47/Pr esentacionDrSergioDiazGranados.pdf

Ministerio de Comercio, Industria y Turismo República de Colombia. (Junio de 2008). Documento CONPES 3527. Política Nacional de Competitividad y Productividad. Obtenido de https://www.mincomercio.gov.co/descargar.php?id=19810

Ministerio de Comercio, Industria y Turismo República de Colombia. (2009). Seguridad Turística: Reto competitivo de Colombia. Obtenido de http://www.citur.gov.co/LinkClick.aspx?fileticket=wok-gRf912Y\%3D\&tabid=75

Ministerio de Culturas y Turismo República de Bolivia. (2013). Sitio Oficial de Turismo de Bolivia. Obtenido de http://www.bolivia.travel/

Ministerio de Defensa Nacional República de Colombia. (2003). Política de defensa y seguridad democrática. Obtenido de http://www.oas.org/csh/spanish/documentos/Colombia.pdf

Ministerio de Hacienda y Crédito Público. (2012). ¿Qué caracteriza a la economía colombiana? Obtenido de http://www.minhacienda.gov.co/HomeMinhacienda/ComovalaEconomia/quecaracte rizaalaeconomia

Ministerio de Planificación del Desarrollo República de Bolivia. (2006). Plan Nacional de Desarrollo de Bolivia. Obtenido de http://www.planificacion.gob.bo/sites/folders/documentos/plan.pdf

Ministerio de Relaciones Exteriores de la República de Colombia. (s.f.). Alianza del Pacífico. Obtenido de http://www.cancilleria.gov.co/international/consensus/pacific-alliance

Ministerio de Relaciones Exteriores República de Colombia. (11 de Septiembre de 2012). En la nueva marca país, la respuesta es Colombia. Obtenido de http://www.cancilleria.gov.co/content/en-la-nueva-marca-pa\%C3\%ADs-larespuesta-es-colombia

Ministerio de Relaciones Exteriores República de Colombia. (2013). Divulgación Marca Pais. Obtenido de http://www.cancilleria.gov.co/sites/default/files/Normograma/docs/circular_minrela ciones_0011_2013.htm 
Ministerio de Turismo República de Brasil. (s.f.). Visit Brasil. Obtenido de http://www.visitbrasil.com/

Ministerio de Turismo República de Ecuador. (2001). Racional Creativo de la Marca País. Quito.

Ministerio de Turismo y Deporte - República de Uruguay. (s.f.). Uruguay Natural. Obtenido de http://www.uruguaynatural.com/es-ES/

Ministerio del Poder Popular para el Turismo República Bolivariana de Venezuela. (s.f.). Sitio Oficial de la Marca Turística. Obtenido de http://www.venezuelaturismo.gob.ve/principal.php

Ministerio del Poder Popular para la Comunicación y la Información República Bolivariana de Venezuela. (2004). Portal Oficial del Ministerio del Poder Popular para la Comunicación y la Información. Recuperado el 29 de noviembre de 2010, de http://www.minci.gob.ve/

Ministério do Turismo Governo Federal do Brasil. (s.f.). Portal do Ministério do Turismo. Obtenido de http://www.turismo.gov.br/turismo/espanhol/embratur/

Mirzaei, A., Gray, D., \& Baumann, C. (2011). Developing a new model for tracking brand equity as a measure of marketing effectiveness. Marketing Review, 11(4), 323-336.

Moffett, M. (2008). Colombia Wants the World to Recognize Its Passion. Wall Street Journal - Eastern Edition, p. B4.

Mohammadian, M., \& Mohammadreza, M. (2012). Identify the Success Factors of Social Media (Marketing Perspective. International Business \& Management, 4(2), 58-66. doi:10.3968/j.ibm.1923842820120402.1120.

Moilanen, T., \& Rainisto, S. K. (2009). How to brand nations, cities and destinations: A planning book for place branding. Palgrave Macmillan.

Monocle. (2012). Soft Power Survey - 2012. Retrieved from http://monocle.com/film/affairs/soft-power-survey-2012/

Monroy, H. (2009). Imagen de Colombia en el exterior, una historia de altibajo. Obtenido de http://www.usergioarboleda.edu.co/altus/imagen-colombia.htm

Mora, L. (2008). Gerente Financiera de Colombia es Pasión. (E. Rosker, Entrevistador)

Morgan, J. (2011). Brand Against the Machine: How to Build Your Brand, Cut Through the Marketing Noise, and Stand Out from the Competition . Canada: Wiley. 
Morgan, N., \& Pritchard, A. (2004). Meeting the destination branding challenge. Destination branding, 59-79.

Morgan, N., Pritchard, A., \& Piggott, R. (2003). Destination branding and the role of the stakeholders: The case of New Zealand. Journal Of Vacation Marketing, 9(3), 284.

Mukoma, R. (2008, January 8). Brand Kenya Idea Should Be On Its Feet to Foster Unity And Growth. Business Daily, pp. 1-2.

Muñiz, N., \& Cervantes, M. (2010). Marketing de ciudades y Place Branding. Obtenido de http://www3.unileon.es/pecvnia/pecvnia2010/2010_123_149.pdf

Murphy, P. E. (2013). Tourism: A community approach. Routledge.

Nagarajan, R., Scutari, M., \& Lebre, S. (2013). Bayesian Networks in R: with Applications in Systems Biology (Use R!). USA: Springer.

Najafizadeh, N., Mehrabi, M., Karjalian, R., \& Mashayekhnia, A. (2013). Study of the relationship between the country of origin and bran equity case study: Grad. Jounrla of Marketing Management, 7(17), 83-96.

Nakata, C., \& Sivakumar, K. (2001). Instituting the Marketing Concept in a Mutual Setting: The Role of National Culture. Journal of the Academy of Marketing Science, 29(3), 255-275.

Narayanan, A., Padhi, A., \& Williams, J. (2012). Designing products for value in emerging markets. Mckinsey Quarterly(4), 46-49.

Naylor, R., Lamberton, C., \& West, P. M. (2012). Beyond the "Like" Button: The Impact of Mere Virtual Presence on Brand Evaluations and Purchase Intentions in Social Media Settings. Journal Of Marketing, 76(6), 105-120.

Negrea, A. (2012). Globalization and the identity dilemma. Theoretical \& Applied Economics, 19(9), 93-116.

Newell, R. (2011, June). Restoring Mexico's International Reputation. Retrieved from http://www.wilsoncenter.org/sites/default/files/Restoring\%20Mexico\%20Report.pdf

Nicolau, K., \& Aires, G. (2010). Marketing turístico internacional: La Marca Brasil. Revista Estudios y perspectivas en turismo, 19(2), 241-267.

Niesing, E. (2013). Nation Branding Practices in Latin America: A Diagnosis of Brazil, Chile and Colombia. GRIN Verlag. 
Nikolova, M. S., \& Hassan, S. S. (2013). Nation branding effects on retrospective global evaluation of past travel experiences. Journal Of Business Research, 66(6), 752-758. doi:10.1016/j.jbusres.2011.09.014.

Nordstróm, L. (2008). Embajadora de Suecia en Colombia. (L. Echeverri, Entrevistador)

Noseworthy, T., \& Trudel, R. (2011). Looks Interesting, but What Does It Do?? Evaluation of Incongruent Product Form Depends on Positioning. Journal Of Marketing Research, 48(6), 1008-1019. doi:10.1509/jmr.10.0384.

Nost, E. (2013). The power of place: tourism development in Costa Rica. Tourism Geographies, 15(1), 88-106.

Noya, J., \& Prado, F. (2012). Real instituto Elcano . From Marcas-país: éxitos y fracasos en la gestión de la imagen exterior: http://www.realinstitutoelcano.org/wps/portal/rielcano/contenido?WCM_GLOBAL _CONTEXT=/elcano/elcano_es/zonas_es/imagen+de+espana/dt13-2012_noyaprado_gestion_marcas-pais_imagen-exterior

O’Shaughnessy, J., \& O’Shaughnessy, N. J. (2000). Treating the nation as a brand: some neglected issues. Journal of Macromarketing, 20(1), 56-64.

O'Connor, B. (2007). Anti-Americanism: History, Causes, Themes. Oxford: Greenwood.

Olins, W. (2002). Branding the nation--the historical context. Journal Of Brand Management, 9(4/5), 241.

Olins, W. (2006, May). ¿Why brand a nation? Retrieved from A design Indaba Project: http://www.designindaba.com/article/why-brand-nation

Olins, W. (2008). Las Marcas Segun Wally Olins. United States of America: Turner.

Omaniuk, J., Bogomolova, S., \& Riley, F. (2012). Brand Image and Brand Usage. Journal Of Advertising Research, 52(2), 243-251. doi:10.2501/JAR-52-2-243-251.

OMT. (2009). Colombia de nuevo en el mapa del turismo mundial. Latin Trade, 17(2), 60.

Oppenheimer, A. (2011). El creciente riesgo en América latina. Recuperado el 22 de julio de 2011, de http://www.periodismodeverdad.com.ar/2011/04/20/el-creciente-riesgoen-america-latina-por-andres-oppenheimer/

Organización Mundial del Turismo. (2000). Turismo: Panorama 2020 Las Américas. Obtenido de http://apps.mintur.gub.uy/pmb/opac_css//doc_num.php?explnum_id=30 
Organización Mundial del Turismo. (2007). Entender el turismo. Obtenido de http://media.unwto.org/es/content/entender-el-turismo-glosario-basico

Organización Mundial del Turismo. (2010). Panorama OMT del turismo internacional. Madrid: Departamento de Comunicaciones de la OMT.

Organización Mundial del Turismo. (2012). Colombia - De nuevo en el mapa del turismo mundial. Obtenido de http://www2.unwto.org/es/agora/colombia-de-nuevo-en-elmapa-del-turismo-mundial

Organización para la Cooperación y el Desarrollo Económico. (13 de Julio de 2012). Crecerá economía mexicana $3.6 \%$ en 2012 Obtenido de http://noticierostelevisa.esmas.com/nacional/446726/ocde-crecera-economiamexicana-3.6-2012/

Otero, D. F. (Enero de 2012). El sector energético-minero y la economía colombiana. Obtenido de http://www.indepaz.org.co/wp-content/uploads/2012/04/El-sectorenerg\%C3\%A9tico-minero-y-la-econom\%C3\%ADa-colombiana.pdf

Padilla, L. (2013). La marca país 'Ecuador Ama la Vida' gozará de protección a escala mundial . Obtenido de http://www.andes.info.ec/es/economia/marca-pais-ecuadorama-vida-gozara-proteccion-escala-mundial.html

Palencia, G., \& Barera, A. (1 de Julio de 2013). Exportaciones de café de Honduras caen 14 pct en junio por roya. Obtenido de Reuters México: http://mx.reuters.com/article/topNews/idMXL2N0F71OY20130701?pageNumber= $2 \&$ virtualBrandChannel $=0$

Papadopoulos, N., \& Heslop, L. (1993). Product-Country Images: Impact and Role in International Marketing. New York: International Business Press.

Parsa, A., Eidelou, P., Abdolah, S., \& Maleki, M. (2013). A Review of the Affecting Factors on Brand Equity from the Customer Perspective (By Using Aker Views). Interdisciplinary Journal Of Contemporary Research In Business, 4(11), 712-719.

Passow, T., Fehlmann, R., \& Grahlow, H. (2005). Country Reputation From Measurement to Management: The Case of Liechtenstein. Corporate Reputation Review, 7(4), 309326.

Paz, S. (23 de Noviembre de 2006). Proyecto I+D Gestión estratégica urbana. (U. N. Quilmes, Ed.) Recuperado el 6 de Agosto de 2008, de Citizen branding: diseño, creación y gestión del marketing territorial: http://hm.unq.edu.ar/CotelcoUNQ/Sergio_Paz\%5B20061107\%5D.pdf 
Pearl, J. (1988). Probabilistic reasoning in intelligent systems: networks of plausible inference. Los Altos: Morgan Kaufmann.

Peña, G. (2007). Marca País: Introducción a la problemática desde los ejecutivos de compañías top. Revista Científica UCES, 145-164.

Periódico El País. (2012). Presidente Santos defendió con cifras la política de seguridad democrática. Obtenido de http://www.elpais.com.co/elpais/colombia/noticias/presidente-santos-defendio-concifras-politica-seguridad-democratica

Petroll, M., Damacena, C., \& Merino, M. (2008). Medición y determinantes del valor de la marca en la perspectiva del consumidor. Contabilidad y Negocios, 19-37.

Pew Research Center. (2013). Pew Research Center. Retrieved Enero 21, 2013, from http://www.pewresearch.org/about/mission-and-history/

Pew Reserch Center Project. (2009, July 23). The pew global project attitudes. Retrieved from http://www.pewglobal.org/files/pdf/264.pdf

Pike, A. (2011). Brands and Branding Geographies. United Kingdom: Edward Elgar Publishing Limited.

Pipoli, G. (2009). La importancia de la estrategia de marca país en la promoción del turismo, inversiones y exportaciones de los países latinoamericanos. Leadership: Magazine for Managers, 6(20), 40-41.

Pipoli, G., \& Flores, A. (2006). Los productos bandera como componente estratégico del diseño de la marca país Perú. (U. d. pacífico, Ed.) Revista Punto de equilibrio(89).

Pomering, A. (2013). Indigenous Identity in the Nation Brand: Tension and Inconsistency in a Nation's Tourism Advertising Campaigns. Corporate Reputation Review, 16(1), 6679. doi:10.1057/crr.2012.26.

Portal público de noticias de la República Argentina. (29 de agosto de 2008). Argentina: una marca para el mundo. Recuperado el 22 de abril de 2010, de http://bit.ly/mCvkZ9

Porter, M. (Abril de 1994). Informe Monitor. Recuperado el 20 de Junio de 2008, de Creando la Ventaja Competitiva de Colombia: www.camaramed.org.co/docs/01informe_monitor_colombia.doc 
Porter, M. (abril de 1994). Informe Monitor. Recuperado el 20 de junio de 2008, de Creando la Ventaja Competitiva de Colombia: www.camaramed.org.co/docs/01informe_monitor_colombia.doc

Porter, M. (2005). In Search of a Competitive Identity: Towards A Competitiveness Agenda for Colombia. Cartagena.

Prado, F. (2007). Marcas, Reputaciones y Territorios. Obtenido de http://reputationinstitute. com/events/Marcas_Reputaciones_y_Territorios_Badajoz2007.pdf.

Prasad, M. (2011, May). Cause Branding and its Impact on Corporate Image. Journal of Marketing \& Communication, 7(1), 41-44.

Prebežac, D., \& Mikulić, J. (2008). Destination image and key drivers of perceived destination attractiveness. Trziste / Market, 20(2), 163-178.

Presidencia de la República de Guatemala. (2012). Política Nacional para el Turismo Sostenible de Guatemalar Obtenido de http://www.segeplan.gob.gt/downloads/clearinghouse/politicas_publicas/Turismo/P olitica_Nacional_DTS_Guatemala_2012_2022.pdf

Prochile. (s.f). From http://www.prochile.us/sites/default/files/1472b5b3a213012431\%20Imagen\%20Pais\%20-\%20WEB\%202.pdf

ProChile. (s.f.). ProChile. Recuperado el 3 de Febrero de 2011, de Programa de fomento a las exportaciones chilenas, dependiente del ministerio de Relaciones Exteriores.: http://www.prochile.cl

Proexport Colombia. (2005). Acta \#133. Libro de Actas del Consejo Asesor de Imagen País. Bogotá.

Proexport Colombia. (2006). Acta \#145. Libro de Actas del Consejo Asesor de Imagen País. Bogotá.

Proexport Colombia. (2006). Acta \#145. Libro de Actas del Consejo Asesor de Imagen País. Bogotá.

Proexport Colombia. (2007). Acta \#160. Libro de Actas del Consejo Asesor de Imagen País. Bogotá.

Proexport Colombia. (2008). Informes de la dirección Colombia es Pasión. Bogotá.

Proexport Colombia. (2010a). Informes de la dirección Colombia es Pasión. Bogotá. 
Proexport Colombia. (2010b). Proyección y tendencias de turismo . Obtenido de Subdirección de Inteligencia de Mercados - DIC: http://www.proexport.com.co/sites/default/files/DocNewsNo10306DocumentNo899 3.pdf

Proexport Colombia. (2012). Sector Agroindustrial Colombiano. Obtenido de http://www.inviertaencolombia.com.co/sectores/agroindustria.html

Proexport Colombia. (2013). ¿Qué es Proexport? Obtenido de Sitio Oficial de Proexport Colombia: http://www.proexport.com.co/proexport/que-es-proexport

Proexport Colombia. (2013). Informe Turismo Extranjero en Colombia. Obtenido de Cifras de enero-junio de 2013: http://www.proexport.com.co/sites/default/files/informe_proexport_turismo_extranj ero_en_colombia_a_junio_2013_version_final.pdf

PromPerú. (s.f.). Todos hacemos Perú. Obtenido de http://internacional.peru.info/

Proulx, M. U., \& Tremblay, D. (2006). Marketing territorial et positionnement mondial. Géographie, économie, société, 8(2), 239-256.

Pucci, T., Simoni, C., \& Zanni, L. (2013). Country of origin effect, brand image and retail management for the exploitation of 'Made in Italy'. International Marketing and the Country of Origin Effect: The Global Impact of'made in Italy', 154.

Rafi, A., Ahsan, M., Saboor, F., Hafeez, S., \& Usman, M. (2011). Knowledge Metrics of Brand Equity: Critical Measure of Brand Attachment and Brand Attitude Strength. Asian Journal Of Business Management, 3(4), 294-298.

Raharjo, L. (2012). Country Image Perception on Tertiary Education: A Pilot Study. Contemporary Management Research, 8(1), 85-92.

Ramírez, M. (21 de enero de 2013). Los diez desafíos del Segundo Obama. Recuperado el 21 de 01 de 2013, de Elmundo.es: http://www.elmundo.es/america/2013/01/21/estados_unidos/1358731956.html

Ramos, M., \& Noya, J. (30 de Mayo de 2006). América Latina: del riesgo país a la Marca. Recuperado el 23 de Junio de 2008, de http://www.realinstitutoelcano.org/documentos/242/242_RamosNoyaImagenMarca PaisAmericaLatina.pdf. 
Rasmussen, R., \& Merkelsen, H. (2012). The new PR of states: How nation branding practices affect the security function of public diplomacy. Public Relations Review, 38(5), 810-818. doi:10.1016/j.pubrev.2012.06.007.

Rector, I., Bagautdinova, N., Novenkova, A., \& Kalenskaya, N. (2013). Territorial marketing as successful strategy for regional development. Annual International Conference On Qualitative \& Quantitative Economics Research, 18-23. doi:10.5176/22512012_QQE13.18.

Ren, C., \& Blichfeldt, B. (2011). One Clear Image? Challenging Simplicity in Place Branding. Scandinavian Journal Of Hospitality \& Tourism, 11(4), 416-434. doi:10.1080/15022250.2011.598753.

Reputation Institute. (n.d.). Managing Your Country's Reputation with 2013 Country RepTrak ${ }^{\mathrm{TM}}$. Retrieved from http://www.reputationinstitute.com/thoughtleadership/country-reptrak

Revista Container. (11 de diciembre de 2009). Cuál es el lugar exacto de Argentina en el comercio mundial. Recuperado el 15 de febrero de 2010, de http://www.revistacontainer.com/website/?p=1817

Revista Emprende. (s.f.). Exportaciones,el objetivo de los emprendedores. Obtenido de http://www.revistaemprende.com/index.php?option=com_content\&view=article\&id =106:exportacionesel-objetivo-de-losemprendedores \&catid=46: speciales $\&$ Itemid $=61$

Revista Summa. (2 de Septiembre de 2013). La marca país como imán de viajeros. Obtenido de http://www.revistasumma.com/especiales/turismo-2013/41610-la-marca-paiscomo-iman-de-viajeros.html

Reyes, D. (2013). Director de Comunicaciones de Marca País Colombia. (A. Rodríguez, Entrevistador)

Reyna , J. (16 de Abril de 2012). Creció 3\% en primer bimestre la llegada de turistas internacionales. Obtenido de Periódico La Jornada: http://www.jornada.unam.mx/2012/04/16/politica/016n2pol

Reynolds, T., \& Phillips, C. (2005). In Search of True Brand Equity Metrics: All Market Share Ain't Created Equal. Journal Of Advertising Research, 45(2), 171-186.

Ridgen, J. (2011). Emotional labour and the pursuit of the personal brand: Public relations practitioners' use of social media. Journal Of Media Practice, 12(1), 61-76. doi:10.1386/jmpr.12.1.61_1. 
Ritchie, J., J. R. Brent, \& Robin J. B. Ritchie. (1998). The Branding of Tourism Destinations: Past Achievements and Future Challenges. Proceedings of the 1998 Annual Congress of the International Association (pp. 89-116). Morocco: International Association of Scientific Experts in Tourism.

Ritson, M. (2010). Countries are countries, not brands . Marketing Week(01419285), 33(18), 54.

Roberts, K. (2005). Lovemarks. PowerHouse Books; Revised Edition edition .

Robichaud, F., Richelieu, A., \& Kozak, R. (2012). Branding as a communications strategy: A framework for desired brand identity. Journal Of Brand Management, 19(8), 712 734. doi:10.1057/bm.2011.61.

Robles, F. (1996). Identidad e imagen nacional: variables internas de la política exterior. Revista Colombia Internacional.

Roche, D. (2012). Marketing Trends of Industrial Tourism. China-USA Business Review, 11(9), 1307-1315.

Rodríguez, G. (2010). Breve recopilación de Marcas Perú. Obtenido de http://disenoperu.blogspot.com/2010/04/breve-recopilacion-de-marcas-peru.html

Rodríguez, M. (2011). Embajador de Colombia en Inglaterra. (L. Echeverri, Entrevistador)

Rojas-Méndez, J., Murphy, S., \& Papadopoulos, N. (2013). Measuring and Positioning Nation Brands: A Comparative Brand Personality Approach. Corporate Reputation Review, 16, 48-6. 
Roldán, S. (s.f.). Del top of mind al top of heart y del top of hand al top of tongue; principios del posicionamiento de las marcas en la era digital. Obtenido de El poder del marketing: http://www.elpoderdelmarketing.com/edicion04/art-06-top-mind-topheart-top-hand-top-tongue.html

Romaniuk, J. (2012). Are You Ready for the Next Big Thing?: New Media Is Dead! Long Live New Media! Journal Of Advertising Research, 52(4), 397-399. doi:10.2501/JAR-52-4-397-399.

Ross, M. (2010). Branding Basics for Small Business: How to Create an Irresistible Brand on Any Budget. United States of America: Norlightspress.Com .

Rossiter, J., \& Bellman, S. (2012). Emotional Branding Pays Off. Journal Of Advertising Research, 52(3), 291-296. doi:10.2501/JAR-52-3-291-296 S.

Roth, M. (1995). Effects of Global Market Conditions on Brand Image Customization and Brand Performance. Journal of Advertising, XXIX(4), 55-72.

Roth, M., \& Romeo, J. (1992). Matching Product. Journal of International Business Studies, 23(3), 477-97.

Ruíz, A. (2012). Tendencias recientes del mercado internacional del petróleo. Obtenido de CEPAL: www.eclac.org/publicaciones/xml/5/14385/1cl2021e.pdf

Ruíz, O. (Junio de 2008). Turismo: Factor de desarrollo y competitividad en Mexico. Obtenido de Centro de Estudios Sociales y de Opinión Pública: http://www.google.com.co/url?sa=t\&rct=j\&q=\&esrc=s\&frm=1\&source=web\&cd=1 \&ved=0CFAQFjAA\&url=http $\% 3 \mathrm{~A} \% 2 \mathrm{~F} \% 2 \mathrm{Fwww}$.diputados.gob.mx\%2Fcamara $\%$ 2Fcontent\%2Fdownload\%2F193936\%2F465242\%2Ffile\%2FTURISMO_factor_de sarrollo_competitividad_Docto46.pdf\&ei=MzIEUJyTBYaw8ATzm

Saavedra, J. L. (2006). Manual práctico para construir una marca. Debates IESA, 83 - 86.

Saavedra, J. L. (2007). Capital de marca como fenómeno cultural: El metodo etnográfico como herramienta de medición en mercadeo. Espacio Abierto Cuadeno Venezolano de Sociología.

Salvador, M. (2001). Análisis de conglomerados o cluster. Obtenido de http://www.5campus.org/leccion/cluster

Salvador, M. (2003). Análisis de Correspondencias. Obtenido de http://www.5campus.com/leccion/correspondencias 
Samimi, P., Lim, G., \& Buang, A. (2011). Globalization Measurement: Notes on Common Globalization Indexes. Journal of Knowledge Management, Economics and Information Technology, 1(7), 197-216.

Sánchez, E. (1999). Latin America: Shifting to New Paradigms. Business Economics, 34(3), 7.

Sánchez, M., \& Stephan, N. (2003). Principales tipos de investigación. (Candidus, Ed.) Cuadernos Monográficos Candidus, 1, 8 .

Santamaría, R. (2010). Positivo Balance de la campaña el riesgo es que te quieras quedar. Diario El Tiempo.

Santana, G. (2001). Tourism in South America: A Brief Overview. International Journal of Hospitality \& Tourism Administration, 1(3), 1-19.

Sartori, A., Mottironi, C., \& Corigliano, M. (2012). Tourist destination brand equity and internal stakeholders: An empirical research. Journal Of Vacation Marketing, 18(4), 327-340. doi:10.1177/1356766712459689.

Secretaría de Turismo de la Nación. (2010). Portal de la Marca País de Argentina. Recuperado el 12 de marzo de 2011, de http://bit.ly/mPxZAU

Secretaría de Turismo de México. (2011a). Acuerdo Nacional por el Turismo. Obtenido de http://www.sectur.gob.mx/work/models/sectur/Resource/1323/1/images/10\%20Ejes .pdf

Secretaría de Turismo de México. (26 de Mayo de 2011b). Estadísticas más recientes de la actividad del sector turismo. Obtenido de http://datatur.sectur.gob.mx/work/docs/5_reporte_semana/sem202011.pdf

Secretaría de Turismo de México. (17 de Marzo de 2011c). Boletín 43 Refuerza CPTM Estrategia de Promoción de Nuestro País. Obtenido de SECTUR: http://www.sectur.gob.mx/es/sectur/Boletin_43

Secretaría de Turismo de México. (2012). Boletín 25 Registra México en el 2011 cifra histórica en turistas nacionales e internacionales. Obtenido de http://www.turismo.gob.mx/es/sectur/Boletin_25_

Secretaría de Turismo de México. (2013). Consejo de Promoción Turística. Obtenido de http://www.cptm.com.mx/ 
Segura, G. (1998). Comentarios acerca de la Campaña de Costa Rica en los Estados Unidos, 1996-1997. Obtenido de http://www.incae.edu/es/clacds/publicaciones/pdf/cen652.pdf

Šeric, N. (2011). Management of national touristic brand: the role of the branding strategy in Croatia. International Journal Of Management Cases, 13(4), 6-11.

Serra Cantallops, A. (2002). Marketing turístico. Ediciones pirámide.

Serrano-Puche, J. (2012). Herramientas web para la medición de la influencia digital: Análisis de Klout y PeerIndex. El Profesional De La Información, 21(3), 298-303. doi:10.3145/epi.2012.may.11.

Servicio Nacional de Turismo. (2008). Pasos para construir la marca de un destino turístico.

Obtenido de http://api.ning.com/files/FwyaxkoAerVOnXoBIlv9MGLvViVTlfEIrTfIUtb*k1A_/ PasosparaConstruirMarcadelDestinoTurstico.pdf

Servicio Nacional de Turismo de Chile. (s.f.). Sitio Oficial de Turismo de Chile. Obtenido de http://chile.travel/

Sherman, S. M. (2013). False recall and recognition of brand names increases over time. Memory, 21(2), 219-229. doi:10.1080/09658211.2012.720992.

Shillington , A. (2012). Branding for Good. Canada: Brands for the People.

Signorelli, J. (2012). StoryBranding: Creating Stand-Out Brands Through The Power of Story. Texas: Greenleaf Book Group Press .

Silverman, D. (2013). Doing qualitative research: A practical handbook. Uunited States of America: SAGE Publications Limited.

Solé, M. L. (2003). Los consumidores del siglo XXI (Segunda ed.). ESIC Editorial.

Souiden, N., Pons, F., \& Mayrand, M. (2011). Marketing high-tech products in emerging markets: the differential impacts of country image and country-of-origin's image. Journal Of Product \& Brand Management, 20(5), 356-367. doi:10.1108/10610421111157883.

Stahl, F., Heitmann, M., Lehmann, D., \& Neslin, S. (2012). The Impact of Brand Equity on Customer Acquisition, Retention, and Profit Margin. Journal Of Marketing, 76(4), 44-63. doi:10.1509/jm.10.0522. 
Stieglitz, S., \& Dang-Xuan, L. (2013). Emotions and Information Diffusion in Social MediaSentiment of Microblogs and Sharing Behavior. Journal Of Management Information Systems, 29(4), 217-248. doi:10.2753/MIS0742-1222290408.

Stock, F. (2009). Identity, image and brand: A conceptual framework. Place Branding \& Public Diplomacy, 5(2), 118-125. doi:10.1057/pb.2009.2.

Strauss , R., \& Neal, W. (2008). Value Creation: The Power of Brand Equity. United States of America: South-Western Educational Publishing and AMA.

Superbrands. (2006). Superbrands México.

Supphellen, M., \& Nygaardsvik, I. (2002). Testing country brand slogans: Conceptual development and empirical illustration of a simple normative model. The Journal of Brand Management, 9(3), 385-395.

Suri, R., \& Thakor , M. (2013). Made in Country Versus Made in County: Effects of Local Manufacturing Origins on Price Perceptions. Psychology \& Marketing, 30(2), 121132. doi:10.1002/mar.20592.

Szondi, G. (2010). From image management to relationship building: A public relations approach to nation branding. Place Branding \& Public Diplomacy, 6(4), 333-343.

Tamayo, M. T. (2004). El proceso de investigación científica. México: Limusa.

Task Force on Travel \& Competitiveness. (2012). National Travel \& Tourism Strategy.

Tatevossian, A. (2008). Domestic society's (often-neglected) role in nation branding. Place Branding \& Public Diplomacy, 4(2), 182-190. doi:10.1057/pb.2008.8.

Terrés, G. (11 de mayo de 2010). El beneficio de una "Marca País" fuerte. Recuperado el 28 de febrero de 2011, de CNNExpansión: http://www.cnnexpansion.com/opinion/2010/05/10/marca-mexico-pais-percepcionexpansion

The Brand USA. (2012a). Request for a proposal publishing. United States: CTC.

The Brand USA. (2012b). Brand USA Fiscal Year: 2012 Annual Report. Retrieved from http://www.thebrandusa.com/ /media/FY2012\%20Brand\%20USA\%20Annual\%20 Report.pdf

The Caims Post. (2010). South America on tourism radar. The Caims Post, p. 12. 
The New Economics Foundation. (2013). Happy Planet Index. Retrieved from http://www.happyplanetindex.org/countries/costa-rica/

Thoma, V., \& Williams, A. (2013). The devil you know: The effect of brand recognition and product ratings on consumer choice. Judgment and Decision Making, 8(1), 34-44.

Tourist Destination Branding. (2012). Zbornik Radova Ekonomskog Fakulteta u Istocnom Sarajevu, 6, 503-514.

Trajkov, A., Biljan, J., \& Kostoski, S. (2012). Brendiranje destinacije: konkurentski potencijal ohrida kao turističkog brenda. (Slovenian). Economic Themes, 50(4), 651668.

Transparency International. (2011). Corruption Perceptions Index. Retrieved from http://www.transparency.org/country\#MEX

Transparency International. (2012). Corruption Perceptions Index. Retrieved from http://www.transparency.org/gcb2013/country/?country=venezuela

Trout, J., \& Ries, A. (1993). Las 22 Leyes Inmutables Del Marketing. Estados Unidos: McGraw-Hill Companies.

Trout, J., \& Rivkin, S. (2010). Differentiate or Die: Survival in Our Era of Killer Competition. United States of America: Wiley.

Trout, J., Kotler, P., \& Ries, A. (2000). Positioning: The Battle for Your Mind. United States of America: McGraw-Hill.

Trujillo, C. (2013). VP Marketing Digital de JWT. (A. Rodríguez, Entrevistador)

Trujillo, E. (2003). Marca País e Imagen Corporativa del Ministerio de Turismo. Obtenido de http://www.razonypalabra.org.mx/anteriores/n32/etrujillo.html

Trujillo, L. (2012). Gerente Comercial y de Marketing de Marca País. (L. Echeverri, Entrevistador)

Trujillo, L. (2012a). Entrevista a Gerente de Marketing de Marca País Colombia. (L. M. Echeverri, Entrevistador)

Trujillo, L. (2013). Consultor Senior FutureBrand. (A. Rodríguez, Entrevistador)

Turismo Sostenible CST: Certificación para la Sostenibilidad Turística en Costa Rica. (2010). Obtenido de http://www.turismo-sostenible.co.cr/es/acerca-del-cst/cuandoy-por-que.html 
Turnovsky, S. J. (1969). A Bayesian Approach to the Theory of Expectation. Journal Of Economic Theory, 1(2), 220.

Uddin, J., Parvin, S., \& Rahman, M. (2013). Factors Influencing Importance of Country of Brand and Country of Manufacturing in Consumer Product Evaluation. International Journal Of Business \& Management, 8(4), 65-74. doi:10.5539/ijbm.v8n4p65.

UNFPA - United Nations Population Fund. (2012). Población y salud. Obtenido de Análisis de Situación de Población: http://unfpa.org/psa/wp-content/uploads/2012/11/2Poblacion-y-Salud.pdf

UNICEF Chile. (2006). Evolución de la Pobreza e Indigencia . Recuperado el 1 de diciembre de 2010, de http://www.unicef.cl/unicef/index.php/Pobreza

United Nations Conference on Trade and Development. (2012). World Investment Report, 2011. UNCTAD.

Urrutia, A. (2006). Marca país: concepto multidimensional. Revista Mexicana de Comunicación, 19(102), 33-35.

US Department of Commerce, I. T. (2013). Summary of International Travel to the United States.

Usunier, J.-C. (2006). Relevance in business research: the case of country-of-origin research in. European Management Review, 3, 60-73.

Valls, J.-F. (1992). La imagen de marca de los paises. Madrid: McGraw Hill.

Van der Horst, A. (11 de marzo de 2010). Coloquio sobre "marca país" con buen sabor de boca. Recuperado el marzo de 4 de 2011, de http://bit.ly/kHVSRC

Vanella, R. (16 de Julio de 2000). Para poder vender más en el exterior hay que desarrollar una marca país. Periódico La Nación, pág. 11.

Velilla, J. (2010). Branding. Tendencias y retos en la comunicación de marca (Primera ed.). Barcelona: Editorial UAOC.

Vera, J. (2008). Perfil de valor de marca y la medición de sus componentes. Revista Academia(41), 69-89.

Vergara, C. (2012). Colombia y su marca país: un secreto de Estado. Obtenido de http://www.revistapym.com.co/destacados/colombia-su-marca-pais-secreto-estado 
Verlegh, P. (2001). Country-of-origin effects on consumer product evaluations. Wageningen, the Netherlands: Wageningen University.

Vidic, F., \& Vadnjal, J. (2013). The Role of Branding in SMEs: Different Perspective on the Market. China-USA Business Review, 12(1), 79-88.

Villar, A. (2010). La competencia intercultural en el mundo de la empresa: el peso de los estereotipos. España: Fundación Comillas.

Villarejo-Ramos, A., \& Sánchez-Franco, M. (2005). The impact of marketing communication and price promotion on brand equity. Journal Of Brand Management, $12(6), 431-444$.

Vissak, T. (2010). Recommendations for using the case study method in international business research. The Qualitative Report, 15(2), 370-388.

Vivanco, L. (2012). Certifying Sustainable Tourism in Costa Rica. Central America in the New Millennium: Living Transition and Reimagining Democracy, 102, 212.

Wang, C., Li, D., Barnes, B. R., \& Ahn, J. (2012). Country image, product image and consumer purchase intention: Evidence from an emerging economy. International Business Review, 21(6), 1041-1051. doi:10.1016/j.ibusrev.2011.11.010.

Westjohn, S., Singh, N., \& Magnusson, P. (2012). Responsiveness to Global and Local Consumer Culture Positioning: A Personality and Collective Identity Perspective. Journal Of International Marketing, 20(1), 58-73. doi:10.1509/jim.10.0154.

Wheeler, A. (2012). Designing Brand Identity: An Essential Guide for the Whole Branding Team. New Jersey: Wiley.

Whetten, D., \& Mackey, A. (2001). A social actor conception of organisational identity and its implications for the study of organisational reputation. Business \& Society, 93414.

White, C. (2012). Brands and national image: An exploration of inverse country-of-origin effect. Place Branding \& Public Diplomacy, 8(2), 110-118. doi:10.1057/pb.2012.6.

Woo Jin, C., \& Winterich, K. (2013). Can Brands Move In from the Outside? How Moral Identity Enhances Out-Group Brand Attitudes. Journal Of Marketing, 77(2), 96-111.

World Economic Forum. (2011). The Global Competitiveness Report 2011-2012. Retrieved from World Economic Forum - Geneva Switzerland 2011: http://reports.weforum.org/global-competitiveness-2011-2012/\#= 
World Economic Forum. (2013). The Global Competitiveness Report 2012-2013. Retrieved from http://www3.weforum.org/docs/WEF_GlobalCompetitivenessReport_201213.pdf

World Economic Forum. (2013). The Travel \& Tourism Competitiveness Report 2013. Retrieved from http://www3.weforum.org/docs/WEF_TT_Competitiveness_Report_2013.pdf

Wreden, N. (2002). FusionBranding: How To Forge Your Brand for the Future. Canada: Accountability Press.

Yang, S., Shin, H., Lee, J., \& Wrigley, B. (2008). Country Reputation in Multidimensions: Predictors, Effects, and Communication Channels. Journal of Public Relations Research, 421-440 doi:10.1080/10627260802153579.

Yin, R. (2011). Applications of case study research. SAGE Publishing.

Young-A, S., \& Yongjun, S. (2013). Antecedents of Nation Brand Personality. Corporate Reputation Review, 16(1), 80-94. doi:10.1057/crr.2012.24.

Zelanski, P., \& Fisher, M. P. (2001). Color. Ediciones AKAL.

Żemła, M. (2012). The idea of destination branding licensing and the question of its effectiveness. Tourism \& Hospitality Management, 18(2), 297-312.

Zenker, S., \& Martin, N. (2011). Measuring success in place marketing and branding. Place Branding \& Public Diplomacy, 7(1), 32-41. doi:10.1057/pb.2011.5.

Zingshem, J. (2012). How Influential Are You? Business NH Magazine, 29(3), 30.

Zouganeli, S., Trihas, N., Antonaki, M., \& Kladou, S. (2012). Aspects of Sustainability in the Destination Branding Process: A Bottom-up Approach. Journal Of Hospitality Marketing \& Management, 21(7), 739-757. doi:10.1080/19368623.2012.624299. 


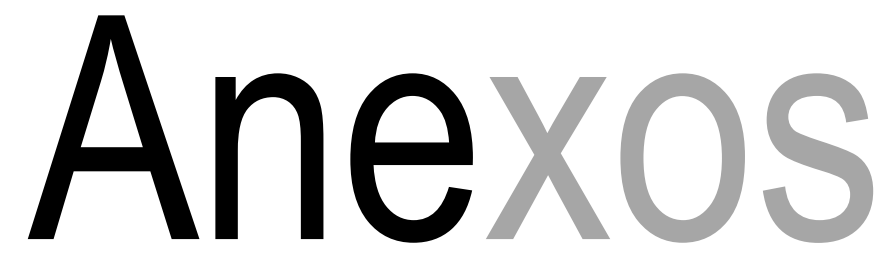




\section{Anexo 1. Fichas técnicas de Entrevistas}

\begin{tabular}{ll}
\hline Fecha & Marzo 18 de 2008 \\
Entrevistado & Carolina Arango \\
Entidad & Colombia es Pasión \\
Entrevistadores & $\begin{array}{l}\text { Eduardo Rosker - Martha Restrepo - Lina } \\
\text { María Echeverri }\end{array}$ \\
\hline & \\
\hline Fecha & Marzo 27 de 2008 \\
Entrevistados & Jaime Bermúdez - Alicia mejía \\
Entidad & Colombia es Pasión \\
Entrevistadores & Eduardo Rosker - Lina María Echeverri \\
\hline & \\
\hline Fecha & Abril 8 de 2008 \\
Entrevistado & Lucely Mora \\
Entidad & Colombia es pasión \\
Entrevistador & Eduardo Rosker - Lina María Echeverri \\
\hline & \\
\hline Fecha & Abril 9 de 2008 \\
Entrevistado & Alicia Mejía \\
Entidad & Inexmoda \\
Entrevistador & Martha Lucía Restrepo \\
\hline & Abril 9 de 2008 \\
\hline Fecha & Munir Falah \\
Lugar & Eduardo Rosker \\
\hline Entrevistador & \\
\hline
\end{tabular}

\begin{tabular}{|c|c|}
\hline Fecha & Abril 9 de 2008 \\
\hline Entrevistado & Nayib Neme \\
\hline Lugar & Organización Chaid Neme \\
\hline Entrevistador & Eduardo Rosker \\
\hline Fecha & Abril 10 de 2008 \\
\hline Entrevistados & Liliana Medina - Saúl Cardozo \\
\hline Entidad & Colombia es pasión \\
\hline Entrevistador & Lina María Echeverri \\
\hline Fecha & Abril 10 de 2008 \\
\hline Entrevistado & Diana Herazo \\
\hline Entidad & Colombia es pasión \\
\hline Entrevistador & Lina María Echeverri \\
\hline Fecha & Abril 10 de 2008 \\
\hline Entrevistado & María Juliana Lora \\
\hline Entidad & Colombia es pasión \\
\hline Entrevistador & Eduardo Rosker - Lina María Echeverri \\
\hline Fecha & Abril 10 de 2008 \\
\hline Entrevistados & Nataly Aya - Olga Lucía Ortiz \\
\hline Entidad & Colombia es pasión \\
\hline Entrevistador & Lina María Echeverri \\
\hline
\end{tabular}




\begin{tabular}{ll}
\hline Fecha & Abril 14 de 2008 \\
Entrevistado & Marcelo Arango \\
Entidad & Sancho BBDO \\
Entrevistador & Eduardo Rosker \\
\hline Fecha & Abril 25 de 2008 \\
Entrevistado & Hans Peter Knudsen \\
Lugar & Universidad del Rosario \\
Entrevistador & Eduardo Rosker - Lina María Echeverri \\
\hline & \\
\hline Fecha & Abril 23 de 2008 \\
Entrevistado & Fabio Valencia Cossio \\
Lugar & Casa de Nariño \\
Entrevistador & Eduardo Rosker \\
\hline & \\
\hline Fecha & Abril 25 de 2008 \\
Entrevistado & Jorge Eatsman \\
Lugar & Casa de Nariño \\
Entrevistador & Eduardo Rosker \\
\hline Fecha & Abril 29 de 2008 \\
Entrevistado & Lena Nordström \\
Eugar & Linbajada de Suecia \\
Entrevistador & María Echeverri \\
\hline Entrevistador & Lina María Echeverri \\
\hline
\end{tabular}

\begin{tabular}{ll}
\hline $\begin{array}{l}\text { Fecha } \\
\text { Entrevistado }\end{array}$ & Mayo 15 de 2008 \\
Lugar & CESA \\
Entrevistador Rodríguez & Eduardo Rosker - Lina María Echeverri \\
\hline & Mayo 21 de 2008 \\
\hline Fecha & Diana Zapata \\
Lugar & Frito Lay \\
Entrevistador & Lina María Echeverri \\
\hline & \\
\hline Fecha & Junio 3 de 2008 \\
Entrevistado & Juan Pablo García \\
Lugar & SOFASA \\
Entrevistador & Lina María Echeverri \\
\hline & \\
\hline Fecha & Junio 4 de 2008 \\
Entrevistado & Isabel Cristina Sierra \\
Lugar & BBVA \\
Entrevistador & Lina María Echeverri \\
\hline & Junio 9 de 2008 \\
\hline Entrevistado & María Claudia Lacourture \\
Eugar & Lolombia es pasión \\
\hline
\end{tabular}




\begin{tabular}{|c|c|}
\hline Fecha & Junio 13 de 2008 \\
\hline Entrevistado & Nibaldo Toledo \\
\hline Lugar & Telefónica Telecom \\
\hline Entrevistador & Lina María Echeverri \\
\hline Fecha & Junio 25 de 2008 \\
\hline Entrevistado & Cristina Pacheco \\
\hline Lugar & Petrobras \\
\hline Entrevistador & Lina María Echeverri \\
\hline Fecha & Julio 9 de 2008 \\
\hline Entrevistado & Nohora Elizabeth Hoyos \\
\hline Lugar & Maloka \\
\hline Entrevistador & Lina María Echeverri \\
\hline Fecha & Marzo 20 de 2013 \\
\hline Entrevistado & Claudia Hoyos \\
\hline Lugar & Oficina de Marca País \\
\hline Entrevistador & Lina María Echeverri \\
\hline Fecha & Noviembre 15 de 2012 \\
\hline Entrevistado & León Trujillo \\
\hline Lugar & Oficina de Marca País \\
\hline Entrevistador & Lina María Echeverri \\
\hline
\end{tabular}

\begin{tabular}{ll}
\hline Fecha & Julio 29 de 2013 \\
Entrevistado & $\begin{array}{l}\text { Mónica Garbrecht } \\
\text { Gerente de Planeación en Marca } \\
\text { País Colombia }\end{array}$ \\
Entrevistadores & Adriana Rodriguez \\
\hline & \\
\hline Fecha & Julio 31 de 2013 \\
Entrevistado & Juliana Lora \\
Entidad & Marca Colombia \\
Entrevistadores & Adriana Rodriguez \\
\hline
\end{tabular}




\section{Anexo 2. Guía de preguntas para la Entrevistas Exhaustivas}

\section{Sección 1. Fundamentos de la marca país}

1. ¿Qué motivó la creación de la marca país? Cómo nació la idea?

2. ¿Cuáles son los objetivos de crear una marca país? ¿Para qué fue creada?

3. ¿De quién fue la idea original de esta iniciativa?

4. ¿Por qué marca país para Colombia?

5. ¿Por qué Colombia es importante para el mundo? ¿Qué ofrece el país?

6. ¿Cuál es la experiencia internacional en las acciones de Marca País que sirve como referente para Colombia?

7. ¿Qué expectativas se manejaron?

8. ¿En qué se diferencia la marca país de Colombia de otras marcas país?

9. ¿Por qué en algunos medios online se reconoce la marca Café de Colombia como marca país? ¿Esto, no genera confusión?

10. ¿Existían iniciativas anteriores a la marca país de Colombia?

11. ¿Para usted qué significa marca país?

\section{Sección 2. Organización}

1. ¿Qué personas y grupos de interés intervinieron en la construcción de la marca país?

2. ¿Para la creación de marca país, qué recursos (humanos, financieros, materiales) utilizaron?

3. ¿Por qué se asesoraron de un extranjero y no de un colombiano para crear la marca país?

4. ¿Cómo es la estructura organizacional del equipo?

5. ¿Qué funciones tienen?
6. ¿Cuál fue el presupuesto inicial para el lanzamiento de la marca?

7. ¿Cuál es el presupuesto anual para su funcionamiento?

8. ¿Cuáles eran los ingresos que recibieron por concepto de la tarifa inicial en el uso de la marca?

9. ¿Cuál fue el criterio para determinar inicialmente el valor de tarifa, y que después tomaran la decisión de que fuera gratis?

10. ¿Sus ingresos de que fuentes se generan?

11. ¿Proexport Colombia hace aportes?

12. ¿La marca país de qué organismo depende?

13. ¿Cuál fue el criterio de que la marca está prevista para que dure 10 años?

14. ¿Cuántas empresas están vinculadas? ¿Cuántas nacionales, cuántas internacionales?

15. ¿Qué porcentaje de participación tiene el gasto en comunicación de la marca en el presupuesto anual?

16. ¿Cuáles son los costos críticos de una estrategia de marca país?

17. ¿Cuál ha sido la mejor experiencia de co-branding de la marca país?

18. ¿Cuándo se termine el periodo presidencial, qué sucederá con la marca?

19. ¿Cómo darle perdurabilidad a una marca que hace parte de una política pública de gobierno de turno?

20. ¿Las campañas de promoción turística generan confusión con la estrategia de marca país?

\section{Sección 3. Proceso de creación de la marca}

21. ¿Quién diseño la imagen?

22. ¿Cómo se diseñó el logotipo?

23. ¿Qué factores culturales y sociales influyeron en el diseño de la marca? 
24. ¿Cómo fue el proceso de lanzamiento de la estrategia de marca país?

25. ¿Sobre qué atributos se pretendió hacer esta construcción?

26. ¿De qué se trata el proyecto en todas sus partes?

27. ¿Qué criterios sociales, estéticos, políticos, comerciales acompañaron el proceso?

28. ¿Qué participación se dio a la ciudadanía en la creación de esta marca? ¿Y al empresariado? ¿Y a la gente de la política?

29. ¿Cómo fue la investigación de mercados? ¿Que arrojó?

30. ¿Qué conceptos giraron en torno a la marca?

31. ¿Cuáles fueron las preocupaciones esenciales en el proceso creativo, conceptual, comunicativo y de marketing?

32. ¿Cuánto ha costado? Cuánto se ha invertido? ¿Que ROI se ha calculado? ¿Qué ROI se tiene como referencia ahora?

33. ¿Qué estrategias desarrollaron?

34. ¿Qué características culturales se consideraron para definirla marca país?

35. ¿Quiénes participaron en el proceso de creación de marca país?

36. ¿Qué pruebas hicieron antes de hacerla marca país visible al público?

37. ¿Cuánto se invirtió en la creación de la marca país? superó lo presupuestado inicialmente?

38. ¿Cómo fue el proceso de construcción de la marca?

39. ¿Cuál es la promesa de valor de la marca país?

40. ¿Cuáles han sido las mejores y peores estrategias de comunicación empleadas para impulsar la marca país?

41. ¿Cómo se desarrolló la marca país? ¿Cuánto tiempo duró?

\section{Sección 4. Resultados observados - Impacto}

42. ¿Cuáles han sido las mayores críticas o controversias generadas en el lanzamiento de la marca?
43. ¿Cuáles han sido los logros y limitantes de posicionar la marca país?

44. ¿Cómo ha sido percibida la marca país por los empresarios?

45. ¿Cómo ha sido percibida la marca país por los consumidores?

46. ¿Cómo se evidencia el apalancamiento de marca con la experiencia de marca país?

47. ¿Cuál es la estrategia de posicionamiento utilizada para la marca? ¿Han utilizado varias? ¿o solo una?

48. ¿Qué beneficios ha proporcionado la creación de la marca país?

49. ¿Cuáles han sido las reacciones frente a la marca por parte del gobierno, gremios, empresarios y consumidores?

50. ¿Que ha motivado a los empresarios o entidades a solicitar la licencia de la marca?

51. ¿Qué ventajas y desventajas ha generado la inclusión de la marca país?

52. Si bien una de las variables de medición de ranking de marcas país es el turismo. En el caso de Colombia ¿qué acciones se han orientado a mejorar este indicador?

53. ¿La marca país ha generado un mayor etnocentrismo del colombiano?

54. ¿Cuál es el grado de satisfacción con los productos y servicios colombianos en el exterior? ¿algunos de ellos ya han incorporado la marca país?

55. ¿Qué contribuciones ha hecho la marca país a la pymes?

56. ¿Cómo trabajan con las Pymes? ¿Cómo se contactan con las Pymes?

57. ¿Cómo ayuda la marca país a las exportaciones?

58. En cuanto a exportaciones, ¿hay un estimado de cuantas transacciones se generó a partir de la creación de Marca País?

59. Más allá de la reputación que tienen los productos colombianos en el exterior, ¿la Marca País los valoriza?

60. ¿Qué emociones o sentimientos le produce la marca país en Colombia? 
61. Una de las preguntas utilizadas en las investigaciones de mercado, fue "¿Cómo visualiza la pasión (o la respuesta es Colombia)?", ahora después de la experiencia con esta marca, ¿Cuál sería la respuesta a esta pregunta?

62. ¿Cómo ha evolucionado el proyecto?

63. ¿Qué resultados ha generado?

64. ¿Qué beneficios se han podido identificar?

65. ¿Cómo podemos entender el impacto?

66. ¿Cómo piensan continuar el desarrollo de marca?

67. ¿Qué proyectos estratégicos los ocupan?

\section{Sección 5. Prescriptores}

68. ¿En qué se diferencia Colombia de otros países latinoamericanos?

69. ¿Por qué es importante para Colombia tener una marca país?

70. ¿Para usted que significa marca país?

71. ¿La marca país es una estrategia competitiva para el sector empresarial colombiano? ¿Por qué?

72. ¿Conoce otras marcas país diferente a la de Colombia? ¿Cuáles y opina al respecto?

73. ¿Cómo se puede fomentar la participación de los empresarios para que promuevan la marca país?

74. ¿Cuáles son los sectores económicos que podrían adoptar en el corto plazo la marca país?

75. ¿Qué opina de la marca país anterior y la nueva? ¿Distingue diferencias?

76. ¿Hace cuánto tiempo lleva utilizando la marca país en su empresa? ¿Utilizó la anterior?

77. ¿Cómo han utilizado la marca? (mercadeo interno, diseño de nuevos productos, etc.)

78. ¿Que lo motivó a incorporar la marca país?

79. ¿Qué ventajas y desventajas tiene para su empresa la marca país?

80. ¿Cuál ha sido el impacto en ventas por usar la marca país?
81. ¿Cómo ha sido su experiencia con el uso de la marca país?

82. ¿Qué recomendaciones haría a la marca país?

83. ¿Usted considera que el uso de la marca a través de su empresa ha generado mayor patriotismo?

84. ¿Sus clientes han identificado la marca país a través de su inversión publicitaria?

85. ¿Cuál es la percepción de sus clientes después de incorporar la marca país?

86. ¿El uso de la marca en su empresa afecta el proceso de compra de sus clientes? ¿Cómo?

87. ¿Ha realizado estudios de mercados sobre el impacto de la marca país sobre la decisión de compra de sus clientes?

88. ¿Cuáles son los efectos generados para su empresa al incorporar la marca país?

89. ¿De qué forma se evidencia la marca país en su empresa? (Anuncios publicitarios, empaques, etiquetas, etc.)

90. ¿Cuál es el porcentaje sobre sus ventas que invierte en la adquisición de la licencia de marca país?

91. ¿Cuál ha sido el valor agregado que le ha proporcionado la marca país para su empresa?

92. ¿Cuál es la percepción de sus empleados o colaboradores sobre el uso de la marca?

93. ¿Cuáles son los obstáculos que se han identificado en el proceso de vinculación de la marca país en su empresa?

94. ¿En que ha contribuido la marca país al sector empresarial?

95. ¿Cómo se percibe desde los mercados extranjeros la marca país?

96. ¿Por qué las compañías deben invertir en Colombia?

97. ¿Por qué las compañías deben hacer negocios con Colombia?

98. ¿Por qué los turistas deben visitar a Colombia? 


\section{Anexo 3. Cuestionario para extranjeros visitantes empleado para la investigación empírica}

ENCUESTA A VISTANTES

DATOS DELENTREVISTADO

Entrevista No

País de Origen

DEMOGRAFICOS

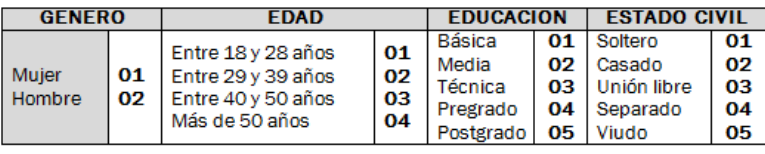

Por favor, dedique unos momentos a completar esta encuesta, su opinión es muy valiosa para nosotros. Sus respuestas serán tratadas de forma confidencial y no serán utilizadas para ningú

P 1. ¿En qué país de América del Sur le gustaría vivir? (ENC. LEAY ESCRIBALA RESPUESTA)

P 2. ¿Qué país de América del Sur le gustaría visitar? (ENC. LEAY ESCRIBA LARESPUESTA) P 3. ¿Qué es lo primero que piensa cuándo oye la palabra "Colombia"? (ENC. LEAY ESCRIBA LA
RESPUESTA)

P 4. ¿En una sola palabra describa algo positivo de Colombia? (ENC. LEAY ESCRIBA LA RESPUESTA)

P 5. ¿En una sola palabra describa algo negativo de Colombia? (ENC. LEAY ESCRIBA LARESPUESTA)

P 6. ¿Qué características tienen los colombianos? (ENC- LEA Y ESCRIBA LARESPUESTA)

P 7. ¿Para usted qué color tiene Colombia? (ENC: LEA Y ESCRIBA LA RESPUESTA)

P 8. ¿ Para usted que olor tiene Colombia? (ENC: LEAY ESCRIBA LA RESPUESTA)

P 9. ¿Qué símbolo representa a Colombia? (ENC. LEAY ESCRIBALARESPUESTA)
P 10. ¿Cuando se menciona a Colombia con que producto la asocia? (ENC: LEAY ESCRIBA LA RESPUESTA)

P 11 ¿Cuando se menciona a Colombia qué ciudad se le viene a la mente? (ENC. LEAY ESCRIBALA RESPUESTA)

P12. ¿Cuando se menciona a Colombia con qué persona la asocia? (ENC. LEAY ESCRIBA LARESPUESTA)

P 13. ¿Cuántas veces ha visitado a Colombia? (ENC. LEAY ESCRIBA LA RESPUESTA)

P 14. ¿En su visita que fue lo que más le gustó de Colombia? (ENC. LEAY ESCRIBALARESPUESTA)

P 15. ¿En su visita que fue lo que menos le gustó de Colombia? (ENC. LEAY ESCRIBA LA RESPUESTA)

P 16. ¿En su última visita cambió su opinión del país? (ENC. LEA, ACEPTE UNA RESPUESTA)

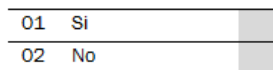

P 17. ¿Visitaría de nuevo a Colombia? (ENC. LEA, ACEPTE UNA RESPUESTA)

$$
\begin{array}{ll}
\hline 01 & \mathrm{Si} \\
\hline 02 & \text { No } \\
\hline
\end{array}
$$

P 18. ¿Recomendaría a un amigo visitar a Colombia? (ENC- LEA ACEPTEUNA RESPUESTA)

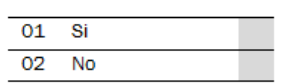




\section{Anexo 4. Cuestionario para extranjeros prospectos empleado para la investigación empírica}

ENCUESTA A PROSPECTOS

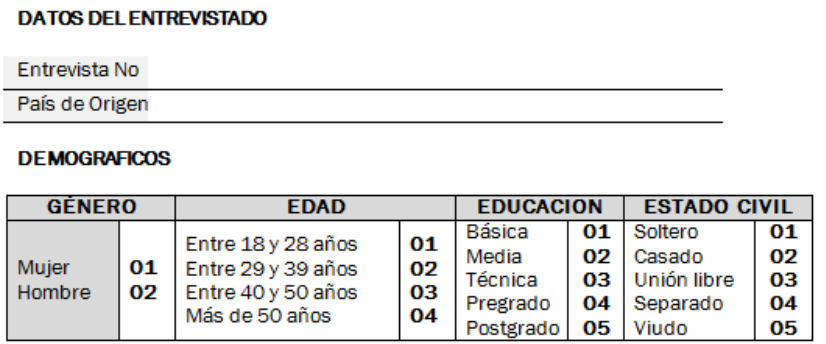

Por favor, dedique unos momentos a completar esta encuesta, su opinión es muy valiosa para

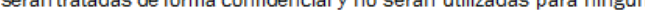
propóstio distinto a la investigacion.

P 1. ¿En qué país de América del Sur le gustaría vivir? (ENC: LEAY ESCRIBA LA RESPUESTA)

P 2. ¿Qué país de América del Sur le gustaría visitar? (ENC. LEAY ESCRIBA LA RESPUESTA)

P 3. ¿Qué es lo primero que piensa cuándo oye la palabra "Colombia"? (ENC. LEAY ESCRIBA LA

P 4. ¿En una sola palabra describa algo positivo de Colombia? (ENC. LEAY ESCRIBALA RESPUESTA)

P 5. ¿ En una sola palabra describa algo negativo de Colombia? (ENC. LEAY ESCRIBA LA RESPUESTA)

P 6. ¿Qué características tienen los colombianos? (ENC. LEA Y ESCRIBA LA RESPUESTA)
P 7. ¿Qué símbolo representa a Colombia? (ENC: LEAY ESCRIBA LARESPUESTA)

P 8. ¿Cuándo se menciona a Colombia con que producto la asocia? (ENC LEA Y ESCRIBA LA RESPUESTA)

P 9. ¿Cuando se menciona a Colombia qué ciudad se le viene a la mente? (ENC: LEAY ESCRIBALA RESPUESTA

P 10. ¿Cuando se menciona a Colombia con qué persona la asocia? (ENC: LEAY ESCRIBA LA RESPUESTA)

P 11 ¿Compraría productos de origen colombiano? (ENC.LEA, ACEPTE UNA RESPUESTA) \begin{tabular}{ll}
\hline 01 & $\mathrm{Si}$ \\
\hline 02 & $\mathrm{No}$
\end{tabular}

P 12. ¿Estaría interesado en visitar a Colombia? (ENC. LEA, ACEPTE UNA RESPUESTA)

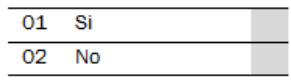

(ENC: AGRADEZCAY TERMINELA ENCUESTA) 


\section{Anexo 5. Listado de publicaciones}

\begin{tabular}{|c|c|c|c|c|c|}
\hline Producto & $\begin{array}{c}\text { Tipo de } \\
\text { publicación }\end{array}$ & Referencia bibliográfica de las publicaciones simultáneas a la Tesis & $\begin{array}{l}\text { factor de } \\
\text { Impacto }\end{array}$ & Publicación indexada & $\begin{array}{c}\text { Ubicación de } \\
\text { la referencia } \\
\text { en la Tesis } \\
\text { Doctoral }\end{array}$ \\
\hline P1 & $\begin{array}{l}\text { Trabajo en eventos } \\
\text { (Capítulo de } \\
\text { memoria) }\end{array}$ & $\begin{array}{l}\text { Echeverri, L. M. (2008). El país como una marca: el caso de Colombia es pasión. XXIII } \\
\text { Encuentro de Docentes Universitarios de Comercialización y cátedras afines de Argentina y } \\
\text { América Latina. Paraná: EDUCAAL. }\end{array}$ & N/D & N/D & $\begin{array}{l}\text { CAPÍTULO } 3 \\
\text { La marca país } \\
\text { de Colombia }\end{array}$ \\
\hline P2 & $\begin{array}{l}\text { Trabajo en eventos } \\
\text { (Capítulo de } \\
\text { memoria) }\end{array}$ & $\begin{array}{l}\text { Echeverri, L. M. (2009a). La imagen país: ¿Cómo se aplica el marketing a una nación? XLIV } \\
\text { Asamblea Anual CLADEA 2009. Ecuador: CLADEA. }\end{array}$ & N/D & N/D & $\begin{array}{l}\text { CAPÍTULO } 2 \\
\text { El país como } \\
\text { una marca }\end{array}$ \\
\hline $\mathbf{P 3}$ & $\begin{array}{l}\text { Trabajo en eventos } \\
\text { (Capítulo de } \\
\text { memoria) }\end{array}$ & $\begin{array}{l}\text { Echeverri, L. M. (2009b). La marca país: el reflejo de la identidad cultural y empresarial de una } \\
\text { Nación. Responsabilidad social de la administración en el mundo (pág. 24). Bucaramanga: } \\
\text { ASCOLFA. }\end{array}$ & N/D & N/D & $\begin{array}{l}\text { CAPÍTULO } 2 \\
\text { El país como } \\
\text { una marca }\end{array}$ \\
\hline P4 & $\begin{array}{l}\text { Artículo en revista } \\
\text { indexada }\end{array}$ & $\begin{array}{l}\text { Echeverri, L. M. \& Estay-Niculcar, C. (2013). El rol del turismo como pilar estratégico de la } \\
\text { marca país Argentina. Revista Cientifica Visión de Futuro, 186-199. }\end{array}$ & $\begin{array}{c}\text { SCIELO } \\
0.0833\end{array}$ & SCIELO, DOAJ, LATINDEX, Cengaje Learning & $\begin{array}{l}\text { CAPÍTULO } 2 \\
\text { El país como } \\
\text { una marca }\end{array}$ \\
\hline P5 & $\begin{array}{l}\text { Artículo en revista } \\
\text { indexada }\end{array}$ & $\begin{array}{l}\text { Echeverri, L. M., Estay-Niculcar, C., Herrera, C., \& Santamaría, J. (2013). Desarrollo de marca } \\
\text { país y turismo: el caso de estudio de México. Revista Estudios y Perspectivas en Turismo, } \\
22(6), 1121-1139 .\end{array}$ & $\begin{array}{c}\text { SCIELO } \\
0.0964\end{array}$ & $\begin{array}{l}\text { C.I.R.E.T., Latindex, Qualis, SciELO, Unired, Redalyc, } \\
\text { EBSCO, DIALNET, Informe Académico y Academic } \\
\text { OneFile }\end{array}$ & $\begin{array}{l}\text { CAPÍTULO } 2 \\
\text { El país como } \\
\text { una marca }\end{array}$ \\
\hline P6 & $\begin{array}{l}\text { Trabajo en eventos } \\
\text { (Capitulo de } \\
\text { memoria) }\end{array}$ & $\begin{array}{l}\text { Echeverri, L. M., Estay-Niculcar, C., \& Parra, H. (2013a). Estudio sobre la imagen país de } \\
\text { Colombia desde la perspectiva mexicana. XVIII Congreso Internacional de Contaduría, } \\
\text { Administración e Informática. México D.F.: UNAM. }\end{array}$ & N/D & ( & $\begin{array}{l}\text { CAPÍTULO } 5 \\
\text { Resultados }\end{array}$ \\
\hline P7 & $\begin{array}{l}\text { Trabajo en eventos } \\
\text { (Capítulo de } \\
\text { memoria) }\end{array}$ & $\begin{array}{l}\text { Echeverri, L. M., Estay-Niculcar, C., \& Parra, H. (2013b). Percepción de los visitantes } \\
\text { estadounidenses, venezolanos y ecuatorianos sobre la imagen país de Colombia. III Encuentro } \\
\text { Internacional de Investigadores en Administración. Bogotá: Universidad del Externado de } \\
\text { Colombia. }\end{array}$ & N/D & N/D & $\begin{array}{l}\text { CAPÍTULO } 5 \\
\text { Resultados }\end{array}$ \\
\hline P8 & $\begin{array}{l}\text { Artículo en revista } \\
\text { indexada }\end{array}$ & $\begin{array}{l}\text { Echeverri, L. M., Estay-Niculcar, C., \& Rosker, E. (2012). Estrategias y experiencias en la } \\
\text { construcción de marca país en América del Sur. Revista Estudios y Perspectivas en Turismo, } \\
21 \text { (1), 288-305. }\end{array}$ & $\begin{array}{l}\text { SCIELO } \\
0.0964\end{array}$ & $\begin{array}{l}\text { C.I.R.E.T., Latindex, Qualis, SciELO, Unired, Redalyc, } \\
\text { EBSCO, DIALNET, Informe Académico y Academic } \\
\text { OneFile }\end{array}$ & $\begin{array}{l}\text { CAPÍTULO } 2 \\
\text { El país como } \\
\text { una marca }\end{array}$ \\
\hline P9 & Libro & $\begin{array}{l}\text { Echeverri, L. M., Restrepo, M. L., \& Rosker, E. (2008). Colombia es pasión - Caso académico. } \\
\text { Bogotá: Universidad del Rosario-CESA. }\end{array}$ & N/D & N/D & $\begin{array}{l}\text { CAPÍTULO } 3 \\
\text { La marca país } \\
\text { de Colombia }\end{array}$ \\
\hline P10 & $\begin{array}{l}\text { Artículo en revista } \\
\text { indexada }\end{array}$ & $\begin{array}{l}\text { Echeverri, L. M., Restrepo, M. L., \& Rosker, E. (2010). Los orígenes de la Marca País Colombia } \\
\text { es Pasión. Revista Estudios y Perspectivas en Turismo, 409-421. }\end{array}$ & $\begin{array}{l}\text { SCIELO } \\
0.0964\end{array}$ & $\begin{array}{l}\text { C.I.R.E.T., Latindex, Qualis, SciELO, Unired, Redalyc, } \\
\text { EBSCO, DIALNET, Informe Académico y Academic } \\
\text { OneFile }\end{array}$ & $\begin{array}{l}\text { CAPÍTULO } 3 \\
\text { La marca país } \\
\text { de Colombia }\end{array}$ \\
\hline P11 & $\begin{array}{l}\text { Artículo en revista } \\
\text { indexada }\end{array}$ & $\begin{array}{l}\text { Echeverri, L. M., \& Rosker, E. (2011). Diferencias en la construcción de marca país: Canadá y } \\
\text { Colombia. Revista Virtual Universidad Católica Del Norte (33), 1-29. }\end{array}$ & $\begin{array}{l}\text { PUBLINDEX } \\
\text { Categoría B }\end{array}$ & $\begin{array}{l}\text { Publindex, Latindex, EBSCO Information Services, } \\
\text { Redalyc, Dialnet, DOAJ, Actualidad lberoamericana, } \\
\text { Indice de Revistas de Educación Superior e } \\
\text { Investigación Educativa (IRESIE) de la Universidad } \\
\text { Autónoma de México }\end{array}$ & $\begin{array}{l}\text { CAPÍTULO } 2 \\
\text { El país como } \\
\text { una marca }\end{array}$ \\
\hline P12 & Libro & $\begin{array}{l}\text { Echeverri, L. \& Trujillo, L. (Forthcoming-2014). Una marca país para Colombia. Bogotá: Editorial } \\
\text { CESA. }\end{array}$ & N/D & (2) & N/D \\
\hline P13 & $\begin{array}{l}\text { Artículo en revista } \\
\text { indexada }\end{array}$ & $\begin{array}{l}\text { Echeverri, L., Estay-Niculcar, C., \& Parra, H. (Forthcoming-2014a). Impresiones de los } \\
\text { mexicanos sobre la imagen pais de Colombia. Revista Clío América. }\end{array}$ & $\begin{array}{l}\text { PUBLINDEX } \\
\text { Categoría C }\end{array}$ & Publindex, Latindex, Ulrich's & $\begin{array}{l}\text { CAṔ́TULO } 5 \\
\text { Resultados }\end{array}$ \\
\hline P14 & $\begin{array}{l}\text { Artículo en revista } \\
\text { indexada }\end{array}$ & $\begin{array}{l}\text { Echeverri, L., Estay-Niculcar, C., \& Parra, H. (Forthcoming-2014b). Imagen país de Colombia } \\
\text { desde la perspectiva estadounidense. Revista Hallazgos. }\end{array}$ & $\begin{array}{l}\text { PUBLINDEX } \\
\text { Categoría B }\end{array}$ & Publindex, EBSCO, DOAJ, Dialnet, Ulrich, Latindex & $\begin{array}{l}\text { CAPÍTULO } 5 \\
\text { Resultados }\end{array}$ \\
\hline
\end{tabular}




\section{Anexo 6. Componentes de la Tesis y ubicación de las publicaciones}

En la Tesis Doctoral se integran las publicaciones realizadas de manera simultánea durante el desarrollo del proceso investigativo y que se han referenciado en los contenidos de la misma. Como se puede observar en la Figura 101, los contenidos que componen la Tesis Doctoral referencian los resultados de las publicaciones $(\mathrm{P})$ referenciadas en el Anexo 5:

Figura 101. Componentes de la Tesis Doctoral y las publicaciones simultáneas

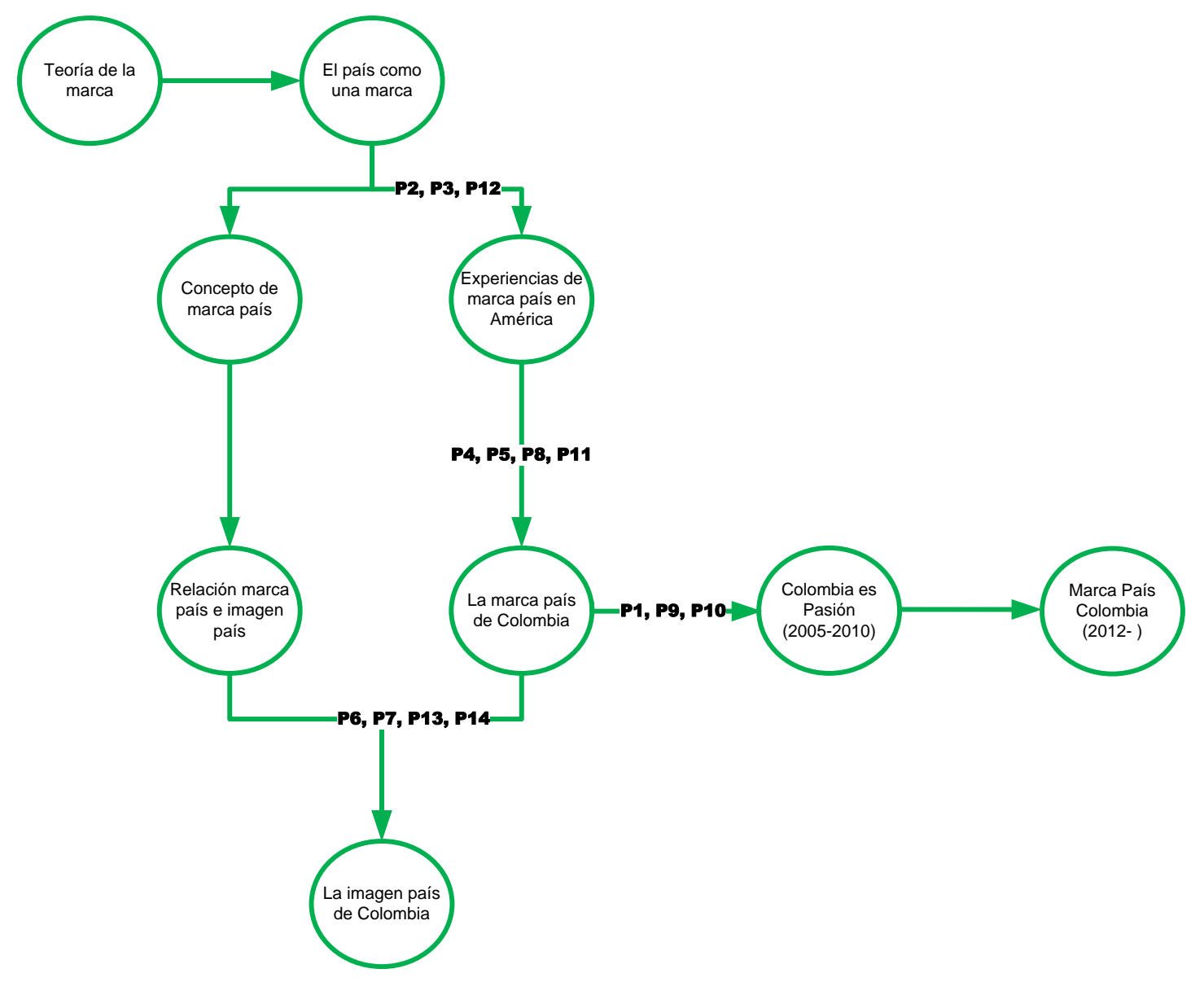

Fuente: elaboración propia. 